\title{
Hydrogeology of the Unsaturated Zone, North Ramp Area of the Exploratory Studies Facility, Yucca Mountain, Nevada
}

Edited by Joseph P. Rousseau, Edward M. Kwicklis, and Daniel C. Gillies

U.S. GEOLOGICAL SURVEY

Water-Resources Investigations Report 98-4050

Prepared in cooperation with the NEVADA OPERATIONS OFFICE, U.S. DEPARTMENT OF ENERGY, under Interagency Agreement DE-Al08-97NV12033, Contract DE-AC04-94AL85000

DISTRAIUTION OF THIS DOCUMENT IS URLMUTED 


\title{
U.S. DEPARTMENT OF THE INTERIOR BRUCE BABBITT, Secretary
}

\author{
U.S. GEOLOGICAL SURVEY
}

Charles G. Groat, Director

The use of firm, trade, and brand names in this report is for identification purposes only and does not constitute endorsement by the U.S. Geological Survey.

For additional information write to:

Chief, Earth Science Investigations Program

Yucca Mountain Project Branch

U.S. Geological Survey

Box 25046, MS 421

Denver Federal Center

Denver, CO 80225
Copies of this report can be purchased from:

U.S. Geological Survey

Information Services

Box 25286

Federal Center

Denver, CO 80225 


\section{DISCLAIMER}

This report was prepared as an account of work sponsored by an agency of the United States Government. Neither the United States Government aor any agency thereof. nor any of their employees, makes any wartanty, express or implied, or assumes any legal liability or responsibility for the accuracy, completeness, or usefulness of any information, apparatus, product, or process disclosed. or represents that its use would not infringe privately owned rights. Refereace berein to any specific commercial product, process, or service by trade name. Isademark, manufac. turer, or otherwise does not necessarily constitute or imply its endorsemeat, recommendation, or favoring by the United States Government or any agency thereof. The views and opinions of authors expressed herein do not aecescarily state or reflect those of the United States Government or any agency thereof. 


\section{DISCLAIMER}

Portions of this document may be illegible in electronic image products. Images are produced from the best available original document. 


\section{CONTENTS}

Abstract

Introduction

D.C. Gillies

Purpose and Scope

D.C. Gilles

Quality Assurance

D.C. Gilles

Regional Hydrogeologic Setting of the Yucca Mountain Area.

L.E. Flint

Regional Stratigraphic and Structural Setting

R.W. Spengler

Stratigraphy

Structure

Local Hydrogeologic Setting of Yucca Mountain

L.E. Flint

Climate and Precipitation

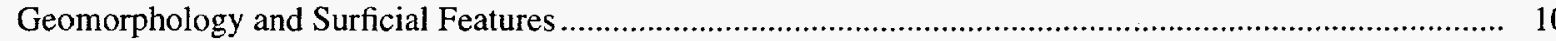

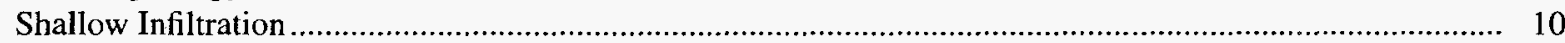

Exploratory Studies Facility North Ramp Study Area ...................................................................... 13

Geologic Framework of the North Ramp Area of the Exploratory Studies Facility, Yucca Mountain ............................ 17

Stratigraphic Framework of the North Ramp Area of the Exploratory Studies Facility, Yucca Mountain ................ 17

D.C. Buesch and R.W. Spengler

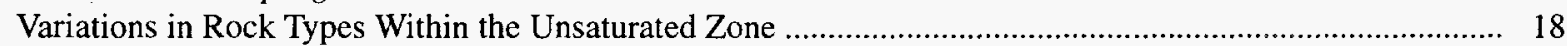

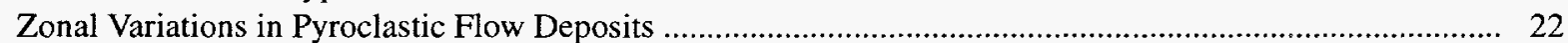

Correlation of the Lithostratigraphic and Hydrogeologic Frameworks .................................................... 24

Evaluation of the Three-Dimensional Lithostratigraphic Model of the Central Block of Yucca Mountain ..... 26

Variability in Thickness of Selected Lithostratigraphic and Hydrogeologic Units ............................ 30

Tiva Canyon Tuff ............................................................................................. 30

Paintbrush Nonwelded Hydrogeologic Unit ............................................................... 31

Topopah Spring Tuff................................................................................................ 31

Calico Hills Hydrogeologic Unit............................................................................. 31

Geometry and Lateral Continuity of Selected Lithostratigraphic and Hydrogeologic Units ............... 33

Base of the Tiva Canyon Tuff ...................................................................................... 33

Top of the Densely Welded Rocks of the Topopah Spring Tuff ................................................ 33

Top of the Crystal-Poor Vitrophyre of the Topopah Spring Tuff .............................................. 36

Base of the Calico Hills Formation ......................................................................... 36

Aqueous Alteration of Glass and Fumarolic Alteration and Crystallization........................................... 36

Alteration in the PTn Hydrogeologic Unit ........................................................................... 36

Alteration in the Calico Hills Hydrogeologic Unit................................................................ 39

Modeling of the Vitric-Zeolitic Boundary .......................................................................... 40

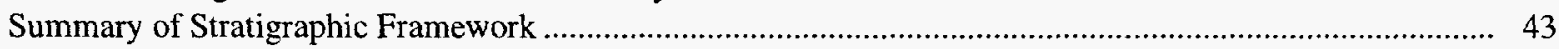

Structural Setting of the North Ramp of the Exploratory Studies Facility......................................................... 44

W.C. Day, D.S. Sweetkind, C.J. Potter, S.C. Beason (Bureau of Reclamation), and R. W. Spengler

Setting of Structural Subdomains

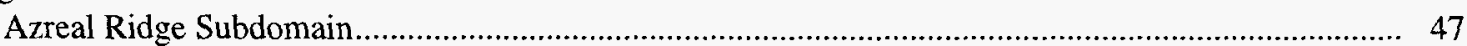

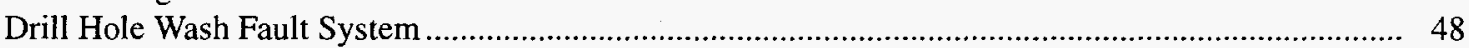

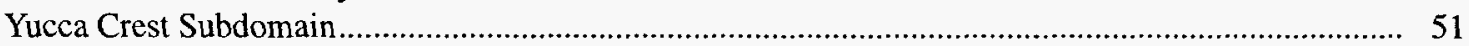

Comparison of Fractures in Surface Outcrops from the Azreal Ridge and Yucca Crest Subdomains.... 51

Fracture Characteristics of the Paintbrush Nonwelded Hydrogeologic Unit ........................................... 53

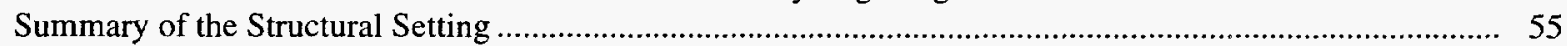


Unsaturated Zone Gaseous-Phase (Pneumatic) System ....................................................................................... 55

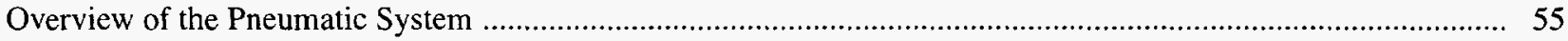

J.P. Rousseau

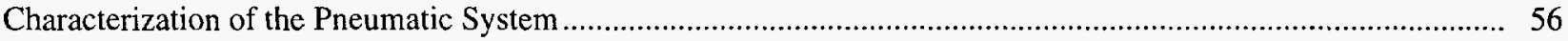

Pneumatic Properties Determined from Analysis of Rock Cores . .................................................. 61

L.E. Flint

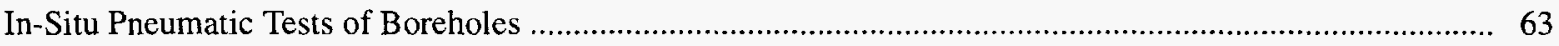

G.D. LeCain

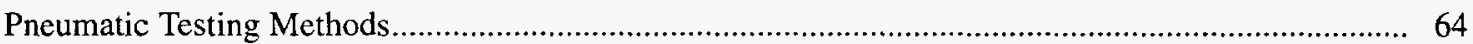

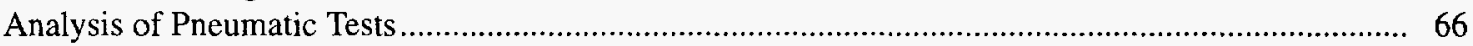

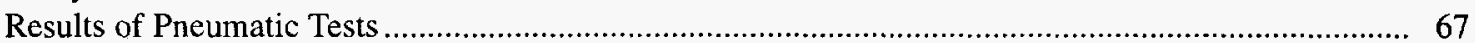

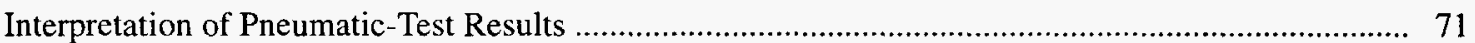

Results of In-Situ Pneumatic Monitoring in Boreholes......................................................................... 77

In-Situ Pneumatic-Pressure Response to Atmospheric Pressure Change ..................................... 77

J.P. Rousseau and G.L. Patterson

Pressure Response in the Tiva Canyon Welded Hydrogeologic Unit....................................... 89

Pressure Response in the Paintbrush Nonwelded Hydrogeologic Unit..................................... 93

Pressure Response in the Topopah Spring Welded Hydrogeologic Unit.................................. 96

Pressure Response in the Calico Hills Nonwelded Hydrogeologic Unit................................... 97

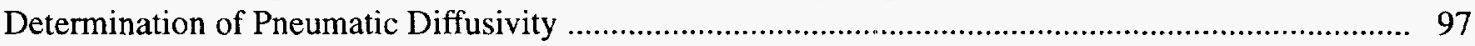

E.M. Kwicklis

Drill Hole Wash Boreholes ............................................................................................ 98

Pagany Wash Boreholes................................................................................................... 102

Interpretation of Pneumatic-Diffusivity Determinations .................................................... 106

Summary of Pneumatic-Diffusivity Analyses ................................................................ 109

Effects of Excavation of the North Ramp on In-Situ Pneumatic-Pressure Measurements ................... 110

J.P. Rousseau and G.L. Patterson

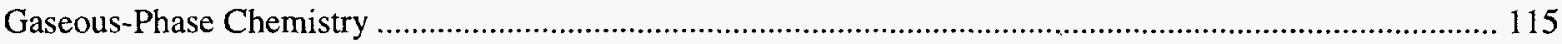

I.C. Yang

Carbon Dioxide Concentration in Gas Samples From Borehole USW UZ-1 .............................. 116

Delta Carbon-13 and Carbon-14 Content of Gas Samples From Borehole USW UZ-1 ..................... 116

Carbon Dioxide Concentration and Carbon-Isotope Content of Gas Samples From Selected

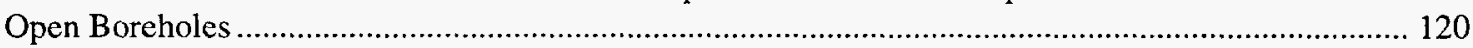

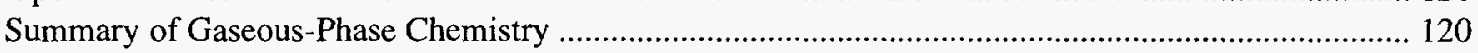

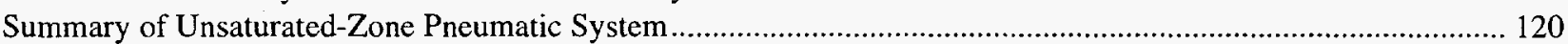

J.P. Rousseau

Unsaturated Zone Aqueous-Phase (Hydrologic) System ............................................................................. 122

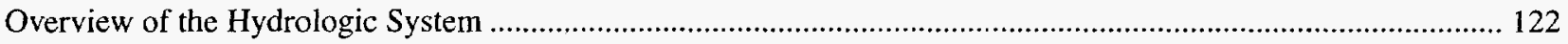

J.P. Rousseau

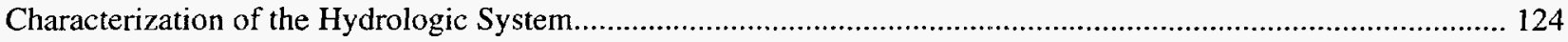

Physical and Hydrologic Properties Determined from Analysis of Rock Cores .................................. 125

L.E. Flint

Correlation of Hydrologic Properties With Physical and Lithologic Properties ................................. 137

Borehole Core Saturations.................................................................................................... 139

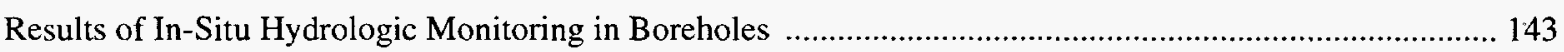

J.P. Rousseau

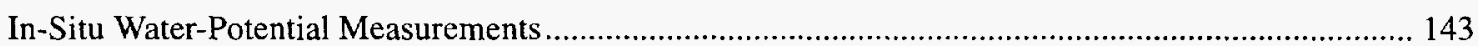

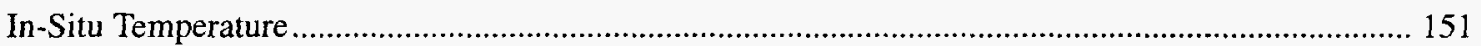

Temperature Measurements and Gradients ..................................................................... 152 
Aqueous-Phase Chemistry

I.C. Yang

Pore-Water Composition from Boreholes USW UZ-14, USW NRG-6, and USW NRG-7a

Aqueous-Phase Isotopic Data from Boreholes USW UZ-14, UE-25 UZ\#4, UE-25 UZ\#5,

USW NRG-6, and USW NRG-7a.

Tritium.

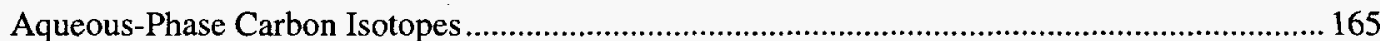

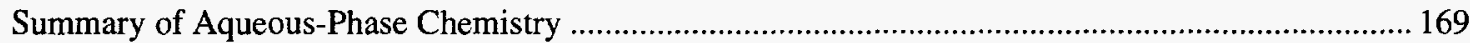

Occurrences of Perched Water in the Vicinity of the Exploratory Studies Facility North Ramp .................... 170

G. L. Patterson

Borehole UZ-1.

Borehole UZ-14...

Borehole NRG-7a

Borehole SD-9.

Relation of North Ramp Perched Water to Lithology and Geologic Structure .................................... 171

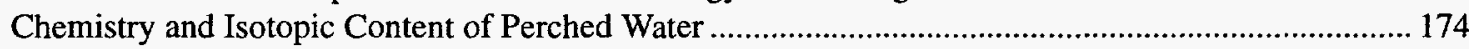

I.C. Yang and Z.E. Peterman

Chemical Composition of Perched Water

Relation of Perched Water to Ground Water and Precipitation.................................................... 177

Possible Source and Residence Time of Perched Water ................................................................. 178

Strontium Isotope Content of Perched Water ............................................................................... 180

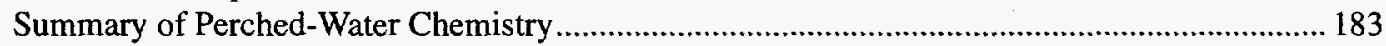

Integration and Synthesis of Existing Hydrologic Data.....

Comparison and Assessment of Field-Scale and Core-Scale Water Potentials and Water-Potential

Gradients

J.P. Rousseau

Analysis of Percolation Flux Based on Heat Flow Estimated in Boreholes

E.M. Kwicklis and J.P. Rousseau

Numerical Analysis of Heat Flow and Percolation in Pagany Wash

Gas, Liquid, and Heat Flow Through a Schematic Cross Section .................................................. 191

Liquid Flow and Heat Flow in Pagany Wash ................................................................................ 197

Inferences Concerning Heat Flow and Percolation in Drill Hole Wash.................................................. 204

Summary of Heat-Flow and Percolation-Flux Analyses....................................................................... 207

Analysis of Percolation Flux Based on Observations Related to the Perched Water Underlying

Drill Hole Wash

E.M. Kwicklis

Aqueous-Phase Chemical Considerations.

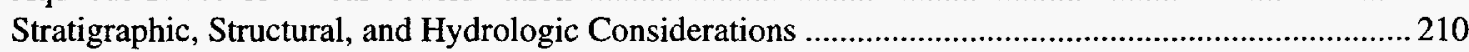

Calculation of Percolation Flux in the Vicinity of the UZ-14 Perched-Water Reservoir........................ 212

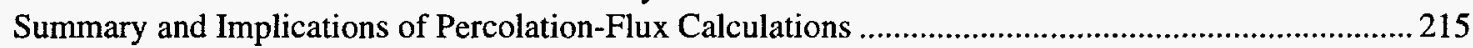

Evidence for Preferential Fracture Flow and Lateral Flow Within the Paintbrush Nonwelded

Hydrogeologic Unit.

E.M. Kwicklis

Summary and Conclusions

D.C. Gillies

References Cited

Appendix

Implications for Waste Isolation at the Potential High-Level Radioactive Waste Repository at

Yucca Mountain, Nevada. 239

E.M. Kwicklis and J.P. Rousseau 
1. Map showing location of Yucca Mountain region ............................................................................

2. Map showing location of Yucca Mountain, Nye County, Nevada .........................................................

3. Graph showing water-content changes in neutron boreholes during the winter of 1995 for representative alluvium adjacent to borehole USW UZ-N37 and bedrock adjacent to borehole USW UZ-N36 locations ... 12

4. Diagram showing estimates of shallow infiltration along the trace of the North Ramp of the Exploratory Studies Facility

5-7. Maps showing:

5. Exploratory Studies Facility North Ramp study area and location of selected boreholes and geologic sections

6. Boreholes and faults in the lithostratigraphic model YMP.R2.0 of the central block of Yucca Mountain

7. Lithostratigraphic units at the base of the unsaturated zone at Yucca Mountain ............................ 21

8. East-west geologic section through boreholes USW SD-9 and UE-25 NRG\#4, Yucca Mountain ............... 27

9. North-south geologic section through boreholes USW NRG-7a and USW G-4, Yucca Mountain ............... 28

10. Northwest-trending geologic section through boreholes USW UZ-14 and USW NRG-6, Yucca Mountain

11-21. Maps showing:

11. Variation in thickness of the Paintbrush nonwelded hydrogeologic unit at Yucca Mountain.............. 32

12. Structure contours of the base of the Tiva Canyon Tuff at Yucca Mountain ..................................... 34

13. Structure contours of the top of the densely welded rocks of the Topopah Spring Tuff at Yucca Mountain

14. Structure contours of the top of the crystal-poor vitrophyre of the Topopah Spring Tuff at Yucca Mountain

15. Structure contours of the base of the Calico Hills Formation at Yucca Mountain.

16. Isochores of vitric material in the Calico Hills Nonwelded Hydrogeologic Unit at Yucca Mountain

17. Structure contours of the vitric-zeolitic boundary in the Calico Hills nonwelded hydrogeologic unit at Yucca Mountain

18. Generalized regional block-bounding faults near Yucca Mountain

19. Bedrock geologic map of the North Ramp area of the Exploratory Studies Facility, Yucca Mountain

20. Structural subdomains within the North Ramp area of the Exploratory Studies Facility, Yucca Mountain

21. Dominant faults within the North Ramp area of the Exploratory Studies Facility, Yucca Mountain

22. Equal-area lower-hemisphere stereonet of the median value of cooling joints and tectonic-fracture sets from the Azreal Ridge and Yucca Crest structural subdomains

23-26. Diagrams showing:

23. Lithostratigraphic symbols and nomenclature for lithostratigraphic and hydrogeologic units at Yucca Mountain

24. Fracture histograms and lithology for boreholes USW UZ-14 and USW SD-9.

25. Fracture histograms and lithology for boreholes USW NRG-7a and USW NRG-6

26. Fracture histograms and lithology for boreholes UE-25 NRG\#5 and UE-25 NRG\#4 60

27-30. Graphs showing:

27. Porosity and relative saturation for samples for three radial boreholes in Alcove 1 in the Exploratory Studies Facility.

28. Porosity and air permeability for three radial boreholes in Alcove 1 in the Exploratory Studies Facility.

29. Air permeability corrected for Klinkenberg effects relative to porosity for nonwelded and bedded samples from boreholes in the North Ramp area...

30. Air permeability corrected for Klinkenberg effects relative to water permeability for nonwelded and bedded samples from boreholes in the North Ramp area..

31. Schematic of pneumatic (air-injection) testing system 
32-40. Graphs showing:

32. Arithmetic relation between absolute pressure and time in the injection and guard intervals during test 68 at borehole USW NRG-7a...

33. Log-log relation between differential pressure and time in the injection interval during test 68 at borehole USW NRG-7a

34. Arithmetic relation between steady-state differential pressures squared and flow rate tests 37,38 , and 39 at borehole USW NRG-7a

35. Semilog relation between test-interval air-permeability values, depth, and lithostratigraphic unit at borehole USW NRG-7a

36. Semilog relation between test-interval air-permeability values, depth, and lithostratigraphic unit at borehole USW NRG-6.

37. Cumulative probability of air-permeability values of the Topopah Spring Tuff from boreholes USW NRG-6 and USW NRG-7a

38. Cumulative probability of the natural $\log$ air-permeability values of the Topopah Spring Tuff from boreholes USW NRG-6 and USW NRG-7a

39. Relation between test-interval permeability values and the number of natural fractures identified in the test interval at borehole USW NRG-7a.

40. Relation between test-interval permeability values and the number of natural fractures identified in the test interval at borehole USW NRG-6.

41. Locations of instrument stations in monitored boreholes within the North Ramp study area ...

42-61. Graphs showing:

42. Pneumatic pressure records for instrument stations $1,2,3,4,5$, and 6 located in the Paintbrush nonwelded hydrogeologic unit at borehole USW UZ-1

43. Pneumatic pressure records for instrument stations $7,8,9,10,12,13$, and 15 located in the Topopah Spring welded hydrogeologic unit at borehole USW UZ-1

44. Pneumatic pressure records for the Zone 1 instrument station located in the Topopah Spring welded hydrogeologic unit and the Paintbrush nonwelded hydrogeologic unit, the Zone 2 instrument station located in the Calico Hills nonwelded hydrogeologic unit, and instrument station 0 located at the land surface at borehole USW SD-9

45. Pneumatic pressure records for instrument station $D$ located in the Paintbrush nonwelded hydrogeologic unit, instrument station $E$ located in the Tiva Canyon welded hydrogeologic unit, and instrument station $L$ located at the and surface at USW NRG-7a ....

46. Pneumatic pressure records for instrument stations A, B, and C located in the Topopah Spring welded hydrogeologic unit at borehole USW NRG-7a

47. Pneumatic pressure records for instrument station 0 located at the land surface and instrument stations 1 and 2 located in the Tiva Canyon welded hydrogeologic unit at borehole UE-25 NRG\#5

48. Pneumatic pressure records for instrument stations 3,4 , and 5 located in the Paintbrush nonwelded hydrogeologic unit at borehole UE-25 NRG\#5

49. Pneumatic pressure records for instrument stations $6,7,8$, and 9 located in the Topopah Spring welded hydrogeologic unit at borehole UE-25 NRG\#5

50. Pneumatic pressure records for instrument stations $10,11,12,13$, and 14 located in the Topopah Spring welded hydrogeologic unit at borehole UE-25 NRG\#5.

51. Pneumatic pressure records for instrument stations $F$ and $G$ located in the Paintbrush nonwelded hydrogeologic unit and instrument station $L$ located at the land surface at borehole USW NRG-6.

52. Pneumatic pressure records for instrument stations A, B, C, D, and E located in the Topopah Spring welded hydrogeologic unit at borehole USW NRG-6

53. Pneumatic pressure records for instrument station 0 located at the land surface, instrument stations 1 and 2 located in the Tiva Canyon welded hydrogeologic unit, and instrument station 3 located in the Paintbrush nonwelded hydrogeologic unit at borehole UE-25 NRG\#4

54. Pneumatic pressure records for instrument stations 4, 5, 6, and 7 located in the Topopah Spring welded hydrogeologic unit at borehole UE-25 NRG\#4 
55. Pneumatic pressure records for instrument station $M$ located at the land surface, instrument station $\mathrm{G}$ located in the Tiva Canyon welded hydrogeologic unit, and instrument station $\mathrm{H}$ located in the Paintbrush nonwelded hydrogeologic unit at borehole UE-25 UZ\#4

56. Pneumatic pressure records for instrument stations $\mathrm{C}, \mathrm{D}, \mathrm{E}$, and $\mathrm{F}$ located in the Paintbrush nonwelded hydrogeologic unit at borehole UE-25 UZ\#4.

57. Pneumatic pressure records for instrument station A located in the Topopah Spring welded hydrogeologic unit and instrument station B located in the Paintbrush nonwelded hydrogeologic unit at borehole UE-25 UZ\#4

58. Pneumatic pressure records for instrument station $M$ located at the land surface, instrument station $\mathrm{H}$ located in the Tiva Canyon welded hydrogeologic unit, and instrument station $\mathrm{G}$ located in the Paintbrush nonwelded hydrogeologic unit at borehole UE-25 UZ\#5

59. Pneumatic pressure records for instrument stations C, D, E, and F located in the Paintbrush nonwelded hydrogeologic unit at borehole UE-25 UZ\#5.

60. Pneumatic pressure records for instrument station A located in the Topopah Spring welded hydrogeologic unit and instrument station B located in the Paintbrush nonwelded hydrogeologic unit at borehole UE-25 UZ\#5..

61. Pneumatic pressure records for instrument stations located immediately below the Paintbrush

62-77. Graphs showing: nonwelded hydrogeologic unit contact with the Topopah Spring welded hydrogeologic unit.

62. Measured pneumatic pressure record used to estimate the pneumatic diffusivities at borehole USW NRG-6...

63. Comparison of simulated and measured pneumatic pressures for instrument stations $E, F$, and $\mathrm{G}$ at borehole USW NRG-6.

64. Comparison of simulated and measured pneumatic pressures for instrument stations $C, D$, and E at borehole USW NRG-6.

65. Comparison of simulated and measured pneumatic pressures for instrument stations A, B, and C at borehole USW NRG-6

66. Measured pneumatic pressure records used to estimate the pneumatic diffusivities at borehole USW NRG-7a

67. Comparison of simulated and measured pneumatic pressures for instrument stations $C, D$, and E at borehole USW NRG-7a

68. Comparison of simulated and measured pneumatic pressures for instrument stations A, B, and C at borehole USW NRG-7a.

69. Measured pneumatic pressure records used to estimate the pneumatic diffusivities at borehole UE-25 UZ\#5.

70. Comparison of simulated and measured pneumatic pressures for instrument stations $F, G$, and $\mathrm{H}$ at borehole UE-25 UZ\#5.

71. Comparison of simulated and measured pneumatic pressures for instrument stations $D, E$, and $F$ at borehole UE-25 UZ\#5.

72. Comparison of simulated and measured pneumatic pressures for instrument stations $A, B$, and $\mathrm{C}$ at borehole UE-25 UZ\#5

73. Measured pneumatic pressure records used to estimate the pneumatic diffusivities at borehole UE-25 UZ\#4.

74. Comparison of simulated and measured pneumatic pressures for instrument stations $F, G$, and $\mathrm{H}$ at borehole UE-25 UZ\#4

75. Comparison of simulated and measured pneumatic pressures for instrument stations $C, D$, and E at borehole UE-25 UZ\#4

76. Comparison of simulated and measured pneumatic pressures for instrument stations $A$ and $B$ at borehole UE-25 UZ\#4.

77. Comparison of field-scale estimates of permeability based on pneumatic pressure with air permeabilities measured on core at boreholes UE-25 UZ\#4 and UE-25 UZ\#5. 
78-80. Graphs showing:

78. Percent carbon dioxide concentration in gas samples from borehole USW UZ-1: (A) 1983-87 and (B) 1988-94

79. Delta carbon-13 values, in per mil, in carbon-dioxide gas samples from borehole USW UZ-1:

(A) 1984-87 and (B) 1988-94

80. Carbon-14 activity in carbon dioxide gas samples from borehole USW UZ-1: (A) 1984-87 and

(B) 1988-94

81-91. Graphs showing:

81. Porosity, saturation, and water-potential data for borehole USW SD-9.....

82. Porosity, saturation, and water-potential data for borehole USW UZ-14

83. Saturation and porosity with depth for boreholes USW NRG-7a and USW NRG-6.

84. Moisture-retention curves from laboratory measurements of core for (A) pre-Yucca Mountain

bedded tuff (Tpbt3), (B) upper lithophysal unit of the Topopah Spring Tuff (Tptpul),

(C) middle nonlithophysal zone of the Topopah Spring Tuff (Tptpmn), and (D) basal vitrophyre of the Topopah Spring Tuff (Tptpv3)

85. Particle density with depth for boreholes USW UZ-14 and USW SD-9.

86. Saturation and porosity with depth for boreholes USW UZ-N33 and USW UZ-N34 ...................... 134

87. Saturation and porosity with depth for boreholes USW UZ-N37 and USW UZ-N38 ...................... 135

88. Saturation and porosity with depth for boreholes UE-25 UZ\#5 and UE-25 UZ\#4 …......................... 136

89. Water permeability with depth for borehole USW SD-9.................................................................. 138

90. Relation between porosity and water permeability for borehole USW SD-9 .................................... 139

91. Measured saturation with depth for borehole USW UZ-14 and estimates of saturation using in-situ measurements of water potential in nearby borehole USW UZ-1

92-102. Graphs showing:

92. Selected water-potential profiles for borehole USW UZ-1

93. Selected water-potential and temperature profiles for borehole USW NRG-7a $\ldots \ldots \ldots \ldots \ldots \ldots \ldots \ldots \ldots \ldots \ldots . . . . . . . . . . . . . .147$

94. Selected water-potential and temperature profiles for borehole USW NRG-6 .................................. 148

95. Time-series water-potential records for instrument stations at borehole USW NRG-7a ..................... 149

96. Time-series water-potential records for instrument stations at borehole USW NRG-6 ....................... 149

97. Selected water-potential profiles for boreholes UE-25 UZ\#5 and UE-25 UZ\#4 …............................ 150

98. Time-series water-potential records for instrument stations in borehole UE-25 UZ\#4....................... 151

99. Time-series water-potential records for instrument stations in borehole UE-25 UZ\#5 ...................... 151

100. Selected temperature profiles for boreholes UE-25 UZ\#5 and UE-25 UZ\#4 .................................. 153

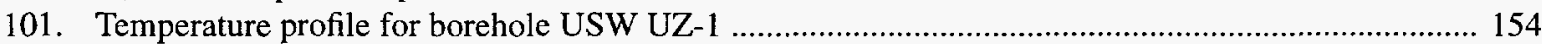

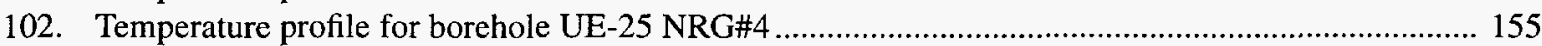

103. Piper diagram showing pore-water compositions of borehole USW UZ-14 …........................................... 162

104. Piper diagram showing pore-water compositions of boreholes USW NRG-6 and USW NRG-7a................ 164

105-107. Graphs showing:

105. Water content and tritium concentrations from boreholes (A) UE-25 UZ\#4 and

(B) UE-25 UZ\#5

106. Tritium, carbon-14, and carbon-13 values from borehole USW UZ-14: (A) for the top

120 meters of the borehole, and (B) for the Calico Hills nonwelded hydrogeologic unit.

107. Tritium and carbon-14 (pore water) concentrations from boreholes: (A) USW NRG-6 and

(B) USW NRG-7a.

108. Structure contour map of the top of the crystal-poor vitrophyre of the Topopah Spring Tuff showing

the estimated extent of the perched-water reservoir near borehole USW UZ-14.

109. Diagram showing the relation between perched water in Drill Hole Wash boreholes and a

projected growth fault in the vicinity of boreholes USW UZ-14 and USW G-1

110. Piper diagram showing perched-water composition, along with saturated-zone water composition 
111-113. Graphs showing:

111. Delta oxygen-18 and delta deuterium for 1984 storms, saturated-zone water, and perched water ...... 178

112. Carbon data for perched water: (A) apparent carbon-14 percent modern carbon and

(B) delta carbon-13

113. Variation in delta strontium- 87 as a function of cumulative pumpage from

borehole USW UZ-14.

114. Graph showing time-series temperature records for instrument stations located below the influence of seasonal, land-surface temperature changes at borehole UE-25 UZ\#4.

115. Graph showing time-series temperature records for instrument stations located below the influence of seasonal, land-surface temperature changes at borehole UE-25 UZ\#5

116. Schematic isotherm section through boreholes UE-25 UZ\#4 and UE-25 UZ\#5 located in the Pagany Wash drainage, North Ramp study area.

117. Graph showing shallow time-lapse temperature profiles at boreholes UE-25 UZ\#4 and UE-25 UZ\#5 in the zone affected by seasonal, land-surface temperature changes

118. Graph showing thermal-conductivity values for welded and nonwelded tuffs as a function of saturation and porosity at a temperature of 20 degrees Celsius

119-125. Diagrams showing:

119. Computational mesh used in heat-flow simulations 192

120. Simulated temperature contours and heat-flow vectors for Case A.

121. Simulated temperature contours and heat-flow vectors for Case B

122. Simulated gas-pressure contours and gas-flow vectors for Case $C$.

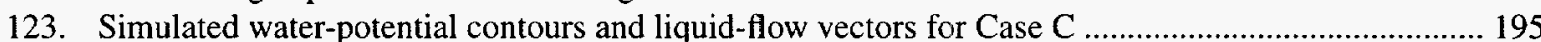

124. Simulated temperature contours and heat-flow vectors for Case D ............................................... 195

125. Simulated temperature contours and heat-flow vectors for Case $E$............................................... 196

126. Graphs showing simulated temperature profiles (A) beneath the wash, (B) beneath the ridgetops, and (C) at the water table

127. Diagram showing computational mesh and stratigraphy used in the Pagany Wash simulations 198

128. Diagram showing simulated temperature contours and heat-flow vectors near Pagany Wash for a zero percolation flux

129. Graphs showing simulated (A) temperature and (B) heat flow as a function of elevation at boreholes UE-25 UZ\#4 and UE-25 UZ\#5 for a zero percolation flux

130. Diagram showing simulated water-saturation contours and liquid-flow vectors near Pagany Wash for an infiltration flux of 20 millimeters per year in the wash

131. Diagram showing simulated temperature contours and heat-flow vectors near Pagany Wash for an infiltration flux of 20 millimeters per year in the wash.

132-135. Graphs showing:

132. Simulated temperatures as a function of elevation at boreholes UE-25 UZ\#4 and UE-25 UZ\#5 for an inflation flux of 20 millimeters per year in Pagany Wash.

133. Comparison of measured temperatures at boreholes UE-25 UZ\#4 and UE-25 UZ\#5 with best-fit simulated temperatures using a one-dimensional model and steady-state infiltration fluxes of 18 millimeters per year at boreholes UZ\#4 and 5 millimeters per year at borehole UE-25 UZ\#5

134. Comparison of measured temperatures at borehole UE-25 UZ\#4 with simulated temperatures using a one-dimensional model and steady-state infiltration fluxes of $0.1,1.0,10.0$, and 20.0 millimeters per year

135. Comparison of measured temperatures at borehole UE-25 UZ\#5 with simulated temperatures using a one-dimensional model and steady-state infiltration fluxes of $0.1,1.0,10.0$, and 20.0 millimeters per year

136. Graph showing chloride concentration and summary of selected carbon-14 data for water samples from borehole USW UZ-14

137. Diagram showing conceptual model of the flow field in the vicinity of the perched-water reservoir intercepted by borehole USW UZ-14. 
TABLES

1. Borehole data for the North Ramp study area at Yucca Mountain .....

2. Correlation of bedrock lithostratigraphic units with lithostratigraphic-model units in YMP.R2.0 and hydrogeologic units in the unsaturated zone.

3. Statistical summary of air-injection permeability values by hydrogeologic and lithostratigraphic unit for boreholes NRG-6 and NRG-7a

4. Statistical summary of Topopah Spring Tuff air-injection permeability values for boreholes NRG-6 and NRG-7a

5. Statistical summary of Topopah Spring Tuff natural-log air-permeability values for boreholes NRG-6 and

NRG-7a and results of Z-test of the means and F-test of variances

6. Goodness-of-fit values $\left(\mathrm{R}^{2}\right)$ from univariate regression analysis between air-injection permeability values and six explanatory variables.....

7. Spectral analyses of in-situ pneumatic-pressure responses to the synoptic barometric-pressure signal before interference from excavation of the North Ramp tunnel

8. Thickness of the Paintbrush nonwelded hydrogeologic unit (PTn) in monitored boreholes in the North Ramp study area

9. Results of model calibration using pneumatic-pressure data from instrumented borehole NRG-6

10. Results of model calibration using pneumatic-pressure data from instrumented borehole NRG-7a

11. Results of model calibration using pneumatic-pressure data from instrumented borehole UZ\#5.

12. Results of model calibration using pneumatic-pressure data from instrumented borehole UZ\#4.

13. Summary of pneumatic-interference events from excavation of the North Ramp of the Exploratory Studies Facility

14. Spectral analyses of in-situ pneumatic-pressure responses to the synoptic barometric-pressure signal after interference from excavation of the North Ramp Tunnel

15. Results from error analysis of drilling and sample-handling effects on saturation and water potential, moisture-retention curves, and instrument errors for samples from borehole SD-9

16. Mean saturation of core samples from boreholes in the North Ramp area.

17. Temperature gradients in boreholes for the Paintbrush nonwelded and Topopah Spring welded hydrogeologic units

18. Isotopic composition for samples of perched water

19. Strontium isotopic and concentration data for samples of perched water

20. Summary calculations of vertical and horizontal heat flow at UE-25 UZ\#4 and UE-25 UZ\#5 in Pagany Wash.

21. Summary of the five cases considered for the simulations of heat flow through a schematic cross section......

22. Hydrologic and thermal properties used in simulations of water flow and heat flow beneath Pagany Wash

23. Darcy fluxes for the perched water through the Topopah Spring Tuff crystal-poor vitrophyre near UZ-14, calculated for different combinations of effective porosity and residence time 


\begin{tabular}{|c|c|c|}
\hline Multiply & By & To obtain \\
\hline centimeter $(\mathrm{cm})$ & 0.3937 & inch \\
\hline gram per cubic centimeter $\left(\mathrm{g} / \mathrm{cm}^{3}\right)$ & 62.4220 & pound per cubic foot \\
\hline joule $(\mathrm{J})$ & 0.23884 & calorie \\
\hline joule per second per meter per ${ }^{\circ} \mathrm{C}\left(\mathrm{J} / \mathrm{s} / \mathrm{m} /{ }^{\circ} \mathrm{C}\right)$ & 1.0 & watt per meter per ${ }^{\circ} \mathrm{C}$ \\
\hline kilogram (kg) & 2.205 & pound \\
\hline kilometer $(\mathrm{km})$ & 0.6214 & mile \\
\hline square kilometer $\left(\mathrm{km}^{2}\right)$ & 0.3861 & square mile \\
\hline kilopascal $(\mathrm{kPa})$ & 0.1450 & pound per square inch \\
\hline liter $(\mathrm{L})$ & 0.2642 & gallon \\
\hline meter $(\mathrm{m})$ & 3.281 & foot \\
\hline meter (of water head) (m) & 1.43 & pound per square inch \\
\hline square meter $\left(\mathrm{m}^{2}\right)$ & $9.87 \times 10^{-13}$ & darcy \\
\hline square meter $\left(\mathrm{m}^{2}\right)$ & 10.76 & square foot \\
\hline millijoule per second per meter squared $\left(\mathrm{mJ} / \mathrm{s} / \mathrm{m}^{2}\right)$ & 1.0 & milliwatt per meter squared \\
\hline milliliter $(\mathrm{mL})$ & 0.03382 & ounce, fluid \\
\hline micrometer $(\mu \mathrm{m})$ & $1.0 \times 10^{-6}$ & meter \\
\hline millimeter $(\mathrm{mm})$ & 0.03937 & inch \\
\hline nanometer $(\mathrm{nm})$ & $1.0 \times 10^{-9}$ & meter \\
\hline pascal $(\mathrm{Pa})$ & $1.45 \times 10^{-4}$ & pound per square inch \\
\hline
\end{tabular}

${ }^{1}$ Temperature in degrees Celsius $\left({ }^{\circ} \mathrm{C}\right)$ may be converted to degrees Fahrenheit $\left({ }^{\circ} \mathrm{F}\right)$ as follows:

$$
{ }^{\circ} \mathrm{F}=\left(1.8 \times{ }^{\circ} \mathrm{C}\right)+32
$$

${ }^{2}$ Temperature in kelvin $(\mathrm{K})$ may be converted to degree Fahrenheit $\left({ }^{\circ} \mathrm{F}\right)$ by using the following equation:

$$
{ }^{\circ} \mathrm{F}=1.8 \times \mathrm{K}-459.67
$$

Nevada State Plane Coordinate System: Nevada State Plane Coordinates (in feet) are widely used on the Yucca Mountain Project. These coordinates are for the central zone of Nevada, and are based on a Transverse Mercator projection. The origin of this projection for the central zone of Nevada is latitude $34^{\circ} 45^{\prime} \mathrm{N}$, and the central meridian is at longitude $116^{\circ} 40^{\prime} \mathrm{W}$. Metric conversions of Nevada State Plane Coordinates are not the same as metric coordinates obtained using the 10,000 -meter Universal Transverse Mercator grid, Zone II.

Sea level: In this report, "sea level" refers to the National Geodetic Vertical Datum of 1929 (NGVD of 1929) - a geodetic datum derived from a general adjustment of the first-order level nets of both the United States and Canada, formerly called Sea Level Datum of 1929.

Altitude, as used in this report, refers to distance above or below sea level. 
Specific conductance is given in microsiemens per centimeter at 25 degrees Celsius $(\mu \mathrm{S} / \mathrm{cm}$ at $25^{\circ} \mathrm{C}$ ).

Concentrations of chemical constituents in water are given either in milligrams per liter (mg/L) or micrograms per liter $(\mu \mathrm{g} / \mathrm{L})$.

NOTE TO USGS USERS: Use of hectare (ha) as an alternative name for square hectometer $\left(h \mathrm{~m}^{2}\right)$ is restricted to the measurement of small land or water areas. Use of liter $(\boldsymbol{L})$ as a special name for cubic decimeter $\left(\mathrm{dm}^{3}\right)$ is restricted to the measurement of liquids and gases. No prefix other than milli should be used with liter. Metric ton $(t)$ as a name for megagram $(\mathrm{Mg})$ should be restricted to commercial usage, and no prefixes should be used with it. 


\title{
Hydrogeology of the Unsaturated Zone, North Ramp Area of the Exploratory Studies Facility, Yucca Mountain, Nevada
}

\author{
Edited by Joseph P. Rousseau, Edward M. Kwicklis, and Daniel C. Gillies
}

\begin{abstract}
Yucca Mountain, in southern Nevada, is being investigated by the U.S. Department of Energy as a potential site for a repository for high-level radioactive waste. This report documents the results of surface-based geologic, pneumatic, hydrologic, and geochemical studies conducted during 1992 to 1996 by the U.S. Geological Survey in the vicinity of the North Ramp of the Exploratory Studies Facility (ESF) that are pertinent to understanding multiphase fluid flow within the deep unsaturated zone. Detailed stratigraphic and structural characteristics of the study area provided the hydrogeologic framework for these investigations.

Multiple lines of evidence indicate that gas flow and liquid flow within the welded tuffs of the unsaturated zone occur primarily through fractures. Fracture densities are highest in the Tiva Canyon welded (TCw) and Topopah Spring welded (TSw) hydrogeologic units. Although fracture density is much lower in the intervening nonwelded and bedded tuffs of the Paintbrush nonwelded hydrogeologic unit (PTn), pneumatic and aqueous-phase isotopic evidence indicates that substantial secondary permeability is present locally in the PTn, especially in the vicinity of faults. Borehole air-injection tests indicate that bulk air-permeability ranges from $3.5 \times 10^{-14}$ to $5.4 \times 10^{-11}$ square meters for the welded tuffs and from $1.2 \times 10^{-13}$ to $3.0 \times 10^{-12}$ square meters for the nonwelded and bedded tuffs of the PTn. Analyses of in-situ pneumatic-pressure data from moni-
\end{abstract}

tored boreholes produced estimates of bulk permeability that were comparable to those determined from the air-injection tests. In many cases, both sets of estimates are two to three orders of magnitude larger than estimates based on laboratory analyses of unfractured core samples. The in-situ pneumatic-pressure records also indicate that the unsaturated-zone pneumatic system consists of four subsystems that coincide with the four major hydrogeologic units of the unsaturated zone at Yucca Mountain. In descending order, these hydrogeologic units are the Tiva Canyon welded (TCw), Paintbrush nonwelded (PTn), Topopah Spring welded (TSw), and Calico Hills nonwelded (CHn).

Deep percolation takes place as episodic pulses of inflow that propagate rapidly to depth and apparently bypass most of the rock matrix. Field-scale and core-scale water potentials throughout much of the PTn and TSw are very high, generally greater than -0.3 megapascals, and are nearly depth invariant. Thus, the imbibition capacity of the densely welded tuffs, at least near fractures, is very small because of low matrix permeabilities and low water-potential gradients across the fracture-matrix interface. The combination of high fracture permeability, high water potentials, high matrix saturations, and low matrix permeabilities results in a percolation environment that favors deep fracture flow. The episodic pulses of inflow are evidenced in the sporadic but nevertheless commonplace occurrence of water with concentrations of radioactive isotopes indicative of origins postdating the atmospheric testing 
of nuclear weapons. High concentrations of tritium have been detected at many horizons within the PTn and in the top of the TSw. Much lower concentrations of tritium, indicating the mixing of a bomb-pulse component with older water, have been detected in the deeper sections of the TSw and in the CHn.

Evidence for fracture flow also is apparent in the widespread occurrence of perched water with chemical and isotopic signatures that indicate a fracture-flow origin for at least some of this water. In the North Ramp area, perched water has been detected at the base of the Topopah Spring Tuff or in the top of the underlying nonwelded to partially welded tuffs of the Calico Hills Formation in every dry-drilled borehole of sufficient depth to penetrate the Topopah Spring TuffCalico Hills Formation contact. The concentrations of the major ions of the perched water are similar to that of TSw pore water at borehole UZ-14, CHn pore water, and saturated-zone water at boreholes NRG-7a and SD-9. The absolute chloride concentration of the perched water, however, is much lower than the chloride concentration of pore water from either the PTn or the TSw. The chemical and isotopic compositions of perched water indicate that this water was derived primarily from fracture flow, with little or no contribution from water in the matrix of the overlying rock. Carbon-14 ages of perched water range from 3,000 to 7,000 years. Strontium- 87 isotope ratios indicate dissolution of surficial pedogenic calcite and calcite fracture fillings, which supports a fracture-flow origin for perched water. Moreover, carbon-13 and deuterium isotope values indicate rapid infiltration into fractures with little or no prior evaporation.

Evidence for deep fracture flow into the Calico Hills Formation at UZ-14 is indicated by carbon-14 values that are from 65 and 95 percent modern carbon, equivalent to apparent ages of about 3,500 to 500 years. Some of these ages are younger than age estimates for perched water in the overlying Topopah Spring Tuff and are much younger than any that could be derived from a matrix-flow model.
Evidence is lacking for extensive lateral flow within the PTn or for interception and diversion of this flow downward along structural pathways (faults), two key features of the original conceptual model for unsaturated flow at Yucca Mountain. Where data are available to infer lateral flow in the PTn, it is not certain that fracture flow could not have produced the same results. Pneumatic data, derived primarily from analysis of the interference effects from excavation of the North Ramp tunnel, indicate that faults within the Topopah Spring Tuff are open over substantial distances and are very permeable. Tunnel-boring-induced pneumatic disturbances have been propagated along these faults over distances that exceed 500 meters. These disturbances also have been detected in the pneumaticpressure record of the overlying PTn in the vicinity of these faults. In spite of the apparent high permeability of faults, the existing data have neither confirmed nor refuted the hypothetical role of these faults in intercepting lateral flow from within or from above the PTn and diverting this flow downward into the deeper subsurface.

On the basis of measured temperature gradients within the TSw, deep percolation appears to be greatest beneath active channels of major drainages, diminishing toward the margins and hillslopes bordering these channels. Numerical simulations indicate that this downward percolation is accompanied by lateral spreading as the percolation front moves downward through the PTn and across the contact between the PTn and underlying TSw. Temperature data from a well-documented site in Pagany Wash indicate the presence of a significant heat-flow deficit between the PTn and underlying TSw that most likely is due to nonconductive heat-flow processes with substantial capacity to extract heat. Percolation fluxes on the order of 10 to 20 millimeters per year beneath the Pagany Wash channel and on the order of 5 millimeters per year or less beneath the hillslopes bordering this drainage accounted for the apparent heat-flow deficit. Analyses of borehole temperature gradients in Drill Hole Wash indicate similar percolation fluxes and flux 
distributions within that drainage. An analysis of residence times estimated from uncorrected carbon-14 activities of perched-water samples and estimates for the volume of the structurally controlled reservoir, however, showed that the perched-water reservoir intersected by borehole UZ-14 under Drill Hole Wash could be sustained by percolation fluxes through the TSw of as little as 0.001 to 0.29 millimeter per year.

The significance and implications of these findings with respect to waste isolation are discussed in the appendix of this report.

\section{INTRODUCTION}

The predecessor of the Yucca Mountain Project (YMP) began in 1977 when the U.S. Department of Energy (DOE) began evaluating the feasibility of disposing of radioactive waste in a geologic repository in the vicinity of the Nevada Test Site (NTS) near Mercury, Nevada, which is about 95 kilometers $(\mathrm{km})$ northwest of Las Vegas, Nevada. The U.S. Geological Survey (USGS) was one of several agencies that assisted DOE with these evaluations. After investigating a number of sites in the vicinity of the NTS, DOE decided to concentrate its investigations on the volcanic tuffs of Yucca Mountain. In 1980, DOE began a formal, structured analysis of Yucca Mountain and in 1983 identified Yucca Mountain as a potentially acceptable site for a geologic repository (U.S. Department of Energy, 1995, chap. 1). The Nuclear Waste Policy Act of 1982 established a national policy for the disposal of highly radioactive waste, specifically commercial-reactor, spent nuclear fuel, and defense high-level waste. The act also created the Office of Civilian Radioactive Waste Management (OCRWM) within the DOE and assigned OCRWM the responsibility for conducting evaluations of Yucca Mountain and other candidate sites in the United States. After the issuance of siting guidelines and an environmental assessment, surface-based studies in accordance with the act began at Yucca Mountain in 1986. Initially, these studies consisted of nonsurface-disturbing testing in existing exploratory boreholes and wells; analyses of previously collected rock and water samples; geophysical surveys; meteorological, hydrologic, and seismic monitoring; geologic mapping; and sampling and testing of surficial materials. In 1987, the Amendments to the Nuclear Waste Policy Act designated Yucca Mountain as the only site to be characterized to determine its suitability as a geologic repository. In 1988, OCRWM issued the Site Characterization Plan (SCP) for Yucca Mountain (U.S. Department of Energy, 1988), which describes detailed, site-specific investigations and evaluations to assess the suitability of the Yucca Mountain site. The SCP also describes the preliminary design of a potential repository located in the Topopah Spring Tuff in the unsaturated zone at Yucca Mountain. In 1991, new surface-disturbing activities began at Yucca Mountain, including drilling of new exploratory boreholes for geologic and hydrologic studies, excavation of trenches for near-surface geologic studies, and preparation for excavation of the underground Exploratory Studies Facility (ESF). After completion of the ESF North Portal pad, the necessary surface facilities, and the starter tunnel, excavation of the ESF North Ramp began in late 1994 using a 7.6-m-diameter tunnel boring machine (TBM).

\section{Purpose and Scope}

This report documents the results of surfacebased geologic, pneumatic, hydrologic, and geochemical studies by the USGS in the vicinity of the ESF North Ramp that are pertinent to the understanding of multiphase fluid flow within the deep unsaturated zone. These studies were conducted at the Yucca Mountain site from about May 1992 to April 1996. Shallow infiltration is not discussed in detail in this report because the focus is on three major aspects of the deep unsaturated-zone system: geologic framework, the gaseous-phase system, and the aqueousphase system. However, because the relation between shallow infiltration and deep percolation is important to an overall understanding of the unsaturated-zone flow system, a summary of infiltration studies conducted to date at Yucca Mountain is provided in the section titled Shallow Infiltration. This report describes results of several SCP studies that were ongoing at the time excavation of the ESF North Ramp began and that continued as excavation proceeded. These studies include the following: 
- Characterization of the Vertical and Lateral Distribution of Stratigraphic Units Within the Site Area (Study 8.3.1.4.2.1)

- Characterization of Structural Features Within the Site Area (Study 8.3.1.4.2.2)

- Characterization of Percolation in the Unsaturated Zone-Surface-Based Study (Study 8.3.1.2.2.3)

- Characterization of Gaseous-Phase Movement in the Unsaturated Zone (Study 8.3.1.2.2.6)

- Hydrochemical Characterization of the Unsaturated Zone (Study 8.3.1.2.2.7)

- Site Unsaturated-Zone Modeling and Synthesis (Study 8.3.1.2.2.9)

Although all of these studies consist of site-characterization activities for the entire Yucca Mountain area, this report documents only those results that are pertinent to the ESF North Ramp area.

As excavation of the ESF North Ramp began, concerns were raised about the extent to which the excavation itself might alter the ambient pneumatic and hydrologic conditions in the unsaturated zone, possibly making characterization of the natural system difficult or impossible. As a result, USGS implemented for the YMP a twofold approach to studies of the North Ramp area: first, to characterize the natural pneumatic, hydrologic, and geochemical conditions; and second, to determine the effects of ESF excavation on these conditions. This was accomplished by modifying the strategies for implementation of several of the studies listed above to ensure characterization of pre-ESF excavation conditions. Specifically, the methodologies for several of these studies were adapted to exploration boreholes (North Ramp Geology, or NRG boreholes) drilled primarily for engineering purposes along the proposed alignment of the ESF North Ramp prior to ESF excavation.

Although the same tests were not conducted in each of the NRG boreholes, a wide variety of tests were performed, including thermal-mechanical and hydrologic analyses of rock cores; borehole geophysics; fracture logging; perched-water testing; air-permeability testing; chemical analyses; and instrumentation for monitoring pneumatic pressure, temperature, and water potential. One of the Systematic Drilling (SD) boreholes, although drilled primarily to determine geologic and engineering properties for the repository block, was adapted for pneumatic monitoring. Two Unsaturated Zone (UZ) boreholes were instrumented for pneumatic, temperature, and water-potential monitoring prior to completion of excavation of the ESF North Ramp. Previously collected data from one UZ borehole instrumented in 1983 were retrieved and analyzed to corroborate observations made in boreholes instrumented recently.

The data obtained from the boreholes mentioned above are the primary focus of the report, although data from other sources are discussed. These data and the results of analyses are described in detail in subsequent sections of this report.

\section{Quality Assurance}

Most of the data described and interpreted in this report were collected in compliance with the approved USGS, YMP quality-assurance (QA) program and can be used in interpretations for site characterization. However, some data cited and used in the report were collected prior to implementation of the approved USGS YMP QA program or were collected by agencies other than the USGS; these data are not qualified (non-Q). Generally, these non- $Q$ data are used as background information or to corroborate findings and conclusions that are supported by data that are fully qualified under the approved USGS YMP QA program. The use of non-Q data generally is intended to add scientific confidence to the findings and conclusions in this report. Throughout the text of this report, descriptions of the use of non-Q data are provided, as well as explanations of the effect, if any, of the use of the non-Q data on major findings and conclusions.

\section{Regional Hydrogeologic Setting of the Yucca Mountain Area}

Yucca Mountain is located in southern Nevada (fig. 1) about $145 \mathrm{~km}$ northwest of Las Vegas within the Basin and Range physiographic province (Grayson, 1993). Basin and range physiography is defined by the linear mountains and valleys of this area that have a distinct north-to-northwest trend, reflecting late Cenozoic structural characteristics. The valleys are closed topographic basins, except for an area that 
EASTING, IN METERS

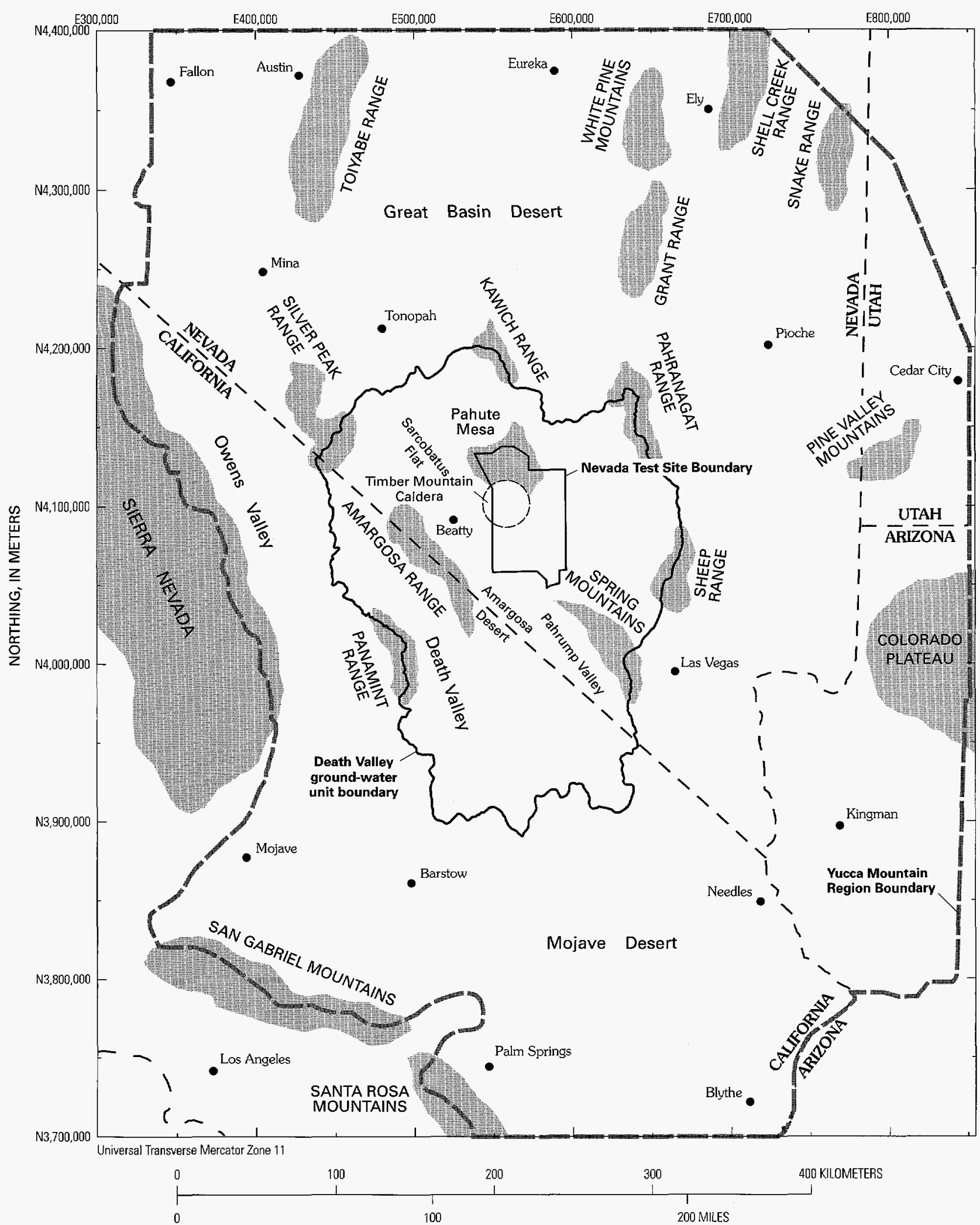

Figure 1. Location of Yucca Mountain region. 
drains to the Colorado River. The region ranges in elevation from $86 \mathrm{~m}$ below sea level at Death Valley, the lowest point in the United States, to about $3,600 \mathrm{~m}$ above sea level. Elevations of basins generally are less than $800 \mathrm{~m}$ above sea level, and the mountaintops generally are above $2,400 \mathrm{~m}$.

Within the Basin and Range physiographic province, Yucca Mountain is in the topographic region named for Death Valley (fig. 1), which is the largest and most prominent desert basin in the province. The Death Valley region is primarily within the northern Mojave Desert but extends northward into the Great Basin Desert. Under current climatic conditions, the Death Valley region is in the rain shadow of the Sierra Nevada, which are just west of the Yucca Mountain region, resulting in a climate that is arid to semiarid. Precipitation on the valley floors of the Amargosa Desert, Death Valley, and basins at low elevations in the southern part of the region averages less than 70 millimeters $(\mathrm{mm})$ per year. Precipitation in the mountains commonly ranges from 100 to $150 \mathrm{~mm}$ per year, with annual precipitation as much as 500 to $750 \mathrm{~mm}$ in the Sheep Range just east of the Yucca Mountain region and the Spring Mountains (fig. 1), the highest mountains in the region (Bedinger and others, 1989). The mean-annual, free-water-surface evaporation for the area ranges from $1,250 \mathrm{~mm}$ to more than 2,500 mm (Bedinger and others, 1989).

The Death Valley ground-water flow system (fig. 1) is composed of several local systems, some of which extend beneath the divides of one or more closed topographic basins (Winograd and Thordarson, 1975). Within the ground-water systems, recharge occurs at higher elevations by infiltration of precipitation or by infiltration of ephemeral runoff. Discharge occurs largely by spring flow and by evaporation and transpiration in and near the playas in several intermediate areas that are geomorphically, stratigraphically, and structurally controlled. Ultimately, some ground water also discharges into Death Valley, but the flow system is complex and involves both Proterozoic and Paleozoic rocks. The deepest part of the system consists of Late Proterozoic rocks and Paleozoic carbonate aquifers that connect closed topographic basins at depth.

The closed basin in which Yucca Mountain is located was studied using a regional three-dimensional ground-water flow model for predicting the effect of climatic changes on regional hydrology and possible waste migration from Yucca Mountain (D'Agnese and others, 1997). The modeled area (approximately $45,900 \mathrm{~km}^{2}$ ), referred to as the Death Valley regional ground-water flow system (fig. 1), also was the subject of a geostatistical analysis to estimate average annual precipitation and recharge on a regional basis (Hevesi and Flint, in press).

The Death Valley regional ground-water flow system is underlain by extensive Paleozoic carbonaterock aquifers and associated confining beds, which, collectively, account for most of the interbasin movement of ground water in the region (Winograd and Thordarson, 1975). Structural and lithologic controls compartmentalize the ground-water flow in this unit, which results in a very complex flow system.

Discharge from the regional system unit occurs in Sarcobatus Flat, Amargosa Desert, and Pahrump Valley, and ultimately in Death Valley (fig. 1). The predominant direction of drainage for surface-water and ground-water flow in the regional system is from north to south because of a decrease in average topographic elevations from north to south in the southern Basin and Range.

\section{Regional Stratigraphic and Structural Setting}

Yucca Mountain is located within the southern part of the Great Basin, midway between the Sierra Nevada and the Colorado Plateau (fig. 1). At its southern terminus, the mountain forms a series of north- to northeast-trending, low-lying ridges that rise above the floor of the Amargosa Desert at an elevation of about $800 \mathrm{~m}$ (fig. 1). The relief along these ridges progressively increases northward for about $26 \mathrm{~km}$ to a dissected summit area where, at about an elevation of $1,800 \mathrm{~m}$, the mountain merges with an arcuate set of ridges that form the southern part of a conspicuous physiographic feature known as the Timber MountainOasis Valley Caldera complex (fig. 1).

\section{Stratigraphy}

Rocks within the Death Valley region range in age from Late Proterozoic to Quaternary. At a regional scale, the bulk of the rock mass consists predominantly of a thick sequence of middle to late Miocene volcanic rocks that rest unconformably on sedimentary and metasedimentary strata of Late Proterozoic to Paleozoic age. The 600- to 300 -million- 
year-old Late Proterozoic and Paleozoic rocks, best exposed at highlands 8 to $24 \mathrm{~km}$ west, east, and southeast of Yucca Mountain, chiefly consist of highly deformed, carbonate and siliceous, clastic deposits that probably formed a composite thickness of more than $11 \mathrm{~km}$ prior to deformation. The rock sequence is dominated by limestone, dolomite, shale, argillite, and quartzite that can be divided into four basic hydrogeologic units of regional significance: lower and upper carbonate aquifers separated by lower and upper clastic confining units (Winograd and Thordarson, 1975; Waddell and others, 1984).

Fluvial and lacustrine sedimentary rocks of Oligocene to middle Miocene age probably covered most of the upper Paleozoic sequence in the southern Great Basin, and these rocks commonly form discontinuous outcrops along the flanks of many of the dominant mountain ranges. These rocks consist of siltstone, algal limestone, claystone, sandstone, pyro-. clastic flow and fall deposits, and conglomerate. Near the southern edge of the Nevada Test Site (fig. 1), these deposits reach a composite thickness of as much as $1,100 \mathrm{~m}$ (Hinrichs, 1968). About $19 \mathrm{~km}$ east of Yucca Mountain, these deposits, referred to as the Pavits Spring and Horse Spring Formations, reach an aggregate thickness of about $300 \mathrm{~m}$ (Sargent and Stewart, 1971). These deposits have not been identified in any boreholes at Yucca Mountain, but based on the observations east of Yucca Mountain, the possibility of relatively thick Oligocene to middle Miocene deposits directly beneath Yucca Mountain cannot be ruled out.

In the general vicinity of the Nevada Test Site (fig. 1), middle Miocene sedimentary deposits are mostly overlain by a thick sequence of mostly rhyolitic to quartz latitic lavas and pyroclastic deposits that cover an extensive area of over 13,000 square kilometers $\left(\mathrm{km}^{2}\right)$ (Byers and others, 1976), known as the southern Nevada volcanic field. Most of the volcanic deposits within this field issued from source areas within an elliptical, $39-\mathrm{km}^{2}$ area composed of a group of nested and overlapping cauldrons and calderas, known as the Timber Mountain-Oasis Valley caldera complex (fig. 1) (Byers and others, 1976), which was active from 14 to 11.5 million years ago (Sawyer and others, 1994). In the vicinity of Yucca Mountain, situated directly south of the caldera complex, geophysical evidence (Snyder and Carr, 1984 ) indicates that the Tertiary volcanic sequence commonly varies in thickness from 1 to $3 \mathrm{~km}$. From older to younger, some of the regionally extensive pyroclastic-flow sheets include the Lithic Ridge Tuff, the Tram, Bullfrog, and Prow Pass Tuffs of the Crater Flat Group, the Calico Hills Formation, and the Topopah Spring and Tiva Canyon Tuffs of the Paintbrush Group (Carr, Byers, and Orkild, 1986; Sawyer and others, 1994; Buesch and others, 1996b). The Topopah Spring and Tiva Canyon Tuffs, with estimated volumes of 250 and 1,000 cubic kilometers $\left(\mathrm{km}^{3}\right)$, respectively (Byers and others, 1976), contain thick welded and fractured interiors. From north to south, these important pyroclastic flows of the Paintbrush Group form wedge-shaped deposits that are thickest beneath the central block of Yucca Mountain but that thin significantly beneath the Amargosa Desert (fig. 1; Spengler and Fox, 1989).

\section{Structure}

Late Proterozoic and Paleozoic rocks have been faulted and folded during several Mesozoic episodes of compressional deformation. These deformed rocks are part of the Sevier orogenic belt, a $50-\mathrm{km}$-wide structural zone that extends over much of the southern Great Basin. North- to northeast-trending thrust faults and folds, characteristic structural features within this zone, are extensively exposed to the south in the Spring Mountains and to the north of the Amargosa Range (fig. 1; Burchfiel and others, 1974). Discontinuous remnants of this thrust system also are exposed $14 \mathrm{~km}$ west and east of Yucca Mountain. At these exposures, carbonate rocks of Devonian, Silurian, and Ordovician age (rocks of the upper carbonate aquifer) have been thrust over younger rocks of Permian, Pennsylvanian, and Mississippian age (rocks of the upper clastic confining unit) and have been eroded, leaving isolated remnants, or klippen (Carr and Monson, 1988; Carr, 1984). Some investigators have speculated that the same structural relation may exist directly beneath Yucca Mountain (Fox and others, 1990). Alternative structural models portray the Paleozoic strata underlying much of the Nevada Test Site as an $80-\mathrm{km}$-wide synclinoral basin, enclosed by uplifted clastic rocks of Late Proterozoic age along the flanks with Permian and Pennsylvanian carbonate rocks forming the core (Robinson, 1985). It has been conceptualized that within this synclinoral basin, north- to northeasttrending, concentric, open subordinate folds, several of which lie beneath the Yucca Mountain region, plunge northward, which is consistent with the config- 
uration of the top of the Paleozoic surface (Snyder and Carr, 1984). Only one borehole (UE-25 p\#1) penetrates Paleozoic strata along eastern Yucca Mountain (fig. 2). Here, northward-dipping Silurian carbonate rocks were penetrated at a depth of about $1,240 \mathrm{~m}$ (Carr, Waddell, and others, 1986). Speculations that the upper Paleozoic sequence beneath much of the Yucca Mountain site area forms the axis of a northeast-plunging syncline (Robinson, 1985) or that rocks of the lower carbonate aquifer form the upper plate of a thrust fault overlying rocks of the upper clastic confining unit (Fox and others, 1990) remain as two of the leading hypotheses for the configuration of the Paleozoic strata.

Cenozoic tectonism of the southern Great Basin is evident in the existence of three dominant but varied styles of crustal extension: (1) block-bounding planarrotational faults, (2) strike-slip faults, and (3) lowangle detachment faults. Evidence of all three styles of extension are recorded within the middle to late Miocene volcanic and volcaniclastic rocks of the southern Nevada volcanic field, and specifically within the Yucca Mountain region (Carr, 1984; Fox and Carr, 1989).

The most conspicuous physiographic and structural feature of the southern Great Basin is the northto northeast alignment of east- to southeast-tilted ranges, forming an alternating pattern of horsts and grabens. These ranges are bounded by north- to northeast-trending range-front faults that produce a pattern similar to that of a tilted stack of dominoes. This regional structural pattern also is manifested at smaller scales such as in the Yucca Mountain region, where a series of 0.8 - to $4.0-\mathrm{km}$-wide, east-tilted structural blocks are bounded by north-trending faults planes and show evidence of dip slip and oblique slip.

The southern Nevada volcanic field is between the Las Vegas Valley Shear Zone to the southeast and tha Walker Lane to the northwest. These two major northwest-trending shear zones include northwesttrending right-lateral faults, northeast-trending leftlateral strike-slip faults, and oroflexural bending that indicate major right-lateral displacement. Although the shear zones extend over a combined distance of more than $640 \mathrm{~km}$ and project into the region of the Nevada Test Site (fig. 1), no conspicuous throughgoing fault or geophysical expression has been found that links the two zones. However, there are several pieces of indirect evidence in the vicinity of Yucca Mountain that indicate that the two shear zones may be linked. These include (1) a set of widely distributed northwest-trending strike-slip faults of relatively short trace lengths (Carr, 1984), such as those occupied by the washes north of Drill Hole Wash within the central block of Yucca Mountain (fig. 2); (2) the northwestward alignment of calderas in the southern Nevada volcanic field (Christiansen and others, 1965); and (3) the 30-degree clockwise axial rotation of paleomagnetic poles of the Tiva Canyon Tuff (Scott and Rosenbaum, 1986). These features commonly are cited as indirect evidence of the existence of a strikeslip shear regime concealed beneath a thick cover of Tertiary volcanic rocks.

Low-angle extensional faults are exposed northwest and southeast of the Yucca Mountain region near Beatty, Nevada, and near the southeastern edge of the Nevada Test Site (fig. 1). At these localities, middle to late Miocene volcanic rocks are in fault contact with the underlying upper surface of Paleozoic rocks. A detachment fault along the northern extent of Bare Mountain, near Beatty, separates Miocene volcanic rocks from Paleozoic rocks and dips northward by 25 to 40 degrees beneath the alluvial cover (Carr and Monson, 1988). Block-bounding faults at Yucca Mountain have been postulated to be listric normal faults that flatten and merge at depth into a low-angle fault or faults near the top of or within the Paleozoic rocks (Fox and Carr, 1989). This hypothesis is not supported by recently acquired and interpreted regional seismic-reflection profiles across Yucca Mountain that appear to image a west-side-down, stair-step pattern at the top of the Paleozoic rocks and several deep, high-angle reflectors (interpreted as faults) within the Paleozoic section (Brocher and others, 1996). Neither interpretation implies a smooth curvilinear surface that flattens with depth (Brocher and others, 1996).

\section{Local Hydrogeologic Setting of Yucca Mountain}

The local hydrogeologic setting of Yucca Mountain is a direct result of the climate and geologic history of the northern Mojave Desert. The outcome is a hydrogeologic system consisting of a 500- to 750-m-thick unsaturated zone overlying a relatively flat regional water table in the vicinity of the central block of Yucca Mountain. The regional water table is not well defined by the potentiometric measurements 


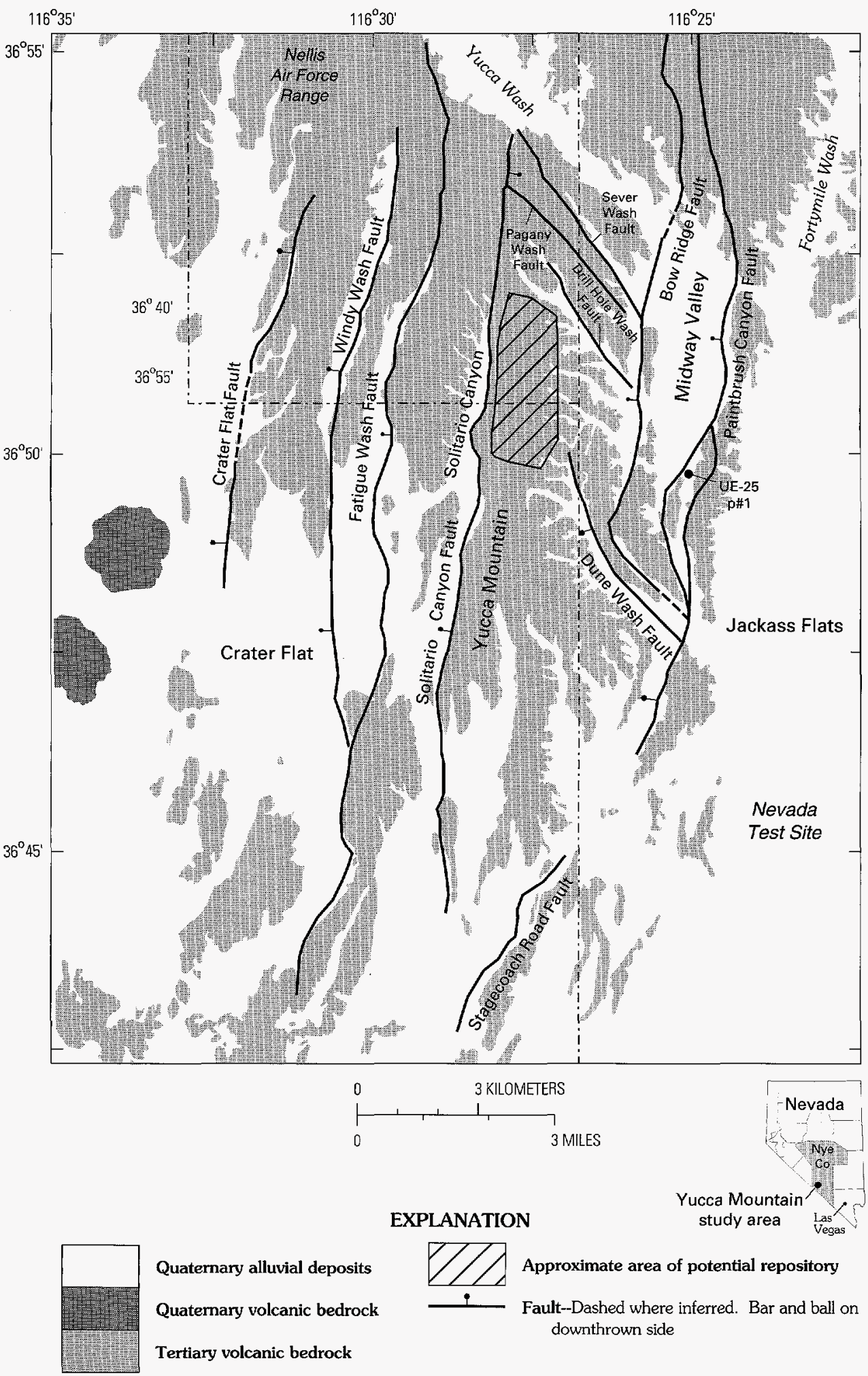

Figure 2. Location of Yucca Mountain, Nye County, Nevada. 
to the north and west of the central block, where distinctions between the water table (which may or may not be unconfined) and potential perched-water reservoirs are not yet clear. Several maps of the potentiometric surface have been developed for Yucca Mountain (Robison, 1984; Wittwer and others, 1992; Ervin and others, 1994; Tucci and Burkhardt, 1995), but a common feature shared by each map is that the potentiometric surface (hereinafter referred to as the water table) transects several structural blocks and numerous lithostratigraphic units. The Topopah Spring Tuff, the Calico Hills Formation, and the Prow Pass and Bullfrog Tuffs are present locally at the water table. (See section titled Variations in Rock Types Within the Unsaturated Zone.)

\section{Climate and Precipitation}

Yucca Mountain has an arid climate with an average annual precipitation of about $165 \mathrm{~mm}$ (Hevesi and Flint, in press), ranging from $130 \mathrm{~mm}$ for the southern part of the mountain to $250 \mathrm{~mm}$ for the higher elevations in the northern part. These values are non- $Q$ because of their dependence on regional precipitation data that were collected outside of the YMP. Summer precipitation results primarily from localized convective storms that develop during monsoonal weather periods (French, 1983; Houghton, 1969). Most of the water from summer storms is lost to evapotranspiration within a week unless a storm is intense enough to produce runoff or unless subsequent storms provide additional water for deep infiltation. Local thunderstorms can result in runoff in one wash while an adjacent wash receives little or no rain. Winter precipitation primarily results from frontal systems moving inland from the Pacific Ocean and occurs as snow or rain. Evapotranspiration is low during the winter, and water from less intense storms or slowly melting snow may infiltrate deeper into the subsurface than during the summer.

\section{Geomorphology and Surficial Features}

Physiographic elements of the Yucca Mountain area (fig. 2) can be divided into (1) ridges and valleys of Yucca Mountain, (2) piedmont slopes surrounding Yucca Mountain on the south and east, (3) Fortymile Wash east of Yucca Mountain, and (4) the broad alluvial flats, Crater Flat and Jackass Flats, to the west and east of Yucca Mountain, respectively (U.S. Geological
Survey, 1984). The topographic features of Yucca Mountain result from the interaction of tectonic and geomorphic processes. The topography is controlled primarily by the high-angle, westward-dipping faults and the eastward tilt of the resistant volcanic strata. The surface has been shaped by erosional processes on the eastward-sloping ridge of the mountain and along faults and fault scarps (fig. 2) that have created a series of washes that are downcut to varying degrees into different bedrock layers. Slopes are locally steep on the west-facing escarpments eroded along the faults and in some of the valleys that cut into the more gentle, eastward-facing dip slopes. Narrow valleys and ravines are cut in bedrock; wider valleys are covered by alluvial deposits with terraces cut by intermittent streams. Locally, small sandy fans extend down the lower slopes and spread out on the valley floors. East of the crest of Yucca Mountain, drainage is into Fortymile Wash; west of the crest, streams flow southwestward down fault-controlled canyons and discharge into Crater Flat (fig. 2). The mountain comprises two distinct geomorphic regimes, one south and one north of Drill Hole Wash. The washes in the southern area trend eastward, are relatively short (less than $2 \mathrm{~km}$ ), and have erosional channels with gently sloping sides. The washes north of Drill Hole Wash, such as Sever Wash and Yucca Wash, are northwest trending, are 3 to $4 \mathrm{~km}$ long, and because they are controlled by fault features, have steeper sideslopes.

Alluvial deposits, consisting of fluvial sediments and debris flows, are present in the valley floors and washes. These deposits have varying degrees of soil development and thickness and have a gravelly texture with rock fragments constituting between 20 and 80 percent of the total volume. The alluvial deposits range from $100 \mathrm{~m}$ thick in Midway Valley (fig. 2) to less than $30 \mathrm{~m}$ thick in the mouths of the smaller washes. In the middle of the washes, most alluvial fill (soils) is less than $15 \mathrm{~m}$ thick. Many of these soils contain cemented calcium carbonate layers. More stable surfaces, generally on the flat upland ridges, have developed soils 0.5 to $2.0 \mathrm{~m}$ thick with greater clay contents.

\section{Shallow Infiltration}

Flint and Flint (1995) described four general topographic zones at Yucca Mountain that are important for examination of infiltration processes and mechanisms: ridgetops, sideslopes, terraces, and 
channels. At Yucca Mountain, ridgetops make up about 14 percent of the total area, sideslopes 62 percent, terraces 22 percent, and active channels 2 percent. Ridgetops generally are flat to gently sloping with thin (less than $0.5 \mathrm{~m}$ ) to no soil and are relatively stable morphologically. Although thin, ridgetop soils are fairly well developed, and thin calcium carbonate layers are common. Soils are somewhat thicker in small, ephemeral channels that have developed on the ridgetops. Bedrock on the ridgetops is moderately to densely welded (Flint and others, 1996) and moderately to highly fractured. Vegetation consists of well-established, relatively shallow-rooted, blackbrush/desert thorn associations (O'Farrell and Collins, 1984). The slope and elevation on ridgetops are conducive to retaining snowfall in the winter for several weeks at a time. When the snow melts, concentrated surface runoff occurs at times in the ridgetop channels.

Because of the difficulty of drilling boreholes on steep sideslopes, field data are collected only from sites on the lower sideslopes of washes. Sideslopes are distinguished from terraces and channels by depth of soils and by slope. Soil cover is thin (less than $0.5 \mathrm{~m}$ ) in most locations, and exposed bedrock, which is densely welded and highly fractured, constitutes approximately 10 percent of the area. The sideslopes are approximately north- or south-facing in the southern section of the site and, therefore, have different seasonal solar-radiation loads. In the northern washes, where sideslopes generally face southwest and northeast, the steepness of the slopes accentuates the seasonal radiation differences. In some locations, side channels concentrate runoff water.

Terraces and channels are located at lower elevations in the main washes, with thin soil cover in the upper parts of the washes and thicker soils farther down. The mean thickness of soil is $7.2 \mathrm{~m}$ and $7.9 \mathrm{~m}$ for channels and terraces, respectively (Flint and Flint, 1995). Very little bedrock is exposed in the washes. Although present to varying degrees in the soils, calcium carbonate cementation is quite extensive. The porosity of the soil ranges from 0.15 to 0.5 with an average of about 0.3 . The surfaces of terraces and channels are relatively flat and are dissected by active as well as old, abandoned alluvial channels. Channels differ from terraces in that they are subject to periodic runoff during extreme precipitation events. Terraces generally are well vegetated with deeply rooted creo- sote and other smaller plants. Channels occupy a very small percentage of the area of the washes and are more sparsely vegetated than the terraces.

All four of the topographic zones are present in the vicinity of the ESF North Ramp and have significant effect on the distribution of shallow infiltration.

Using a soil-physics approach, Flint and Flint (1994) calculated steady-state net infiltration solely on the basis of the relative permeability calculated from the measured saturation of the rock matrix underlying the alluvium, and excluding any flow due to fractures. The analysis assumed that water movement was downward from the depth below which seasonal fluctuations in water content could no longer be observed in boreholes. Areally averaged, the infiltration rate over Yucca Mountain was estimated to be $1.5 \mathrm{~mm}$ per year. In the vicinity of the ESF North Ramp, net infiltration in the matrix, excluding any flow in the fractures, was estimated to range from $0.02 \mathrm{~mm}$ per year in welded tuffs under alluvium to $13.4 \mathrm{~mm}$ per year in the upper channels of Drill Hole Wash, where high-porosity bedrock is exposed in channels. The relatively high estimated infiltration for this area is consistent with several observations: greater precipitation (as well as more winter snow) to the north, steeper slopes that result in lower radiation loads and evapotranspiration, and downcutting of the main wash into higher porosity rocks, which are thicker to the north of the potential repository area.

More recent studies of infiltration at Yucca Mountain (D.B. Hudson and A.L. Flint, U.S. Geological Survey, unpub. data, 1996), based on precipitation, alluvial depth, and measurements of water-content changes in shallow boreholes during the last 9 years, indicate that thickness of alluvium has a substantial effect on shallow infiltration under any rainfall conditions. This analysis indicates that shallow infiltration in the Drill Hole Wash channel is low because most of the high-porosity bedrock is covered with alluvium. Further, net infiltration is greatest on the sideslopes and ridgetops where there is little or no alluvium. The influence of the thickness of alluvium on changes in volumetric water content with time is illustrated in figure 3 (from Flint and Flint, 1995) by moisture profiles for two boreholes during the winter of 1994 95. Moisture pulses penetrated to below $10 \mathrm{~m}$ where the alluvium is thin (N36), whereas moisture did not penetrate below $3 \mathrm{~m}$ where the alluvium is thicker (N37). Given that the same volume of precipitation fell at each borehole location, the high storage 

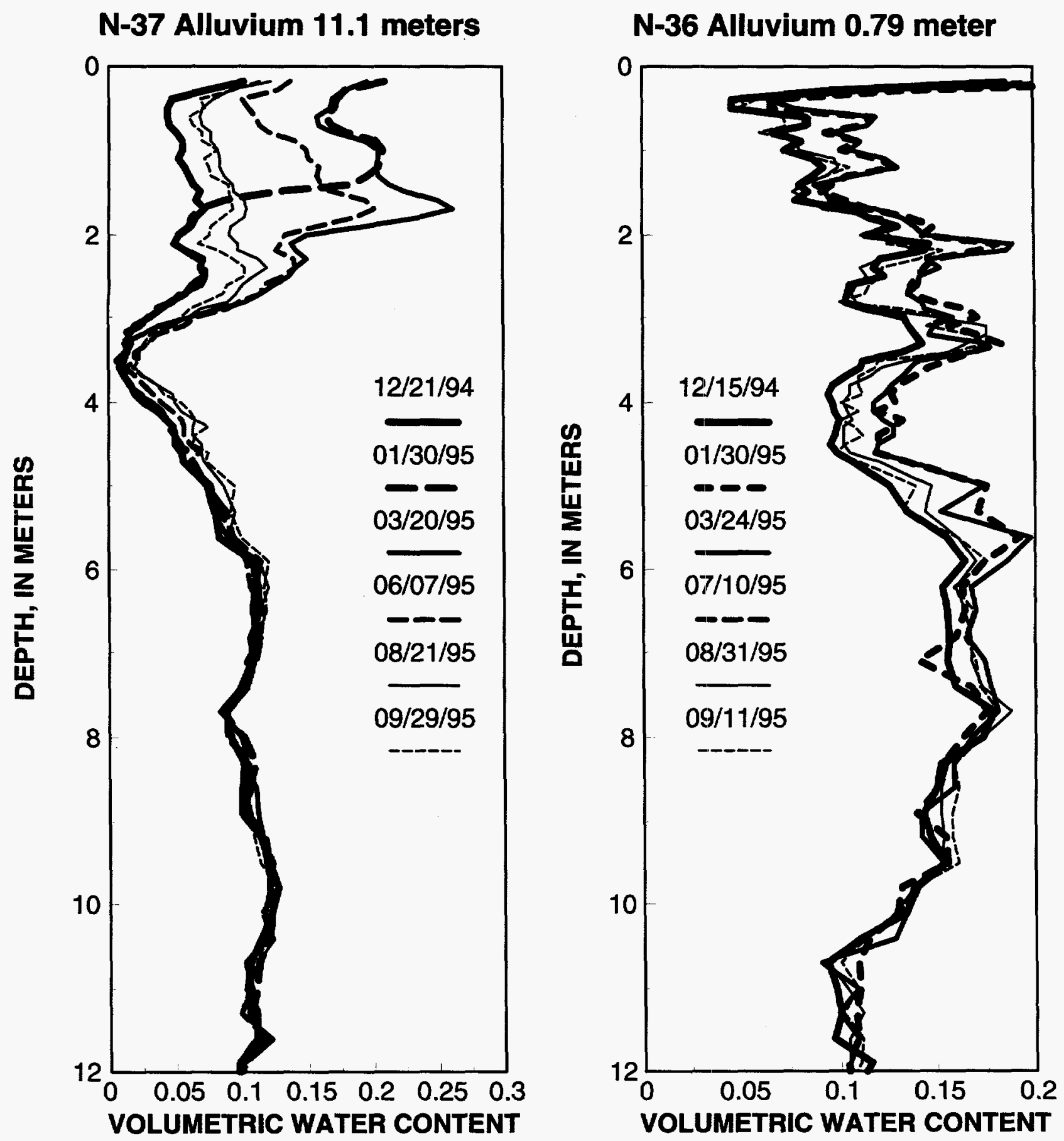

Figure 3. Water-content changes in neutron boreholes during the winter of 1995 for representative alluvium adjacent to borehole USW UZ-N37 and bedrock adjacent to borehole USW UZ-N36 locations. 
capacity of the soils at $\mathrm{N} 37$ resulted in the water being held within the shallow, soil root zone, where it was moved subsequently back into the atmosphere by evapotranspiration. At N36, where the alluvium is thin and the bedrock is fractured, water infiltrated rapidly to the alluvium-bedrock interface, producing sufficiently high water potentials to initiate flow into the fractures. Having entered the fractures in the bedrock, the water infiltrated rapidly enough and to sufficient depth that it was not returned to the atmosphere by evapotranspiration and thus became net infiltration. At both locations, the subsurface became significantly wetter in late January and March in response to major rainfall events and then dried out over the next 6 months.

Estimates of shallow infiltration along the trace of the ESF North Ramp (D.B. Hudson and A.L. Flint, unpub. data, 1996) are shown in figure 4. The range in infiltration rates from 0 to $25 \mathrm{~mm} / \mathrm{yr}$ reflects the effects of topography and geomorphic position, which incorporates washes with thick alluvium and ridges with thin alluvium. These estimates are non- $Q$ because of their dependence on regional precipitation data that were collected outside of the YMP. The estimates may be high because they are based on a data set that includes two of the wettest winters in the last 40 years of record. The winter season of 1995 was the wettest in 40 years of record with about $250 \mathrm{~mm}$ of precipitation between January and March. A study currently (1996) underway will attempt to normalize the infiltration rates discussed above over the longer term climatic record, as well as to refine the error analysis for the data set used.

\section{Exploratory Studies Facility North Ramp Study Area}

The ESF North Ramp study area is the area around the North Ramp of the ESF tunnel, which generally follows Drill Hole Wash (fig. 5). Drill Hole Wash is the boundary between the area of east-westoriented washes to the south and the area of northwesttrending, fault-controlled washes to the north.

Most of the hydrologic data described and interpreted in this report were collected in boreholes (fig. 5) drilled for the YMP. All hydrologic data available from boreholes in the North Ramp area are listed in table 1, including the QA status of the data.

[Geologic data from additional boreholes were used to construct and evaluate a three-dimensional lithostratigraphic model of the central block of Yucca Mountain (see section titled Evaluation of the ThreeDimensional Lithostratigraphic Model of the Central

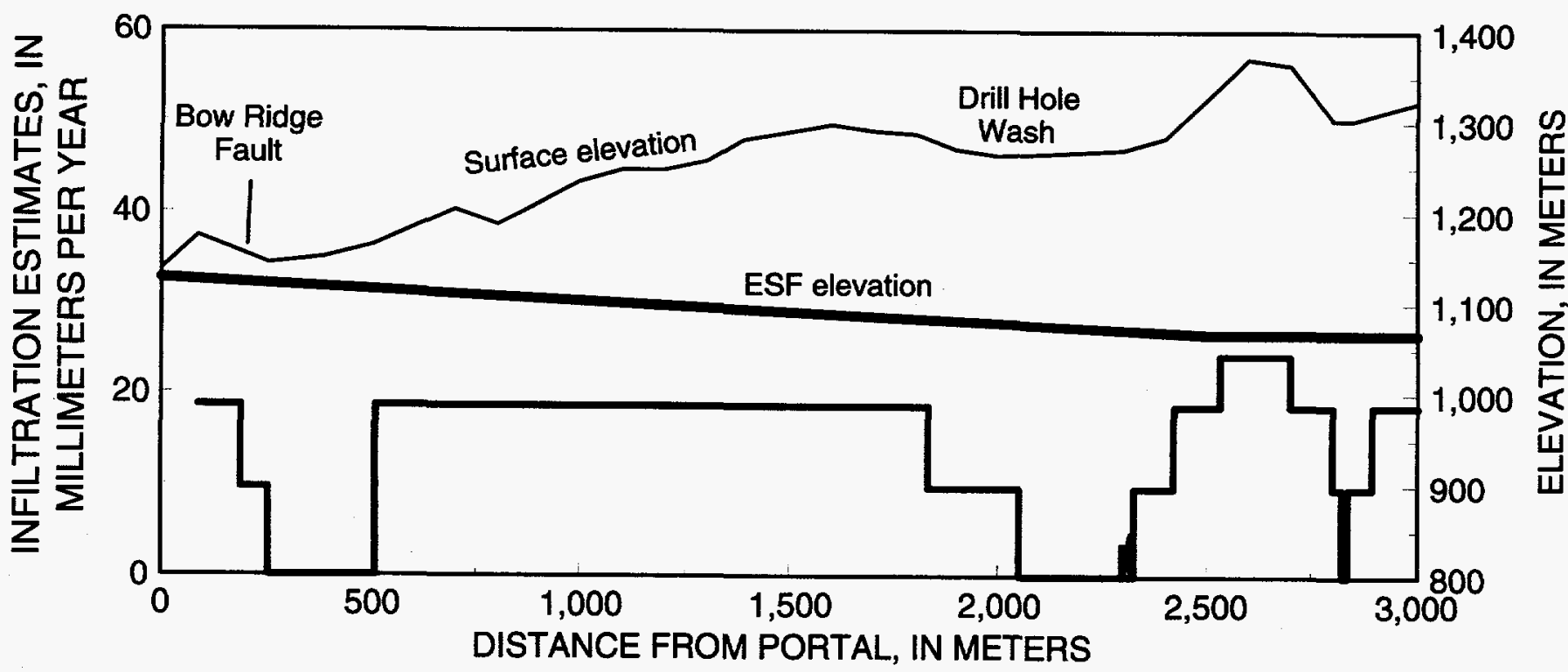

Figure 4. Estimates of shallow infiltration along the trace of the North Ramp of the Exploratory Studies Facility. 
EASTING, IN FEET

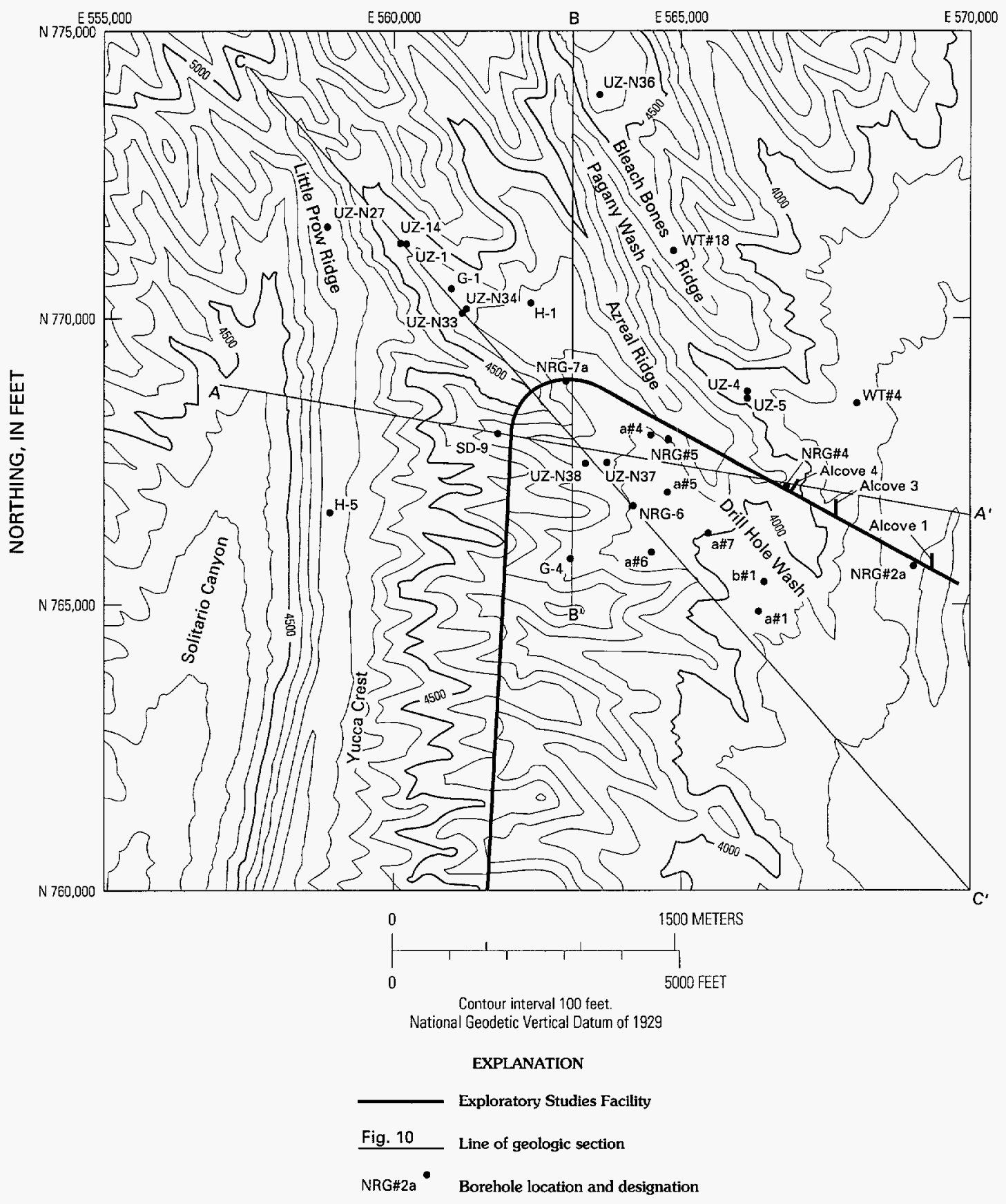

Figure 5. Exploratory Studies Facility North Ramp study area and location of selected boreholes and geologic sections. 
Table 1. Borehole data for the North Ramp study area at Yucca Mountain

[Borehole elevation, depth, and quality-assurance status are from Buesch, Nelson, and others (1996a). Core analysis: H, hydrologic properties; TM, thermal-mechanical properties; P, permeability; R, moisture retention. Borehole geophysics: PN, P.H. Nelson, U.S. Geological Survey (written commun., 1996; Nelson and others, 1991); BT, B. Thompson, Science Applications International Corporation (written commun., 1996). Field water analysis: SZ, saturated zone pumping or depth measurements; PW, perched-water testing; $\mathrm{NH}$, neutron-moisture measurements. Air permeability: number of test intervals. Fracture $\log$ : B, borehole $\log ; \mathrm{C}$, core $\log$. Chemistry analysis: $\mathrm{W}$, water analysis; $\mathrm{G}$, gas analysis. Borehole instrumentation: number of measurement locations. Non- $Q$ status is indicated by bold]

\begin{tabular}{|c|c|c|c|c|c|c|c|c|c|}
\hline $\begin{array}{l}\text { Borehole } \\
\text { number }\end{array}$ & $\begin{array}{c}\text { Elevation } \\
\text { (meters) }\end{array}$ & $\begin{array}{c}\text { Depth } \\
\text { (meters) }\end{array}$ & $\begin{array}{c}\text { Core } \\
\text { anal- } \\
\text { ysis }\end{array}$ & $\begin{array}{c}\text { Bore- } \\
\text { hole } \\
\text { geo- } \\
\text { physics }\end{array}$ & $\begin{array}{l}\text { Field } \\
\text { Water } \\
\text { anal- } \\
\text { ysis }\end{array}$ & $\begin{array}{c}\text { Air } \\
\text { perme- } \\
\text { abilty }\end{array}$ & $\begin{array}{c}\text { Frac- } \\
\text { ture } \\
\text { log }\end{array}$ & $\begin{array}{l}\text { Chem- } \\
\text { istry } \\
\text { anal- } \\
\text { ysis }\end{array}$ & $\begin{array}{c}\text { Bore- } \\
\text { hole } \\
\text { instru- } \\
\text { ment- } \\
\text { ability }\end{array}$ \\
\hline USW G-1 & $1,325.4$ & $1, \mathbf{8 2 8 . 7}$ & $\mathbf{H}$ & $\overline{\text { PN }}$ & SZ & - & $\overline{\mathbf{C}}$ & - & -- \\
\hline USW G-4 & $1,270.0$ & 914.7 & ${ }^{1} \mathbf{H}$ & PN & SZ & -. & $\mathbf{B}, \mathbf{C}$ & -. & -- \\
\hline USW H-1 & $1,302.8$ & $1,828.7$ & ${ }^{2} \mathbf{H}$ & PN & SZ & -- & -- & -- & -- \\
\hline USW H-5 & $1,478.5$ & $1,219.1$ & & PN & SZ & -- & -- & - & -- \\
\hline UE-25 NRG\#2A & $1,152.3$ & 81.0 & TM & BT & -- & -- & C & -- & -- \\
\hline UE-25 NRG\#4 & $1,249.4$ & 221.3 & TM & $\mathrm{BT}$ & -- & -- & $\mathrm{C}$ & -- & ${ }^{3} 7$ \\
\hline UE-25 NRG\#5 & $1,251.5$ & 411.5 & TM & $\mathrm{BT}$ & -- & -- & $\mathrm{C}$ & -. & 14 \\
\hline USW NRG-6 & $1,247.2$ & 335.3 & $\mathrm{H}, \mathrm{TM}$ & BT & -- & 38 & $\mathrm{C}$ & G, W & 10 \\
\hline USW NRG-7a & $1,282.2$ & 461.3 & $\mathrm{H}, \mathrm{TM}$ & BT & PW & 60 & C & $G, W$ & 8 \\
\hline UE-25 UZ\#4 & $1,200.4$ & 111.7 & $\mathbf{H}, \mathbf{P}$ & - & -- & -- & B & $\mathbf{w}$ & 11 \\
\hline UE-25 UZ\#5 & $1,204.4$ & 110.6 & $\mathbf{H}, \mathbf{P}$ & -- & - & -- & B & $\mathbf{w}$ & 12 \\
\hline USW UZ-1 & $1,349.0$ & 387.1 & -- & PN & PW &.- & B & $G, \mathbf{W}$ & 15 \\
\hline USW UZ-14 & $1,349.0$ & 677.8 & $\mathbf{H}, \mathrm{P}, \mathbf{R}$ & $\mathrm{BT}$ & SZ, PW & -- & $\mathrm{C}$ & W & -- \\
\hline USW UZ-N27 & $1,481.1$ & 61.7 & $\mathbf{H}, \mathrm{P}, \mathrm{R}$ & -- & NH & -- & -- & -- & -- \\
\hline USW UZ-N33 & $1,320.2$ & 22.9 & $\mathrm{H}$ & - & NH & - & -. & - & -- \\
\hline USW UZ-N34 & $1,318.0$ & 25.6 & $\mathbf{H}$ & -- & NH & - & -. & - & -- \\
\hline USW UZ-N36 & $1,414.8$ & 18.2 & $\mathbf{H}$ & - & NH & -- & -- & -- & -- \\
\hline USW UZ-N37 & $1,256.9$ & 82.7 & $\mathbf{H}$ & -- & NH & -- & -- & - & -- \\
\hline USW UZ-N38 & $1,264.5$ & 27.2 & $\mathbf{H}$ & - & $\mathrm{NH}$ & -- & -- & -- & -- \\
\hline UE-25 WT\#18 & $1,335.9$ & 622.7 & -- & PN & SZ & -- & B & -- & -- \\
\hline UE-25 WT\#4 & $1,167.1$ & 481.6 & .. & PN & sz & -- & B & -- & -- \\
\hline UE-25 a\#1 & $1,198.7$ & 762.1 & $\mathbf{H}, \mathbf{P}$ & PN & -- & -- & C & -- & -- \\
\hline UE-25 a\#4 & $1,249.8$ & 152.4 & $\mathbf{H}, \mathbf{P}$ & PN & -- & -- & -. & -- & -- \\
\hline UE-25 a\#5 & $1,236.5$ & 148.4 & $\mathbf{H}, \mathbf{P}$ & PN & -- & -- & -- & -- & -- \\
\hline UE-25 a\#6 & $1,235.3$ & 152.4 & $\mathbf{H}, \mathbf{P}$ & PN & -- & -- & - & -- & -- \\
\hline UE-25 a\#7 & $1,220.7$ & 305.4 & $\mathbf{H}, \mathbf{P}$ & PN & -- & -- & - & -- & -- \\
\hline USW SD-9 & $1,302.2$ & 677.6 & $\mathrm{H}, \mathrm{P}, \mathrm{R}$ & BT & SZ, PW & -- & $\mathrm{C}$ & w & 2 \\
\hline
\end{tabular}

Block of Yucca Mountain)]. The locations of the boreholes used for the lithostratigraphic model are shown in figure 6. In the Yucca Mountain area, boreholes west of the NTS have designations with a prefix of USW and a hyphen (-) in the number. Boreholes within the NTS have a prefix of UE-25 and a pound sign (\#) in the number. Although complete borehole designations are provided in table 1 , for brevity the prefixes generally are not used in the remainder of this report.

The YMP developed a system for designating locations within the ESF tunnel that is based on the linear distance (in meters) from the portal of the North Ramp. The digits preceding the $(+)$ sign indicate hundreds of meters, whereas the digits following the (+) sign indicate tens and single meters. For example, 


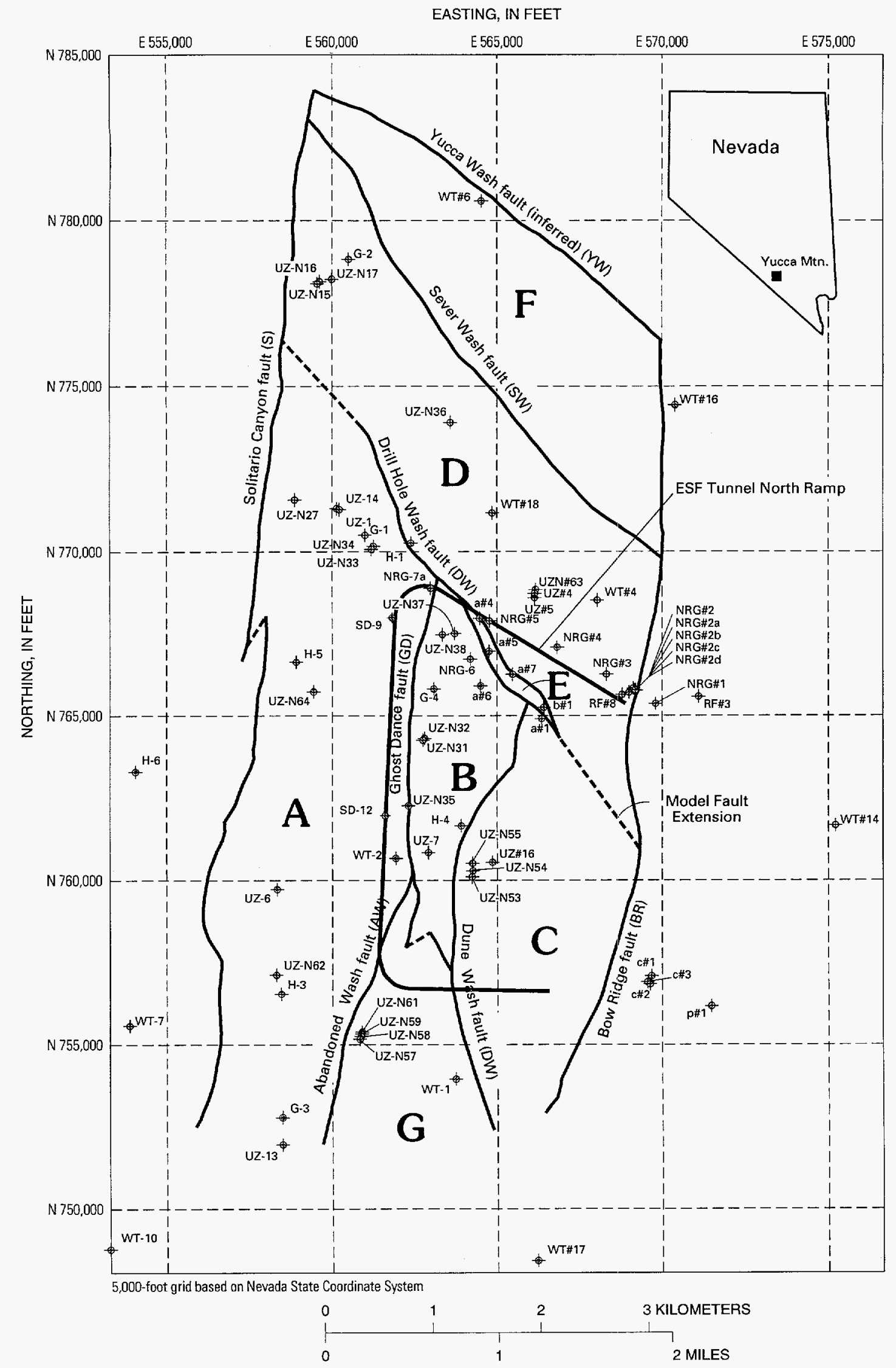

Figure 6. Boreholes and faults in the lithostratigraphic model YMP.R2.0 of the central block of Yucca Mountain. 
ESF station $10+25$ is $1,025 \mathrm{~m}$ from the North Ramp portal and station $19+01$ is $1,901 \mathrm{~m}$ from the portal. This system is used in this report to identify the location of various geologic, structural, and hydrogeologic features within the ESF North Ramp study area.

\section{GEOLOGIC FRAMEWORK OF THE NORTH RAMP AREA OF THE EXPLORATORY STUDIES FACILITY, YUCCA MOUNTAIN}

Yucca Mountain is underlain by a thick sequence of Miocene volcanic rocks and localized Quaternary to Pliocene(?) alluvial deposits (Scott and Bonk, 1984) and is broken into several east-tilted structural blocks that are bounded by north-trending normal faults (Frizzell and Shulters, 1990; Scott, 1990). The central structural block of Yucca Mountain is bounded by the Solitario Canyon and Bow Ridge Faults on the west and east, respectively (fig. 6). The geologic framework of a $33-\mathrm{km}^{2}$ area at Yucca Mountain is described in detail in a three-dimensional lithostratigraphic model referred to as YMP.R2.0 (Buesch, Nelson, and others, 1996). A primary purpose for the development of the lithostratigraphic model was to provide a geologic framework for the development of a flow model of the unsaturated zone. Therefore, the preliminary site-scale unsaturated-zone flow model (Wittwer and others, 1995), which covers a nearly identical area of $34 \mathrm{~km}^{2}$, used the lithostratigraphic framework described in the YMP.R2.0 model. The area of these two models consists of the central block of Yucca Mountain, bounded on the north by Yucca Wash and on the south by an east-west line near borehole G-3 (fig. 6).

Variations in lithostratigraphy and orientation of the layered Miocene volcanic sequence at Yucca Mountain are a direct result of the initial processes of eruption and deposition with cooling and crystallization in some ignimbrites and lava flows, and postdepositional processes of alteration and tectonics. Knowledge of these processes and the resultant distribution of volcanic rock types are not only critical to the development of a reliable lithostratigraphic framework (Buesch, Nelson, and others, 1996) but also to the understanding of variations in the distribution of hydrologic and pneumatic properties in the unsaturated zone near the ESF at Yucca Mountain. Lithostratigraphic units are based on depositional, welding, crystallization, alteration, and fracture characteristics (Buesch, Spengler, and others, 1996), and many hydrogeologic properties correlate with many of these lithostratigraphic features. Boundaries that separate fundamental variations in hydrologic properties and define the four major bedrock hydrogeologic units of the unsaturated zone (Montazer and Wilson, 1984) match those of mappable and laterally continuous lithostratigraphic units (Buesch, Spengler, and others, 1996; see section of this report titled Physical and Hydrologic Properties Determined from Analysis of Rock Cores). Use of these lithostratigraphic, hydrogeologic, and pneumatic relations may allow confident prediction of hydrologic properties in poorly sampled areas of the central block.

The North Ramp of the ESF transects the central structural block of Yucca Mountain to the north of Drill Hole Wash where northwest-trending washes and faults are the dominant physiographic surface and structural features (figs. 2 and 6). These northwesttrending strike-slip faults have variable amounts of strike-slip separation, but dip-slip separation is typically less than a few meters (Scott and Bonk, 1984; Buesch, Nelson, and others, 1996). Near the Bow Ridge Fault, the eastern margin of the central block has numerous north-trending dip-slip faults with separations typically less than $10 \mathrm{~m}$ (Scott and Bonk, 1984; Buesch, Dickerson, and others, 1994; Buesch, Nelson, and others, 1996). In marked contrast, the central block to the south of Drill Hole Wash is characterized by numerous east-trending washes and north-trending faults (figs. 2 and 6). Several of these north-trending faults have dip-slip separations greater than $15 \mathrm{~m}$ (Scott and Bonk, 1984; W.C. Day, U.S. Geological Survey, written commun., 1995; Buesch, Nelson, and others, 1996).

\section{Stratigraphic Framework of the North Ramp Area of the Exploratory Studies Facility, Yucca Mountain}

The stratigraphic framework of the area of the current site-scale unsaturated zone flow model (Wittwer and others, 1995), from top to bottom, consists of Quaternary alluvial deposits (Lundstrom and others, in press) that discontinuously overlie 11.4- to 13.4-million-year-old formations of the Timber Mountain (Tm) and Paintbrush (Tp) Groups, the Calico Hills Formation (Tac), and the Crater Flat 
Group (Tc) (table 2; Scott and Bonk, 1984; Sawyer and others, 1994; Buesch, Nelson, and others, 1996). Detailed lithostratigraphic nomenclature recently has been described for the tuffs at Yucca Mountain (many of which are formations) and interstratified informal units in the Paintbrush Group (Buesch, Spengler, and others, 1996) and for the Calico Hills Formation and the Prow Pass Tuff (Moyer and Geslin, 1995). Locally, the Timber Mountain Group is represented by the Rainier Mesa Tuff (Tmr) and the pre-Rainier Mesa Tuff bedded tuff (Tmbt1) (Geslin and others, 1995). The Paintbrush Group consists of the Tiva Canyon (Tpc), Yucca Mountain (Tpy), Pah Canyon (Tpp), and Topopah Spring (Tpt) Tuffs, with interstratified informal units of bedded tuffs (Tpbt5, Tpbt4, Tpbt3, Tpbt2, and Tpbt1). Locally, rocks of the Crater Flat Group, represented by the Prow Pass Tuff (Tcp) or the Bullfrog Tuff (Tcb), compose the lower part of the unsaturated zone.

On the basis of hydrologic properties affected by welding, the unsaturated zone at Yucca Mountain consists of four bedrock hydrogeologic units (table 2): Tiva Canyon welded (TCW), Paintbrush nonwelded (PTn), Topopah Spring welded (TSw), and Calico Hills nonwelded (CHn) (Montazer and Wilson, 1984). For example, the Tiva Canyon and Topopah Spring Tuffs range from nonwelded near the top and bottom of each unit to densely welded in the interior. Although the densely welded tuffs are highly fractured, the matrix generally has low porosity and permeability. Nonwelded tuffs have higher matrix porosity and permeability but are sparsely fractured, resulting in lower bulk permeabilities than the welded units. Bedded ash-fall tuffs are interlayered between the major tuff units and have the highest porosity and permeability of any of the rock units. Although the Calico Hills Formation is nonwelded and generally has high matrix porosity, it has low permeability due to zeolitic alteration over most of the Yucca Mountain area. Because of these differences in hydrologic properties, the hydrogeologic units do not correspond to the major lithostratigraphic units (generally formations) even though they have similar names. For example, the TSw consists only of the densely welded units of the Topopah Spring Tuff (table 2). The moderately welded to nonwelded units near the base of the Topopah Spring Tuff are part of the $\mathrm{CHn}$, and the moderately welded to nonwelded units near the top of the Topopah Spring Tuff are part of the PTn (table 2). Similarly, the moderately welded to nonwelded units near the base of the Tiva Canyon Tuff are part of the PTn.

\section{Variations in Rock Types Within the Unsaturated Zone}

The unsaturated zone within the central block is dominantly made up of thick, pyroclastic flow deposits separated by relatively thin sequences of bedded tuff (Buesch, Spengler, and others, 1996; Moyer and Geslin, 1995; Moyer and others, 1995). Each of the formations-including the Rainier Mesa, Tiva Canyon, Yucca Mountain, Pah Canyon, and Topopah Spring Tuffs, the Calico Hills Formation, and the Prow Pass and Bullfrog Tuffs-consist of small- to largevolume, nonwelded to densely welded, vitric to crystallized pyroclastic flow deposits with minor amounts of fallout tephra deposits. Bedded tuffs that separate formations are typically composed of fallout tephra deposits, small-volume pyroclastic flow deposits, and locally redeposited tuffaceous material. In the northern part of the central block, the Calico Hills Formation contains vitric and devitrified rhyolitic lava flows interstratified with pyroclastic flow and fallout deposits.

Definition of the spatial distribution of lithostratigraphic units at the base of the unsaturated zone was a critical prerequisite to the development of the preliminary unsaturated-zone flow model (Wittwer and others, 1995). Careful definition of the hydrologic properties at the interface between unsaturated and saturated conditions was particularly important given the contrasting properties of hydrogeologic units deep in the unsaturated zone (for example, the TSw and the $\mathrm{CHn}$ ). Distribution of lithostratigraphic units at the base of the unsaturated zone was determined by combining the potentiometric surface of Wittwer and others (1992 and 1995) with the lithostratigraphic model YMP.R2.0 (Buesch, Nelson, and others, 1996). The result of this analysis is shown in figure 7 , which depicts the lithostratigraphic units at the base of the unsaturated zone, the traces of the major faults, and the elevation of the potentiometric surface (water table). Within the central block of Yucca Mountain, the base of the unsaturated zone is in the Topopah Spring Tuff within only a very small area at the eastern edge of the central block (fig. 7). In much of the eastern and northern part of the central block, the base of the unsaturated zone is in the Calico Hills Formation, and through the central part of the block it 
Table 2. Correlation of bedrock lithostratigraphic units with lithostratigraphic-model units in YMP.R2.0 and hydrogeologic units in the unsaturated zone

[YMP.R2.0 model units from Buesch, Nelson, and others (1996); lithostratigraphic unit nomenclature from Buesch, Spengler, and others (1996) with formation names in bold type; hydrogeologic units from Montazer and Wilson (1984)]

\begin{tabular}{|c|c|c|}
\hline $\begin{array}{l}\text { Lithostratigraphic- } \\
\text { model units }\end{array}$ & Bedrock lithostratigraphic units & Hydrogeologic units \\
\hline \multirow{4}{*}{ (not modeled) } & Rainier Mesa Tuff (Tmr) & \multirow{9}{*}{$\begin{array}{l}\text { (These lithostratigraphic units gen } \\
\text { erally are not present at Yucca } \\
\text { Mountain due to erosion) }\end{array}$} \\
\hline & Pre-Rainier Mesa Tuff bedded tuff (Tmbt1) & \\
\hline & Tuff unit " $x$ " (Tpki) of the rhyolite of Comb Peak & \\
\hline & Post-Tiva Canyon Tuff bedded tuff (Tpbt5) & \\
\hline \multirow{16}{*}{ Tpcun $^{1}$} & Tiva Canyon Tuff $(\mathrm{Tpc})$ & \\
\hline & Crystal-rich & \\
\hline & Vitric & \\
\hline & Nonwelded (rv3) & \\
\hline & Moderately welded (rv2) & \\
\hline & Densely welded (rvl) $)^{2}$ & \multirow{11}{*}{$\begin{array}{l}\text { Tiva Canyon welded hydrogeo- } \\
\text { logic unit (TCw) }\end{array}$} \\
\hline & Nonlithophysal (rn) & \\
\hline & Crystal-poor & \\
\hline & Upper lithophysal (pul) & \\
\hline & Middle nonlithophysal (pmn) & \\
\hline & Lower lithophysal (pll) & \\
\hline & Lower nonlithophysal (pln) & \\
\hline & Hackly (plnh) & \\
\hline & Columnar (plnc) & \\
\hline & Vitric & \\
\hline & Densely welded (pv3) $)^{2,3}$ & \\
\hline \multirow{2}{*}{ Tpcpv } & Moderately welded (pv2) & \multirow{12}{*}{$\begin{array}{l}\text { Paintbrush nonwelded hydrogeo- } \\
\text { logic unit (PTn) }\end{array}$} \\
\hline & Partially welded to nonwelded (pv1) & \\
\hline \multirow{2}{*}{ Tpy } & Pre-Tiva Canyon Tuff bedded tuff (Tpbt4) & \\
\hline & Yucca Mountain Tuff (Tpy) & \\
\hline Tpbt3 & Pre-Yucca Mountain Tuff bedded tuff (Tpbt3) & \\
\hline \multirow[t]{4}{*}{ Tpp } & Pah Canyon Tuff (Tpp) & \\
\hline & Pre-Pah Canyon Tuff bedded tuff (Tpbt2) & \\
\hline & Topopah Spring Tuff (Tpt) & \\
\hline & Crystal-rich & \\
\hline \multirow[t]{3}{*}{ Tptrv } & Vitric & \\
\hline & Nonwelded (rv3) & \\
\hline & Moderately welded (rv2) & \\
\hline
\end{tabular}


Table 2. Correlation of bedrock lithostratigraphic units with lithostratigraphic-model units in YMP.R2.0 and hydrogeologic units in the unsaturated zone-Continued

[YMP.R2.0 model units from Buesch, Nelson, and others (1996); lithostratigraphic unit nomenclature from Buesch, Spengler, and others (1996) with formation names in bold type; hydrogeologic units from Montazer and Wilson (1984)]

\begin{tabular}{|c|c|c|}
\hline $\begin{array}{l}\text { Lithostratigraphic- } \\
\text { model units }\end{array}$ & Bedrock lithostratigraphic units & Hydrogeologic units \\
\hline \multirow{2}{*}{ Tptrn } & Densely welded (rv1) ${ }^{2}$ & \multirow{10}{*}{$\begin{array}{l}\text { Topopah Spring welded hydrogeo- } \\
\text { logic unit (TSw) }\end{array}$} \\
\hline & Nonlithophysal (m) & \\
\hline \multirow{3}{*}{ Tptpul } & Lithophysal (rl) & \\
\hline & Crystal-poor & \\
\hline & Upper lithophysal (pul) & \\
\hline \multirow{3}{*}{ Tptpln } & Middle nonlithophysal (pmn) & \\
\hline & Lower lithophysal (pll) & \\
\hline & Lower nonlithophysal (pln) & \\
\hline \multirow[b]{2}{*}{ Tptpv3 } & Vitric & \\
\hline & Densely welded (pv3) ${ }^{2}$ & \\
\hline \multirow[b]{2}{*}{ Tptpv1 and 2} & Moderately welded (pv2) & \multirow{4}{*}{$\begin{array}{l}\text { Calico Hills nonwelded hydrogeo- } \\
\text { logic unit }(\mathrm{CHn})\end{array}$} \\
\hline & Nonwelded (pv1) & \\
\hline Tac & $\begin{array}{l}\text { Pre-Topopah Spring Tuff bedded tuff (Tpbtl) } \\
\text { Calico Hills Formation } \\
\text { Prow Pass Tuff }\end{array}$ & \\
\hline Tcp (not modeled) & Bullfrog Tuff & \\
\hline
\end{tabular}

${ }^{1}$ Tiva Canyon undifferentiated: includes all zones and subzones of the Tiva Canyon Tuff except the lowermost partially welded to nonwelded and moderately welded, vitric intervals which compose the uppermost part of the Paintbrush nonwelded hydrogeologic unit (Buesch, Nelson, and others, 1996).

${ }^{2}$ The densely welded subzones in the Tiva Canyon and Topopah Spring Tuffs ( $\mathrm{vl}$ l and pv3) consist of the vitrophyre and clastic texture intervals (Buesch, Spengler, and others, 1996).

${ }^{3}$ Where preserved, the base of the densely welded subzone forms the base of the TCw hydrogeologic unit (Buesch, Spengler, and others, 1996). 


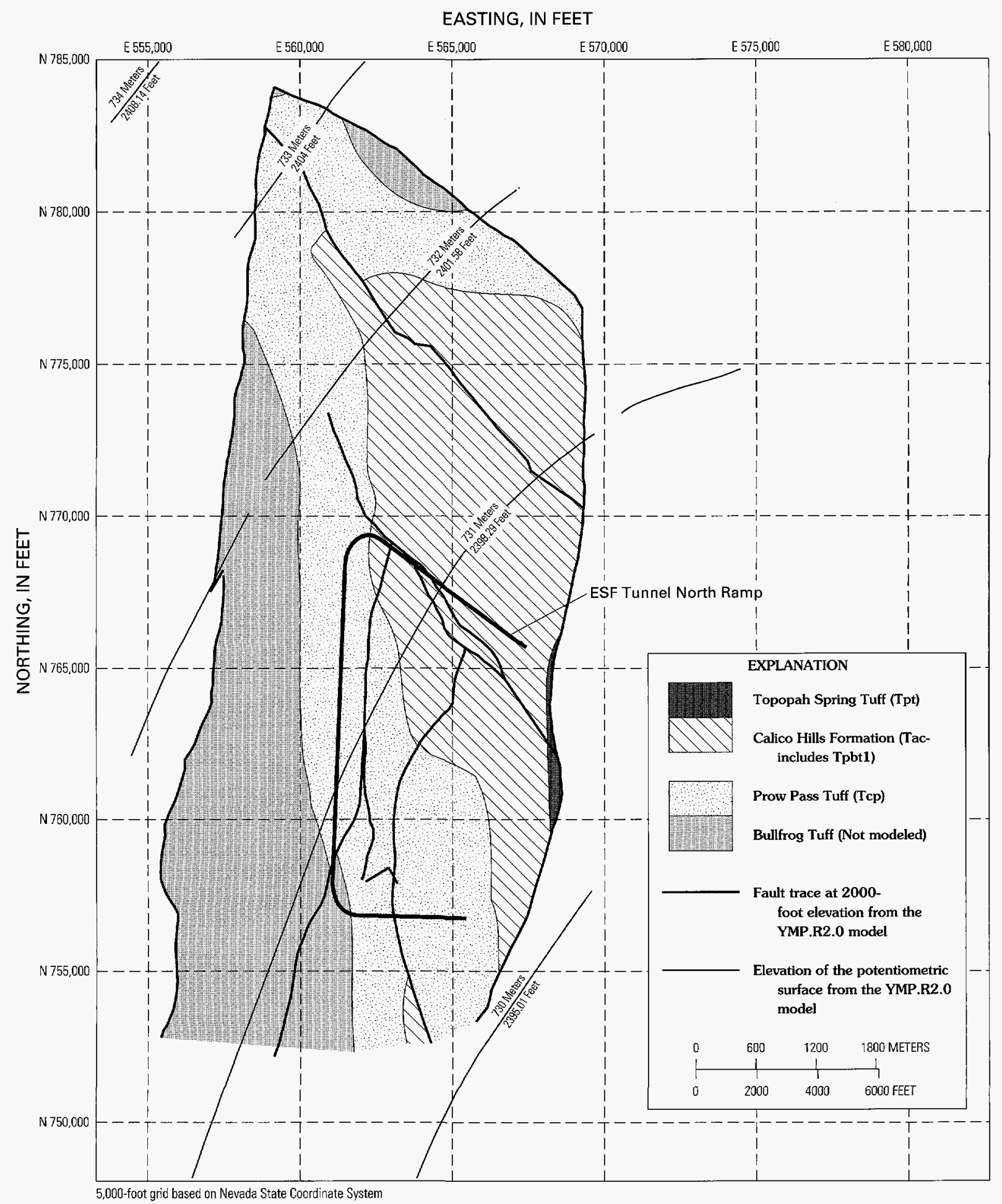

Figure 7. Lithostratigraphic units at the base of the unsaturated zone at Yucca Mountain. 
is in the older Prow Pass Tuff (fig. 7). Farther to the west, the base of the unsaturated zone is in the still older Bullfrog Tuff, reflecting the generally eastward slope of the Miocene tuffs underlying Yucca Mountain. Throughout most of the ESF North Ramp study area, the base of the unsaturated zone is in the Calico Hills Formation (fig. 7).

Distribution of physical and hydrologic properties such as grain density, bulk density, porosity, pore size distribution, permeability, and water content are controlled largely by variations in the grain size and sorting, degree of welding, the abundance of volcanic glass, types and abundance of primary crystallization and secondary alteration, and fracture characteristics (Scott and others, 1983; Montazer and Wilson, 1984; Flint and Flint, 1990; Rautman and Flint, 1992; Istok and others, 1994; Moyer and others, 1996; Rautman and others, 1995; Flint and Flint, 1995). Thickness, geometry, and internal heterogeneity of these lithologic components are influenced by the initial processes of eruption, deposition, and the cooling and crystallization of lava flows and some pyroclastic flow deposits, and by the post-depositional processes of alteration of glass to clay and zeolites by reaction with aqueous solutions (commonly referred to as secondary alteration) and tectonism. Knowledge of these processes is important for estimating and predicting the lateral continuity and heterogeneity of properties of the hydrologic framework.

\section{Zonal Variations in Pyroclastic Flow Deposits}

Characteristics of welded pyroclastic flow deposits typically result from the sequential development of depositional features, zones of welding, and zones of crystallization, although in some rocks welding can be coincident with deposition, and crystallization can occur synchronously with welding to inhibit development of welding (Smith, 1960a and 1960b; Chapin and Lowell, 1979; Fisher and Schmincke, 1984; Riehle and others, 1995). Characterization of welding typically includes the nonwelded, partially welded, moderately welded, and densely welded zones. These zones are vertically distributed in a simple cooling unit-nonwelded rocks at the top and bottom with increased welding toward the center of the deposit. Laterally, thick deposits can have the complete range in welding, but thin deposits can lack the more densely welded central parts. The five zones of crystallization include the high-tempera- ture devitrification, vapor-phase crystallization, vaporphase corrosion, lithophysal, and fumarolic alteration and crystallization.

At Yucca Mountain, the overlap of depositional and zonal features typically results in an internal stratigraphy that is stratiform on regional and subregional scales; but locally, complex, detailed lithostratigraphic relations may exist (Moyer and Geslin, 1995; Buesch, Spengler, and others, 1996; Moyer and others, 1996). Zones of welding and crystallization are variously developed in the Rainier Mesa, Tiva Canyon, Yucca Mountain, Pah Canyon, Topopah Spring, Prow Pass, and Bullfrog Tuffs.

The Tiva Canyon and Topopah Spring Tuffs compose the largest volume of rocks in the unsaturated zone, and their detailed lithostratigraphy forms the fundamental framework of many studies. Although the Topopah Spring Tuff is commonly 2 to 3 times thicker than the Tiva Canyon Tuff, these formations are strikingly similar in the relative distribution and thickness of the crystal-rich and crystal-poor members; the vitric, lithophysal, and nonlithophysal units; and the fracture characteristics of each unit (Buesch, Spengler, and others, 1996). One hydrogeologically significant difference between the two formations is the development of the crystal-poor, vitric, densely welded unit that is commonly generalized as the crystal-poor vitrophyre (see Buesch, Spengler, and others, 1996, for detailed descriptions). This crystalpoor vitrophyre is well developed in the Topopah Spring Tuff but is present in the Tiva Canyon Tuff only in the southwestern part of Yucca Mountain. Both formations have densely welded, crystal-rich rocks that span the vitric-crystallized unit boundary and overlie rocks of the nonlithophysal unit that have a secondary porosity imparted by vapor-phase corrosion of glass shards and pumice clasts during initial stages of cooling. In rocks where secondary porosity developed, the porosity can be anomalously high compared to that which would be estimated on the basis of textures of welding (Buesch, Spengler, and others, 1996; Moyer and others, 1996). Secondary porosity also forms where vitric, partially to moderately welded rocks are in contact with crystallized, moderately to densely welded rocks (Buesch, Spengler, and others, 1996). This type of secondary porosity is evident in exposures in Solitario Canyon in areas as much as $90 \mathrm{~m}$ across in the crystal-rich, vitric, moderately welded unit of the Topopah Spring Tuff, and similar dimensions are inferred from boreholes 
(Buesch, Nelson, and others, 1996; Buesch, Spengler, and others, 1996; Moyer and others, 1996). Secondary porosity in the crystal-rich, vitric, moderately welded unit of the Topopah Spring Tuff is not evident in exposures in the ESF. In central and northern Yucca Mountain, secondary porosity commonly is present in the lower part of the columnar unit and in the upper part of the vitric, moderately welded unit of the crystal-poor Tiva Canyon Tuff. This secondary porosity is particularly well developed where the vapor-phase corrosion has propagated down into the increasingly porous parts of the moderately welded rocks. Good examples of secondary porosity texture in the columnar and vitric, moderately welded units in the Tiva Canyon Tuff are exposed near and in Alcove 3 of the ESF (fig. 5) (also referred to as the Upper Paintbrush Tuff Contact Alcove). These overall similarities in the lithostratigraphic units of the Tiva Canyon and Topopah Spring Tuffs indicate that the welding and cooling histories of these two large-volume tuffs were also similar and probably represent simple cooling units in the Yucca Mountain area.

Variable zones of welding and crystallization are overprinted on depositional features in the Rainier Mesa, Yucca Mountain, Pah Canyon, Prow Pass, and Bullfrog Tuffs, in contrast to the Calico Hills Formation, in which the rocks are characteristically nonwelded. The Rainier Mesa Tuff is present only on the eastern side of the central block of Yucca Mountain near the Bow Ridge Fault, where it is nonwelded to partially welded and commonly vitric (Scott and Bonk, 1984; Blout and others, 1994; Geslin and others, 1995; Geslin and Moyer, 1995). Regionally, the Yucca Mountain Tuff is a simple cooling unit. Within the central block, the Yucca Mountain Tuff varies from densely welded tuff in exposures near Yucca Wash, which are locally crystallized at high temperature, to nonwelded and vitric tuff in the area south of NRG-7a and SD-9 (fig. 6) (Moyer and others, 1996). At Yucca Mountain, the Pah Canyon Tuff is a simple cooling unit and consists of multiple flow units with variable amounts of crystallization at high temperature, vapor-phase mineralization, and alteration to clays and zeolites (Moyer and others, 1996). In the northern part of Yucca Mountain, including exposures in Yucca and Sever Washes and in core from borehole G-2 (fig. 6), the Pah Canyon Tuff has relatively complex stratigraphic relations of pumice clast shapes and, based on field exposures and compensated density geophysical logs in G-2, the tuff is moderately welded and crystallized (Moyer and others, 1996). South of boreholes NRG\#4, UZ-14, and SD-9 (fig. 6), most of the Pah Canyon Tuff is nonwelded and vitric or variably altered to clays and zeolites. The Prow Pass Tuff is typically devitrified with vapor-phase mineralization and variably altered to clays and zeolites and is vitric only near the top in the southernmost boreholes and exposures (Moyer and Geslin, 1995). In the northern part of the central block of Yucca Mountain, the tuff has the appearance of a simple cooling unit, but multiple cooling units are present in the southern part of the mountain, and therefore the Prow Pass Tuff is a compound cooling unit (Spengler and others, 1981; Moyer and Geslin, 1995). All ignimbrites in the Calico Hills Formation are nonwelded; thus, differences in depositional features such as phenocryst and clast types provide lithostratigraphic context for the formation. However, in the context of hydrogeologic properties, the most important vertical and lateral variation is the distribution of vitric and zeolitized material (Montazer and Wilson, 1984; Moyer and Geslin, 1995; Buesch, Spengler, and others, 1996).

The relation of increased abundance of fractures in welded and crystallized rocks in comparison to the small number of fractures in vitric, nonwelded tuffaceous deposits has been recognized for many years (Spengler and others, 1979, 1981, 1984; Spengler and Rosenbaum, 1980; Maldonado and Koether, 1983; Montazer and Wilson, 1984; Scott and Castellanos, 1984). Individual lithostratigraphic units, whether nonwelded and vitric or zeolitic, or welded and vitric, or crystallized, each have relatively characteristic fracture geometry (measured on a scale of decimeters to meters) and surface roughness (measured on a scale of millimeters), and many of these fractures are strata-bound (Spengler and others, 1994; Brechtel and others, 1995a and 1995b;

C.J. Potter, U.S. Geological Survey, written commun., 1995; D.S. Sweetkind, U.S. Geological Survey, written commun., 1995; Buesch, Spengler and others, 1996; also see section of this report titled Comparison of Fractures in Surface Outcrops from Azreal Ridge and Yucca Crest Subdomains). In welded and crystallized units such as the Tiva Canyon and Topopah Spring Tuffs, and locally the Yucca Mountain, Pah Canyon, Prow Pass, and Bullfrog Tuffs, these fracture characteristics are initially developed in response to localized stress during the cooling and crystallization of the deposit. With an increase in welding, vitric 
nonwelded to moderately welded rocks have increasingly better developed fractures that become more planar in fracture geometry and smoother in surface roughness. Nonlithophysal units typically have more planar geometry and smoother roughness than the lithophysal units. Several lithostratigraphic units such as the hackly unit in the lower nonlithophysal unit and some of the vitric, densely welded rocks are highly fractured. These initial fractures establish a heterogeneity in the rock that subsequently can be reactivated during structural deformation.

\section{Correlation of the Lithostratigraphic and Hydro- geologic Frameworks}

Lithologic units described previously have been grouped into hydrogeologic units, based principally on major variations in the degree of welding and fracture characteristics (Montazer and Wilson, 1984). However, as modeling and cross-correlations of physical and hydrologic parameters have progressed, additional lithologic components such as relative abundances of vitric material, primary crystallization phases, and secondary alteration have been useful for mapping the lateral continuity of additional, and perhaps more subtle, hydrogeologic boundaries (Buesch, Spengler, and others, 1996; L.E. Flint, U.S. Geological Survey, oral commun., 1996; see section of this report titled Physical and Hydrologic Properties Determined from Analysis of Rock Cores). Beneath the alluvium, the four major bedrock hydrogeologic units consist of the Tiva Canyon welded unit (TCw), Paintbrush nonwelded unit (P'Tn), Topopah Spring welded unit (TSw), and Calico Hills nonwelded unit (CHn) (Montazer and Wilson, 1984). Boundaries between the four major bedrock hydrogeologic units generally correspond to one of contacts between the many lithostratigraphic units listed in table 2. Thus, specific subdivisions of either tuff formations or major hydrogeologic units can be uniquely identified by referring to one of the lithostratigraphic units listed in table 2 . Although Buesch, Spengler, and others (1996) describe the lithostratigraphic units at Yucca Mountain using a system that specifies stratigraphic rank (formation, member, zone, subzone, interval), in this report, subdivisions within formations and major hydrogeologic units generally are referred to simply as "units," which are the lithostratigraphic units listed in table 2 .

The Tiva Canyon welded (TCw) hydrogeologic unit consists of crystallized densely welded tuff
(Montazer and Wilson, 1984; Buesch, Spengler, and others, 1996). By analogy with the Topopah Spring welded hydrogeologic unit, the top of the $\mathrm{TCw}$ is the top of the vitric, densely welded unit of the crystalrich member in the Tiva Canyon Tuff. The crystalrich, vitric, densely welded unit (Tpcrv1) typically is eroded and is present only locally in the central block in borehole NRG\#2a (Geslin and others, 1995) and trench WBRT-1 on Whale Back Ridge near borehole USW SD-12 (fig. 6; E.M. Taylor, U.S. Geological Survey, written commun., 1996). The base of the TCw typically is the contact between the crystallized, columnar unit of the lower nonlithophysal unit and the vitric, moderately welded unit of the crystal-poor member of the Tiva Canyon Tuff where the vitric, densely welded unit is absent (Buesch, Spengler, and others, 1996; Moyer and others, 1996). This lower contact can be sharp where the high-temperature crystallization coincides with a change from densely to moderately welded rocks, or it can be gradational across several meters where high-temperature crystallization or vapor-phase corrosion occurred in moderately welded rocks. In the southwestern part of the central block, the base of the TCw is the contact between the vitric, densely, and moderately welded units (Buesch, Spengler, and others, 1996; Moyer and others, 1996).

The TCw can be divided into five hydrogeologic subunits based on changes in porosity and moisture retention, although additional units might be defined after completion of sensitivity-analysis modeling (L.E. Flint, oral commun., 1996). From the top down, these hydrogeologic subunits typically correspond to (1) the densely welded rocks of the crystal-rich vitric unit and the subvitrophyre in the nonlithophysal unit, (2) rocks with well-developed secondary porosity in the crystal-rich nonlithophysal unit, (3) the crystalpoor upper lithophysal unit, (4) a combination of the crystal-poor middle nonlithophysal, lower lithophysal, and lower nonlithophysal units, but excluding the lowermost part of the columnar unit where measured matrix porosity is greater than 0.15 , and (5) rocks with greater than 0.15 porosity and the argillic pumice interval in the columnar unit.

The Paintbrush nonwelded (PTn) hydrogeologic unit consists of rocks with low density and high porosity that are interstratified with rocks with high density and low porosity (Montazer and Wilson, 1984; Buesch, Spengler, and others, 1996; Moyer and others, 1996). In the northern part of the central block of 
Yucca Mountain and in the North Ramp area of the ESF, the top of the PTn typically corresponds with the lithostratigraphic contact of the columnar subunit of the lower nonlithophysal unit and the vitric, moderately welded unit in the crystal-poor member of the Tiva Canyon Tuff where the vitric, densely welded unit is absent (Buesch, Spengler, and others, 1996; Moyer and others, 1996). In the ESF, and locally throughout the North Ramp area, an interval of secondary porosity several meters thick pervades the moderately to densely welded rocks in the lower part of the columnar subunit with minor amounts in the upper part of the vitric, moderately welded unit. Based on the limit of 0.15 bulk porosity (L.E. Flint, oral commun., 1996; see section of this report titled Physical and Hydrologic Properties Determined from Analysis of Rock Cores), the top of the PTn in the ESF is at the top of the several-meters-thick interval of secondary porosity. The upper part of the vitric, moderately welded unit is partially altered to red clay. This argillic alteration commonly is present near the top of the PTn, based on surface exposures and core from boreholes (Moyer and others, 1996), and has been inferred in several boreholes on the basis of geophysical logs of calculated porosity (Nelson, 1994; P.H. Nelson, U.S. Geological Survey, written commun., 1995). The base of the PTn is in the crystalrich member of the Topopah Spring Tuff and typically corresponds with the contact of the vitric, moderately and densely welded units (Tptrv2 and Tptrv1) where the transition from nonwelded to densely welded rocks is commonly less than $2 \mathrm{~m}$ thick (Buesch, Spengler, and others, 1996; Moyer and others, 1996). Locally, where a vitric, densely welded unit does not exist, the base of the PTn is where the moderately welded rocks with vapor-phase crystallization and visible secondary porosity are in contact with a crystallized, densely welded subunit locally present within the nonlithophysal unit (Buesch, Spengler, and others, 1996; Moyer and others, 1996).

The PTn commonly is modeled as a single hydrogeologic unit but can be divided into several subunits (Moyer and others, 1996; L.E. Flint, oral commun., 1996; see section of this report titled Physical and Hydrologic Properties Determined from Analysis of Rock Cores). Many of the lithostratigraphic units in the PTn that consist of nonwelded fallout tephra and pyroclastic flow deposits have relatively similar hydrogeologic properties (Moyer and others, 1996). The red argillic zone developed on the top of unit $\mathrm{C}$ of the pre-Pah Canyon Tuff bedded tuff (Tpbt2C, see Moyer and others, 1996) is laterally extensive and has a higher density and lower porosity than the subjacent fallout tephra deposits (Moyer and others, 1996). Although the red argillic zone is too thin to constitute a hydrogeologic subzone, the small grain size and clay-rich characteristics might result in this layer forming a capillary barrier as described in Montazer and Wilson (1984) or form part of a barrier in the pneumatic system. Paleosols developed on the nonwelded deposits have not been sampled but probably have properties similar to the red argillic zone. Welding and crystallization in the Yucca Mountain Tuff, and possibly in the Pah Canyon Tuff, indicate that these lithostratigraphic units can be identified as hydrogeologic units (Moyer and others, 1996).

The Topopah Spring welded (TSw) hydrogeologic unit consists of crystallized, moderately to densely welded tuff (Montazer and Wilson, 1984; Buesch, Spengler, and others, 1996; Moyer and others, 1996). The top of the TSw correlates with the top of the vitric, densely welded unit of the crystal-rich member in the Topopah Spring Tuff; or locally, where there is no vitric, densely welded unit, the top is a densely welded subunit locally present in the nonlithophysal unit (Buesch, Spengler, and others, 1996). The upper contact of the TSw typically is sharp or gradational across less than $0.5 \mathrm{~m}$. The base of the TSw is the contact of the vitric, densely welded and moderately welded units of the crystal-poor member in the Topopah Spring Tuff, and this contact can be gradational across several meters (Buesch, Spengler, and others, 1996). Based on changes in porosity and moisture-retention characteristics, the TSw can be divided into eight hydrogeologic subunits, although additional units might be defined after completion of sensitivityanalysis modeling (L.E. Flint, oral commun., 1996). From the top down, these hydrogeologic subunits typically correspond to the (1) densely welded rocks of the crystal-rich vitric unit and a densely welded subunit locally present in the nonlithophysal unit, (2) rocks with well-developed secondary porosity in the crystalrich nonlithophysal unit, (3) crystal-rich lithophysal and crystal-poor upper lithophysal units, (4) crystalpoor middle nonlithophysal unit, (5) crystal-poor lower lithophysal unit, (6) upper part of the crystalpoor lower nonlithophysal unit, (7) lower part of the crystal-poor lower nonlithophysal unit, and (8) crystalpoor, vitric, densely welded unit. 
The Calico Hills nonwelded (CHn) hydrogeologic unit, which has been defined only for the unsaturated zone, consists of all rocks below the base of the crystal-poor, vitric, densely welded unit of the Topopah Spring Tuff where they are present above the water table, except locally where the Crater Flat ( $\mathrm{CFu}$ ) hydrogeologic unit is present above the water table (Montazer and Wilson, 1984). The CFu is present above the water table along the western edge of the central block where it is represented by the Bullfrog Tuff (fig. 7). Wittwer and others (1995) use the definition of Montazer and Wilson (1984) for the $\mathrm{CHn}$ and include the minimally represented CFu with the $\mathrm{CHn}$. The term "Calico Hills nonwelded hydrogeologic unit" has not been applied where this lithostratigraphic sequence dips beneath the water table in the vicinity of Yucca Mountain. This hydrogeologic unit is composed of a wide variety of lithostratigraphic units including: (1) vitric, moderately welded to nonwelded, crystal-poor Topopah Spring Tuff; (2) vitric, nonwelded, pre-Topopah Spring Tuff bedded tuff; (3) vitric, crystallized, or altered, tuffaceous rocks and lava flows of the Calico Hills Formation; (4) vitric, crystallized and altered, nonwelded to moderately welded Prow Pass Tuff; and locally, (5) altered and crystallized, nonwelded to moderately welded Bullfrog Tuff (Buesch, Spengler, and others, 1996; Moyer and Geslin, 1995). The tuffaceous lithostratigraphic units form three fundamentally different groups, where each group shares similar hydrogeologic properties. These groups include the vitric, nonwelded to moderately welded rocks; zeolitized, nonwelded to moderately welded rocks; and crystallized, welded tuffs; but interstratification of the different lithostratigraphic units precludes a simple division of the $\mathrm{CHn}$ into only three units.

\section{Evaluation of the Three-Dimensional Lithostratigraphic Model of the Central Block of Yucca Mountain}

Selected elements of the existing three-dimensional lithostratigraphic model (YMP.R2.0) of the central block of Yucca Mountain (Buesch, Nelson, and others, 1996) can be used as a valuable tool to evaluate spatial characteristics of the hydrogeologic framework (table 2; Buesch, Nelson, and others, 1996). The model data base contains 74 boreholes, and there are 13 modeled lithostratigraphic units from the Tiva
Canyon Tuff to the Prow Pass Tuff with 8 model block- and subblock-bounding faults (fig. 6; Buesch, Nelson, and others, 1996). Contacts of modeled units are stored as structure-contour maps that show the spatial position of units within the area of the preliminary site-scale unsaturated-zone flow model (Wittwer and others, 1995). Variations in thickness of units can be derived by taking the difference between the values of structure contours for the top of one unit and those of the top of the underlying unit. Similar to modeled units, modeled faults are stored as structure-contour maps that show orientation and amount of separation along the fault. For the most part, lithostratigraphic contacts have been modeled. However, several contacts were selected to coincide with (1) contacts of hydrogeologic units in support of hydrogeologic studies and (2) contacts between thermal/mechanical units in support of engineering design of the ESF and the potential repository. Although scientifically valid and rigorous, the three-dimensional lithostratigraphic model described herein is non- $Q$ because most of the borehole data used to construct the model were collected prior to implementation of the approved YMP quality-assurance (QA) program. Therefore, all of the maps and geologic sections depicting the distribution and thickness of lithostratigraphic units are non-Q. However, because the existence and geologic properties of the lithostratigraphic units are based on data that are fully qualified under an approved YMP QA program, the conclusions in this report regarding the hydrogeologic properties of the lithostratigraphic units are not compromised by the non-Q status of the lithostratigraphic model.

Three geologic sections from the lithostratigraphic model (trace of geologic sections shown in figure 5) illustrate the lateral changes in thickness and orientation of the lithostratigraphic units (figs. 8, 9, and 10). These geologic sections form the basis for the lithostratigraphy described in this section of this report and illustrate several geometric relations that are fundamental to the discussions of perched water and other topics. The eastward dips and eastward thinning of post-Calico Hills Formation lithostratigraphic units, the relatively flat water table (Wittwer and others, 1992) with perched water in the vitric, densely welded units of the crystal-poor Topopah Spring Tuff (Tptpv1, 2, 3) in borehole SD-9, the proximity of the vitric-zeolitic boundary to the base of the densely welded rocks of the crystal-poor vitric Topopah Spring 


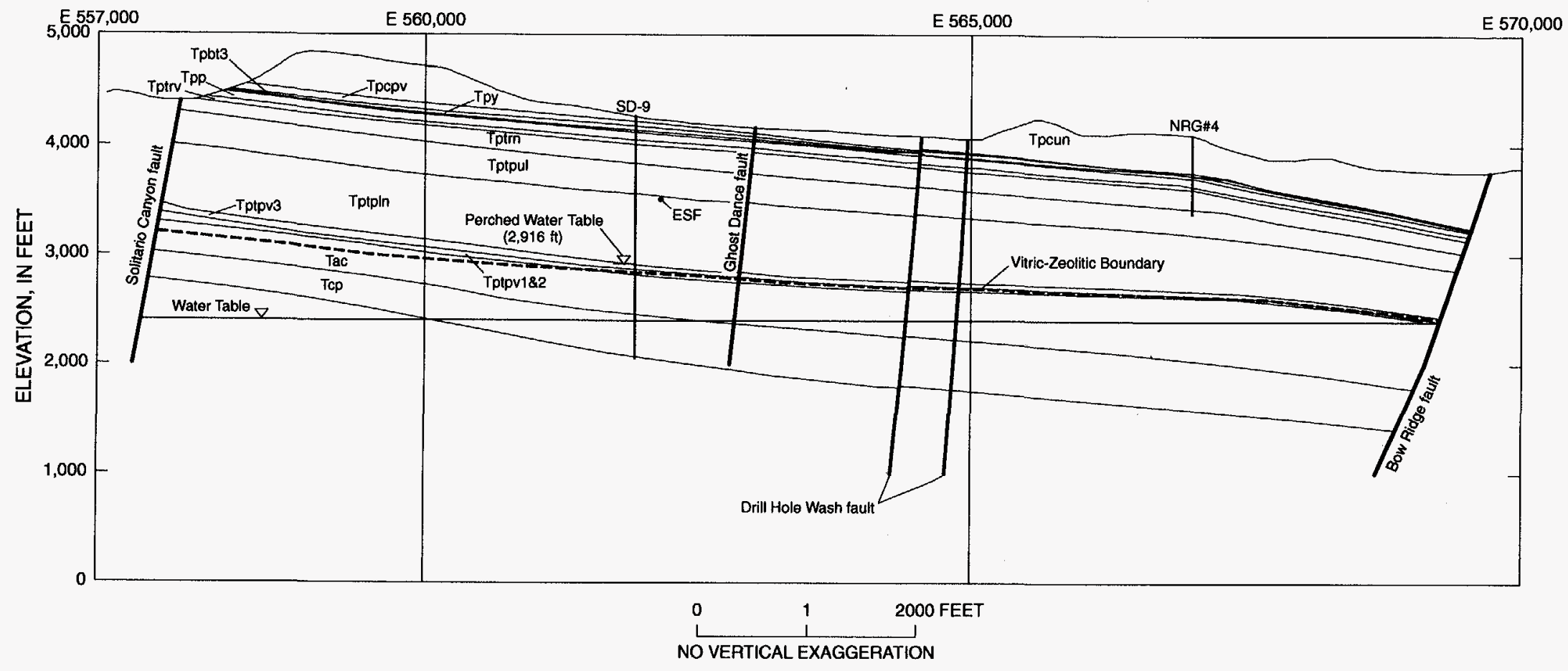

Figure 8. East-west geologic section through boreholes USW SD-9 and UE-25 NRG\#4, Yucca Mountain. (Location of section shown in figure 5.) 

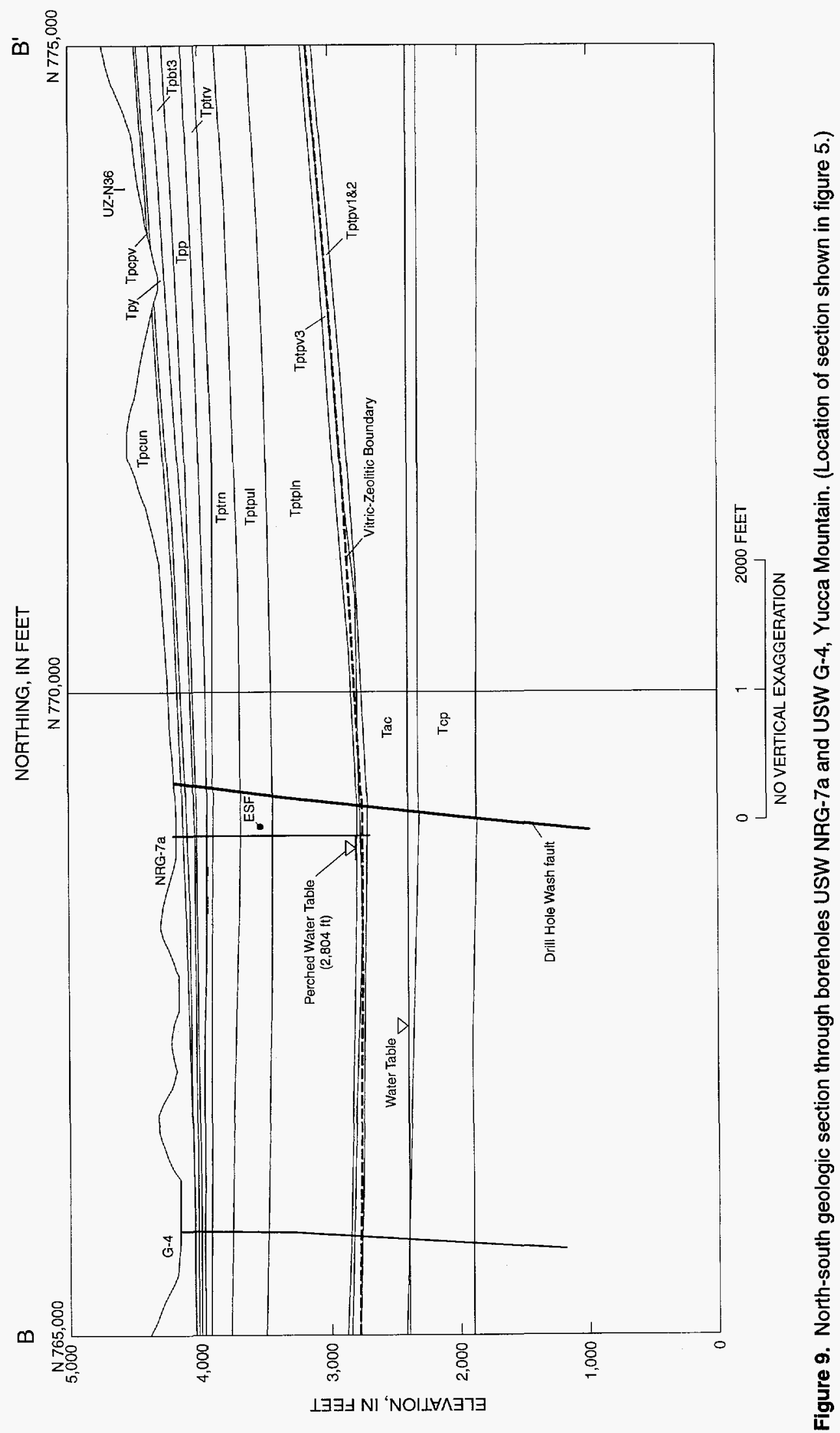


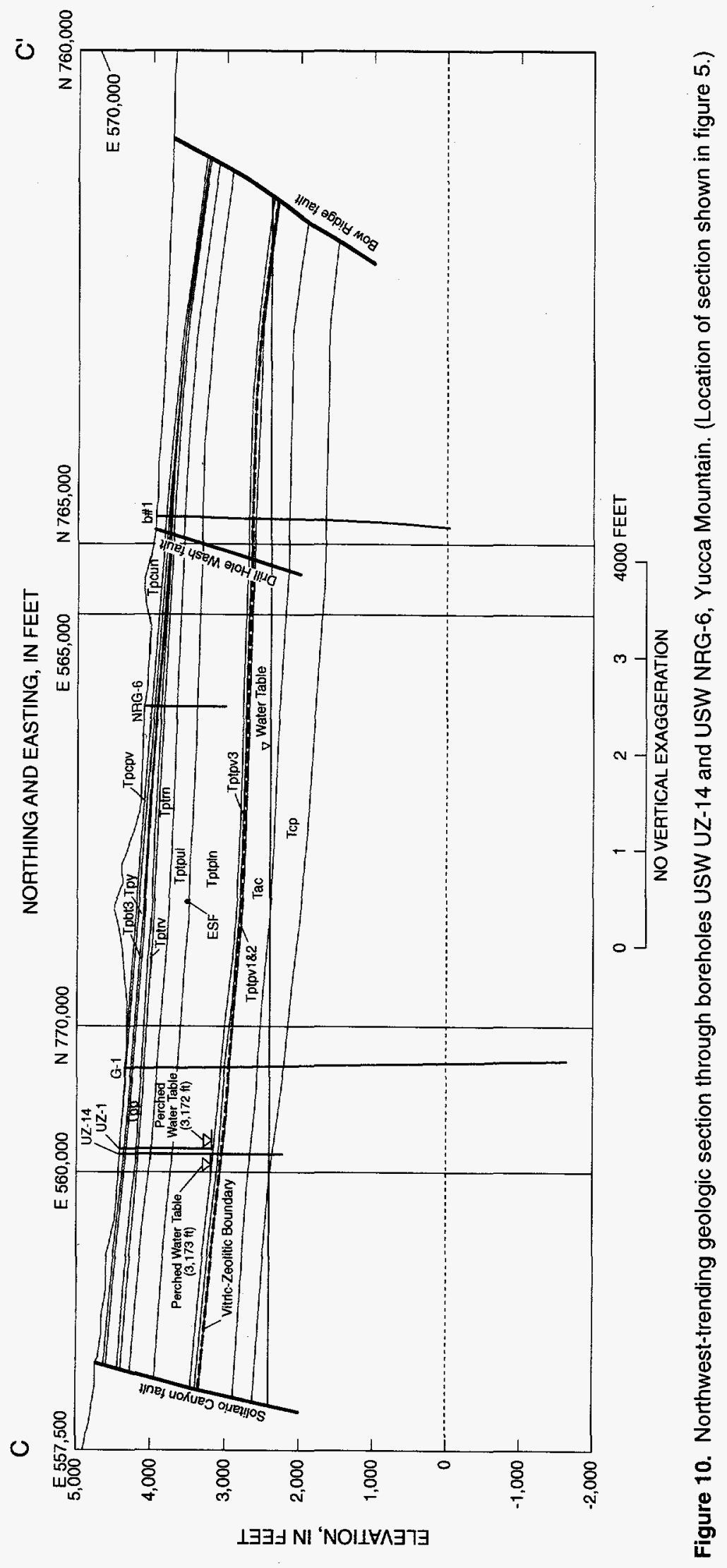


Tuff (Tptpv), and the inflection in model units east of borehole NRG\#4 that results from not modeling discrete faults (Buesch, Nelson, and others, 1996), are illustrated in figure 8 . The southward dips and changes in thickness of lithostratigraphic units such as the Pah Canyon Tuff (Tpp) and Topopah Spring Tuff (Tpt), the position of the vitric-zeolitic boundary (see the section of this report titled Modeling of the VitricZeolitic Boundary), and the water table as modeled by Wittwer and others (1992) are illustrated in figure 9. The southeasterly dips in the area near Drill Hole Wash, changes in thickness of lithostratigraphic units such as the Yucca Mountain Tuff (Tpy) and Pah Canyon Tuff (Tpp), the position of the vitric-zeolitic boundary near the base of the densely welded rocks of the crystal-poor Topopah Spring Tuff, and the water table (Wittwer and others, 1992) with perched water in the vitric, densely welded unit of the crystal-poor Topopah Spring Tuff in boreholes UZ-14 and UZ-1, are illustrated in figure 10. The relations between perched water and lithostratigraphy and structure are described in detail in the section of this report titled Relation of North Ramp Perched Water to Lithology and Geologic Structure.

\section{Variability in Thickness of Selected Lithostratigraphic and Hydrogeologic Units}

On the basis of results of lithostratigraphic modeling, all lithostratigraphic units display some degree of thickness variability within the central block of Yucca Mountain. General volcanology principles (Fisher and Schmincke, 1984; Cas and Wright, 1987) can be used to understand and model lithostratigraphic relations at Yucca Mountain where thickness variations are attributable to differences in modes of emplacement, pre-eruptive topography, and possibly removal by erosion. Deposits of fallout tephra are either uniform in thickness or thin gradually across the area, and topographic control on their thickness is minimal. Pyroclastic flow deposits typically fill topographically low areas and become thinner or pinch out as they onlap topographically high areas. Individual pyroclastic flow deposits, or the distal parts of the deposits, can develop a complex lobate form (Rowley and others, 1981). The relief and irregular profiles on pre-existing topography can be largely smoothed out where the pyroclastic flow deposits are thicker than the relief on the pre-existing surface. Primary controls on the geometry of pyroclastic flow deposits are the volume of material deposited, distance from their source, and relief on the pre-existing topography. Lava flows typically accumulate in low topographic areas, but near-vent deposits can be on steep slopes if the vent is on a ridge. Primary controls on the geometry of lava flows are the erupted volume and viscosity of the lava. Rhyolite lava flows in the Paintbrush Group and Calico Hills Formation exposed near Yucca Mountain are typically steep sided and can be traced for as much as 2 to $3 \mathrm{~km}$ from the vent (Christiansen and Lipman, 1965; R.P. Dickerson, Science Applications International Corporation, oral commun., 1995).

\section{Tiva Canyon Tuff}

The Tiva Canyon Tuff forms most of the exposed bedrock at Yucca Mountain, but the accuracy in determining the original thickness of the formation is limited because the top is commonly eroded, the base is rarely exposed, and only eight boreholes penetrate nearly the entire section. In the vicinity of the North Ramp, the thickest section is $148 \mathrm{~m}$, in borehole $\mathrm{H}-5$ (fig. 6). The formation appears to become thinner to the north, east, and south from this location. In the northern area, the approximate thickness of the formation is 73 to $85 \mathrm{~m}$ near Yucca Wash (Scott and Bonk, 1984), and $69 \mathrm{~m}$ in G-2, $105 \mathrm{~m}$ in WT\#18, and $102 \mathrm{~m}$ in NRG\#4 (Buesch, Nelson, and others, 1996). To the south, measured sections in Solitario Canyon indicate thicknesses of 115 and $125 \mathrm{~m}$ (J.K. Geslin, Science Applications International Corporation, written commun., 1995), but these sections are not complete because the top of the formation is not preserved. Thinning of the formation, and zones within it, to the north and northeast apparently results from deposition of the tuff on topographically higher areas produced by thick accumulation of the Yucca Mountain and Pah Canyon Tuffs and the bedded tuffs of Tpbt2, Tpbt3, and Tpbt4. The hydrogeologic subunit, which is represented by the vaporphase corroded rocks that include the lower part of the subvitrophyre transition, mixed pumice, and pumicepoor subunits of the crystal-rich nonlithophysal unit, is an important unit to infiltration studies (Flint and Flint, 1994). Rocks in the pumice-poor and mixed pumice subzones typically are exposed on the ridge crests in the northern area but less typically in the central areas. 


\section{Paintbrush Nonwelded Hydrogeologic Unit}

Almost all lithostratigraphic units included within the PTn hydrogeologic unit are thickest in the northern area of the central block of Yucca Mountain and thin southward (Buesch, Spengler, and others, 1996; Moyer and others, 1996). Isochore maps of the PTn (Buesch, Spengler, and others, 1996; Moyer and others 1996) show that the greatest change in total thickness of the PTn and several individual lithostratigraphic units occurs in the area near the western end of the North Ramp (near boreholes NRG-7a, NRG-6, and G-4). Modeling of thicknesses of the PTn (Buesch, Nelson, and others, 1996) indicates a southward decrease in thickness of approximately $58 \mathrm{~m} / \mathrm{km}$ for areas north of borehole NRG-7a and $20 \mathrm{~m} / \mathrm{km}$ for areas south of borehole NRG-7a (fig. 11). Most of this southward thinning of lithostratigraphic units in the PTn results from changes in thickness of the Yucca Mountain and Pah Canyon Tuffs and an unnamed pyroclastic flow deposit in the pre-Yucca Mountain Tuff bedded tuff (Moyer and others, 1996). In the area of the North Ramp and Drill Hole Wash structure, lithostratigraphic units in the PTn commonly have highly varied thicknesses that probably result from the effects of combinations of paleotopography, depositional mode, and possibly erosion (Buesch and others, 1994; Moyer and others, 1996). Many individual units within the formations and bedded tuffs of the PTn, even those that are only a few centimeters thick, can be correlated across the northern and central parts of the central block of Yucca Mountain in numerous boreholes and in the North Ramp of the ESF.

\section{Topopah Spring Tuff}

The Topopah Spring Tuff is thickest at the northwestern edge of the North Ramp, where borehole thicknesses measure $370 \mathrm{~m}$ in NRG-7a, $369 \mathrm{~m}$ in $\mathrm{H}-1$, and $368 \mathrm{~m}$ in SD-9 (borehole locations shown in figure 6). The formation becomes significantly thinner to the north and northeast from the area near borehole NRG-7a and becomes slightly thinner to the south. In the northern and central areas, the formation is approximately 93 to $109 \mathrm{~m}$ thick near Yucca Wash, and $288 \mathrm{~m}$ thick in borehole G-2, $281 \mathrm{~m}$ in borehole WT\#18, $219 \mathrm{~m}$ in borehole NRG\#4, $150 \mathrm{~m}$ in borehole WT\#16, $332 \mathrm{~m}$ in a\#1, $328 \mathrm{~m}$ in b\#1, $359 \mathrm{~m}$ in $\mathrm{G}-4$, and $353 \mathrm{~m}$ in H-5 (Buesch, Nelson, and others, 1996; (borehole locations shown in figure 6). Most zones and subzones can be mapped across the central block.
The lithophysal zones appear to become thicker as the middle and lower nonlithophysal zones become thinner to the north and east. At a few localities along Yucca Wash, lithophysal and nonlithophysal zones are difficult to identify as separate units. In borehole H-5, the vitric, densely welded unit of the crystal-poor member is the thickest at approximately $22 \mathrm{~m}$. This vitric, densely welded unit becomes thinner to the north and east to approximately 9 to $12 \mathrm{~m}$ thick near Yucca Wash, $11 \mathrm{~m}$ in the vicinity of boreholes WT\#16 and $\mathrm{b} \# 1,7 \mathrm{~m}$ in borehole WT\#4, and $9 \mathrm{~m}$ in borehole G-4; but it becomes thicker again to the south, where it is $25 \mathrm{~m}$ thick in borehole GU-3, a shallower hole at the location of borehole G-3 (Buesch, Nelson, and others, 1996). Thinning of the formation, and zones within it, to the north and northeast apparently results from deposition of the tuff on topographically higher areas produced by thick deposits of lava flows in the Calico Hills Formation.

\section{Calico Hills Hydrogeologic Unit}

Because the base of the $\mathrm{CHn}$ corresponds with the top of the saturated zone (Montazer and Wilson, 1984), thickness variations of the $\mathrm{CHn}$ are dependent on the interpreted elevation of the water table throughout the central block. Several models of the water table indicate a steeper hydraulic gradient across the northern part of Yucca Mountain in contrast to a relatively flat water table to the southeast of Yucca Mountain (Robison, 1984; Ervin and others, 1994; Tucci and Burkhardt, 1995), whereas other models portray a relatively planar water table without a steep gradient (Wittwer and others, 1992 and 1995). In models that assume a steep hydraulic gradient, the $\mathrm{CHn}$ becomes substantially thinner northward from $163 \mathrm{~m}$ in borehole G-1 to $25 \mathrm{~m}$ in borehole G-2. Alternatively, recent evaluations of hydrologic data from G-2 have questioned the steep hydraulic gradient in this area and used temperature logs and spinner and tracejector surveys to identify transmissive zones in the Calico Hills Formation and Prow Pass Tuff (Czarnecki and others, 1994). Using the interpretation of Czarnecki and others (1994), including the transmissive zone identified at the base of the 150 -m-thick interval with a small thermal gradient, the thickness of the $\mathrm{CHn}$ increases from borehole $\mathrm{G}-1$, where it is $162 \mathrm{~m}$ thick, to borehole G-2, where it is interpreted to be $284 \mathrm{~m}$ thick. This increased thickness to the north results primarily from a higher interpreted elevation of the base of the crystal-poor vitrophyre in the Topopah 


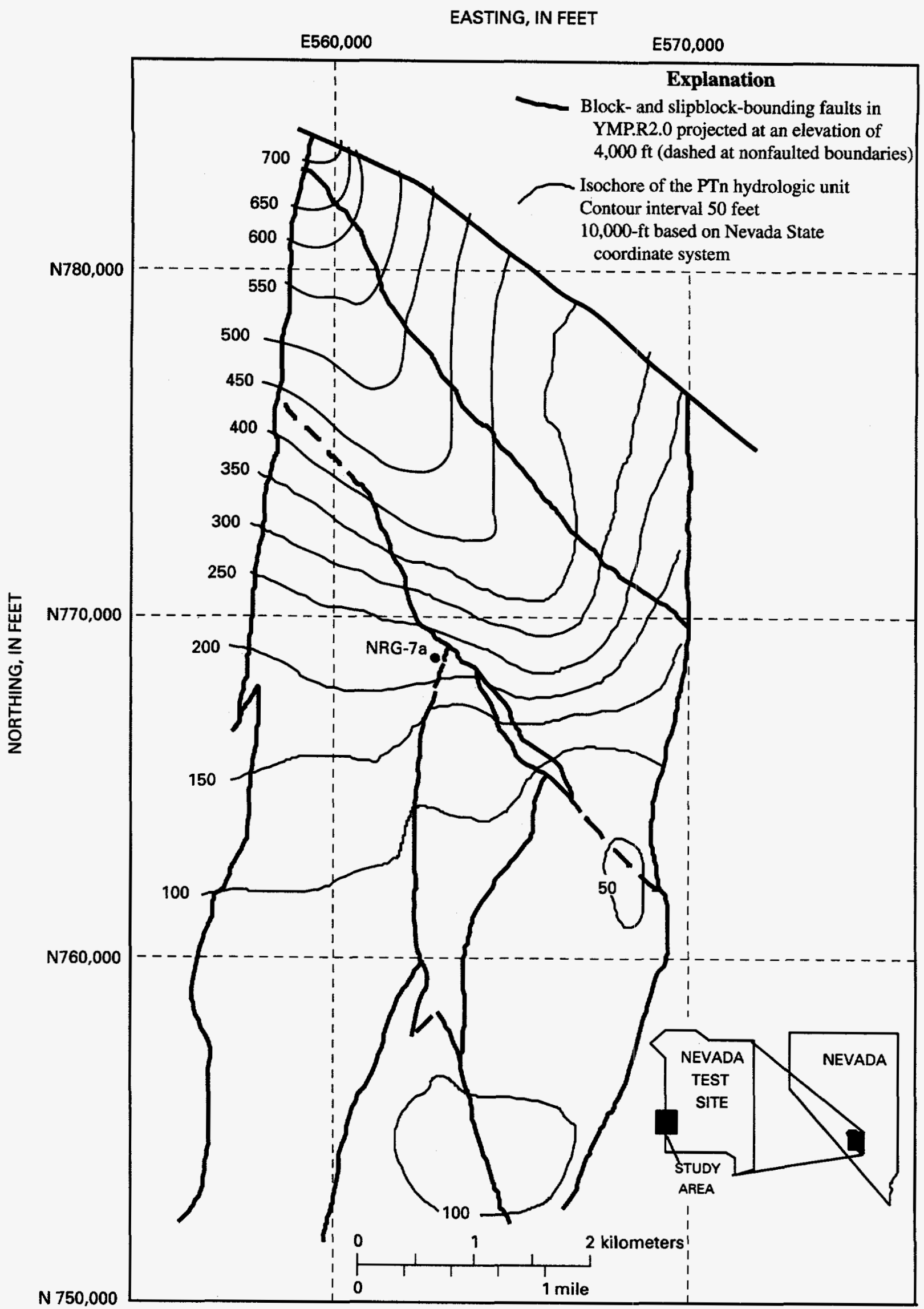

Figure 11. Variation in thickness of the Paintbrush nonwelded hydrogeologic unit at Yucca Mountain. 
Spring Tuff. The possible influence of the hydrologic characteristics of lava flows in the Calico Hills Formation on the geometry of the water table has not been evaluated.

\section{Geometry and Lateral Continuity of Lithostratigraphic and Hydrogeologic Units}

Selected structure-contour maps from the lithostratigraphic model illustrate the lateral and vertical variations in orientation of lithostratigraphic units at Yucca Mountain. A structure-contour map of the base of a modeled unit indicates subtle lateral variations in orientation of a contact at a sub-block scale. In the following sections, several different structure contour maps are interpreted and compared to detect vertical variations in the orientation of units within the central block. These structure contour maps include the (1) base of the Tiva Canyon Tuff, (2) top of the densely welded rocks of the Topopah Spring Tuff, (3) top of the crystal-poor vitrophyre of the Topopah Spring Tuff, and (4) base of the Calico Hills Formation. This selection provides examples of the general character of structure contour maps of major stratigraphic contacts, of lithostratigraphic contacts, and of surfaces that separate major hydrogeologic units. In general, all surfaces follow similar trends; therefore, layers are stratiform and can be modeled by using traditional stratigraphic principles. Minor vertical separation of surfaces north of Drill Hole Wash and the ESF reflect the dominance of strike-slip faults in the Azreal Ridge subdomain, whereas vertical separation is characteristic of the dip-slip faults in the Yucca Crest subdomain (see section of this report titled Structural Setting of the North Ramp of the Exploratory Studies Facility). Subtle variations in orientation are described below, but the major change in orientation of all units is from the northerly strikes in the central part of the block to the northeast strikes in the northeast with a southeast-plunging axis of change in the orientation located near Drill Hole Wash (Buesch and others, 1993; Buesch, Nelson, and others, 1996). These major changes in strike and dip are interpreted as representing deposition across a paleotopographic highland that resulted initially from the thick accumulation of lava flows in the Calico Hills Formation and was reestablished by thick accumulation of pre-Tiva Canyon Tuff and post-Topopah Spring Tuff tuffaceous rocks.

\section{Base of the Tiva Canyon Tuff}

The base of the Tiva Canyon Tuff is the bestconstrained lithostratigraphic contact at Yucca Mountain. The structure contour map for the base of the Tiva Canyon Tuff was constructed primarily from contacts in 31 boreholes, including information on the dip of units from the boreholes, and from surface exposures for the location and orientation of the base (Buesch, Nelson, and others, 1996). For most of the central block of Yucca Mountain, the base of the Tiva Canyon Tuff strikes north and dips gently eastward (fig. 12). North of boreholes WT\#18 and WT\#4, the base strikes approximately N. $45^{\circ} \mathrm{E}$. and dips gently southeast. The change in orientation occurs over a wide area and forms a broad, southeast-plunging trough. The axis, which represents a shift from northerly to northeasterly strikes, appears approximately aligned with Drill Hole Wash (Spengler and Rosenbaum, 1980; Scott and others, 1984; Buesch, Nelson, and others, 1996). In the North Ramp of the ESF, the strike of the base of the Tiva Canyon Tuff estimated from the model is N. $10^{\circ} \mathrm{E}$. (Buesch, Nelson, and others, 1996) and the measured strike is N. $12^{\circ} \mathrm{E}$. (S.C. Beason, Bureau of Reclamation, written commun., 1996).

\section{Top of the Densely Welded Rocks of the Topopah Spring Tuft}

For most of the central block of Yucca Mountain, the top of the densely welded rocks in the Topopah Spring Tuff strikes north and dips gently eastward; but north and east of WT\#18, the top strikes approximately N. $60^{\circ} \mathrm{E}$. to N. $65^{\circ} \mathrm{E}$. and dips gently southeast (fig. 13). This contact is described by data from 40 boreholes (Buesch, Spengler, and others, 1996). The area of transition from northerly to northeasterly strikes forms a southeast plunging trough that is slightly narrower than the trough formed by the base of the Tiva Canyon Tuff and described above. The transitional axis also appears to shift to the northeast by about $610 \mathrm{~m}$ (Buesch, Nelson, and others, 1996). Where the top of the densely welded rocks transects the ESF, the modeled strike is N. $1^{\circ} \mathrm{E}$. and the measured strike is N. $21^{\circ} \mathrm{E}$. This difference in orientation probably results from a combination of factors including (1) the decision not to model several specific faults in the area and (2) the presence of numerous small faults in the top of the densely welded rocks of 


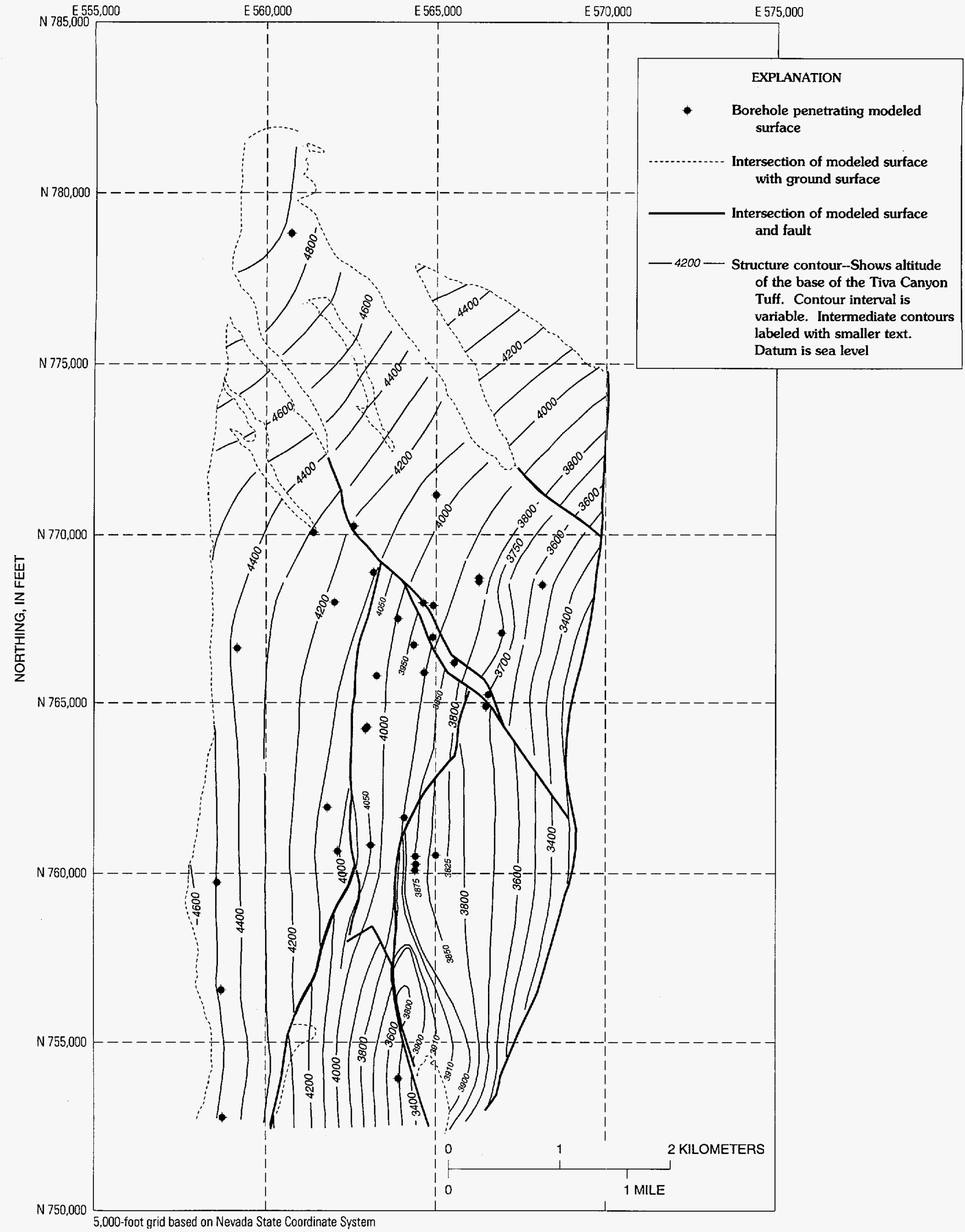

Figure 12. Structure contours of the base of the Tiva Canyon Tuff at Yucca Mountain. 


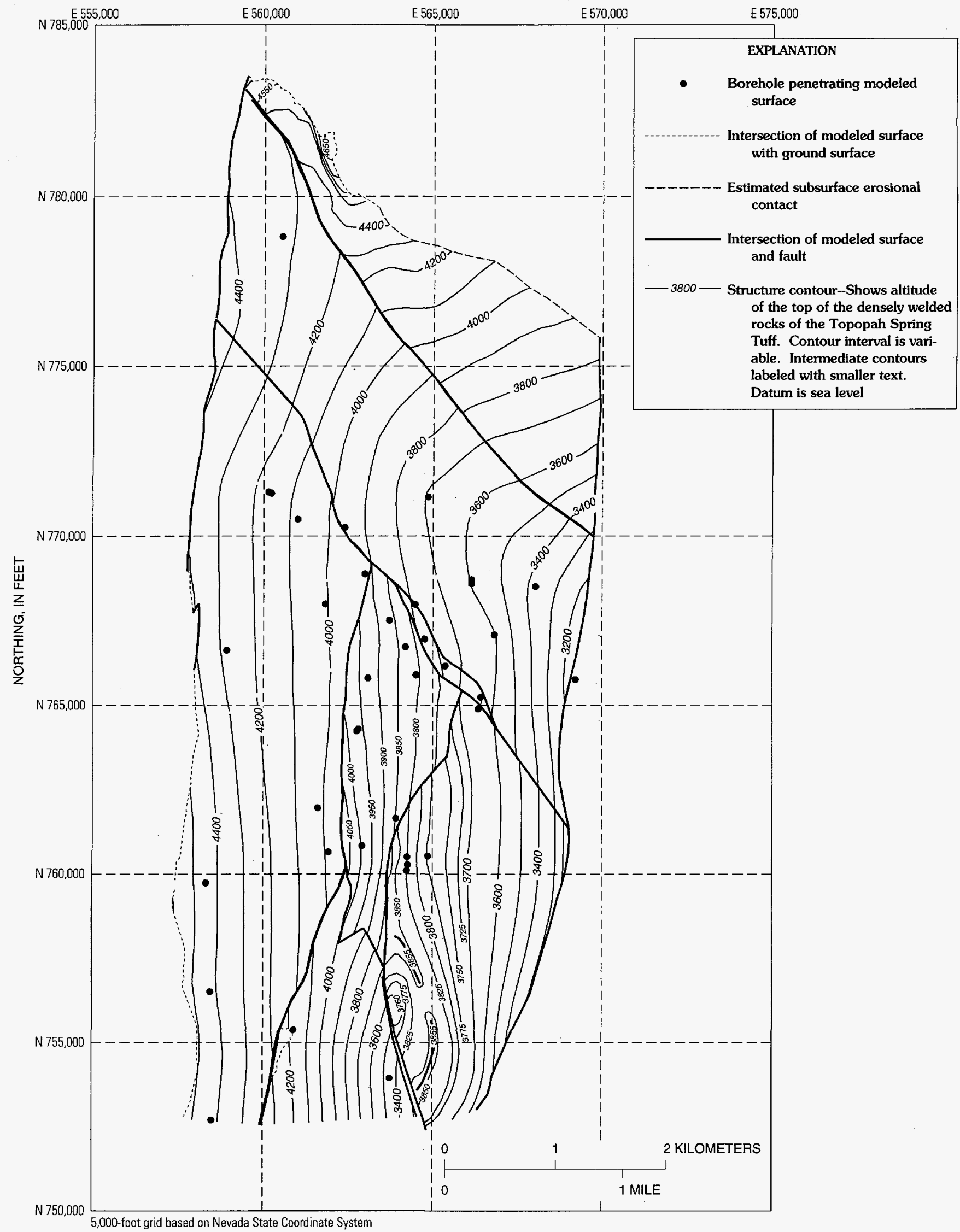

Figure 13. Structure contours of the top of the densely welded rocks of the Topopah Spring Tuff at Yucca Mountain. 
the Topopah Spring Tuff (Buesch, Nelson, and others, 1996).

\section{Top of the Crystal-Poor Vitrophyre of the Topopah Spring Tuff}

The contact between the nonlithophysal unit and vitrophyre of the vitric, densely welded unit in the crystal-poor Topopah Spring Tuff represents a relatively abrupt contact between high-temperature crystallized rock and underlying glassy rock; but commonly, a thin transition interval consists of welldeveloped argillic alteration (Levy, 1984a, 1984b; Buesch, Spengler, and others, 1996). For most of the central block of Yucca Mountain, the top of the vitrophyre strikes approximately N. $12^{\circ} \mathrm{W}$. and dips gently eastward; but north and east of WT\#18, the top strikes approximately N. $80^{\circ} \mathrm{W}$. and dips gently southwest (fig. 14). The shift from northerly strikes in the south and west to northeasterly strikes in the northeast occurs across a slightly broader southeasterlyplunging trough than the trough on top of the densely welded rocks of the crystal-rich Topopah Spring Tuff; again, the axis is moderately well defined and approximately coincides with Drill Hole Wash (Buesch, Nelson, and others, 1996).

\section{Base of the Calico Hills Formation}

For most of the central block of Yucca Mountain, the base of the Calico Hills Formation strikes approximately $\mathrm{N} .15^{\circ} \mathrm{W}$. and dips gently eastward (fig. 15). North of Drill Hole Wash, the base of the formation, except for one data point, is inferred from the projected thickness and, therefore, is highly interpretive.

\section{Aqueous Alteration of Glass and Fumarolic Alteration and Crystallization}

Analyses of rock samples from the unsaturated zone of Yucca Mountain indicate that smectite, clinoptilolite, and mordenite are the dominant low-temperature alteration products (Bish and Chipera, 1989). The low-temperature alteration potential of any lithologic unit is dependent on (1) rock composition, (2) rock texture, (3) proximity to structure, and (4) water/rock interaction. Volcanic glass that crystallized at high temperature is not susceptible to alteration except under high-temperature hydrothermal conditions. High porosity and permeability, however, whether inherited from the process of deposition or induced by fracturing, typically promotes alteration of glass because of the large surface area of the particles. Moderately to densely welded glassy rocks, including the lower vitrophyre of the Topopah Spring Tuff or obsidian in the lava flows, have relatively low porosity and permeability and do not readily alter. Alteration to clays and zeolites occurs in three fundamentally different lithostratigraphic, structural, and hydrologic settings (Broxton and others, 1987). Alteration within the unsaturated zone is suspected to be associated with (1) faults and throughgoing fracture systems; (2) perched-water horizons or horizons of lateral flow, typically resulting in localized alteration; and (3) rocks beneath an ancient or the present water table.

\section{Alteration in the PTn Hydrogeologic Unit}

Rocks in the PTn hydrogeologic unit are commonly vitric; but locally, smectite and zeolites have been detected near faults and fractures or along strata-bound or subparallel bedding. Lithostratigraphic units in the PTn are typically vitric in the central area of the central block, but alteration is more common in the northern area. Samples from boreholes a\#1, G-2, and G-4 locally contain 0 to 50 volumetric percent of smectite, and G-2 locally contains 0 to 25 volumetric percent clinoptilolite (Bish and Chipera, 1989). Calculated porosity logs show the locally interstratified alteration of vitric rocks and the vertical characteristics of transition zones between dominantly vitric and dominantly altered rocks (P.H. Nelson, 1993, 1994, and written commun., 1995). Numerous calculated porosity logs indicate an altered horizon in the vitric, moderately welded unit of the crystal-poor Tiva Canyon Tuff that probably correlates to argillic alteration near the top of the PTn. Zeolitization has been recognized in the lower part of the Pah Canyon Tuff and the pre-Pah Canyon Tuff bedded tuffs in NRG\#4 (Geslin and others, 1995; Moyer and others, 1996), and based on calculated porosity logs (P.H. Nelson, 1994, and written commun., 1995), zeolitized rocks are inferred in WT\#18. In the ESF, the lower part of the Pah Canyon Tuff and the pre-Pah Canyon Tuff bedded tuffs are partially zeolitized (S.C. Beason, oral commun., 1995).

Fumarolic alteration of nonwelded to moderately welded fallout tephra beds deposited on the pyroclastic flow deposit that forms most of the Topopah Spring Tuff has been observed locally in core from 


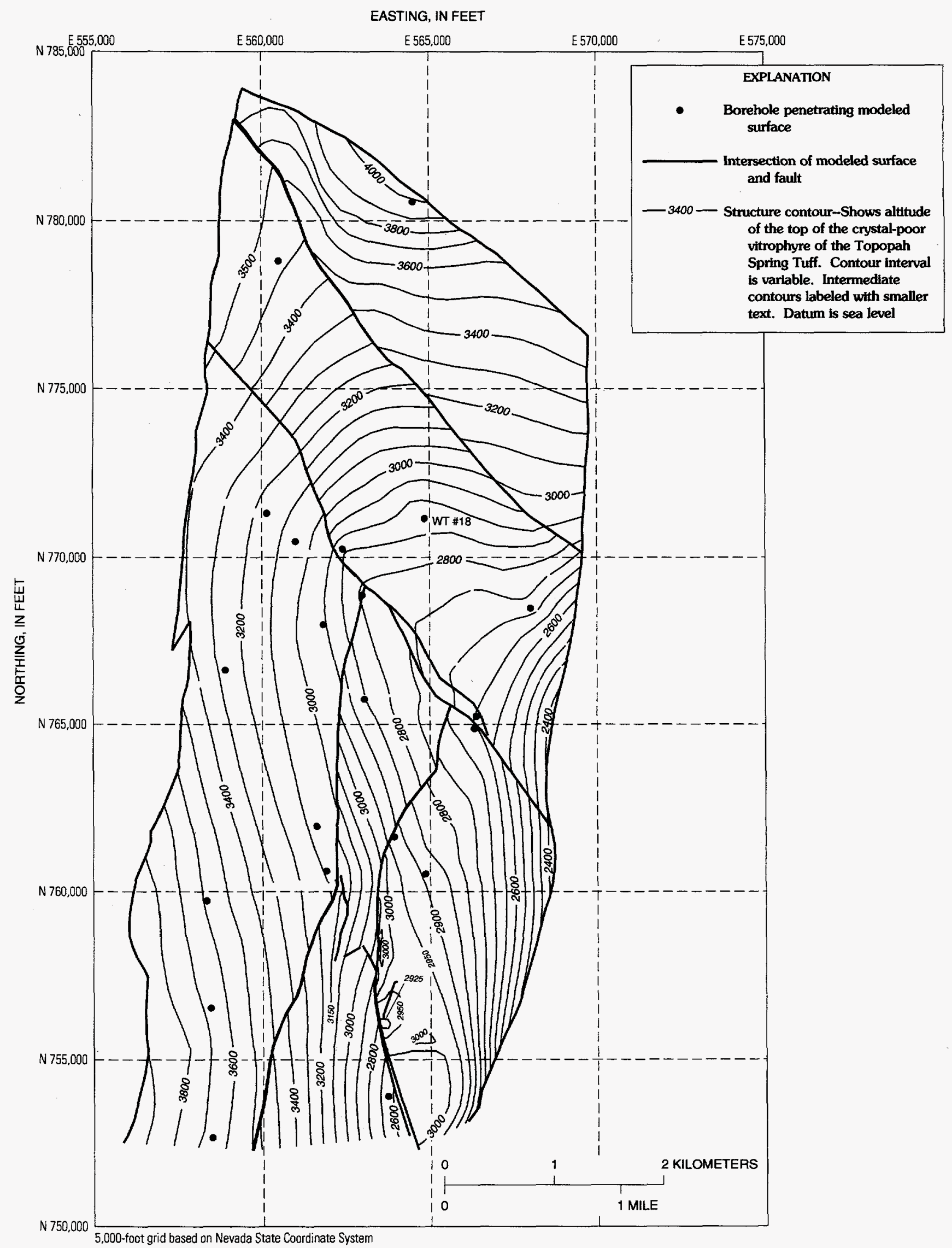

Figure 14. Structure contours of the top of the crystal-poor vitrophyre of the Topopah Spring Tuff at Yucca Mountain. 
EASTING, IN FEET

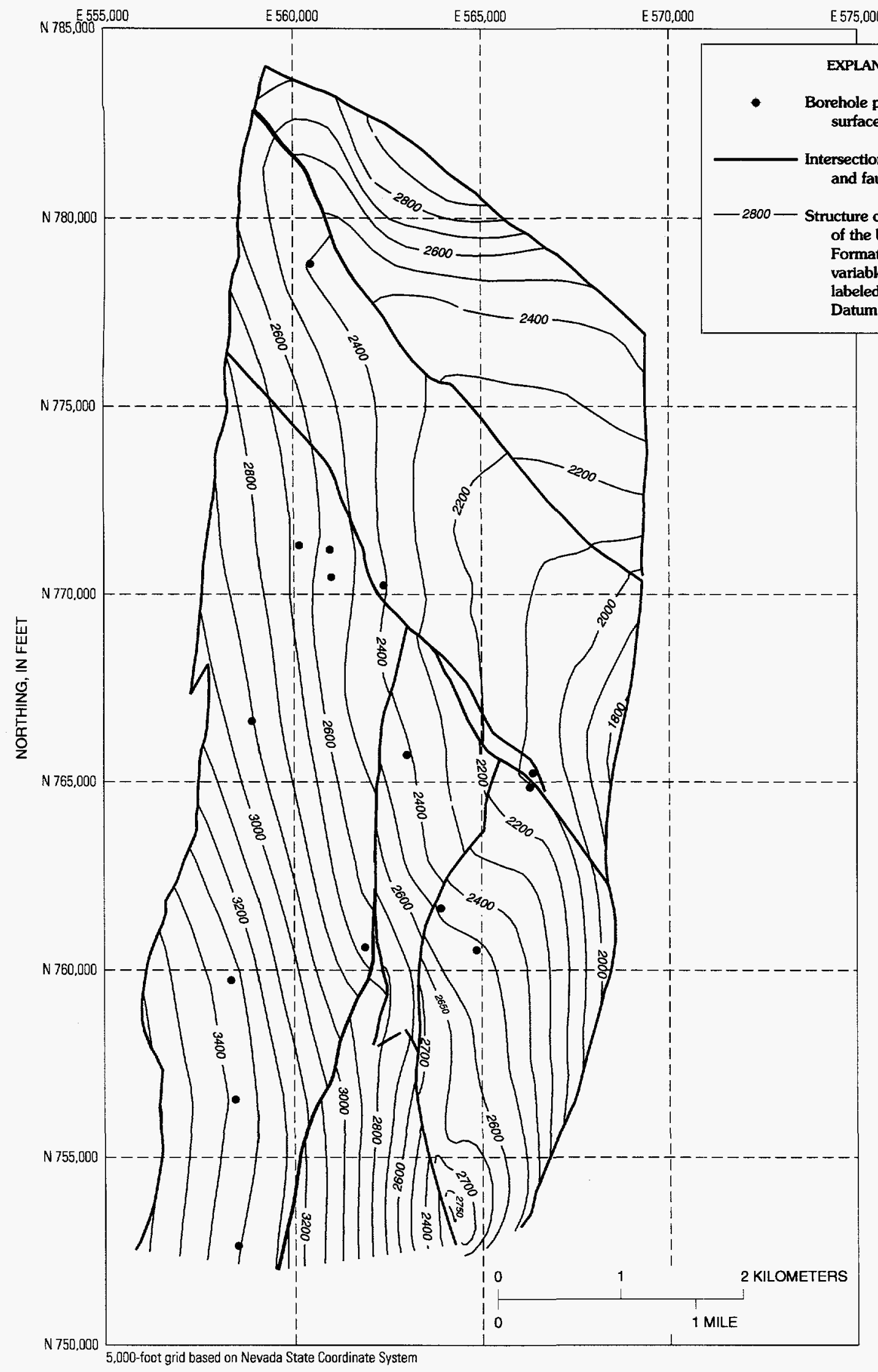

Figure 15. Structure contours of the base of the Calico Hills Formation at Yucca Mountain. 
boreholes and in surface exposures in the southern part of Yucca Mountain and along Solitario Canyon (Levy, 1993; Buesch, Spengler, and others, 1996; Moyer and others, 1996). These pumiceous deposits are included in the pre-Pah Canyon Tuff bedded tuffs (Tptbt2) (Buesch, Spengler, and others, 1996; Moyer and others, 1996). On the basis of mapped geometric relations, S.C. Beason (written commun., 1995) has suggested that a probable fumarole was transected near stations $10+25$ to $10+44 \mathrm{~m}$ in the ESF. Quantitative mineralogy indicates a smectite-rich assemblage with minor opal-CT, microcrystalline quartz, and cristobalite, and fractures coated with drusy quartz crystals; this assemblage is consistent with fumarolic alteration (Levy and others, 1996). The top surface of this feature is a red, argillically altered, pumiceous fallout deposit that can be traced into alcove 4 of the ESF (fig. 5), which also is referred to as the Lower Paintbrush Tuff Contact Alcove. This argillically altered material in alcove 4 probably also contains a smectite-rich mineral assemblage, but it has not been analyzed. A red, argillically altered, pumiceous fallout deposit is evident in most boreholes that penetrate into the uppermost Topopah Spring Tuff (Geslin and others, 1995; Geslin and Moyer, 1995; Moyer and others 1995; Buesch, Spengler, and others, 1996; Moyer and others, 1996). On the basis of geophysical logs of calculated porosity (Nelson, 1994; P.H. Nelson, written commun., 1995), an altered horizon is indicated in many boreholes, and this horizon is at approximately the same stratigraphic position as the red, argillically altered deposits. Map relations of the probable fumarole in the ESF and the lateral continuity of the argillically altered fallout deposit indicate that this argillic alteration probably represents a dispersed form of fumarolic alteration at or near the post-Topopah Spring Tuff paleogeomorphic surface.

\section{Alteration in the Calico Hills Hydrogeologic Unit}

The intense zeolitic alteration that appears pervasively throughout much of the $\mathrm{CHn}$ was associated with the Timber Mountain caldera system approximately 10.7 million years ago, and no significant hydrothermal alteration has occurred since that time (Bish and Aronson, 1993). Much of the CHn in the northern and eastern parts of the central block, including the area of the North Ramp of the ESF, contains significant proportions of clinoptilolite and mordenite in contrast to areas to the south and south- west, where the unit has remained relatively unaltered (Broxton and others, 1987; Bish and Chipera, 1989, Broxton and others, 1993; Bish and Aronson, 1993; Bish and others, 1995; Buesch, Spengler, and others, 1996). Although the division of the unit into two alteration zones implies a relatively simple geometry and history (altered and nonaltered), there is variability in the details of which rocks have been altered, where alteration occurred, and how alteration products affect hydrologic properties of specific rocks and the general unsaturated-zone system. The products of alteration vary on scales from millimeters to hundreds of meters and include grain-size textural changes, strata-bound alteration, alteration along faults, and the alteration of dense glass along fractures. These factors result in a gradational boundary from vitric to zeolitic that may span a vertical interval of as much as $30 \mathrm{~m}$.

The approximately 15 -m-thick section of bedded tuff and sandstone that forms the base unit of the Calico Hills Formation appears to be more extensively zeolitized than the overlying and underlying pyroclastic flow deposits of the Calico Hills Formation and Prow Pass Tuff, respectively (Moyer and Geslin, 1995). This highly zeolitic interval could potentially form a strata-bound barrier to flow. Moyer and Geslin (1995) suggested that this stratigraphic relation may be a result of variable abundances of primary glass, and they concluded that the bedded tuffs probably had a slightly different alteration history than the underlying and overlying pyroclastic flow deposits. Similar differences in the amount of alteration in thin bedded tuffs within sequences of pyroclastic flow deposits are found in other parts of the Calico Hills Formation. The apparent correlation of increased zeolitization in bedded tuffs, parts of which include tuffaceous sandstone, compared to adjacent pyroclastic flow deposits may indicate that the initial grain-size distribution and sorting imparted at the time of deposition resulted in preferential flow paths during alteration. After alteration, these bedded tuffs could form strata-bound barriers to flow.

Faults and fractures form structural discontinuities that can be conduits for altering solutions, and many form preferred locations of zeolite precipitation. Zeolitization along faults is evident in field exposures around Yucca Mountain (Broxton and others, 1993; R.P. Dickerson, Science Applications International Corporation, unpub. data, 1995) but is not well documented in boreholes at Yucca Mountain. Alteration along fractures of obsidian in lava flows and vitro- 
phyres such as in the crystal-poor member of the Topopah Spring Tuff has been documented in numerous boreholes (Broxton and others, 1987; Geslin and others, 1995; Buesch, Spengler, and others, 1996). Dense glass typically has less than a small percent porosity and very small surface area, and therefore, it is difficult for water to penetrate and alter these units. This characteristic low porosity, in addition to the relative lack of alteration, is one of the main reasons why the crystal-poor vitrophyre of the Topopah Spring Tuff was not included in the Calico Hills hydrogeologic unit. Fractures that permit access of water can develop during cooling of a deposit, hydration of glass to form perlitic fractures, or tectonic activity. In boreholes WT\#4, WT\#6, WT\#16, WT\#18, and WT-7, alteration along fractures has been inferred in the crystal-poor vitrophyre of the Topopah Spring Tuff and obsidian of the Calico Hills Formation by comparing calculated porosity logs that indicate alteration (Nelson, 1993; Nelson, 1994, and written commun., 1995) with the distribution of vitric material, including vitrophyre and obsidian, based on lithologic.logs derived from cuttings, borehole video, and geophysical logs. In borehole WT\#4, zeolitization along fractures in the crystal-poor vitrophyre of the Topopah Spring Tuff is not indicated, but it is evident in the obsidian of the Calico Hills Formation. In WT\#6, WT\#16, and WT\#18, some zeolitization is evident $6 \mathrm{~m}$ to more than $18 \mathrm{~m}$ above the base of the crystal-poor vitrophyre. In WT-7, the entire crystalpoor vitrophyre may be partially altered.

\section{Modeling of the Vitric-Zeolitic Boundary}

Vitric and zeolitic rocks in the unsaturated zone have long been recognized as important components in hydrologic modeling (Montazer and Wilson, 1984), but although the distribution of such rocks has been pertrayed in geologic sections and fence diagrams (Broxton and others, 1987), only a few distribution maps of the rocks have been compiled (Montazer and Wilson, 1984; Moyer and Geslin, 1995). Many studies have focused on the vertical distribution of glass and minerals in boreholes and the characteristics of the transition from vitric to zeolitic rocks (Broxton and others, 1987; Broxton and others, 1993; Bish and others, 1995; Chipera and others, 1995). The vitriczeolitic boundary is interpreted as an ancient water table that was probably associated with the peak period of zeolitization, approximately 10.7 million years ago (Broxton and others, 1987; Broxton and others, 1993; Bish and Aronson, 1993; Buesch, Spengler, and others, 1996). The assumption that the vitric-zeolitic boundary represents an older water table implies that the boundary can be mapped in three dimensions. Mapping the vitric-zeolitic boundary is intended to provide a general geometry of this alteration boundary, but not as an attempt to represent all the details of the vitric-zeolitic transition, such as localized perched zones and the transition to saturated rocks near the water table that commonly is referred to as a capillary fringe. Construction of the vitriczeolitic boundary map follows the methods utilized in development of the most recent lithostratigraphic model (Buesch, Nelson, and others, 1996).

The vitric-zeolitic boundary transects formation contacts and is lowest in the stratigraphic section in the southwest part of the central block of Yucca Mountain. At most locations in the northern and eastern areas of the central block, including the area near the North Ramp of the ESF, the vitric material is less than $6 \mathrm{~m}$ thick, and the vitric-zeolitic boundary is within the upper part of the vitric, moderately welded unit in the crystal-poor Topopah Spring Tuff; but the vitrophyre is not altered (fig. 16). Locally in the northernmost area, the vitric-zeolitic boundary is located slightly above the base of the crystal-poor vitrophyre, and the alteration is probably along fractures in the vitrophyre. In the southwest, the boundary is as much as $140 \mathrm{~m}$ below the crystal-poor vitrophyre and is below the crystallized, moderately welded rocks of unit 3 in the Prow Pass Tuff (see Moyer and Geslin, 1995) (fig. 16). The isochore map of vitric material shows a relatively sharp increase in thickness near the alignments of the Ghost Dance and Sundance Faults and respective fault systems.

The contacts of lithostratigraphic units and the vitric-zeolitic boundary are similarly oriented, but none are coplanar (compare fig. 12 to figs. 15 and 17), nor are they coplanar with the current water table. This noncoplanar relation exists regardless of the various representations of the water table, including with or without steep gradients (Robison, 1984; Wittwer and others, 1992; Ervin and others, 1994; Tucci and Burkhardt, 1995; Wittwer and others, 1995). Several interpretations can be drawn from these geometric relations. In the southwestern and western part of Yucca Mountain, the strikes of lithostratigraphic units and the vitric-zeolitic boundary trend north to slightly northwest; therefore, the south- 


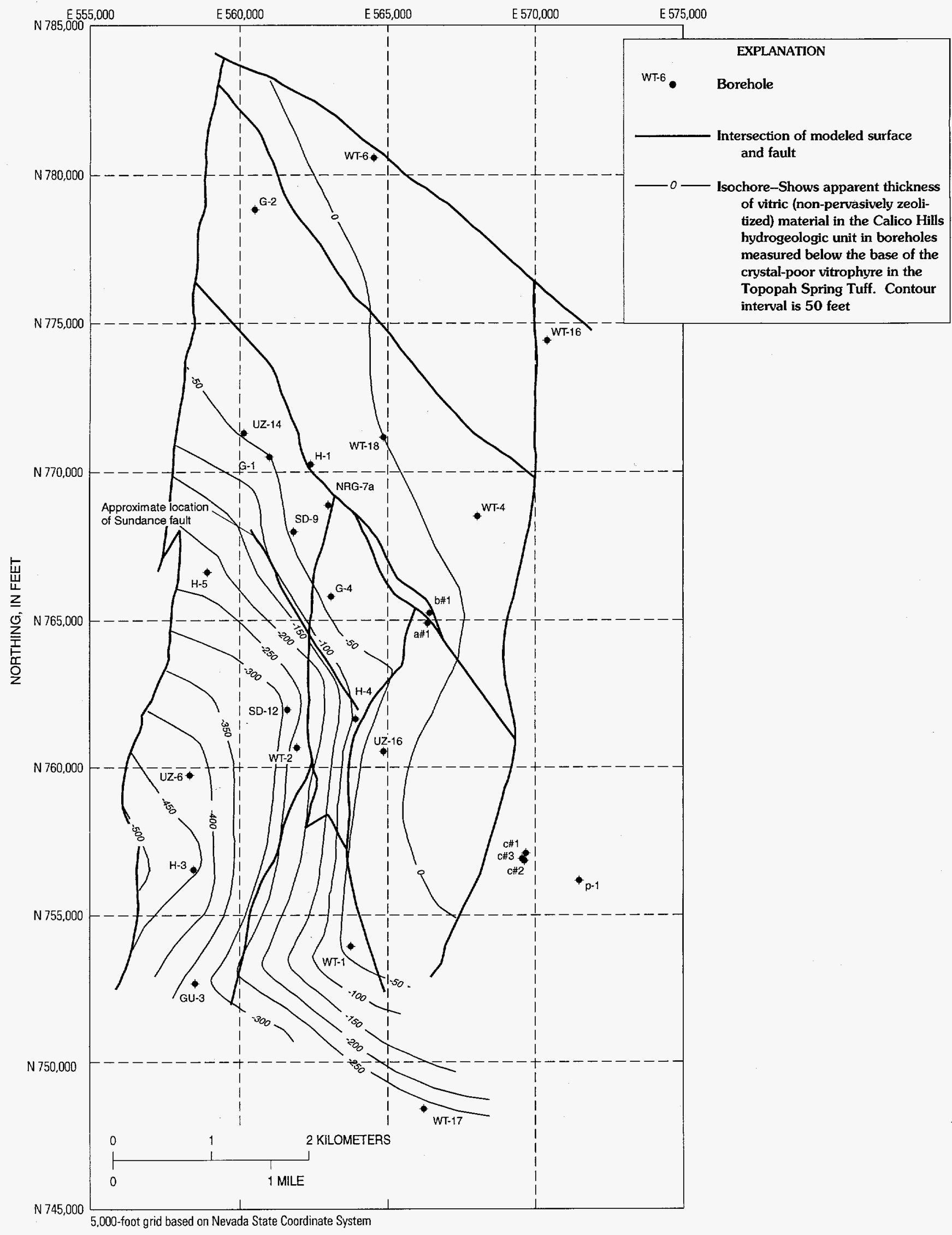

Figure 16. Isochores of vitric material in the Calico Hills nonwelded hydrogeologic unit at Yucca Mountain. 


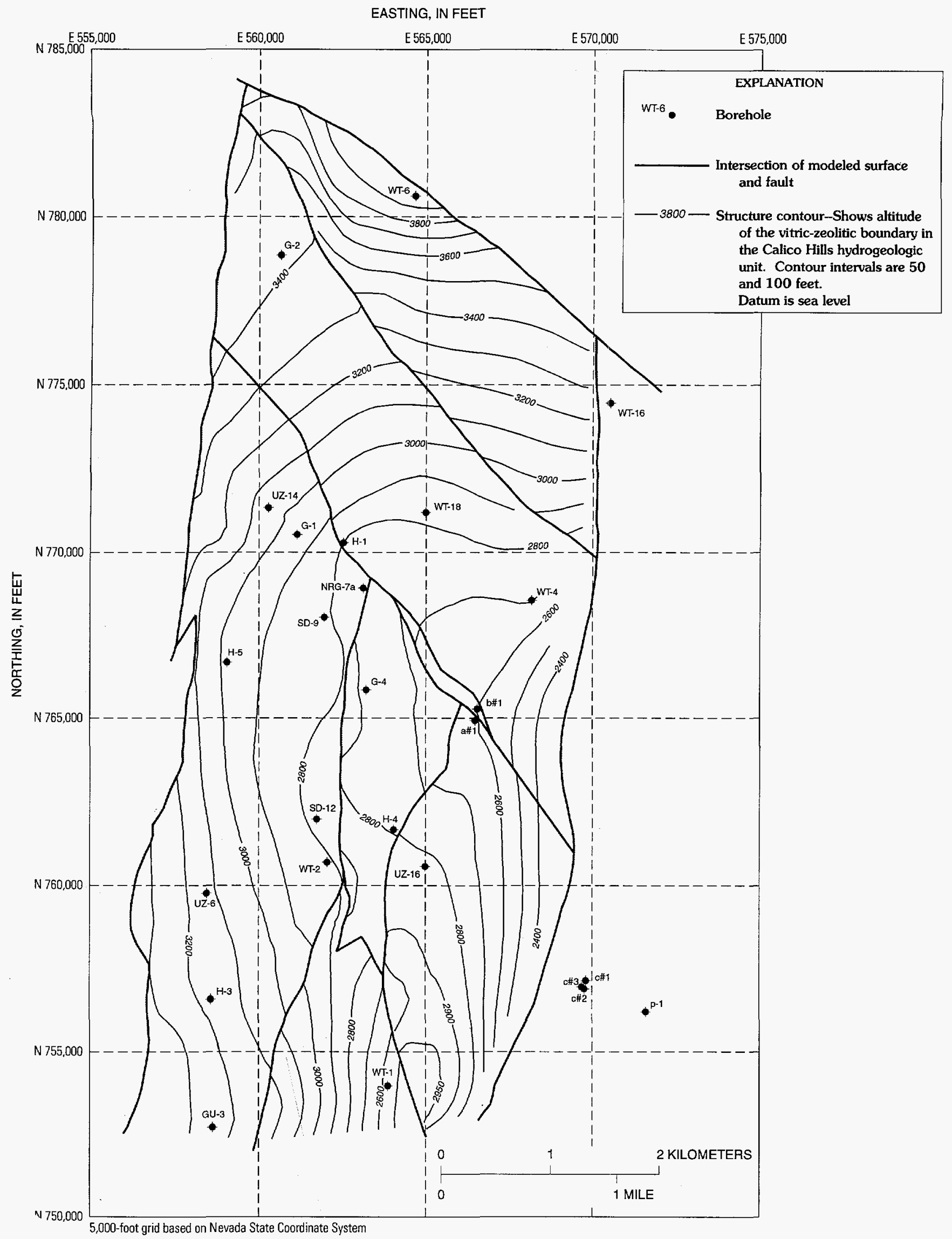

Figure 17. Structure contours of the vitric-zeolitic boundary in the Calico Hills nonwelded hydrogeologic unit at Yucca Mountain. 
western part of the mountain was probably elevated more than the area near Drill Hole Wash. In the northern part of the mountain, well-developed eastward strikes of the lithostratigraphic units probably represent onlap relations with paleotopographic highlands. The close spatial position of the vitriczeolitic boundary with the base of the crystal-poor vitrophyre of the Topopah Spring Tuff indicates that the densely welded rocks might have acted as an effective low-permeability cap for the hydrothermal system. Locally, where the vitric-zeolitic boundary is above the base of the crystal-poor vitrophyre, these rocks were probably below the water table during peak alteration. The noncoplanar geometry probably represents three stages in the geologic evolution of Yucca Mountain: (1) eastward tilting of rocks in a structural block accompanied by minor northward tilting, (2) pervasive zeolitization during peak hydrothermal activity, and (3) continued (or renewed) eastward tilting of the structural block accompanied by minor northward tilting. This scenario implies a structural evolution with periods of deformation interspersed with quiescence and does not require large fluctuations in the water table during peak hydrothermal alteration. Alternatively, the tectonic history of eastward tilting of the structural block accompanied by minor northward tilting could be the same, although not constrained to periodic deformation, and the water table during peak alteration could have been higher with steeper gradients that simply lowered with time to the recent geometry of the water table.

Location of and separation along faults affect the interpretation of the vitric-zeolitic boundary geometry. The Ghost Dance fault system separates the Yucca Crest structural subdomain into the slightly more faulted and steeper dipping lithostratigraphic units on the east from the slightly less faulted and shallower dipping units to the west (W.C. Day, U.S. Geological Survey, written commun., 1995; also see section of this report titled Structural Setting of the North Ramp of the Exploratory Studies. Facility). Lithostratigraphic units and the vitric-zeolitic boundary show a flexure in elevation near borehole SD-9 in a north-south geologic section, and this coincides with the beginning of the southward increase in stratigraphic separation between the base of the vitric densely welded rocks of the Topopah Spring Tuff and the vitric-zeolitic boundary (figs. 9, 16, and 17). The Sundance Fault (fig. 16) would intersect the geologicsection plane just south of the edge of figure 9 and projects obliquely away from the geologic section at approximately N. $20^{\circ}$ W. to N. $40^{\circ}$ W. The Sundance Fault system consists of numerous small, northwesttrending faults, many of which have an apparent southwest-side-up separation (Spengler and others, 1994; C. J. Potter, U.S. Geological Survey, written commun., 1995). Therefore, the Sundance Fault system (1) appears to coincide with the northern end of the southward increase in elevation of rocks toward the maximum elevation along Yucca Crest near $\mathrm{H}-3$ and G-3 and (2) might represent a brittle response to the formation of the flexure in this part of the central block. The relatively sharp increase in thickness of vitric material near the alignments of the Ghost Dance and Sundance Fault systems and the near parallelism of the isochores with the fault systems can be indicators that some faults acted as hydrologic barriers during the main zeolitization event(s) (Buesch and others, 1995). In this scenario, hydrothermal waters could have flowed southward from the Timber Mountain caldera area, reached faults such as the Ghost Dance and Sundance Fault systems, and been diverted around the block that now underlies the southwest area of Yucca Mountain. Hydrogeologic properties of these faults are not known-they could have acted as low-permeability barriers against which waters ponded on the up-flow side, or as high-permeability zones along which water drained to lower aquifers. With either set of properties, the vitric rocks to the south and west of the faults were not affected by zeolitizing waters. Subsequent tectonic activity may have disrupted these apparently fault-related barriers of the middle Miocene, and therefore the hydrologic properties of faults are not necessarily maintained through time. Locally along some faults, the vitric-zeolitic boundary lies at different stratigraphic positions in adjacent structural blocks. This geometry can result where the fault was a hydrologic barrier to flow; but alternatively, this geometry can represent a fault that was active before and after the most intense alteration.

\section{Summary of Stratigraphic Framework}

Lithostratigraphy and the geometry of lithostratigraphic units are fundamental controls on the spatial distribution of the hydrogeologic properties of rocks at Yucca Mountain. Hydrologic properties such as bulk density, porosity, permeability, and saturation are governed by the distribution of volcanic glass and the crystallization or alteration of glass, nonwelded to 
densely welded textures, and fracture characteristics. The mechanisms of eruption (explosive or effusive) and transport (pyroclastic flow or fallout, or lava flow) influence the geometry and type of resulting deposit, and this determines the initial temperature of the deposit that ultimately governs whether (1) the rock can weld, (2) the deposit is composed of volcanic glass or is crystallized to a high-temperature mineral assemblage, or (3) fractures can develop. Mapped geometric relations in the ESF, in boreholes, and in outcrop indicate that fallout tephra that overlie the Topopah Spring Tuff are locally argillic, possibly due to fumarolic activity related to the cooling of the Topopah Spring Tuff. Alteration of glass to clays and zeolites typically occurs at relatively low temperatures in aqueous solutions. Although the basic process of alteration is the same in the PTn and CHn hydrogeologic units, alteration in the PTn appears to be a highly local phenomenon and poorly developed. In contrast, pervasive zeolitization is characteristic of the $\mathrm{CHn}$ through much of the central block. Contacts of lithostratigraphic units closely approximate the major changes in hydrologic properties associated with the four major bedrock hydrogeologic units and most of the proposed subunits; therefore, the lithostratigraphic framework can be used as an effective tool in the modeling of hydrogeology in the unsaturated zone.

Several lithostratigraphic units, which are important to modeling of the unsaturated zone, vary significantly in thickness and orientation near the northwestern extent of the North Ramp of the ESF. The conspicuous northward decrease in thickness of the Topopah Spring Tuff and the shift in orientation from a northerly strike in the south to an easterly strike in the north are interpreted to be results of onlap of the tuff on a paleotopographic highland formed from thick lava flows of the Calico Hills Formation along the northeastern part of the central block. The thickness of the PTn decreases abruptly south of the North Ramp area. The overall thinning is primarily a result of the sharp decrease in thickness of the pyroclastic flow deposits in the Yucca Mountain and Pah Canyon Tuffs and pre-Yucca Mountain Tuff bedded tuffs. The sharp northward decrease in thickness of the Tiva Canyon Tuff and the shift in orientation from a northerly strike in the south to a northeasterly strike in the north are interpreted to be results of onlap of the tuff on a paleotopographic highland formed from thick accumulation of pre-Tiva Canyon Tuff and postTopopah Spring Tuff deposits along the northern part of the central block. Three-dimensional geologic modeling of the vitric-zeolitic boundary indicates the vitric material is typically less than $6 \mathrm{~m}$ thick in most of the northern and eastern areas of the central block, especially near the North Ramp of the ESF. Thick intervals of vitric material in the southwest, as much as $140 \mathrm{~m}$, might result from tilting of structural blocks prior to zeolitization, but the coincident alignment of the sharp increase in thickness aligned with the Ghost Dance and Sundance Faults indicates a possible structural control to the distribution of intense zeolitic alteration of the $\mathrm{CHn}$ hydrogeologic unit within the central block of Yucca Mountain.

\section{Structural Setting of the North Ramp of the Exploratory Studies Facility}

The thick sequence of Miocene volcanic rocks that underlie Yucca Mountain is broken into several east-tilted structural blocks that are bounded by northtrending normal faults (Frizzell and Shulters, 1990; Scott, 1990; Day and others, 1998). The central structural block of Yucca Mountain is bounded by the Solitario Canyon Fault on the west and by the Bow Ridge Fault on the east (fig. 18). Knowledge of several of these faults and important structural relations has been enhanced by excavation of the Exploratory Studies Facility (ESF) tunnel. The ESF bores northwesterly under Azreal Ridge (North Ramp), penetrates the Drill Hole Wash Fault system, and the turns and proceeds southward under Diabolus Ridge (Main Drift) through the central part of the proposed repository area west of the Ghost Dance Fault (figs. 18 and 19).

\section{Setting of Structural Subdomains}

Yucca Mountain is in the Crater Flat tectonic domain Fridrich and Price (1992), which is a unique and internally coherent terrane made up of structural subdomains. The Crater Flat domain contains several coherent structural blocks, or subdomains, which are defined in this report as fault-bound blocks of bedrock that have internally consistent strata dips and consistent styles and orientations of faulting and fracturing that differ from those of adjacent subdomains. Geologic mapping at a scale of 1:6,000 (Day and others, 1998) (fig. 19) delineated two structural subdomains in the North Ramp area west of the Bow Ridge Fault (fig. 18) that have internally consistent structural and stratigraphic characteristics, but between which there are distinct differences (fig. 20). The northern structural block, termed the Azreal Ridge subdomain, is made up of northwest-trending ridges and washes 


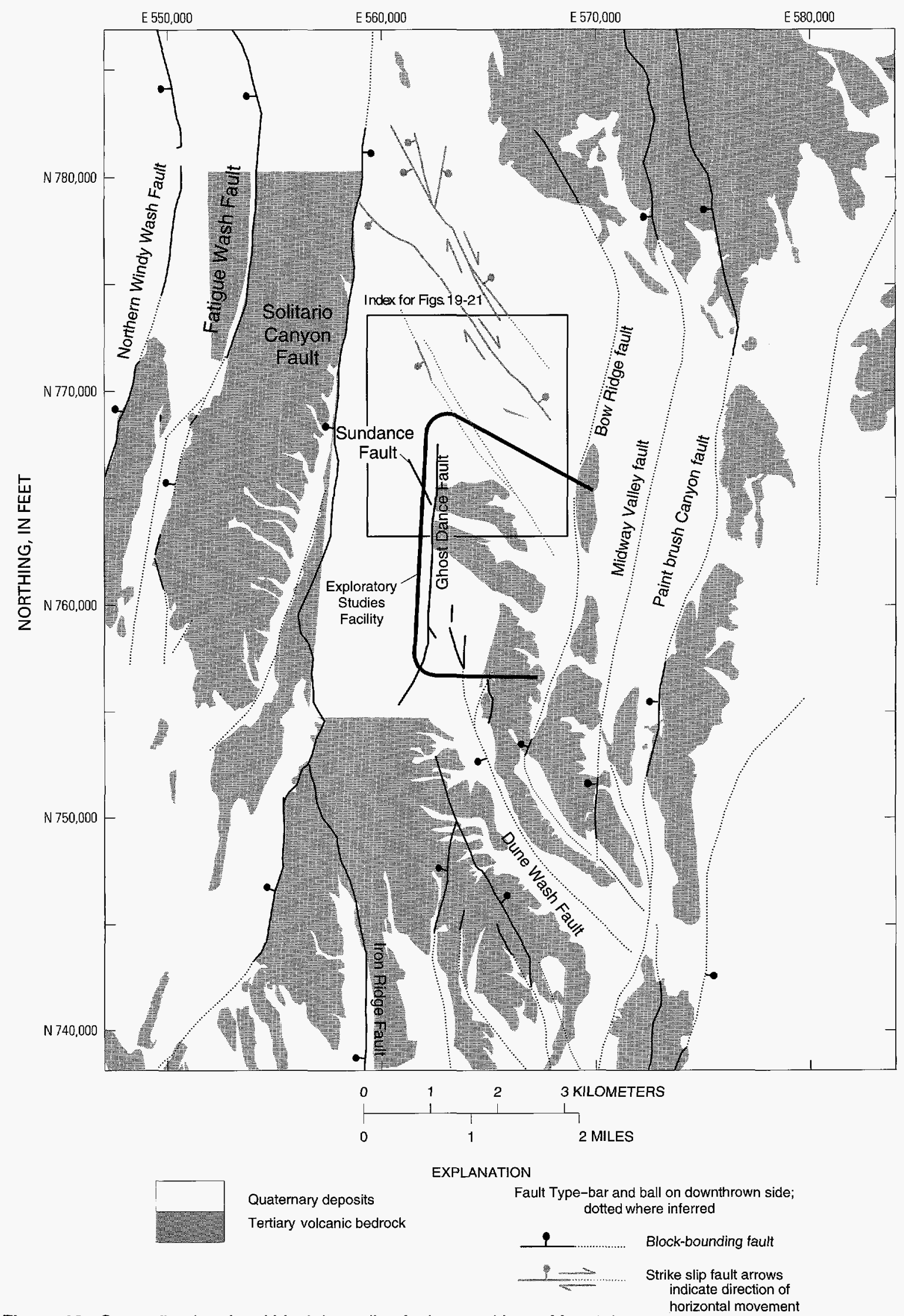

Figure 18. Generalized regional block-bounding faults near Yucca Mountain. 


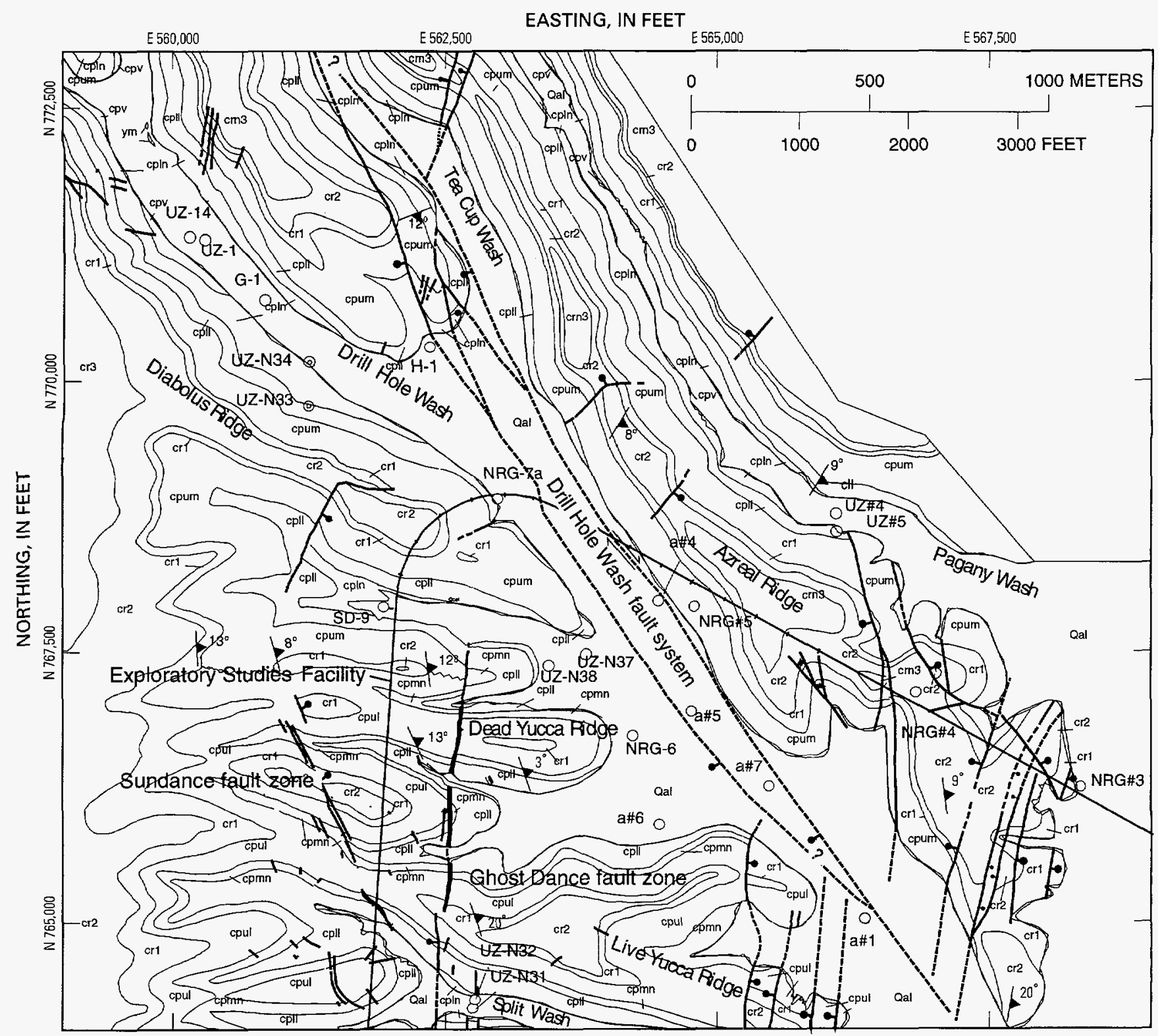

EXPLANATION

\begin{tabular}{|c|c|}
\hline Qa & Quaternary deposits \\
\hline \multicolumn{2}{|r|}{ Tertiary Tiva Canyon Tuff, } \\
\hline \multicolumn{2}{|r|}{ Crystal-Rich Member: } \\
\hline crn3 & pumice-poor subzone \\
\hline $\mathrm{cr} 2$ & mixed pumice subzone \\
\hline cr1 & crystal transition subzone \\
\hline \multicolumn{2}{|r|}{ Crystal-Poor Member: } \\
\hline cpum & $\begin{array}{l}\text { upper lithophysal and middle } \\
\text { nonlithophysal zone-undifferentiated }\end{array}$ \\
\hline cpul & upper lithophysal zone \\
\hline cpmn & middle nonlith ophysal zone \\
\hline cpll & lower lithophysal zone \\
\hline cpln & lower nonlithophysal zone \\
\hline cpv & vitric zone \\
\hline
\end{tabular}

ym Tertiary Yucca Mountain Tuff

Map Symbols

- Contact

†--.. Fault-Dotted where concealed; bar and ball on downthrown side; arrows in direction of horizontal movement

a\#4 Borchole location and designation

$b^{10^{\circ}}$ Strike and dip of compaction foliation

Figure 19. Bedrock geologic map of the North Ramp area of the Exploratory Studies Facility, Yucca Mountain. 


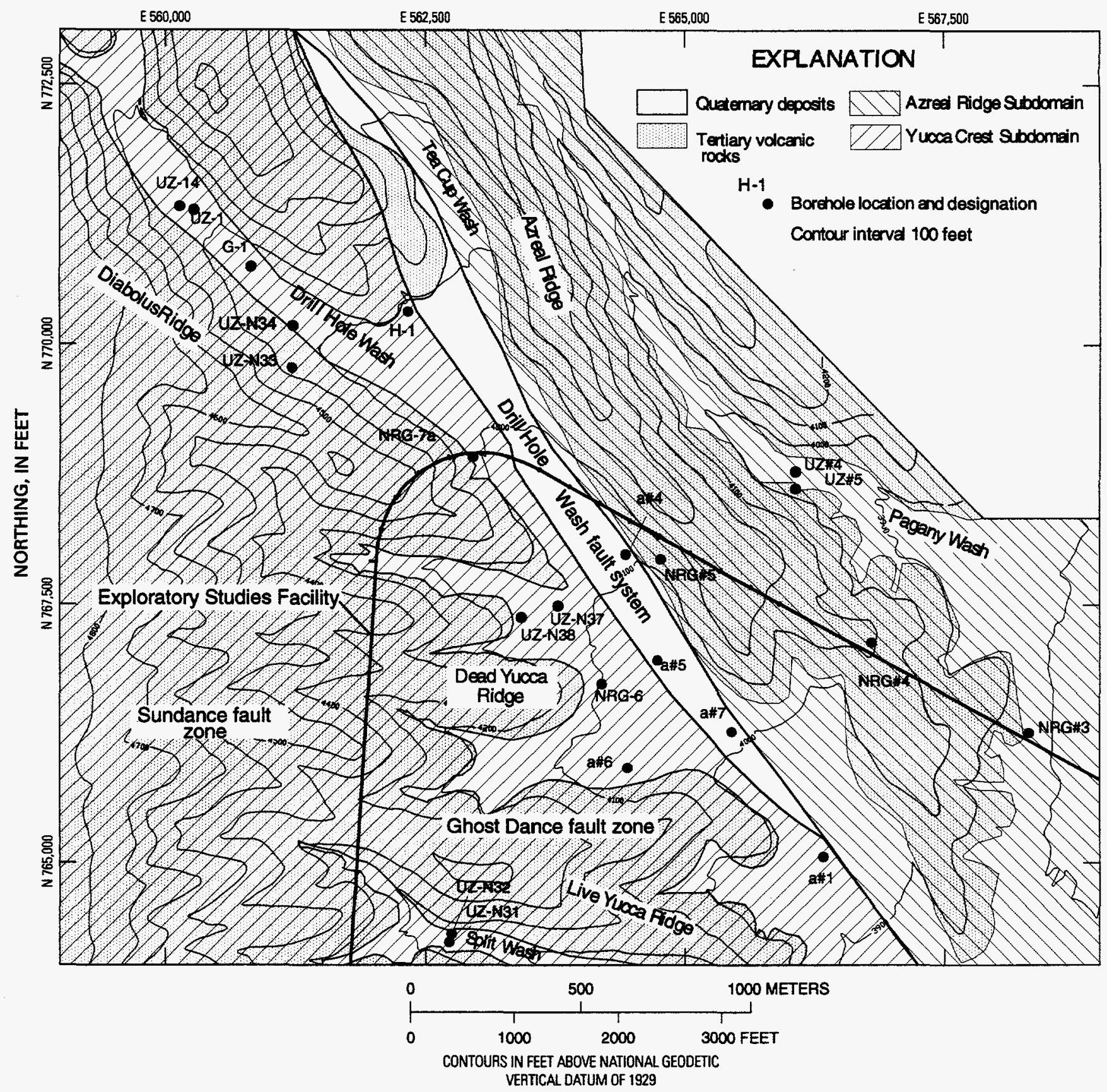

Figure 20. Structural subdomains within the North Ramp area of the Exploratory Studies Facility, Yucca Mountain.

that extend northward from Azreal Ridge to Yucca Wash. The southern structural block is the Yucca Crest subdomain and contains the northern part of the potential repository as well as two dominant fault zones, the Ghost Dance and Sundance Faults. The Drill Hole Wash Fault system separates the Azreal and Yucca Crest subdomains and is made up of two domi- nant northwest-striking faults (fig. 20) that are thought to be kinematically linked.

\section{Azreal Ridge Subdomain}

The Azreal Ridge subdomain is a relatively simple and competent sequence of layered volcanic rocks that strike northeasterly and dip gently to the 
southeast. The Azreal Ridge subdomain abuts the Solitario Canyon Fault on the west and terminates against the Bow Ridge Fault on the east (fig. 18). The dominant faults within the Azreal Ridge subdomain are northwest-trending and steeply dipping and had dextral strike-slip motion, coupled with a southwestside-down dip-slip component (fig. 19). The amount of offset and brecciation associated with these faults is minimal. The Azreal Ridge subdomain (fig. 20) is a structurally coherent block with exposures of the Tiva Canyon Tuff that strike approximately N. $10^{\circ} \mathrm{E}$. to N. $30^{\circ} \mathrm{E}$. and dip gently to the southeast (fig. 19). Bedrock exposures on the southeastern tip of Azreal Ridge exhibit numerous minor north-trending and northwest-trending faults between boreholes NRG\#3 and NRG\#4 (fig. 21). Scott (1990) originally defined the north-trending faults as being part of a northtrending imbricate fault zone. However, recent bedrock geologic mapping (Day and others, 1998) as well as mapping within the ESF (S.C. Beason, written commun., 1995) indicate that the north-trending faults are cut by previously unrecognized northwest-trending normal faults (faults 1 and 2 in fig. 21). The northwest-trending faults commonly have wide fracture and breccia zones at the surface that coalesce downward into narrower fault zones. Vertical horsetailing of the faults is characterized by wide zones of rock breakage with numerous fault splays at the surface that merge into more discrete narrower fault zones at depth. One such fault zone is west of borehole NRG\#4 (fault 3 in fig. 21). As opposed to the numerous minor faults in the eastern part, the western part of the Azreal Ridge subdomain is cut by only a few minor northeasttrending faults that are dominantly downthrown to the west (faults $4-7$ in fig. 21).

\section{Drill Hole Wash Fault System}

The Drill Hole Wash Fault system in the central part of the study area is made up of several fault splays (faults 8-11 in fig. 21), which are interpreted to have been kinematically related (Day and others, 1998). Most of the fault system lies buried beneath Quaternary alluvial deposits in the wash. The main trace and associated strands of the fault zone are exposed only on a small ridge at the intersection of Tea Cup Wash and Drill Hole Wash (faults 8-10 in fig. 21) and in the ESF. Prior to development of the ESF, the subsurface information was limited to surface-based geophysical studies and a few boreholes. These early data led to suggestions that there was a wide zone of strong brecciation and fractured rock beneath the wash. Higher electrical conductance in this zone (Smith and others, 1984, OFR 84-567) implied that Drill Hole Wash was underlain by a major fault zone with a significantly greater degree of fracturing and brecciation than the surrounding rock. Spengler and Rosenbaum (1980) reported shear fractures in borehole a\#4 and fault breccia in a\#5 (fig. 21) and interpreted them to be intercepts of faults associated with a large fault zone. The brecciation identified in the boreholes and inferred from ground-based geophysical studies was interpreted to be evidence for complex faulting beneath the floor of the wash. However, recent exposure of the splays of the Drill Hole Wash Fault zone underground in the ESF has shown that the amount of brecciation and fracturing in rock between the dominant faults (faults 8 and 11 in fig. 21) is minimal and is no greater than in unfaulted areas.

Scott and others (1984) proposed that the Drill Hole Wash Fault was one of several northwesttrending faults (like the faults in Pagany Wash, Sever Wash, and the one inferred in Yucca Wash; see fig. 18) with dominantly right-lateral strike-slip offset in the northeast part of Yucca Mountain. The total offset on most of the faults, including the Drill Hole Wash Fault zone, has been estimated to be minimal, with a dip-slip component (downthrown to the west) of as much as $4 \mathrm{~m}$ coupled with right-lateral horizontal displacement of as much as $43 \mathrm{~m}$ (Spengler and Rosenbaum, 1980; Scott and others, 1984). Recent surface bedrock mapping (fig. 19) confirms the previous estimates of limited vertical motion on the southwestern splay of the Drill Hole Wash Fault system (fault 8 in fig. 21). The northeasternmost splay identified in borehole a\#4 and in the ESF is inferred to be on the northern margin of Drill Hole Wash (fault 11 in fig. 21). A smaller fault exposed in the drill pad cut at NRG\#5 is kinematically related to this splay. The other main splay, which forms the southern margin of the zone, is exposed on the small ridge near borehole $\mathrm{H}-1$ (fault 8 in fig. 21). Surface bedrock mapping has shown that the southern fault (fault 8 in fig. 21) strikes approximately N. $30^{\circ} \mathrm{W}$., dips steeply $80^{\circ}-85^{\circ}$ to the southwest, and is downthrown approximately $10 \mathrm{~m}$ to the west.

Detailed geologic mapping in the ESF has identified two dominant north-to-northwest-trending, southwest-dipping fault splays under Drill Hole Wash. The northeasternmost splay (fault 11 in fig. 21) 


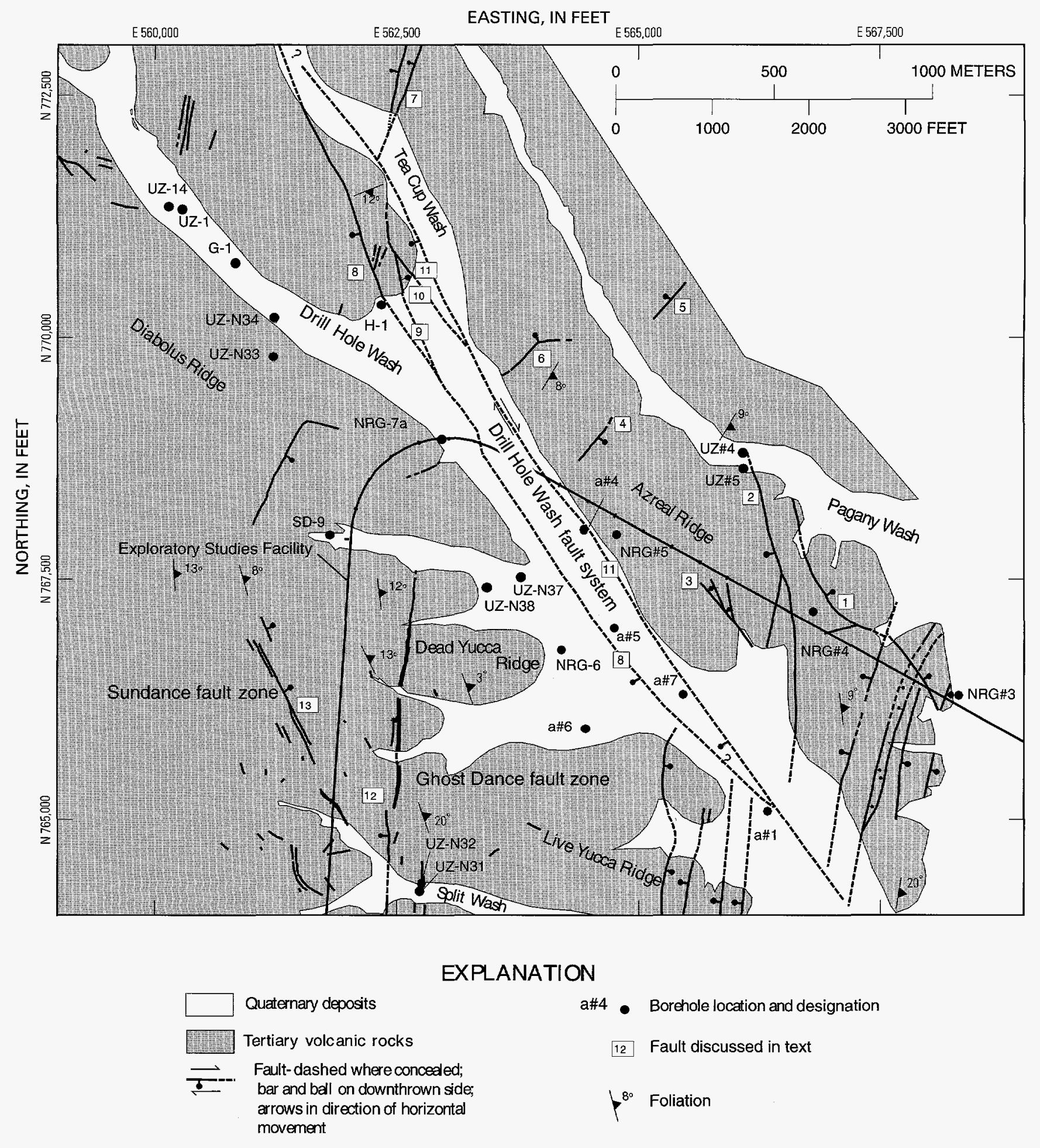

Figure 21. Dominant faults within the North Ramp area of the Exploratory Studies Facility, Yucca Mountain. 
encountered in borehole a\#4 (Spengler and Rosenbaum, 1980) is thought to correlate with two northwest-trending faults encountered in the ESF in the area between stations $19+01 \mathrm{~m}$ and $19+42 \mathrm{~m}$, which are downthrown to the west and have a cumulative 4 to $6 \mathrm{~m}$ down-to-the-southwest vertical displacement. The two fault planes exposed in the ESF have horizontal slickensides, indicating that the latest motion had a strike-slip dextral component of motion. Numerous small-scale faults are present between station 19+01 m, which is the northeasternmost splay (fault 11 in fig. 21), and the southwestern splay exposed at station $22+65 \mathrm{~m}$ in the ESF (fault 8 in fig. 21). The fault at station $22+65 \mathrm{~m}$ projects to the surface beneath the center of Drill Hole Wash. This fault is unique in that it is relatively open, with uncemented breccia, approximately $2 \mathrm{~m}$ wide, and contains rotated blocks up to $1 \mathrm{~m}$ wide. The zone narrows to less than $1 \mathrm{~m}$ wide in the crown of the ESF. The margins of the fault are irregular because of the open nature of the fault. On the southwest side of the ESF North Ramp, the margin of the fault trends between N. $11^{\circ} \mathrm{W}$. and N. $30^{\circ} \mathrm{W}$, and on the northeast side of the North Ramp it trends between N. $0^{\circ} \mathrm{W}$. and N. $15^{\circ} \mathrm{W}$.; both sides dip to the southwest. The fault has an average trend of $\mathrm{N} .10^{\circ} \mathrm{W}$. and dips $80^{\circ}$ southwest. Apparent offset across the zone is at least $1.5 \mathrm{~m}$ down-to-the-southwest. The fault at station $22+65 \mathrm{~m}$ cannot be correlated with the small fault exposed at the surface south of borehole NRG-7a because their trends are perpendicular to each other, which would indicate a geometry not seen in this part of Yucca Mountain.

Fault 8 (fig. 21) exposed at the surface is correlated with the open fault at station $22+65 \mathrm{~m}$ in the ESF. At the surface, fault 8 has a demonstrable vertical down-to-the-southwest offset of approximately $9 \mathrm{~m}$; in the ESF the offset is estimated at $1.5 \mathrm{~m}$ down-to-thesouthwest. The amount of vertical offset is estimated by correlating lithophysal partings in the Topopah Spring Tuff, whereas the strike-slip component of offset is indeterminant because of the lack of a piercing point. Assuming the $1.5 \mathrm{~m}$ of vertical offset is correct, then the disparity documents an upward intensification of deformation associated with the fault. If the displacement was dominantly strike-slip, albeit with a minimal amount of offset (Scott and others, 1984), the upward-increasing deformation may be due to a concealed flower-structure style of faulting, common to strike-slip fault zones (Sylvester, 1988).

Geometric constraints provided by recent threedimensional lithostratigraphic modeling (Buesch, Nelson, and others, 1996) have interpreted a buried "pull-apart" structure beneath Drill Hole Wash to account for apparent discrepancies detected in the boreholes (Buesch and others, 1994). One such graben structure is partially exposed on the northeastern flank of the ridge northwest of borehole $\mathrm{H}-1$ (fig. 21). In contrast to most of the faults in the Drill Hole Wash Fault system, fault 10, which defines the southwestern margin of the graben, is northeastdipping and is downthrown approximately $11 \mathrm{~m}$ to the northeast (fig. 21). It cannot be an extension of the small fault identified in borehole a\#4 on the northern margin of Drill Hole Wash (fault 11 in fig. 21) because fault 10 is downthrown to the east, which is opposite of that observed in the ESF where it crosses fault 11. Fault 10 also is distinct from the two small faults exposed on trend with this fault to the north on the flank of Azreal Ridge, which are downthrown to the west (fault 7 in fig. 21). Therefore, fault 10 (north of borehole $\mathrm{H}-1$ ) forms the southwest margin of a small pull-apart graben structure bounded on the northeast by the main northwest-trending fault inferred on the northern margin beneath Drill Hole Wash (fault 11 in fig. 21).

Buesch and others (1994) recognized the complex nature of faulting in the Drill Hole Wash Fault system when they prepared structural isopach maps to be used in the three-dimensional lithostratigraphic model. For instance, in comparing stratigraphic data from borehole G-1 (south of the Drill Hole Wash Fault system) with that from H-1 (north of one of the main traces of the Drill Hole Wash system; fault 8 in fig. 21), they noted that the base of the Tiva Canyon Tuff drops approximately 5 to $11 \mathrm{~m}$ down-tothe-southwest across the fault. In the stratigraphically lower Topopah Spring Tuff, however, the top of the crystal-rich vitric unit is down-to-the-northeast by about $35 \mathrm{~m}$. This could be accounted for by either stratigraphic variations in the two units, or two distinct phases of motion on the fault, one of which was prior to eruption and deposition of the Tiva Canyon Tuff. Geologic mapping does record such lateral variations in stratigraphic thicknesses in the volcanic units. 


\section{Yucca Crest Subdomain}

The Yucca Crest subdomain lies south of Drill Hole Wash where the volcanic bedrock strikes more northerly, dips to the east, and becomes more dissected with north-trending faults farther to the south (Day and others, 1998). The dominant faults within the subdomain strike north-south and have down-to-thewest dip-slip offset, although there are examples of down-to-the-east dip-slip motion (fig. 19). The northern part of the subdomain is a relatively coherent block of Tiva Canyon Tuff (Day and others, 1998) that dips gently to the east-southeast and strikes to the northeast (N. $5^{\circ}$ E. to N. $15^{\circ}$ E.). To the south near Dead Yucca Ridge (fig. 19) the strike becomes more northerly (N. $0^{\circ}$ E. to N. $10^{\circ}$ E.).

The density of recognizable faults within the Yucca Crest subdomain increases southward, from a relatively sparsely faulted area on Diabolus Ridge to a zone of intense fracturing and faulting on Live Yucca Ridge near the Ghost Dance and Sundance Fault zones (fig. 21). The Ghost Dance Fault zone is the main thoroughgoing fault in the central part of Yucca Crest subdomain (fault 12 in fig. 21). Deformation along the Ghost Dance Fault zone varies from north to south, with a marked transition near Split Wash (Spengler and others, 1993, 1994). The northern terminus of the Ghost Dance Fault was recognized by Scott and Bonk (1984) to be on the southern flank of Diabolus Ridge, in a zone of intense brecciation but with no vertical offset of stratigraphy (figs. 19 and 21). Between Diabolus Ridge and Split Wash, it is a relatively simple 3- to 4-m-wide fault zone downthrown to the west 2 to $3 \mathrm{~m}$. To the south of Split Wash, the fault zone broadens into a complex zone about $152 \mathrm{~m}$ wide with numerous splays that have a cumulative vertical offset of approximately $14 \mathrm{~m}$ on Antler Ridge, which represents one of the areas of maximum brecciation and deformation along the fault trace (south of the area of figure 21; see Spengler and others, 1993).

The Sundance Fault zone (fault 13 in fig. 21) is a northwest-trending, down-to-the-northeast normal fault approximately $450 \mathrm{~m}$ long that cuts both the crystal-rich and crystal-poor members of the Tiva Canyon Tuff with a cumulative northeast-side-down displacement of 1.5 to $11 \mathrm{~m}$ (Potter and others, in press). Numerous small, northwest-trending faults are en echelon with the main trace of the Sundance Fault (fig. 21). These are recognized in the crystal-poor member of the Tiva Canyon Tuff, but seem to diminish in number up section in the units of the crystal-rich member. This stratigraphic control on the distribution of faulting was noted by Potter and others (in press) and led them to propose a model in which the strain associated with the formation of the fault and associated brecciation and fracturing was distributed over a broader area within the crystal-poor member but focused into discrete zones in the overlying crystalrich member. Recent mapping by Potter and others (in press) has shown that displacement on the Sundance Fault decreases to zero on the south flank of Live Yucca Ridge in the area of Split Wash and is partitioned by offset of a series of variously reactivated cooling joints.

\section{Comparison of Fractures in Surface Outcrops from the Azreal Ridge and Yucca Crest Subdomains}

Throckmorton and Verbeek (1995) conducted a regional study of fracture orientation on numerous outcrops throughout Yucca Mountain. They differentiated joints and fractures formed during initial cooling and contraction of the ignimbrite sheets from those that resulted from fracturing of the rock as a result of tectonic processes. From this analysis, they defined several sets of cooling joints and tectonic fractures present throughout Yucca Mountain, which yield a consistent relative timing of formation as well as general orientation (fig. 22). The sequential formation of fracture sets has been determined using mapped termination relations, inferred fracture origin, and fracture-reactivation and offset relations (D.S. Sweetkind, written commun., 1995).

Cooling joints formed prior to tectonic fractures and represent important discontinuities in the bedrock that were available for reactivation during subsequent tectonism. Faults and tectonic fractures commonly exploit preexisting cooling joints because they are weakness planes in the bedrock and have minimal internal cohesion. Two sets of steeply dipping cooling joints are present at most outcrops. The cooling joints strike either to the northwest $(\mathrm{C} 1)$ at about $\mathrm{N} .45^{\circ} \mathrm{W}$. or to the northeast $(\mathrm{C} 2)$ at N. $50^{\circ}$ E. and dip steeply.

Primary cooling joints are more numerous in the Azreal Ridge subdomain than in the Yucca Crest subdomain to the south. However, more of the subsequent tectonic fractures are present in the Yucca Crest subdomain. Both at the surface and in the ESF, the Paintbrush nonwelded hydrogeologic unit (PTn) shows relatively low fracture densities within either 


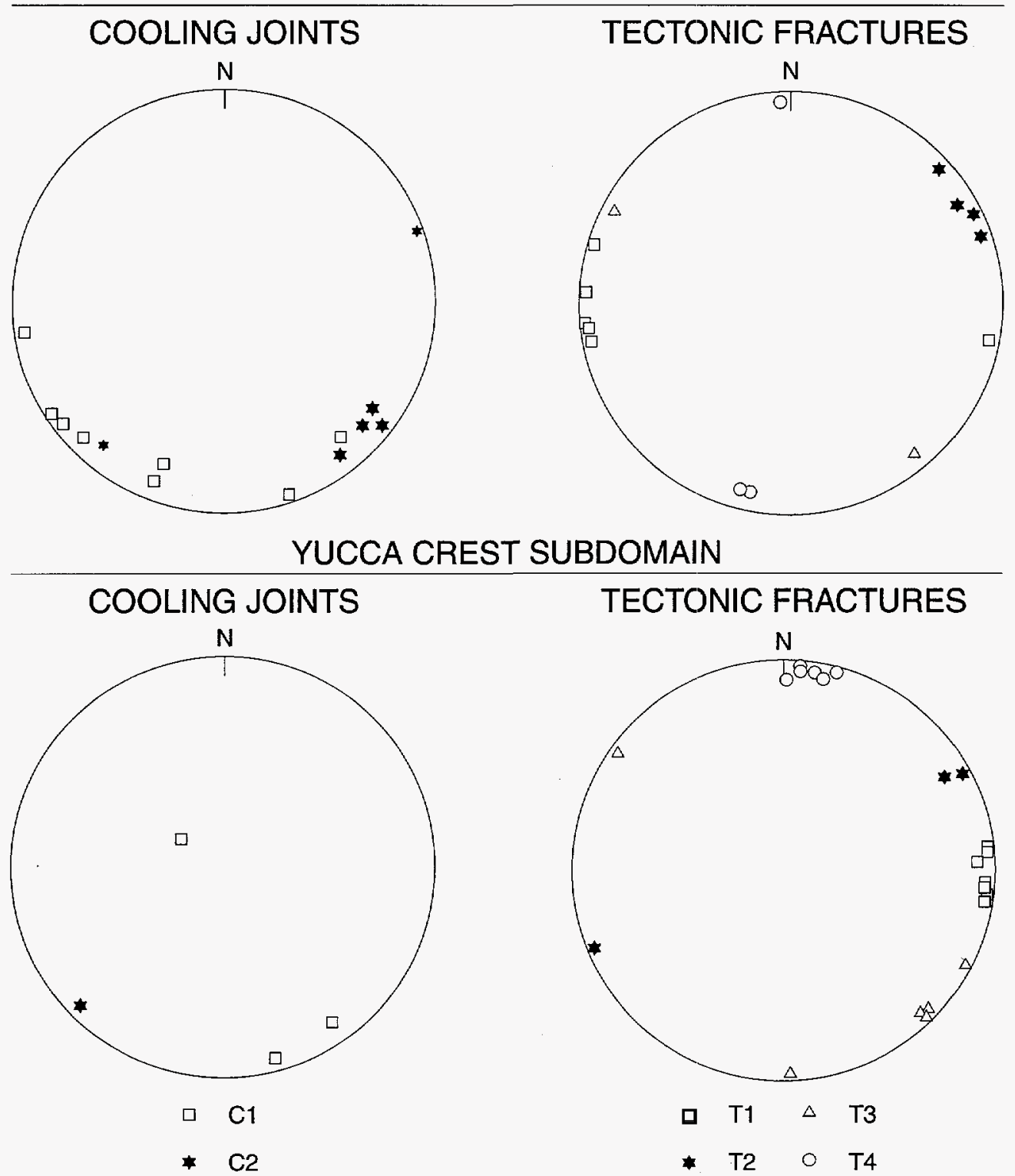

Figure 22. Equal-area lower-hemisphere stereonet of the median value of cooling joints and tectonic-fracture sets from the Azreal Ridge and Yucca Crest structural subdomains (from Throckmorton and Verbeek, 1995).

subdomain. However, because pyroclastic flows within the PTn are more welded in the northern part of the study area compared with their stratigraphic equivalents to the south in the Yucca Crest subdomain, the fracture density and hydrologic interconnectivity of the fracture networks within the PTn unit should be relatively greater in the Azreal Ridge subdomain.

Throckmorton and Verbeek (1995) identified four sets of tectonic fractures within the North Ramp area. All four sets are extensional fractures, with the oldest set of tectonic fractures (T1) striking north- south and dipping nearly vertically (fig. 22). The second set of tectonic fractures (T2) strikes northwest and generally dips steeply to the southwest. A third set of fractures (T3) strikes northeast and also dips nearly vertically. The fourth and youngest set of fractures (T4) strikes east-west and is nearly vertical. These fracture sets record noncoaxial extension through time during Neogene Basin and Range extensional tectonism.

One method of comparing and contrasting the nature of jointing and fracturing between the 
subdomains within the study area is to examine their distribution within each subdomain. Throckmorton and Verbeek's (1995) data allow for partial analysis of the spatial differences of joint and fracture development. They examined outcrops primarily from the upper portion of the Tiva Canyon Tuff, and many of those units examined were in the crystal-rich member. Therefore, generalizations presented here refer primarily to joint and fracture development in the upper part of the Tiva Canyon Tuff, which is important for providing fracture-controlled pathways for surface infiltration of water as well as near-surface pneumatic pathways. Correlation with subsurface joint and fracture data, however, is beyond the scope of this report. This discussion, although limited in scope, provides a comparison of fracture development in the separate structural subdomains primarily as a tool for defining differences in structural elements in the subdomains. The data points in figure 22 are the median values of the cooling joint (table 1 of Throckmorton and Verbeek, 1995) and tectonic fracture sets (table 2 of Throckmorton and Verbeek, 1995) measured in each outcrop station to give a general overview of the differences in distribution of fracture populations between the Azreal Ridge and Yucca Crest subdomains (fig. 20).

Throckmorton and Verbeek (1995) studied nine outcrop stations in the Azreal Ridge subdomain and eight in the Yucca Crest subdomain. The median value from each station within either the Azreal Ridge or Yucca Crest is plotted in figure 22. In comparing the distribution of cooling joints, more cooling joints were recognized by Throckmorton and Verbeek (1995) in the Azreal Ridge subdomain than in the Yucca Crest subdomain. Of the nine stations in the Azreal Ridge subdomain, eight contained $\mathrm{C} 1$ joints and six recorded $\mathrm{C} 2$ joints. In the eight stations in Yucca Crest subdomain that are within this study area, only three contained the $\mathrm{Cl}$ cooling joint set, with one of those being nearly subhorizontal, and only one station contained the $\mathrm{C} 2$ cooling joint set (fig. 22). The conclusions reached for the Yucca Crest subdomain mirror those from Spengler and others (1993), who observed that in 745 fracture measurements taken near the Ghost Dance Fault zone (in the Yucca Crest subdomain) there are two dominant fracture trends of N. $40^{\circ}$ E. and N. $50^{\circ} \mathrm{W}$. Spengler and others (1993) reported that they combined measurements of tectonic and cooling joints, but noted that cooling joints were often reactivated during later tectonism, thereby controlling the orientation of subsequent tectonic fractures.

Throckmorton and Verbeek (1995) noted only minor differences between the two subdomains in the older T1 and T2 fracture sets. Older T1 (north-southtrending) and T2 (northwest-trending) fracture sets are observed in an equal number of outcrop stations in both domains. The $\mathrm{T} 1$ fracture set dips steeply to the east in the Azreal Ridge subdomain but steeply to the west in the Yucca Crest subdomain. The T2 fractures dip consistently to the south in the Azreal Ridge subdomain but dip both to the north and south in the Yucca Crest subdomain.

Throckmorton and Verbeek's data (1995) corroborate the southward intensification of faulting noted between the two subdomains (fig. 21). Although 17 outcrop stations within the entire study area do not allow a statistically rigorous assessment, Throckmorton and Verbeek identified more sites that contain the T3 and T4 fracture sets in the Yucca Crest subdomain than in the Azreal Ridge subdomain (fig. 22).

\section{Fracture Characteristics of the Paintbrush Nonwelded Hydrogeologic Unit}

The hydrologically important Paintbrush nonwelded hydrogeologic unit (PTn) is exposed sporadically in outcrop within the study area and in the ESF. The PTn unit has been defined as the stratigraphic interval of variably welded pyroclastic deposits within the Paintbrush Group between the base of the densely welded part of the Tiva Canyon Tuff and the top of the densely welded unit of the underlying Topopah Spring Tuff (Montazer and Wilson, 1984; Ortiz and others, 1985). This interval includes the crystal-rich member of the Topopah Spring Tuff above the densely welded unit, the Pah Canyon Tuff, the Yucca Mountain Tuff, the vitric unit of the crystalpoor member of the Tiva Canyon Tuff, and interstratified bedded tuffaceous deposits. In contrast to the enclosing, moderately to densely welded, generally devitrified rocks, the PTn unit includes strata with moderate to high porosity and permeability and generally low grain density (Montazer and Wilson, 1984; Ortiz and others, 1985; Rautman and others, 1995). As such, the PTn unit represents the first major subsurface change in lithology and material properties. Subsurface water flow within the welded units of the Paintbrush Group is largely through the fracture 
networks; flow appears to be impeded at the contacts of the PTn unit as a result of capillary barriers created by differences in size between the pore spaces of the PTn matrix and the fracture apertures of the welded units (Montazer and Wilson, 1984; Kwicklis and others, 1994). Fracture networks developed within the PTn unit could affect the anticipated flow paths and increase the vertical flow rates through the PTn. Understanding the controls on PTn fracture-network geometry, density, and connectivity is an integral part of hydrologic and structural investigations at Yucca Mountain.

The number of fracture sets and sequence of fracture formation in the PTn are similar to those documented for the welded units of the Paintbrush Group (D.S. Sweetkind, written commun., 1995; Throckmorton and Verbeek, 1995). A network of cooling joints is developed where pyroclastic flows are welded. This network consists of two orthogonal sets that are steeply dipping and, less frequently, a third subhorizontal set. A younger network of tectonic fractures consists of at least three sets of steeply dipping fractures, the oldest of which are oriented north-south, followed by northwest-trending and finally northeasttrending sets.

The relative expression of the fracture sets within the PTn unit varies considerably with lithology and degree of welding (D.S. Sweetkind, written commun., 1995). Within the welded pyroclastic flows, fracture density and connectivity increase with degree of welding. As the degree of welding increases, the formation of quick-cooling joints is promoted, and the number and size of tectonic fractures increase. Therefore, the fracture density dies out upward and downward from the more welded units in the PTn. Within the nonwelded pyroclastic deposits, fracture development is primarily controlled by lithology. As a general rule, increasing pumice content is correlated to decreasing fracture density. Fracture trace lengths in pumice-rich units are shorter, fewer fractures from each set are present, and there is a greater proportion of blind fracture terminations; many PTn fractures terminate at contacts between zones of contrasting pumice content. Clast size has a lesser role in determining fracture character; but in general, coarser units are not as fractured as fine-grained deposits. Pumicerich units apparently accommodate extensional strains without fracturing, and large lithic clasts appear to interfere with fracture propagation.
As observed at surface exposures, overall fracture density of the PTn unit is low, and fractures are poorly connected within and between PTn lithostratigraphic units. Each of the PTn units appears to have its own fracture network with characteristic fracture spacing, density, and termination style; however, most of the fractures in the PTn section are strata-bound and terminate at welding breaks or lithologic breaks. Fracture density in the welded, crystalpoor, vitric unit of the Tiva Canyon Tuff and in the Yucca Mountain Tuff in surface exposures approaches that documented for the other parts of the Paintbrush Group, but connectivity is poorer. Fracture density and connectivity for surface exposures of the nonwelded and bedded PTn units are much lower than for the welded units. The welding transitions at the top and base of the PTn unit tend to limit fracture connectivity with the welded portions of the Paintbrush Group. In the ESF, PTn exposures have much lower fracture densities than are observed in surface exposures. Nearly all discontinuities are minor faults with dips less than 75 degrees; slickensides indicate almost exclusively dip-slip movement. These planar zones are quite thin, generally less than 4 centimeters (cm). Nearly all of the faults in the PTn, both at the surface and in the ESF, have thin (less than $0.5 \mathrm{~cm}$ ) silica or calcite fillings. These data support the existing hydrologic models of the PTn that assume relatively unfractured rock and little vertical fracture flow through the unit.

Three pyroclastic flows within the PTn unit, the Pah Canyon Tuff, the Yucca Mountain Tuff, and an unnamed flow within the pre-Yucca Mountain bedded tuffs, increase in thickness and degree of welding in the northern part of the Azreal Ridge structural subdomain (Moyer and others, 1995). On the basis of the controls on fracture character discussed previously, significant changes in structural and hydrologic properties of the PTn unit are expected from north to south as a consequence of the depositional extent and degree of welding of the pyroclastic flows. The PTn unit would be expected to be more intensely fractured and to have greater vertical continuity of fractures and possibly greater connectivity with the Tiva Canyon Tuff and Topopah Spring Tuff in the northern part of the Azreal Ridge structural subdomain than in the Yucca Crest structural subdomain. 


\section{Summary of the Structural Setting}

1. The orientation of the welded units of the Tiva Canyon Tuff and underlying PTn units exposed at the surface makes a gradual transition from dominantly northeast-striking north of Drill Hole Wash in the Azreal Ridge area to dominantly north-trending strike directions south of Drill Hole Wash.

2. Faults in the eastern parts of the Azreal and Yucca Crest subdomains related to the imbricate fault zone of Scott (1990) do not project across Drill Hole Wash as depicted by Scott and Bonk (1984). Although individual faults cannot be correlated, the intense faulting that characterizes the imbricate fault zone in the Yucca Crest subdomain steps to the right (eastward) on the northeast side of Drill Hole Wash in the Azreal Ridge subdomain. This is consistent with a rightlateral sense of offset along the Drill Hole Wash Fault system, assuming the development of the north-south-trending imbricate faults preceded development of the Drill Hole Wash system.

3. West of borehole NRG\#5, the Azreal Ridge subdomain becomes structurally coherent and contains only a few northeast-trending faults.

4. As exposed in the ESF, the intensities of faulting and brecciation beneath Drill Hole Wash are much less at depth than at the surface and much less than anticipated, based on previous borehole and surficial geophysical studies. Although offset is minimal, there are several splays of kinematically related northwest-trending faults, two of which define the Drill Hole Wash Fault system. There is a demonstrable decrease in deformation with depth based on the amount of offset on the southwesternmost splay observed in outcrop compared with offset estimated from its exposure in the ESF.

5. The Yucca Crest subdomain contains the Ghost Dance and Sundance Fault zones. The subdomain is structurally coherent in the north in the Diabolus Ridge area but becomes more faulted to the south of Dead Yucca Ridge.

6. Cooling joints and tectonic fractures are preserved in both the Azreal Ridge and Yucca Crest subdomains. The regional distribution of fractures, however, indicates that more of the stations studied in the Azreal Ridge subdomain contain cooling joints than those to the south in the Yucca
Crest subdomain. Both the older T1 (northsouth-oriented) and T2 (northwest-trending) tectonic fractures are present in the Azreal Ridge and Yucca Crest subdomains. However, more of the younger T3 (northeast-trending) and T4 (east-west-trending) tectonic fractures were recorded to the south in the Yucca Crest subdomain.

7. Surface and subsurface exposures of the PTn unit show very low fracture densities. Fracture density is expected to be higher in the northern part of the Azreal Ridge structural subdomain, where pyroclastic flow units within the PTn thicken and become welded.

\section{UNSATURATED ZONE GASEOUS-PHASE (PNEUMATIC) SYSTEM}

Fluid flow in the unsaturated zone and the properties that control fluid flow are presented in two major sections in this report. This section addresses the gaseous-phase, or pneumatic, system. A subsequent section of the report addresses the aqueous-phase, or hydrologic, system.

\section{Overview of the Pneumatic System}

Gas and water-vapor movement through the unsaturated zone is driven by changes in barometric pressure, temperature-induced density differences, and wind effects. Changes in barometric pressure at the land surface result in corresponding changes in pneumatic pressure in the unsaturated subsurface. This corresponding pressure change in the subsurface commonly is amplitude attenuated and time lagged relative to the pressure change at the surface. The attenuation and lag are functions of the air permeability and the associated pneumatic diffusivity of the rock material. Temperature-induced density effects are significant only in hilly terrain and are dominated by drier, cooler air entering along hillsides and moving through the subsurface. This air becomes geothermally heated as it moves through the rock and eventually can move vertically upward to exhaust along hillcrests. Wind effects are significant only in hilly terrain and are due to a drag effect along hillsides and a lift effect along hillcrests. Wind blowing against the side of the hill generally causes increased pressure that 
allows air to flow into the rock. Wind blowing over the crest of the hill generally causes lower pressure that allows air to flow out of the rock.

This report focuses on data pertaining to the effects of barometric pressure changes and corresponding pressure changes in the subsurface. In the vicinity of the North Ramp of the ESF, no data have been collected to assess the effects of atmospheric temperature or wind on gas movement in the unsaturated zone. Although the predominant wind direction at Yucca Mountain is from the southeast, data collected by the National Weather Service indicate that the stronger winds are generally from the west or northwest. Hence, most of the area discussed in this report is sheltered from the stronger winds that might affect gas movement in the unsaturated zone. Exceptions within the North Ramp area might be parts of Azreal Ridge and Little Prow (fig. 5).

The subsurface-pressure response to surface barometric changes is dominated by the bulk pneumatic diffusivity of the layers of rock present at a given location. Consequently, the subsurface responses are controlled by the distribution and interconnectedness of fractures, the presence of faults and their capacity to conduct gas and vapor, and the moisture content and matrix permeability of the rock units themselves. Specific aspects of the pneumatic system discussed in this report include the ability of the Paintbrush nonwelded hydrogeologic unit, vitric units, and perched-water zones to act as impediments to the propagation of surface barometric-pressure changes and thus act as impediments to gas and vapor movement.

Lithostratigraphic symbols and nomenclature from table 2 that are used throughout the remainder of this report to describe and interpret subsurface data are shown in figure 23. Figures 24,25 , and 26 show fracture density (in number of fractures per $3.05 \mathrm{~m}$ of core) and core recovery (in percent missing) data for boreholes UZ-14, SD-9, NRG-7a, NRG-6, NRG\#5, and NRG\#4. The values of fracture density are the sum of natural and indeterminate fractures; coringinduced fractures are not included in these values. For borehole UZ-14, the fracture-density data are from the YMP Sample Management Facility composite borehole $\log$, except for the interval from $213 \mathrm{~m}$ to $259 \mathrm{~m}$, which are from the Sandia National LaboratoriesAgapito and Associates geology and rock-structure $\log$. For borehole SD-9, the fracture-density data are from the YMP Sample Management Facility composite borehole log. For boreholes NRG-7a, NRG\#5, and NRG\#4, the fracture-density data are from the Sandia National Laboratories-Agapito and Associates geology and rock-structure logs.

The fracture-density data are presented here to support later discussions of pneumatic, water-potential, and perched-water data. Data from each borehole generally indicate similar characteristics that include (1) high fracture density near the contacts between vitric units (both crystal-rich and crystal-poor) and nonlithophysal units, (2) relatively higher fracture density within the nonlithophysal units as compared to the lithophysal units, (3) relatively lower fracture density within the Paintbrush nonwelded hydrogeologic unit (PTn), and (4) very low fracture density within the Calico Hills Formation and the Prow Pass and Bullfrog Tuffs of the Crater Flat Group. Specific features relevant to fracture densities and distribution within individual boreholes are discussed in later sections of this report.

Percent core recovery information is presented in these figures to acknowledge the limitation inherent in using these data for detailed analyses. Because the fracture-density data have not been interpolated or adjusted to account for the lack of core recovery, the numerical value of fractures per 3-m interval cannot be used as an accurate representation of in-situ fracture density. The consistent trends, however, appear to be representative of actual conditions. Core recovery can be affected by many phenomena, such as high fracture density resulting in broken rock, or a partial intersection of lithophysal cavities resulting in broken rock or small sections where no rock is present; core recovery also might be affected by the coring technology used. Core recovery generally was poorest through the lithophysal units, which likely is because of the presence of the lithophysal cavities themselves.

\section{Characterization of the Pneumatic System}

In the sections that follow, results of major studies designed to characterize the pneumatic system in the unsaturated zone are described. The major topics discussed are (1) pneumatic properties determined from analysis of rock cores; (2) in-situ, interactive, pneumatic testing in boreholes, principally airpermeability testing; (3) in-situ monitoring of pneumatic pressure in boreholes; and (4) gaseous-phase chemistry. 


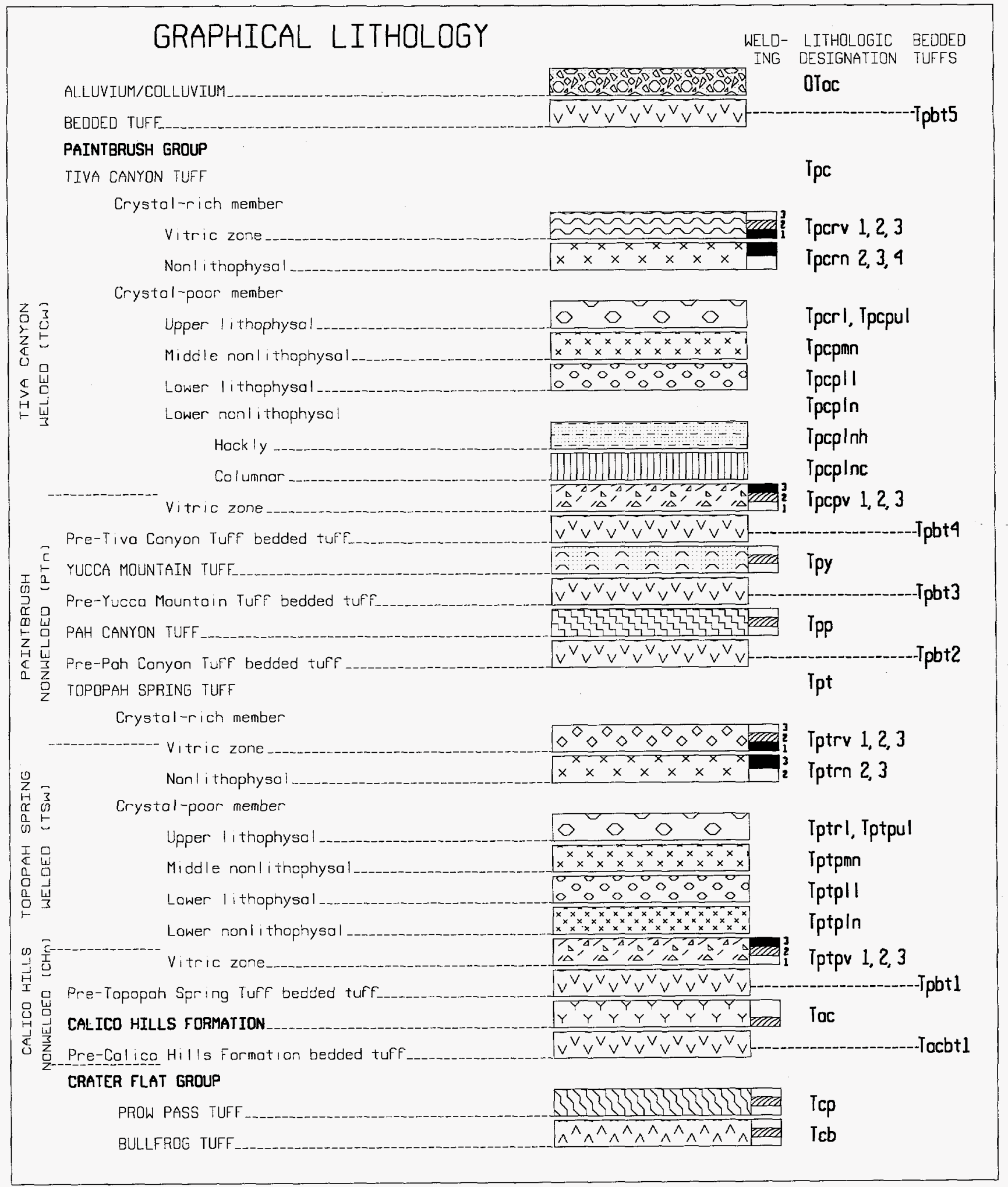

Figure 23. Lithostratigraphic symbols and nomenclature for lithostratigraphic and hydrogeologic units at Yucca Mountain. Clear boxes under welding indicate nonwelded; diagonally striped boxes indicate moderately welded; and filled boxes indicate densely welded. 

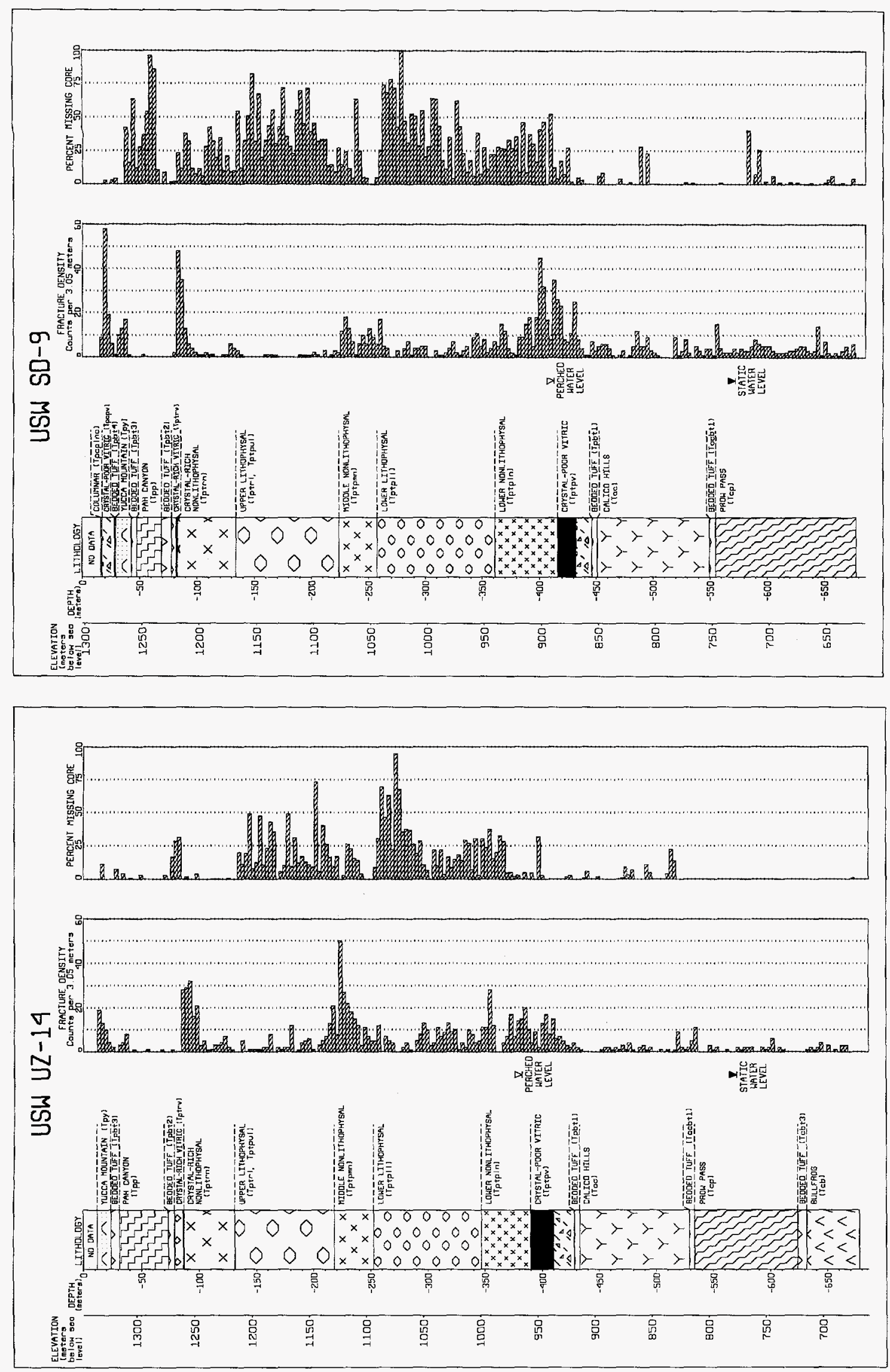

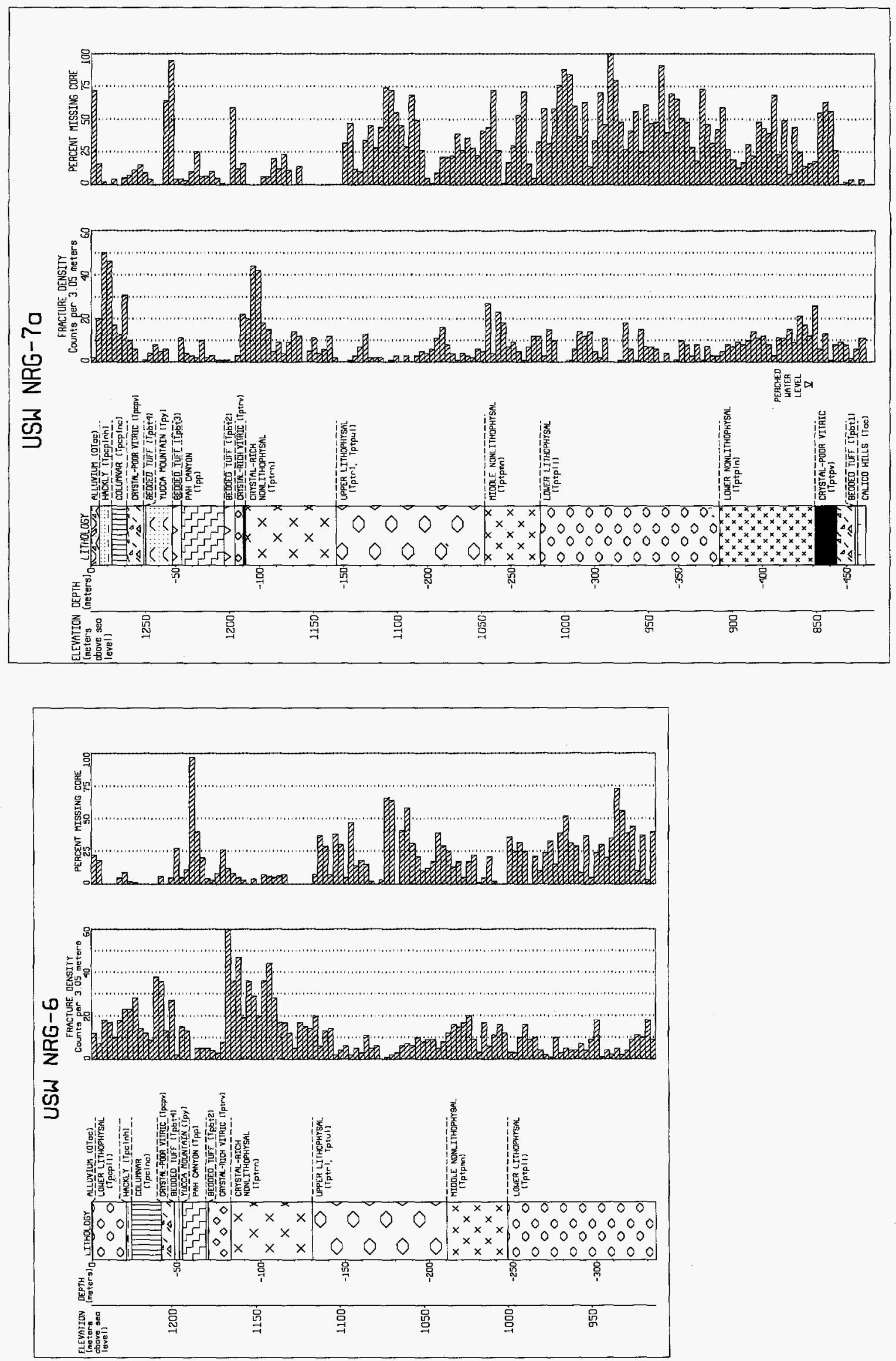

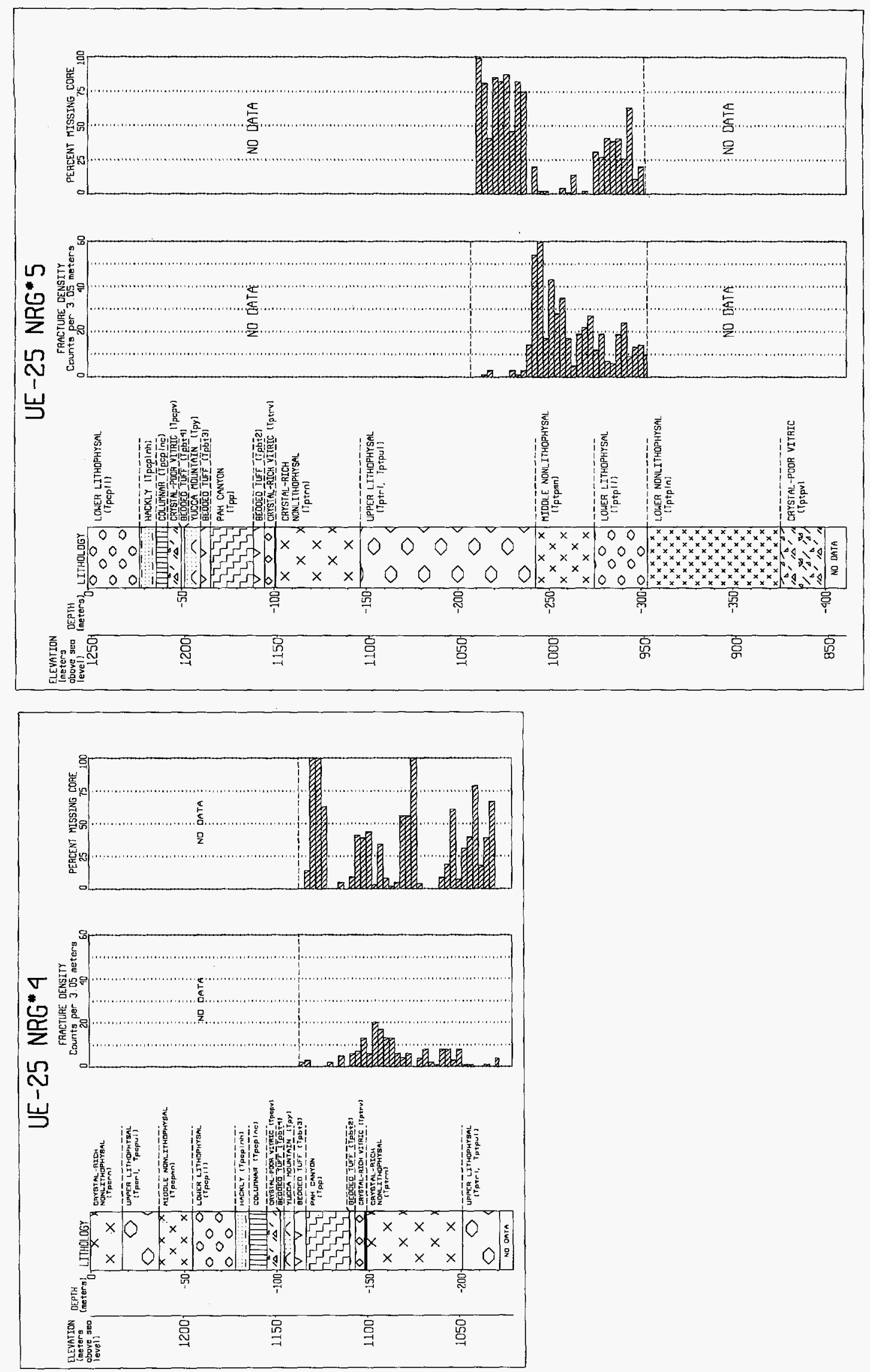


\section{Pneumatic Properties Determined from Analysis of} Rock Cores

Large-scale pneumatic testing, such as that discussed in later sections of this report (In-Situ Pneumatic Tests of Boreholes and Results of In-Situ Pneumatic Monitoring in Boreholes), encompasses mechanisms and processes acting at a scale that involves fractures, faults, and air-filled matrix porosity. The contribution of the matrix of the tuff units at Yucca Mountain to bulk air permeability depends on the degree of fracturing in any given rock unit. If fractures are present in a rock with relatively low matrix permeability, generally there will be little or no influence of the matrix flow pathways on the resulting bulk permeability. If bulk air-permeability measurements are higher than those measured for the rock matrix, it can be inferred that flow was through fractures. To understand the pneumatic properties of the rock matrix, core samples are used for laboratory measurements of air permeability. Permeability through the rock matrix is a function of the interconnected pores, pore size, microfractures, and products from secondary alteration that fill pore channels or throats. Laboratory measurements can be done at various water contents to simulate field conditions. Instead of air-permeability measurements, saturated hydraulic conductivity can be measured and, accounting for the properties of water, can be converted to permeability that, in theory, describes only the properties of the media, not the fluid. Although the values of water permeability do not necessarily coincide with those of air permeability, these measurements can be used to infer relative differences between lithologic units and can provide a baseline understanding of the potential for pneumatic flow through the matrix.

Laboratory measurements of air permeability were made on $2.5-\mathrm{cm}$-diameter core plugs prepared from samples obtained from horizontal boreholes RBT1, RBT2, and RBT3 located in the Upper Tiva Canyon Alcove (Alcove 1, fig. 5) in the ESF in the densely welded, crystal-poor upper lithophysal unit of the Tiva Canyon Tuff (Tpcpul). Hydrologic properties also were measured on the core plugs, using the methodology described in Flint and others (1996). Despite the uniformity of the porosity profiles for the samples from the three boreholes, each about $30 \mathrm{~m}$ in length (fig. 27), saturation values are scattered from about 0.35 to 0.90 , with most values less than 0.75 . Although some of this scatter is due to drying during sample handling and drilling with air, most of the variation probably is due to the high fracture permeability to air of these rocks, which are close to the land surface.

Air permeability for the three boreholes (fig. 28) shows a narrow range that relates fairly linearly to porosity, which has a mean of 0.12 for the three boreholes. The arithmetic mean air permeability for the three boreholes is $1.5 \times 10^{-16}$ square meters $\left(\mathrm{m}^{2}\right)$ for all 11 samples and $4.7 \times 10^{-17} \mathrm{~m}^{2}$ when the "outlier" from RBT3 is excluded. The second mean value is reasonably close to the water permeability of $8.57 \times 10^{-18} \mathrm{~m}^{2}$ measured on a sample in the same lithologic unit (located in borehole $\mathrm{N}-27$ ) that has a similar porosity of 0.115 . The similarity indicates that the water permeability values of welded tuffs are a useful indicator of air permeability.

Samples were taken from boreholes drilled in the North Ramp area in 1983 and 1984: UZ\#4 and UZ\#5 located in Pagany Wash, G-1 in upper Drill Hole Wash, and boreholes a\#1, a\#4, and a\#6 in lower Drill Hole Wash. All samples and methodologies are described in Flint and Flint (1990). (Because these analyses were performed prior to implementation of the approved USGS YMP quality-assurance program, the derived results and conclusions, although scientifically valid, are non-Q.) Slip-corrected air permeability (Klinkenberg, 1941), water permeability, and physical properties were measured on all nonwelded core samples. The relation between log of air permeability and porosity (fig. 29) shows a distribution of permeabilities from $3.0 \times 10^{-13} \mathrm{~m}^{2}$ to less than $2.0 \times 10^{-17} \mathrm{~m}^{2}$. The Calico Hills samples from borehole G-1 are lower in permeability, approximately $2.5 \times 10^{-17} \mathrm{~m}^{2}$, and the samples from the nonwelded PTn average about $3.0 \times 10^{-14} \mathrm{~m}^{2}$. When compared to water permeabilities measured on the same samples (fig. 30), all samples have lower permeabilities to water than to air. One-half of the Calico Hills samples and four of the PTn samples deviate significantly, possibly indicating interaction between the water and perhaps alteration materials (clays or zeolites) that do not occur with air. Additional measurements of water permeability are described in the section of this reporttitled Correlation of Hydrologic Properties with Physical Lithologic Properties.

In summary, measurements of permeability on core samples describe the matrix properties only and are functions of interconnected pores, pore size, microfractures in densely welded vitrophyres, and of 


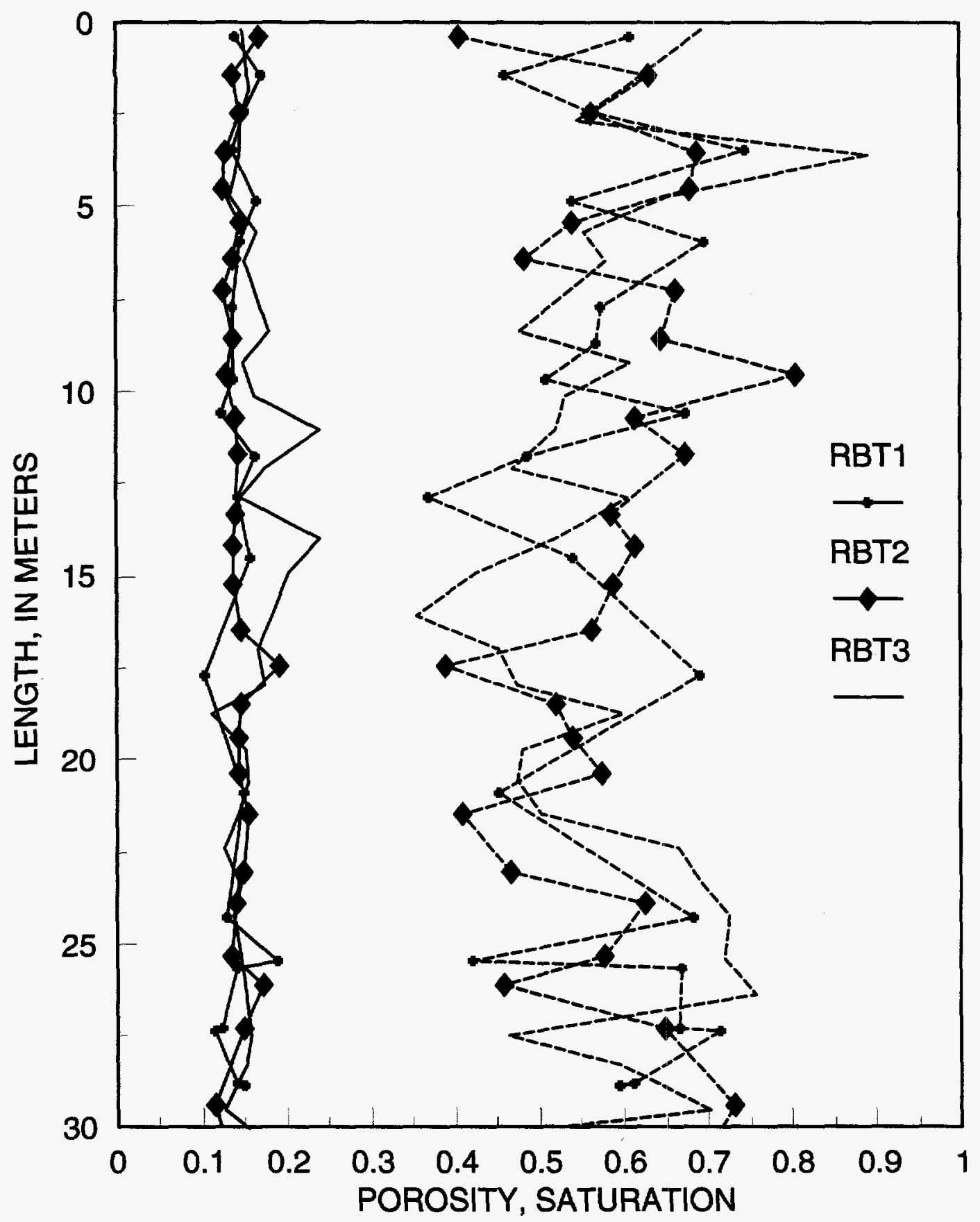

Figure 27. Porosity and relative saturation for samples from three radial boreholes in Alcove 1 in the Exploratory Studies Facility.

secondary alteration products that fill pore channels or throats. Water-permeability measurements were always lower than air-permeability measurements yet can represent the relative differences between rocks units, except where there are large degrees of alteration such as in the zeolitized rocks below the
Topopah Spring Tuff. In general, the core-scale measurements of either air or water permeability adequately describe the permeability of the matrix of the various lithologic units and provide lower bounds for analyses of bulk-permeability measurements from borehole tests. 


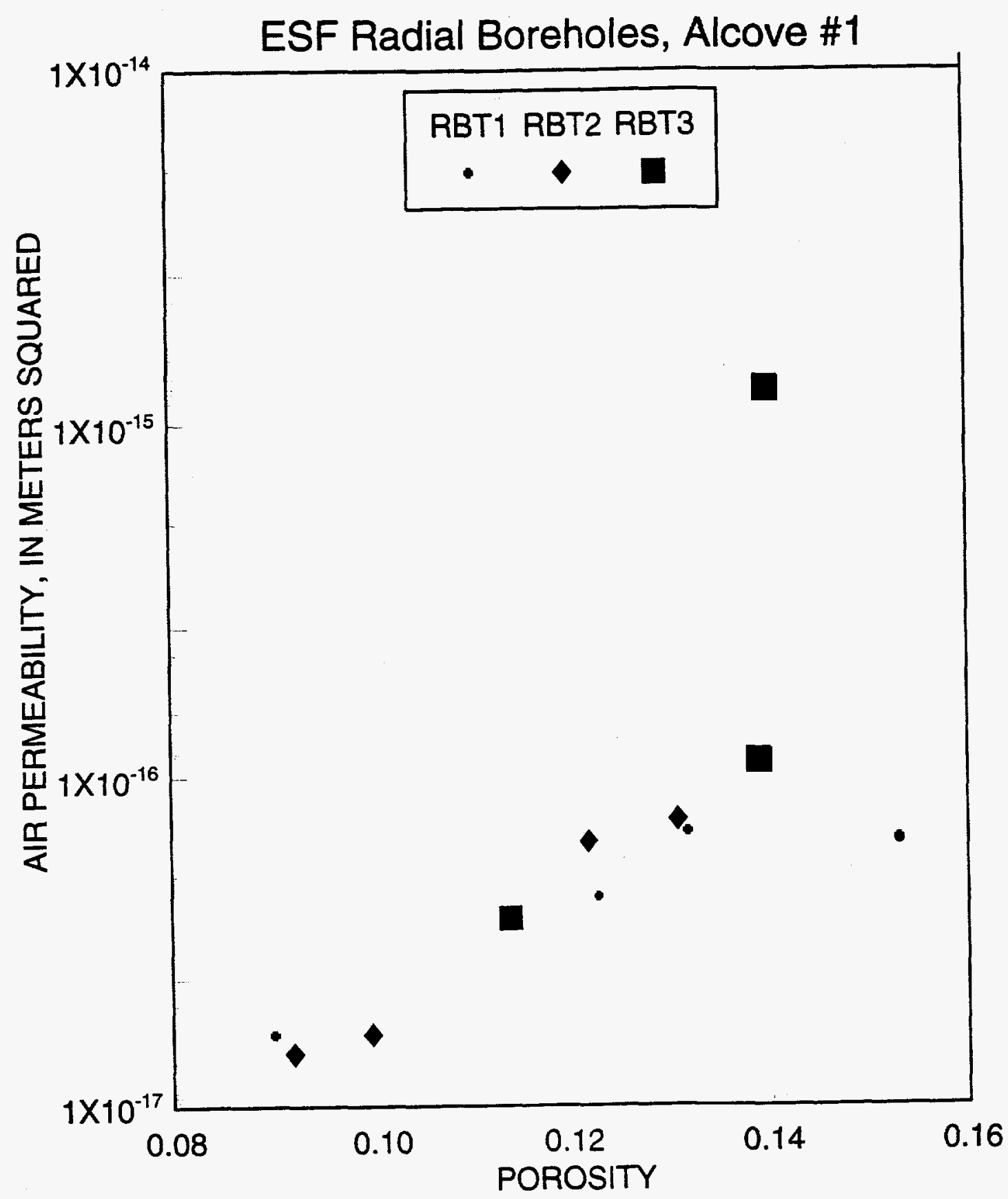

Figure 28. Porosity and air permeability for three radial boreholes in Alcove 1 in the Exploratory Studies Facility.

\section{In-Situ Pneumatic Testing of Boreholes}

The purpose of conducting pneumatic tests (air injection) in the surface-based vertical boreholes at Yucca Mountain is to quantify the in-situ air permeability of the unsaturated tuff. Laboratory permeability testing by Flint and Flint (1990) and Anderson (1994) have provided estimates of the matrix permeability values. The goal of the in-situ testing is to quantify the fracture-permeability values. The permeability of these tuffs, combined with the pneumatic and hydraulic gradients, controls the movement of all fluids in Yucca Mountain. This includes the potential transmission of water from the surface downward to the repository horizon and the movement of gas, including water vapor, from the repository horizon to the surface. Variations in the tuff permeability can 


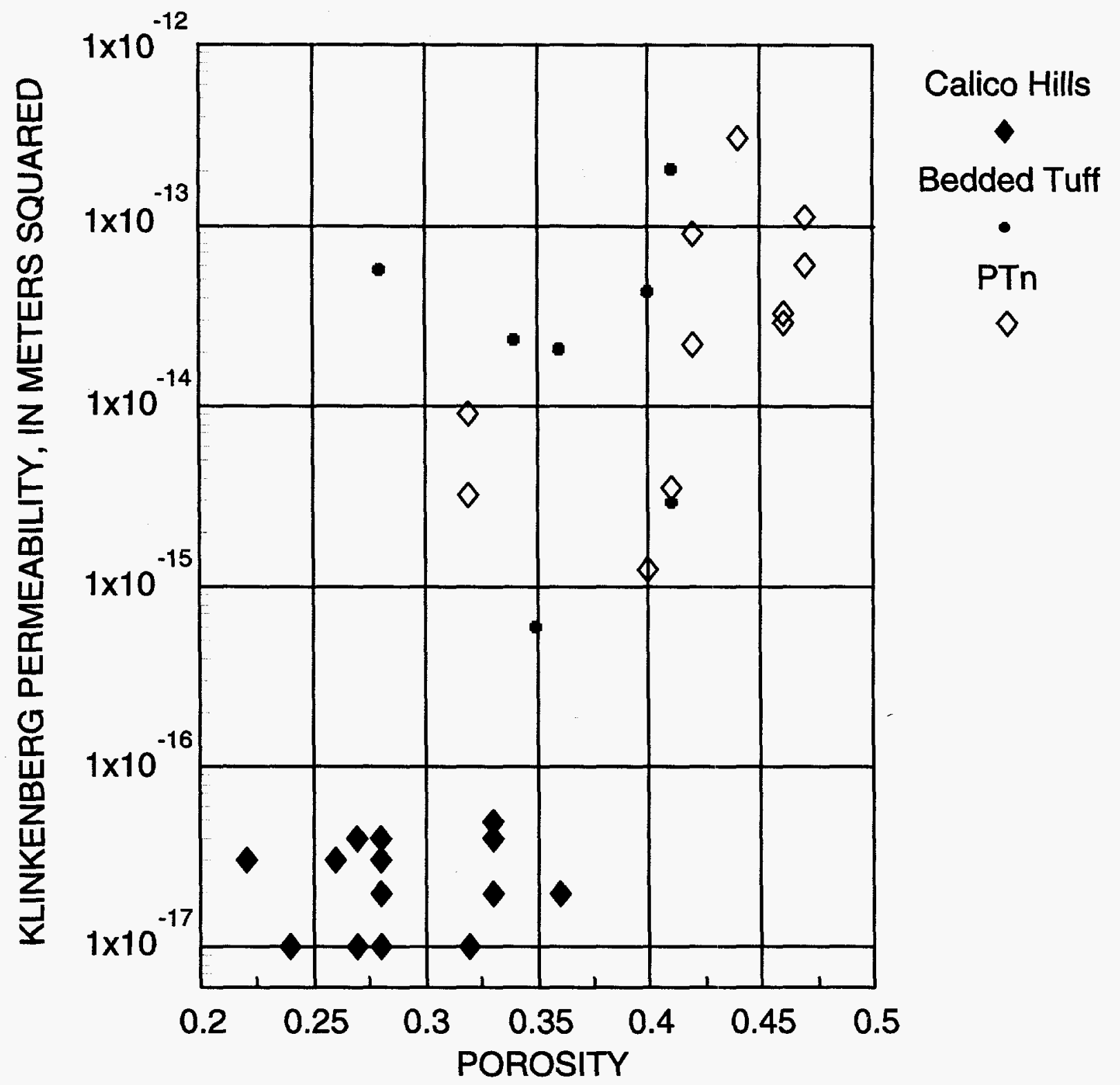

Figure 29. Air permeability corrected for Klinkenberg effects relative to porosity for nonwelded and bedded samples from boreholes in the North Ramp area.

result in perched-water zones, preferential pathways, and capillary barriers. These variations are evident between stratigraphic units and within individual stratigraphic units.

\section{Pneumatic Testing Methods}

The surface-based air-permeability testing equipment consists of state-of-the-art hydraulic, pneumatic, and electrical systems that allow the installation of pneumatic packers to isolate selected test intervals in the boreholes. Pneumatic testing (air injection) is then performed on the isolated test interval (see fig. 31).

The four packers are assembled end to end, connected by aluminum pipe, forming a packer assembly with three intervals between the four packers. Each of the intervals contains a pressure transducer for measuring absolute pressure and a thermistor for measuring temperature. The middle airinjection interval is the test interval. The two end intervals are called guard intervals. The packer system is connected to the surface with a tubing bundle that 


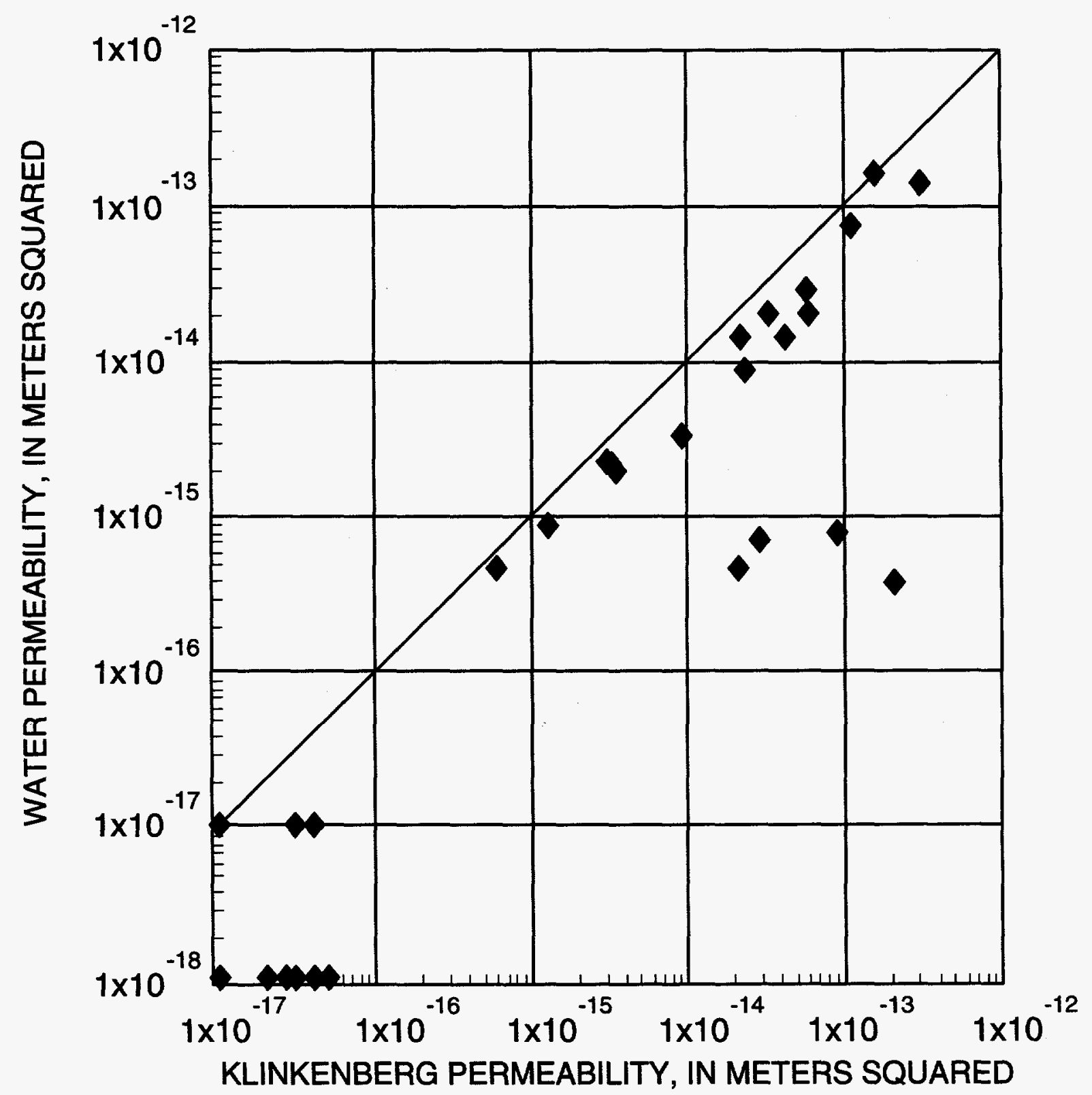

Figure 30. Air permeability corrected for Klinkenberg effects relative to water permeability for nonwelded and bedded samples from boreholes in the North Ramp area.

contains (1) electrical cable for powering and monitoring the instruments, (2) nylon tubing for inflation of the packers and injection of air, and (3) a steel cable to support the weight of the packers and tubing bundle. The packer assembly is lowered and raised in the borehole with a surface-mounted hydraulic winch. The instruments are powered and monitored and the data are recorded by data loggers at the surface. When a test interval is located, the packer assembly is lowered to the selected interval, and all four packers are inflated. Air is then injected downhole into the test interval at a constant flow rate of 1.0 to $1,500.0$ standard liters per minute (slpm). The injected air causes pressure and temperature responses in the test and guard intervals. The data from the pressure transducer and thermistor are then converted into engineering units of pressure and temperature. The pressure and temperature responses are used to calculate the permeability of the test interval. The purpose of the guard intervals is to monitor for leakage around the packers isolating the test interval. 


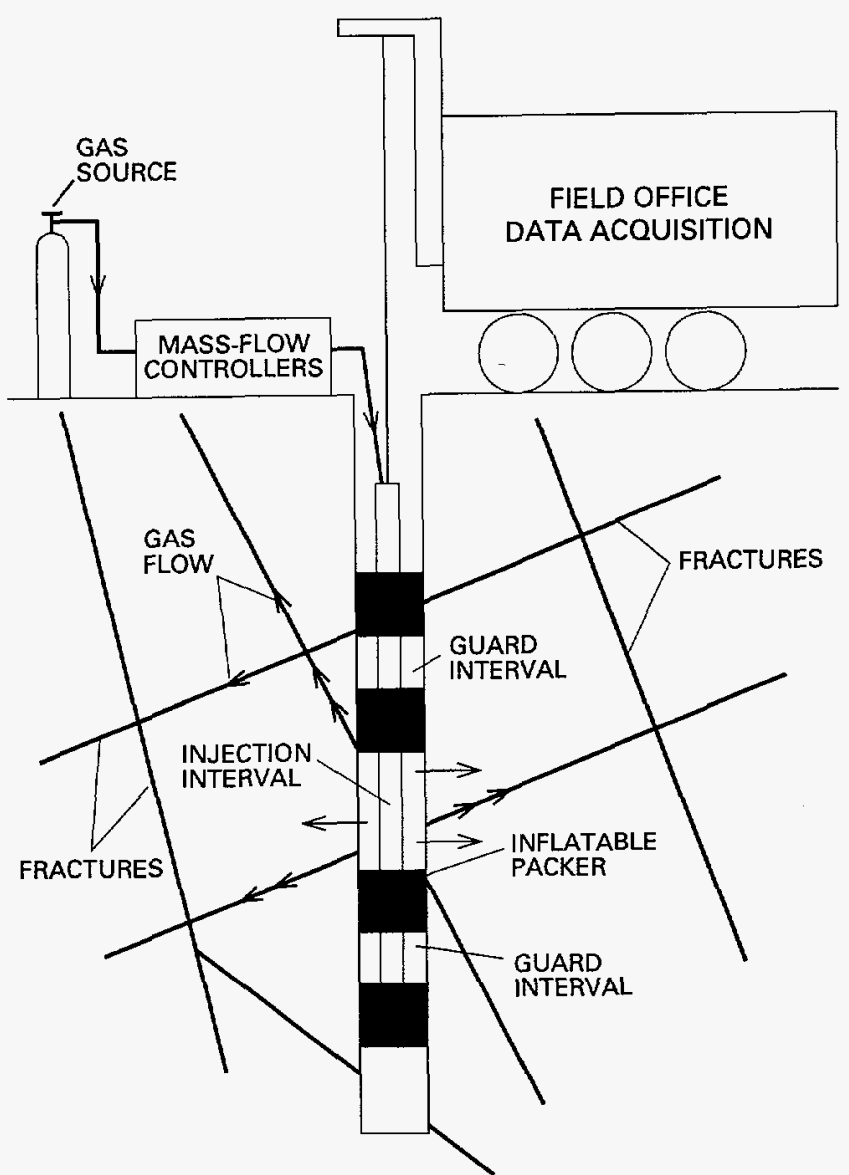

Figure 31. Schematic of pneumatic (air injection) testing system.

\section{Analysis of Pneumatic Tests}

The analysis method and model that were used in analyzing the pneumatic testing were originally developed for incompressible fluids. Modification to deal with compressible fluids (air or other gas) and model geometry requires the following assumptions.

1. The ideal gas law applies and, therefore, the compressibility of the gas is inversely related to the pressure.

2. The system is isothermal and, therefore, the gas density and viscosity, which are both temperature dependent, remain constant.

3. Gravitational effects can be excluded.

4. Flow is laminar.

5. The medium is homogeneous, isotropic, and incompressible.

Steady-state analysis was used to evaluate the injection-interval pressure response. The analysis uses a modified version of the Hvorslev (1951) solution for steady-state elliptical flow (equation 1). The complete derivation of the equation is presented in LeCain (1997).

$$
k=\frac{P_{s c} Q_{s c} \mu \ln \left(\frac{L}{2 r_{w}} \sqrt{1+\left(\frac{L}{2 r_{w}}\right)^{2}}\right) T_{f}}{\pi L\left(P_{2}^{2}-P_{1}^{2}\right) T_{s c}}
$$

where

$k=$ permeability, in square meters;

$P_{s c}=$ pressure at standard conditions, in pascals;

$Q_{\mathrm{sc}}=$ flow at standard conditions, in cubic meters per second;

$\mu=$ dynamic viscosity, in pascal-seconds;

$L=$ length of injection interval, in meters;

$r_{w}=$ well radius, in meters;

$T_{f}=$ formation temperature, in kelvins;

$P_{2}=$ final pressure, in pascals;

$P_{1}=$ starting pressure, in pascals; and

$T_{s c}=$ temperature at standard conditions, in kelvins.

To deal with the assumption that the system is isothermal, injection pressures were limited to minimize temperature changes caused by gas expansion, and thermistors were installed to monitor any temperature changes.

The assumption that gravitational forces can be excluded is reasonable because the increased pressure from the weight of the higher density gas is small compared to the injection pressure.

Evaluation of the nonlaminar influences is done by conducting steady-state testing at different gas-injection rates. An arithmetic plot with the steady-state $\triangle P 2$ on the $y$-axis and the gas-injection rate on the $\mathrm{x}$-axis is prepared. If the plot is a straight line passing through the origin, the flow is laminar; if not, the permeability may not be independent of the flux. Textbooks on porous media flow (Dullien, 1992) provide methodologies for dealing with the nonlinearity due to inertial influences. This methodology also might be applied to turbulent flow in fractured media. The methodology consists of testing at increasing gas-injection rates and using the Forchheimer method to estimate the inertial coefficient and ultimately the Darcian flow permeability; this would require a minimum of six tests per test interval. Airinjection testing by LeCain (1995) in moderately 
welded tuff near Superior, Ariz., indicated that, if the differential pressure was limited to a maximum of 160 kilopascals $(\mathrm{kPa})$, air-injection testing in both fractured and nonfractured intervals showed no apparent decrease in permeability with increasing flow rates. On the other hand, Sully and others (1993), while testing in desert alluvium, found that in some test intervals inertial effects could be seen when differential pressures were as small as $10 \mathrm{kPa}$. Because the Yucca Mountain study plan (U.S. Department of Energy, written commun., 1991) for Site Characterization Plan (U.S. Department of Energy, 1988) activity 8.3.1.2.2.3.2 (Site Vertical Borehole Studies) called for air-injection testing in as many as 29 boreholes, the decision was made to try to keep the air-injection testing in the laminar-flow range and to minimize the number of repetitive tests. This was to be accomplished by limiting air-injection rates in an attempt to limit the resulting differential injection pressures to a . maximum of $30 \mathrm{kPa}$. Three tests at different flow rates were conducted on each test interval. The three steady-state $\Delta \mathrm{P}^{2}$ values were then plotted against flow rate and the plot examined for linearity.

The homogeneous and isotropic assumptions are questionable in most test situations and are even more suspect when testing in fractured rock. Fractures, by their nature, are not isotropic, and the fact that fractures are present in a low-permeability matrix means that the rock is not homogeneous. The rationale used to justify these assumptions involves consideration of the scale of testing and the representative elementary volume (REV). In the simplest terms, the REV is the minimum sample size at which variability in properties is averaged out so that the rock may be considered homogeneous. Testing of a fractured medium at a scale smaller than the REV will mean the test response is controlled by the localized fracture geometry. Tests conducted at a scale larger than the REV may result in the loss of information on the variability that exists in even the most consistent rock formations. The testing goal was to select test intervals that were long enough to intercept enough fractures so that the flow system behaved as an equivalent porous medium, yet short enough to measure variability in properties within the REV. The test-interval lengths selected were about $3 \mathrm{~m}$ for borehole NRG-7a and about $4 \mathrm{~m}$ for NRG-6. The test-interval lengths were selected on the basis of the fracture densities from the Agapito and Associates (1995a, b) core logs. The lengths for the two boreholes are different because different borehole diameters, 15 and $20 \mathrm{~cm}$, respectively, required that modifications be made to the packer systems.

Because the air permeability of a rock changes with water content, a given permeability also has an associated capillary pressure. Capillary pressure is the pressure difference across the interface between the gas and liquid phases. Capillary pressure increases when this interface is confined to smaller pores or fractures and decreases as this interface moves to larger pores and fractures. The larger pores and fractures are potentially the most conductive features but also have the lowest capillary pressures except under very wet conditions, which are rare. Using the capillary equations of Bikerman (1958), it is possible to approximate the size of the pores and fractures that will be dry at a given capillary pressure and, conversely, the size of pores and fractures from which water would be displaced if the injection pressure exceeded the capillary pressure. Testing in NRG-7a or NRG-6, however, showed no indication that water had been forced from the fractures or matrix. Had this occurred, alteration of the rock water content would have been identified as a negative slope in the plot of test-interval pressure response (LeCain, 1995). This means that the in-situ capillary pressures of the tuff were larger than the injection pressures and that no water in pores or fractures was displaced by air during testing.

\section{Results of Pneumatic Tests}

The pressure responses in the test interval and guard intervals during test 68 in borehole NRG-7a are shown in figure 32. Test 68 was conducted in the Topopah Spring Tuff middle nonlithophysal unit at the repository level. This pressure response is typical of the tests conducted on welded and fractured tuff. The test-interval pressure begins to rise approximately 3 seconds following the start of air injection. The 3 -second delay is due to the compressibility of the injection air and the 700-m length of the air-injection tubing. The test-interval pressure increases for approximately 300 seconds and reaches steady state at $96.5 \mathrm{kPa}$. The short time period required to reach steady state supports the findings of Kearl and others (1990), whose air-injection testing in the Bandelier Tuff near Los Alamos, New Mexico, indicated that "steady-state conditions were generally obtained a few minutes after the air injection was initiated." The 


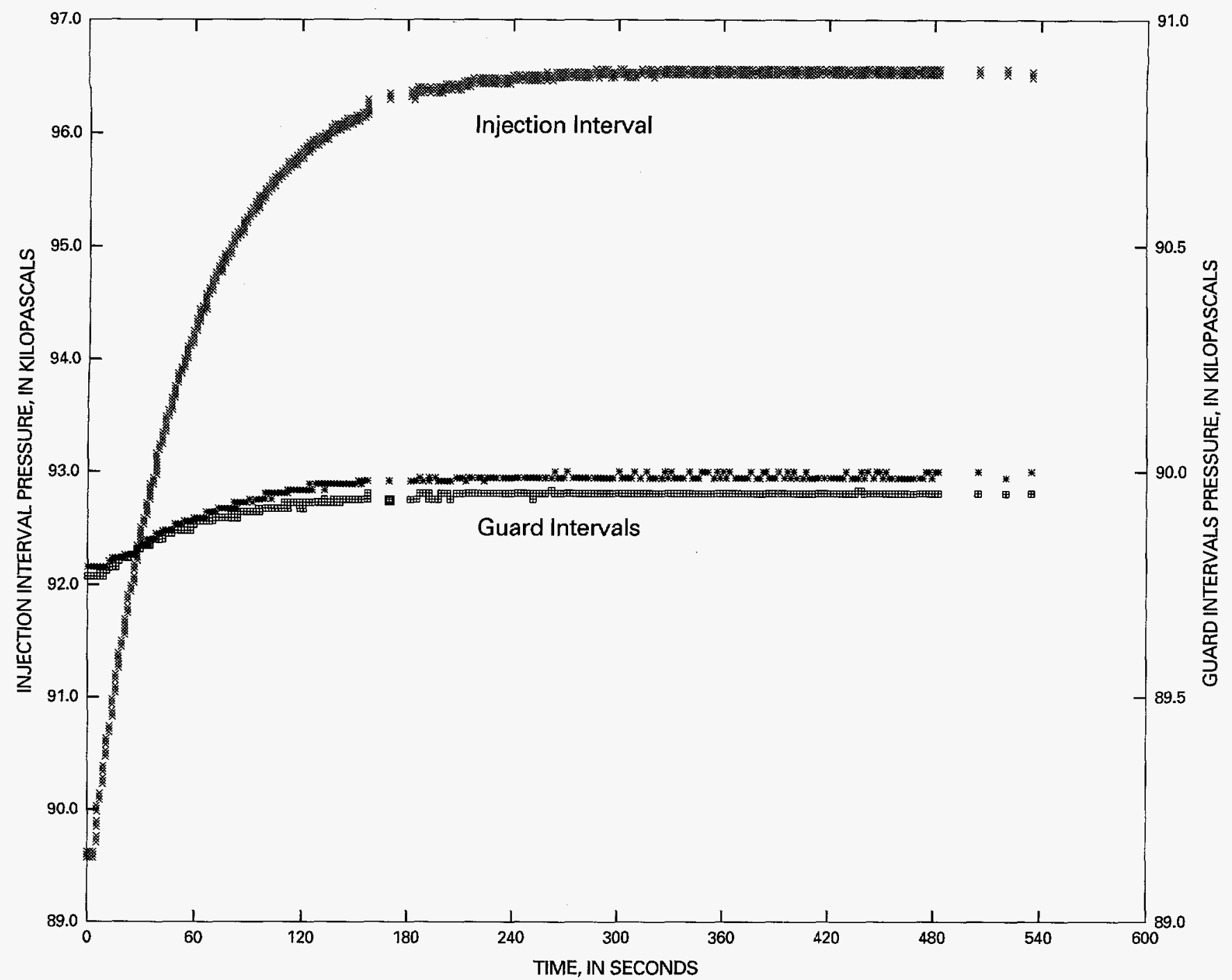

Figure 32. Arithmetic relation between absolute pressure and time in the injection and guard intervals during test 68 at borehole USW NRG-7a.

pressure responses in the guard intervals lag those in the test interval by approximately 10 seconds and reach steady state at significantly lower pressures, 89.95 and $89.98 \mathrm{kPa}$. The time response lag and lower steady-state pressures indicate that the packers have seated properly, and the test is acceptable. The absence of a guard-interval time lag or a pressure response approaching that of the test interval would indicate that the test-interval packers have not isolated the test interval, and the test is void. Tests conducted on the bedded tuffs show similar pressure responses except that the guard-interval lag times are much longer, approximately 3 minutes. This increase is due to the higher porosity associated with matrix flow in the bedded tuff as opposed to the fracture flow in the welded and fractured tuff. Most of the pressure plots have similar shapes. This indicates that the flow geometry was stable and met test assumptions.

The log-log relation between differential pressure and time for NRG-7a test 68 shown in figure 33 is used to identify periods when air flow was not constant. The compressibility of the injection air and length of the injection tubing can cause problems with maintaining a constant flow rate during the early period of a test. Assuming that the injection air behaves as an ideal gas, the slope of a log-log plot of differential pressure and time should not exceed 1. A slope greater than 1 means the flow rate is increasing at the injection interval; a slope equal to one means that all the flow is going into well-bore storage. Figure 33 shows that during approximately the first 25 seconds of test 68 the flow rate was not constant. 


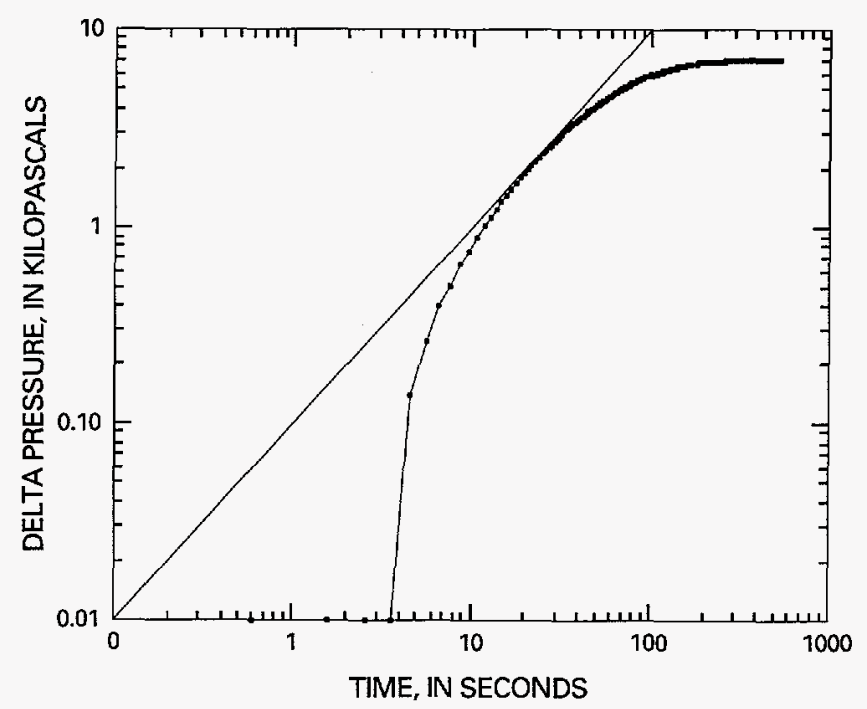

Figure 33. Log-log relation between differential pressure and time in the injection interval during test 68 at borehole USW NRG-7a.

This is due to the 700-m length of the injection tubing. Because the early-time, transient flow period is short in relation to the time allocated for the tests to reach steady state, the transient flow did not influence any of the test results.

A plot of the square of the steady-state differential pressures relative to flow rate for borehole NRG-7a tests 37,38 , and 39 is shown in figure 34 . The tests were conducted on the same test interval, in the Topopah Spring Tuff upper lithophysal unit, at

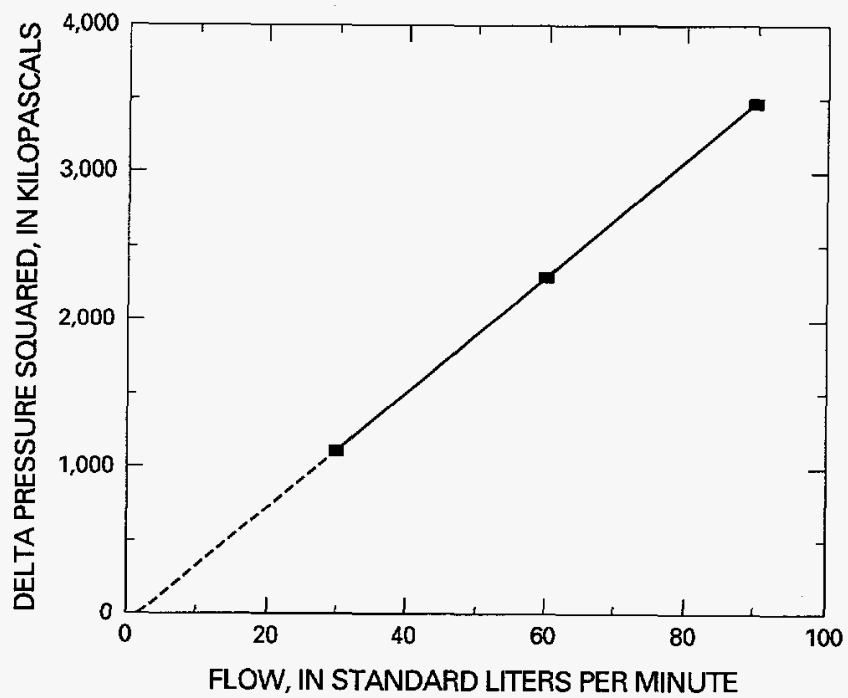

Figure 34. Arithmetic relation between steady-state differential pressures squared and flow rate during tests 37 , 38 , and 39 at borehole USW NRG-7a. flow rates of 30,60 , and $90 \mathrm{slpm}$. The plot is linear and passes near, if not through, the origin. This indicates that the flow is Darcian, and turbulence was not a problem at this test interval. While some of the test intervals did show turbulent influences, indicated by a decrease in permeability with increasing flow rate, the effect was minimized by limiting the air-injection rates and thereby limiting the steady-state injection pressures. Of the 95 test intervals in NRG-6 and NRG-7a where multiple tests were conducted, 48 had a minimum permeability value within 12 percent of their maximum permeability value, and 92 were within 30 percent. This compares well with testing to evaluate the range of permeability values measured when all variables are held constant. Testing in borehole SD-12, located south of the North Ramp study area, included five 300-slpm tests of a single test interval. The permeability values were $1.6,1.6,1.7$, 1.7 , and $1.5 \times 10^{-12} \mathrm{~m}^{2}$, a range of 12 percent.

The permeability values with depth of the test intervals successfully tested in boreholes NRG-7a and NRG-6 are shown in figures 35 and 36 . The permeability value assigned to each test interval is from the test that had the smallest steady-state differential pressures. These permeability values had the smallest probability of being affected by turbulent or inertial forces. It is these test-interval permeability values that were used to prepare the figures, tables, and statistical analyses presented in this section of the report. The lithostratigraphic units tested also are indicated in these figures. Because the borehole wall of NRG-7a was smooth and uniform in diameter, most of the borehole could be tested. Permeability values ranged from $3.5 \times 10^{-14} \mathrm{~m}^{2}$ to $5.4 \times 10^{-11} \mathrm{~m}^{2}$. Most permeability values were between $10^{-13} \mathrm{~m}^{2}$ to $10^{-12} \mathrm{~m}^{2}$ and were independent of the geologic units. Seven of the test intervals had permeability values greater than $10^{-12}$ $\mathrm{m}^{2}$. Of the seven, five were within $60 \mathrm{~m}$ of the land surface. Of the three permeability values larger than $10^{-11} \mathrm{~m}^{2}$, all were within $20 \mathrm{~m}$ of the ground surface. The borehole wall of NRG-6 was not smooth and uniform in diameter, most notably through the PTn bedded units and in much of the lower Topopah Spring Tuff crystal-poor upper lithophysal unit; therefore, these zones could not be tested. Permeability values for the tested zones ranged from $8.2 \times 10^{-14} \mathrm{~m}^{2}$ to $2.8 \times 10^{-11} \mathrm{~m}^{2}$. Sixteen of the NRG-6 test intervals had permeability values greater than $10^{-12} \mathrm{~m}^{2}$. Of the four test intervals with permeability values greater than 


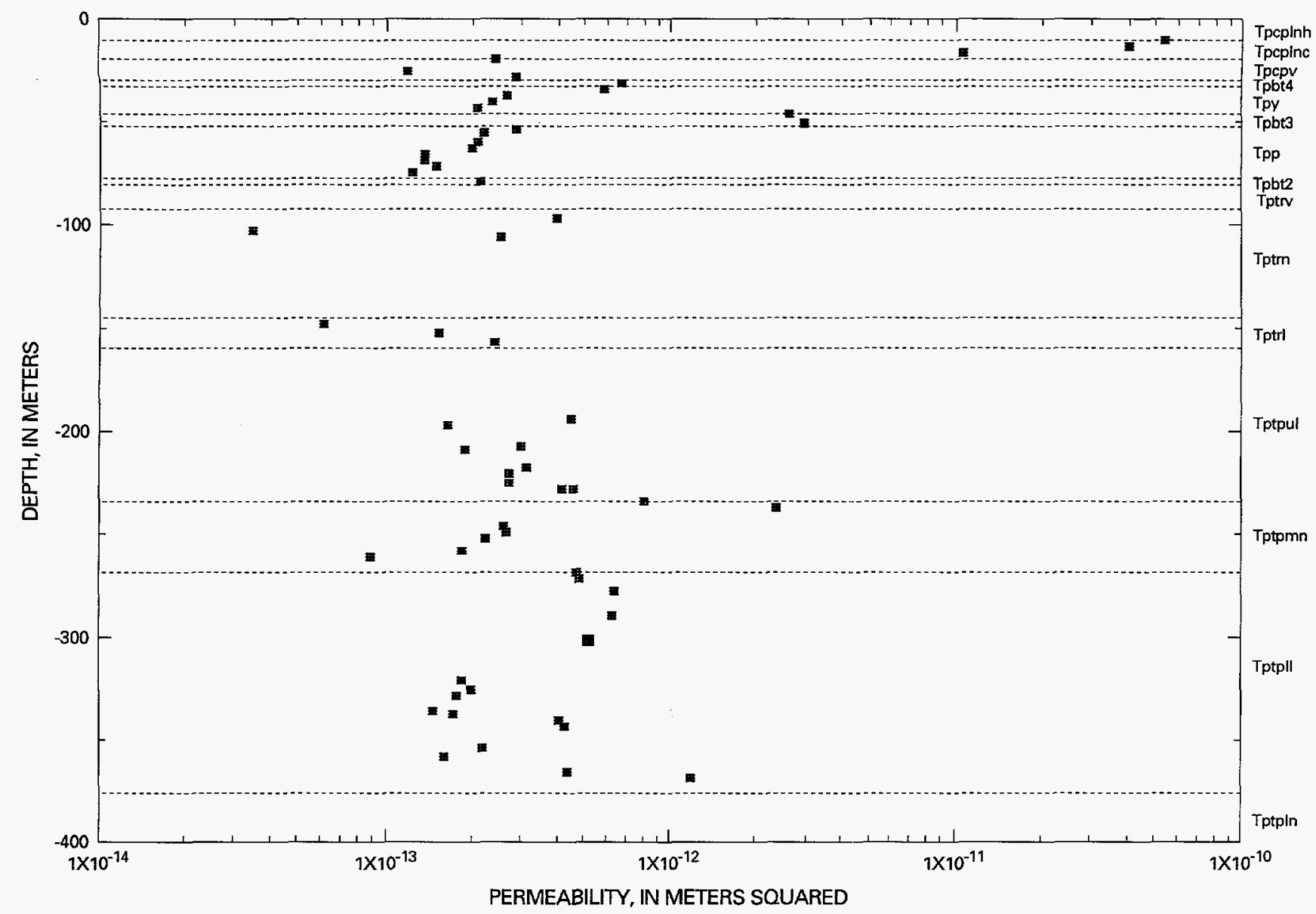

Figure 35. Semilog relation between test-interval air-permeability values, depth, and lithostratigraphic unit at borehole USW NRG-7a.

$10^{-11} \mathrm{~m}^{2}$, two were within $26 \mathrm{~m}$ of the land surface.

Permeability values of the Topopah Spring Tuff crystal-rich nonlithophysal unit (Tptrn) indicate a decrease in permeability with depth.

The statistical analysis of the permeability values of boreholes NRG- 6 and NRG-7a is listed in table 3 by hydrogeologic and lithostratigraphic unit. The table contains the arithmetic mean, number of test intervals, and standard deviations.

The statistical summary of all intervals tested in the Topopah Spring Tuff in table 4 indicates that the air permeabilities for the two boreholes are significantly different from one another. The 34 intervals tested in NRG-6 have a mean of $2.1 \times 10^{-12} \mathrm{~m}^{2}$ with a large variance $\left(20.2 \times 10^{-12} \mathrm{~m}^{2}\right)$, whereas the 38 intervals tested in NRG-7a have a mean of $0.4 \times 10^{-12} \mathrm{~m}^{2}$ with a much smaller variance $\left(0.16 \times 10^{-12} \mathrm{~m}^{2}\right)$. The cumulative probability plots of the Topopah Spring Tuff air-permeability values from NRG-6 and NRG$7 \mathrm{a}$, shown in figure 37 , indicate that the values are not normally distributed. The cumulative probability plots of the Topopah Spring Tuff natural log air-permeability values of NRG-6 and NRG-7a, shown in figure 38 , indicate that the natural-log values could be considered to be normally distributed. Because the distribution of the permeability values is not normal, it is necessary to use the normally distributed natural-log values for statistical comparison. A statistical summary of the arithmetic mean, number of tests, and variances of the Topopah Spring Tuff natural-log airpermeability values of boreholes NRG-6 and NRG-7a is presented in table 5. The p-values of an F-test between the variances and a Z-test between the means are less than 0.01 , indicating a high probability that the means and the variances are different.

Plots of the test-interval permeability values and the number of natural fractures in the test intervals are shown in figures 39 and 40 . The welded and fractured tuff of NRG-6 has an average of 24.3 total fractures and 9.3 natural fractures per test interval. The 


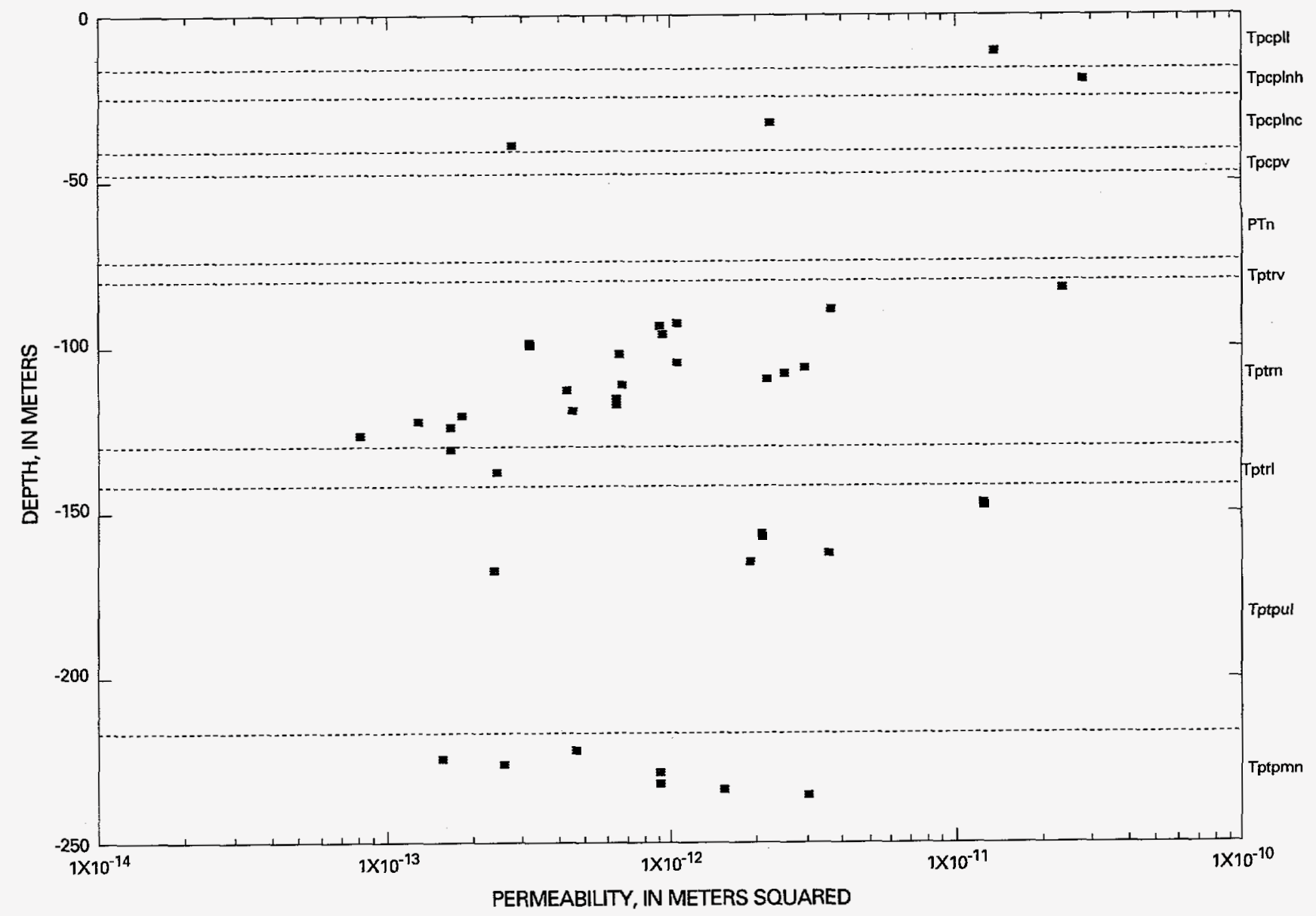

Figure 36. Semilog relation between test-interval air-permeability values, depth, and lithostratigraphic unit at borehole USW NRG-6.

welded and fractured tuff of NRG-7a has an average of 9.6 total fractures and 4.3 natural fractures per test interval. ("Total fractures" consists of fractures that are believed to have been present prior to drilling [natural fracture], fractures induced by the drilling and coring, and fractures that are indeterminate.)

Goodness-of-fit values $\left(\mathrm{R}^{2}\right)$ from univariate regression analysis between air-injection permeability values and six explanatory variables are presented in table 6. All fracture, lithophysal, and core data are from the borehole geology and rock structure logs prepared by J.F.T. Agapito \& Associates Inc. for Sandia National Laboratories (Agapito, 1995a, b). For borehole NRG-7a, there is a small correlation $(0.21)$ between the number of total fractures and permeability and between the number of natural fractures and permeability $(0.24)$. There is no correlation between permeability and the number of indeterminate fractures, percentage of lithophysal cavities, percentage of core rubble, or percentage of core lost. Similar results were obtained for borehole NRG-6. The small correlation of permeability with fractures is surprising. Intuitively, one would expect the correlation to be greater. Assuming that core rubble and core lost are due to intense fracturing, a small correlation with permeability would be expected. The near zero correlation indicates that the core characteristics may not be associated with fracturing and that the fracture-topermeability correlations are not biased by rubbled or lost core.

\section{Interpretation of Pneumatic-Test Results}

The large statistical differences between the variances and the means of the Topopah Spring Tuff natural-log permeability values in boreholes NRG-6 and NRG-7a (table 5) show that the data are from two different populations. This indicates that the Topopah Spring Tuff is heterogeneous within the North Ramp area. Examination of figures 35 and 36 shows that the 
Table 3. Statistical summary of air-injection permeability values by hydrogeologic and lithostratigraphic unit for boreholes NRG-6 and NRG-7a

[Mean, arithmetic mean permeability; \#, number of test intervals; St. Dev., standard deviation. Permeability values are expressed as $10^{-12} \mathrm{~m}^{2}$ ]

\begin{tabular}{|c|c|c|c|c|c|c|c|}
\hline $\begin{array}{c}\text { Hydrogeologic } \\
\text { unit }\end{array}$ & Lithostratigraphic unit & $\begin{array}{c}\text { Borehole } \\
\text { NRG-6 } \\
\text { (Mean) }\end{array}$ & $\begin{array}{c}\text { Borehole } \\
\text { NRG-6 } \\
\text { (\#) }\end{array}$ & $\begin{array}{c}\text { Borehole } \\
\text { NRG-6 } \\
\text { (St. Dev.) }\end{array}$ & $\begin{array}{c}\text { Borehole } \\
\text { NRG-7a } \\
\text { (Mean) }\end{array}$ & $\begin{array}{c}\text { Borehole } \\
\text { NRG-7a } \\
\text { (\#) }\end{array}$ & $\begin{array}{c}\text { Borehole } \\
\text { NRG-7a } \\
\text { (St. Dev.) }\end{array}$ \\
\hline \multirow{4}{*}{$\begin{array}{c}\text { Tiva Canyon } \\
\text { welded }\end{array}$} & Tiva Canyon lower lithophysal & 14.0 & 1 & $\mathrm{NA}$ & & & \\
\hline & Tiva Canyon lower nonlithophysal hackly & & & & & & \\
\hline & $\begin{array}{l}\text { Tiva Canyon lower nonlithophysal } \\
\text { columnar }\end{array}$ & 1.3 & 2 & 1.0 & 25.7 & 2 & 14.9 \\
\hline & Tiva Canyon crystal-poor vitric 3 & & & & & & \\
\hline \multirow{9}{*}{$\begin{array}{l}\text { Paintbrush } \\
\text { nonwelded }\end{array}$} & Tiva Canyon crystal-poor vitric 2 & & & & & & \\
\hline & Tiva Canyon crystal-poor vitric 1 & & & & 0.2 & 2 & 0.1 \\
\hline & bedded tuff 4 & & & & & & \\
\hline & Yucca Mountain Tuff & & & & 0.3 & 4 & 0.2 \\
\hline & bedded tuff 3 & & & & 3.0 & 1 & NA \\
\hline & Pah Canyon Tuff & & & & 0.2 & 7 & 0.04 \\
\hline & bedded tuff 2 & & & & & & \\
\hline & Topopah Spring crystal-rich vitric 3 & & & & & & \\
\hline & Topopah Spring crystal-rich vitric 2 & & & & & & \\
\hline \multirow{6}{*}{$\begin{array}{l}\text { Topopah Spring } \\
\text { welded }\end{array}$} & Topopah Spring crystal-rich vitric 1 & & & & & & \\
\hline & Topopah Spring crystal-rich nonlithophysal & 2.2 & 20 & 5.0 & 0.2 & 3 & 0.1 \\
\hline & Topopah Spring crystal-rich lithophysal & 0.3 & 1 & NA & 0.2 & 3 & 0.1 \\
\hline & Topopah Spring upper lithophysal & 4.1 & 5 & 4.4 & 0.3 & 9 & 0.1 \\
\hline & Topopah Spring middle nonlithophysal & 1.1 & 7 & 0.9 & 0.6 & 6 & 0.8 \\
\hline & Topopah Spring lower lithophysal & & & & 0.4 & 15 & 0.3 \\
\hline
\end{tabular}

permeability values from NRG-6 have a larger range than those measured in NRG-7a. The Topopah Spring Tuff permeability values from NRG-7a generally are truncated at $10^{-12} \mathrm{~m}^{2}$. The truncation is not induced by drilling because the NRG-7a Tiva Canyon test intervals, which were exposed to drilling influences for a longer time period than the deeper Topopah Spring Tuff test intervals, have permeability values greater than $10^{-11} \mathrm{~m}^{2}$. One possible explanation is the difference in fracture density. On average, borehole NRG-7a has one-half the total fracture density of NRG-6. Note, however, that the largest permeability values measured are in the upper $20 \mathrm{~m}$ of borehole NRG-7a and that the shallower depths also are an exception to the fracture distribution. The average total fracture density per test interval in the upper three intervals of NRG-7a is 26.3 , whereas the average number of total fractures per test interval in NRG-6 is 24.3. Although the regression analysis indicates only
Table 4. Statistical summary of Topopah Spring Tuff air-injection permeability values for boreholes NRG-6 and NRG-7a

[Permeability values are expressed as $10^{-12}$ square meter]

\begin{tabular}{lccc}
\hline Borehole & $\begin{array}{c}\text { Topopah Spring Tuff } \\
\text { air-permeability } \\
\text { arithmetic mean }\end{array}$ & $\begin{array}{c}\text { Number of } \\
\text { test intervals }\end{array}$ & Variance \\
\hline NRG-6 & 2.1 & 34 & 20.2 \\
NRG-7a & 0.4 & 38 & 0.16 \\
\hline
\end{tabular}

a small correlation between fracture density and permeability, these data indicate that increasing fracture density leads to increased permeability values. The exact cause and effect between the number of fractures and the permeability value is unclear, as correlation analysis has shown. The relation may be a function of fracture aperture. In this concept, only one or a few fractures with large apertures will result in a high permeability value, while test zones with dozens 


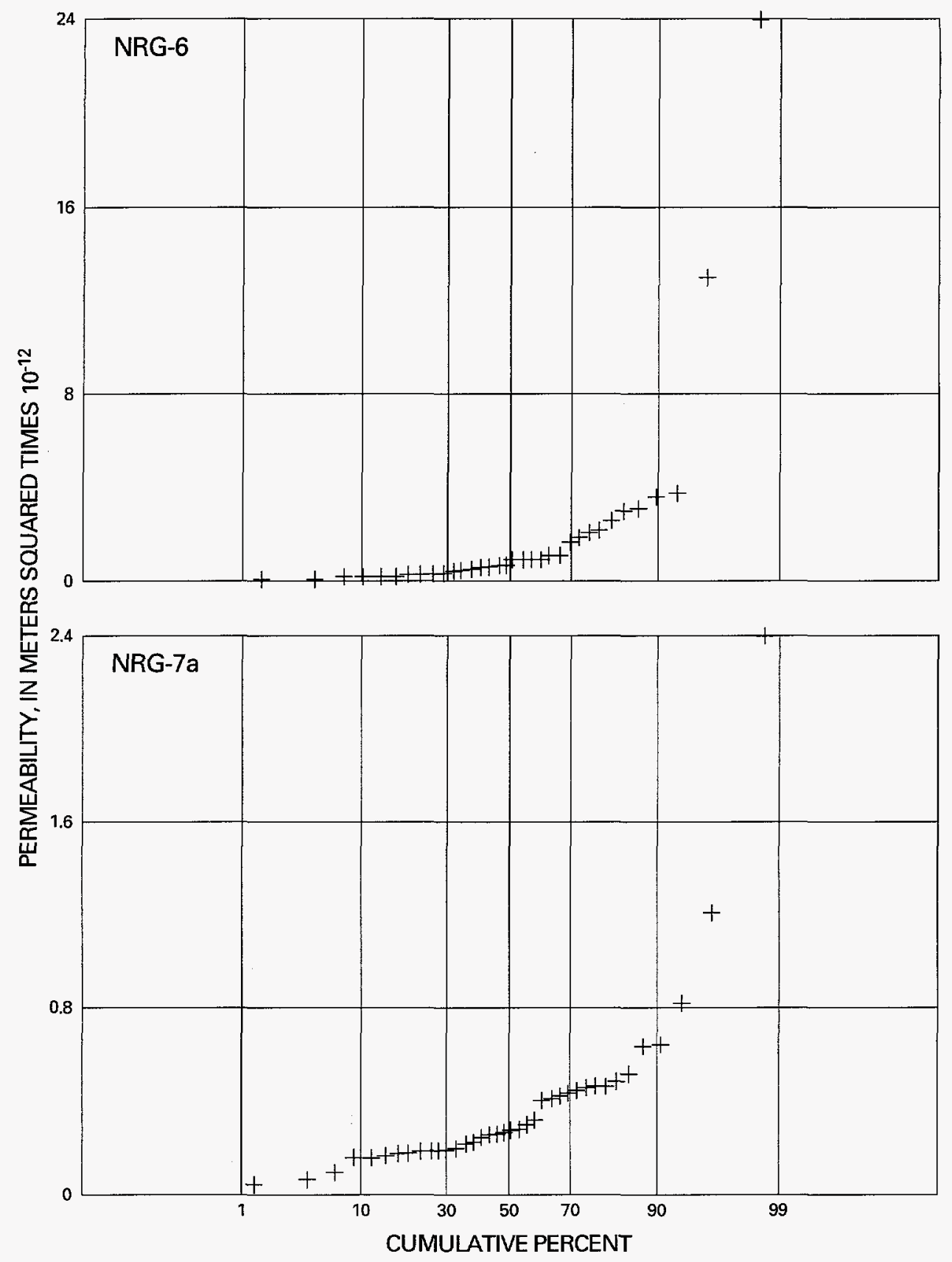

Figure 37. Cumulative probability of air-permeability values of the Topopah Spring Tuff from boreholes USW NRG-6 and USW NRG-7a. 


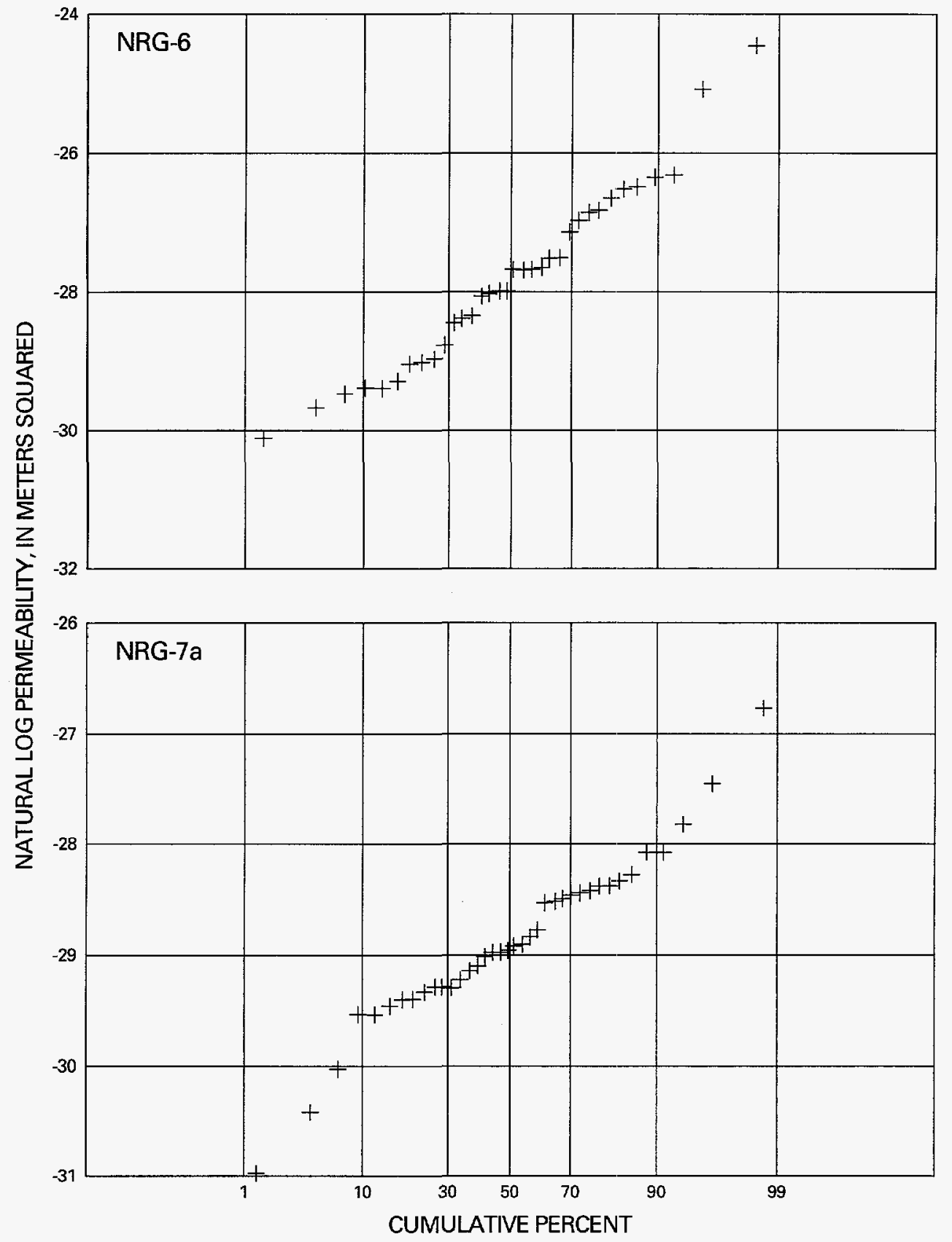

Figure 38. Cumulative probability of the natural log air-permeability values of the Topopah Spring Tuff from boreholes USW NRG-6 and USW NRG-7a. 
Table 5. Statistical summary of Topopah Spring Tuff natural-log air-permeability values for boreholes NRG-6 and NRG-7a and results of Z-test of the means and F-test of variances

$[<$, less than]

\begin{tabular}{lccc}
\hline Borehole & $\begin{array}{c}\text { Topopah Spring } \\
\text { Tuff air- } \\
\text { permeability } \\
\text { natural-log } \\
\text { arithmetic mean }\end{array}$ & $\begin{array}{c}\text { Number of } \\
\text { test } \\
\text { intervals }\end{array}$ & Variance \\
\hline NRG-6 & $1_{-27.83}$ & 34 & $2_{21.7}^{2}$ \\
NRG-7a & $1_{-28.88}$ & 38 & ${ }^{2} 20.6$ \\
Z-test p-value & $<0.01$ & & \\
F-test p-value & & & $<0.01$ \\
\hline
\end{tabular}

${ }^{1} \mathrm{p}$-value from Z-test of means is less than 0.01 .

${ }^{2} \mathrm{p}$-value from $\mathrm{F}$-test of variances is less than 0.01 . of small aperture fractures have low permeability values. This concept explains the minimal correlation between fracture number and permeability. In addition, assuming that the fracture aperture distribution is constant, the overall permeability of a geologic unit would increase as the fracture density increases. At this point, no geologic structure or feature can be identified as influencing the different fracture-density and permeability values seen in the two boreholes. Both boreholes are on the edge of the Drill Hole Wash Fault zone, and both are in the Yucca Crest subdomain.

In-situ testing produced permeability values for the welded units that ranged from $3.5 \times 10^{-14} \mathrm{~m}^{2}$ to $5.4 \times 10^{-11} \mathrm{~m}^{2}$. This range indicates that, at the scale of testing (approximately $4 \mathrm{~m}$ ), the formations are heterogeneous. Water-injection testing of Yucca Mountain welded tuff core samples by Anderson (1994) showed permeability values that ranged from

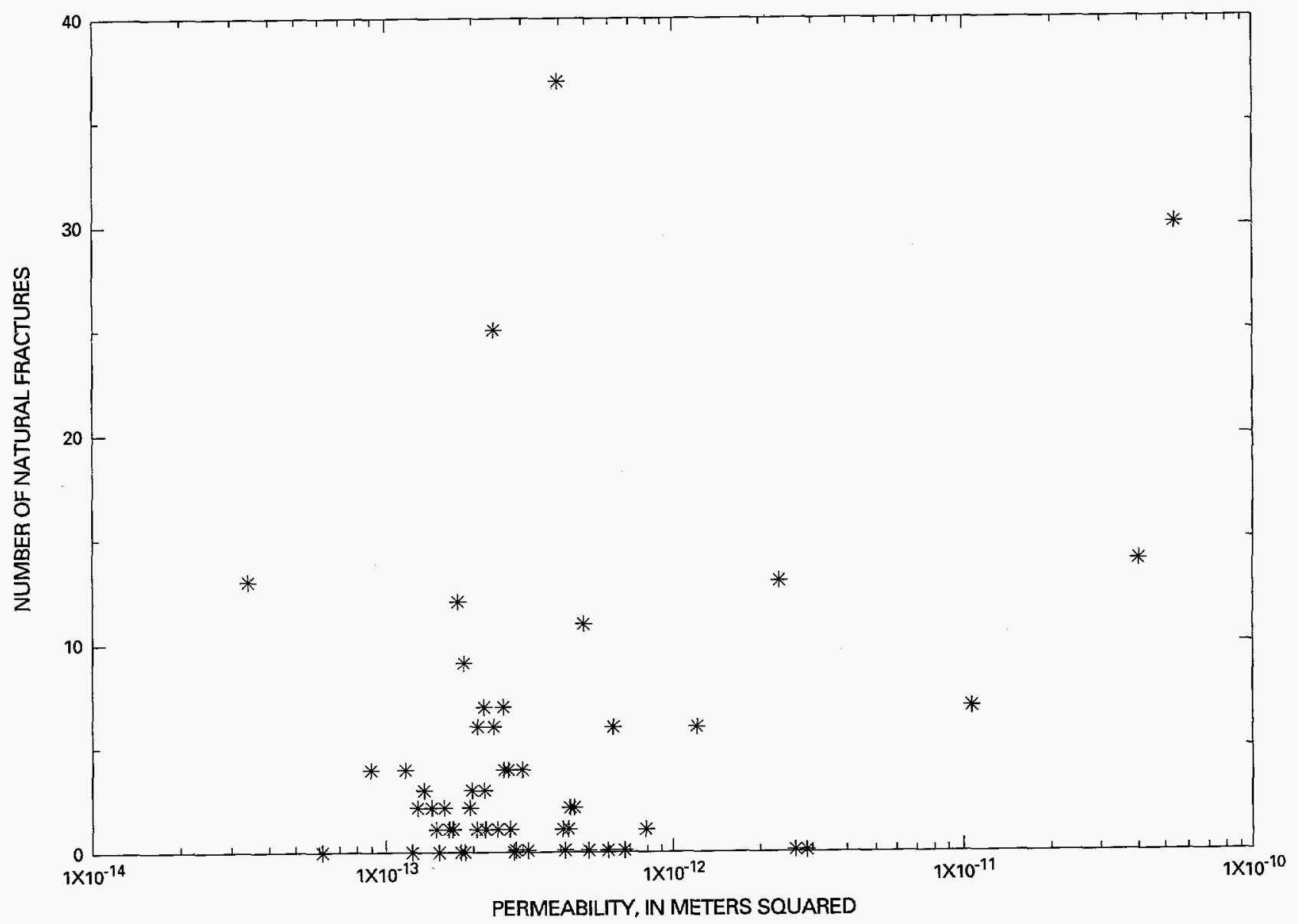

Figure 39. Relation between test-interval permeability values and the number of natural fractures identified in the test interval at borehole USW NRG-7a. 


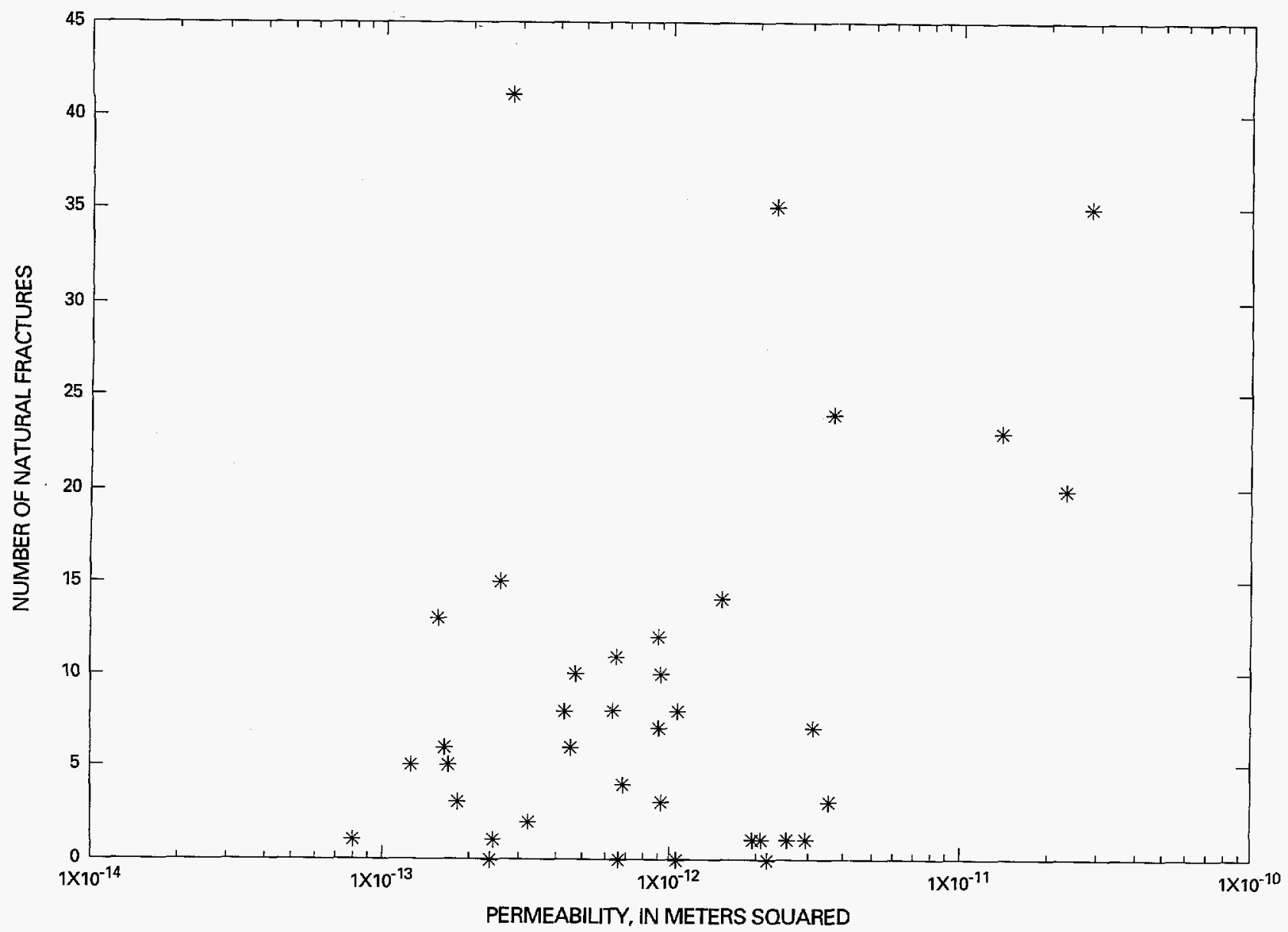

Figure 40. Relation between test-interval permeability values and the number of natural fractures identified in the test interval at borehole USW NRG-6.

less than $1.04 \times 10^{-21} \mathrm{~m}^{2}$ to $7.2 \times 10^{-15} \mathrm{~m}^{2}$. The difference in permeability reflects the testing procedure used-fracture flow dominates the in-situ testing, whereas matrix flow dominates the core testing. The Agapito \& Associates structural logs (Agapito, 1995a, b) show that most of the fractures in the North Ramp area are near vertical. This dominant fracture orientation can cause a sampling bias when testing in vertical boreholes. A vertical borehole will intersect fewer fractures than a horizontal borehole. A formation dominated by vertical fractures has a high probability of being anisotropic with a vertical permeability that may be significantly larger than the horizontal permeability. Another possible source of bias may be associated with the increased fracture density and greater permeability values measured at shallow depths. Although only seven intervals were tested in the Tiva Canyon Tuff, these data indicate that the Tiva Canyon Tuff is more permeable than the Topopah Spring Tuff. It is possible that the larger permeability
Table 6. Goodness-of-fit values $\left(R^{2}\right)$ from univariate regression analysis between air-injection permeability values and six explanatory variables

$[<$, less than $]$

\begin{tabular}{lcc}
\hline \multicolumn{1}{c}{ Independent variable } & $\begin{array}{c}\text { Borehole NRG-7a } \\
\left(\mathbf{R}^{\mathbf{2}}\right)\end{array}$ & $\begin{array}{c}\text { Borehole NRG-6 } \\
\left(\mathbf{R}^{\mathbf{2}}\right)\end{array}$ \\
\hline Number of total fractures & 0.21 & 0.10 \\
Number of natural fractures & 0.24 & 0.22 \\
Number of indeterminate & 0.04 & $<0.01$ \\
$\quad$ fractures & & \\
Percent lithophysal cavities & 0.01 & 0.01 \\
Percent core rubble & 0.01 & $<0.01$ \\
Percent core lost & 0.04 & $<0.01$ \\
\hline
\end{tabular}

values may be due to stress-relief fracturing or stressrelief opening of fractures associated with the lower overburden pressures.

In-situ permeability values of the Paintbrush nonwelded hydrogeologic unit (PTn) ranged from 
$0.12 \times 10^{-12} \mathrm{~m}^{2}$ to $3.0 \times 10^{-12} \mathrm{~m}^{2}$, and at the scale of testing (approximately $4 \mathrm{~m}$ ), the PTn is vertically heterogeneous. The mean of the 14 intervals tested in NRG-7a is $0.58 \times 10^{-12} \mathrm{~m}^{2}$. Matrix air-permeability testing by Flint and Flint (1990) showed the range of permeability values of the Yucca Mountain Tuff to be $0.005 \times 10^{-12} \mathrm{~m}^{2}$ to $0.31 \times 10^{-12} \mathrm{~m}^{2}$ and the Pah Canyon Tuff to be $0.002 \times 10^{-12} \mathrm{~m}^{2}$ to $0.11 \times 10^{-12} \mathrm{~m}^{2}$.

Although the in-situ data base is very small, the data indicate that the permeability values from in-situ testing are greater than the matrix permeability values. On the basis of the limited in-situ data base from a single borehole, NRG-7a, comparison with the matrix values indicates that the PTn has secondary permeability due to fracturing.

\section{Results of In-Situ Pneumatic Monitoring in Boreholes}

As a part of the Yucca Mountain site-characterization project, several deep boreholes in the unsaturated zone have been instrumented and continuously monitored to record changes in pneumatic pressure at depth. The purposes of pneumatic monitoring are threefold: (1) to measure in-situ pneumatic-pressure response to atmospheric pressure changes in order to determine the influence of lithostratigraphy, bulk properties, and major structural features on the natural gaseous-phase circulation system; (2) to utilize the response of the system at depth to changes in atmospheric pressure to estimate pneumatic diffusivities and, ultimately, effective gas permeabilities of the lithostratigraphic layers; and (3) to document and quantify the effects of excavation of the ESF North Ramp on in-situ pneumatic pressure and on the overall gaseous-phase-circulation system.

\section{In-Situ Pneumatic-Pressure Response to Atmospheric Pressure Change}

In-situ pneumatic pressures have been monitored in eight boreholes within the North Ramp Study Area. Two of these boreholes, UZ\#4 and UZ\#5, are located in Pagany Wash; one borehole, NRG\#4, is located near the crest of Azreal Ridge, which forms the drainage divide between Pagany Wash and Drill Hole Wash; and the remaining five boreholes, UZ-1, SD-9, NRG-7a, NRG\#5, and NRG-6, are located in Drill Hole Wash (fig. 21). UZ-1, NRG-6, NRG-7a, UZ\#4, and UZ\#5 were instrumented with downhole pressure transducers that measure absolute pneumatic pressure. Individual monitoring stations in these boreholes were back-filled or packed with porous stemming materials (polyethylene beads or coarse sand) to couple the monitoring zone to the formation rock of interest. Isolation of individual instrument stations in these boreholes was achieved with intervening lifts of stemming materials consisting of grout and sand (Kume and Rousseau, 1994; J.P. Rousseau, U.S. Geological Survey, written commun., 1995), and in the case of UZ-1, with alternating lifts of grout, silica flour, and bentonite (Montazer, 1987). Monitoring at NRG\#4 also was accomplished with downhole pressure transducers that measure absolute pressure. Individual monitoring stations in this borehole are isolated from each other with a string of inflatable packers (Multimedia Environmental Technology, Inc., 1995).

At NRG\#5, downhole pressures are sensed at the land surface through individual tubes that are connected to open ports located along the length of an impermeable membrane liner. The liner is inflated to seal the formation wallrock from direct communication with the atmosphere. Pressures are measured using a differential pressure transducer at the land surface that is referenced to atmospheric pressure at the time measurements are taken. A second pressure transducer is used to measure absolute atmospheric pressure. This measurement is added back to the differential pressure measurement to compute the pneumatic pressure potential at the location of the sensor port. Pressure due to the weight of the column of air in the tube is not included in the measurement.

At SD-9, pneumatic pressures also were measured at the land surface in a manner similar to that for NRG\#5. Downhole pressures, however, were sensed through access tubes inserted into the annular spaces between a pair of nested casings (Zone 2) and between the outer casing and formation wallrock (Zone 1). Zone 1 represents a composite pressure measurement from the PTn and the Topopah Spring Tuff; measurements from Zone 2 represent pressures within the Calico Hills Formation between a zone of perched water located at a depth of $413 \mathrm{~m}$ and the water table (see section of this report titled Occurrences of Perched Water in the Vicinity of the Exploratory Studies Facility North Ramp). The locations of monitoring stations in each instrumented borehole within the North Ramp study area are shown in figure 41 .

Pneumatic pressure records for instrument stations in monitored boreholes within the North Ramp study area are reproduced in figures 42 through 60 . Records are presented by borehole (from northwest to southeast across the study area) in the following order: UZ-1, SD-9, NRG-7a, NRG\#5, NRG-6, NRG\#4, UZ\#4, and UZ\#5. 


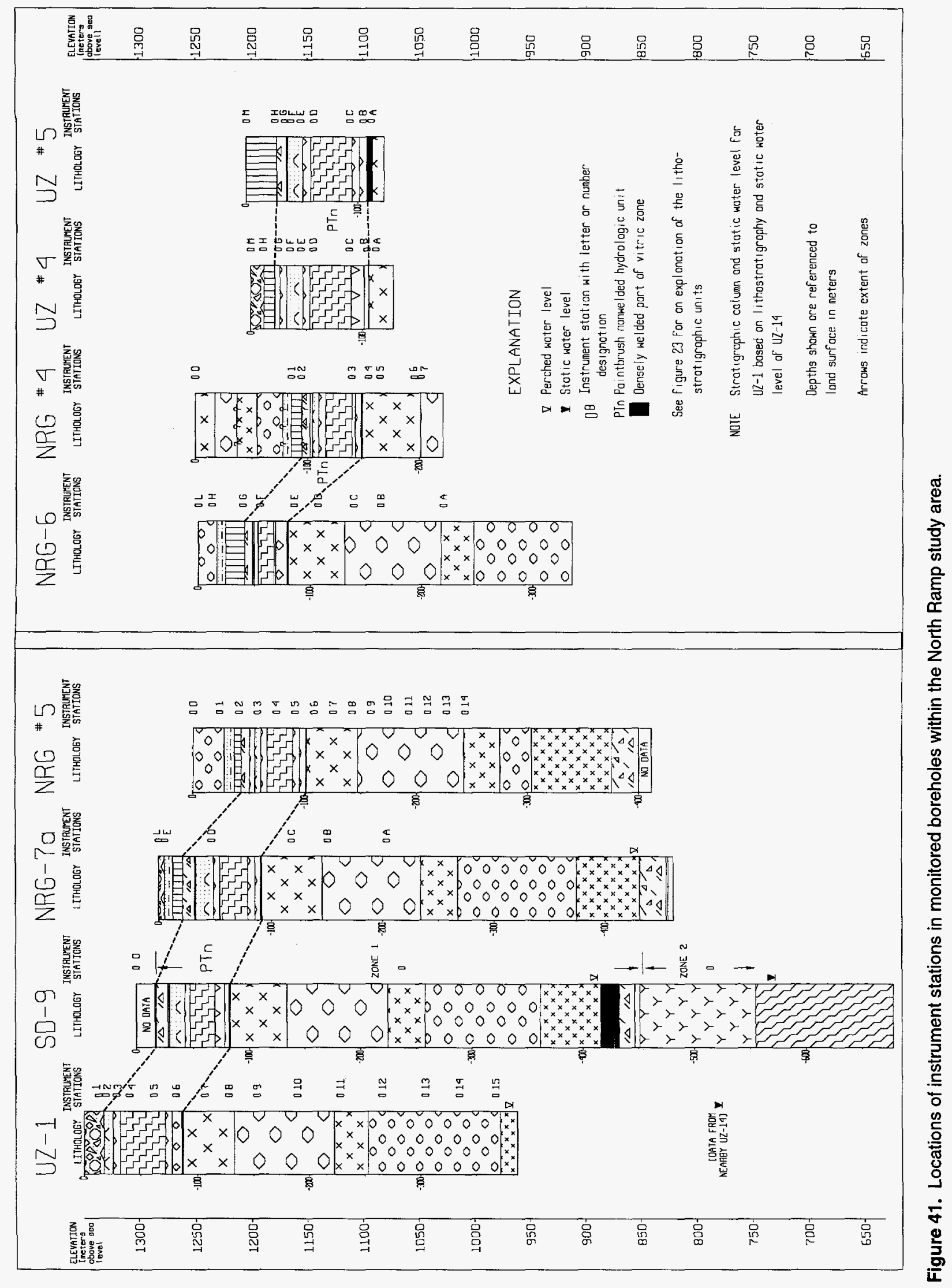




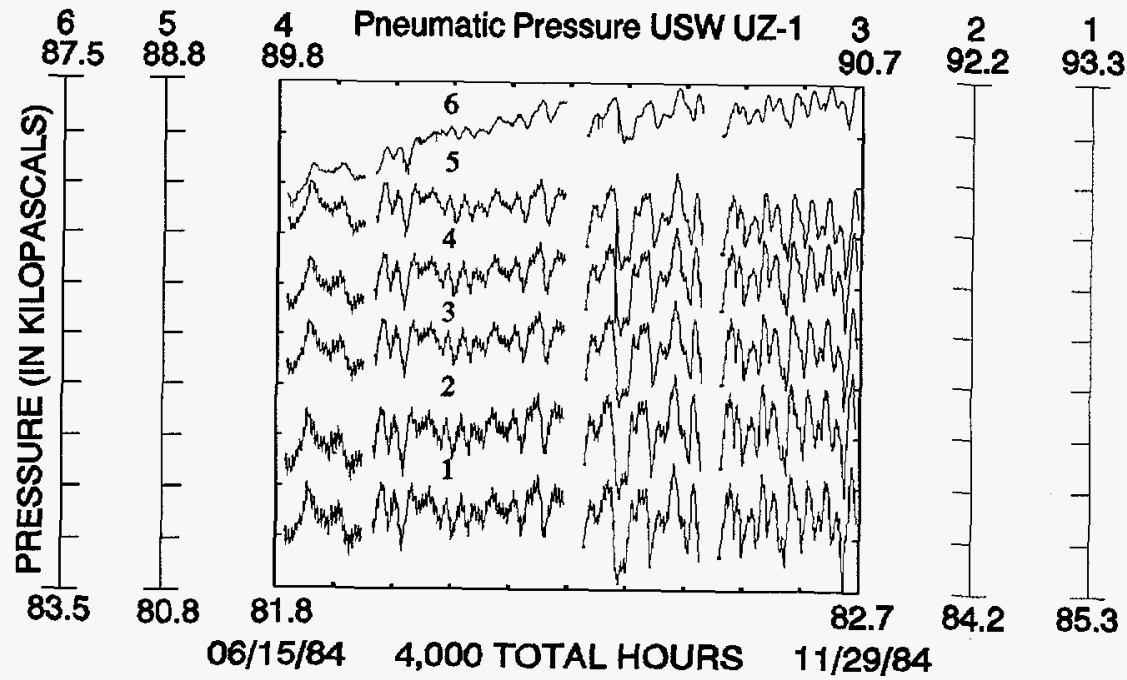

Figure 42. Pneumatic pressure records for instrument stations $1,2,3,4,5$, and 6 located in the Paintbrush nonwelded hydrogeologic unit at borehole USW UZ-1.

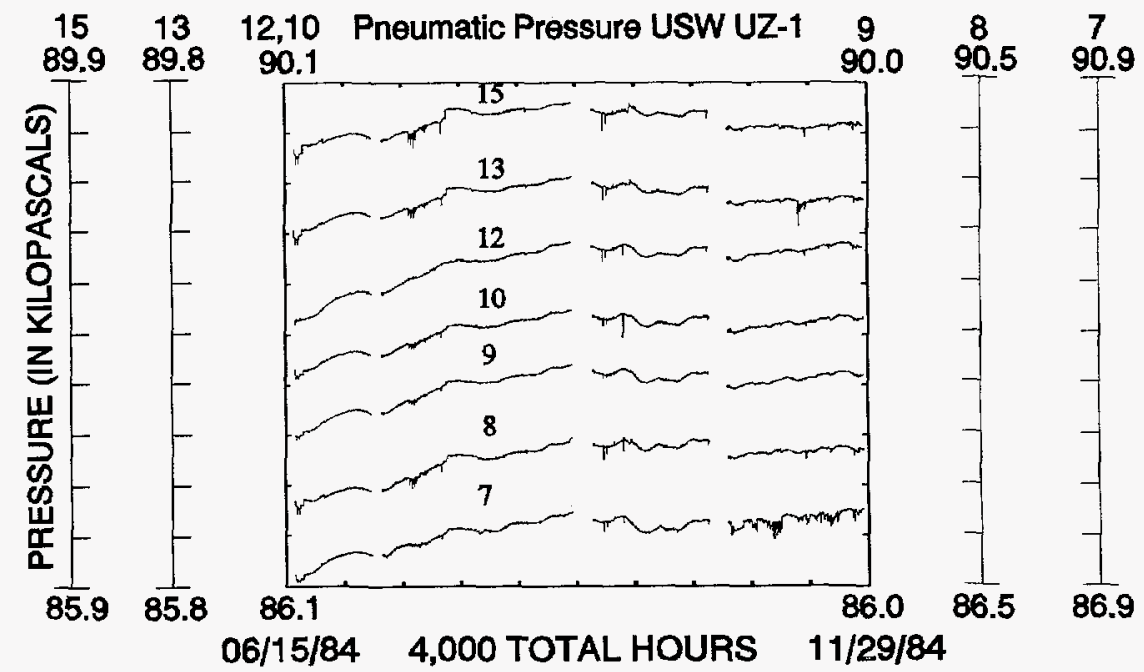

Figure 43. Pneumatic pressure records for instrument stations $7,8,9,10,12,13$, and 15 located in the Topopah Spring welded hydrogeologic unit at borehole USW UZ-1. 


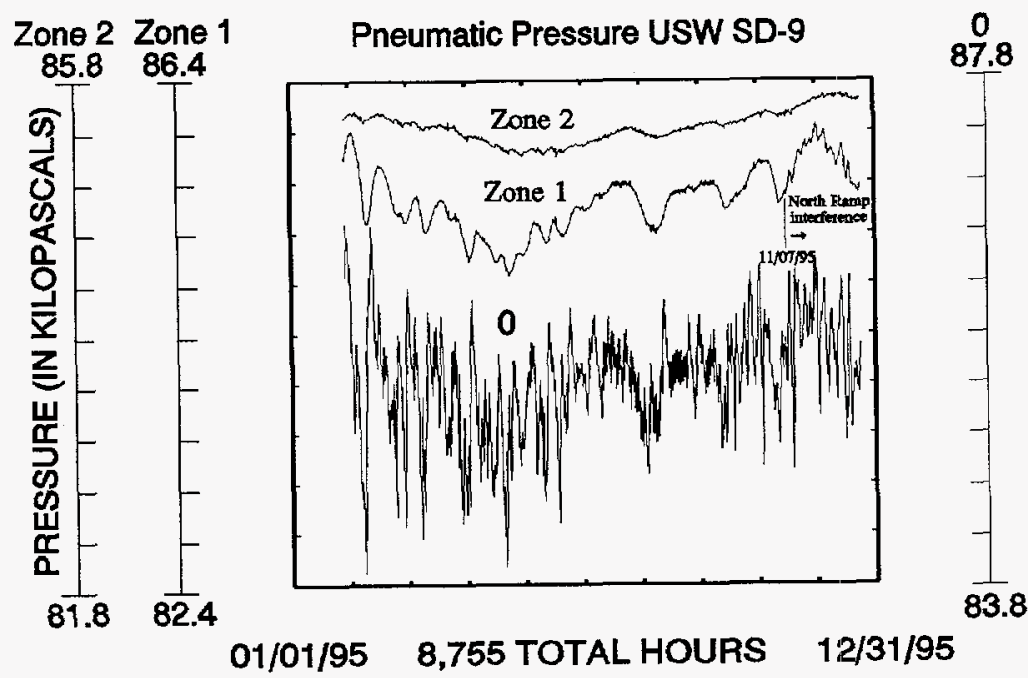

Figure 44. Pneumatic pressure records for the Zone 1 instrument station located in the Topopah Spring welded hydrogeologic unit and the Paintbrush nonwelded hydrogeologic unit, the Zone 2 instrument station located in the Calico Hills nonwelded hydrogeologic unit, and instrument station 0 located at the land surface at borehole USW SD-9.

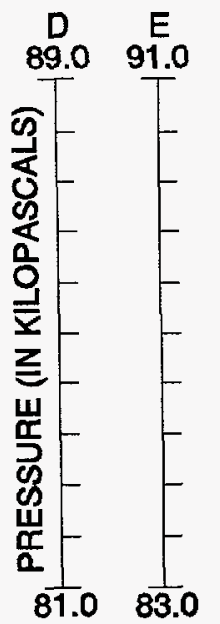

Pneumatic Pressure USW NRG-7a

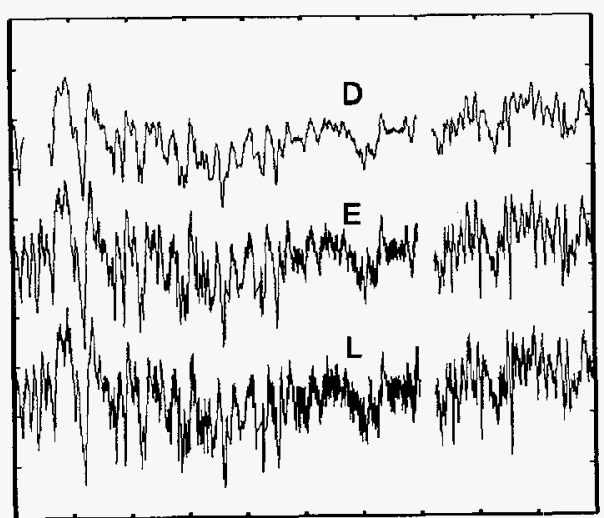

01/01/95 $\quad 8,755$ TOTAL HOURS 12/31/95
L

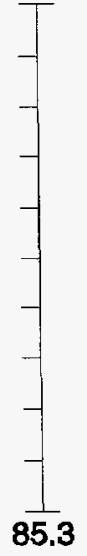

Figure 45. Pneumatic pressure records for instrument station $D$ located in the Paintbrush nonwelded hydrogeologic unit, instrument station $E$ located in the Tiva Canyon welded hydrogeologic unit, and instrument station $L$ located at the land surface at borehole USW NRG-7a. 


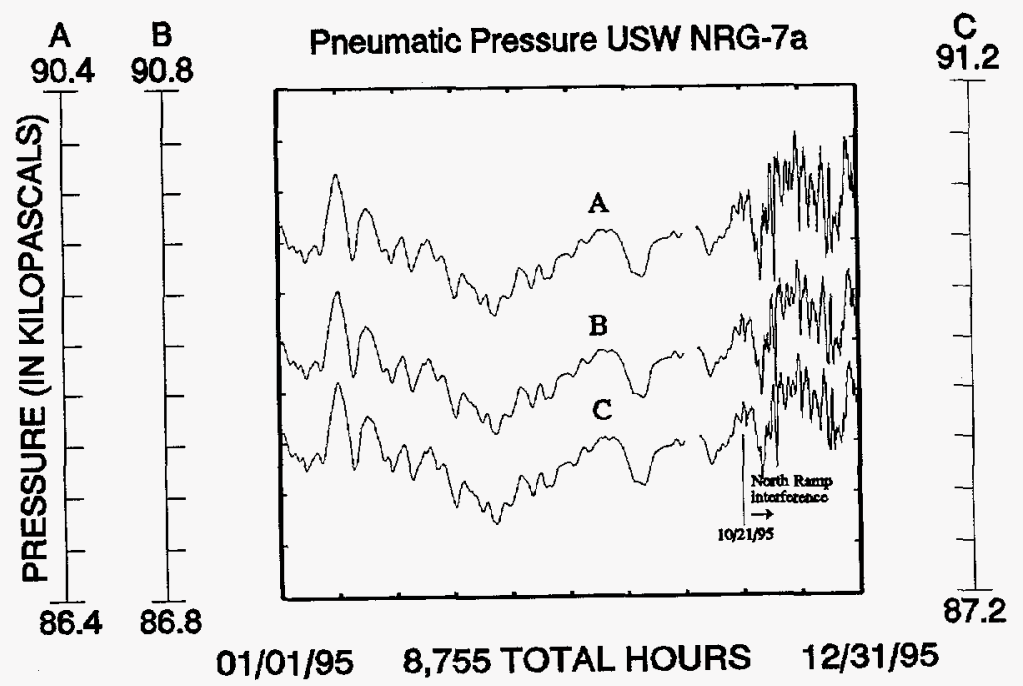

Figure 46. Pneumatic pressure records for instrument stations $A, B$, and $C$ located in the Topopah Spring welded hydrogeologic unit at borehole USW NRG-7a.

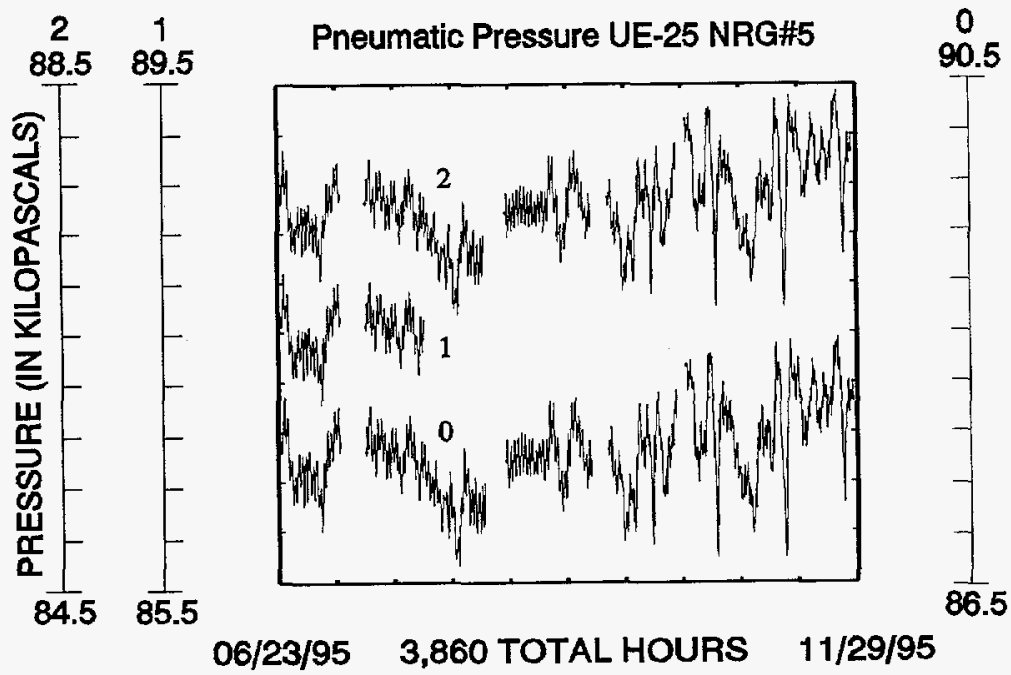

Figure 47. Pneumatic pressure records for instrument station 0 located at the land surface and instrument stations 1 and 2 located in the Tiva Canyon welded hydrogeologic unit at borehole UE-25 NRG\#5. 


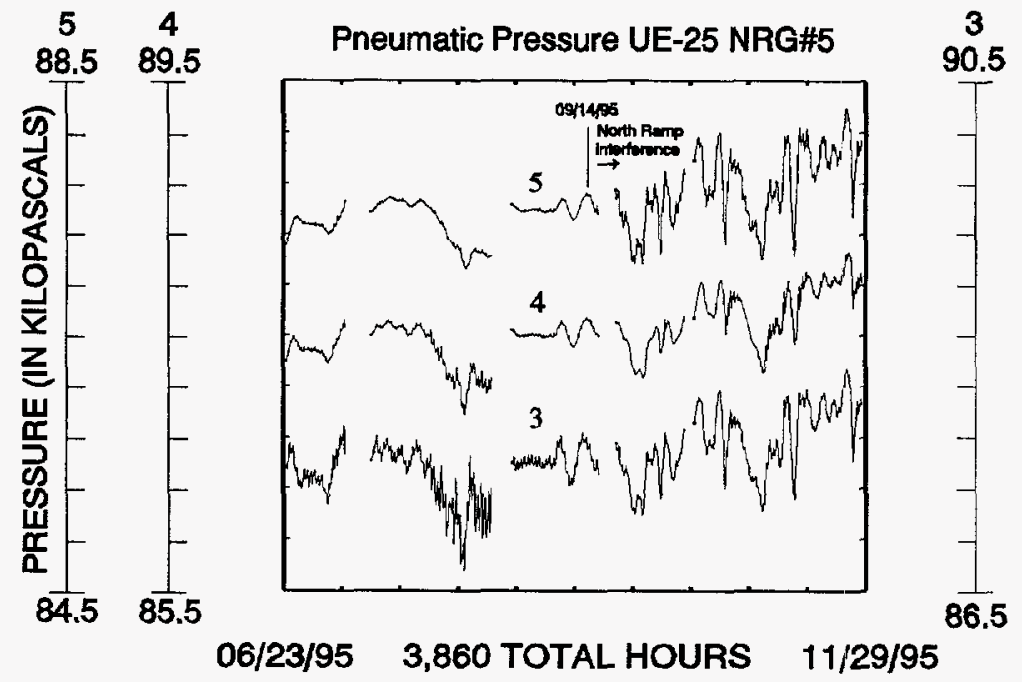

Figure 48. Pneumatic pressure records for instrument stations 3,4 , and 5 located in the Paintbrush nonwelded hydrogeologic unit at borehole UE-25 NRG\#5.

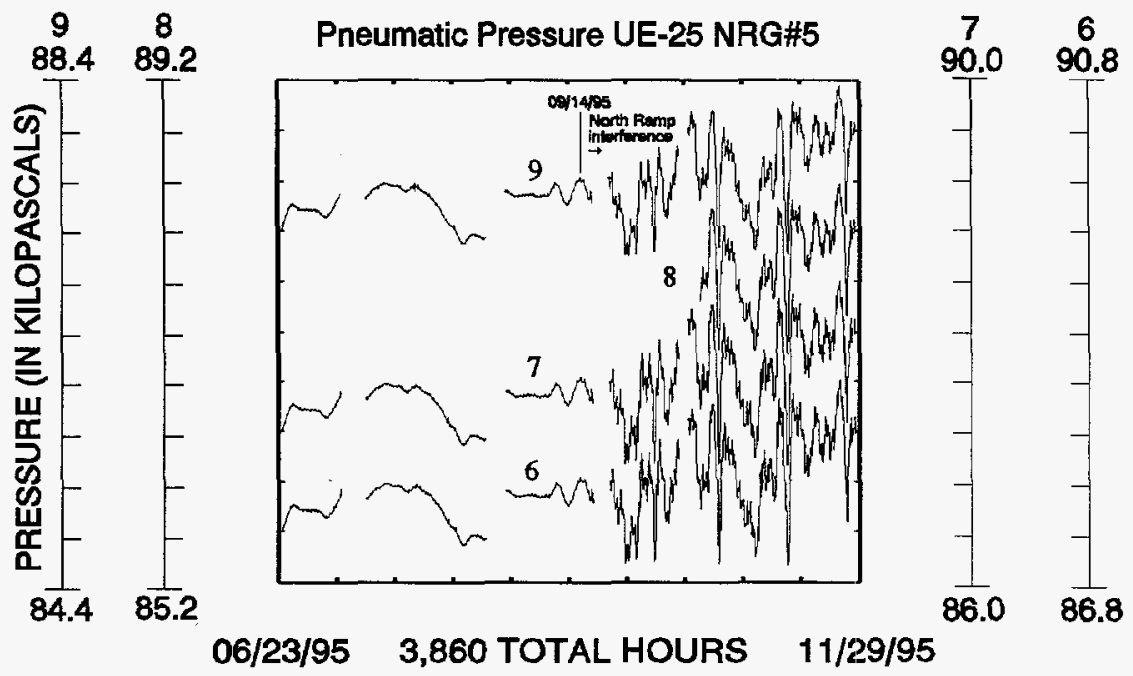

Figure 49. Pneumatic pressure records for instrument stations $6,7,8$, and 9 located in the Topopah Spring welded hydrogeologic unit at borehole UE-25 NRG\#5. 


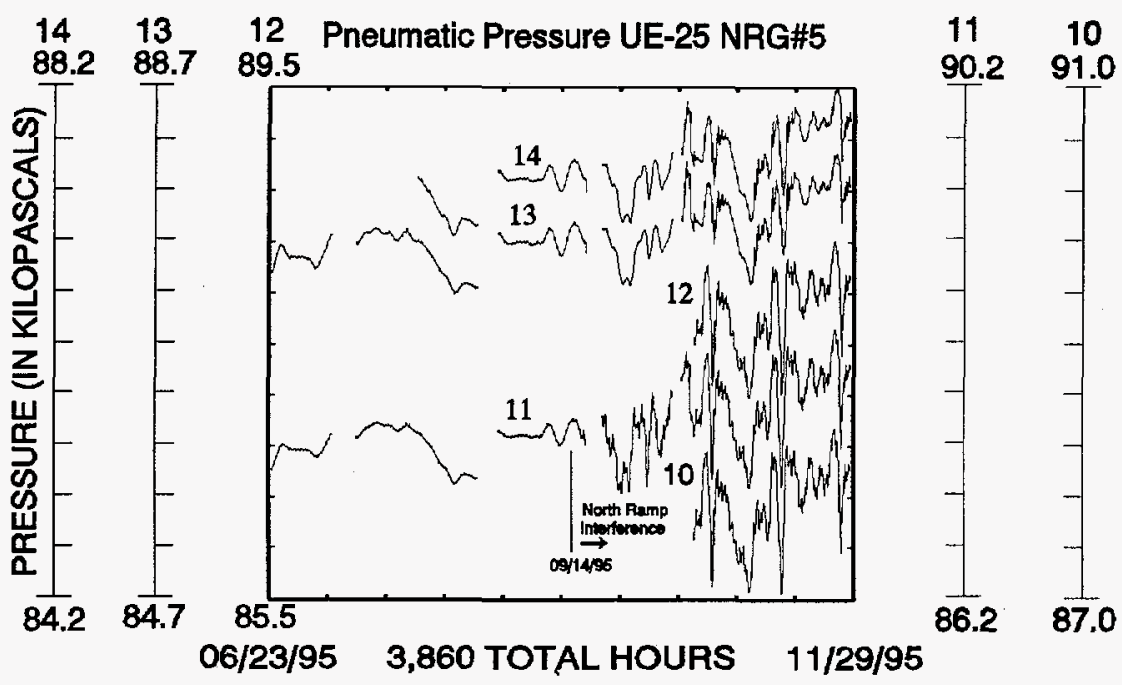

Figure 50. Pneumatic pressure records for instrument stations $10,11,12,13$, and 14 located in the Topopah Spring welded hydrogeologic unit at borehole UE-25 NRG\#5.

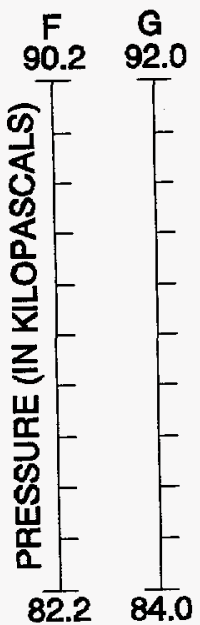

Pneumatic Pressure USW NRG-6

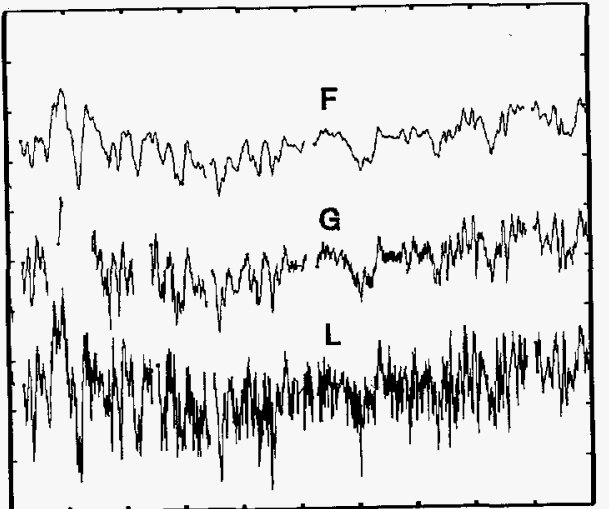

8,755 TOTAL HOURS $\quad 12 / 31 / 95$
93.6

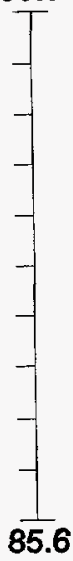

Figure 51. Pneumatic pressure records for instrument stations $F$ and $G$ located in the Paintbrush nonwelded hydrogeologic unit and instrument station $L$ located at the land surface at borehole USW NRG-6. 


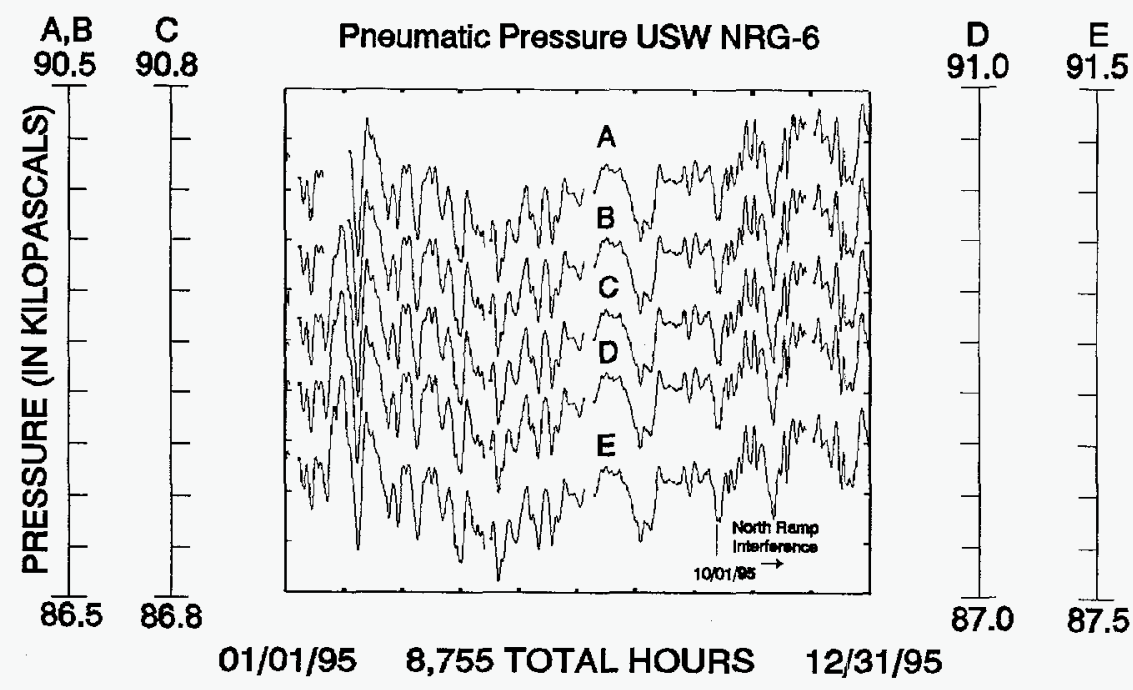

Figure 52. Pneumatic pressure records for instrument stations $A, B, C, D$, and $E$ located in the Topopah Spring welded hydrogeologic unit at borehole USW NRG-6.

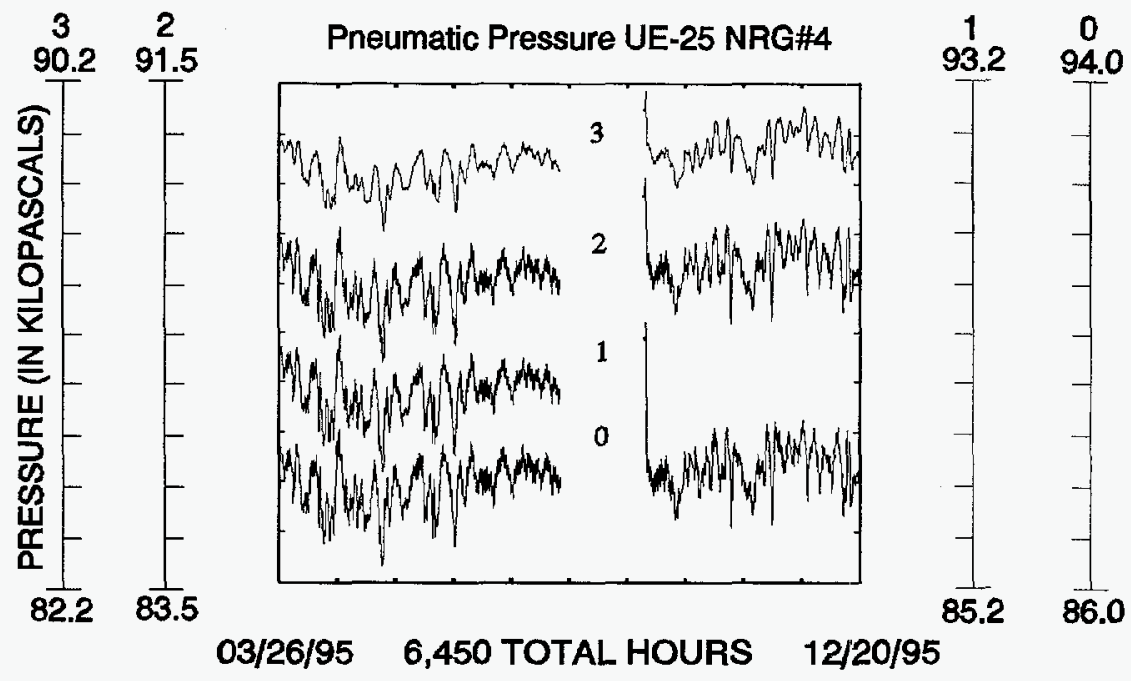

Figure 53. Pneumatic pressure records for instrument station 0 located at the land surface, instrument stations 1 and 2 located in the Tiva Canyon welded hydrogeologic unit, and instrument station 3 located in the Paintbrush nonwelded hydrogeologic unit at borehole UE-25 NRG\#4. 


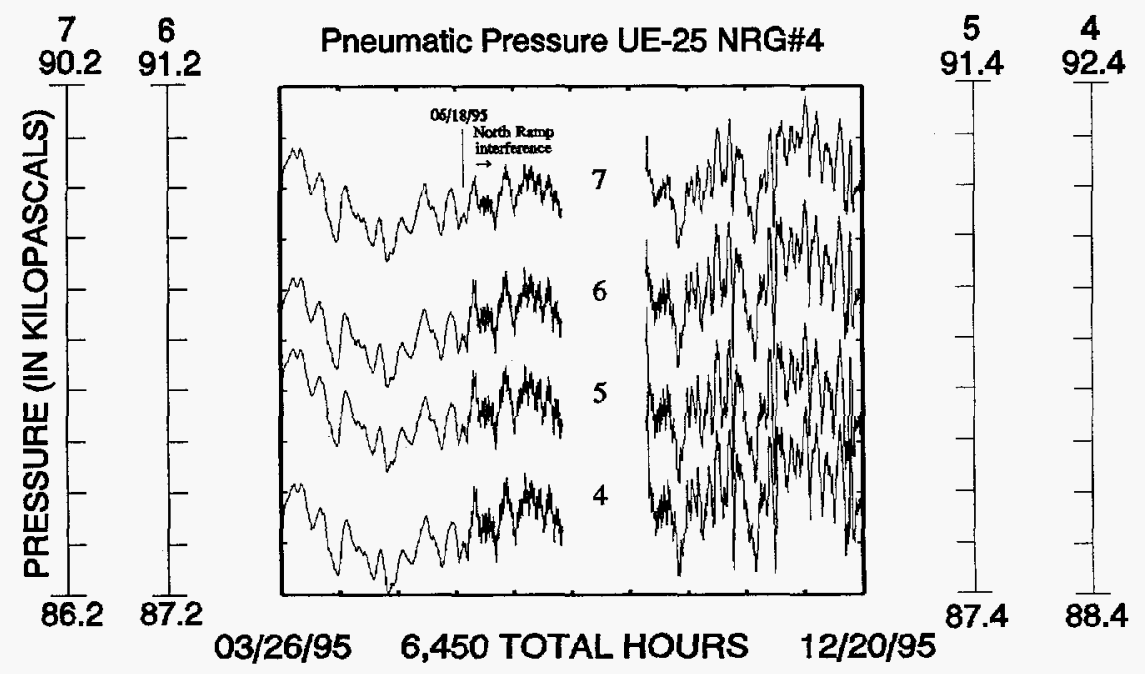

Figure 54. Pneumatic pressure records for instrument stations 4, 5, 6, and 7 located in the Topopah Spring welded hydrogeologic unit at borehole UE-25 NRG\#4.

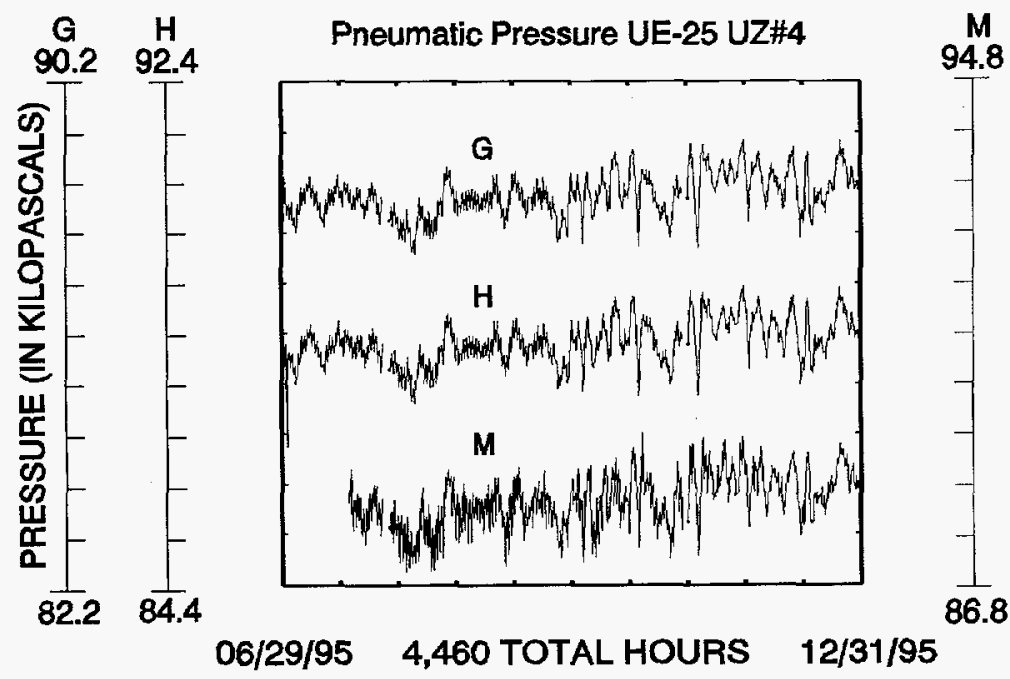

Figure 55. Pneumatic pressure records for instrument station $M$ located at the land surface, instrument station G located in the Tiva Canyon welded hydrogeologic unit, and instrument station $\mathrm{H}$ located in the Paintbrush nonwelded hydrogeologic unit at borehole UE-25 UZ\#4. 


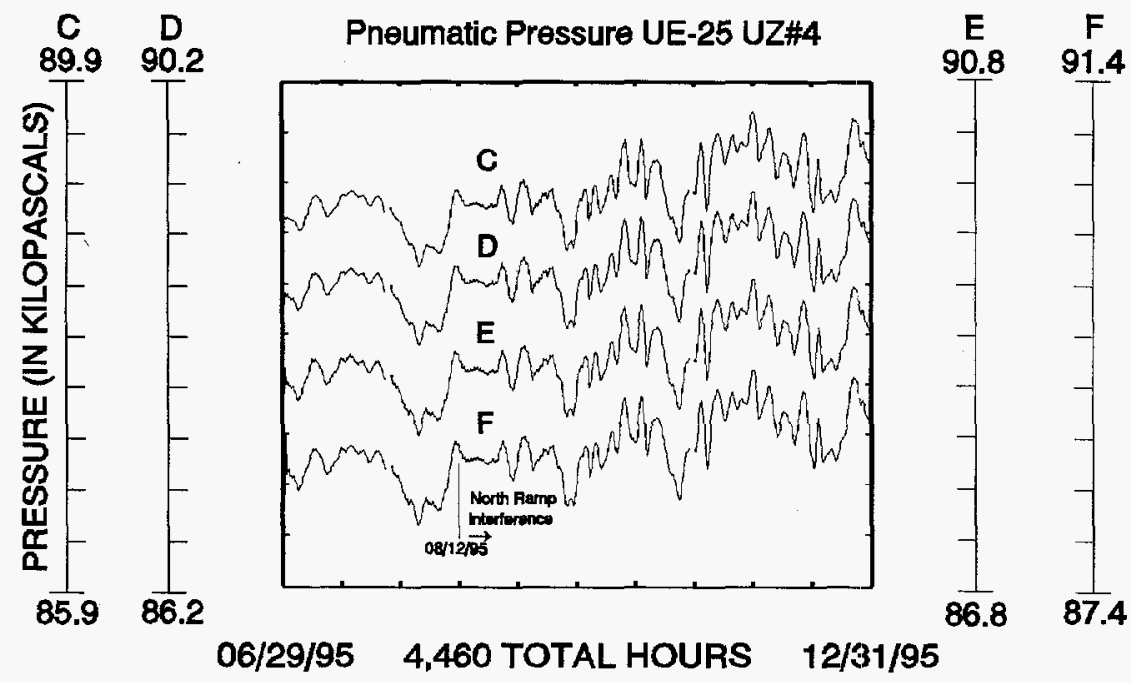

Figure 56. Pneumatic pressure records for instrument stations $C, D, E$, and $F$ located in the Paintbrush nonwelded hydrogeologic unit at borehole UE-25 UZ\#4.

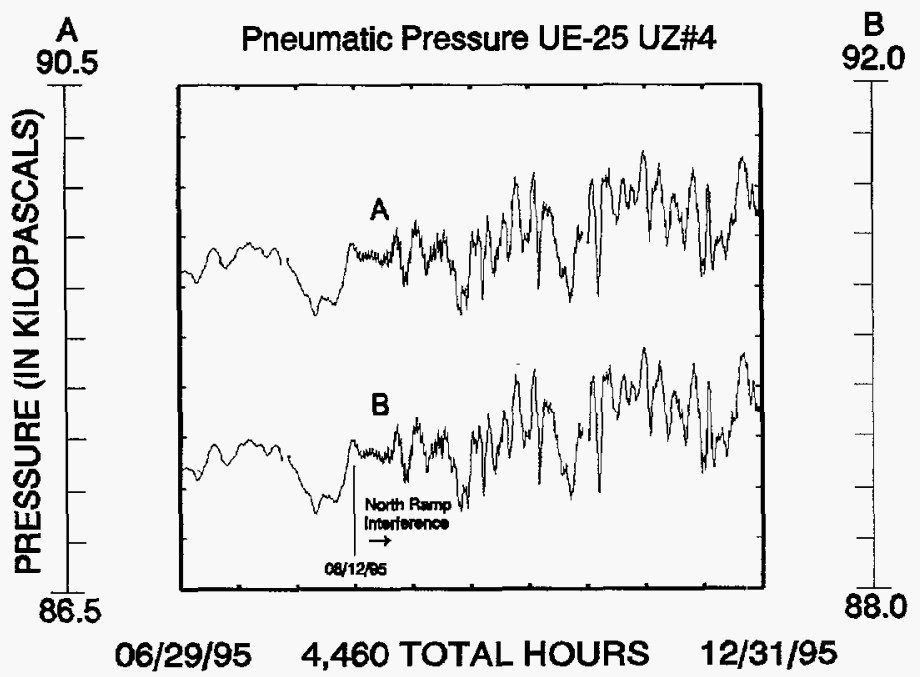

Figure 57. Pneumatic pressure records for instrument station A located in the Topopah Spring welded hydrogeologic unit and instrument station B located in the Paintbrush nonwelded hydrogeologic unit at borehole UE-25 UZ\#4. 


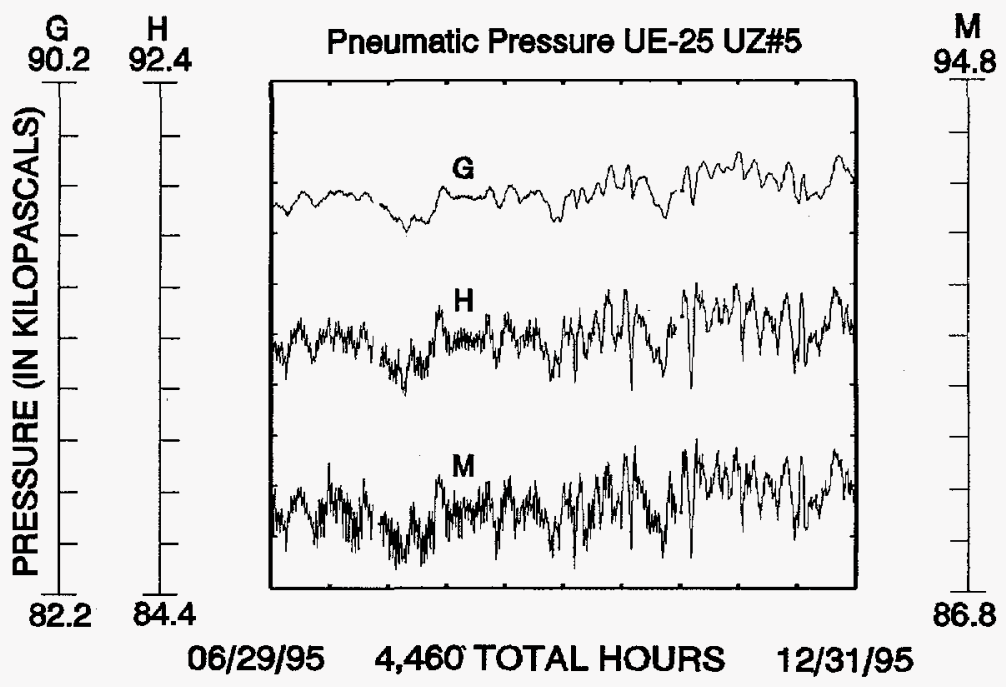

Figure 58. Pneumatic pressure records for instrument station $\mathrm{M}$ located at the land surface, instrument station $\mathrm{H}$ located in the Tiva Canyon welded hydrogeologic unit, and instrument station $\mathrm{G}$ located in the Paintbrush nonwelded hydrogeologic unit at borehole UE-25 UZ\#5.
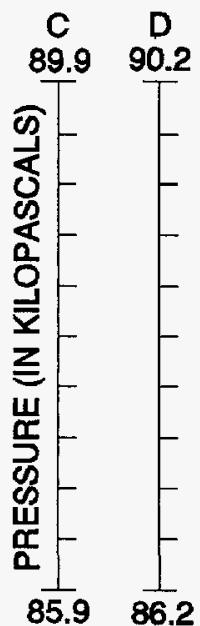

Pneumatic Pressure UE-25 UZ\#5
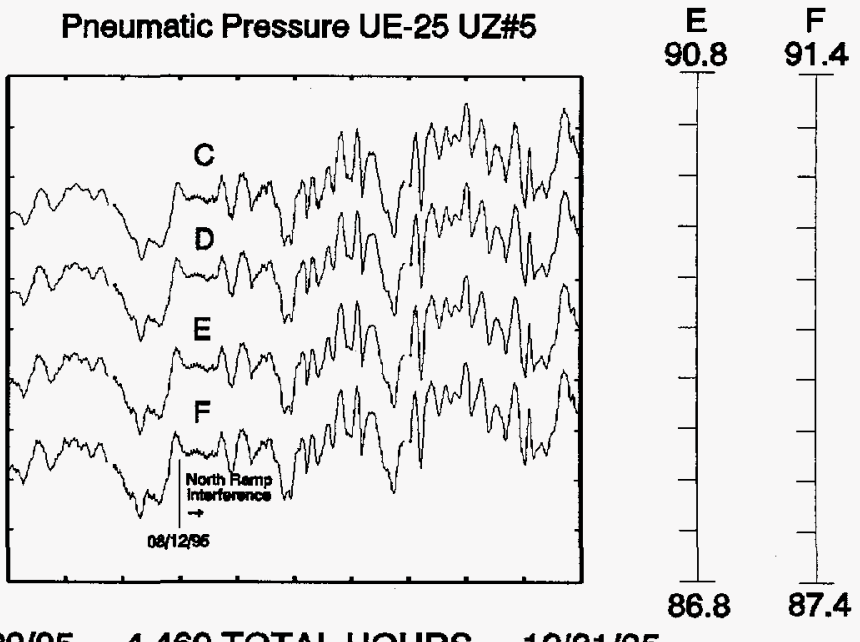

Figure 59. Pneumatic pressure records for instrument stations $C, D, E$, and $F$ located in the Paintbrush nonwelded hydrogeologic unit at borehole UE-25 UZ\#5. 


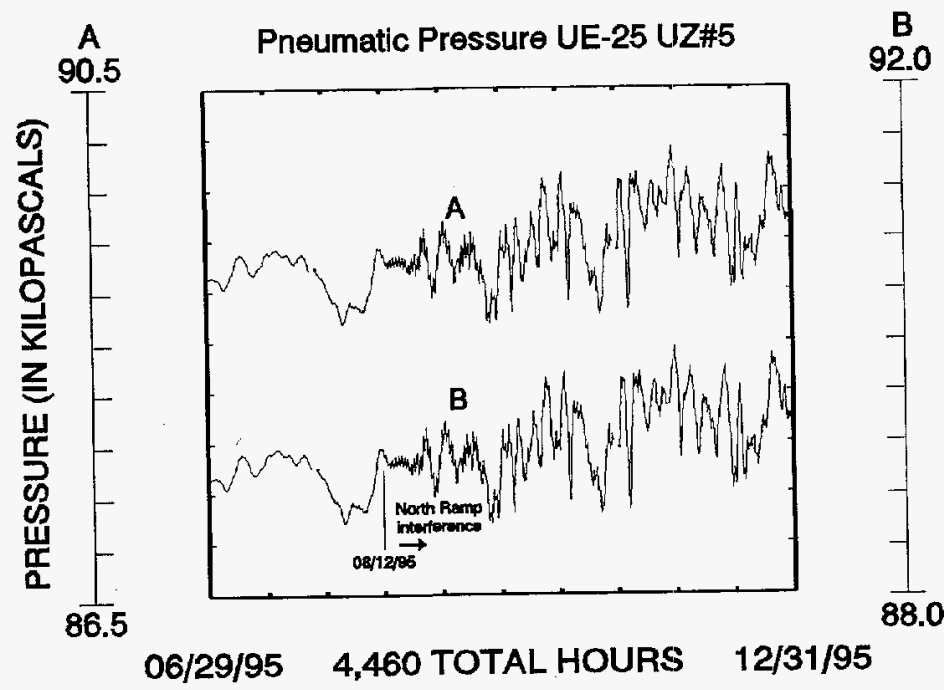

Figure 60. Pneumatic pressure records for instrument station A located in the Topopah Spring welded hydrogeologic unit and instrument station B located in the Paintbrush nonwelded hydrogeologic unit at borehole UE-25 UZ\#5.

For the most part, these records represent all of the pneumatic pressure data that were available as of December 31,1995 . Only a portion of the pressure record for UZ-1 is reproduced. This borehole was instrumented in October 1983 and monitored through October 1987. Because of sensor drift problems, only the early-time pressure records for all but two instrument stations in this borehole (stations 11 and 14) are considered reliable. Furthermore, the pressure data collected from UZ-1 are non-Q because they were collected prior to implementation of the fully approved USGS YMP QA program. Similarly, the pressure data collected from NRG\#4 are non-Q because they were not collected under an approved Yucca Mountain Project quality-assurance program. Nevertheless, the pressure data from these boreholes are important for purposes of characterizing the pneumatic system in the North Ramp study area because the UZ-1 record includes data from the deeper parts of the Topopah Spring Tuff that are not available from other monitored boreholes. Additionally, qualitative application of the data from both UZ-1 and NRG\#4 tend to corroborate and support observations made elsewhere, especially with regard to the pneumatic characteristics of the Paintbrush nonwelded hydrogeologic unit.

The pressure data presented cover time periods that range from less than 6 months (UZ-1, NRG\#5,
UZ\#4, and UZ\#5; figures 42, 43, 47-50, and 55-60) to 9 months (NRG\#4, figures 53 and 54) and up to 1 year (NRG-6, NRG-7a, and SD-9; figures 44-46, 51, and 52). The longer period records include downhole pressure measurements that cover most of the annual barometric pressure cycle, undisturbed by interference from excavation of the North Ramp tunnel. Seasonal components of the annual barometric pressure cycle are characterized by high frequency, large-amplitude synoptic (up to five times larger than the diurnal signal) pressure signals during the fall and winter and by lower frequency, smaller amplitude synoptic pressure signals during the spring and summer. Mean atmospheric pressures also are higher during the fall and winter than during the spring and summer. The first observed occurrences of tunnel-induced pneumatic interference effects are shown in the pressure records of all monitored boreholes provided in this section. These interference effects were observed in NRG\#4, UZ\#4, UZ\#5, NRG\#5, NRG-6, NRG-7a, and SD-9.

Undisturbed, in-situ pressure data, those obtained prior to the onset of North Ramp tunnel interference, were used to estimate pneumatic diffusivities of individual and combined stratigraphic layers bounded by monitoring stations (see the section of this report titled Determination of Pneumatic Diffusivity). In-situ pressure data, both prior to and after the onset 
of North Ramp tunnel interference, were analyzed using cross-spectral estimation techniques (Bendat and Piersol, 1986) to describe the character of the time-varying response of in-situ pressure to changes in the synoptic barometric signal.

The power spectral density of barometric pressure and the transfer function from barometric pressure to in-situ pressure were estimated using the Spectrum subroutine from the Matlab Signal Processing Toolbox (Little and Shure, 1988). Generally, this subroutine uses Fourier transform algorithms that can detect narrow-band frequency signals that are buried in wide-band noise. The barometric signal is a broad frequency-band pressure fluctuation that contains predominant semidiurnal, diurnal, and longer period (synoptic) frequencies. The synoptic frequencies, associated with the passage of storm fronts, provide a longer term pressure fluctuation and, therefore, provide a better developed downhole pressure response. For these analyses, the synoptic barometric frequency having the greatest power spectral density at each borehole was selected, and the residual amplitude $(R A)$ and phase lag $(P L)$ of that signal at each downhole sensor were calculated using the following relations:

$$
\begin{gathered}
R A=\left(\operatorname{Re}^{2}+I \mathrm{~m}^{2}\right)^{0.5} \text { and } P L=\tan ^{-1}(\mathrm{Im} / \mathrm{Re})(\text { rate of } \\
\text { measurement })
\end{gathered}
$$

where

$R e$ and $I m$ are the real and imaginary parts of the transfer function, respectively.

Table 7 shows the calculated residual amplitude and phase lag for each sensor, along with the period of record and synoptic period analyzed for each individual borehole before the effects of North Ramp tunnel interference. The results of the cross-spectral analysis of data collected after the onset of tunnel interference are discussed in the section of this report titled Effects of Excavation of the North Ramp on In-Situ Pneumatic-Pressure Measurements.

The computed phase lags and residual amplitudes of the in-situ pressure data indicate that individual lithostratigraphic units can be grouped conveniently into four distinct pneumatic systems: (1) the Tiva Canyon welded (TCw) hydrogeologic unit, which consists of the welded units of the Tiva Canyon Tuff; (2) the Paintbrush nonwelded (PTn) hydrogeologic unit, which consists of the crystal-poor vitric base of the Tiva Canyon Tuff (Tpcpv1,2), the Yucca Mountain and Pah Canyon Tuffs and associated bedded tuffs, and the crystal-rich vitric units at the top of the Topopah Spring Tuff (Tptrv2,3); (3) the Topopah Spring welded (TSw) hydrogeologic unit, which consists of the welded lithophysal and nonlithophysal units of the Topopah Spring Tuff; and (4) the Calico Hills nonwelded hydrogeologic unit (Chn), which consists of the moderately welded and nonwelded units at the base of the Topopah Spring Tuff (Tptpv1,2), the pre-Topopah Spring Tuff bedded tuff (Tpbt1), the nonwelded tuffs of the Calico Hills Formation, and the pre-Calico Hills Formation bedded tuff. This grouping is consistent with the definition of the major hydrogeologic units presented in table 2 . The responses observed in each of these pneumatic systems to the propagation of atmospheric pressure changes from land surface to depth are discussed in the sections that follow.

\section{Pressure Response in the Tiva Canyon Welded Hydrogeologic Unit}

For the most part, pneumatic pressure records for the Tiva Canyon welded hydrogeologic unit ( $\mathrm{TCw}$ ) display very little attenuation and lagging of the synoptic pressure signal (figs. $45,47,53,55$, and 58). One significant exception is the pneumatic pressure record from station $\mathrm{G}$ located at the base of the Tiva Canyon Tuff columnar unit at NRG-6 (fig. 51). Table 7 indicates that the residual amplitude of the pressure signal at this instrument station is only 43 percent of the synoptic signal and that its phase lag is on the order of 9.6 hours. These spectral parameters are significantly different from those of other pressure records from the $\mathrm{TCW}$ monitoring stations. The residual amplitudes of the synoptic signal from all other monitoring stations in the $\mathrm{TCw}$ are on the order of 97 percent or greater, and phase lags in these stations are less than 5 hours. Comparison of the residual-amplitude and phase-lag data for NRG-6 for the periods $2 / 23 / 95$ to $6 / 10 / 95$ (table 7 ) and $6 / 18 / 95$ to 12/31/95 (table 14 in the section of this report titled Effects of Excavation of the North Ramp on In-Situ Pneumatic-Pressure Measurements) indicates that a significant change occurred in the residual amplitudes and phase lags of all instrument stations in this borehole. At station $\mathrm{G}$, the residual amplitude increased from 43 percent to 66 percent, and the phase lag decreased from 9.6 hours to 2.1 hours. It is unlikely 
Table 7. Spectral analyses of in-situ pneumatic-pressure responses to the synoptic barometric-pressure signal before interference from excavation of the North Ramp tunnel

[N/A, not analyzed; N/D, no data available]

\begin{tabular}{|c|c|c|c|c|c|}
\hline Borehole & $\begin{array}{l}\text { Period of } \\
\text { analysis } \\
\text { (synoptic } \\
\text { frequency) }\end{array}$ & $\begin{array}{l}\text { Instrument } \\
\text { station }\end{array}$ & $\begin{array}{l}\text { Lithostratigraphic } \\
\text { unit }\end{array}$ & $\begin{array}{l}\text { Residual } \\
\text { amplitude } \\
\text { (percent of } \\
\text { synoptic } \\
\text { signal) }\end{array}$ & $\begin{array}{c}\text { Phase } \\
\text { lag } \\
\text { (hours) }\end{array}$ \\
\hline \multirow{7}{*}{$\begin{array}{l}\text { NRG\#4 } \\
\text { (Non-Q) }\end{array}$} & $03 / 29 / 95$ & 1 & Tiva Canyon hackly (Tpcplnh) & 96 & 1.1 \\
\hline & \multirow{2}{*}{$\begin{array}{l}\text { to } \\
05 / 10 / 95\end{array}$} & 2 & Tiva Canyon columnar (Tpcplnc) & 96 & 1.1 \\
\hline & & 3 & Pah Canyon Tuff (Tpp) & 50 & 15.0 \\
\hline & \multirow[t]{4}{*}{ (128 hours) } & 4 & $\begin{array}{l}\text { Topopah Spring crystal-rich nonlithophysal } \\
\text { (Tptrn) }\end{array}$ & 15 & 39.3 \\
\hline & & 5 & $\begin{array}{l}\text { Topopah Spring crystal-rich nonlithophysal } \\
\text { (Tptrn) }\end{array}$ & 15 & 39.4 \\
\hline & & 6 & $\begin{array}{l}\text { Topopah Spring crystal-rich nonlithophysal } \\
\text { (Tptrn) }\end{array}$ & 15 & 39.2 \\
\hline & & 7 & $\begin{array}{l}\text { Topopah Spring upper lithophysal } \\
\text { (Tptrl, Tptpul) }\end{array}$ & 15 & 40.8 \\
\hline \multirow[t]{8}{*}{$\mathrm{UZ \# 4}$} & \multirow{3}{*}{$\begin{array}{l}07 / 21 / 95 \\
\text { to } \\
07 / 31 / 95\end{array}$} & $\mathrm{H}$ & Alluvium/Colluvium (OTac) & N/A & N/A \\
\hline & & G & Tiva Canyon crystal-poor vitric (Tpcpv) & N/A & N/A \\
\hline & & $\mathrm{F}$ & Yucca Mountain Tuff (Tpy) & 21 & 15.9 \\
\hline & \multirow[t]{5}{*}{ (128 hours) } & $\mathrm{E}$ & Yucca Mountain Tuff (Tpy) & 21 & 16.5 \\
\hline & & $\mathrm{D}$ & Pah Canyon Tuff (Tpp) & 21 & 20.3 \\
\hline & & $\mathrm{C}$ & Pah Canyon Tuff (Tpp) & 16 & 26.5 \\
\hline & & B & Topopah Spring crystal-rich vitric (Tptrv) & 15 & 23.7 \\
\hline & & A & $\begin{array}{l}\text { Topopah Spring crystal-rich nonlithophysal } \\
\text { (Tptrn) }\end{array}$ & 16 & 22.9 \\
\hline \multirow[t]{8}{*}{ UZ\#5 } & $07 / 21 / 95$ & $\mathrm{H}$ & Tiva Canyon columnar (Tpcplnc) & N/A & N/A \\
\hline & to & G & Tiva Canyon crystal-poor vitric (Tpcpv) & 62 & 0.3 \\
\hline & $07 / 31 / 95$ & $\mathbf{F}$ & Yucca Mountain Tuff (Tpy) & 19 & 10.9 \\
\hline & \multirow{5}{*}{ (128 hours) } & $\mathbf{E}$ & Yucca Mountain Tuff (Tpy) & 15 & 20.3 \\
\hline & & $\mathrm{D}$ & Pah Canyon Tuff (Tpp) & 14 & 20.5 \\
\hline & & $\mathrm{C}$ & Pah Canyon Tuff (Tpp) & 15 & 21.2 \\
\hline & & $\mathrm{B}$ & Pre-Pah Canyon Tuff bedded tuff (Tpbt2) & 15 & 19.8 \\
\hline & & A & $\begin{array}{l}\text { Topopah Spring crystal-rich nonlithophysal } \\
\text { (Tptrn) }\end{array}$ & 14 & 20.5 \\
\hline
\end{tabular}


Table 7. Spectral analyses of in-situ pneumatic-pressure responses to the synoptic barometric-pressure signal before interference from excavation of the North Ramp tunnel-Continued

[N/A, not analyzed; N/D, no data available]

\begin{tabular}{|c|c|c|c|c|c|}
\hline Borehole & $\begin{array}{l}\text { Period of } \\
\text { analysis } \\
\text { (synoptic } \\
\text { frequency) }\end{array}$ & $\begin{array}{l}\text { Instrument } \\
\text { station }\end{array}$ & $\begin{array}{l}\text { Lithostratigraphic } \\
\text { unit }\end{array}$ & $\begin{array}{c}\text { Residual } \\
\text { amplitude } \\
\text { (percent of } \\
\text { synoptic } \\
\text { signal) }\end{array}$ & $\begin{array}{l}\text { Phase } \\
\text { lag } \\
\text { (hours) }\end{array}$ \\
\hline \multirow[t]{14}{*}{ NRG\#5 } & $08 / 21 / 95$ & 1 & Tiva Canyon upper lithophysal (Tpcpul) & N/D & N/D \\
\hline & \multirow{2}{*}{$\begin{array}{l}\text { to } \\
09 / 11 / 95\end{array}$} & 2 & Tiva Canyon columnar (Tpcplnc) & 99 & 0.3 \\
\hline & & 3 & Yucca Mountain Tuff (Tpy) & 58 & 8.3 \\
\hline & \multirow{11}{*}{ (128 hours) } & 4 & Pah Canyon Tuff (Tpp) & 32 & 21.8 \\
\hline & & 5 & Pre-Pah Canyon Tuff bedded tuff (Tpbt2) & 28 & 24.9 \\
\hline & & 6 & $\begin{array}{l}\text { Topopah Spring crystal-rich nonlithophysal } \\
\text { (Tptrn) }\end{array}$ & 29 & 20.6 \\
\hline & & 7 & $\begin{array}{l}\text { Topopah Spring crystal-rich nonlithophysal } \\
\text { (Tptrn) }\end{array}$ & 29 & 20.5 \\
\hline & & 8 & $\begin{array}{l}\text { Topopah Spring crystal-rich nonlithophysal } \\
\text { (Tptrn) }\end{array}$ & N/D & N/D \\
\hline & & 9 & $\begin{array}{l}\text { Topopah Spring upper lithophysal } \\
\text { (Tptrl, Tptpul) }\end{array}$ & 29 & 21.4 \\
\hline & & 10 & $\begin{array}{l}\text { Topopah Spring upper lithophysal } \\
\text { (Tptrl, Tptpul) }\end{array}$ & N/D & N/D \\
\hline & & 11 & $\begin{array}{l}\text { Topopah Spring upper lithophysal } \\
\text { (Tptrl, Tptpul) }\end{array}$ & 28 & 22.4 \\
\hline & & 12 & $\begin{array}{l}\text { Topopah Spring upper lithophysal } \\
\text { (Tptrl, Tptpul) }\end{array}$ & N/D & N/D \\
\hline & & 13 & $\begin{array}{l}\text { Topopah Spring upper lithophysal } \\
\text { (Tptrl, Tptpul) }\end{array}$ & 35 & 23.8 \\
\hline & & 14 & Topopah Spring middle nonlithophysal (Tptpmn) & 34 & 23.5 \\
\hline \multirow[t]{5}{*}{ NRG-7a } & \multirow{5}{*}{$\begin{array}{c}01 / 25 / 95 \\
\text { to } \\
10 / 08 / 95 \\
\\
\text { (128 hours) }\end{array}$} & $\bar{E}$ & Tiva Canyon hackly (Tpcplnh) & 97 & 4.1 \\
\hline & & $\mathrm{D}$ & Yucca Mountain Tuff (Tpy) & 58 & 17.3 \\
\hline & & $\mathrm{C}$ & $\begin{array}{l}\text { Topopah Spring crystal-rich nonlithophysal } \\
\text { (Tptrn) }\end{array}$ & 6 & 45.5 \\
\hline & & B & $\begin{array}{l}\text { Topopah Spring upper lithophysal } \\
\text { (Tptrl, Tptpul) }\end{array}$ & 6 & 46.7 \\
\hline & & A & $\begin{array}{l}\text { Topopah Spring upper lithophysal } \\
\text { (Tptrl, Tptpul) }\end{array}$ & 5 & 48.5 \\
\hline \multirow[t]{7}{*}{ NRG-6 } & \multirow{7}{*}{$\begin{array}{c}02 / 23 / 95 \\
\text { to } \\
06 / 10 / 95 \\
\text { (160 hours) }\end{array}$} & G & Tiva Canyon columnar (Tpcplnc) & 43 & 9.6 \\
\hline & & $\mathrm{F}$ & Pah Canyon Tuff (Tpp) & 30 & 27.1 \\
\hline & & E & $\begin{array}{l}\text { Topopah Spring crystal-rich nonlithophysal } \\
\text { (Tptrn) }\end{array}$ & 24 & 37.8 \\
\hline & & $\mathrm{D}$ & $\begin{array}{l}\text { Topopah Spring crystal-rich nonlithophysal } \\
\text { (Tptrn) }\end{array}$ & 25 & 37.7 \\
\hline & & $\mathrm{C}$ & $\begin{array}{l}\text { Topopah Spring upper lithophysal } \\
\text { (Tptrl, Tptpul) }\end{array}$ & 25 & 37.9 \\
\hline & & B & $\begin{array}{l}\text { Topopah Spring upper lithophysal } \\
\text { (Tptrl, Tptpul) }\end{array}$ & 25 & 38.3 \\
\hline & & A & Topopah Spring middle nonlithophysal (Tptpmn) & 25 & 38.6 \\
\hline
\end{tabular}


Table 7. Spectral analyses of in-situ pneumatic-pressure responses to the synoptic barometric-pressure signal before interference from excavation of the North Ramp tunnel-Continued

[N/A, not analyzed; N/D, no data available]

\begin{tabular}{|c|c|c|c|c|c|}
\hline Borehole & $\begin{array}{l}\text { Period of } \\
\text { analysis } \\
\text { (synoptic } \\
\text { frequency) }\end{array}$ & $\begin{array}{l}\text { Instrument } \\
\text { station }\end{array}$ & $\begin{array}{l}\text { Lithostratigraphic } \\
\text { unit }\end{array}$ & $\begin{array}{c}\text { Residual } \\
\text { amplitude } \\
\text { (percent of } \\
\text { synoptic } \\
\text { signal) } \\
\end{array}$ & $\begin{array}{l}\text { Phase } \\
\text { lag } \\
\text { (hours) }\end{array}$ \\
\hline \multirow{15}{*}{$\begin{array}{l}\text { UZ-1 } \\
\text { (Non-Q) }\end{array}$} & \multirow{15}{*}{$\begin{array}{c}09 / 12 / 84 \\
\text { to } \\
10 / 13 / 84 \\
\\
\text { (192 hours) }\end{array}$} & 1 & Alluvium/Colluvium (OTac) & N/A & N/A \\
\hline & & 2 & Yucca Mountain Tuff (Tpy) & N/A & N/A \\
\hline & & 3 & Pre-Yucca Mountain Tuff bedded tuff (Tpbt3) & 85 & 2.6 \\
\hline & & 4 & Pah Canyon Tuff (Tpp) & 85 & 3.1 \\
\hline & & 5 & Pah Canyon Tuff (Tpp) & 85 & 5.0 \\
\hline & & 6 & Topopah Spring crystal-rich Vitric (Tptrv) & 21 & 16.3 \\
\hline & & 7 & $\begin{array}{l}\text { Topopah Spring crystal-rich nonlithophysal } \\
\text { (Tptrn) }\end{array}$ & 5 & 50.3 \\
\hline & & 8 & $\begin{array}{l}\text { Topopah Spring crystal-rich nonlithophysal } \\
\text { (Tptrn) }\end{array}$ & 4 & 60.5 \\
\hline & & 9 & $\begin{array}{l}\text { Topopah Spring upper lithophysal } \\
\text { (Tptrl, Tptpul) }\end{array}$ & 4 & 61.8 \\
\hline & & 10 & $\begin{array}{l}\text { Topopah Spring upper lithophysal } \\
\text { (Tptrl, Tptpul) }\end{array}$ & 4 & 62.6 \\
\hline & & 11 & Topopah Spring middle nonlithophysal (Tptpmn) & $\mathrm{N} / \mathrm{D}$ & $\mathrm{N} / \mathrm{D}$ \\
\hline & & 12 & Topopah Spring lower lithophysal (Tptpll) & 4 & 70.1 \\
\hline & & 13 & Topopah Spring lower lithophysal (Tptpll) & 3 & 74.8 \\
\hline & & 14 & Topopah Spring lower lithophysal (Tptpil) & N/D & N/D \\
\hline & & 15 & Topopah Spring lower lithophysal (Tptpll) & 2 & 88.2 \\
\hline
\end{tabular}


that the changes in the TCw pressure responses can be attributed to interference effects from excavation of the North Ramp tunnel (see the section of this report titled Effects of Excavation of the North Ramp on In-Situ Pneumatic-Pressure Measurements). It is more likely that the observed changes are the result of transient infiltration associated with the unusually high precipitation of late 1994 and early 1995. Temporary pneumatic sealing of near-surface fractures and shallow soil cover by infiltrating water seems to be a more plausible explanation to account for changes in the synoptic spectral parameters and for the small residual amplitudes and large phase lags in the early pressure record for station G at NRG-6. Careful review of the NRG-7a spectral parameters before and after interference from excavation of the North Ramp tunnel (table 7 and table 14, respectively) indicates similar behavior; however, the TCw instrument station (E) at this borehole is only about $5 \mathrm{~m}$ below land surface. NRG-6 and NRG-7a were the only boreholes to be instrumented in time to register the effects of transient infiltration events on shallow pneumatic pressures.

\section{Pressure Response in the Paintbrush Nonwelded Hydrogeologic Unit}

The Paintbrush nonwelded hydrogeologic unit (PTn) includes the crystal-poor vitric units (Tpcpv1,2) at the base of the Tiva Canyon Tuff, the crystal-rich vitric units (Tptrv2,3) at the top of the Topopah Spring Tuff, and the intervening Yucca Mountain, Pah Canyon, and associated bedded tuffs. In the monitored boreholes the PTn is thickest (84.1 m) at UZ\#4 and thinnest $(38.0 \mathrm{~m})$ at NRG-6 (table 8). Although there are some complex variations, across the study area the PTn generally becomes thinner from northwest to southeast (fig. 11). The PTn is overlain by the $\mathrm{TCw}$ in all monitored boreholes except UZ-1. UZ-1 is located in Drill Hole Wash, and erosion has removed all of the Tiva Canyon Tuff and a portion of the upper Yucca Mountain Tuff of the PTn.

Pneumatic pressure records from monitoring stations immediately above and below the PTn (figs. 45, 47, 51, 53, 55, and 58) indicate that the attenuation and phase lag of the synoptic pressure signal across the PTn are greatest in the western part of the study area (UZ-1) and decrease in a south to southeasterly direction across the study area. This conclusion,

Table 8. Thickness of the Paintbrush nonwelded hydrogeologic unit (PTn) in monitored boreholes in the North Ramp study area

\begin{tabular}{|c|c|c|c|c|}
\hline \multirow{2}{*}{ Borehole } & \multirow{2}{*}{$\begin{array}{c}\text { Total thickness } \\
\text { of the PTn, } \\
\text { in meters }\end{array}$} & \multicolumn{3}{|c|}{$\begin{array}{l}\text { Thickness of the vitric units of the PTn, } \\
\text { in meters }\end{array}$} \\
\hline & & $\begin{array}{l}\text { Tiva Canyon Tuff } \\
\text { crystal-poor unit } \\
\text { (Tpcpv1,2) }\end{array}$ & $\begin{array}{l}\text { Topopah Spring Tuff } \\
\text { crystal-rich unit } \\
\text { (Tptrv2,3) }\end{array}$ & Total vitric \\
\hline UZ-1 ${ }^{1,2}$ & 68.9 & 0.0 & 3.7 & 3.7 \\
\hline SD- $9^{3}$ & 64.4 & 10.7 & 3.9 & 14.6 \\
\hline NRG- $7 a^{4}$ & 69.0 & 10.1 & 4.9 & 15.0 \\
\hline NRG\#5 $5^{3,5}$ & 57.9 & 7.3 & 5.5 & 12.8 \\
\hline NRG- $6^{5}$ & 38.0 & 7.1 & 4.0 & 11.1 \\
\hline NRG\#4 $4^{3,5}$ & 53.1 & 7.3 & 5.2 & 12.5 \\
\hline UZ\#4 ${ }^{6}$ & 84.1 & 4.5 & 4.3 & 8.8 \\
\hline $\mathrm{UZ} \# 5^{6}$ & 80.5 & 8.5 & 6.4 & 14.9 \\
\hline $\begin{array}{l}{ }^{1} \text { Whitfield an } \\
{ }^{2} \text { R.W. Speng } \\
{ }^{3} \text { Moyer, Ges } \\
{ }^{4} \text { Geslin and } ~ \\
{ }^{5} \text { Geslin, Moy } \\
{ }^{6} \text { Loskot and }\end{array}$ & $\begin{array}{l}\text { ers (1990). } \\
\text { d D.C. Buesch, U.S. } \\
\text { d Buesch (1995). } \\
\text { r (1995). } \\
\text { d Buesch (1995). } \\
\text { mermeister (1992). }\end{array}$ & ological Survey, writte & ommun., 1996). & \\
\hline
\end{tabular}


however, although probably valid scientifically, is non- $Q$ because it is based on pneumatic-pressure data from UZ-1 that are non-Q. Variability in the pneumatic impeding characteristics of the PTn is illustrated in the pressure records from instrument stations located in the crystal-rich nonlithophysal unit of the Topopah Spring Tuff. These records, reproduced in figure 61, cover the period from May 24, 1995, to September 1, 1995. Data from UZ-1 are not available for this record period. Examination of the pneumaticpressure data from instrument stations located within and across various lithostratigraphic units that comprise the PTn indicates that the pressure-attenuating and lagging characteristics of these units are different from one location to another and that the composite thickness of the PTn is insufficient to uniquely account for differences in the magnitude of the residual amplitude and phase lag of the synoptic pressure signal transmitted across this unit.

At borehole UZ-1, maximum attenuation and lagging of the synoptic pressure signal occur across the lower section of the Pah Canyon Tuff (figs. 42 and 43), between instrument stations 5 and 6 ( 85 percent to 21 percent residual amplitude) and between instrument stations 6 and 7 ( 21 percent to 5 percent residual amplitude). Thus, the lower $30 \mathrm{~m}$ of the composite PTn section, which is $68.9 \mathrm{~m}$ thick at UZ-1 (table 8), accounts for 80 percent of the total attenuation. This conclusion, however, although probably valid scientifically, is non- $Q$ because it is based on pneumatic-pressure data from UZ-1 that are non-Q.

In borehole SD-9, no instrument stations are isolated within any of the lithostratigraphic units that comprise either the TSw or the PTn. The pressure record from Zone 1 (fig. 44) presumably represents a composite pressure from the combined PTn and TSw. The pressure record from the crystal-rich nonlithophysal unit of the TSw at NRG-7a, which is approximately 442 m northeast of SD-9 (fig. 21), is similar to the pressure record from Zone 1 at SD-9. The similarity in these two pressure records indicates that the pressure-attenuating characteristics of the PTn at SD-9 are comparable to those at NRG-7a. The composite thicknesses of the PTn at both locations also are similar: $64.4 \mathrm{~m}$ at SD-9 and $69.0 \mathrm{~m}$ at NRG-7a (table 8).

At NRG-7a, only one instrument station is within the PTn. Instrument station D (fig. 45) is in a bedded unit above the Pah Canyon Tuff, approximately midway between the top of the crystal-rich, densely welded vitric unit of the Topopah Spring Tuff and the bottom of the crystal-poor, densely welded vitric unit of the Tiva Canyon Tuff. The decrease in the residual amplitude of the synoptic pressure signal

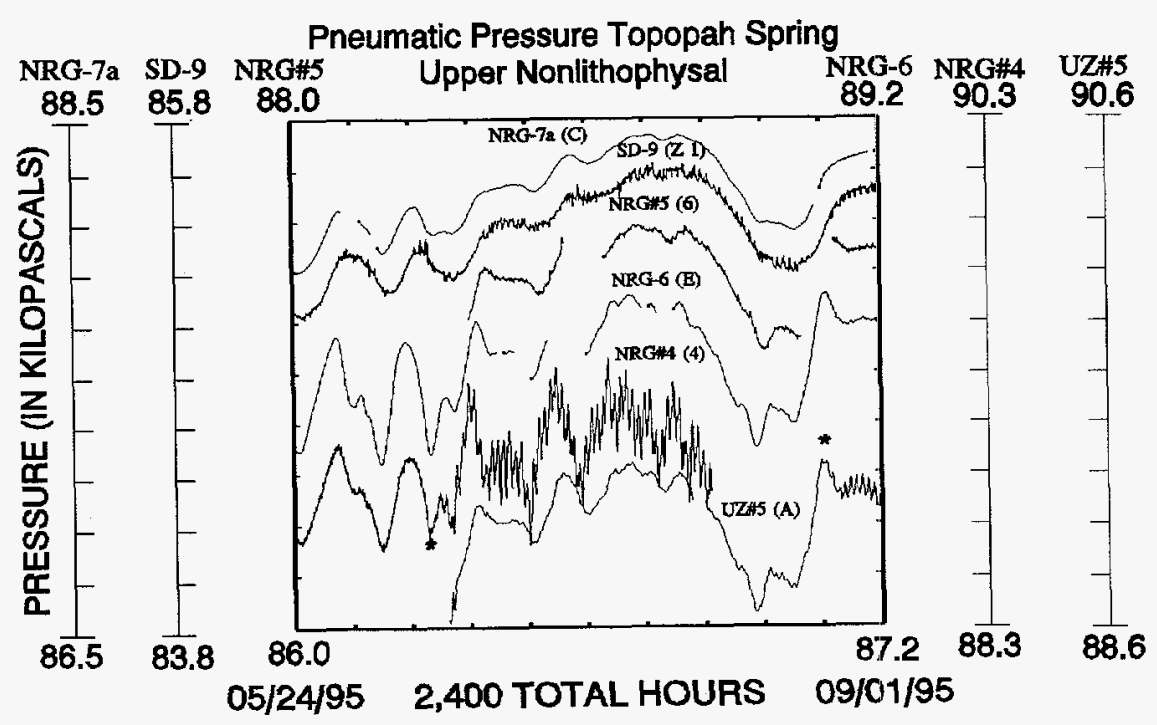

Figure 61. Pneumatic pressure records for instrument stations (shown in parentheses) located immediately below the Paintbrush nonwelded hydrogeologic unit contact with the Topopah Spring welded hydrogeologic unit. Asterisk indicates onset of interference effects from excavation of the North Ramp Tunnel. 
across the upper $30 \mathrm{~m}$ of the PTn is approximately 39 percent ( 58 percent residual amplitude at instrument station D). At instrument station $C$, in the crystal-rich nonlithophysal unit of the Topopah Spring Tuff, the residual amplitude is only about 6 percenta decrease of 52 percent across the lower $39 \mathrm{~m}$ of the PTn. At NRG-7a, there appears to be uniform decay in the synoptic pressure signal across the upper and lower halves of the PTn section. Because only one instrument station is within the PTn at NRG-7a, finer discrimination of the attenuating characteristics of individual units is not possible.

At NRG\#5 (figs. 47 and 48), most of the attenuation of the synoptic signal occurs across the Yucca Mountain Tuff, between instrument stations 2 and 3 (41 percent reduction in the residual amplitude) and across the upper Pah Canyon Tuff and bedded tuff units between instrument stations 3 and 4 ( 26 percent reduction in the residual amplitude). Very little signal attenuation, if any, is associated with the relatively thick $(5.5 \mathrm{~m})$, crystal-rich vitric unit at the base of the PTn. The upper $30 \mathrm{~m}$ of the PTn at NRG\#5 accounts for approximately 68 percent, and the lower $27 \mathrm{~m}$ accounts for only about 4 percent of the total synoptic signal attenuation across the PTn.

At NRG\#4, the lower crystal-rich vitric unit of the PTn is $5.2 \mathrm{~m}$ thick (table 8) and the reduction in the residual amplitude of the synoptic pressure signal across this interval, between instrument stations 3 and 4 is very large, approximately 35 percent. Instrument stations 2 and 3 bound a composite section of the PTn that is $53.1 \mathrm{~m}$ thick and includes the crystal-poor vitric unit, the Yucca Mountain Tuff, an intercalated bedded tuff unit, and the Pah Canyon Tuff. The change in the residual amplitude of the synoptic signal between instrument stations 2 and 3 is approximately 46 percent. Thus, a substantial portion of the total attenuated signal at NRG\#4 is accounted for by the, crystal-rich, vitric unit at the base of the PTn. This conclusion, although scientifically valid, is non- $Q$ because it is based on pressure data collected at NRG\#4 that are non-Q.

Attenuation of the synoptic pressure signal across the composite PTn at NRG-6 is minimal in comparison to other monitored boreholes. Most of the synoptic signal attenuation in this borehole (fig. 51) appears to occur across the $\mathrm{TCW}$ (43 percent residual at instrument station $\mathrm{G}$ located at the base of the Tiva Canyon Tuff columnar unit). (See the discussion of possible transient infiltration effects in the section of this report titled Pressure Response in the Tiva Canyon Welded Hydrogeologic Unit.) Between instrument stations $F$ and $G$, a distance of $15 \mathrm{~m}$, the residual amplitude of the synoptic signal is reduced by about 13 percent. These instrument stations bound the crystal-poor vitric unit of the Tiva Canyon Tuff and the PTn and a bedded tuff unit of the PTn. The change in residual amplitude is only about 6 percent between instrument stations $E$ and $F$ that bound a $26-\mathrm{m}$ section of the Pah Canyon and crystal-rich vitric unit of the PTn and Topopah Spring Tuff. Station E straddles the contact between the crystal-rich vitric unit of the PTn and the crystal-rich nonlithophysal unit of the Topopah Spring. The combination of the video log (not shown) and fracture-density log of borehole NRG-6 (fig. 25) indicates intense fracturing across this contact, with individual fracture openings that are several centimeters acrosss. The lack of significant signal attenuation across the PTn at NRG- 6 may be more a result of the effects of localized fracturing (faulting?) than a reflection of the relative thinness of the PTn at this location.

Instrument stations at UZ\#4 and UZ\#5 were positioned to examine the pneumatic characteristics of individual lithostratigraphic units within the PTn. Among the monitored boreholes, the thickness of the PTn is greatest at UZ\#4 and UZ\#5 (table 8). Instrument stations in both of these boreholes bound the three PTn bedded units with instrument stations that are located at the top and bottom of the Yucca Mountain Tuff and the Pah Canyon Tuff (fig. 41). Instrument stations also are located in the crystal-poor vitric and crystal-rich vitric units of the PTn. The total attenuation of the synoptic pressure signal (residual amplitude equal to 15 percent) across the PTn is almost identical at UZ\#4 and UZ\#5, even though attenuation across the Tiva Canyon Tuff crystal-poor vitric unit differs between the two boreholes. Attenuation of the pressure signal in the Tiva Canyon Tuff crystal-poor vitric unit at $\mathrm{UZ \# 4} \mathrm{(station} \mathrm{G}$ in table 7) is so small that it could not be computed. ("N/A" for $\mathrm{UZ \# 4}$ station $\mathrm{G}$ in table 7 indicates that the residual amplitude is very close to 100 percent.) In the same unit at UZ\#5 (station G in table 7), however, the residual amplitude is 62 percent, indicating significant attenuation. Comparison of the raw pressure records for UZ\#4 and UZ\#5 (figs. 55 and 58) also indicates a significant difference in attenuation in the Tiva Canyon Tuff crystal-poor vitric unit. The difference is evident in the observation that at UZ\#4, the pressure 
record in this unit (station $\mathrm{G}$ in figure 55) is very similar to that of the atmosphere (station $\mathrm{M}$ ), whereas at $U Z \# 5$, the pressure record in this unit (station $\mathrm{G}$ in figure 58) is more subdued and smoothed than the atmospheric record (station M). The Tiva Canyon Tuff crystal-poor vitric unit is about half as thick at $\mathrm{UZ \# 4}$ as it is at UZ\#5 (table 8), and it is quite possible that monitoring station $\mathrm{G}$ at UZ\#4 may not be completely isolated from the overlying Tiva Canyon Tuff columnar unit. The pneumatic pressure signals from instrument station $F$, located below the upper bedded units at UZ\#4 and UZ\#5, are almost identical, also indicating that complete isolation of instrument station $\mathrm{G}$ may not have been achieved at $\mathrm{UZ \# 4.}$

Within the PTn most of the synoptic signal attenuation occurs across the crystal-poor vitric unit ( 80 percent reduction in the surface amplitude). Minimal attenuation occurs across the crystal-rich vitric unit and the other bedded and nonwelded tuffs of the PTn (table 7).

Pneumatic pressure data from monitoring stations within the PTn and from monitoring stations located above and below this unit indicate that the pneumatic characteristics of the individual lithostratigraphic units are quite different from one location to another. The total thickness of the PTn alone is not sufficient to account for the total residual amplitude and phase lag of the synoptic pressure signal seen in the crystal-rich nonlithophysal unit of the Topopah Spring. Differences in the pneumatic diffusivities of individual units within the PTn are obviously present. These differences are more than likely a reflection of local differences in the saturation of individual units and/or a reflection of the presence or absence of open fractures within these units, especially at UZ\#4 and UZ\#5 (see also the section of this report titled Effects of Excavation of the North Ramp on In-Situ Pneumatic-Pressure Measurements). In the absence of localized fracturing, the very low matrix porosities of the crystal-rich vitric and crystal-poor vitric units render the pneumatic permeabilities of these units particularly sensitive to small changes in moisture content. Locally, the pneumatic characteristics of the crystal-rich vitric unit appear to be dominated by fracturing. This is especially true at NRG-6, UZ\#4, and UZ\#5.

\section{Pressure Response in the Topopah Spring Welded Hydrogeologic Unit}

Pressure data from instrument stations located in the lithophysal and nonlithophysal units of the Topopah Spring welded (TSw) hydrogeologic unit exhibit negligible attenuation and lagging of the pneumatic pressure signals transmitted across the crystalrich vitric unit of the PTn (see figs. 42, 43, 44, 46, 49, $50,52,54,57$, and 60). Pressure signals appear to be transmitted nearly instantaneously throughout the entire thickness of the TSw. Instrument stations at UZ-1 are located through the entire thickness of the $\mathrm{TSw}$, a distance of approximately $275 \mathrm{~m}$ (fig. 41). The deepest station, instrument station 15 , is located near the bottom of the crystal-poor, lower nonlithophysal unit of the Topopah Spring Tuff. The amplitude and phase lag of the pressure record at this location are nearly identical to that from the shallowest instrument station in the TSw, station 7, located near the top of the crystal-rich nonlithophysal unit of the Topopah Spring Tuff (fig. 43).

At SD-9, the Zone 1 pressure record (fig. 44) is nearly identical to the TSw pressure records from instrument stations $\mathrm{A}, \mathrm{B}$, and $\mathrm{C}$ in nearby NRG-7a (fig. 46). Zone 1 data presumably represent a composite pressure measurement that includes the entire TSw, $283 \mathrm{~m}$ thick, and the PTn (see section of this report titled Pressure Response in the Paintbrush Nonwelded Hydrogeologic Unit). The similarity in the pressure records from Zone 1 at SD-9 and the TSw instrument stations at NRG-7a indicate that the Zone 1 pressure record at SD-9 is dominated by gas flow within the TSw and that attenuation of pneumatic pressure signals across the PTn at SD-9 is comparable to that at NRG-7a.

The only borehole in which any significant change in pneumatic pressures within the TSw is displayed is NRG\#5. The residual amplitude of the pneumatic pressures from instrument stations 13 and 14 (fig. 50; pre-North Ramp interference, 09/14/95), located in the upper section of the middle nonlithophysal and lower section of the upper lithophysal units of the Topopah Spring Tuff, respectively, are approximately 5 percent greater than those in the overlying TSw instrument stations. Phase lags from the two lowermost instrument stations also are slightly greater by 2 to 3 hours (see table 7) than are the phase lags from stations higher in the section. These data indicate the possible existence of a preferential pathway, possibly a nearby fault (for example, the Drill Hole 
Wash Fault system). Pressure records for the TSw from NRG-6 and NRG\#4 (figs. 52 and 54) display negligible amplitude attenuation and phase lagging with increasing depth below the PTn. Pressure data from all the TSw instrument stations indicate that the pneumatic diffusivity of this unit is very high (see also the section of this report titled Determination of Pneumatic Diffusivity). Fractures within the TSw apparently are very permeable and highly interconnected within both the lithophysal and nonlithophysal units.

Pressure Response in the Calico Hills Nonwelded Hydrogeologic Unit

The only monitoring station with pneumatic pressure data from the Calico Hills nonwelded hydrogeologic unit (CHn) is in SD-9 (fig. 44). As described previously, pressures in the $\mathrm{CHn}$ are monitored from inside the annular space of a nested pair of casings that are open between the bottom of a perched water zone located at a depth of $413 \mathrm{~m}$ and the top of the water table located at a depth of $573 \mathrm{~m}$. The Zone 2 pressure record for this borehole indicates that pneumatic pressure changes in the Calico Hills Formation follow a seasonal trend. Individual synoptic pressure signals do not appear in this record, but do appear as composite, time-averaged signals that are superimposed on the seasonal pressure wave. The synoptic signal in the overlying TSw is strongly attenuated across the crystal-poor vitric unit of the Topopah Spring Tuff. At SD-9, this unit is saturated (see the section of this report titled Occurrences of Perched Water in the Vicinity of the Exploratory Studies Facility North Ramp) and acts as a pneumaticimpeding layer to vertical propagation of pneumatic pressures. The areal extent of this impeding layer cannot be established with the few data that are currently available, but it is very likely that the layer exists wherever perched water is in contact with the crystal-poor vitric unit of the Topopah Spring Tuff (that is, NRG-7a, UZ-1, and UZ-14).

\section{Determination of Pneumatic Diffusivity}

Pneumatic-pressure records at boreholes NRG-6 and NRG-7a in Drill Hole Wash and boreholes UZ\#4 and UZ\#5 in Pagany Wash were used to estimate the pneumatic diffusivities, and ultimately, the effective gas permeabilities of the stratigraphic layers bounded by the monitoring stations. Similar analyses of pneumatic pressure at Yucca Mountain have been reported previously for borehole NRG\#4 (Multimedia Environmental Technology, Inc., 1995) and a subset of the monitoring stations at boreholes UZ-1 (Montazer and others, 1985) and NRG-6 and NRG-7a (Ahlers and others, 1995). Additional analyses have been done recently using pneumatic-pressure data from boreholes SD-9 and NRG\#5 (E.P. Weeks, U.S. Geological Survey, written commun., 1996).

As discussed above in the section titled In-Situ Pneumatic-Pressure Response to AtmosphericPressure Change, the pneumatic-pressure data at the monitoring boreholes show phase shifts and amplitude reductions in surface barometric pressure changes as they propagate through the subsurface. The magnitudes of these amplitude reductions and phase shifts in pneumatic pressure are a reflection of the pneumatic diffusivities of the layers through which the pneumatic-pressure signal has passed and can be described by the transient gas diffusion equation. The AIRK program (Weeks, 1978) solves the gas diffusion equation numerically by using the finite-difference method to estimate the time-dependent vertical distribution of gas pressure, given initial and boundary conditions provided by the data from the instrumented boreholes. By beginning at the bottom of a stack of layers, the pneumatic diffusivity of each layer in a stack of layers can be estimated one layer at a time, using the pressure at the upper station of the pair as the upper boundary condition for that layer. The estimate of pneumatic diffusivity of the layer is adjusted, either manually by the user or automatically by the program, until the pressure at the lower station in the pair is satisfactorily predicted by the model. As the next higher layer is added to the stack, the pressures at the monitoring station, which had previously provided the upper boundary condition for the model, become the basis for optimizing the pneumatic diffusivity of the overlying layer. As layers are added to the stack, the underlying layers for which pneumatic diffusivities have already been estimated are retained because the pneumatic properties of these layers will influence estimates of pneumatic diffusivity of layers higher in the stack. The reader is referred to Weeks (1978) for further information concerning the solution algorithm. Pneumatic diffusivity is defined as (Weeks, 1978)

$$
D_{p}=k k_{r a} P / \mu_{a} \phi_{a}
$$


where:

$D_{p}$ is effective pneumatic diffusivity, $\left[\mathrm{L}^{2} \mathrm{~T}^{-1}\right]$;

$k$ is intrinsic permeability, $\left[\mathrm{L}^{2}\right]$;

$k_{r a}$ is the relative permeability of the medium to air at the prevailing moisture content, $[\mathrm{L}]$;

$P$ is mean pressure during the observation period, $\left[\mathrm{ML}^{-1} \mathrm{~T}^{-2}\right]$;

$\mu_{a}$ is the absolute viscosity of air at the prevailing temperature, $\left[\mathrm{ML}^{-1} \mathrm{~T}^{-1}\right]$; and

$\phi_{a}$ is the interconnected air-filled porosity at the prevailing moisture content, $\left[\mathrm{L}^{0}\right]$.

The units for these terms are length [L], time $[\mathrm{T}]$, and mass $[\mathrm{M}]$. The symbol $\left[\mathrm{L}^{0}\right]$ indicates the term is dimensionless. As indicated by equation 2, pneumatic diffusivity is a function of both the effective permeability to air of the medium $\left(k k_{r a}\right)$ and the airfilled porosity $\left(\phi_{a}\right)$. In order to obtain estimates of $k k_{r a}$ for the intervals bounded by the monitoring stations, independent estimates of $\phi_{a}$ for these intervals were made using porosity and water-saturation data available for the Drill Hole Wash and Pagany Wash boreholes (see the section of this report titled Physical and Hydrologic Properties Determined from Analysis of Rock Cores). Thus, except where noted otherwise, values of $\phi_{a}$ were assumed to be known at each borehole during the parameter-estimation process, and all uncertainty in $D_{p}$ for an interval was attributed to uncertainty in $k k_{r a}$.

Before performing the analyses with the AIRK program, which does not consider gravitational effects, the pressures recorded at the borehole monitoring stations were adjusted to remove the pressure differences due to differences in station elevation and possible offsets in measured mean pressure related to transducer calibration. This was done by adjusting the pressure records for the individual stations to the same mean pressure as the measured pressure at the wellhead of that borehole for the period of analysis. When the effects of elevation differences are removed, small phase lags and amplitude reductions between stations at a borehole become more discernible. Comparisons between measured and simulated pneumatic pressures presented below are made with the effects of differences in station elevations removed.

As discussed in other sections of this report (InSitu Pneumatic-Pressure Response to AtmosphericPressure Change and Effects of Excavation of the North Ramp on In-Situ Pneumatic-Pressure Measurements), excavation of the North Ramp eventually affected pneumatic pressures measured in each of the
Drill Hole Wash and Pagany Wash boreholes. This section analyzes only the early parts of the borehole pneumatic-pressure records, before the interference effects of North Ramp excavation were observed.

\section{Drill Hole Wash Boreholes}

The part of the measured pneumatic-pressure record used to estimate the pneumatic diffusivities at borehole NRG-6 is shown in figure 62. The most significant impedance to the pneumatic-pressure signal occurs between stations $\mathrm{G}$ and $\mathrm{F}$, an interval that includes subunits of the lower TCw (Tpcplnc and Tpcpv) and subunits of the PTn (Tpbt4, Tpy, and the uppermost part of the Tpp). Further reductions in signal amplitude and increases in phase offset occur between stations $\mathrm{F}$ and $\mathrm{E}$, an interval that includes subunits of the PTn (Tpp, Tpbt2, and Tptrv) and the uppermost part of the TSw (Tptrn). Stations in the TSw below station $\mathrm{E}$ (stations $\mathrm{D}, \mathrm{C}, \mathrm{B}$, and $\mathrm{A}$ ) respond almost identically to station $\mathrm{E}$. The nearly identical behavior of these stations to station $E$ indicates either that pneumatic diffusivities are very large relative to those in the overlying nonwelded units, so that the signal passing through the nonwelded units propagates almost instantaneously throughout the TSw, or that nearby faults are short-circuiting the pneumatic system and affecting each of the stations below station E equally. Because the AIRK program is one-dimensional, this analysis will focus on identifying the pneumatic-diffusivity values that would permit nearinstantaneous equilibration of the pneumatic-pressure signal throughout the TSw.

The match between the simulated and measured pneumatic pressures at borehole NRG- 6 generally is very good, as shown in figures 63 through 65 . The largest discrepancies, in absolute terms, are associated with the pneumatic pressures at station G. The simulated pneumatic pressures at that station are insufficiently damped relative to the observed pneumatic pressures during periods when pressure oscillations recorded at the wellhead station (L) were large and abrupt. The numerical model was able to replicate the absence of amplitude reductions or temporal offset in the pneumatic pressures between stations E, D, C, B, and A (figs. 64 and 65).

The depth interval, the stratigraphic units in that depth interval, and values of $k k_{r a}$ and $\phi_{a}$ estimated for each interval defined by the monitoring stations at borehole NRG-6 are listed in table 9. The absence of 


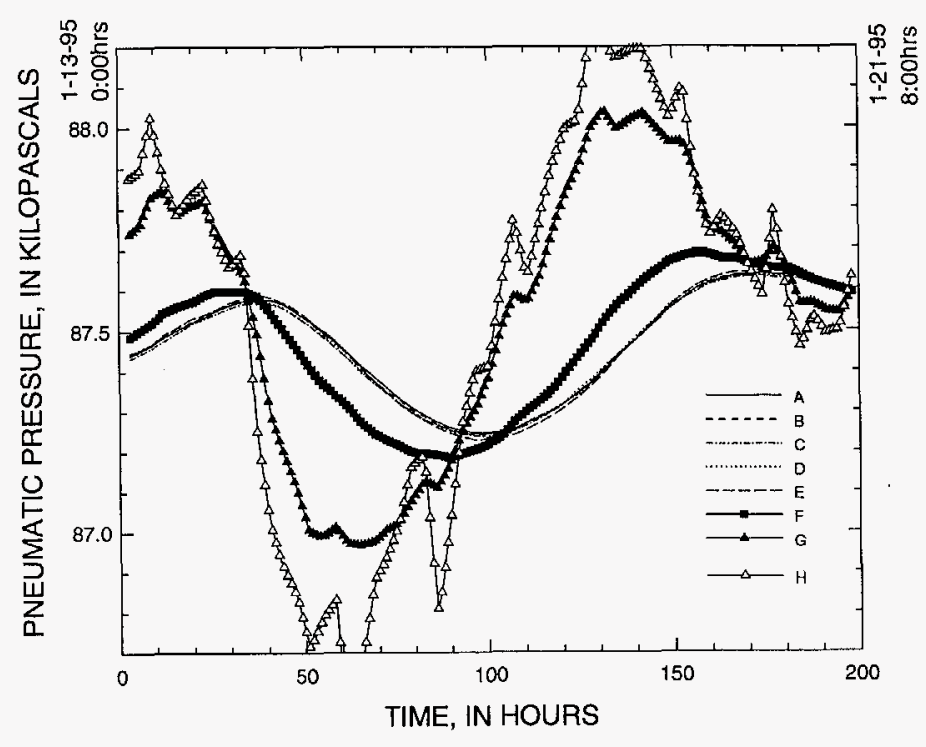

Figure 62. Measured pneumatic pressure record used to estimate the pneumatic diffusivities at borehole USW NRG-6.

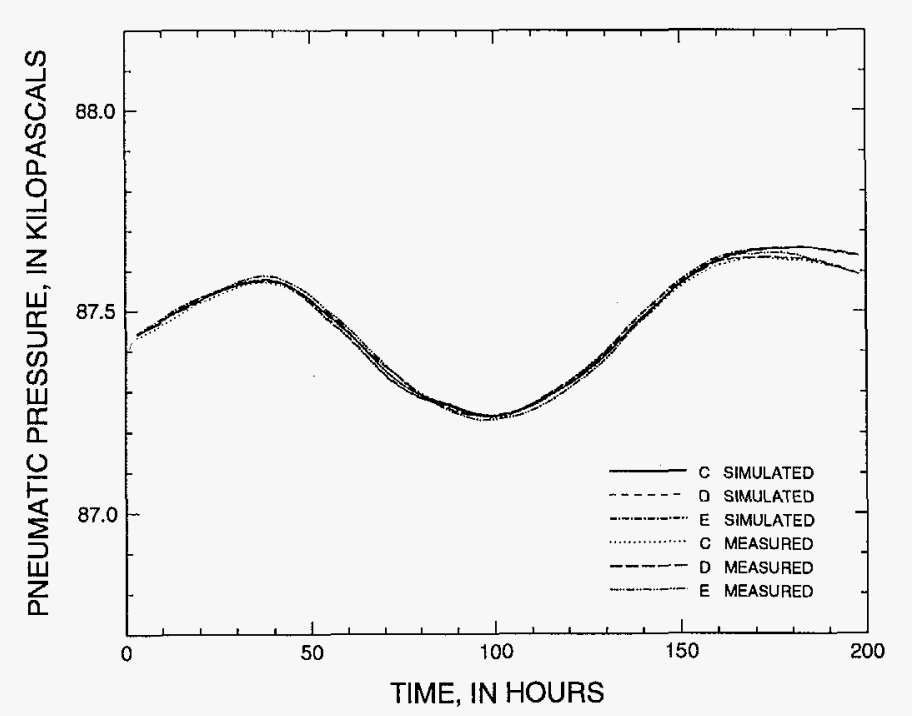

Figure 64. Comparison of simulated and measured pneumatic pressures for instrument stations $C, D$, and $E$ at borehole USW NRG-6.

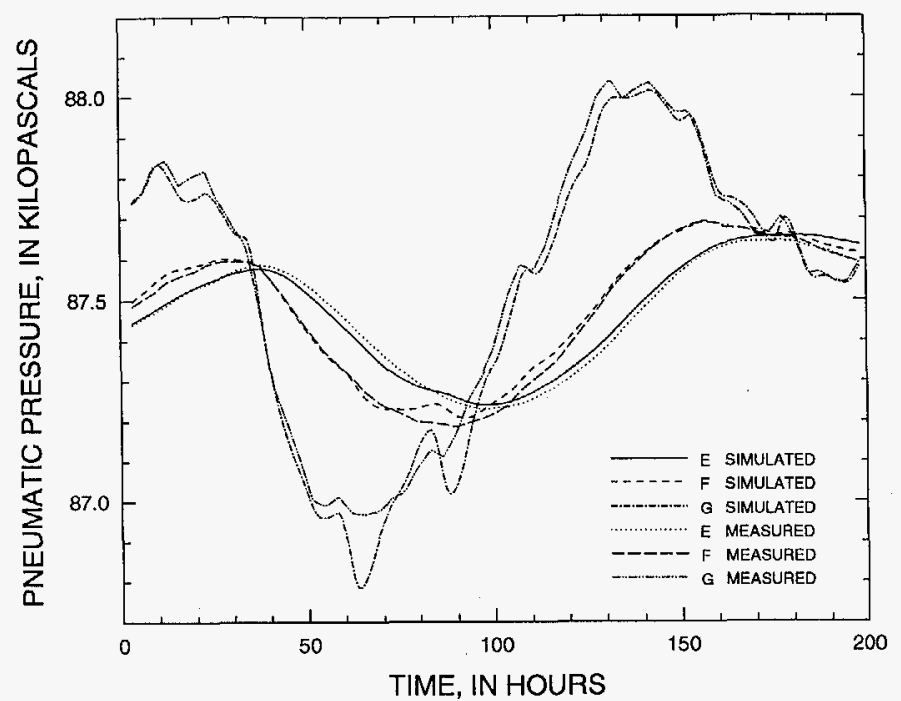

Figure 63. Comparison of simulated and measured pneumatic pressures for instrument stations $E, F$, and $G$ at borehole USW NRG-6.

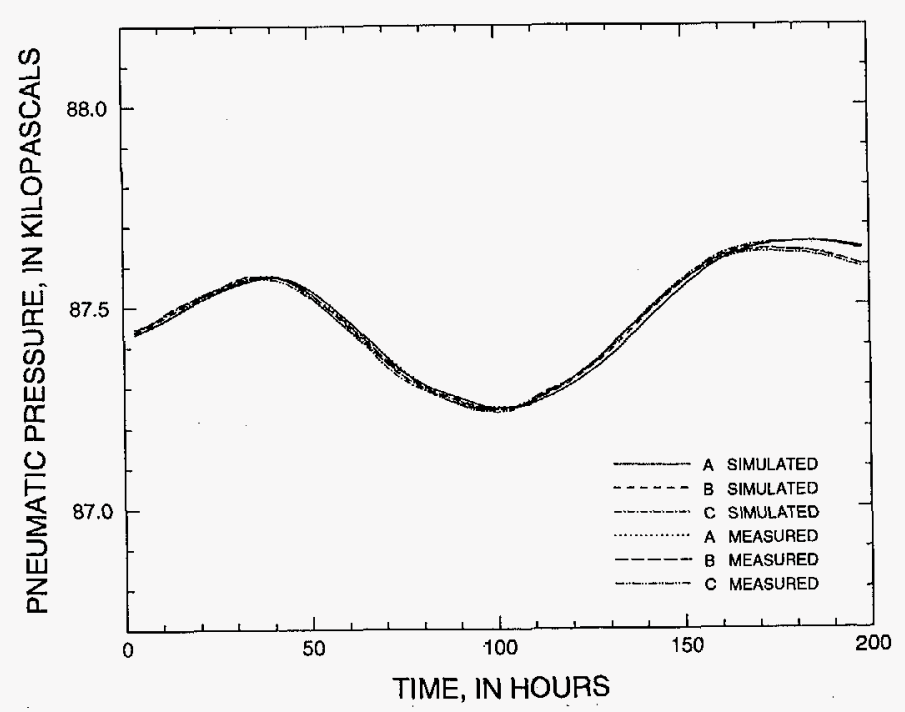

Figure 65. Comparison of simulated and measured pneumatic pressures for instrument stations $A, B$, and $C$ at borehole USW NRG-6. 
Table 9. Results of model calibration using pneumatic-pressure data from instrumented borehole NRG-6

$\left[k k_{r a}=\right.$ effective permeability to air; $\phi_{a}=$ air-filled porosity; SS=sum of squared differences between measured and simulated pressures; $\mathrm{kPa}{ }^{2}=\mathrm{kilo}-$ pascal squared; \%=percent; lithostratigraphic units are defined in table 2]

\begin{tabular}{|c|c|c|c|c|c|c|c|c|}
\hline $\begin{array}{l}\text { Depth } \\
\text { interval } \\
\text { (meters) }\end{array}$ & $\begin{array}{c}\text { Litho- } \\
\text { stratigraphic } \\
\text { units in depth } \\
\text { interval }\end{array}$ & $\begin{array}{c}\text { Baseline } \\
k_{k_{r a}} \\
\left(m^{2}\right)\end{array}$ & $\begin{array}{c}\text { Baseline } \\
\phi_{\mathbf{a}}\end{array}$ & $\begin{array}{c}\text { SS Base- } \\
\text { line } \\
k k_{\text {ram }} \phi_{a} \\
\left(\mathbf{k P a}^{2}\right)\end{array}$ & $\begin{array}{c}S S \\
k k_{r a}+50 \% \\
\left(k P a^{2}\right)\end{array}$ & $\begin{array}{c}\text { SS } \\
k k_{r a}^{-50 \%} \\
\left(\mathrm{kPa}^{2}\right)\end{array}$ & $\begin{array}{c}\text { SS } \\
\phi_{\mathrm{a}}+10 \% \\
(\mathbf{k P a})\end{array}$ & $\begin{array}{c}\text { SS } \\
\phi_{\mathrm{a}}-10 \% \\
\left(\mathbf{k P a} \mathbf{a}^{2}\right)\end{array}$ \\
\hline 219 to 163 & $\begin{array}{l}\text { top of Tptpmn, } \\
\text { Tptpul-Tptrl }\end{array}$ & $10.0 \times 10^{-12}$ & 0.050 & $8.380 \times 10^{-3}$ & $3.053 \times 10^{-3}$ & $4.323 \times 10^{-2}$ & $1.059 \times 10^{-2}$ & $6.451 \times 10^{-3}$ \\
\hline 163 to 139 & Tptpul-Tptrl & $10.0 \times 10^{-12}$ & 0.077 & $5.028 \times 10^{-2}$ & $4.021 \times 10^{-2}$ & $9.411 \times 10^{-2}$ & $5.068 \times 10^{-2}$ & $4.983 \times 10^{-2}$ \\
\hline 139 to 107 & $\begin{array}{l}\text { top of Tptpul- } \\
\text { Tptrl, Tptrn }\end{array}$ & $14.7 \times 10^{-12}$ & 0.060 & $5.856 \times 10^{-2}$ & $4.319 \times 10^{-2}$ & $1.282 \times 10^{-1}$ & $5.913 \times 10^{-2}$ & $5.800 \times 10^{-2}$ \\
\hline 107 to 85 & Tptrn & $50.0 \times 10^{-12}$ & 0.074 & $1.757 \times 10^{-1}$ & $1.683 \times 10^{-1}$ & $2.000 \times 10^{-1}$ & $1.759 \times 10^{-1}$ & $1.756 \times 10^{-1}$ \\
\hline 85 to 55 & Tptrv, Tpbt2, Tpp & $2.1 \times 10^{-12}$ & ${ }^{*} 0.375$ & $2.737 \times 10^{-1}$ & $5.875 \times 10^{-1}$ & $2.550 \times 10^{0}$ & $2.941 \times 10^{-1}$ & $2.613 \times 10^{-1}$ \\
\hline 55 to 40 & $\begin{array}{l}\text { Tpbt3, Tpy, } \\
\text { Tpbt4, Tpcpv }\end{array}$ & $0.45 \times 10^{-12}$ & ${ }^{*} 0.275$ & $2.599 \times 10^{-1}$ & $2.047 \times 10^{0}$ & $3.243 \times 10^{0}$ & $2.457 \times 10^{-1}$ & $2.837 \times 10^{-1}$ \\
\hline 40 to 0 & $\begin{array}{l}\text { Tpcplnc, Tpcplnh, } \\
\text { Tpcpll }\end{array}$ & $3.1 \times 10^{-12}$ & ${ }^{*} 0.140$ & $7.591 \times 10^{-1}$ & $1.376 \times 10^{0}$ & $2.522 \times 10^{0}$ & $7.616 \times 10^{-1}$ & $7.612 \times 10^{-1}$ \\
\hline
\end{tabular}

*The estimates for $\phi_{a}$ for these depth intervals were manually adjusted, along with $k k_{r a}$ in order to match the pneumatic-pressure data.

differences in the pressure response at the lower stations makes it impossible to identify unique $k k_{r a}$ values for the intervals defined by those stations because any sufficiently large permeability value for those intervals would result in the same responsethat is, no temporal offset or amplitude reduction across that interval relative to the overlying station. The $k k_{r a}$ values in table 9 for the lower four layers are estimates of the minimum permeability values that result in that response. Permeabilities smaller than the listed values begin to cause visually obvious separation in the pneumatic-pressure responses between the upper and lower monitoring stations defining that interval. The $k k_{r a}$ values estimated as the minimum necessary to reproduce the observed coalescence of the pressure-response curves in the Topopah Spring Tuff range from $10^{-11}$ to $5 \times 10^{-11} \mathrm{~m}^{2}$. The largest value $\left(5 \times 10^{-11} \mathrm{~m}^{2}\right)$ is present in a depth interval that includes a zone of unusually high fracture density (fig. 25). The $k k_{r a}$ values for the nonwelded intervals were $2.1 \times 10^{-12}$ and $0.45 \times 10^{-12} \mathrm{~m}^{2}$, and the value for the TCw was estimated to be $3.1 \times 10^{-12} \mathrm{~m}^{2}$.

In table 9 sums of squared differences between the measured and simulated pneumatic pressures are listed as a measure of the fit (column 5). The sum of squared differences reflects the degree of mismatch between the simulated and measured pneumatic pres- sures in that interval and all underlying intervals. Also listed are the sum of squared differences when the baseline $k k_{r a}$ is changed by plus or minus 50 percent, or when the baseline $\phi_{a}$ is changed by plus or minus 10 percent. Within a given depth interval, the change in the sum of squared differences indicates the relative sensitivity to increases or decreases in the value of a given parameter. In the lowermost four depth intervals, the sum of squares decreases slightly when pneumatic diffusivity is increased by either an increase in $k k_{r a}$ or decrease in $\phi_{a}$. Conversely, the sum of squares increases more substantially when the pneumatic diffusivity is decreased, particularly through permeability reductions of 50 percent. This supports the visual observations made during the calibration process, wherein visual separation between the pneumatic pressure at the upper and lower stations defining an interval occurred when permeability decreased below the values listed in column 3 . In the upper three stations, where separation in the pressure responses was pronounced, changes in $k k_{r a}$ of either plus or minus 50 percent resulted in a substantial increase in the sum of the squared differences. The sum of squared differences calculated for changes of plus or minus 10 percent in $\phi_{a}$ indicated that the baseline value listed column 4 was not necessarily the optimum value. The small decreases in the sum of squares, 
however, indicate the fit would be improved only slightly with these new values of $\phi_{a}$.

The part of the NRG-7a pneumatic-pressure record that was used to estimate pneumatic diffusivities and permeabilities is shown in figure 66. This figure shows that the signal at the base of the alluvium (station E) is nearly identical to that at the wellhead (station L). Moderate attenuation of the pressure
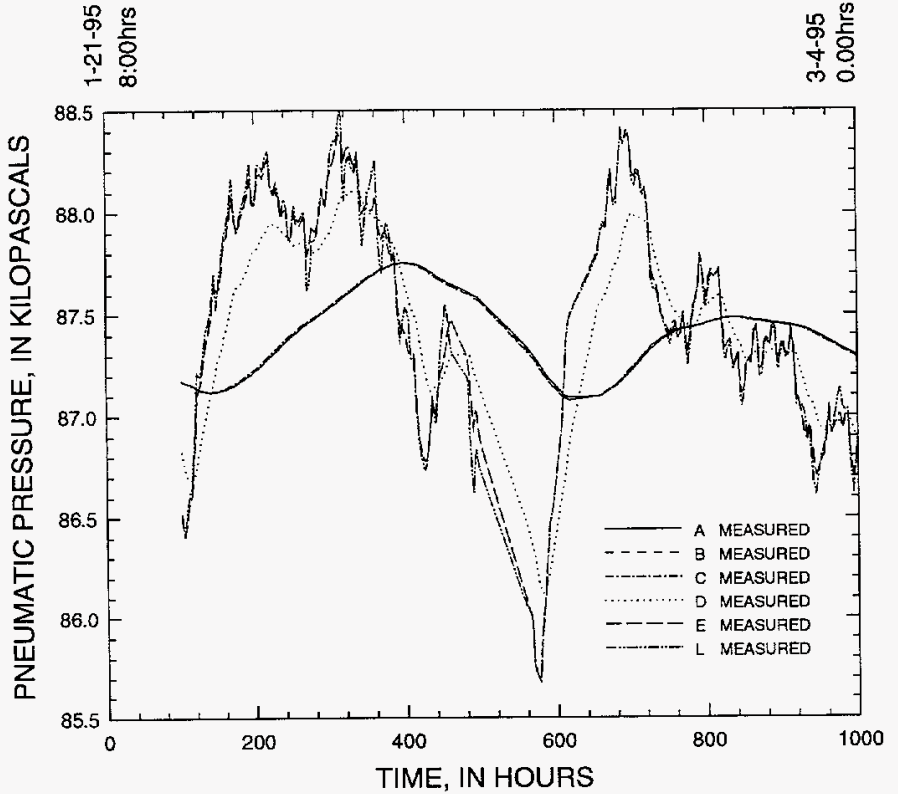

Figure 66. Measured pneumatic pressure records used to estimate the pneumatic diffusivities at borehole USW NRG-7a.

signal occurs between stations $E$ and $D$, an interval that includes subunits of the TCw (Tpcplnh, Tpcplnc, and Tpcpv) and subunits of the PTn (Tpbt4 and Tpy). More substantial attenuation of the pressure signal was between stations $\mathrm{D}$ and $\mathrm{C}$, an interval that includes subunits of the PTn (Tpbt3, Tpp, Tpbt2, and Tptrv) and a part of the TSw (Tptrn). Similar to what was observed at NRG-6, there is no visible separation in the pressure signal measured at NRG-7a in the lower stations in the units of the TSw (stations C, B, and A).

The match between the observed and simulated pressures at each of the stations at NRG-7a is very good, as shown in figures 67 and 68 . The lack of phase offset or amplitude reduction between the pressure responses at stations $\mathrm{C}, \mathrm{B}$, and $\mathrm{A}$ in the TSw can again be explained with the one-dimensional pressurediffusion model, given that estimates of $k k_{r a}$ for the lower two depth intervals are sufficiently large relative to pneumatic permeabilities for the overlying units.

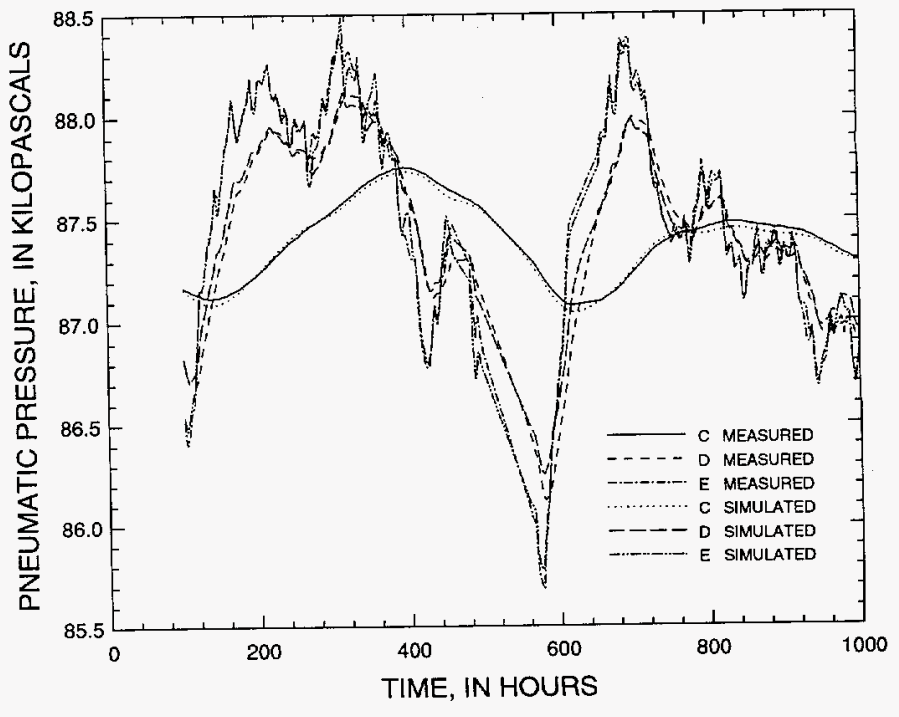

Figure 67. Comparison of simulated and measured pneumatic pressures for instrument stations $C, D$, and $E$ at borehole USW NRG-7a.

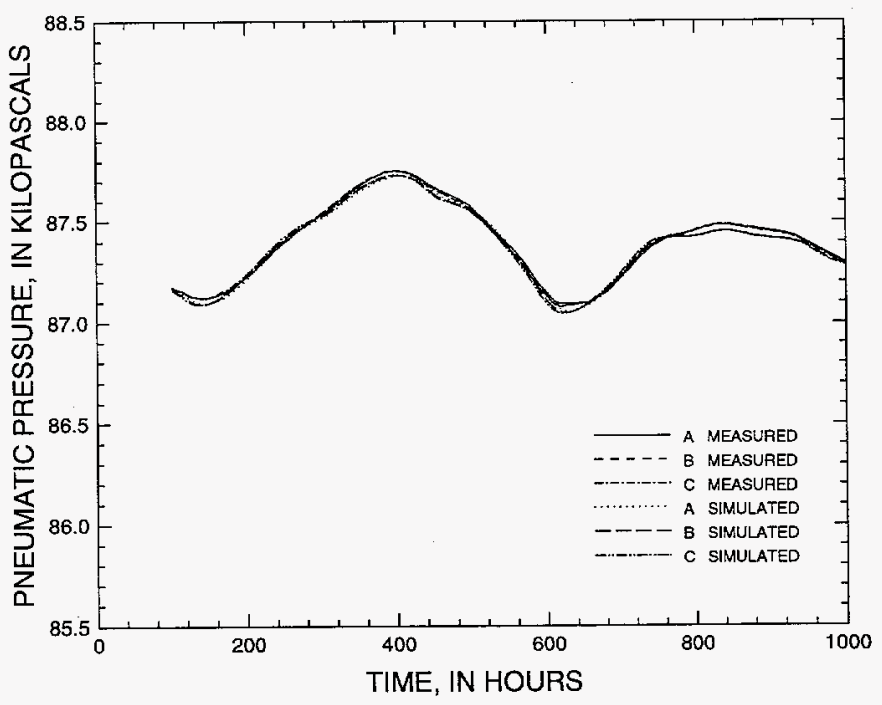

Figure 68. Comparison of simulated and measured pneumatic pressures for instrument stations $A, B$, and $C$ at borehole USW NRG-7a.

The depth intervals for NRG-7a considered by the analysis, the stratigraphic units encompassed by that depth interval, values of $k k_{r a}$ and $\phi_{a}$ estimated in the analysis, and the sum of squared differences between the measured and simulated pneumatic pressures for the baseline estimates of $k k_{r a}$ and $\phi_{a}$ are listed in table 10. Also tabulated are the sum of squared pressure differences when the baseline estimate of $k k_{r a}$ is changed by plus or minus 50 percent, and when the baseline estimate of $\phi_{a}$ is changed by plus or minus 10 percent. 
Table 10. Results of model calibration using pneumatic-pressure data from instrumented borehole NRG-7a

$\left[k k_{r a}=\right.$ effective permeability to air; $\phi_{a}=$ air-filled porosity; SS=sum of squared differences between measured and simulated pressures; $\mathrm{kPa}^{2}=\mathrm{kilopascal}$ squared; $\%=$ percent; lithostratigraphic units are defined in table 2]

\begin{tabular}{|c|c|c|c|c|c|c|c|c|}
\hline $\begin{array}{l}\text { Depth } \\
\text { interval } \\
\text { (meters) }\end{array}$ & $\begin{array}{l}\text { Litho- } \\
\text { stratigraphic units } \\
\text { in depth interval }\end{array}$ & $\begin{array}{c}\text { Baseline } \\
\qquad \boldsymbol{k}_{r a} \\
\left(\mathrm{~m}^{2}\right)\end{array}$ & $\begin{array}{c}\text { Baseline } \\
\phi_{.}\end{array}$ & $\begin{array}{c}\text { SS } \\
\text { Baseline } \\
\boldsymbol{k} \boldsymbol{k}_{r a \phi_{a}} \\
\left(\mathbf{k P a}^{2}\right)\end{array}$ & $\begin{array}{c}\text { SS } \\
k k_{r a}+50 \% \\
\left(k \mathrm{~Pa}^{2}\right)\end{array}$ & $\begin{array}{c}\text { SS } \\
k k_{r a}-50 \% \\
\left(\mathbf{k P a}^{2}\right)\end{array}$ & $\begin{array}{c}\text { SS } \\
\phi_{a}+10 \% \\
\left(\mathrm{kPa}^{2}\right)\end{array}$ & $\begin{array}{c}S S \\
\phi_{a}-10 \% \\
\left(k P a^{2}\right)\end{array}$ \\
\hline 204 to 151 & Tptpul-Tptrl & $10.0 \times 10^{-12}$ & 0.065 & $2.610 \times 10^{-2}$ & $6.945 \times 10^{-3}$ & $2.098 \times 10^{-1}$ & $3.719 \times 10^{-2}$ & $1.791 \times 10^{-2}$ \\
\hline 151 to 118 & $\begin{array}{l}\text { top of Tptpul-Tptrl, } \\
\text { Tptrn }\end{array}$ & $10.0 \times 10^{-12}$ & 0.055 & $1.077 \times 10^{-1}$ & $5.606 \times 10^{-2}$ & $4.066 \times 10^{-1}$ & $1.087 \times 10^{-1}$ & $1.067 \times 10^{-1}$ \\
\hline 118 to 47 & $\begin{array}{l}\text { Tptrn, Tptrv, Tpbt } 2 \text {, } \\
\text { Tpp, Tpbt } 3\end{array}$ & $0.65 \times 10^{-12}$ & 0.250 & $4.115 \times 10^{0}$ & $2.244 \times 10^{1}$ & $4.360 \times 10^{1}$ & $4.456 \times 10^{0}$ & $4.069 \times 10^{0}$ \\
\hline 47 to 5 & $\begin{array}{l}\text { Tpbt3, Tpy, Tpbt4, } \\
\text { Tpcpv, Tpcplnc }\end{array}$ & $1.30 \times 10^{-12}$ & 0.120 & $5.452 \times 10^{0}$ & $1.009 \times 10^{1}$ & $2.946 \times 10^{1}$ & $5.242 \times 10^{0}$ & $5.692 \times 10^{0}$ \\
\hline 5 to 0 & Tpcplnh & $1.35 \times 10^{-12}$ & 0.180 & $9.070 \times 10^{0}$ & $9.258 \times 10^{0}$ & $1.047 \times 10^{1}$ & $9.058 \times 10^{0}$ & $9.081 \times 10^{0}$ \\
\hline
\end{tabular}

By the same reasoning that was applied in the discussion of the NRG-6 results, the values of $k k_{r a}$ estimated for the two lowermost intervals at NRG-7a represent lower bounds: larger values of $k k_{r a}$ for these two intervals also would have resulted in an absence of offset in the pressure response between stations C, $\mathrm{B}$, and $\mathrm{A}$, but smaller values of $k k_{r a}$ cause more pronounced separation. There is little improvement in the fit when $k k_{r a}$ is increased further (column 5), but a more substantial increase in the error occurs when $k k_{r a}$ is decreased. Conversely, the 118- to 47-m and 47to 5-m depth intervals, which are composed of predominantly nonwelded rocks, show a large degree of sensitivity to both increases or decreases in $k k_{r a}$ of 50 percent, and therefore estimates of $k k_{r a}$ are considered to be very accurate. The $k k_{r a}$ value estimated for the uppermost depth interval appears to be optimal, although not very sensitive to changes of plus or minus 50 percent. Increases in the values of $\phi_{a}$ estimated for the upper two intervals resulted in a small decrease in the sum of the squared differences, whereas decreases of 10 percent in the lower three intervals resulted in slight improvement in the fit.

\section{Pagany Wash Boreholes}

Boreholes UZ\#4 and UZ\#5 in Pagany Wash were instrumented primarily to monitor pneumatic and hydrologic conditions in the PTn. At their location, the $\mathrm{TCw}$ is thin and, because of their relatively shallow depth, these boreholes barely penetrate the top of the TSw. Consequently, in each borehole, the uppermost instrument station is in the $\mathrm{TCw}$ and the lowermost station is in the Tsw (fig. 41). All of the other instru- ment stations are in the PTn. The part of the measured pneumatic-pressure record used in the analysis of pneumatic diffusivities at borehole UZ\#5 is shown in figure 69. From this adjusted record, the progressive decrease in amplitude and increase in phase lag with increasing station depth is readily apparent. It can be observed that the largest amplitude reduction and phase lag occurs between stations $\mathrm{H}$ and $\mathrm{G}$, which bracket the crystal-poor vitric layer at the base of the Tiva Canyon Tuff (Tpcpv). Conversely, there is no apparent difference in the pressure signal between stations $\mathrm{B}$ and $\mathrm{A}$, which bracket the crystal-rich vitric layer at the top of the Topopah Spring Tuff (Tptrv). Other stations show amplitude reduction and phase lag that are intermediate compared with stations $\mathrm{H}$ and $\mathrm{A}$. The most responsive record is that obtained at station $\mathrm{H}$, which is located at the base of the columnar unit of the Tiva Canyon Tuff. The pneumatic pressure at station $\mathrm{H}$ showed little phase lag or amplitude dampening relative to the barometric pressures recorded at the land surface. In the estimation of pneumatic diffusivities at UZ\#5 using AIRK, the pneumatic pressures at station $\mathrm{H}$ were considered to constitute the final upper boundary conditions for the stack.

The measured and simulated pressures for each of the stations at UZ\#5, using the pneumatic pressure at the base of the columnar unit of the Tiva Canyon Tuff as the upper boundary, are shown in figures 70 through 72. The simulated pneumatic pressures do, in general, very accurately reproduce the amplitude reductions and temporal offsets in the measured pressure responses. 

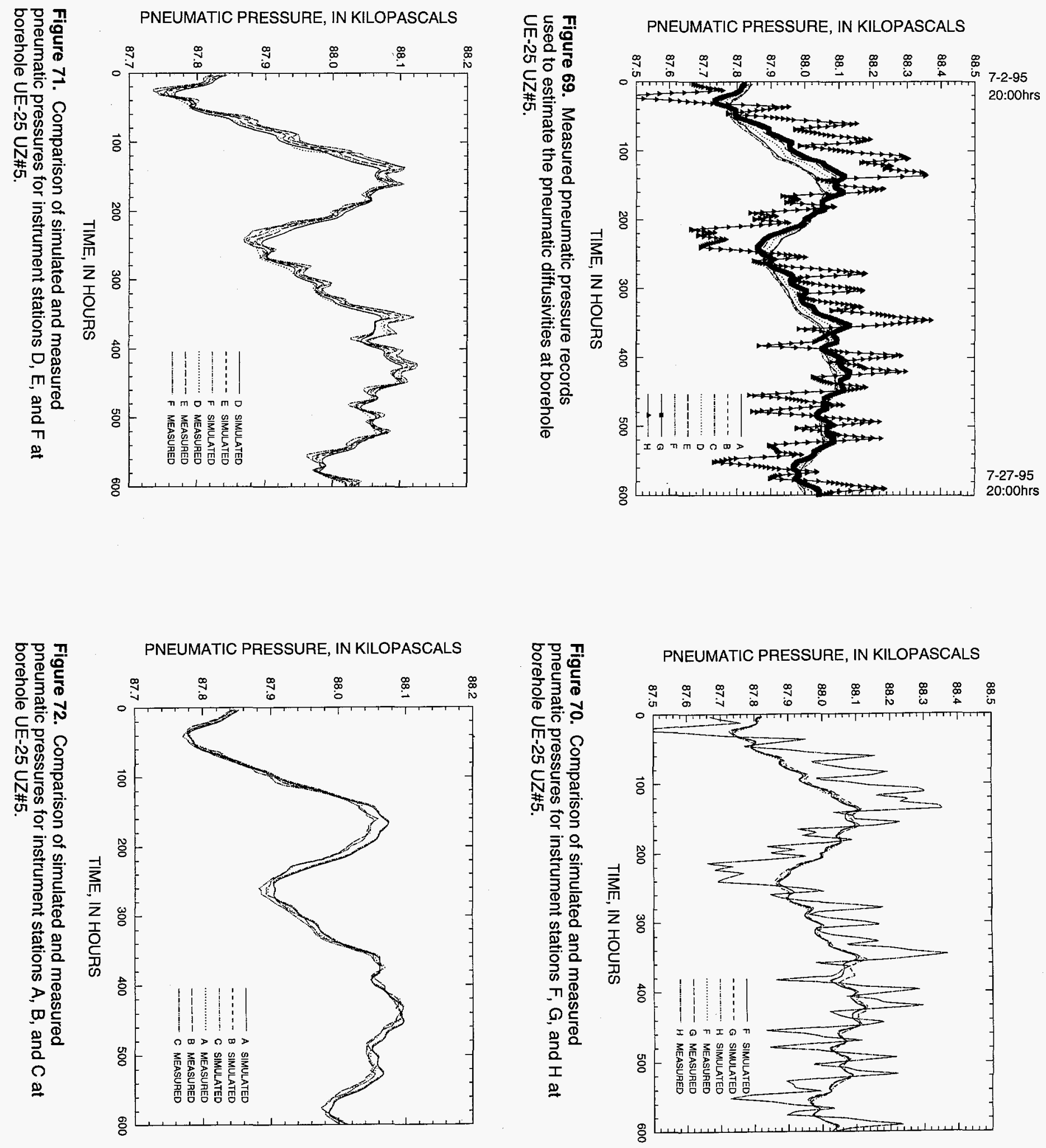
The depth intervals for UZ\#5, the stratigraphic units encompassed by that interval, and the values of $k k_{r a}$ and $\phi_{a}$ estimated for the depth intervals defined by the monitoring stations at UZ\#5 are listed in table 11. With the exception of the Tpcpv unit at a depth of 34 to $25.5 \mathrm{~m}$, all intervals were estimated to have $k k_{r a}$ values greater than $10^{-12} \mathrm{~m}^{2}$ (column 3 ). It was noted earlier that the bottom two stations, B and A, showed no offset or amplitude reductions relative to each other. As was done for the Drill Hole Wash boreholes in cases where there was no offset, a minimum permeability was identified for the interval by determining the threshold $k k_{r a}$ value below which the model predicted that detectable offset would occur in the station pressures.

As a measure of the calibration error, the sums of the squared differences between the measured and simulated pressures were calculated. The values listed in table 11 (column 5) represent the cumulative error in both that layer and the underlying layers. In general, the total error increases as more layers are added, as expected. Occasionally, the total error decreases (in the 34- to 25-m interval), presumably due to compensating errors. Overall, the total error is very small, reflecting the good visual match between the measured and simulated pressures observed in figures 70 through 72 .

As was done for the Drill Hole Wash boreholes, a sensitivity analysis was performed by varying the baseline $k k_{r a}$ values by plus or minus 50 percent, and the baseline $\phi_{a}$ values by plus or minus 10 percent, and calculating a new sum of squared differences. For some depth intervals, such as the 93- to 60-m and 34- to 25-m intervals, this sensitivity analysis showed that the baseline $k k_{r a}$ and $\phi_{a}$ values resulted in a sum of squared differences that was optimal. For others, such as the 105- to 93-m interval, the sensitivity analysis showed that permeability increases could result in small decreases in the sum of squared differences, but that there was much greater sensitivity to permeability reductions. The lack of sensitivity to permeability increases occurred when the offset between that station and the overlying station was very small.

The adjusted pneumatic-pressure data for UZ\#4 (fig. 73) exhibited similar features to the UZ\#5 data (fig. 69). Again, the largest impedance to gas flow is present in the Tpcpv unit, as evidenced by the contrast in the pressure response at station $\mathrm{G}(24 \mathrm{~m})$ and station $\mathrm{F}(35 \mathrm{~m})$. The pneumatic-pressure data at station $\mathrm{B}$ $(104 \mathrm{~m})$ and station A (112 m) showed that no amplitude reductions or phase offsets occurred across the Tptrv unit.

The comparisons between the measured and simulated pressures for the analysis period are shown in figures 74 through 76 . The simulation results in these figures were obtained using the measured pressure response at station $\mathrm{G}(24 \mathrm{~m})$ as the final upper boundary condition for the stack. The simulation

Table 11. Results of model calibration using pneumatic-pressure data from instrumented borehole UZ\#5

$\left[k k_{r a}=\right.$ effective permeability to air; $\phi_{a}=$ air-filled porosity; $S S=$ sum of squared differences between measured and simulated pressures; $k \mathrm{ka}^{2}=$ kilopascal squared; \%=percent; lithostratigraphic units are defined in table 2]

\begin{tabular}{|c|c|c|c|c|c|c|c|c|}
\hline $\begin{array}{l}\text { Depth } \\
\text { interval } \\
\text { (meters) }\end{array}$ & $\begin{array}{c}\text { Lithostratigraphic } \\
\text { units } \\
\text { in depth interval }\end{array}$ & $\begin{array}{l}\text { Baseline } k k_{r a} \\
\qquad\left(m^{2}\right)\end{array}$ & $\begin{array}{c}\text { Baseline } \\
\qquad \phi_{a}\end{array}$ & $\begin{array}{c}\text { SS } \\
\text { Baseline } \\
\boldsymbol{k}_{\mathrm{ra}, \phi_{\mathrm{a}}} \\
\left(\mathrm{kPa}^{2}\right)\end{array}$ & $\begin{array}{c}\text { SS } \\
k k_{r a}+50 \% \\
\left(\mathrm{kPa}^{2}\right)\end{array}$ & $\begin{array}{c}\text { SS } \\
k k_{r a}-50 \% \\
\left(\mathrm{kPa}^{2}\right)\end{array}$ & $\begin{array}{c}\text { SS } \\
\phi_{a}+10 \% \\
\left(\mathrm{kPa}^{2}\right)\end{array}$ & $\begin{array}{c}\mathrm{sS} \\
\phi_{\mathrm{a}}-10 \% \\
\left(\mathrm{kPa}^{2}\right)\end{array}$ \\
\hline 112 to 105 & top of Tptrn, Tptrv & $10.0 \times 10^{-12}$ & 0.05 & $3.081 \times 10^{-3}$ & $3.014 \times 10^{-3}$ & $3.278 \times 10^{-3}$ & $3.105 \times 10^{-3}$ & $3.071 \times 10^{-3}$ \\
\hline 105 to 93 & $\begin{array}{l}\text { Tptrv, Tpbt } 2 \\
\text { base of Tpp }\end{array}$ & $1.81 \times 10^{-12}$ & 0.15 & $9.711 \times 10^{-2}$ & $8.057 \times 10^{-2}$ & $1.577 \times 10^{-1}$ & $9.819 \times 10^{-2}$ & $9.610 \times 10^{-2}$ \\
\hline 93 to 60 & Tpp & $2.71 \times 10^{-12}$ & 0.36 & $1.998 \times 10^{-1}$ & $2.187 \times 10^{-1}$ & $4.418 \times 10^{-1}$ & $2.030 \times 10^{-1}$ & $1.980 \times 10^{-1}$ \\
\hline 60 to 48 & $\begin{array}{l}\text { top of Tpp, } \\
\text { Tpbt3, } \\
\text { base of Tpy }\end{array}$ & $2.17 \times 10^{-12}$ & 0.31 & $4.591 \times 10^{-1}$ & $4.993 \times 10^{-1}$ & $5.287 \times 10^{-1}$ & $4.590 \times 10^{-1}$ & $4.585 \times 10^{-1}$ \\
\hline 48 to 40 & Tpy & $1.81 \times 10^{-12}$ & 0.20 & $5.815 \times 10^{-1}$ & $5.741 \times 10^{-1}$ & $8.609 \times 10^{-1}$ & $5.825 \times 10^{-1}$ & $5.805 \times 10^{-1}$ \\
\hline 40 to 34 & $\begin{array}{c}\text { top of Tpy, Tpbt4, } \\
\text { base of Tpcpv }\end{array}$ & $3.61 \times 10^{-12}$ & 0.29 & $7.106 \times 10^{-1}$ & $7.107 \times 10^{-1}$ & $7.498 \times 10^{-1}$ & $7.110 \times 10^{-1}$ & $7.104 \times 10^{-1}$ \\
\hline 34 to 25 & $\begin{array}{l}\text { Tpcpv, } \\
\text { base of Tpcplnc }\end{array}$ & $0.199 \times 10^{-12}$ & 0.15 & $5.653 \times 10^{-1}$ & $2.055 \times 10^{0}$ & $5.576 \times 10^{0}$ & $5.643 \times 10^{-1}$ & $5.672 \times 10^{-1}$ \\
\hline
\end{tabular}




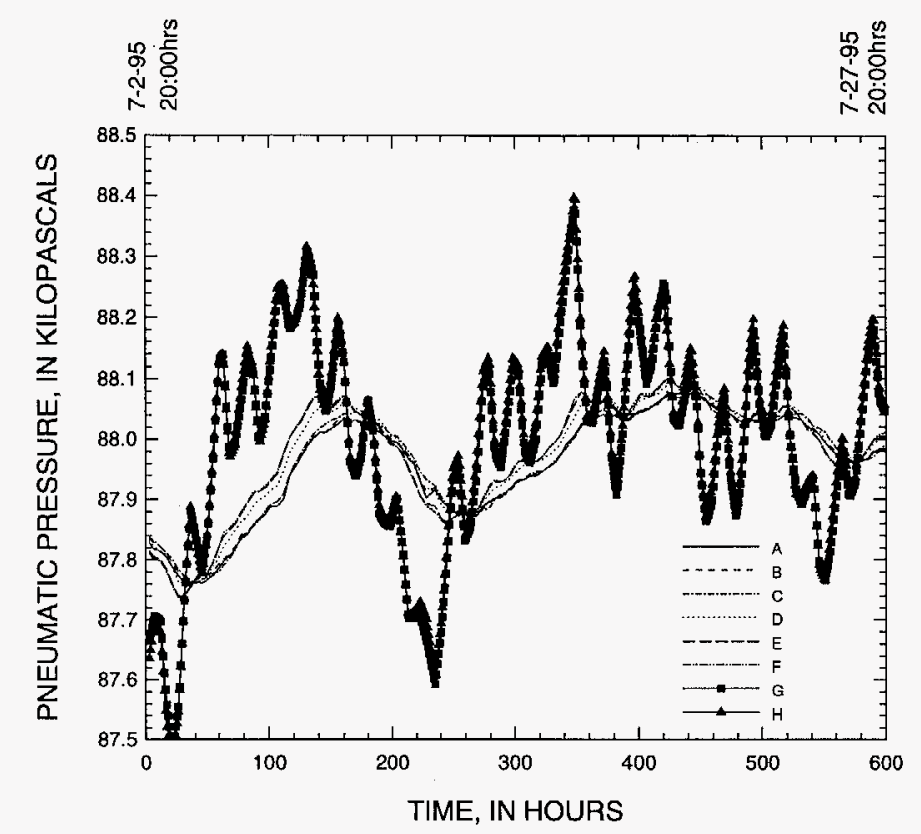

Figure 73. Measured pneumatic pressure records used to estimate the pneumatic diffusivities at borehole UE-25 UZ\#4.

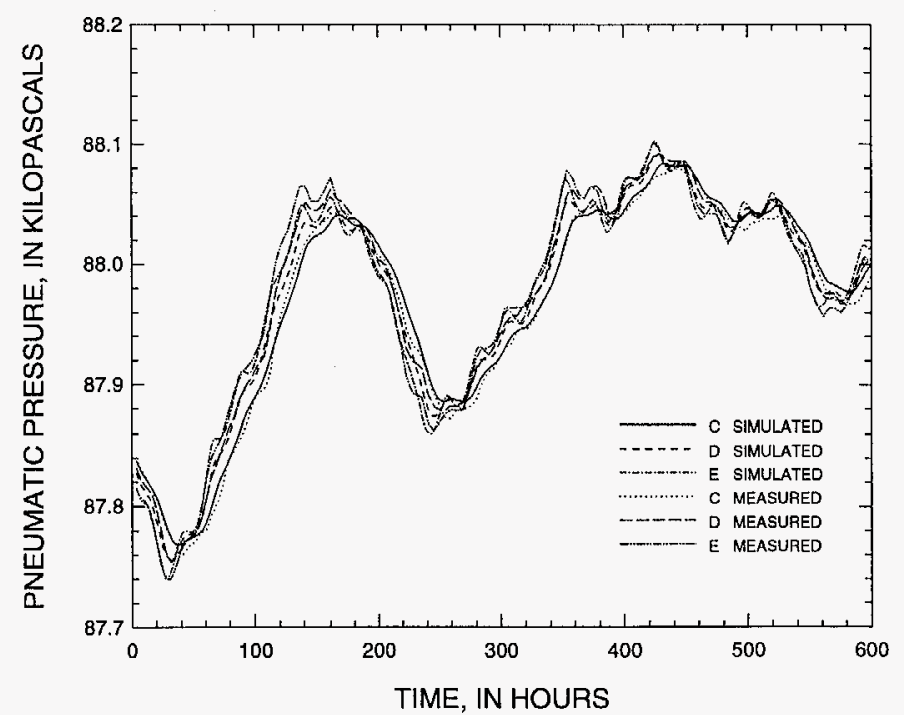

Figure 75. Comparison of simulated and measured pneumatic pressures for instrument stations $C, D$, and $E$ at borehole UE-25 UZ\#4.

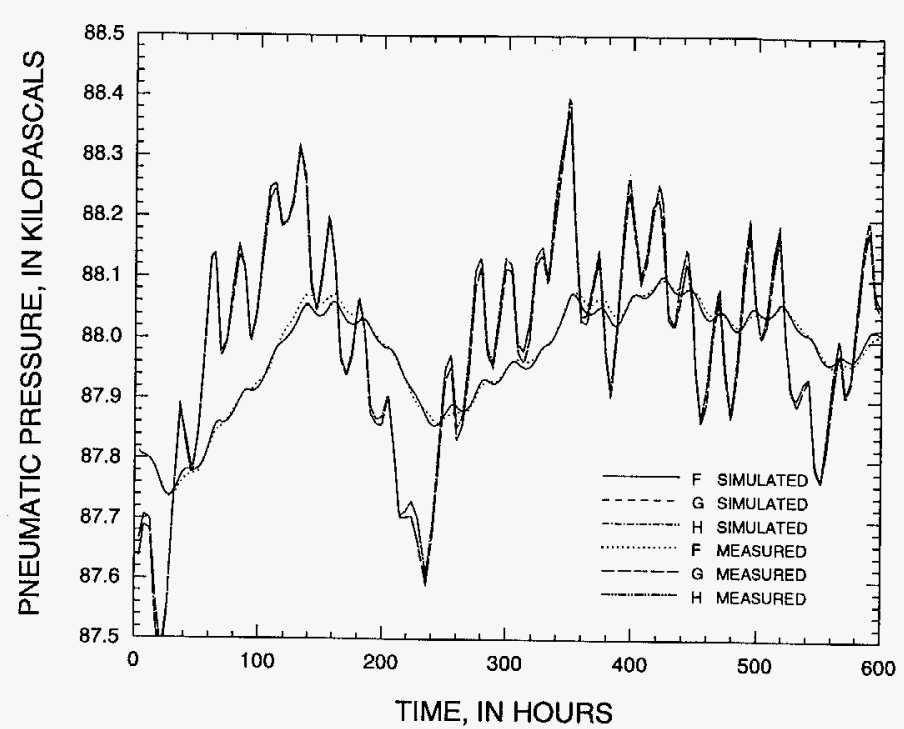

Figure 74. Comparison of simulated and measured pneumatic pressures for instrument stations $F, G$, and $H$ at borehole UE-25 UZ\#4.

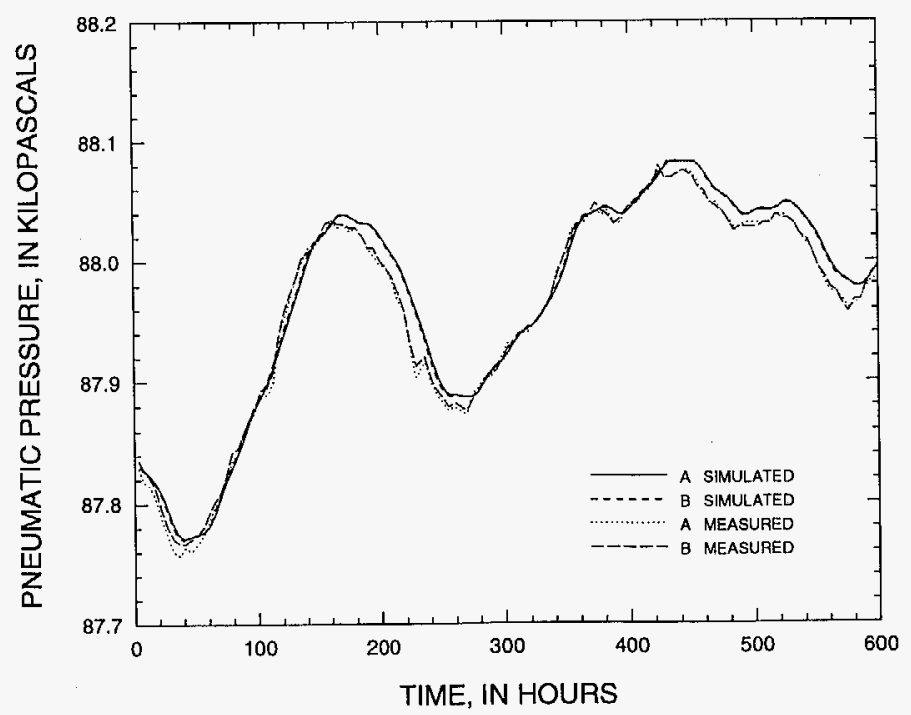

Figure 76. Comparison of simulated and measured pneumatic pressures for instrument stations $A$ and $B$ at borehole UE-25 UZ\#4. 
results again matched the measured pneumaticpressure data very well.

The depth intervals for UZ\#4, the stratigraphic units bounded by those intervals, the $k k_{r a}$ and $\phi_{a}$ values obtained for borehole UZ\#4 for the calibration period, the associated sum of squared differences for the baseline case, and cases in which $k k_{r a}$ was varied by plus or minus 50 percent and $\phi_{a}$ by plus or minus 10 percent are listed in table 12 . Of the nonwelded to partially welded intervals, the Tpcpv interval ( $35 \mathrm{~m}$ to $24 \mathrm{~m}$ ) again had the smallest estimated $k k_{r a}\left(0.181 \times 10^{-12} \mathrm{~m}^{2}\right)$. The depth interval (44 to $35 \mathrm{~m}$ ) containing the Yucca Mountain Tuff (Tpy) had the largest value of $k k_{r a}$ among the nonwelded units $\left(8.59 \times 10^{-12} \mathrm{~m}^{2}\right)$. The depth interval (112 to $104 \mathrm{~m}$ ) containing the densely welded vitric cap rock of the Topopah Spring Tuff had an estimated value of $k k_{r a}\left(1.0 \times 10^{-12} \mathrm{~m}^{2}\right)$ that was an order of magnitude smaller than that obtained at UZ\#5.

All depth intervals with the exception of the 35 - to 24-m interval have small reductions in the sum of squared differences as $k k_{r a}$ is increased 50 percent, but more substantial increases in the sum of squared differences occur when $k k_{r a}$ is reduced by 50 percent (table 12, columns 5 through 7). The 35- to 24-m interval (the Tpcpv unit) experiences substantial increases in the sum of squared differences as $k k_{r a}$ is changed by either plus or minus 50 percent.

Increasing $\phi_{a}$ by 10 percent led to small increases in the sum of squares, whereas reducing $\phi_{a}$ by 10 percent had the opposite effect. Attempts to estimate the pneumatic diffusivity of the $\mathrm{TCw}$ in the $24-$ to $11-\mathrm{m}$ depth interval resulted in a substantial increase in the baseline sum of squares, compared to the $35-$ to $24-\mathrm{m}$ depth interval (column 5), from $3.420 \times 10^{-1} \mathrm{kPa}^{2}$ to $1.048 \times 10^{0} \mathrm{kPa}^{2}$. Therefore, in the simulations used to prepare figures 74 through 76 , measured pressures at the base of this interval (station $G$ ) were used as the upper boundary condition so that errors associated with estimates of pneumatic diffusivity in the $\mathrm{TCw}$ would not mask the excellent match obtained for the underlying units (figs. 74 through 76).

\section{Interpretation of Pneumatic-Diffusivity Determinations}

The pneumatic-pressure data were used to estimate $k k_{r a}$, the effective permeability to air of the depth intervals defined by the monitoring stations. In general, $k k_{r a}$ can be expected to be less than the intrinsic permeability $(k)$ of the medium because of partial obstruction of air movement by water present in the formation. In the moderately to densely welded formations in which formation permeability is dominantly due to fracturing, $k k_{r a}$ may be approximately equal to $k$ if fractures were largely drained during the period of analysis. In formations in which fractures contribute little to the overall permeability, such as may be the case locally in some of the nonwelded to

Table 12. Results of model calibration using pneumatic-pressure data from instrumented borehole UZ\#4

$\left[k k_{r a}=\right.$ effective permeability to air; $\phi_{a}=$ air-filled porosity; $\mathrm{SS}=$ sum of squared differences between measured and simulated pressures; $\mathrm{kPa}=$ kilopascal squared; \%=percent; lithostratigraphic units are defined in table 2]

\begin{tabular}{|c|c|c|c|c|c|c|c|c|}
\hline $\begin{array}{l}\text { Depth } \\
\text { interval } \\
\text { (meters) }\end{array}$ & $\begin{array}{c}\text { Lithostratigraphic } \\
\text { units } \\
\text { in depth interval }\end{array}$ & $\begin{array}{l}\text { Baseline } k k_{r a} \\
\left(m^{2}\right)\end{array}$ & $\begin{array}{c}\text { Baseline } \\
\phi_{\mathbf{a}}\end{array}$ & $\begin{array}{c}\text { SS } \\
\text { Baseline } \\
\boldsymbol{k}_{\text {rag }} \phi_{\mathbf{a}} \\
\left(\mathbf{k P a}^{2}\right)\end{array}$ & $\begin{array}{c}\text { SS } \\
k k_{r a}+50 \% \\
\left(\mathrm{kPa}^{2}\right)\end{array}$ & $\begin{array}{c}\text { SS } \\
k k_{\mathrm{ra}}-50 \% \\
\left(\mathrm{kPa}^{2}\right)\end{array}$ & $\begin{array}{c}\text { SS } \\
\phi_{a}+10 \% \\
\left(\mathrm{kPa}^{2}\right)\end{array}$ & $\begin{array}{c}\text { SS } \\
\phi_{a}-10 \% \\
(\mathbf{k P a})\end{array}$ \\
\hline 112 to 104 & top of Tptrn, Tptrv & $1.00 \times 10^{-12}$ & 0.035 & $1.077 \times 10^{-2}$ & $9.395 \times 10^{-3}$ & $1.729 \times 10^{-2}$ & $1.130 \times 10^{-2}$ & $1.026 \times 10^{-2}$ \\
\hline 104 to 88 & $\begin{array}{l}\text { top of Tptrv, } \\
\text { Tpbt2, } \\
\text { base of Tpp }\end{array}$ & $1.44 \times 10^{-12}$ & 0.17 & $1.193 \times 10^{-1}$ & $1.007 \times 10^{-1}$ & $1.923 \times 10^{-1}$ & $1.217 \times 10^{-1}$ & $1.168 \times 10^{-1}$ \\
\hline 88 to 55 & Tpp & $2.17 \times 10^{-12}$ & 0.35 & $3.441 \times 10^{-1}$ & $3.005 \times 10^{-1}$ & $8.094 \times 10^{-1}$ & $3.590 \times 10^{-1}$ & $3.309 \times 10^{-1}$ \\
\hline 55 to 44 & $\begin{array}{l}\text { top of Tpp, Tpbt } 3 \\
\text { base of Tpy }\end{array}$ & $1.62 \times 10^{-12}$ & 0.29 & $2.886 \times 10^{-1}$ & $2.701 \times 10^{-1}$ & $5.867 \times 10^{-1}$ & $2.905 \times 10^{-1}$ & $2.865 \times 10^{-1}$ \\
\hline 44 to 35 & Tpy & $8.59 \times 10^{-12}$ & 0.18 & $3.203 \times 10^{-1}$ & $3.124 \times 10^{-1}$ & $3.557 \times 10^{-1}$ & $3.205 \times 10^{-1}$ & $3.200 \times 10^{-1}$ \\
\hline 35 to 24 & $\begin{array}{l}\text { top of Tpy, } \\
\text { Tpbt4, Tpcpv }\end{array}$ & $0.181 \times 10^{-12}$ & 0.22 & $3.420 \times 10^{-1}$ & $1.537 \times 10^{0}$ & $5.531 \times 10^{0}$ & $3.504 \times 10^{-1}$ & $3.350 \times 10^{-1}$ \\
\hline 24 to 11 & Tpcpv, Tpcplnc & $10.0 \times 10^{-12}$ & 0.03 & $1.048 \times 10^{0}$ & $1.032 \times 10^{0}$ & $1.112 \times 10^{0}$ & $1.048 \times 10^{0}$ & $1.048 \times 10^{0}$ \\
\hline
\end{tabular}


partially welded units, there is the potential that $k k_{r a}$ could be substantially less than $k$, depending on the water saturation state of the rock and the relation between saturation state and $k k_{r a}$ (effective permeability to air).

Permeability estimates derived from analysis of the pneumatic-pressure records at NRG-6, NRG-7a, UZ\#4, and UZ\#5 were compared with permeability estimates associated with in-situ air-injection testing (see section of this report titled In-Situ Pneumatic Tests of Boreholes) and water permeability measurements made on cores (see section of this report titled Pneumatic Properties Determined from Analysis of Rock Cores), or similar data, in order to assess directional effects and the enhancement of primary permeability as a result of fracturing.

At NRG-6, permeability estimates derived for the Topopah Spring Tuff from analysis of the pneumatic-pressure data $\left(10^{-11}\right.$ to $\left.5 \times 10^{-11} \mathrm{~m}^{2}\right)$ are higher than permeability estimates obtained from analysis of the air-injection tests (fig. 36) by an order of magnitude or more. In contrast, permeability estimates derived for the TCW at NRG-6 from air-injection testing were typically almost an order of magnitude greater than the single value of $3.1 \times 10^{-12} \mathrm{~m}^{2}$ obtained from the pneumatic-pressure analysis. One possible cause of this difference may be that, whereas the airinjection tests are dominated by the formation permeabilities in the horizontal direction, the pneumaticpressure responses are more strongly influenced by the vertical permeability. As a result of stress unloading associated with erosion, open, subhorizontal fractures are more numerous in the shallow subsurface in the Tiva Canyon Tuff than in the Topopah Spring Tuff. The air-injection test responses are dominated by these subhorizontal fractures, but these fractures do not contribute greatly to the vertical permeability. In the Topopah Spring Tuff, these subhorizontal fractures are not as numerous and, where they are present, are narrower as a result of larger lithostatic stresses. Therefore, because the air-injection tests are more strongly influenced by the substantially reduced horizontal permeability, the permeability values estimated from the air-injection tests are smaller than those estimated from the pneumatic-pressure data. The presence of a thin alluvial cover, carbonate fracture fillings, and strata-bound vertical fracturing in the Tiva Canyon Tuff also may have reduced the depthintegrated value of vertical permeability estimated from the pneumatic-pressure data. As discussed in the section of this report titled Pressure Response in the Tiva Canyon Welded Hydrogeologic Unit, it also is possible that the smaller value of permeability estimated for the TCw from the pneumatic-pressure data may have resulted from partial sealing of near-surface fractures, fracture-fill material, or alluvial cover by water that had infiltrated during the unusually wet winter of 1994-95.

Within the Topopah Spring Tuff at NRG-7a, the permeability estimates derived from analyses of the pneumatic-pressure record and those made on the basis of air-injection testing (fig. 35) have a similar relation to those observed at NRG-6: the $k k_{r a}$ values estimated from the pneumatic-pressure monitoring record were larger than those made on the basis of the air-injection tests by one to two orders of magnitude. Probable reasons are similar to those presented in connection with the NRG-6 results. Comparison between the different types of estimates is not as straightforward for depth intervals higher in borehole NRG-7a, because intervals defined in the pneumaticpressure analysis incorporated rocks of sharply contrasting degrees of welding, porosity and permeability. Nevertheless, the $k k_{r a}$ value of $1.30 \times 10^{-12} \mathrm{~m}^{2}$ estimated for the 47- to 5-m depth interval is consistent with the values estimated from the air-injection test data, which range from approximately $0.1 \times 10^{-12}$ to $50.0 \times 10^{-12} \mathrm{~m}^{2}$ over that same interval (fig. 35 ). The $k k_{r a}$ value of $0.65 \times 10^{-12} \mathrm{~m}^{2}$ estimated for the 118 - to 47-m depth interval from the pneumatic-pressure record slightly overestimates the values determined from air-injection testing, which range from 0.1 to $0.4 \times 10^{-12} \mathrm{~m}^{2}$ over the same interval.

Permeabilities were not available for core samples taken from NRG-6 or NRG-7a. However, the water permeabilities measured on core samples taken from nearby SD-9 (see section of this report titled Correlation of Hydrologic Properties With Physical Lithologic Properties) can be compared with the permeability values inferred from the pneumatic-pressure analysis. In the welded intervals of the $\mathrm{TCw}$ and the TSw, the orders-of-magnitude larger permeability values determined from the pneumatic-pressure data clearly indicate enhanced permeability due to fracturing. In the nonwelded and bedded PTn units, the apparent enhancement of primary permeability by fractures appears to vary. In the depth interval at NRG-6 that includes the Tptrv, Tpbt2, and Tpp units ( $(85$ to $55 \mathrm{~m})$, the permeability value of $2.1 \times 10^{-12} \mathrm{~m}^{2}$ estimated from the pneumatic-pressure data is only 
slightly larger than values of approximately $9.0 \times 10^{-14}$ to $9.0 \times 10^{-13} \mathrm{~m}^{2}$ measured on core from the same stratigraphic intervals at SD-9. The permeability value estimated at NRG-7a for the depth interval that encompasses these same stratigraphic units (118 to $47 \mathrm{~m}$ ) is $0.65 \times 10^{-12} \mathrm{~m}^{2}$, indicating minimal (if any) enhancement of permeability as a result of fracturing. In contrast, however, values of permeability estimated from the pneumatic-pressure data at NRG-6 and NRG-7a for stratigraphically higher units in the PTn (such as the Tpbt3, Tpy, Tpbt4, and Tpcpv units) appear to be significantly larger than the permeabilities measured on cores taken from the same units at SD-9. At NRG-6 and NRG-7a, the permeability values inferred from the pneumatic-pressure data for the depth intervals encompassing these stratigraphic units are $0.45 \times 10^{-12} \mathrm{~m}^{2}$ and $1.3 \times 10^{-12} \mathrm{~m}^{2}$, respectively, whereas the core permeabilities can be orders of magnitude smaller (fig. 89 in the section of this report titled Correlation of Hydrologic Properties With Phys- ical Lithologic Properties). Direct comparison with the NRG-7a estimate is complicated by the inclusion of welded and nonwelded units in the same depth interval.

Although no air-injection test data were available for UZ\#4 and UZ\#5, numerous non-Q permeability measurements were made on core samples obtained during the drilling of those boreholes (Flint and Flint, 1990, table 3). The slip-corrected (Klinkenberg, 1941) air permeabilities of the nonwelded cores taken from UZ活4 and UZ\#5 were typically smaller than the permeabilities estimated from pneumaticpressure measurements by two to three orders of magnitude (fig. 77). Because air was used both in the core-scale and field-scale analyses, the smaller permeabilities associated with the cores cannot be attributed to the use of different test fluids. One possible source of the discrepancy between the core-scale and fieldscale permeability values may be that the core measurements have been corrected for slip, whereas

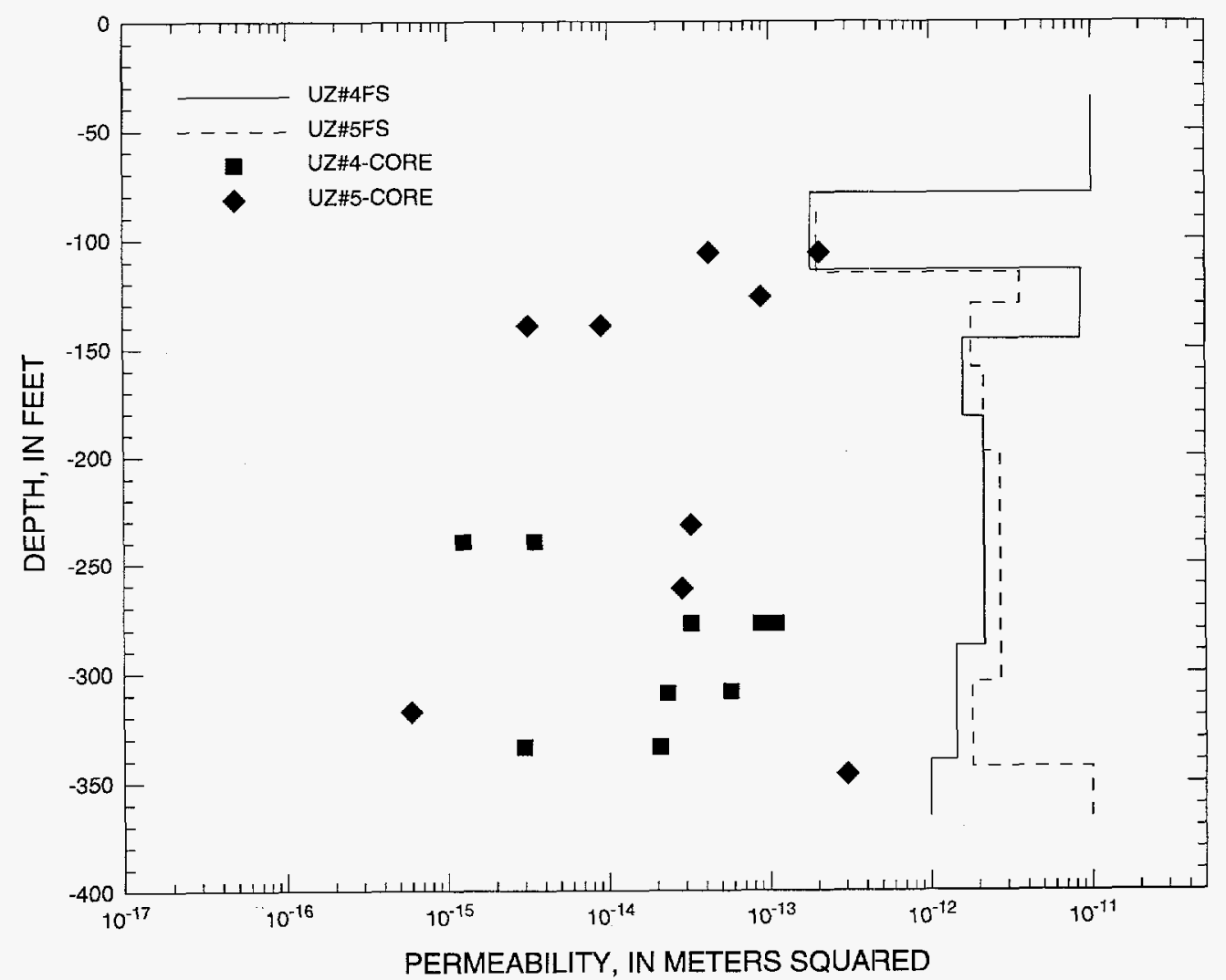

Figure 77. Comparison of field-scale (FS) estimates of permeability based on pneumatic pressure with air permeabilities measured on core at boreholes UE-25 UZ\#4 and UE-25 UZ\#5. 
the field-scale measurements have not. The estimated error associated with slip phenomena, however, does not appear to be large enough to account for the several orders of magnitude difference between the core- and field-scale permeability values (see Katz and others, 1959, p. 45-46). The estimated error introduced by Klinkenberg slip at the average pneumatic pressures existing during the analysis periods is less than +100 percent for depth intervals with an intrinsic permeability of $10^{-15} \mathrm{~m}^{2}$, and less than +50 percent in intervals with an intrinsic permeability of $10^{-14} \mathrm{~m}^{2}$.

The larger permeability values estimated from the field measurements of pneumatic pressure most likely reflect the effects of fractures or microfractures. Mapping of the drift walls within the North Ramp tunnel has shown that the nonwelded units that constitute the PTn hydrogeologic unit have a low fracture density, although the fractures are frequently stratabound, and that many of these fractures are, in fact, minor faults (see section of this report titled Fracture Characteristics of the Paintbrush Nonwelded Hydrogeologic Unit). In particular, the high secondary permeability values inferred for the nonwelded units at boreholes UZ\#4 and UZ\#5 may be reflecting the presence of a north-to-northwesttrending, west-dipping normal fault immediately to the east of these boreholes (fig. 21). Surface bedrock mapping indicates the presence of a wide zone of greater fracture density adjacent to the fault within the moderately to densely welded rocks of the Tiva Canyon Tuff (see fig. 19). This zone becomes considerably narrower with depth, based on subsurface exposures within the North Ramp tunnel (see section of this report titled Azreal Ridge Subdomain), where the fault is intersected within the upper part of the Topopah Spring Tuff. Although there are no direct observations of the width or geologic character of this fracture zone within the PTn, the substantial secondary permeability inferred for the nonwelded units at UZ\#4 and UZ\#5 indicates that, at these boreholes, this fault-associated fracture zone persists through much of the thickness of the PTn. An alternative interpretation-that the PTn is unfractured and that the inferred permeabilities reflect vertical transmission down a permeable fault and lateral movement of gas from the fault within largely unfractured individual beds-cannot be completely eliminated without further analysis. If this were the dominant flow pattern, however, there is a surprising absence of the type of evidence one might expect to observe, such as an instance in which pneumatic pres- sures at a deeper monitoring station responded to a surface barometric pressure change earlier or more strongly than at a shallower station. This type of phenomenon has been observed outside of the North Ramp area where instrumented boreholes have been located adjacent to major faults (J.P. Rousseau, U.S. Geological Survey, oral commun., 1996).

The estimates of permeability determined in this section from the analysis of the pneumatic-pressure data generally are consistent with previously published work. Ahlers and others (1995) used the combined pneumatic-pressure data from boreholes NRG-6 and NRG-7a to estimate permeabilities and drained porosities for five layers within the PTn, with hydrologic properties that were assumed to be spatially invariant. The largest permeabilities were estimated for the Tpp $\left(4.5 \times 10^{-12} \mathrm{~m}^{2}\right)$ and Tpy $\left(7.3 \times 10^{-13} \mathrm{~m}^{2}\right)$ units (Ahlers and others, 1995, table 4.4.2). Somewhat smaller permeabilities were estimated for model layers representing the combined Tpcpv 1 and Tpbt 4 units $\left(1.6 \times 10^{-13} \mathrm{~m}^{2}\right)$, the Tpbt 3 unit $\left(5.0 \times 10^{-14} \mathrm{~m}^{2}\right)$, and the combined Tpbt 2 and Tptrv3 units $\left(2.8 \times 10^{-13} \mathrm{~m}^{2}\right)$. The analyses of the pneumatic data at NRG-6 and NRG-7 a presented in the preceding sections produced estimates of permeability for depth intervals that included multiple stratigraphic layers; therefore, these estimates are not directly comparable to those of Ahlers and others (1995). Using harmonic weighting, however, the permeability estimates of Ahlers and others can be used to calculate effective permeabilities for the depth intervals defined by the monitoring stations. These effective permeabilities are consistent with the permeability values reported in tables 9 and 10 of this study.

The analyses of Montazer and others (1985) of pneumatic-pressure data at borehole UZ-1 are not directly comparable to analyses presented in the preceding sections. However, it is interesting to note that in matching pneumatic-pressure data for the PTn at that borehole, Montazer and others (1985) found it necessary to assume a double-porosity model that required secondary permeability values comparable to those calculated for boreholes UZ\#4 and UZ\#5 in the present study.

\section{Summary of Pneumatic-Diffusivity Analyses}

In summary, numerical simulation of the pneumatic-pressure data with AIRK (Weeks, 1978) showed that the chosen parts of the pressure records at NRG-6, 
NRG-7a, UZ\#4, and UZ\#5 could be accurately replicated with a one-dimensional gas-diffusion model originally developed for porous media. These analyses yielded estimates of effective permeability to air $\left(k k_{r a}\right)$ and air-filled porosity $\left(\phi_{a}\right)$ for the depth intervals bounded by the monitoring stations at these boreholes. The simulations indicated that the absence of phase offset or amplitude reductions in the pneumaticpressure signal at stations located in the TSw hydrogeologic unit could be attributed to the relatively large (vertical) pneumatic diffusivity of that unit. The simulations also indicated that, although the nonwelded and partially welded units within the PTn hydrogeologic unit are the source of most of the amplitude reductions and phase shifts of the pneumatic-pressure signal, they nonetheless possess substantial (generally greater than $10^{-12} \mathrm{~m}^{2}$ ) permeability. Comparison of the estimates of $k k_{r a}$ derived from the analyses of the pneumatic-pressure records with air permeabilities measured on unfractured core samples indicated that fracturing may have locally enhanced the permeability of the nonwelded units by as much as two to three orders of magnitude. The existence of secondary permeability within the PTn was most strongly indicated by the data at boreholes UZ\#4 and UZ\#5, which may be in a fault-affected zone of greater fracture permeability. The representativeness of these results to unfaulted areas is therefore uncertain. Comparison of estimates of $k k_{r a}$ obtained from analyses of the pneumatic-pressure records with the estimates derived from air-injection testing implies anisotropy in the $\mathrm{TCw}$ and $\mathrm{TSw}$. In the $\mathrm{TCw}$, the ratio of horizontal to vertical permeability (approximately 10:1) is attributed to the predominance of subhorizontal unloading fractures in the shallow subsurface. In the TSw, this permeability ratio is reversed, probably as a result of the disappearance or partial closure of the subhorizontal fractures that seem to dominate the shallower depths.

\section{Effects of Excavation of the North Ramp on In-Situ Pneumatic-Pressure Measurements}

Pneumatic-pressure interference effects associated with excavation of the ESF North Ramp by the tunnel-boring machine (TBM) have been detected in all monitored boreholes. The first occurrence of a pneumatic-interference event for each affected borehole in the study area is summarized in table 13.
Detection of the first occurrence of a pneumaticinterference effect may not coincide exactly in time with key excavation events in the North Ramp (for example, penetration of a fault, or removal of a confining or pneumatic-impeding layer). Many of the recorded dates for pneumatic-interference events (table 13) appear in the pneumatic record several days after the actuall excavation event. The apparent lag effect can be attributed to two primary causes. First, changes in the frequency and amplitude of the synoptic-pressure signal as registered downhole are used to determine when an interference effect has occurred. The wave length of this signal is on the order of 96+ hours, depending on the time of year (longer in summer, shorter in winter). To observe a change in in-situ pressure using this signal requires at least a half wavelength of record (that is, 2 days or more) before changes in the amplitude and frequency become apparent. Secondly, the rate of advance of the TBM tends to obscure detection of the first arrival of the pneumatic interference because the interference is propagated initially as a spherical wave front, a "weak" interference that decays inversely with the cube of the distance between the TBM and the borehole. As the TBM advances closer and closer to the affected borehole, the interference gradually evolves into a cylindrical wave front, a stronger interference that decays inversely with the square of the distance between the TBM and the borehole. Obviously, if the TBM is advancing very rapidly, the spherical or "weak" interference may not be readily discernible given the half wavelength delay time ( 2 days or more) needed to confirm a change in the frequency and/or amplitude of the in-situ pressure signal. Many first occurrences are recorded on a Sunday, 2 days following the Friday shutdown of tunneling operations. Pressure interferences that are clearly propagated along fault planes were detected in advance of actual fault penetration at UZ\#4 and UZ\#5, but only because the TBM was shut down for 10 days and did not actually penetrate the fault until 8 days after tunneling operations were resumed. At NRG-6, the pneumatic interference was not detected until 2 days after the Drill Hole Wash Fault system was penetrated, for reasons cited previously.

Penetration of the PTn (crystal-rich vitric unit at the base of the PTn) in the North Ramp tunnel occurred on June 20, 1995. NRG\#4 was the first borehole to register a pneumatic interference to the 
Table 13. Summary of pneumatic-interference events from excavation of the North Ramp of the Exploratory Studies Facility

[TBM, tunnel-boring machine; ESF, Exploratory Studies Facility]

\begin{tabular}{|c|c|c|c|c|}
\hline Borehole & $\begin{array}{l}\text { Date } \\
\text { interference event } \\
\text { first detected }\end{array}$ & $\begin{array}{l}\text { Position of the TBM } \\
\text { referenced to ESF } \\
\text { stations } \\
\text { (distance from North } \\
\text { Ramp portal, } \\
\text { in meters) }\end{array}$ & $\begin{array}{l}\text { Horizontal offset } \\
\text { distance to affected } \\
\text { borehole } \\
\text { (in meters) }\end{array}$ & $\begin{array}{l}\text { Lithostratigraphic unit } \\
\text { exposed at the face of } \\
\text { the North Ramp tunnel }\end{array}$ \\
\hline $\begin{array}{l}\text { NRG\#4 } \\
\text { (Non-Q) }\end{array}$ & $06 / 16 / 95$ & $\begin{array}{l}10+68.3 \\
(1,068.3)\end{array}$ & 25 & $\begin{array}{l}\text { Pre-Pah Canyon Tuff } \\
\text { (Tpbt2) }\end{array}$ \\
\hline $\mathrm{UZ \# 4}$ & $08 / 12 / 95$ & $\begin{array}{l}12+61.8 \\
-(1,261.8)\end{array}$ & 415 & $\begin{array}{l}\text { Crystal-rich nonlithophysal } \\
\text { Topopah Spring } \\
\text { (Tptrn) }\end{array}$ \\
\hline $\mathrm{UZ} \# 5$ & $08 / 12 / 95$ & $\begin{array}{l}12+61.8 \\
(1,261.8)\end{array}$ & 377 & $\begin{array}{l}\text { Crystal-rich nonlithophysal } \\
\text { Topopah Spring } \\
\text { (Tptrn) }\end{array}$ \\
\hline NRG\#5 & $09 / 14 / 95$ & $\begin{array}{l}16+56.3 \\
(1,656.3)\end{array}$ & 93 & $\begin{array}{l}\text { Crystal-rich nonlithophysal } \\
\text { Topopah Spring } \\
\text { (Tptrn) }\end{array}$ \\
\hline NRG-6 & $10 / 01 / 95$ & $\begin{array}{l}20+02.1 \\
(2,002.1)\end{array}$ & 551 & $\begin{array}{l}\text { Upper lithophysal } \\
\text { Topopah Spring } \\
\text { (Tptrl, Tptpul) }\end{array}$ \\
\hline NRG-7a & $10 / 21 / 95$ & $\begin{array}{l}23+46.8 \\
(2,346.8)\end{array}$ & 26 & $\begin{array}{l}\text { Upper lithophysal } \\
\text { Topopah Spring } \\
\text { (Tptrl, Tptpul) }\end{array}$ \\
\hline SD-9 & $11 / 07 / 95$ & $\begin{array}{l}26+54.7 \\
(2,654.7)\end{array}$ & 184 & $\begin{array}{l}\text { Middle nonlithophysal } \\
\text { Topopah Spring } \\
\text { (Tptpmn) }\end{array}$ \\
\hline
\end{tabular}

ambient pressure system (fig. 54). This interference was first detected on June 16, 1995, when the face of the North Ramp tunnel was in the pre-Pah Canyon Tuff (Tpbt2), and the crystal-rich vitric unit at the base of the PTn was still undisturbed. The horizontal offset distance of NRG\#4 from the face of the North Ramp tunnel on June 16, 1995, was approximately $25 \mathrm{~m}$. The pneumatic-interference effects observed at NRG\#4 are the result of the removal of the PTn pneumatic impeding layer, thus exposing the TSw directly to the atmospheric-pressure signal. This conclusion, although scientifically valid, is non- $Q$ because it is based on the pressure data collected from borehole NRG\#4, which are non-Q.

Pneumatic-interference effects at boreholes UZ\#4 and UZ\#5 were first detected on August 12, 1995 (figs. 56, 57, 59, and 60). On that date, the face of the North Ramp tunnel was about 18 m east of the intersection of a north- to-northwest-trending, westdipping, normal fault (fault 2 in fig. 21). This fault was first exposed in the North Ramp tunnel when the TBM advanced to position $12+80(1,280 \mathrm{~m}$ west of the North Ramp portal). This fault as exposed in the North Ramp tunnel is a zone approximately $1 \mathrm{~m}$ wide that consists of several small, but discrete, westdipping offsets. The breccia zone of this fault is approximately $50 \mathrm{~m}$ wide on the land surface. The pneumatic interference observed at UZ\#4 and UZ\#5 on August 12, 1995, was transmitted along this fault zone over a distance of 377 to $415 \mathrm{~m}$ and affected the pneumatic-pressure responses in all of the PTn and TSw instrument stations in these two boreholes. Attenuation of the amplitude of the atmosphericpressure signal at UZ\#4 and UZ\#5 along this pathway is approximately 25 percent, indicating that this particular fault is very permeable. This fault has not been traced across Pagany Wash and appears to terminate in the vicinity of UZ\#4 (fault 2 in fig. 21).

The first indication of a pneumatic interference to the pressure record at NRG\#5 occurred on 
September 14, 1995 (figs. 48, 49, and 50), when the face of the North Ramp was about $93 \mathrm{~m}$ from this borehole and in the lower section of the crystal-rich nonlithophysal unit of the Topopah Spring Tuff. Pneumatic-interference effects were recorded in all of the PTn and TSw instrument stations in this borehole.

Pneumatic-interference effects are present in the pneumatic-pressure record for NRG-6 beginning on October 1, 1995 (fig. 52). These interference effects were recorded approximately 2 days after the TBM intersected the northern boundary of the Drill Hole Wash Fault system on September 29, 1995. The intersection of this fault system with the North Ramp tunnel is near ESF station $20+02(2,002 \mathrm{~m}$ west of the North Ramp portal) and is about $551 \mathrm{~m}$ northwest of NRG-6. Recognition of this interference effect at NRG-6 was not immediately apparent. Several months of additional pressure data at NRG- 6 were required to confirm that there was indeed a change in the amplitude and phase lag of the synoptic-pressure signal in the NRG-6 pressure records for the TSw instrument stations. Numerical model simulations conducted by Lawrence Berkeley National Laboratory (C.F. Ahlers to G.S. Bodvarsson, written commun., May 1, 1996) confirmed and isolated the approximate date of these changes. The numerical-model results corroborate the results of the spectral analysis of the pneumatic-pressure record at NRG- 6 after interference from the TBM (table 14). NRG-6 is located south of the inferred boundaries of the Drill Hole Wash Fault system (fig. 21). It is likely that the weak pressure interference seen at NRG-6 is a reflection of pressure changes that were propagated both along, and perpendicular to, the alignment of this fault system. It is clear from these data that faults in the Drill Hole Wash Fault system are open in the TSw.

At NRG-7a, pneumatic-interference effects were first detected after the North Ramp had advanced past the northwest-trending Drill Hole Wash Fault system (fig. 21). The southern boundary of this fault system was reached when the TBM advanced to ESF station $22+60$ (2,260 $\mathrm{m}$ from the North Ramp portal) on October 16, 1995, indicating that the fault system was approximately $100 \mathrm{~m}$ east of NRG-7a. However, a pneumatic interference at NRG-7a was not detected until the TBM advanced to within $26 \mathrm{~m}$ of this borehole on October 21, 1995, 5 days after crossing the southern boundary of the Drill Hole Wash Fault system. The sequence of events surrounding the first observed occurrence of a pneumatic interference at
NRG-7a indicates that secondary, near-field fracturing associated with the Drill Hole Wash Fault system is very limited immediately south of where the North Ramp crosses this fault system. It should be noted, however, that the rate of advance of the TBM at that time, about $22 \mathrm{~m}$ per day, may have obscured early detection of the first arrival of the pneumaticinterference effect.

Results of a spectral analysis of the pressure records from boreholes affected by excavation of the North Ramp tunnel are reproduced in table 14.

These results indicate that significant change has occurred in the residual amplitudes and phase lags of the transmitted synoptic pressure signal within the TSw for all monitored boreholes in the study area. Evidence indicates significant changes in the PTn instrument stations in some of the boreholes, especially UZ\#4 and UZ\#5. The spectral analysis also indicates that the pneumatic interferences from tunnel excavation are propagated differentially across the TSw, with larger interferences registering in instrument stations that are closer to the tunnel. This observation, coupled with observations of the first occurrence of interference to the pneumatic pressure system, indicates that vertical fracture permeability is greater than lateral fracture permeability. With the exception of UZ\#4, UZ\#5, and NRG-6 (boreholes that are clearly influenced by the presence of a nearby fault), the horizontal offset distances between affected boreholes and the tunnel at the time the pneumatic interference effects were first detected were about 25 to $184 \mathrm{~m}$. The pre-ESF-excavation pneumatic record indicates very little attenuation and lagging of the synoptic pressure signal within the TSw once this signal has traversed the contact between the PTn and the TSw. The amplitude and phase lag of this signal remains virtually intact over vertical distances of at least $270 \mathrm{~m}$ (UZ-1 pneumatic record, figs. 42 and 43). Thus, as a first approximation, an anisotropy ratio of vertical to horizontal fracture permeability within the TSw on the order of 3:1 (or perhaps greater) may be inferred from the existing data. However, this conclusion, although probably valid scientifically, is non- $Q$ because it is based on the pneumatic-pressure data from UZ-1, which are non-Q. The presence of anisotropy within the TSw probably is the result of (1) a fracture system that is dominated by high-angle fractures; thus vertical flow pathways will tend to be much less tortuous than horizontal pathways that must communicate laterally by transmission through a 
Table 14. Spectral analyses of in-situ pneumatic-pressure responses to the synoptic barometric-pressure signal after interference from excavation of the North Ramp Tunnel

[TBM, tunnel-boring machine; N/A, not analyzed; N/D, no data available]

\begin{tabular}{|c|c|c|c|c|c|c|}
\hline Borehole & $\begin{array}{l}\text { Period of } \\
\text { analysis } \\
\text { (synoptic } \\
\text { frequency) }\end{array}$ & $\begin{array}{l}\text { Instrument } \\
\text { station }\end{array}$ & $\begin{array}{c}\text { Residual } \\
\text { amplitude } \\
\text { (percent of } \\
\text { synoptic } \\
\text { signal) }\end{array}$ & $\begin{array}{l}\text { Change in residual } \\
\text { amplitude from } \\
\text { before TBM interference } \\
\text { (percent of synoptic } \\
\text { signal) }\end{array}$ & $\begin{array}{l}\text { Phase } \\
\text { lag } \\
\text { (hours) }\end{array}$ & $\begin{array}{c}\text { Change in phase } \\
\text { lag from } \\
\text { before TBM } \\
\text { interference } \\
\text { (hours) }\end{array}$ \\
\hline \multirow{7}{*}{$\begin{array}{l}\text { NRG\#4 } \\
\text { (Non-Q) }\end{array}$} & $07 / 07 / 95$ & 1 & 97 & +1 & 1.0 & -0.1 \\
\hline & \multirow{2}{*}{$\begin{array}{c}\text { to } \\
07 / 23 / 95\end{array}$} & 2 & 97 & +1 & 0.7 & -0.4 \\
\hline & & 3 & 55 & +5 & 13.2 & -1.8 \\
\hline & \multirow{4}{*}{ (128 hours) } & 4 & 69 & +54 & 1.9 & -37.4 \\
\hline & & 5 & 68 & +53 & 2.1 & -37.3 \\
\hline & & 6 & 66 & +51 & 2.3 & -36.9 \\
\hline & & 7 & 47 & +32 & 5.9 & -34.9 \\
\hline \multirow[t]{8}{*}{ UZ\#4 } & \multirow{3}{*}{$\begin{array}{c}08 / 13 / 95 \\
\text { to } \\
11 / 27 / 95\end{array}$} & H & N/A & N/A & N/A & N/A \\
\hline & & G & $\mathrm{N} / \mathrm{A}$ & N/A & N/A & N/A \\
\hline & & $\mathrm{F}$ & 37 & +16 & 18.5 & +2.6 \\
\hline & \multirow{5}{*}{ (116 hours) } & E & 37 & +16 & 18.7 & +2.2 \\
\hline & & D & 37 & +16 & 19.2 & -1.1 \\
\hline & & $\mathrm{C}$ & 37 & +21 & 18.0 & -8.5 \\
\hline & & B & 54 & +39 & 5.6 & -18.1 \\
\hline & & A & 54 & +38 & 5.1 & -17.8 \\
\hline \multirow[t]{8}{*}{ UZ\#5 } & $09 / 07 / 95$ & $\mathrm{H}$ & 93 & N/A & 1.1 & N/A \\
\hline & \multirow{7}{*}{$\begin{array}{c}10 / 30 / 95 \\
\text { to } \\
\text { (106 hours) }\end{array}$} & G & 44 & -18 & 16.2 & +15.9 \\
\hline & & $\mathrm{F}$ & 43 & +24 & 17.1 & +6.2 \\
\hline & & $\mathrm{E}$ & 42 & +27 & 18.3 & -2.0 \\
\hline & & $\mathrm{D}$ & 42 & +28 & 18.7 & -1.8 \\
\hline & & $\mathrm{C}$ & 44 & +29 . & 15.4 & -5.8 \\
\hline & & B & 69 & +54 & 5.5 & -14.3 \\
\hline & & A & 69 & +55 & 5.5 & -15.0 \\
\hline \multirow[t]{14}{*}{ NRG\#5 } & \multirow{3}{*}{$\begin{array}{c}09 / 22 / 95 \\
\text { to } \\
10 / 02 / 95\end{array}$} & 1 & N/D & N/D & N/D & N/D \\
\hline & & 2 & 99 & 0 & 0.2 & -0.1 \\
\hline & & 3 & 60 & +2 & 5.1 & -3.2 \\
\hline & \multirow{11}{*}{ (128 hours) } & 4 & 37 & +5 & 9.6 & -12.2 \\
\hline & & 5 & 66 & +38 & 3.9 & -21.0 \\
\hline & & 6 & 85 & +56 & 1.1 & -19.5 \\
\hline & & 7 & 85 & +56 & 1.0 & -19.5 \\
\hline & & 8 & $\mathrm{~N} / \mathrm{D}$ & N/D & N/D & N/D \\
\hline & & 9 & 78 & +49 & 2.5 & -18.9 \\
\hline & & 10 & N/D & N/D & N/D & N/D \\
\hline & & 11 & 72 & +44 & 3.3 & -19.1 \\
\hline & & 12 & $\mathrm{~N} / \mathrm{D}$ & N/D & N/D & $\mathrm{N} / \mathrm{D}$ \\
\hline & & 13 & 41 & +6 & 8.9 & -14.9 \\
\hline & & 14 & 46 & +12 & 8.2 & -15.3 \\
\hline
\end{tabular}


Table 14. Spectral analyses of in-situ pneumatic-pressure responses to the synoptic barometric-pressure signal after interference from excavation of the North Ramp Tunnel-Continued

[TBM, tunnel-boring machine; N/A, not analyzed; N/D, no data available]

\begin{tabular}{|c|c|c|c|c|c|c|}
\hline Borehole & $\begin{array}{l}\text { Period of } \\
\text { analysis } \\
\text { (synoptic } \\
\text { frequency) }\end{array}$ & $\begin{array}{l}\text { Instrument } \\
\text { station }\end{array}$ & $\begin{array}{l}\text { Residual } \\
\text { amplitude } \\
\text { (percent of } \\
\text { synoptic } \\
\text { signal) }\end{array}$ & $\begin{array}{l}\text { Change in residual } \\
\text { amplitude from } \\
\text { before TBM interference } \\
\text { (percent of synoptic } \\
\text { signal) }\end{array}$ & $\begin{array}{c}\text { Phase } \\
\text { lag } \\
\text { (hours) }\end{array}$ & $\begin{array}{c}\text { Change in phase } \\
\text { lag from } \\
\text { before TBM } \\
\text { interference } \\
\text { (hours) }\end{array}$ \\
\hline \multirow[t]{5}{*}{ NRG-7a } & $10 / 23 / 95$ & $E$ & N/A & N/A & $\overline{\mathrm{N} / \mathrm{A}}$ & N/A \\
\hline & \multirow{2}{*}{$\begin{array}{c}\text { to } \\
12 / 15 / 95\end{array}$} & D & 70 & +12 & 12.6 & -4.7 \\
\hline & & C & 56 & +50 & 8.7 & -36.8 \\
\hline & \multirow{2}{*}{ (128 hours) } & B & 61 & +55 & 6.8 & -39.9 \\
\hline & & A & 75 & +70 & 3.5 & -45.0 \\
\hline \multirow[t]{7}{*}{ NRG-6 } & \multirow{3}{*}{$\begin{array}{c}06 / 18 / 95 \\
\text { to } \\
12 / 31 / 95\end{array}$} & G & 66 & +23 & 2.1 & -7.5 \\
\hline & & $\mathrm{F}$ & 31 & +1 & 19.1 & -8.6 \\
\hline & & E & 35 & +11 & 25.4 & -12.4 \\
\hline & \multirow[t]{4}{*}{ (116 hours) } & D & 36 & +11 & 25.4 & -12.3 \\
\hline & & $\mathrm{C}$ & 35 & +10 & 25.4 & -12.5 \\
\hline & & B & 36 & +11 & 25.6 & -12.7 \\
\hline & & A & 36 & +11 & 26.2 & -12.4 \\
\hline
\end{tabular}


network of vertically oriented fractures, and (2) the effect of differential loading on the openness and, hence, permeability of individual fracture planes. Studies conducted by Stock and Healy (1988) and Swolfs and others (1988) indicate that the horizontal stress field in the North Ramp study area is 25 to 50 percent less than the vertical stress field. Because of this, loading across high-angle fractures will be less than across low-angle fractures, and the apertures of high-angle fractures will tend, in general, to be larger than the apertures of fractures with low-angle orientations, resulting in higher vertical permeability.

\section{Gaseous-Phase Chemistry}

Gaseous-phase chemistry has been investigated to understand unsaturated-zone gas-transport and flow processes at Yucca Mountain as part of the site-characterization program. The measurement of carbon-14 $\left({ }^{14} \mathrm{C}\right)$ concentration can provide information relevant to the residence time of carbon dioxide $\left(\mathrm{CO}_{2}\right)$ in the unsaturated zone, and delta carbon- $13\left(\delta^{13} \mathrm{C}\right)$ isotopic data can help to identify carbon sources, a necessary step in ${ }^{14} \mathrm{C}$ age estimation. Also, carbon isotopes in the depth profile can provide information on gas-flow mechanisms through the unsaturated zone as well as interactions with the aqueous phase and the mineral calcite. Values of $\delta^{13} \mathrm{C}$ are expressed in parts per thousand, or per mil, using the symbol \%o.

Gas samples were collected from one instrumented borehole (UZ-1) and from two open boreholes (NRG-6 and NRG-7). Gaseous-phase chemical and isotopic data from UZ-1 for 1983-88 were collected prior to implementation of the approved USGS-YMP quality-assurance program and, therefore, are non-Q. However, the data collected from UZ-1 from 1989 to 1994, as well as those from NRG-6 and NRG-7, are fully qualified.

During drilling of UZ-1, sulfur hexafluoride $\left(\mathrm{SF}_{6}\right)$ was used as a gaseous tracer in an attempt to determine drilling-air contamination of the gas in the unsaturated zone. After drilling was completed, an attempt was made to remove the atmospheric air that entered the unsaturated zone during drilling by evacuation with a large-capacity pump. The tracer $\left(\mathrm{SF}_{6}\right)$ concentration in the evacuated air was continuously monitored, and disappearance of the $\mathrm{SF}_{6}$ (concentration less than 0.1 part per million) was assumed to indicate complete removal of drilling air. Generally, gas samples were collected for three types of analyses: $\mathrm{CO}_{2}, \delta^{13} \mathrm{C}$, and ${ }^{14} \mathrm{C}$. For $\mathrm{CO}_{2}$, gas-sampling devices used were $500-\mathrm{cm}^{3}$-per-minute peristaltic pumps connected through $0.95-\mathrm{cm}$-diameter nylon tubes to the underground zones of interest. Gas samples were drawn directly from the nylon tubes through a threeway stopcock into a syringe, and $\mathrm{CO}_{2}$ concentrations were analyzed using a gas chromatograph.

For $\delta^{13} \mathrm{C}$ determination, two gas-sampling methods were used. In the molecular-sieve (MS) method, the gas stream was initially passed continuously through a silica-gel tower to remove moisture, then through a $300-\mathrm{mL}$ stainless-steel cylinder containing a 50-nanometer ( $\mathrm{nm}$ ), anhydrous (dehydrated under a vacuum at $350^{\circ} \mathrm{C}$ ) molecular sieve to trap the $\mathrm{CO}_{2}$ gas. The $\mathrm{CO}_{2}$ was recovered later in the laboratory by heating the stainless-steel cylinder (containing the molecular-sieve pellets) to $350^{\circ} \mathrm{C}$ in a vacuum-line system. Released $\mathrm{CO}_{2}$ was collected in the cold trap, the volume measured and then transferred to the storage cylinders. This method of collection was compared with the potassium hydroxide $(\mathrm{KOH})$-absorption method. Values of $\delta^{13} \mathrm{C}$ obtained by the MS method were lighter by 5 to 6 per mil with respect to $\mathrm{PDB}$ standard, and ${ }^{14} \mathrm{C}$ fractionation is about 1.2 percent. [The standard for $\delta^{13} \mathrm{C}$ is the PDB standard that consists of a calcium carbonate obtained from a belemnite of the Peedee Formation of South Carolina, as described by Gonfiantini (1978). The precision of $\delta^{13} \mathrm{C}$ analysis is about 0.2 per mil.] The MS-collection method was used from 1984 until 1991 when it was replaced by the whole-gas (WG) method. A gas stream was allowed to flow through a $500-\mathrm{mL}$ glass container (or a Mylar balloon) to purge the container several times before sampling. When the gas stream attained a steady flow (indicated by a flow meter), stopcocks at both ends were closed and the glass container removed from the flow line. The collection time was less than 5 minutes. This has become a preferred method and has been used continuously. The WG samples collected in $500-\mathrm{mL}$ glass containers were brought back to the laboratory for processing.

The method of sampling for analysis of ${ }^{14} \mathrm{C}$-sample collection was similar to the MS method used for $\delta^{13} \mathrm{C}$ sampling except that the collection time is 5 to 10 days, depending on the $\mathrm{CO}_{2}$ concentration of the gas. In the earliest stages of this study, some of the ${ }^{14} \mathrm{C}$ samples were collected by sorption in concentrated $\mathrm{KOH}$ solution as described in Haas and others (1983) and Yang and others (1985). $\delta^{13} \mathrm{C}$ and ${ }^{14} \mathrm{C}$ samples were sent to outside laboratories for analysis. 


\section{Carbon Dioxide Concentration in Gas Samples From Borehole USW UZ-1}

As shown in figure $78, \mathrm{CO}_{2}$ concentrations generally are rather large (greater than 0.15 percent by volume) at shallow depths (probes 1, 2, 3, and 4) and near the bottom (probe 15) relative to the concentrations at intermediate depths in the profiles (less than 0.15 percent by volume). The large concentrations at the shallow depths (more than 0.3 percent by volume) also are larger than at other boreholes near and around Yucca Mountain (Thorstenson and others, 1990). This is attributed to biogenic $\mathrm{CO}_{2}\left(\mathrm{CO}_{2}\right.$ gas respired from plant roots) released after the burial of vegetation during construction of the UZ-1 drilling pad. The larger $\mathrm{CO}_{2}$ concentrations at the bottom probe may be attributed to the breakdown of organic polymers from drilling-fluid contamination from nearby $\mathrm{G}-1$. The $\mathrm{CO}_{2}$-concentration profiles as a function of time indicate that low $\mathrm{CO}_{2}$ concentrations were measured in 1983 (fig. 78A) and that, except for probe 13, concentrations steadily increased through 1987 . The atmospheric $\mathrm{CO}_{2}$ concentration ( 0.034 percent by volume) is significantly lower than most of the very shallow $\mathrm{CO}_{2}$ concentrations in UZ-1. Because not all of the drilling air was pumped from borehole UZ-1 before it was instrumented, the early (1983-84) $\mathrm{CO}_{2}$ samples that were diluted by drilling air in the borehole showed relatively low $\mathrm{CO}_{2}$ concentrations. As the semiannual gas-sampling program proceeded (1985-87), more drilling air was removed from the hole and the unsaturated-zone gas composition began to stabilize. From 1988 through 1994, the $\mathrm{CO}_{2}$ concentration from 99 to $366 \mathrm{~m}$ changed very little (fig. $78 \mathrm{~B}$ ). The small and nearly invariant $\mathrm{CO}_{2}$ concentrations at probe 13 have not been explained. A possibly related observation is that, although gas was pumped for 10 days from each probe prior to sampling, probe 13 consistently yielded the smallest amount of $\mathrm{CO}_{2}$ gas.

\section{Delta Carbon-13 and Carbon-14 Content of Gas Samples From Borehole USW UZ-1}

Values of $\delta^{13} \mathrm{C}$ relative to depth in UZ-1

(fig. 79) showed large variations in 1984 and 1985. As was explained previously concerning the $\mathrm{CO}_{2}$ concentration, the 1984 shift was the result of the drilling-air contamination in the borehole. The $\delta^{13} \mathrm{C}$ value of the atmospheric $\mathrm{CO}_{2}$ at Yucca Mountain is about -8.5 per mil (Thorstenson and others, 1990, 1998). The presence of atmospheric air in collected samples would thus lead to larger $\delta^{13} \mathrm{C}$ values. Between 1986 and 1987 (fig. 79A), and 1988 through 1994 (fig. 79B), all $\delta^{13} \mathrm{C}$ values were fairly constant, ranging from -17 to -23 per mil except for probes 9 and 10 in 1992, and near the bottom of the hole (probes 13 and 14), where occasional departures from the average value were observed. The $\delta^{13} \mathrm{C}$ value of about -20 per mil at shallow depths is representative of biogenic $\mathrm{CO}_{2}$ $\left(\mathrm{CO}_{2}\right.$ gas respired from plant roots). The average $\delta^{13} \mathrm{C}$ value of near -20 per mil at all depths indicates that the $\mathrm{CO}_{2}$ gas in the $\mathrm{UZ}$ has not exchanged with nor is in equilibrium with in-situ calcite or caliche because the solid fracture-filling carbonates have a $\delta^{13} \mathrm{C}$ value generally between -9 and -3 per mil in the UZ (Szabo and Kyser, 1990; Whelan and Stuckless, 1990). If exchange had occurred, the $\mathrm{CO}_{2}$ gas $\delta^{13} \mathrm{C}$ values would have become larger over time as more uncontaminated gas was removed during sampling, which was not observed. Also, the ${ }^{14} \mathrm{C}$ age of the $\mathrm{CO}_{2}$ gas would be older than its real age because of the old ${ }^{14} \mathrm{C}$ age of calcite and caliche [greater than 20,000 years to several hundred thousand years; Szabo and Kyser (1990); Whelan and others (1994)].

With regard to the extent of interaction between the gaseous-phase $\mathrm{CO}_{2}$ and the pore-water bicarbonate, most carbon present in the unsaturated zone is in the aqueous phase. If the gaseous $\mathrm{CO}_{2}$ were interacting with a large aqueous-phase carbon reservoir, the gaseous-phase $\mathrm{CO}_{2}$ concentration would be modified, which was not observed. It is conceivable that such nonequilibrium conditions exist between gaseous and aqueous phases in many parts of Yucca Mountain. Due to insufficient gaseous-phase data and the complex nature of the fracture system at Yucca Mountain, however, this conclusion is preliminary.

The ${ }^{14} \mathrm{C}$ data for 1984 and 1985 (fig. 80) have higher ${ }^{14} \mathrm{C}$ activity values than the data from other years. This is consistent with the previous explanation of the drilling-air contamination in the borehole. Present-day ${ }^{14} \mathrm{C}$ activity in the atmospheric air is about 120 percent modern carbon (pmc), which would cause the ${ }^{14} \mathrm{C}$ activity of soil $\mathrm{CO}_{2}$ gas to shift toward higher values. The ${ }^{14} \mathrm{C}$ data are consistent for the last 7 years (fig. 80B), with a gradual decrease in ${ }^{14} \mathrm{C}$ activity with depth to about 20 pmc at $366 \mathrm{~m}$.

The ${ }^{14} \mathrm{C}$ profiles for $1988-94$ (fig. 80b) display an abrupt change in slope at probe 5 . The transport velocity $\left({ }^{14} \mathrm{C}\right.$ concentration gradient over distance) between probes 1 and 5 is slower than the transport velocity between probes 5 and 15 . The slower 


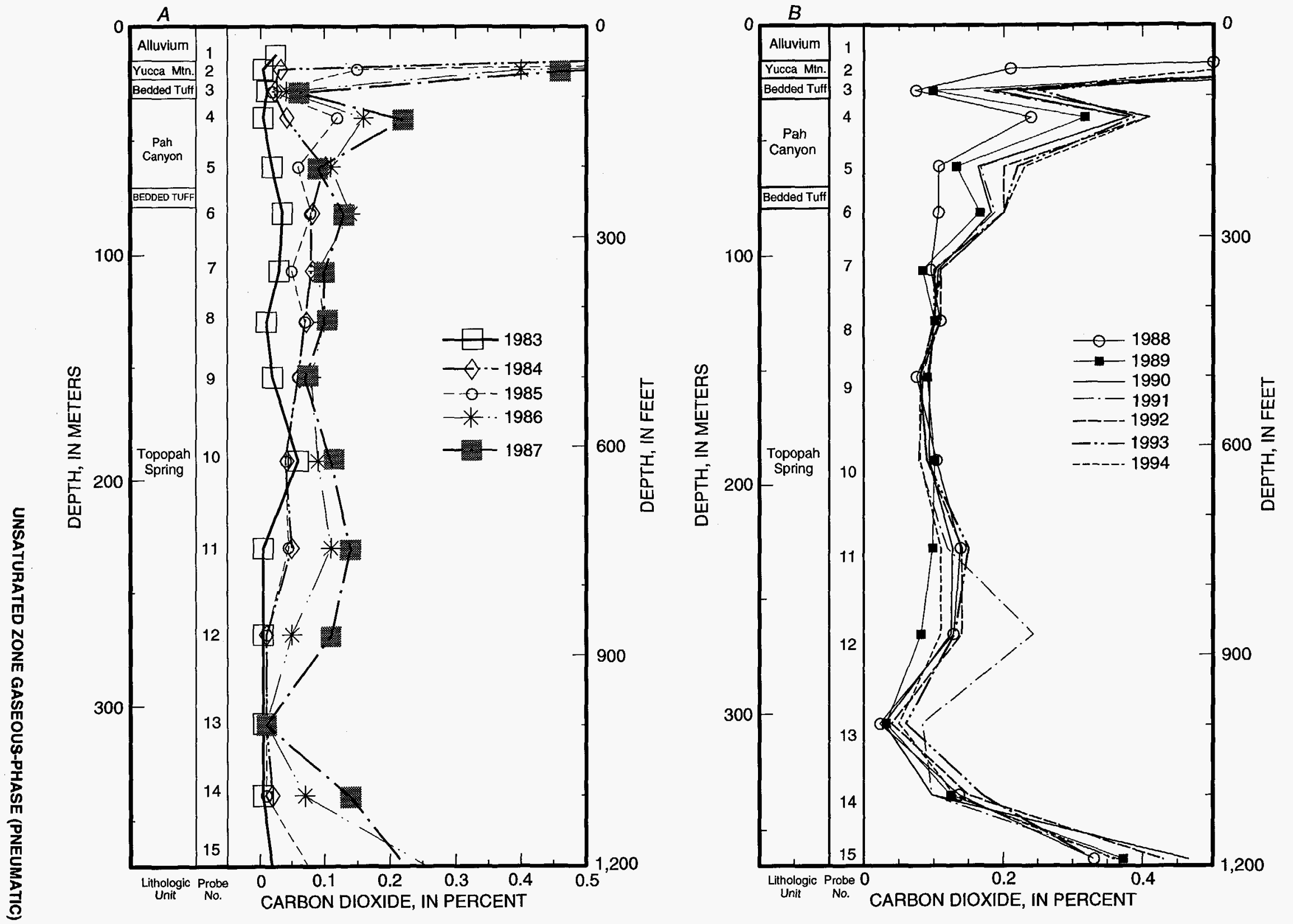

Figure 78. Percent carbon dioxide concentration in gas samples from borehole USW UZ-1: (A) 1983-87 and (B) 1988-94. 


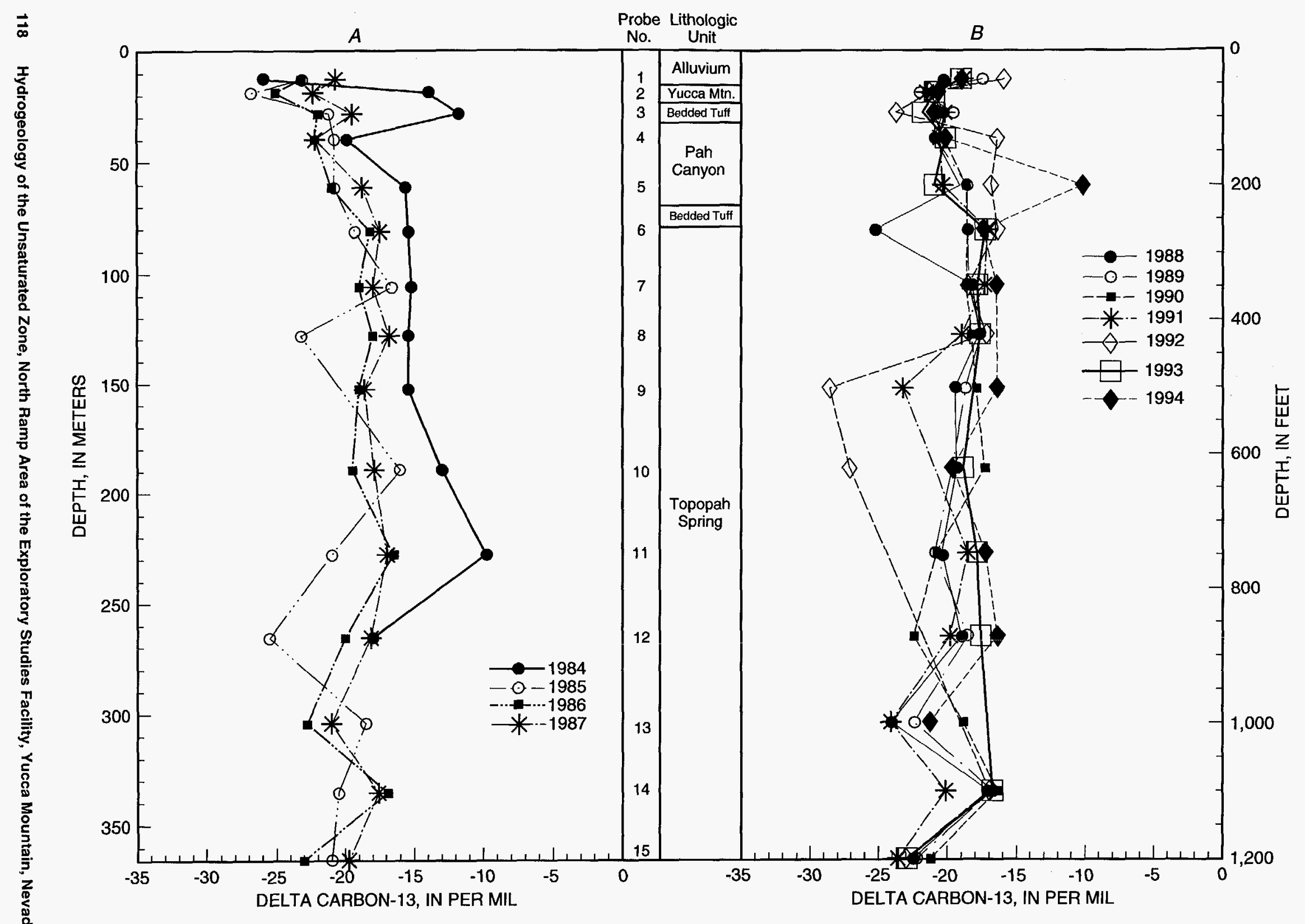

Figure 79. Delta carbon-13 values, in per mil, in carbon-dioxide gas samples from borehole USW UZ-1: (A) 1984-87 and (B) $1988-94$. 

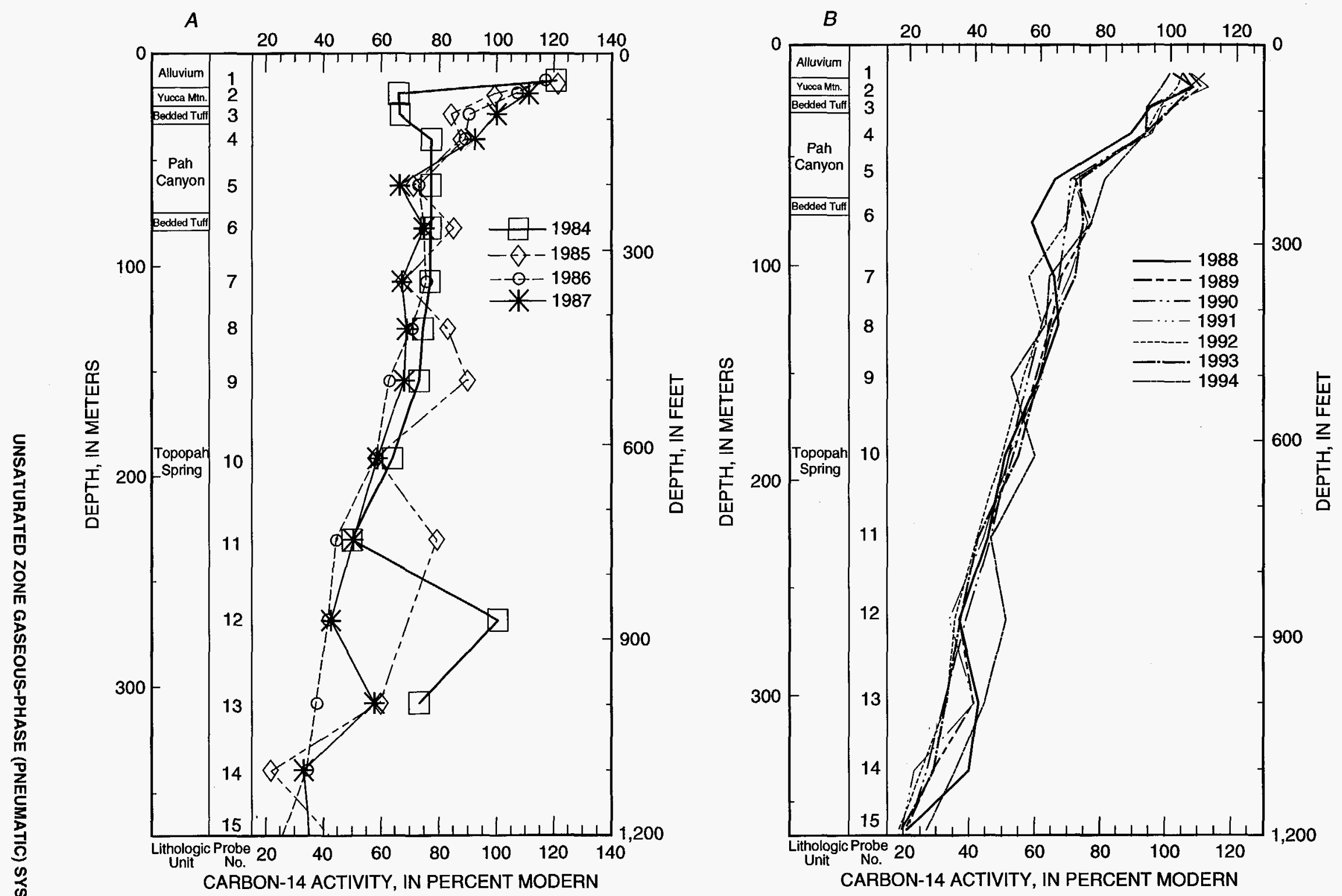

Figure 80. Carbon-14 activity in carbon-dioxide gas samples from borehole USW UZ-1: (A) 1984-87 and (B) 1988-94. 
transport velocity may be due to higher porosity and moisture content in this zone. An estimate of the minimum travel time of gas in the Topopah Spring Tuff (between probes 5 and 15) based on the apparent ${ }^{14} \mathrm{C}$ ages and depths in the borehole yields gas movement of $3.0 \mathrm{~cm}$ per year. This rate, as well as results of gas-transport modeling (Yang and others, 1996), is consistent with downward movement of atmospheric $\mathrm{CO}_{2}$ by simple Fickian diffusion. Although diffusion may not be the only mechanism for gas movement in the Topopah Spring Tuff at UZ-1, it seems to be the dominant mechanism, and it can account for the observed depth distribution of gaseous ${ }^{14} \mathrm{C}$. Although the non-Q data from UZ-1 corroborate this conclusion, it also is supportable using solely the fully qualified data from UZ-1.

\section{Carbon Dioxide Concentration and Carbon-Isotope Content of Gas Samples From Selected Open Boreholes}

Carbon dioxide and carbon-isotopic data also were collected from selected intervals of open boreholes NRG-6 and NRG-7a. The carbon dioxide concentrations ranged from 0.05 to 0.19 percent by volume. The value at the lower end of this range is slightly higher than the atmospheric $\mathrm{CO}_{2}$ concentration, while at the higher end it is within the biogenic $\mathrm{CO}_{2}$ concentration of soil gas. The $\delta^{13} \mathrm{C}$ values in boreholes NRG-6 and NRG-7a are, in general, heavier than the values for $\mathrm{UZ}-1$, and percent modern ${ }^{14} \mathrm{C}$ values do not show a steady decrease with depth as seen in UZ-1. The heavier $\delta^{13} \mathrm{C}$ values and younger ${ }^{14} \mathrm{C}$ values down to $305 \mathrm{~m}$ could be due to contamination with atmospheric air as a consequence of a leaking packer or incomplete removal of drilling air. However, the $\delta^{13} \mathrm{C}$ value of -18.4 per mil in $\mathrm{UZ \# 16}$ (located south of the study area) at a depth of $533 \mathrm{~m}$ is similar to the UZ-1 value. More gas data from stemmed and instrumented boreholes other than UZ-1 are needed to confirm the gaseous-phase behavior at other locations around Yucca Mountain. The longterm carbon isotopic data (more than 10 years of data) from UZ-1, which shows a steady decrease in ${ }^{14} \mathrm{C}$ ages as a function of depth with consistent $\delta^{13} \mathrm{C}$ values, are believed to be the only valid unsaturated-zone gas data available so far in the Topopah Spring Tuff and below.

\section{Summary of Gaseous-Phase Chemistry}

With respect to $\mathrm{CO}_{2}$, composition of gas in the unsaturated-zone at borehole UZ-1 is similar to atmo- spheric air except that $\mathrm{CO}_{2}$ concentrations are generally larger in the gas in the unsaturated zone than in air. The $\delta^{13} \mathrm{C}$ (gas) values of $\mathrm{CO}_{2}$ from UZ-1 average -20 per mil throughout, indicating biogenic sources. Delta ${ }^{13} \mathrm{C}$ (gas) values are fairly constant from the surface to a depth of $366 \mathrm{~m}$, indicating little interaction between the $\mathrm{CO}_{2}$ gas and caliche in the soil. On the basis of ${ }^{14} \mathrm{C}$ data, the dominant mechanism for gas movement in the unsaturated zone at the location of UZ-1 in Drill Hole Wash seems to be downward diffusion of atmospheric gas from the surface.

\section{Summary of Unsaturated-Zone Pneumatic System}

The unsaturated-zone pneumatic system, for both functional and descriptive purposes, can be visualized as consisting of four distinct but interconnected flow regimes or subsystems. These pneumatic subsystems conform to the definitions of the major hydrogeologic units presented in table 2. Discrimination of these subsystems is based on (1) stratigraphic and topographic position, (2) differences in the pneumatic properties between adjacent subsystems, (3) similarities in the matrix and fracture characteristics of individual subsystems, (4) similarities in the insitu pressure responses to atmospheric pressure changes, and (5) chemical and isotopic data that reflect gas-circulation patterns and residence histories that differ significantly. Because of faulting and associated near-field fracturing, extreme heterogeneity may be present locally within any individual subsystem.

The upper flow system is developed in the $\mathrm{TCW}$ hydrogeologic unit that forms the hillslopes and ridges bordering Pagany Wash and Drill Hole Wash and underlies much of the alluvial fill within these washes. In the western part of the study area, this unit has been eroded away in the deeply incised washes and is not present beneath the alluvial fill of these washes.

Because of this subsystem's topographic position and direct exposure to the atmosphere throughout most of the study area, gas flow within the TCw can be expected to be strongly influenced by topographic, wind, and barometric pumping effects. Although chemical data from this unit are not available, gas exchange with the atmosphere probably occurs very rapidly, and residence times of gas within this unit can be expected to be relatively short. One-dimensional diffusivity analyses using in-situ pressure- 
monitoring data indicate that the vertical permeability to air for rock units comprising this subsystem ranges between about $1.0 \times 10^{-12} \mathrm{~m}^{2}$ and $10.0 \times 10^{-12} \mathrm{~m}^{2}$. Airinjection tests indicate that the bulk permeability of these rocks may be as much as an order of magnitude greater, ranging from about $0.3 \times 10^{-12} \mathrm{~m}^{2}$ to as high as $50 \times 10^{-12} \mathrm{~m}^{2}$. The difference in these permeability estimates is attributed to anisotropy within the TCw. Because of the geometry of the tests, the values obtained from the air-injection tests are much more representative of horizontal permeability than the values obtained from analysis of the in-situ borehole measurements. A horizontal to vertical permeability ratio on the order of 10:1 can be inferred from differences in the range of permeabilities obtained from the two different approaches used to estimate permeabilities. Spectral analyses of the subsurface synoptic pressure signal also indicated very rapid transmission of atmospheric pressure changes throughout the $\mathrm{TCw}$. In many cases, it was not possible to distinguish the atmospheric signal from the downhole pressure signal. The matrix porosity of the $\mathrm{TCw}$ is generally less than about 0.1 , and saturation is on the order of 0.7 to 0.9 ; thus, the air-filled porosity of these rocks is very low, generally less than about 0.5 . The pneumatic diffusivity of this subsystem is very high because of high fracture permeability and low air-filled porosity.

As a pneumatic subsystem, the PTn acts as an impeding layer to restrict gas flow between the $\mathrm{TCw}$ and TSw. Most of the atmospheric-pressure signal attenuation and phase lagging observed in the monitored boreholes occurs across this subsystem.

Included in this subsystem are the nonwelded, crystalrich, vitric units (Tptrv2, 3) of the Topopah Spring Tuff, the Yucca Mountain and Pah Canyon Tuffs and associated bedded tuffs, and the nonwelded, crystalpoor, vitric units (Tpcpv1,2) of the Tiva Canyon Tuff. The vitric units exhibit high matrix porosity $(0.3$ to $0.5)$ and are sparsely fractured. The other nonwelded and bedded units of the PTn also exhibit very high matrix porosities $(0.3$ to 0.6$)$ with saturations that are on the order of 0.3 to as high as 0.95 (UZ-14, Tpy); hence, the air-filled porosities of the PTn tend to be very high, 0.15 to 0.35 . Diffusivity analyses of the in-situ pressure-monitoring data indicate that the permeabilities of the rocks that form the PTn range from about $0.1 \times 10^{-12} \mathrm{~m}^{2}$ to $4.0 \times 10^{-12} \mathrm{~m}^{2}$ (one value exceeded $8.0 \times 10^{-12} \mathrm{~m}^{2}$ ). Air-injection test results indicate a similar range in permeabilities for these units $-0.1 \times 10^{-12} \mathrm{~m}^{2}$ to $3.0 \times 10^{-12} \mathrm{~m}^{2}$. The pneumatic diffusivity of the PTn tends to be moderately low because of very high air-filled porosities and low to moderate permeabilities. The thickness of the PTn varies from 38 to $84 \mathrm{~m}$ in monitored boreholes within the study area. The PTn directly underlies alluvial fill in the upper washes of the western part of the study area where the TCw has been eroded away. Saturations of individual units within the PTn tend to be higher beneath alluvial fill where the TCw is thin or has been eroded away. Variations in the thickness of this unit alone do not appear sufficient to account for differences in attenuation and phase lagging of the atmospheric pressure signal observed in the monitored boreholes. At many monitoring sites, signal attenuation and lagging appear to be controlled by one or both of the relatively thin vitric units of the PTn. Suppression of the atmospheric pressure signal across the PTn also appears to increase from east to west, paralleling a trend of increasing saturation within this unit and decreasing thickness of the TCw beneath Drill Hole Wash. The impeding characteristics of the PTn, especially the nonwelded vitric units, thus appear to be strongly influenced by saturation. Locally, fractures in the porous nonwelded and bedded units of the PTn appear to be open to gas flow, especially in areas immediately adjacent to known faults (UZ\#4 and UZ\#5).

The densely welded vitric and densely welded lithophysal and nonlithophysal units of the Topopah Spring Tuff form the third pneumatic subsystem. The crystal-poor vitric unit of the Topopah Spring Tuff (Tptpv3) forms the base of this subsystem and locally forms a horizon on which perched water accumulates. The Topopah Spring Tuff is not exposed at the land surface within the North Ramp study area, but it is exposed along the Solitario Canyon Fault escarp-. ment immediately west of the study area. Fracture densities of the nonlithophysal units tend to be very high. Although there is considerable uncertainty concerning fracture densities of the lithophysal units because of missing core, the fracture densities of the lithophysal units appear to be lower than for the nonlithophysal units. The downhole, synoptic pressure responses of the nonlithophysal units are nearly indistinguishable from those of the lithophysal units. In-situ pressure-monitoring data indicate very little attenuation and phase lagging of the atmosphericpressure signal throughout the TSw subsystem once the pressure signal is transmitted across the overlying PTn impeding layer. Mean permeabilities derived 
from air-injection tests range between $0.4 \times 10^{-12} \mathrm{~m}^{2}$ and $2.1 \times 10^{-12} \mathrm{~m}^{2}$. Results of the pneumatic diffusivity analyses of the in-situ monitoring data indicate permeabilities that range between $1.0 \times 10^{-12} \mathrm{~m}^{2}$ and $50 \times 10^{-12} \mathrm{~m}^{2}$. The lower part of this range in permeabilities is derived from the air-injection tests and is attributed to test geometry and the influence of horizontal permeability.

Interference effects from excavation of the ESF North Ramp indicate a vertical to horizontal anisotropy ratio that is at least 3:1 and may be as high as 10:1. Gas flow within the TSw subsystem occurs primarily along vertically oriented fracture planes. The matrix porosities of these units are generally less than about 0.1 , with saturations ranging from 0.5 to 0.9 ; thus, the pneumatic diffusivity of the TSw is very high. Evidence for extreme heterogeneity and anisotropy within this subsystem is present in the in-situ borehole-monitoring records following the onset of interference to the ambient pneumatic system from excavation of the North Ramp tunnel. The most striking example of this was when the TBM penetrated a north-trending fault in the crystal-rich nonlithophysal unit of the Topopah Spring Tuff northwest of NRG\#4. Interference effects were transmitted along this fault structure and detected at UZ\#4 and UZ\#5, a distance of about $400 \mathrm{~m}$. Another example of extreme heterogeneity was when the TBM penetrated the northern boundary of the Drill Hole Wash fault system. Pneumatic-interference effects were propagated along the alignment of this structure and detected at NRG-6, which is $551 \mathrm{~m}$ southeast of the point where the TBM penetrated the fault. Although the pneumatic diffusivity of the TSw is very high, ${ }^{14} \mathrm{C}$ data indicate limited communication of this system with the atmosphere. Carbon-14 activity decreases nearly linearly with depth and is less than $20 \mathrm{pmc}$ at the base of the Topopah Spring Tuff. Fault structures are open in the TSw but apparently have limited direct communication with the atmosphere because of the impeding characteristics of the overlying PTn.

The nonwelded vitric and zeolitized rocks of the Calico Hills Formation form the lowermost pneumatic subsystem within the study area. Included in this subsystem are the nonwelded vitric units of the Topopah Spring Tuff (Tptpv1, 2), the pre-Topopah Spring bedded tuff (Tpbt1), and the pre-Calico Hills Formation bedded tuff (Tacbt1). Very few data are available to characterize the pneumatic properties of this subsystem, which is overlain by the very low- porosity and low-permeability, densely welded, vitric unit (Tptpv3) of the Topopah Spring Tuff. Locally, this unit is saturated, and perched water is present at the contact of this unit with the overlying lower nonlithophysal unit of the Topopah Spring Tuff or in the bedded tuffs immediately below this densely welded vitric unit of the Topopah Spring Tuff. Pressure data from one monitoring station in the upper part of the Calico Hills Formation indicate that the synoptic pressure signal is not well developed in this unit, and most of the pressure signal appears to be seasonal in character. Core data indicate that matrix porosities are on the order of 0.35 , and saturations, for the most part, are between 0.95 and 1.0. Fracture densities of the Calico Hills Formation and underlying Prow Pass Tuff of the Crater Flat Group are very low (core recovery percentage is very high). Low fracture densities and low air-filled porosities indicate that the pneumatic diffusivity of the Calico Hills pneumatic subsystem is probably much lower than that of any of the other pneumatic subsystems in the study area.

\section{UNSATURATED ZONE AQUEOUS-PHASE (HYDROLOGIC) SYSTEM}

Fluid flow in the unsaturated zone and the properties that control fluid flow are presented in two major sections in this report. The results of studies designed to characterize the gaseous-phase system in the unsaturated zone have been described in the preceding major section of this report. This section describes the results of studies of the aqueous-phase, or hydrologic, system.

\section{Overview of the Hydrologic System}

A conceptual model of fluid flow in the unsaturated zone at Yucca Mountain was developed by the USGS in 1984 (Montazer and Wilson, 1984). The model was developed from very limited hydrologic data, primarily for the purpose of providing preliminary information with which to assess the viability of storing nuclear waste in the unsaturated zone and as a guide for future investigations. The model was developed from application of basic hydrologic principles and then-current understanding of the physics of multiphase fluid flow in layered, heterogeneous, fractured-rock formations. Using available data, 
conservative estimates of net infiltration, and the assumptions of a unit hydraulic gradient and steadystate flow, bounding calculations of flux within each major hydrogeologic unit were made. These calculations indicated that the vertical matrix-flux capacity of the porous and sparsely fractured rocks of the PTn $(0.1$ to $98.6 \mathrm{~mm} / \mathrm{yr}$ ) was much greater than the vertical matrix-to-matrix flux capacity of the underlying, lowporosity, densely welded, but intensely fractured rocks of the TSw $\left(1 \times 10^{-7}\right.$ to $\left.0.2 \mathrm{~mm} / \mathrm{yr}\right)$. Vertical flux through the Calico Hills Formation matrix was estimated to be limited to about $0.006 \mathrm{~mm} / \mathrm{yr}$.

In the 1984 conceptual model, redistribution of vertical flux in the PTn as downdip lateral flow within and/or above the upper contact of this unit with the overlying $\mathrm{TCw}$, with subsequent drainage into bounding structural features, was presented as the most likely mechanism to account for mass-balance deficits in the vertical matrix-flux profile. The lateral. flux capacity of the PTn was estimated to be in excess of $100 \mathrm{~mm} / \mathrm{yr}$. Dipping beds, permeability layering, and capillary-barrier effects were envisioned as the combined hydrogeologic features and hydrologic processes needed to promote lateral flow in the PTn. Thus, most of the flux through the PTn would find its way into the deeper subsurface along major structural pathways through downdip lateral flow, interception, and diversion. One-dimensional, vertical, matrix-tofracture flow between the PTn and the TSw was presumed to be limited because of the capillary-barrier retardation effects between the smaller pores of the high-porosity nonwelded tuff matrix overlying the TSw and the larger fracture apertures of the TSw in contact with this nonwelded facies. The extent of deep fracture flow within the TSw also was presumed to be limited because of imbibition of fracture water into the surrounding matrix. A maximum upper limit of $1 \mathrm{~mm} / \mathrm{yr}$ was proposed for saturated matrix flux in the TSw under an assumed net infiltration rate of $4.5 \mathrm{~mm} / \mathrm{yr}$. Net infiltration in excess of the $1 \mathrm{~mm} / \mathrm{yr}$ estimated to flow through the TSw matrix was presumed to move laterally either within or directly above the PTn towards structural features, which would then intercept and transmit this flow downward to the base of the TSw. Here, the water either would enter the Calico Hills Formation along the same but less permeable structural flow paths or would accumulate as perched water and then move downward into the Calico Hills Formation as matrix percolation. The conceptual model proposed in 1984 heavily empha- sized lateral flow in the PTn, with interception and transmission of this flow along major structural pathways.

Investigations conducted since 1984 tend to support many of the key attributes of the 1984 conceptual model for unsaturated flow at Yucca Mountain (for example, low net infiltration as a percentage of annual precipitation, rapid infiltration into the fractures of the TCw, unit hydraulic gradients within the TSw and PTn units, and perched water at the base of the TSw). Direct evidence to document extensive lateral flow in the PTn and diversion of flow into structural pathways, however, has been elusive. Nevertheless, there is very strong evidence for significant fracture flow within the PTn locally where secondary fracture permeability, in association with mapped faults, is evident. Fracture flow also is evident below the PTn in the highly fractured rocks of the TSw. This flow mechanism was not strongly emphasized in the 1984 conceptual model. For example, perched water has been encountered at the base of the Topopah Spring Tuff or in the top of the nonwelded to partially welded tuffs of the Calico Hills Formation in every dry-drilled borehole drilled deep enough to penetrate the Topopah Spring-Calico Hills contact in the North Ramp study area. Chemical data (see section of this report titled Chemistry and Isotopic Content of Perched Water) indicate that the major-ion chemistry of this perched water is similar to that of the Calico Hills Formation pore water. The chloride concentration of the perched water, however, is much lower than the chloride concentration of pore water from the PTn units and the TSw, indicating very little contribution of water from the matrix of the overlying rocks. Stableisotope data for oxygen- 18 and deuterium are consistent with rapid, fracture infiltration with little or no evaporation. Furthermore, these data and estimates of residence times derived from carbon-14 data indicate a post-glacial age for the perched water, an age that is much younger than any that could be derived using a matrix-to-matrix percolation model. Also, the strontium-87 signature of the perched water is similar to that for surficial pedogenic calcite and calcite fracture fillings in the Yucca Mountain area but is dissimilar to that of the matrix of the TSw. These data indicate that perched water probably attained its isotopic signature from dissolution of shallow surficial calcite during infiltration or during downward percolation through fractures. 
Evidence for rapid, shallow, fracture flow through the TCw and PTn also is found in elevated tritium concentrations of pore water (see section of this report titled Aqueous-Phase Chemistry) at several locations. Tritium profiles across these hydrogeologic units portray pore-water age inversions with older water overlying younger water. At one location, these age inversions were observed down to a depth of about $75 \mathrm{~m}$, just below the PTn-TSw contact. Elevated tritium concentrations at relatively deep depths, and their associated age-inversion profiles, indicate rapid infiltration through fractures in the TCW and Paintbrush nonwelded hydrogeologic unit (PTn). Given the short half-life of tritium (12.5 years), this infiltration must have occurred within at least the last 40 years. In-situ measurements of water potential (see section of this report titled In-Situ Water-Potential Measurements) and core measurements of water potential and saturation (see section of this report titled Physical and Hydrologic Properties Determined from Analysis of Rock Cores) indicate a deep percolation environment that is generally conducive to sustaining deep fracture flow. Water potentials throughout most of the PTn and TSw are very high [greater than -0.3 megapascals (MPa)] and are nearly depth-invariant. Thus, the imbibition capacity of the densely welded rocks, at least near fractures, is very small because of low matrix permeabilities and low water-potential gradients across the fracture-matrix interface. Pneumatic data presented previously (see section of this report titled Unsaturated Zone Gaseous-Phase System) indicate that fracture permeabilities of the densely welded rocks are very high, several orders of magnitude greater than those of the host matrix. The pneumatic data also indicate that the fracture network is globally interconnected throughout the $\mathrm{TS} w$, thus providing a vertically interconnected system of openings to sustain downward liquid flow. Pneumatic data also indicate that fractures within the PTn, although sparse, also are conductive, especially in areas where a well-developed secondary fracture permeability is clearly associated with mapped fault structures. This finding is consistent with high tritium concentrations and age inversions that have been observed within the pore water of the PTn at several locations.

Within the study area, direct evidence for lateral flow within or immediately above the PTn is limited. What data are available only can be used to infer the possible presence of lateral flow in the PTn within geographically restricted areas, primarily channel environments. Although the 1984 conceptual model postulated significant capacity for lateral flow in the PTn matrix, in excess of $100 \mathrm{~mm} / \mathrm{yr}$, data available to date have not demonstrated large-scale lateral flow within this unit. Where data are available to infer lateral flow, it is not absolutely clear that fracture flow could not have produced the same result. Within the lower reach of Pagany Wash, temperature and waterpotential data from two closely spaced boreholes are cited as evidence for downward vertical flow accompanied by lateral spreading within the PTn to account for an apparent heat-flow deficit across the PTn-TSw contact (see section of this report titled Results of InSitu Hydrologic Monitoring in Boreholes). In the upper reach of Drill Hole Wash, gaseous-and aqueousphase ${ }^{14} \mathrm{C}$ isotope data, also from two closely spaced boreholes, are used to infer lateral flow in the PTn (see section of this report titled Evidence for Preferential Fracture Flow and Lateral Flow Within the Paintbrush Nonwelded Hydrogeologic Unit). In both cases where lateral flow is inferred, the boreholes are within or immediately adjacent to active channels and near faults that have been mapped on the surface. These fault associations make it difficult to unequivocally differentiate lateral matrix flow from fracture flow.

Although the issues of extensive lateral flow within the PTn and the effectiveness of structural pathways in intercepting and diverting this flow remain open (and elusive), there is a substantial body of evidence, presented and discussed in the sections that follow, to conclude that fracture flow is an important component of total flux within both the welded and nonwelded rocks of the unsaturated zone at Yucca Mountain.

\section{Characterization of the Hydrologic System}

In the sections that follow, results of studies designed to characterize the hydrologic system in the unsaturated zone are described. The major topics discussed are (1) physical and hydrologic properties determined from analysis of rock cores, (2) in-situ monitoring of water potential and temperature in boreholes, (3) aqueous-phase chemistry, and (4) occurrences of perched water. 


\section{Physical and Hydrologic Properties Determined from Analysis of Rock Cores}

Porosity, saturation, and water potential measured in core samples from boreholes SD-9 and UZ-14 are shown in figures 81 and 82 , respectively. Core measurements represent the physical properties and hydrologic conditions of the rock matrix at a point. Measurements of properties on core samples that are approximately 5 to $8 \mathrm{~cm}$ in diameter and 5 to $10 \mathrm{~cm}$ in length do not incorporate the larger scale features of the rock units represented by large lithophysal cavities, fractures, or broken or brecciated zones. These physical features follow deterministic trends because of the depositional and cooling history of the rocks (Rautman and Flint, 1992), and if an adequate number of samples have been collected, the large-scale character of the formations can be reasonably represented (Flint and others, 1996), especially in a steady-state system. Moisture conditions in a transient, unsaturated system are not as well represented. Transience is shown to be evident at Yucca Mountain in the shallow rocks of the TCw and the PTn, where long-term and short-term climatic cycles (Gauthier and Wilson, 1994; Hevesi and Flint, in press) have a greater influence on the wetting and drying of the rocks than in the deeper hydrogeologic units. This is supported by measured changes in water content (Flint and Flint, 1995) and young isotopic ages of water within the TCw and PTn (Fabryka-Martin and others, 1996). In an unsaturated system, near-saturated conditions must exist to initiate flow into fractures; otherwise, flow will be through the matrix, which is described by the core-scale measurements. The fluctuating upper boundary conditions contribute to temporary high saturations in the shallow part of the unsaturated zone (Flint and Flint, 1995), which results in the periodic transmission of water through faults and fractures (Fabryka-Martin and others, 1996), therefore bypassing matrix blocks. Core-scale measurements of these rocks represent moisture conditions of the matrix only and may or may not reflect larger scale hydrologic conditions. In a steadystate, no-flow system in equilibrium with the water table, the gradient of total hydraulic potential (which is the sum of the water potential and the gravitational potential) within the unsaturated zone is zero. Under these conditions, the numerical value of water potential is equal to the elevation above the water table but opposite in sign when both water potential and eleva- tion are expressed in consistent units. In the absence of evaporation at depth, the water potentials in no-flow equilibrium with the water table (straight lines on water-potential profiles, figs. 81 and 82) represent an effective lower bound for water-potential values at any given depth. Measured water-potential values below this lower bound probably indicate core samples in which the in-situ moisture conditions have been altered during drilling or sample handling. However, these values probably do not represent actual field conditions.

Drilling and sample handling can, to varying degrees, reduce the saturation of core samples so that they do not represent true onsite conditions. Because of the nonlinear relation of water potential with water content, loss of water may be accentuated in the measurement of water potential because small changes in water content may translate into large changes in water potential for a particular rock type. Samples from boreholes NRG-6 and NRG-7a (fig. 83) were inappropriately packaged at the site; recommended methods for preservation of onsite moisture conditions were not followed. Consequently, NRG-6 and NRG-7a core samples have variably reduced saturations compared to those estimated based on water potential and porosity, as shown in figure 83 . Assuming a constant water potential with depth of $-0.25 \mathrm{MPa}$, samples with low porosity have a greater reduction in saturation than samples with high porosity, with a similar volume of water loss due to evaporation from inadequate sample handling.

In order to calculate water potential [or saturation, presented in this report as the value determined using standard oven-drying methods (Flint and others, 1996)] from water content, the relation between the two must be determined. The resulting moistureretention curve describes how tightly water is held within the rock pores at a given water content and can be determined by laboratory measurements of water content and water potential. Water potentials of core samples were measured in the laboratory at various saturations, beginning with a saturated sample and successively desaturating it to produce desorption curves, and allowing the sample sufficient time to redistribute moisture at each saturation (Flint and others, 1996). Desorption of the sample is an upper bound and represents the most water the sample can hold at each water potential. In the field, rocks alternately become wet and dry, and the relation becomes hysteretic. Therefore, field measurements of 


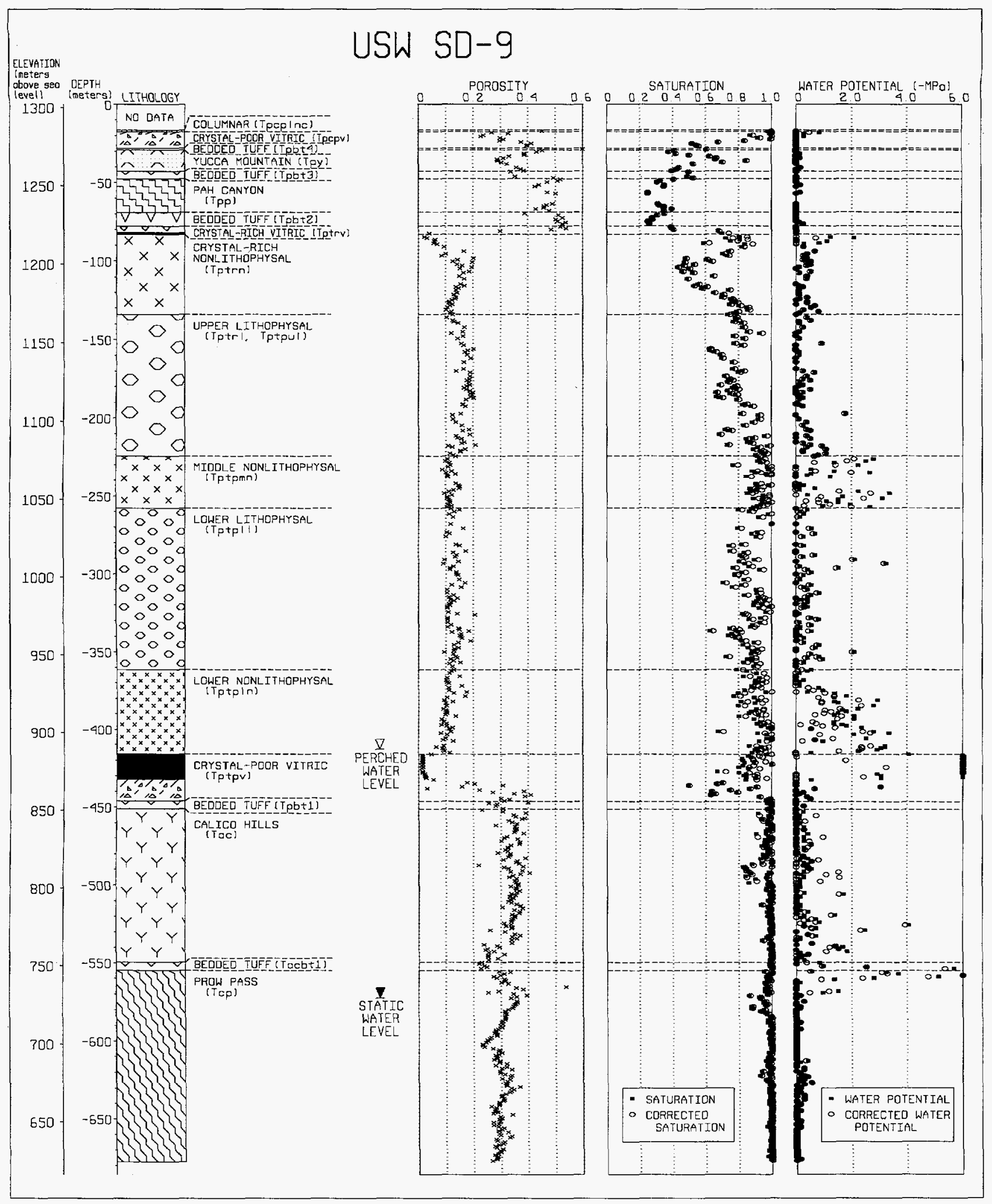

Figure 81. Porosity, saturation, and water-potential data for borehole USW SD-9. Open circles represent corrected saturation and water potentials to account for water losses during drilling and handling. The theoretical no-flow water-potential profile, referenced to the water table, is shown with the water-potential data. 


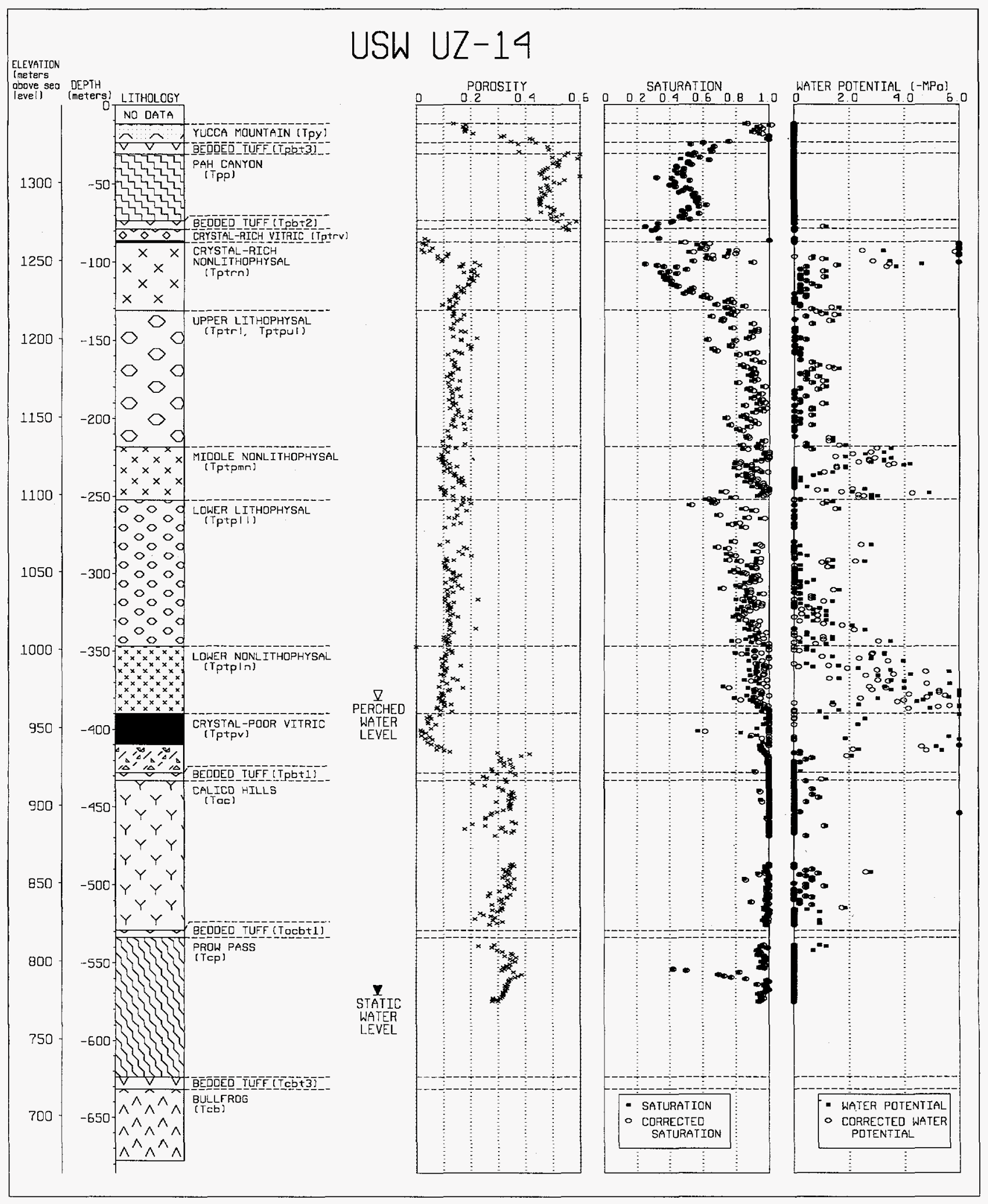

Figure 82. Porosity, saturation, and water-potential data for borehole USW UZ-14. Open circles represent corrected saturation and water potentials to account for water losses during drilling and handling. The theoretical no-flow waterpotential profile, referenced to the water table, is shown with the water-potential data. 

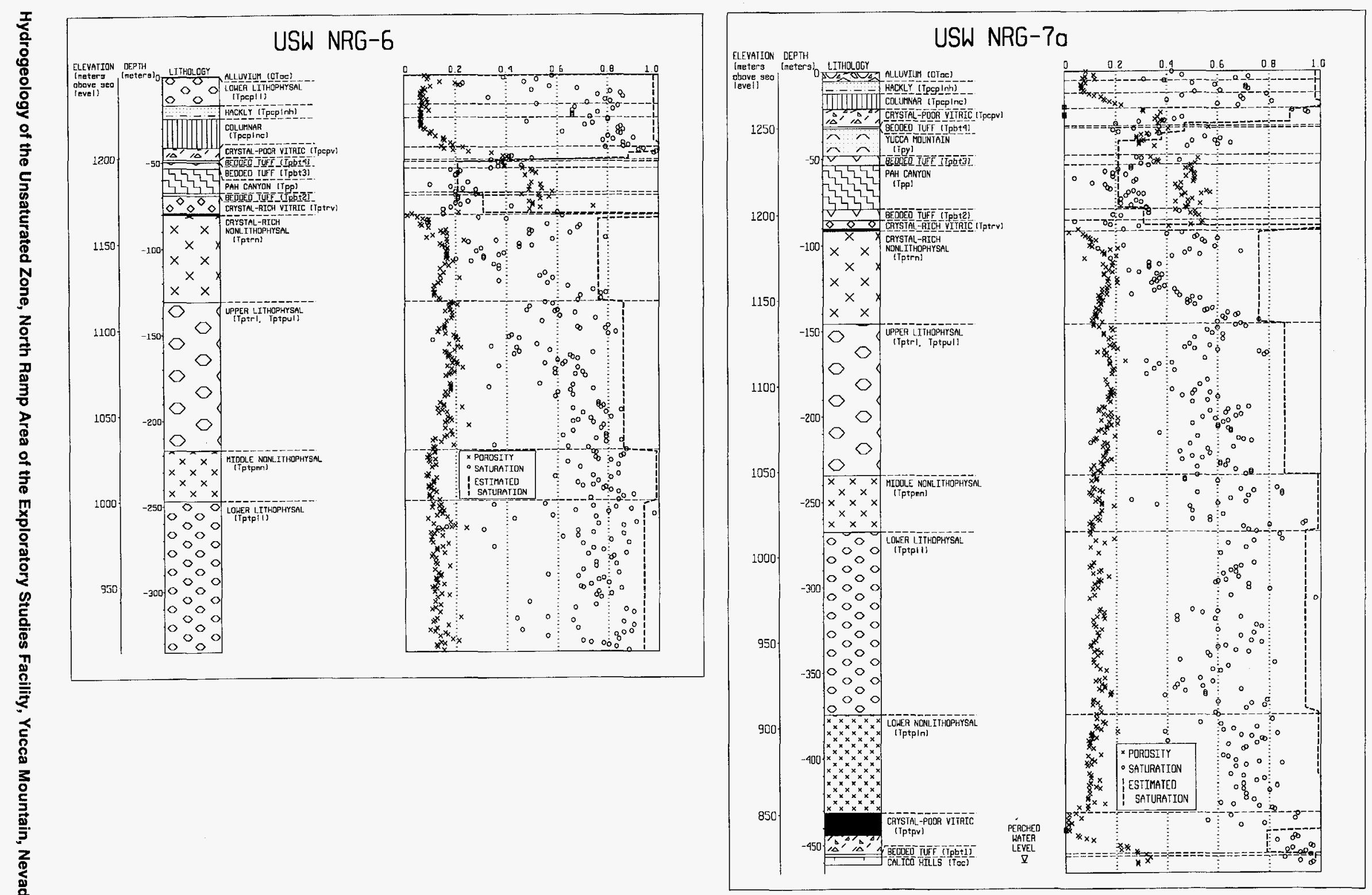

Figure 83. Saturation and porosity with depth for boreholes USW NRG-6 and USW NRG-7a. 
saturation commonly will be lower than laboratory measurements at a given water potential because of entrapped air, particularly for rocks with large pores that are relatively shallow and are influenced by transient infiltration pulses.

Examples of laboratory moisture-retention data and models fit to the data (van Genuchten, 1980) are shown in figure 84 for the (A) pre-Yucca Mountain Tuff bedded tuff (Tpbt3), (B) upper lithophysal unit of the Topopah Spring Tuff (Tptpul), (C) middle nonlithophysal unit of the Topopah Spring Tuff (Tptpmn), and (D) basal vitrophyre of the Topopah Spring Tuff (Tptpv3). Included in each figure is the model fit to the measured data with upper and lower estimates of the error about the model fit, calculated as plus or minus twice the standard error of the van Genuchten model parameters, alpha and $\mathrm{n}$. The resolution of the instrument used to collect the water-potential data is \pm 10.1 percent relative humidity over the entire range of the instrument, which is 100 percent $(0 \pm 0.1 \mathrm{MPa})$ to 11 percent (about $-300 \mathrm{MPa} \pm 3 \mathrm{MPa}$ ). An absolute error using the resolution of the instrument was used to calculate an error in water potential for the range of the instrument. This error in water potential was added to and subtracted from each data point to produce two new data sets, and new models were fit to the data sets. These models and the errors estimated for the model fit to the data are also included in each figure.

The model functions are used to calculate one parameter from the other. The curves (fig. 84) differ primarily due to degree of welding, which is notable when the curve for the bedded tuff (Tpbt 3 ) is compared to those of the welded tuffs (Tptpul, Tptpmn, and Tptpv3). The bedded tuff has an airentry pressure of greater than $-0.1 \mathrm{MPa}$ ( 1 bar), which means that the largest pores drain at a relatively high water potential (very low matric suction). The airentry pressures for the welded rocks range from approximately $-0.2 \mathrm{MPa}$ ( 2 bars) for the Tptpul to approximately $-8 \mathrm{MPa}$ ( 80 bars) for the Tptpv3. The very low air-entry pressure for the Tptpv 3 indicates that the largest pores are extremely small and require a very large matric suction, or a very low water potential, before they will drain. The saturation at which the curve becomes asymptotic in the low saturation range is approximately the residual saturation, which is related to the abundance of very small pores that retain water at approximately 60 percent relative humidity, or $-70 \mathrm{MPa}$. The wet end of the curve is the most impor- tant, however, because most of the rocks from the unsaturated zone are high in saturation, and this part of the curve describes how small changes in saturation will affect the water potential. For example, a reduction in saturation of the bedded tuff from 1.0 to 0.95 will result in a decrease in water potential of less than $0.1 \mathrm{MPa}(0$ to $-0.02 \mathrm{MPa})$, while the same reduction in saturation of the Tptpmn will result in a decrease in water potential from 0 to $-0.6 \mathrm{MPa}$. This phenomenon is significant in flow modeling, as well as in the interpretation of laboratory measurements of water potential, whether from moisture-retention samples or from field samples. Loss of water from field samples due to drilling, packaging, and processing will affect the error in the measurement of water potential on rocks with very small pores (welded tuffs) more than those with larger pores and higher porosity (bedded tuffs).

Results of an analysis to characterize the errors imposed on saturation and water potential of core samples from borehole SD-9 due to drilling and handling are presented in table 15. Samples of 2.5-cm-diameter core plugs representing hydrogeologic units at Yucca Mountain were vacuum-saturated and allowed to evaporate under ambient laboratory conditions on a top-loading balance connected to a computer from which weight readings were recorded every 10 seconds. These data were used to generate evaporation curves over time for all rock types. Water loss was calculated as the percentage of the total volume of water within the pores that evaporated over time. This calculation could be used to correct water loss from borehole samples of various sizes and initial water contents. Using drilling data from SD-9 that recorded the rate of penetration with depth, the amount of time that each rock type was exposed to drilling air was calculated. It was assumed that samples were exposed in the trailer during packaging for an average of 5 minutes and that it took 30 seconds to process each sample in the laboratory to obtain initial water contents. These total times for evaporation are shown for each hydrogeologic unit in table 15.

To correct each sample for error due to evaporation, it was assumed that evaporation was a function of sample size and initial volume of water in the sample. The total volume of water initially in each sample was calculated, and the appropriate percentage of water evaporated was taken from the evaporation curve for the time that the sample depth was exposed to drilling air and sample handling (table 15). This was done for each sample to determine the amount of water to be 
A)

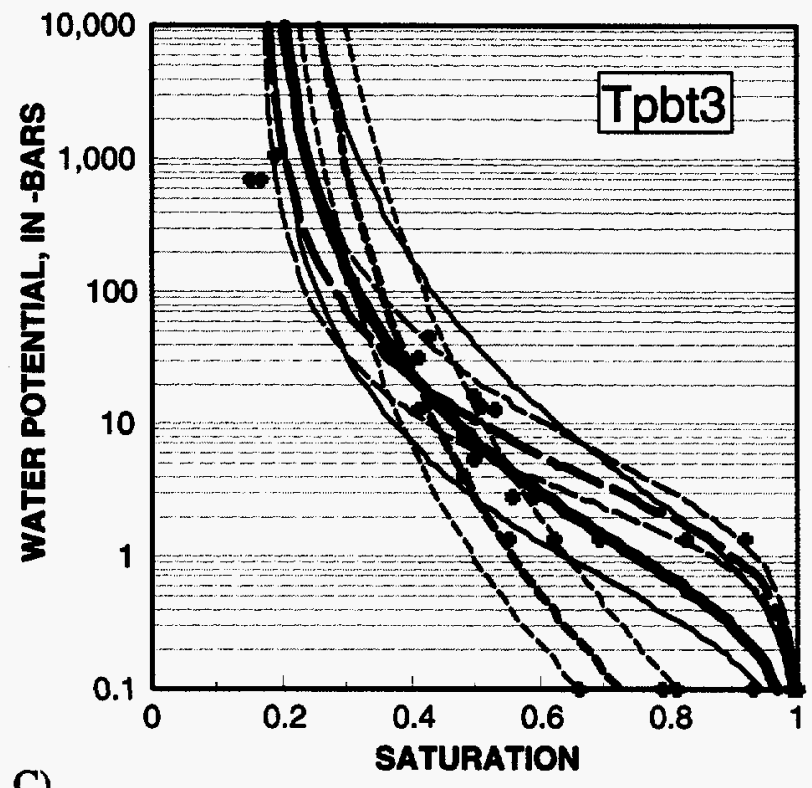

C)

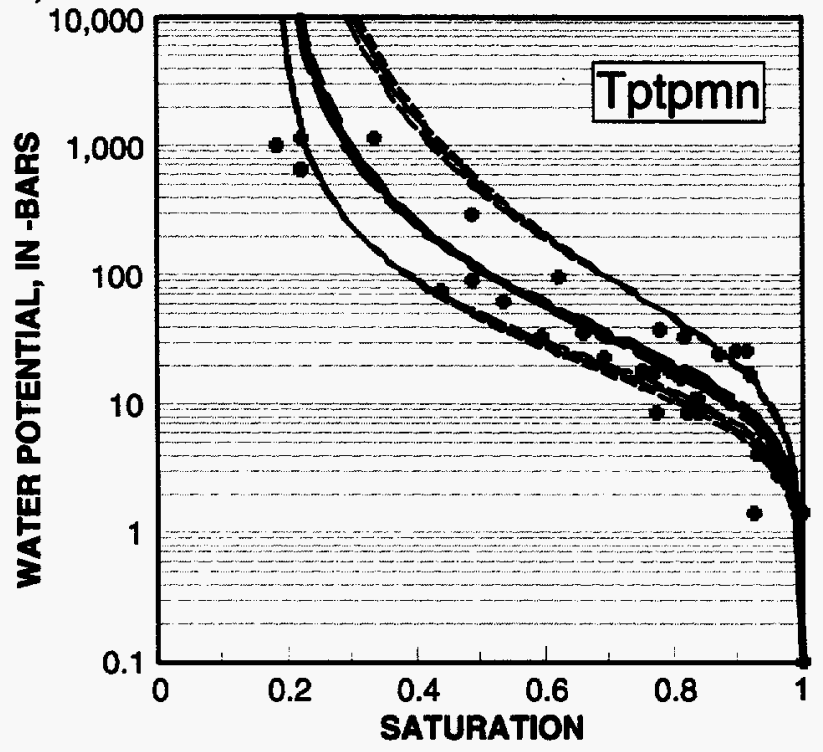

B)

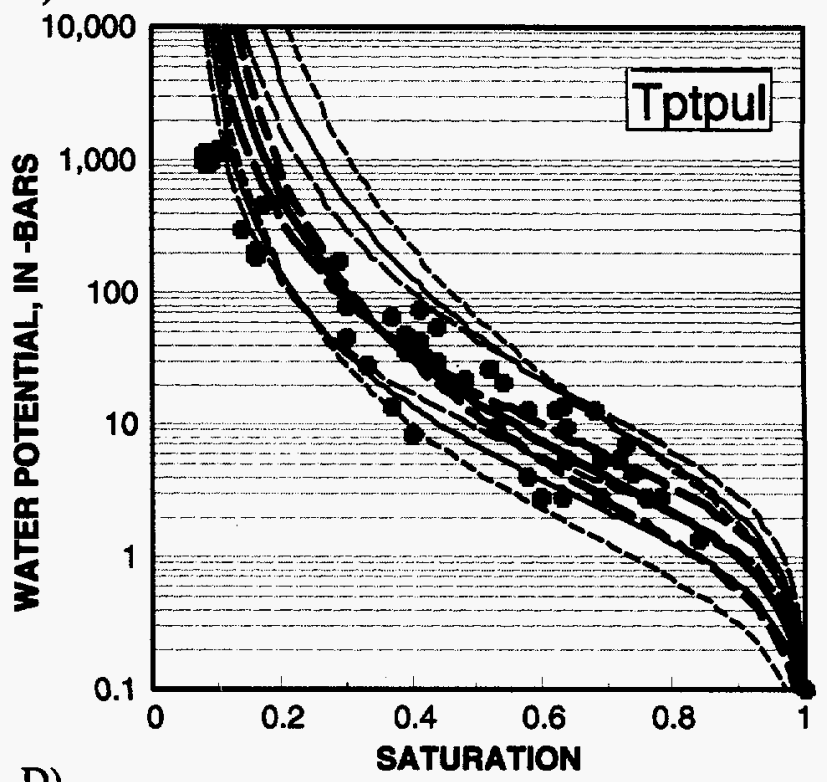

D)

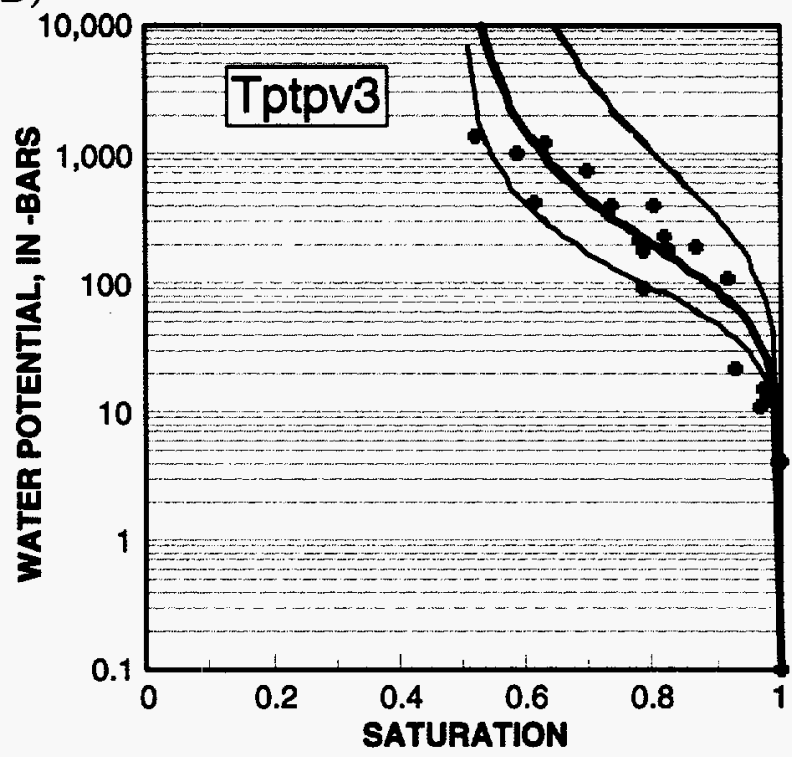

\section{EXPLANATION}

MODEL FIT TO MEASURED DATA - Model is bold line, plus or minus error estimates are lighter lines

MODEL FIT TO DATA SET CALCULATED BY AIDDING THE INSTRUMENT RESOLUTION ERROR TO THE MEASURED DATA - Model is bold line, plus or minus error estimates are lighter lines

MODEL FIT TO DATA SET CALCULATED BY SUBTRACTING THE INSTRUMENT RESOLUTION ERROR FROM THE MEASURED DATA - Model is bold line, plus or minus error estimates are lighter lines

Figure 84. Moisture-retention curves from laboratory measurements of core for (A) pre-Yucca Mountain bedded tuff (Tpbt3), (B) upper lithophysal unit of the Topopah Spring Tuff (Tptpul), (C) middle nonlithophysal unit of the Topopah Spring Tuff (Tptpmn), and (D) basal vitrophyre of the Topopah Spring Tuff (Tptpv3). 
Table 15. Results from error analysis of drilling and sample-handling effects on saturation and water potential, moisture-retention curves, and instrument errors for samples from borehole SD-9

[Average lowest and highest water potential are estimates from moisture-retention curves; min, minutes]

\begin{tabular}{|c|c|c|c|c|c|c|c|}
\hline $\begin{array}{c}\text { Litho- } \\
\text { stratigraphic } \\
\text { unit } \\
\text { (see table 2) }\end{array}$ & $\begin{array}{c}\text { Evapo- } \\
\text { ration } \\
\text { time } \\
\text { (min) }\end{array}$ & $\begin{array}{l}\text { Volume } \\
\text { of water } \\
\text { evaporated } \\
\text { (percent) }\end{array}$ & $\begin{array}{c}\text { Average } \\
\text { saturation } \\
\text { correction }\end{array}$ & $\begin{array}{c}\text { Average } \\
\text { water- } \\
\text { potential } \\
\text { correction } \\
\text { (-MPa) }\end{array}$ & $\begin{array}{c}\text { Average } \\
\text { corrected } \\
\text { water } \\
\text { potential } \\
(-\mathrm{MPa})\end{array}$ & $\begin{array}{c}\text { Average } \\
\text { lowest } \\
\text { water } \\
\text { potential } \\
\text { (-MPa) }\end{array}$ & $\begin{array}{c}\text { Average } \\
\text { highest } \\
\text { water } \\
\text { potential } \\
(-\mathrm{MPa})\end{array}$ \\
\hline Tpcplnc & 6.1 & 0.02 & 0.02 & 0.39 & 0.01 & 5.75 & 0.35 \\
\hline Трсрv2,1 & 5.3 & 0.01 & 0.01 & 0.01 & 0.01 & 10.13 & 0.01 \\
\hline Tpbt4 & 5.0 & 0.01 & 0.01 & 0.01 & 0.01 & 1.32 & 0.02 \\
\hline Tpbt3 & 5.4 & 0.01 & 0.00 & 0.02 & 0.01 & 0.65 & 0.01 \\
\hline Tpp & 5.1 & 0.01 & 0.00 & 0.05 & 0.01 & 1.19 & 0.06 \\
\hline $\begin{array}{r}\text { Tpbt2 and } \\
\text { Tptrv3,2 }\end{array}$ & 5.0 & $0.0 \mathrm{I}$ & 0.00 & 0.02 & 0.04 & 3.82 & 0.02 \\
\hline Tptrv1 & 8.3 & 0.06 & 0.04 & 0.24 & 0.62 & 0.92 & 0.13 \\
\hline Tptrn & 5.7 & 0.02 & 0.01 & 0.02 & 0.31 & 0.21 & 0.01 \\
\hline $\begin{array}{l}\text { Tptrl and } \\
\text { Tptpul }\end{array}$ & 6.6 & 0.02 & 0.02 & 0.03 & 0.33 & 0.23 & 0.07 \\
\hline Tptpmn & 7.5 & 0.04 & 0.04 & 0.2 & 1.20 & 0.65 & 0.28 \\
\hline Tptpll & 7.2 & 0.03 & 0.03 & 0.08 & 0.33 & 0.41 & 0.16 \\
\hline Tptpln2 & 12.0 & 0.05 & 0.04 & 0.30 & 0.24 & 1.16 & 0.64 \\
\hline Tptpln1 & 8.3 & 0.05 & 0.07 & 0.48 & 1.50 & 1.99 & 1.35 \\
\hline Tptpv3 & 6.2 & 0.08 & 0.07 & 2.06 & 2.98 & 5.36 & 2.03 \\
\hline Tptpv2 & 7.5 & 0.01 & 0.01 & 0.01 & 0.01 & 0.21 & 0.01 \\
\hline $\begin{array}{l}\text { Tptpv1 and } \\
\text { Tpbtl }\end{array}$ & 6.4 & 0.01 & 0.01 & 0.13 & 0.30 & 0.14 & 0.07 \\
\hline $\mathrm{Tac}$ & 7.2 & 0.01 & 0.01 & 0.01 & 0.29 & 0.05 & 0.02 \\
\hline Tacbt & 7.8 & 0.01 & 0.02 & 0.20 & 0.67 & 0.38 & 0.19 \\
\hline Тсp4 & 6.1 & 0.01 & 0.01 & 0.48 & 1.55 & 4.05 & 3.50 \\
\hline Tcp3 & 6.0 & 0.01 & 0.01 & 0.01 & 0.05 & 0.01 & 0.01 \\
\hline Tcp2 & 6.1 & 0.01 & 0.01 & 0.01 & 0.02 & 0.02 & 0.01 \\
\hline Tcpl & 6.1 & 0.01 & 0.01 & 0.02 & 0.07 & 0.06 & 0.02 \\
\hline
\end{tabular}

added to the initial weight in order to correct the error in saturation. The moisture-retention function for each hydrogeologic unit was used to calculate the water potential from the initial saturation and the corrected saturation, and the difference between these values was then added to the measured water potential. The average corrections made for each hydrogeologic unit for saturation and water potential are also listed in table 15. The largest possible water-potential errors were calculated for all samples from SD-9 and included drilling and sample-handling damage and water-potential-calculation errors from the moistureretention measurement error plus curve-fit errors. The lowest water potential possible for a sample was calculated from the measured saturation by using the moisture-retention curve with the instrument error added and the model-fit error subtracted. The highest water potential possible for a sample was calculated from the corrected saturation based on evaporation estimates by using the moisture-retention curve with the instrument error subtracted and the model-fit error added. The mean values of these calculations, plus the average corrected water potential, for each rock type are also shown in table 15.

It can be seen that samples in the rock units with small porosity (Tptrv1, Tptpmn, Tptpln, and Tptpv3), for example, which also have small initial water volume, have the largest saturation error due to evaporation. Very little error was calculated for samples with high porosity and volumetric water content such as the PTn (Tpbt3, Tpp, and Tpbt2). The corrected water potential from corrected saturation is the largest 
for the Topopah Spring Tuff vitrophyre (Tptpv3), significant for the other low-porosity tuffs (Tptrvl, Tptpmn, Tptpln, Tacbt, and Tcp unit 4), and very small for high-porosity rocks. This correction introduces the largest errors and has a significant influence on the range of possible water potentials for those samples with initially low measured water potential and high air-entry pressures, such as the Tptpv3. The range in possible water potentials also is large, however, for those samples with low air-entry pressures that are also relatively low in saturation, such as Tpcpv2, Tpbt 4 , and Tpbt 2 . When the average corrected water potential is higher (wetter) than the estimated highest water potential for a rock type, such as shown for samples from the base of the TCw and the PTn, the field samples were higher in water potential than the moisture-retention curves could estimate, supporting the contention that these locations in the borehole are shallow and could be influenced by infiltration pulses that contribute to hysteretic effects not characterized in the moisture-retention curves. In some rock types, the average highest water potential is surprisingly high, especially in the Tptpln 1 and Tptpv3, which are expected to be somewhat wet due to their proximity to a perched-water reservoir where saturated conditions exist. These rock types are more sensitive to drilling or handling damage due to their moisture-retention characteristics. It is important to recognize that these analyses included possible sources of error that could be determined quantitatively from drilling records and laboratory experiments, but that a complete record of all possible handling errors is not achievable. The corrections were added to the saturation and waterpotential data for SD-9 and UZ-14 (figs. 81 and 82).

Porosity, particle density, water content, water potential, and moisture-retention characteristics were measured in the laboratory on borehole core samples by using the methodology described in Flint and others (1996) except for boreholes UZ\#4 and UZ\#5, which were processed according to the methods of Loskot and Hammermeister (1992). Although the data for UZ\#4 and UZ\#5 are scientifically valid, they are non- $Q$ because they were collected prior to implementation of the approved USGS YMP quality-assurance program. To illustrate general trends in the vertical distribution of properties from boreholes in various locations within the North Ramp area, porosity, water saturation, and water potential were presented for boreholes SD-9 (fig. 81) and UZ-14 (fig. 82). Particle density of core samples from SD-9 and UZ-14 is presented in figure 85 . Porosity and water saturation were presented for boreholes NRG-6 and NRG-7a (fig. 83) and are presented for UZ-N33, N34, N37, N38, UZ\#4, and UZ\#5 (figs. 86 through 88).

These figures illustrate the correlation of the physical properties of porosity and particle density with lithology and the corresponding large-scale variation in saturation with rock type and depth. The general trend in porosity is illustrated in boreholes SD-9 and UZ-14 (figs. 81 and 82) with a relatively low porosity in the welded rocks and an increase in the nonwelded rocks. A corresponding trend of particle density with lithology also is evident in these boreholes (fig. 85), in that particle density is consistently between 2.5 and $2.6 \mathrm{~g} / \mathrm{cm}^{3}$ for devitrified samples and typically between 2.1 and $2.4 \mathrm{~g} / \mathrm{cm}^{3}$ for vitric samples, with bedded tuffs as low $2.0 \mathrm{~g} / \mathrm{cm}^{3}$. The obvious transitional zones where properties change rapidly with depth are at the base of the Tiva Canyon Tuff and the top of the Topopah Spring Tuff. Saturation is less correlated to lithology; but in general, the saturation is relatively high at the surface of the borehole, decreases to 0.5 or less in the PTn, and gradually increases with depth in the Topopah Spring Tuff, until almost complete saturation exists in the nonwelded, zeolitized rocks below the Topopah Spring Tuff. NRG-6 and NRG-7a (fig. 83) show the same porosity trends, but the saturations are lower; this is likely due to sample handling, which was different for these boreholes than the others. Data from boreholes UZ-N33, N34, N37, N38, UZ\#4, and UZ\#5 (figs. 86 through 88) illustrate more detail in the base of the Tiva Canyon Tuff and the PTn. N33, N34, UZ\#4, and UZ\#5 show the porosity decrease in the middle of the Yucca Mountain Tuff (Tpy), where it becomes partially to moderately welded. A similar pattern is shown in the Pah Canyon Tuff in boreholes UZ\#4 and UZ\#5. N33, N37, N38, and UZ\#4 show high saturations in the crystal-poor, vitric base of the Tiva Canyon Tuff (Tpcpv2) above the rapid transitional increase in porosity into the PTn. A more detailed discussion of borehole saturations is presented in the section of this report titled Borehole Core Saturations.

Given the episodic nature of precipitation at Yucca Mountain, infiltration probably occurs as periodic inputs which, when averaged over time, result in net downward infiltration. Net downward infiltration at boreholes SD-9 and UZ-14 is indicated by departures of the measured water potentials from the no-flow water-potential lines in figures 81 and 82 . 

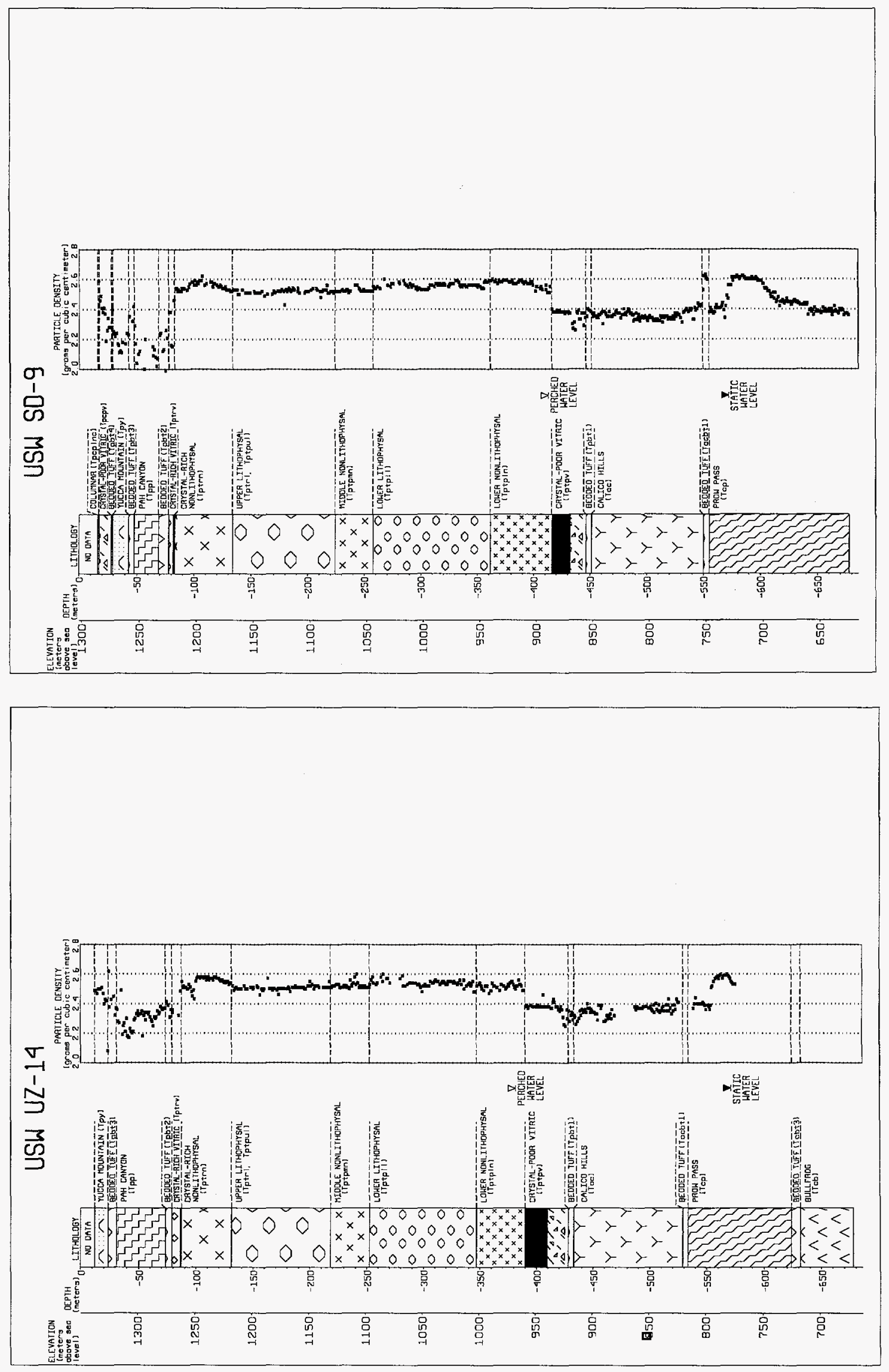


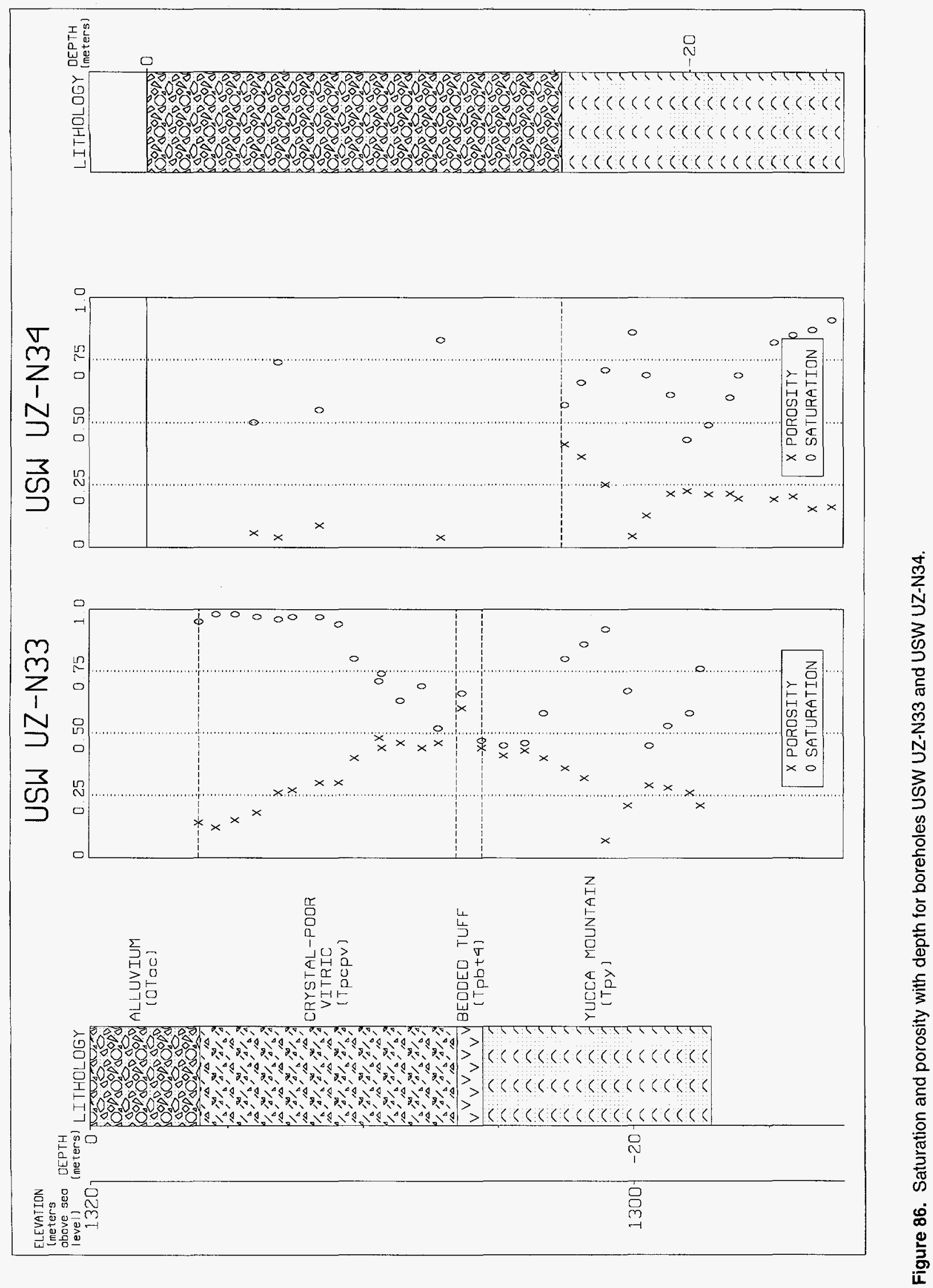




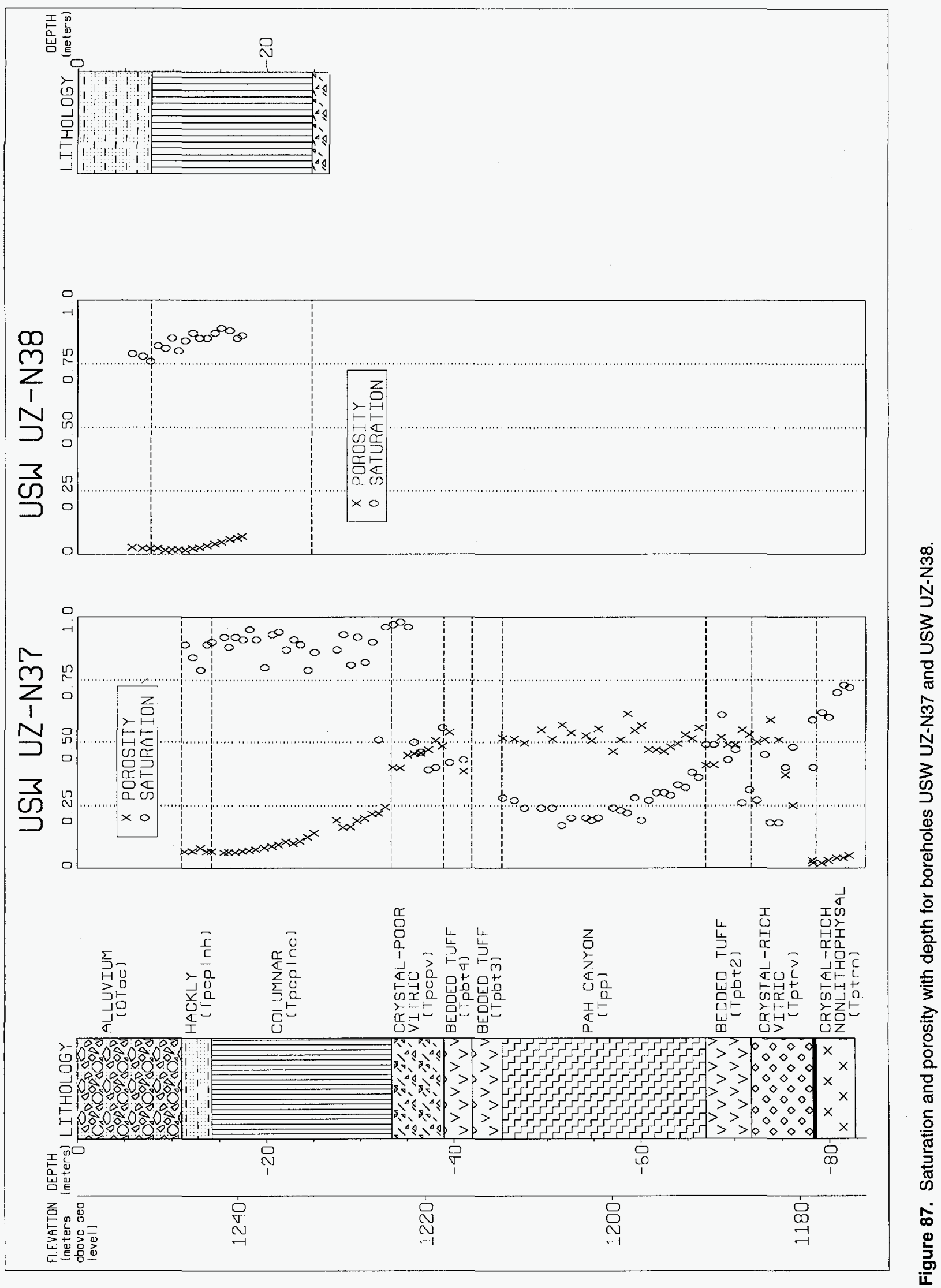




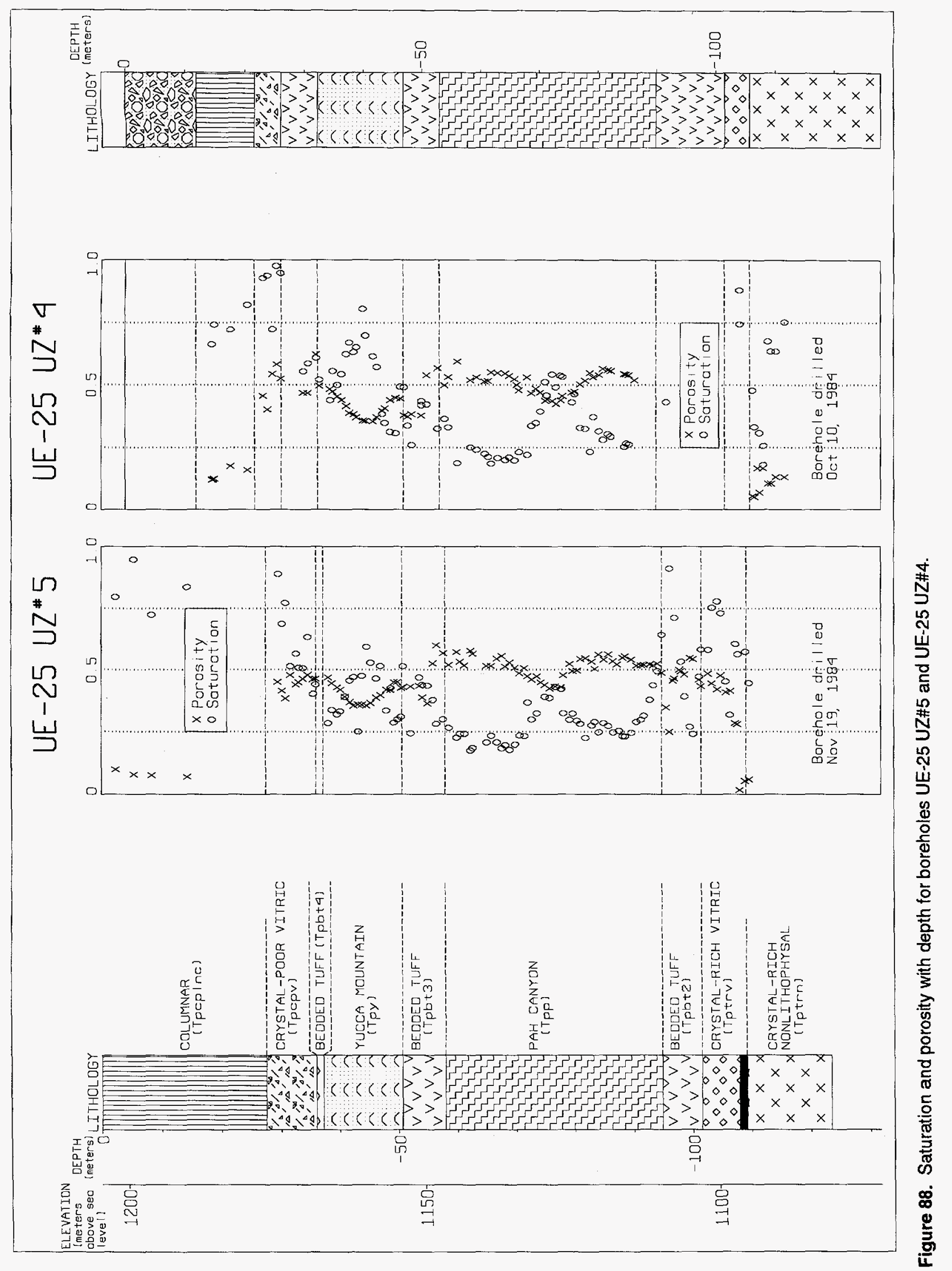


Also, measured water potentials are generally greater than the calculated no-flow water-potential profiles, even if the zero water-potential datums for these profiles are chosen to coincide with the top of the perched-water reservoirs rather than the water table.

\section{Correlation of Hydrologic Properties With Physical and Lithologic Properties}

Matrix hydrologic properties are strongly related to the welding, alteration, and depositional character of the lithostratigraphic units, as described in the section of this report titled Variations in Rock Types Within the Unsaturated Zone. The primary physical factor relating these characteristics is the porosity. Differences in the hydrologic character of the rocks are reflected in the porosity, which can be used to predict permeability, the van Genuchten moisture-retention curve-fit parameter alpha, thermal conductivity, and sorptivity calculated from imbibition experiments (Flint and others, 1996; Istok and others, 1994). Pore-size distribution, which is reflected in the measured moisture-retention curve of a rock, strongly controls the hydrologic character of the rock matrix of the unit. If the moisture-retention characteristics of any associated fractures also can be determined or inferred, the large-scale hydrologic character of the unit can be interpreted more readily. These physical features (along with the upper flux condition) strongly influence the saturations and conductivities and, therefore, the fluxes through the entire profile of rocks in Yucca Mountain. Perched water and lateral diversion are a function of the relative vertical positioning of the rock units with varying porosity, permeability, and moisture-retention characteristics.

In general, porosity can be related primarily to the welding of a rock, with the lowest porosity in the most densely welded rocks and the highest porosity in nonwelded and bedded rocks. Secondarily, porosity is related to alteration because altered minerals are formed or deposited in the pore channels and throats. Altered clay or zeolite zones change the porosity only slightly, but strongly influence the character of the moisture-retention curve and the permeability. Thus, in zones where there is zeolitization or clay alteration from glass, both of which are due to the long-term presence of water in vitric rocks, the rocks generally can maintain a large volume of water and hold it tightly with small pores or pore throats that also reduce the permeability. These zones generally are an important factor contributing to the presence of perched water. Secondary vapor-phase corrosion and/or mineralization can produce porosity profiles that are similar to welding transition zones, gradually increasing or decreasing in porosity and affecting the downward transmission of water. Finally, physical properties are related to the degree of crystallization. Densely welded, vitric rocks have extremely small pores and a unique moisture-retention curve

(L.E. Flint, U.S. Geological Survey, written commun., 1996), as well as commonly having microfractures that may transmit water under highly saturated conditions but tend to produce a permeability barrier. Some of these features can be recognized using the relation of water permeability to porosity.

Water permeability was measured on samples from all units in SD-9 (fig. 89) using the methodology described in Flint and others (1996). Samples in the PTn ranged in permeability from $8.0 \times 10^{-13}$ to $1.0 \times 10^{-15} \mathrm{~m}^{2}$. High permeabilities also are present in the nonwelded base of the Topopah Spring Tuff, as well as in the upper part of the Prow Pass, unit 3. Measurements are shown on a scatterplot of porosity and $\log$ of permeability (fig. 90). In general, high permeabilities are notable in the nonwelded units. Lower permeabilities are found in core from the welded units, and there is a relation between porosity and $\log$ permeability for all the samples represented by circles. Different rock types have characteristics that affect the hydrology of the rocks and are reflected in higher or lower permeabilities. These characteristics are due primarily to zeolites or altered clays as well as microfractures in densely welded vitrophyres. The samples containing zeolites or altered clays (represented by open diamonds in figure 90 ) had permeabilities that were lower in relation to their porosity than the unaltered nonwelded and welded samples. These samples are from the Calico Hills Tuff, the Prow Pass Tuff, and the moderately welded vitric base of the Tiva Canyon Tuff. The zeolites and clay minerals do not reduce the rock porosity but block the flow channels and throats, thus reducing the permeability. The vitric base of the Tiva Canyon (Tpcpv) shows a decline in permeability with decreasing porosity (which occurs with depth), but the slope more closely matches that of the zeolitized rocks, as the Tpcpv increases in altered clay content with depth, thus reducing the permeability relatively more than it reduces the porosity. The microfractures in the very low-porosity vitrophyres transmit water more readily than the pores and result in high permeability even though the porosity is very low. 


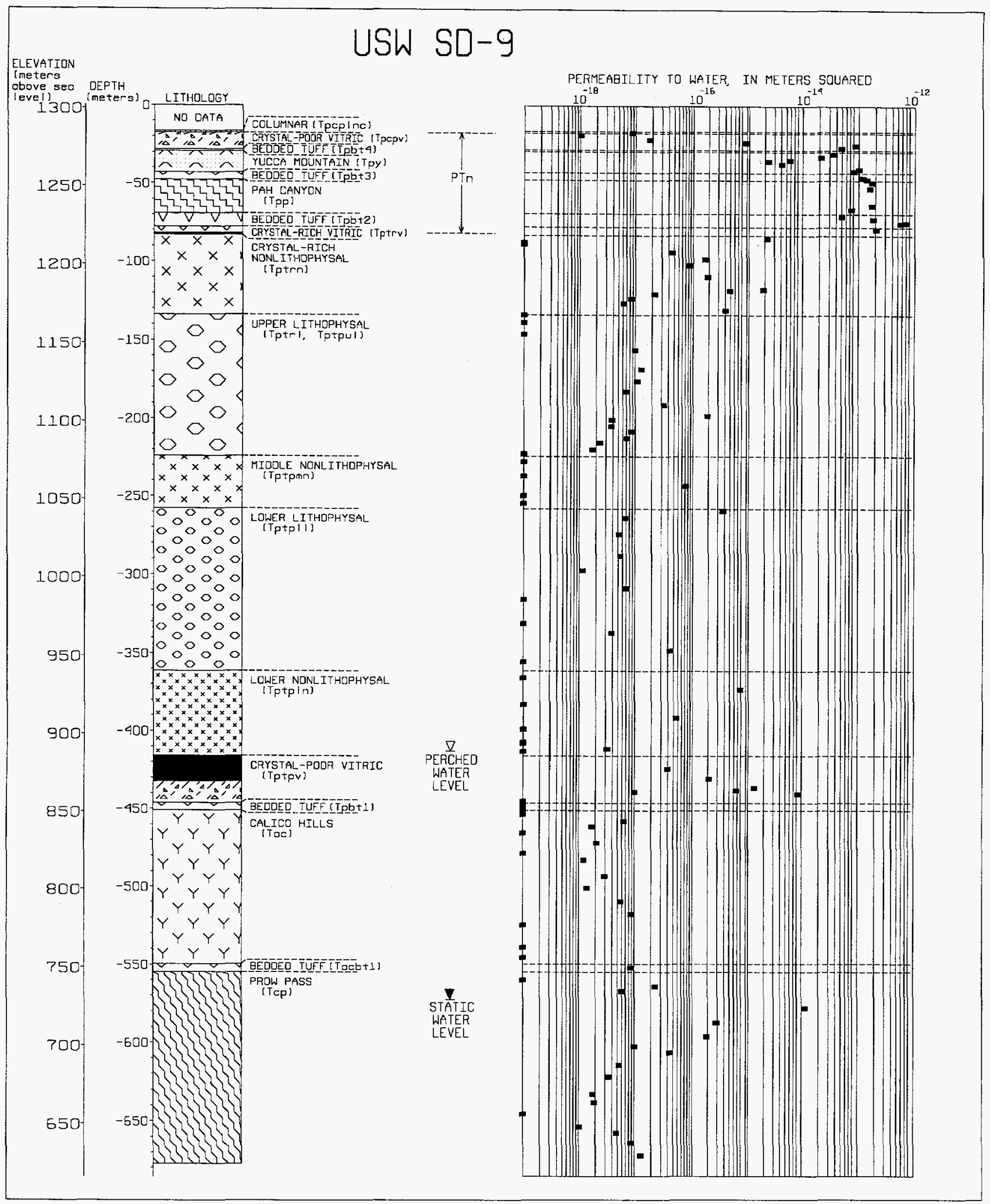

Figure 89. Water permeability with depth for borehole USW SD-9. 


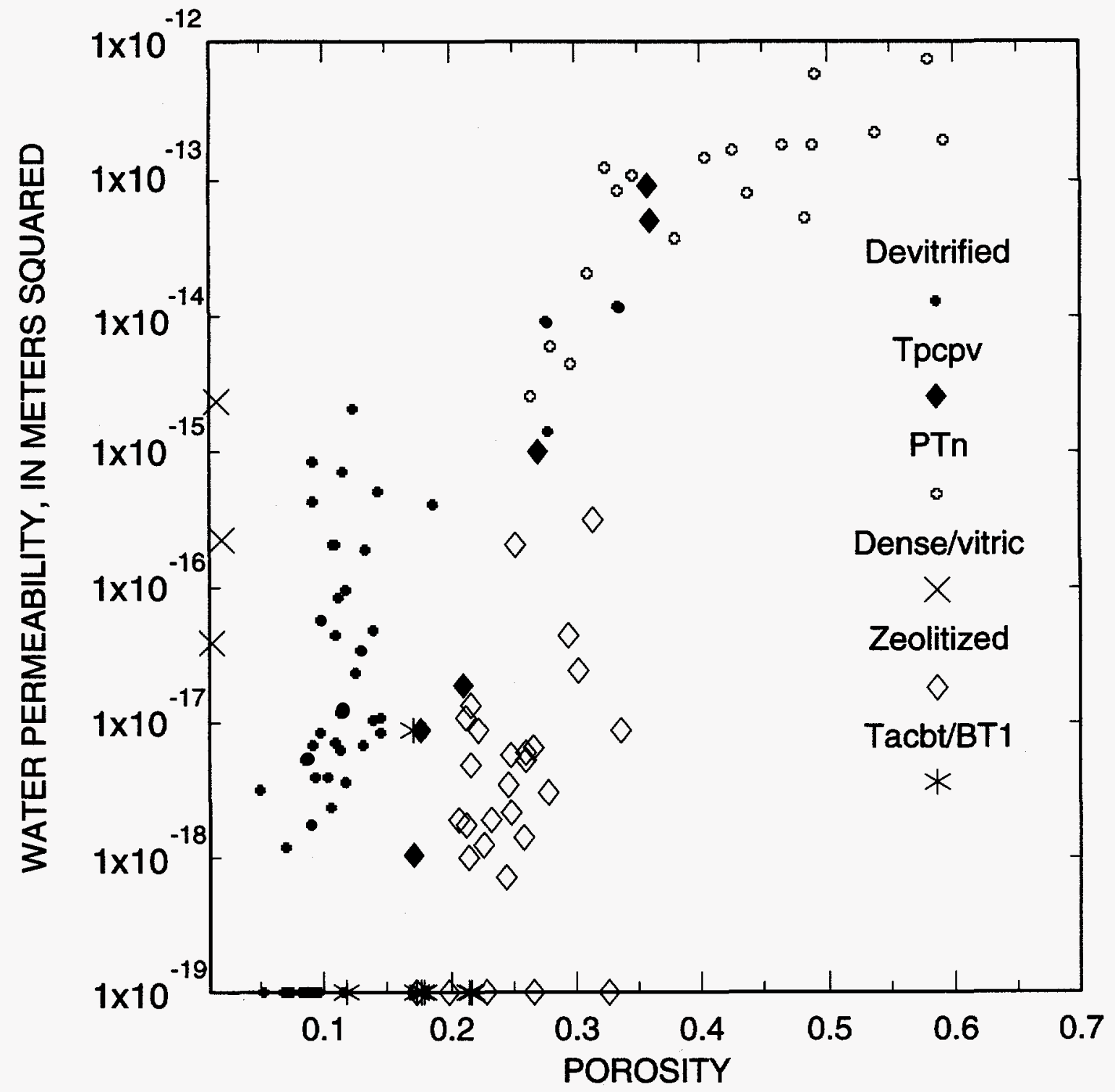

Figure 90. Relation between porosity and water permeability for borehole USW SD-9.

\section{Borehole Core Saturations}

Boreholes UZ-14 and SD-9 are in channels at the upper ends of washes, in areas that have either relatively thin alluvial cover or relatively short distances to concentrated sources of runoff water that, through lateral flow at alluvium/bedrock contacts, could provide a large source for infiltration. Because of the erosion in the channels and the uplifted beds, the Tiva Canyon Tuff is thin or absent at these two boreholes. This erosion exposed high-porosity rocks of the PTn that can absorb large volumes of water. These two factors contribute to the fact that rocks penetrated by these boreholes are wet at the surface, and relatively wet throughout the hole. The average saturations for the combination of the bedded tuff (Tpbt3) and Pah Canyon Tuff (Tpp) are 0.55 in UZ-14 and 0.42 in SD-9 (table 16). Saturations averaged for the Topopah Spring Tuff welded units-Tptpul, Tptpmn, and Tptpll-are 0.85 and 0.86 , respectively, in the two boreholes. Farther down the wash, boreholes N33 and N34, also having thin or no Tiva Canyon Tuff, also show high saturations. Disregarding NRG-6 and NRG-7a due to samplehandling problems, the two holes even farther downwash, N37 and N38, are located in areas with over- 
Table 16. Mean saturation of core samples from boreholes in the North Ramp area

$[\cdots$, no data $]$

\begin{tabular}{|c|c|c|c|c|c|c|c|c|}
\hline \multirow{2}{*}{$\begin{array}{l}\text { Lithostrati- } \\
\text { graphic unit } \\
\text { (see table 2) }\end{array}$} & \multicolumn{8}{|c|}{ Borehole designation } \\
\hline & $U Z-14$ & SD-9 & $\mathrm{N}-33$ & $\mathrm{~N}-34$ & $\mathrm{~N}-37$ & $\mathrm{~N}-38$ & $\begin{array}{c}\text { UZ\#4 } \\
\text { (Non-Q) }\end{array}$ & $\begin{array}{c}\text { UZ\#5 } \\
\text { (Non-Q) }\end{array}$ \\
\hline Tpcplnh & -- & -- & -- & -- & 0.87 & 0.82 & -- & -- \\
\hline Tpcplnc & -- & -- & -- & - & 0.89 & 0.90 & 0.74 & 0.85 \\
\hline Tpcpv2 & -- & 0.96 & 0.97 & - & 0.97 & 0.91 & -- & -- \\
\hline Tpcpv1 & -- & 0.62 & 0.77 & - & 0.46 & -- & 0.88 & 0.72 \\
\hline Tpbt4 & -- & 0.60 & 0.66 & -- & 0.34 & -- & 0.58 & -- \\
\hline Tpy & 0.94 & 0.53 & 0.63 & 0.75 & -- & -- & 0.54 & 0.39 \\
\hline Tpbt3 & 0.60 & 0.50 & -- & -- & -- & -- & 0.37 & 0.38 \\
\hline Tpp & 0.50 & 0.33 & -- & -- & 0.28 & -- & 0.32 & 0.28 \\
\hline Tpbt2 & 0.34 & 0.28 & -- & -. & 0.37 & -- & -- & 0.58 \\
\hline Tptrv3,2 & 0.31 & 0.46 & -- & -- & 0.44 & -- & -- & 0.56 \\
\hline Tptrv1 & 1.00 & 0.74 & -- & -- & 0.51 & -- & -- & 1.00 \\
\hline Tptrn & 0.55 & 0.66 & -- & -- & 0.69 & -- & 0.42 & 0.50 \\
\hline Tptpul & 0.85 & 0.79 & -- & -- & -- & -- & -- & -- \\
\hline Tptpmn & 0.88 & 0.92 & -- & - & -- & -- & - & -- \\
\hline Tptpll & 0.82 & 0.85 & -- & -- & -- & -- & -- & -- \\
\hline Tptpln & 0.89 & 0.89 & -- & -. & -- & -- & -- & -- \\
\hline Tptpv3,2 & 0.96 & 0.84 & -- & -- & -- & -- & -- & -- \\
\hline Tptpvl & 1.00 & 0.79 & -- & - & -- & -- & -- & -- \\
\hline Tpbtl & 1.00 & 1.00 & -- & -- & -- & -- & - & -- \\
\hline Tac & 1.00 & 0.97 & -- & -- & -- & -- & -- & -- \\
\hline Tcp & 0.92 & 0.98 & -- & -. & $\ldots$ & -- & -- & -- \\
\hline
\end{tabular}

lying Tpcpv, Tpcplnc, and Tpcplnh. Tiva Canyon Tuff samples from N37 were relatively wet, probably due to its location in a channel. However, N37 samples from the nonwelded and bedded units had lower saturations ( 0.28 in the Tpp). Similarly, the uppermost rocks (Tiva Canyon Tpcplnc) in boreholes UZ\#4 and UZ\#5 in Pagany Wash show relatively high saturations and lower saturations in the PTn. Samples from

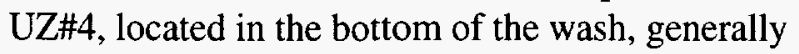
had slightly higher saturations in the PTn than UZ \#5 located on the terrace south of the wash. (UZ\#4 and UZ\#5 saturation data are non-Q.)

Borehole instrumentation can be used to integrate point measurements and can represent larger scale hydrologic conditions of the rocks, primarily by incorporating the fracture system into the measurement volume and including the effects of state variables (temperature and pressure) on water potential. Comparison of these measurements with core-scale point measurements may illustrate the different scale processes that occur and mechanisms that are influ- enced by the effects of temperature and pressure on insitu water potential, as well as conditions that may exist due to fracture flow in the PTn and upper TSw. In-situ measurements of water potential were made in borehole UZ-1, located about $27 \mathrm{~m}$ downwash from UZ-14 (see section of this report titled In-Situ WaterPotential Measurements). Assuming that UZ-1 and UZ-14 were close enough together to be similar in hydrologic character, the in-situ measurements of water potential were used with the moisture-retention curves for each rock type to estimate saturations at borehole UZ-14. The estimated saturations are shown in figure 91 along with the saturations measured in core samples. For several regions of the borehole, there are large differences between in-situ and corescale saturations. Within the PTn (Tpy, Tpbt3, and Tpp) the large-scale saturations estimated from in-situ water-potential measurements predicted drier rocks. Below the PTn in the crystal-rich nonlithophysal unit (Tptrn), the large-scale measurement predicted wetter rocks. Although these observations and predictions 


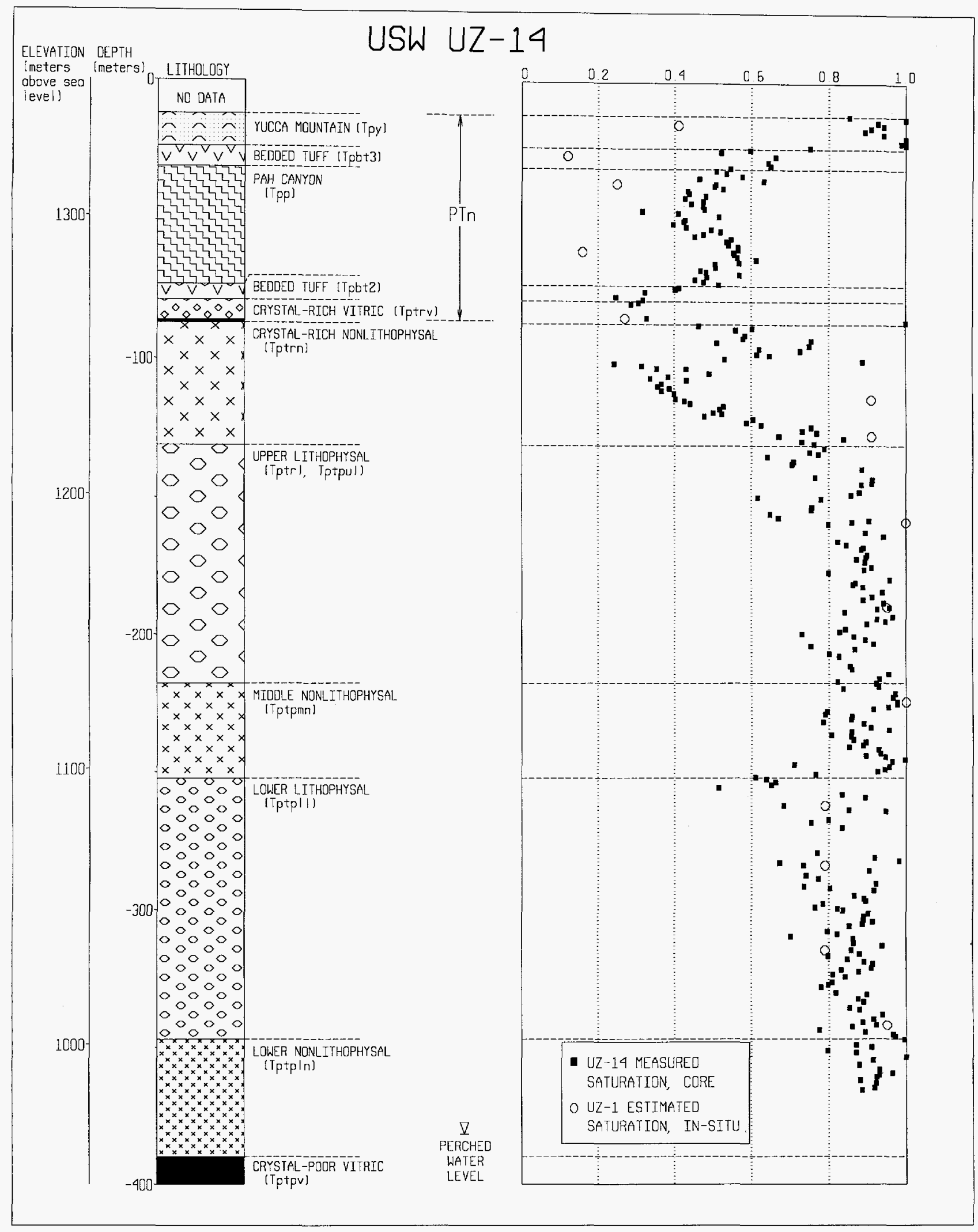

Figure 91. Measured saturation with depth for borehole USW UZ-14 and estimates of saturation using in-situ measurements of water potential in nearby borehole USW UZ-1. 
probably are valid scientifically, they are non-Q because they are based on water-potential data from UZ-1, which are non-Q. The prediction of drier rocks in the PTn may be related to the large diameter of UZ-1 in the PTn that, along with dry stemming materials, may have influenced the equilibration of the borehole and sensors with the formation. The predictions also may be a function of the errors associated with the use of the moisture-retention curves. Another explanation for the drier conditions observed is that the in-situ water-potential measurements may be incorporating shallow, pneumatic pathways within the $\mathrm{PTn}$, and the in-situ water-potential measurements in the Tptrn may be incorporating fracture flow below the PTn. The winter of 1994-95 may have resulted in enough water penetrating the shallow surface rocks at UZ-14 or moving laterally from upwash to increase the saturation toward the base of the PTn, which then contributed to the initiation of fracture flow in the lowporosity welded rocks of the upper part of the TSw.

This transitional zone between the PTn and the TSw warrants further examination because it constitutes an abrupt change in the properties and water content used to calculate flux. The changes with depth in porosity, saturation, and water potential are shown in figures 81 and 82. All units in the PTn, despite having relatively low saturations, are high in porosity with large volumes of water and high water potentials. Moisture-retention data support the evidence for large pores that drain at high water potentials. Although the low saturations within these rock units are expected due to upper boundary conditions that exhibit high evaporation rates and generally low precipitation, periodic wet seasons can result in the rapid transmission of episodic pulses of water through the PTn. Water moving downward must then move through increasingly smaller and fewer pores with the transition into the densely welded, crystal-rich Topopah Spring Tuff (Tptrv1) below the base of the PTn. The transition is rapid, with welding increasing and porosity decreasing from 0.5 to less than 0.05 over a distance of approximately $8 \mathrm{~m}$. This results in large increases in saturation that are countered by large reductions in permeability. These conditions could produce lateral diversion of water at the contact of the moderately welded top of the Topopah Spring Tuff and the vitrophyre that has abruptly contrasting properties. Lateral diversion of water at sloping interfaces is a function of saturated hydraulic conductivity, the angle of incline, the flux rate, and the air-entry pressure of the media (Ross,
1990). To create a capillary barrier with significant diversion capacity, fine-textured material must overlie coarse-textured media with a planar, sloping contact and a low flux rate. Lateral diversion also can be induced by an abrupt permeability barrier. A preliminary model was developed that depicted lateral diversion in a two-dimensional model (Moyer and others, 1996) that represented the PTn as a detailed system but with idealized linear contacts. In the model simulations, almost all of the infiltrating water was diverted laterally along these contacts. The contacts at the top and the bottom of the Ptn, however, are not linear. Rather, they are transitional with frequent lateral heterogeneities, such as fractures and broken zones, especially at the base of the PTn.

Saturation is 1.0 in the uppermost 0.5 to $1.0 \mathrm{~m}$ of the upper vitrophyre of the Topopah Spring Tuff (Tptrv1) in UZ-14 (table 16; fig. 91), where porosity is very low. The rock properties result in a large reduction in the volume of water that can penetrate downward through the matrix of the Tptrv1. If the water is not diverted laterally at this contact, flow must be initiated through fractures or through the local broken or faulted zones. If not diverted, water is likely to be flowing periodically in fractures surrounded by drier matrix in the upper parts of the crystal-rich nonlithophysal unit (Tptrn) because the small volume of water transmitted through the low-porosity rocks cannot saturate the much higher porosity of the underlying nonlithophysal rocks. The crystal-rich nonlithophysal unit (Tptrn) is composed of three subunits: a dense subunit underlying the vitrophyre that commonly has very low porosity ( 0.02 to 0.06 ), a vapor-phase corroded subunit that increases rapidly in porosity with depth, and a crystal-transition subunit that is lower in porosity. In the North Ramp area, the dense subunit is thicker than it is farther south. The vaporphase corroded subunit has porosities of greater than 0.2 near its top, but its porosity drops off rapidly with depth to about 0.12 . The rapid changes in porosity (and permeability) with depth further support the evidence shown in figure 91 that indicates low saturation is maintained just below the upper vitrophyre. These hydrologic characteristics might be a barrier to high flux through the matrix and fractures of the upper rocks of the Topopah Spring Tuff, and more conductive pathways might be necessary to explain the high saturations present throughout the rest of the Topopah Spring Tuff. 
In summary, the measurements of physical and hydrologic properties of borehole core samples in the North Ramp area represent conditions of the rock matrix at a point, do not incorporate large-scale features such as lithophysal cavities or fractures, and generally represent only local moisture conditions. Changes in porosity correlate well with lithostratigraphic contacts because porosity reflects the welding, alteration, and depositional character of the rocks. Porosity also is correlated with the permeability, but the slope of the linear relation changes for borehole intervals where clay or zeolite alteration or microfractures are present. Core-scale variations in water potentials between rock units can be attributed to large errors due to sample handling or laboratory measurements in the low-porosity units. Error analyses of loss of water in core samples due to drilling and sample handling indicate that samples with very low porosity lose the highest percentage of volumetric water content. Corrections to saturation and water-potential results for UZ-14 and SD-9 core samples did not provide an explanation for the dryness of the lowporosity rock units that are deep within the unsaturated zone. The apparent dryness of these units is problematic given their proximity to suspected perched water or the water table.

Core-scale saturations for boreholes in the North Ramp area indicate that the saturation of the PTn is low, whereas the saturation of the TCw and TSw are relatively high. Saturations in the PTn tend to be lower where the PTn is overlain by thick alluvium. Also, where the PTn is relatively thick, the saturation of the top of the TSw tends to be lower. This lower saturation likely is due to water flowing through the transition from high-porosity PTn to very low porosity Tptrv1, where the volume of water flowing through the matrix is greatly reduced. Subsequently, water flows through the transition into the higher porosity, vapor-phase, corroded, crystal-rich, nonlithophysal unit (Tptrn). In the Tptrn, the small volume of water cannot fill the pores of the higher porosity matrix. The increase in water content deeper in the profile is therefore likely due to water that has moved through fractures, broken zones, or faults.

For any single borehole, the core-scale physical and hydrologic properties in the transition from the PTn into the TSw imply that conditions may be favorable for lateral diversion of water, at least locally. When the same physical and hydrologic properties are compared from borehole to borehole, however, the heterogeneities present imply that conditions may not be favorable for lateral diversion at the larger scale. It is important to note that, although lateral diversion has been successfully simulated only in numerical models that depict large-scale, abrupt, linear contacts between the PTn and the overlying and underlying welded tuffs, these simulations disregard the transitional and heterogeneous nature of those contacts. Measurement and analysis of water potential at different scales (core and in-situ) result in different estimates of moisture conditions for the matrix and the matrix/fracture systems at UZ-14 in the PTn and upper TSw. Core-scale measurements of water-potential conditions indicate that water potentials are too high to be in static, no-flow equilibrium either with the water table or the perched-water reservoir at UZ-14. Therefore, some quantity of downward percolation must be occurring deep in the unsaturated zone.

\section{Results of In-Situ Hydrologic Monitoring in Boreholes}

In-situ measurements of water potential and temperature are available from five boreholes in the study area: UZ\#4 and UZ\#5 in Pagany Wash and UZ-1, NRG-7a, and NRG-6 in Drill Hole Wash (figs. 5 and 21). Temperature measurements also are available from NRG\#4 (Multimedia Environmental Technology, Inc., 1995) on Azreal Ridge between Drill Hole Wash and Pagany Wash, and from 10 open boreholes that were scanned with temperature probes intermittently between 1980 and 1984 as part of a regional heat-flow study of Yucca Mountain and vicinity (Sass and others, 1988).

\section{In-Situ Water Potential Measurements}

In-situ water potentials were measured with thermocouple psychrometers. These sensors measure the combined osmotic and matric potential, but not the gravitational potential, of liquid water contained within the pore spaces of the rock matrix and openings of fractures. Psychrometers measure liquid-water potential in the vapor phase by sensing the relative humidity, or vapor pressure, of the formation gas that is in contact with water-filled pores and fracture openings. The vapor concentration of the formation gas is a function of the capillary tension exerted on liquid water contained within the largest filled openings of the media. As saturation increases, larger and larger pores become filled, capillary tension is reduced, and 
the vapor concentration of the air in contact with the liquid water increases. A water potential of zero indicates that the medium is saturated. The kelvin equation (Brown, 1970) expresses the relation between water potential and vapor concentration, or relative humidity ( $\mathrm{RH})$, and is given in equation 3 below as:

$$
\Psi_{w}=\frac{R T}{V_{w}^{o}} \ln \left(\frac{e}{e_{o}}\right)
$$

where:

$$
\begin{gathered}
\Psi_{w}=\text { water potential (osmotic potential }+ \text { matric } \\
\text { potential) in bars, } \\
R=\begin{array}{c}
\text { universal gas constant (milliliter } \times \text { bars } / \\
\text { mole } \times \text { temperature in kelvins) }
\end{array} \\
T=\text { temperature in kelvins, } \\
V_{w}^{o}=\text { molar volume of pure water } \\
\quad \text { (milliliter } / \text { mole), and } \\
e / e_{o}=\text { relative humidity as a decimal. }
\end{gathered}
$$

Note: $\Psi_{w}$ water potential is always less than or equal to zero. In this report, water potential is expressed in megapascals (MPa); a megapascal is equal to 10 bars.

Sensors used to measure in-situ water potential were calibrated over a water-potential range of -0.1 to -7.0 MPa (Loskot, Rousseau, and Kurzmack, 1994), which is equivalent to an $\mathrm{RH}$ range of $99.9+$ to 93 percent $\mathrm{RH}$. Calibration accuracy of these sensors was on the order of $\pm 0.2 \mathrm{MPa}$ ( 95 percent confidence level) over the full range of calibration. The sensitivity, or resolution, of these sensors is on the order of $0.005 \mathrm{MPa}$ (Rousseau and others, 1994).

Psychrometer instrument stations at UZ\#4, UZ\#5, NRG-6, and NRG-7a were back-filled with polyethylene beads and capped with a thin layer of 20/40 silica sand before placement of intervening grout isolation plugs (J.P. Rousseau, written commun., 1995). At UZ-1, instrument stations were backfilled with $12 / 16$ silica sand and capped with dry bentonite and intervening layers of silica flour. Grout isolation plugs were placed at various locations throughout the borehole (Montazer, 1987).

Polyethylene beads were used in all boreholes instrumented after UZ-1 to minimize the time needed for the water potential of the dry stemming materials in the instrument station to equilibrate with the ambient water potential of the surrounding formation. Although the use of polyethylene beads greatly reduced equilibration times, it is apparent that other factors influence equilibration rates.

Equilibration is assumed to occur as a vaportransport process. Coarse stemming materials surrounding the instrument station will tend to act as capillary barriers to liquid flow, particularly in the welded rocks. Vapor transport is driven by diffusion and convection, the former in response to vaporconcentration gradients and the latter in response to barometric-pressure changes at the land surface. Equilibration of the vapor concentration of air inside the instrument station with air in contact with waterfilled pores and fracture openings in the surrounding rocks involves a coupled heat- and vapor-transport process (Crank, 1975). In this process, liquid water evaporates and removes heat from the surrounding rock; vapor condenses inside the instrument station and releases heat to the stemming materials.

Equilibration tends to be characterized by very rapid changes in water potential early in the recovery cycle when diffusion gradients are large, and small changes in vapor concentration cause large changes in the RH. Equilibrium also can be characterized by very slow, asymptotic recovery behavior later in the cycle when diffusion gradients are small, and small changes in vapor concentration produce progressively smaller changes in the $\mathrm{RH}$ at very high vapor concentrations. Differences in recovery rates can be attributed to (1) the volume of dry materials needed to back-fill the instrument station, (2) the moisture retention and adsorption characteristics of the dry stemming materials, (3) the volumetric water content of the surrounding rocks for a given saturation and water potential, (4) the extent to which the borehole may have been disturbed by drilling air or by in-hole air circulation while the borehole was sitting idle, and (5) the presence or absence of fractures in communication with the instrument station.

Fractures in communication with the instrument station can affect recovery rates simply by exposing the instrument station to a much larger volume of rock, thus increasing the effective surface area available for evaporation and the production of water vapor. Fractures also provide preferential, high-permeability pathways for transporting vapor. To some extent, low fracture densities can be used to explain very slow recovery rates that were observed in some instrument stations, particularly at UZ-1.

UZ-1 was instrumented in October 1983. The diameter of this borehole is $45 \mathrm{~cm}$ from a depth of 
about $30 \mathrm{~m}$ to total depth, and $92 \mathrm{~cm}$ from a depth of about $12 \mathrm{~m}$ to about $30 \mathrm{~m}$. Water-potential profiles for UZ-1 are shown in figure 92 for elapsed-time periods of 30 (November 23, 1993), 90 (January 23, 1984), 230 (June 8, 1984), 365 (October 25, 1984), and 730 (October 25, 1985) days following instrumentation of the borehole. Measurement equilibration in this borehole was much longer than for any other monitored borehole in the study area. The large borehole diameter and the type of stemming materials used in this borehole can account for the extended equilibration times.

Water potentials from instrument stations 12 and 13 in the lower lithophysal unit of the Topopah Spring Tuff may not have achieved equilibrium after 2 years of monitoring. Core fracture data from UZ-14 (fig. 24), located about $27 \mathrm{~m}$ northwest of UZ-1, indicate that the fracture density of the lower lithophysal unit at this location is very low, which may account for the very slow rates of recovery at these two instrument stations. Relatively slow rates of recovery also are apparent in the time-lapse profiles for instrument stations 3,5,6,9, and 10. Again, fracture data from nearby UZ-14 indicate low fracture densities of the lithostratigraphic units associated with these instrument stations. Rapid recovery at instrument stations 4 , $7,11,14$, and 15 correlate with zones of high fracture density in nearby UZ-14. Water-potential data from instrument stations 1 and 2 may have been affected by water that was used to drill the first $18 \mathrm{~m}$ of the borehole and may not be reliable (Montazer, 1987). Slow recovery at instrument station 3 probably is a reflection of the large diameter of the borehole at this location, which required a large volume of dry stemming material to backfill. The resultant water-potential profile for October 25, 1985, indicates that waterpotential gradients in all subunits of the TSw, with the possible exception of the lower lithophysal subunit, are very close to zero. As mentioned previously, however, measurement equilibration at instrument stations 12 and 13 may not have been achieved within the 2-year monitoring period. Extrapolation of the observed trend in water potentials at these two stations from October 1984 to October 1985 indicates that the water-potential gradient throughout the TSw is close to zero. Thus, the gravitational potential may be the dominant component of the total hydraulic gradient, which is very close to unity. However, these observations and conclusions, although probably valid scien- tifically, are non-Q because they are based on waterpotential data from UZ-1, which are non-Q.

NRG-7a and NRG-6 were instrumented in October and November of 1994, respectively. The diameters of these boreholes averaged approximately $25 \mathrm{~cm}$, with large breakouts of $30 \mathrm{~cm}$ to $45 \mathrm{~cm}$ present across the Pah Canyon Tuff and crystal-rich vitric units at the base of the PTn. Selected waterpotential profiles for these two boreholes are shown in figures 93 and 94. For NRG-7a (fig. 93), the elapsedtime periods following instrumentation of the borehole are about 4 months (February 5, 1995), 7 months (May 5, 1995), and 13 months (November 1, 1995). For NRG-6 (fig. 94), the elapsed-time periods are about 3 months (February 20, 1995), 6 months (May 24, 1995), and 12 months (November 14, 1995). (Note: the temperature data shown in figures 93 and 94 are discussed in a later section of this report.) Figures 95 and 96 are 100-day, time-series records of water potential in these two boreholes from November 1,1995 , to February 8, 1996, which is a period that begins about a year after the boreholes were instrumented. Water potentials for station B in NRG-7a (fig. 95) and station A in NRG-6 (fig. 96) are plotted slightly above zero because the calibration accuracy of these sensors was on the order of $\pm 0.2 \mathrm{MPa}$, as described previously.

The time-series data for NRG-6 (fig. 96) indicate that water potentials in nearly all the instrument stations in this borehole had equilibrated by November 1995 after about a year of monitoring. Slight increases in water potentials at instrument stations $\mathrm{B}, \mathrm{D}$, and $\mathrm{E}$ (less than about $0.0005 \mathrm{MPa}$ per day based on cumulative changes over a 2,400-hour period) from November 1, 1995, to February 8, 1996, are indicated in the time-series records for NRG-6. The water-potential profile with depth for November 14, 1995 (fig. 94), indicates a water-potential gradient that is very close to zero across the PTn and through the upper part of the TSw.

The time-series data for NRG-7a (fig. 95) indicate that water potentials after November 1, 1995, were still increasing at a rate slightly greater than $0.0005 \mathrm{MPa}$ per day at all but one of the deeper instrument stations (station B) in this borehole. Instrument station $E$ is located at a depth of about $5 \mathrm{~m}$, and its water-potential record is strongly affected by seasonal temperature changes at the land surface. The November 1, 1995, water-potential profile with depth for NRG-7a (fig. 93) indicates a water-potential 


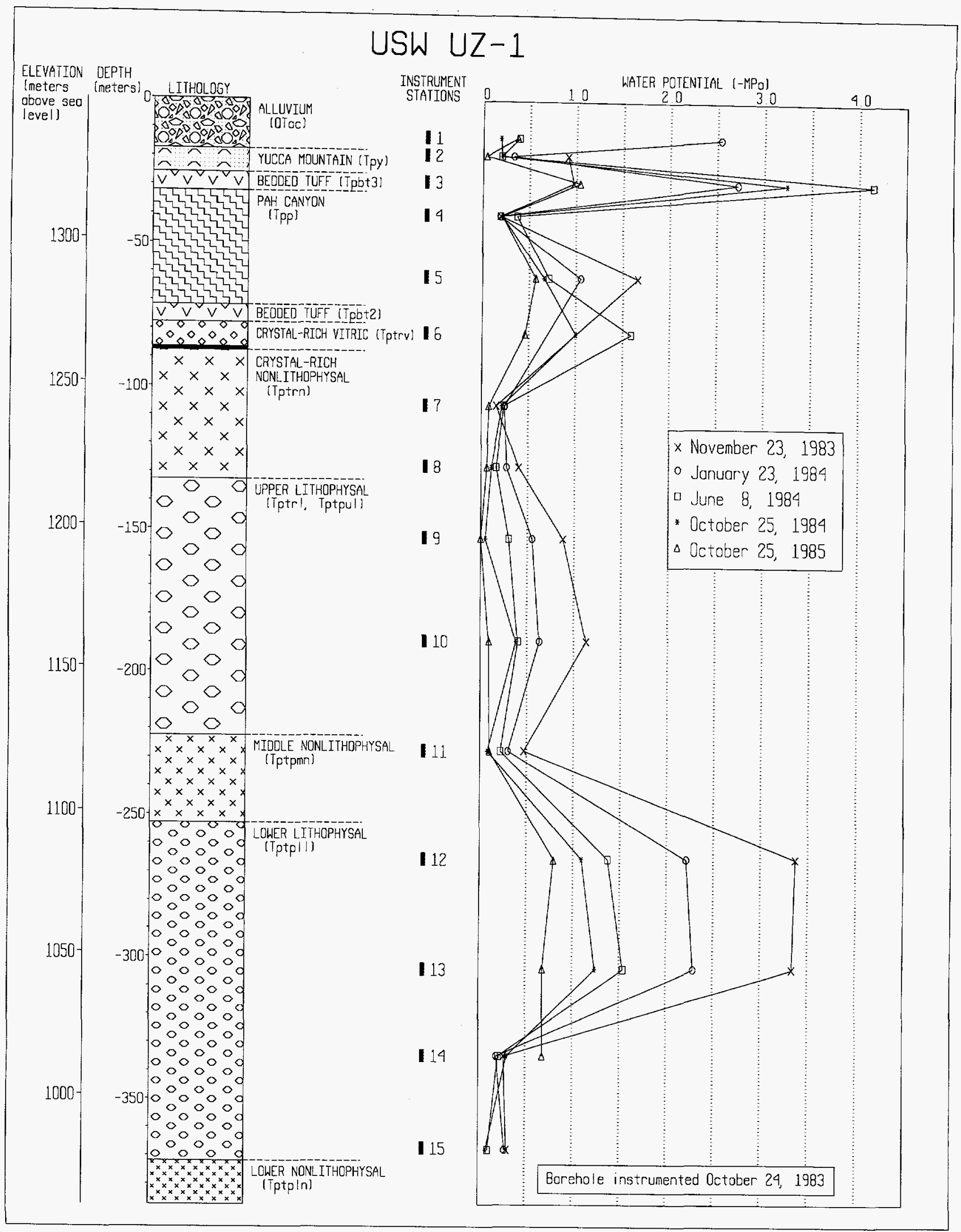

Figure 92. Selected water-potential profiles for borehole USW UZ-1. 


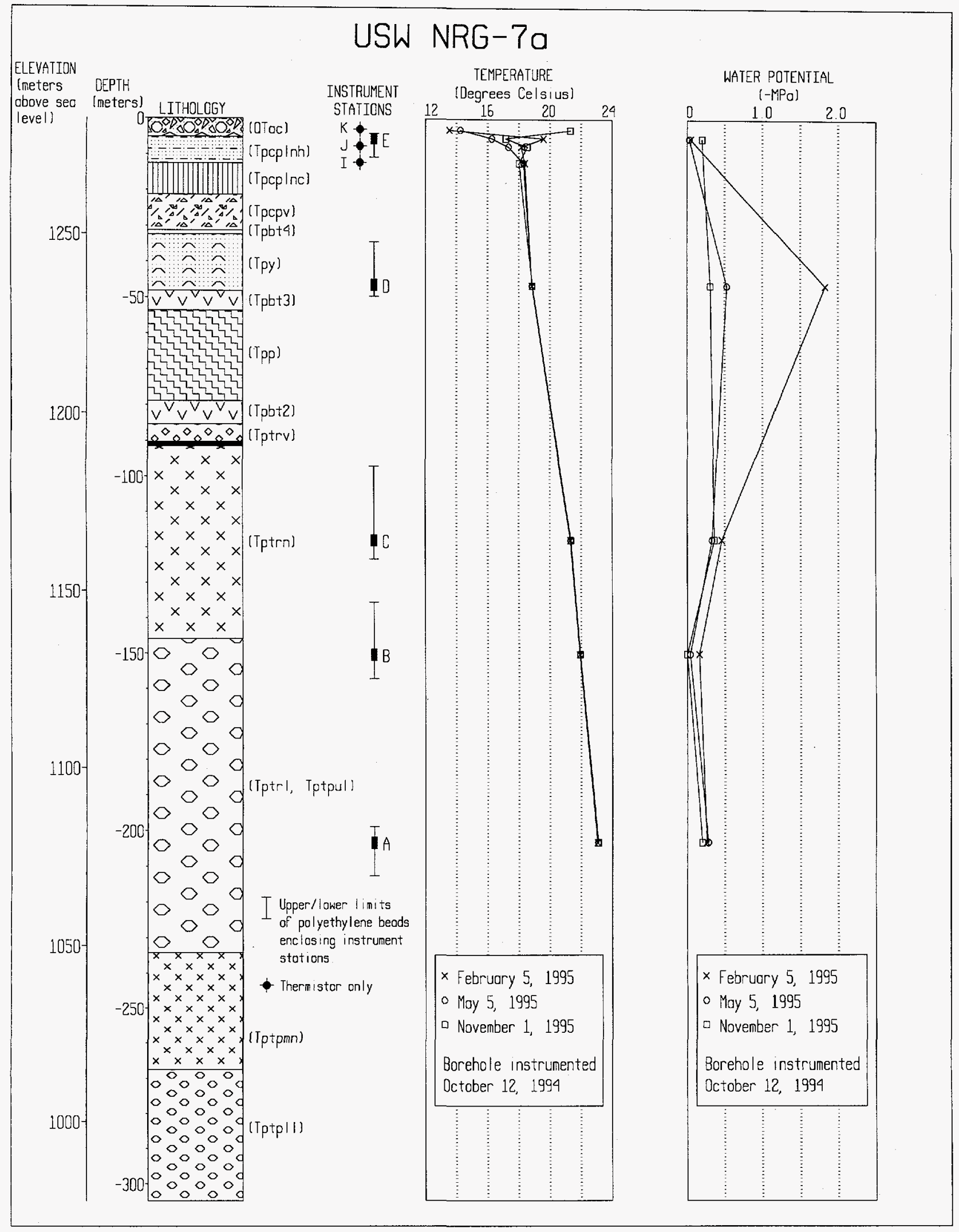

Figure 93. Selected water-potential and temperature profiles for borehole USW NRG-7a. 


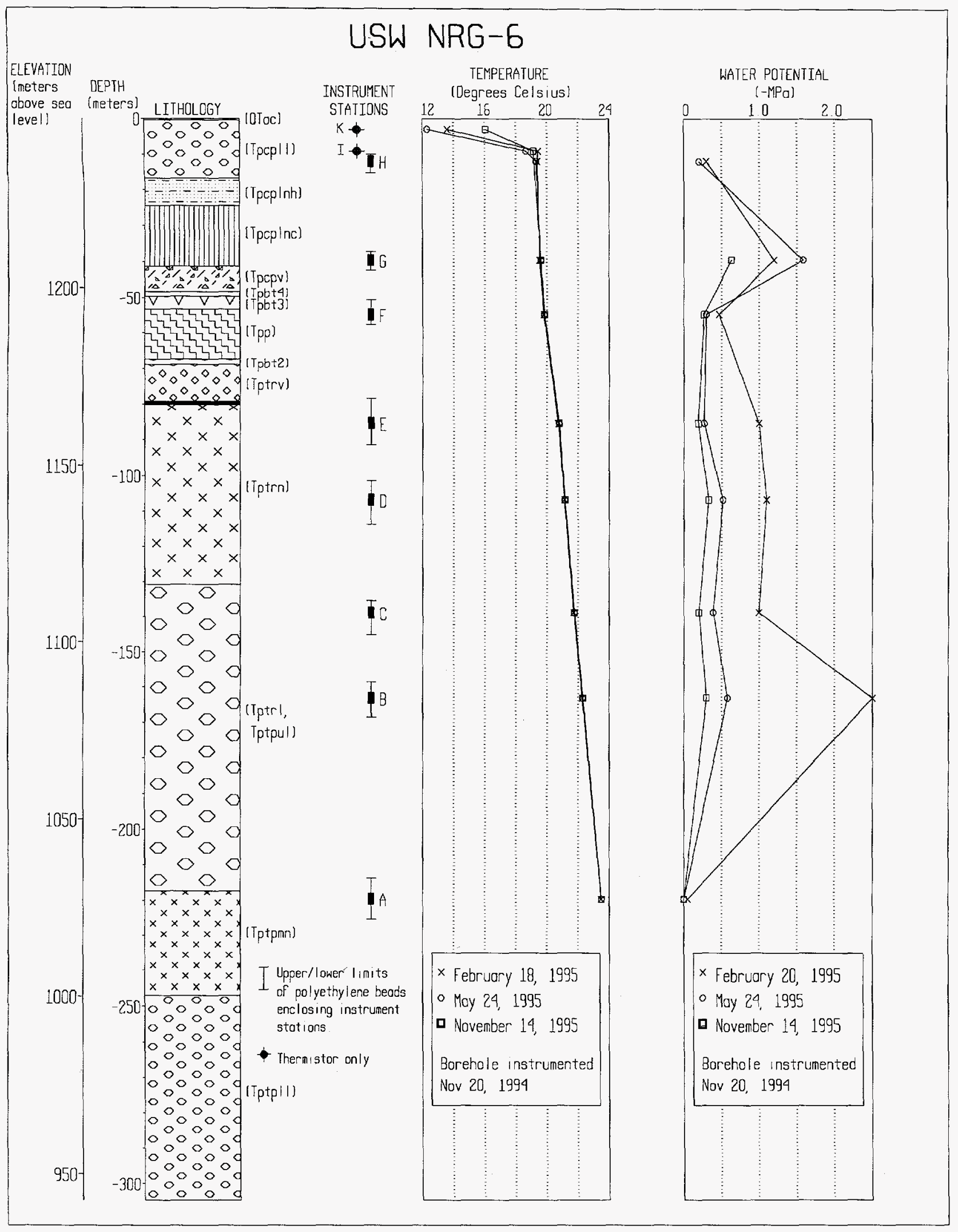

Figure 94. Selected water-potential and temperature profiles for borehole USW NRG-6. 


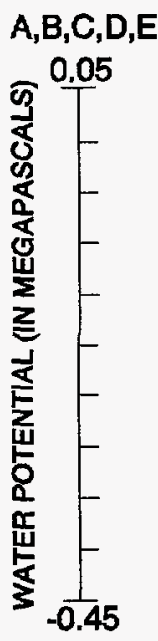

Water Potential USW NRG-7a

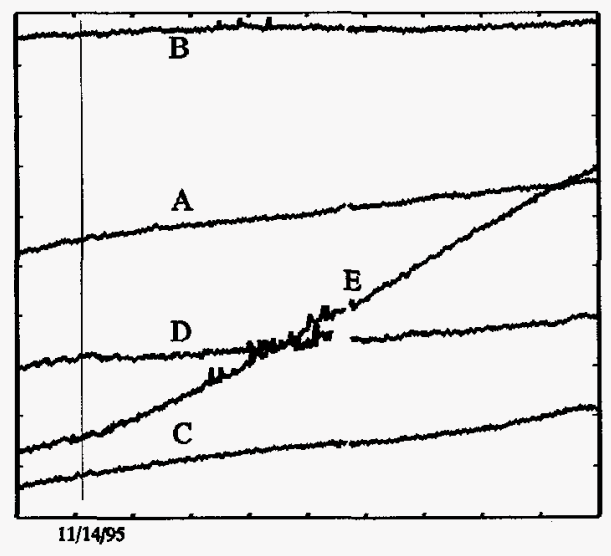

$11 / 01 / 95 \quad 2,400$ TOTAL HOURS $\quad 02 / 08 / 96$

Figure 95. Time-series water-potential records for instrument stations at borehole USW NRG-7a. (Borehole instrumented October 12, 1994)

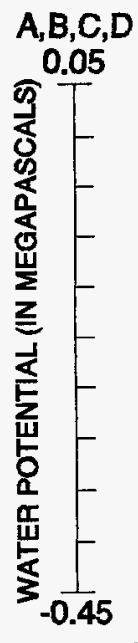

Water Potential USW NRG-6

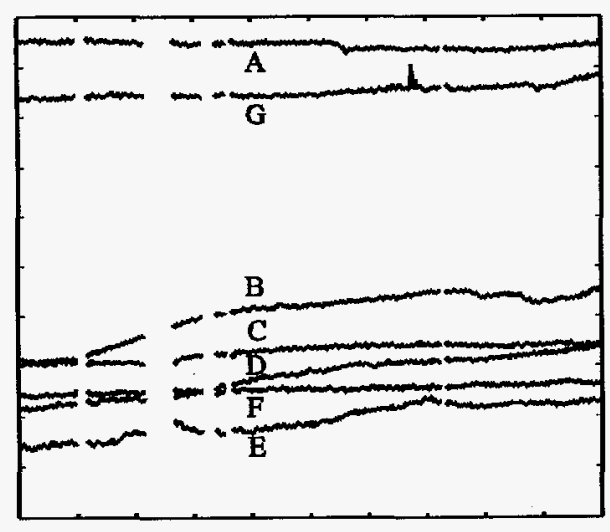

$11 / 01 / 95$

2,400 TOTAL HOURS

02/08/96

Figure 96. Time-series water-potential records for instrument stations at borehole USW NRG-6. (Borehole instrumented November 20, 1994)

gradient that is very close to zero across the entire instrumented section of this borehole.

Water-potential profiles for UZ\#4 and UZ\#5 are shown in figure 97 for elapsed-time periods of about 3 months (September 26, 1995) and 6 months (December 25, 1995) following instrumentation of the boreholes. Also shown on these profiles are measurements of water potentials made on core samples by Loskot and Hammermeister (1992). UZ\#4 and UZ\#5 were drilled between September and November 1984, reamed to a diameter of $22 \mathrm{~cm}$ in April and May 1995, and instrumented in June and July 1995. UZ\#4 is located in the active channel of Pagany Wash, and UZ\#5 is located on a hillslope adjacent to Pagany Wash, approximately $38 \mathrm{~m}$ south of UZ\#4.
At several stations in UZ\#4, there is little or no difference between water potentials measured on September 26, 1995, and those measured on December 25, 1995 (fig. 97). This indicates that water potentials equilibrated fairly rapidly at instrument station A, located at the top of the crystal-rich nonlithophysal unit of the Topopah Spring Tuff, and at instrument stations $\mathrm{E}, \mathrm{F}$, and G, located in the upper subunits of the PTn. Water potentials measured in these stations are between -0.1 and $-0.25 \mathrm{MPa}$. Timeseries records for UZ\#4 (fig. 98) indicate that water potentials at three instrument stations, B, C, and D, were still increasing (slightly) after December 25, 1995. The increasing trend at these stations indicates that the final profile will very closely follow the waterpotential trend derived from core samples and will very closely approximate a zero water-potential gradient across most of the PTn section at this borehole. On the basis of the time-series trends, there is some indication that the December 25, 1995, water potential-gradient (fig. 97) across the pre-Yucca Mountain Tuff bedded tuff (Tpbt3) at UZ\#4 may be preserved after all instrument stations have fully equilibrated. However, accuracy limitations of the psychrometers ( $\pm 0.2 \mathrm{MPa}$ ) may preclude support of this interpretation.

At borehole UZ\#5, the time-series water-potential records (fig. 99) indicate that water potentials at all instrument stations were still increasing (slightly) after December 25, 1995. Equilibration recovery rates at UZ\#5 also are slightly slower than at UZ\#4. The water-potential profile for UZ\#5 as of December 25, 1995 (fig. 97), indicates that the water-potential gradient at this borehole also is nearly zero across the entire PTn section. Water potentials in the upper subunits of the PTn (crystal-poor vitric, Yucca Mountain Tuff and the pre-Yucca Mountain Tuff bedded tuff) are 0.2 to $0.3 \mathrm{MPa}$ lower than water potentials of the same units at UZ\#4. These data may indicate lateral flow from UZ\#4 to UZ\#5. This interpretation, however, is subject to limitations in accuracy of the psychrometers $( \pm 0.2 \mathrm{MPa})$ and uncertainty over final equilibration values. Elevated tritium was detected in the upper PTn units at UZ\#4 and in the crystal-poor vitric unit at UZ\#5 (see section of this report titled Aqueous-Phase Isotopic Data from Boreholes USW UZ-14, UE-25 UZ\#4, UE-25 UZ\#5, USW NRG-6, and USW NRG-7a). These tritium data, as well as temperature data presented in the next section of this report, tend to support an interpretation for lateral flow in the PTn from UZ\#4 to UZ\#5. 


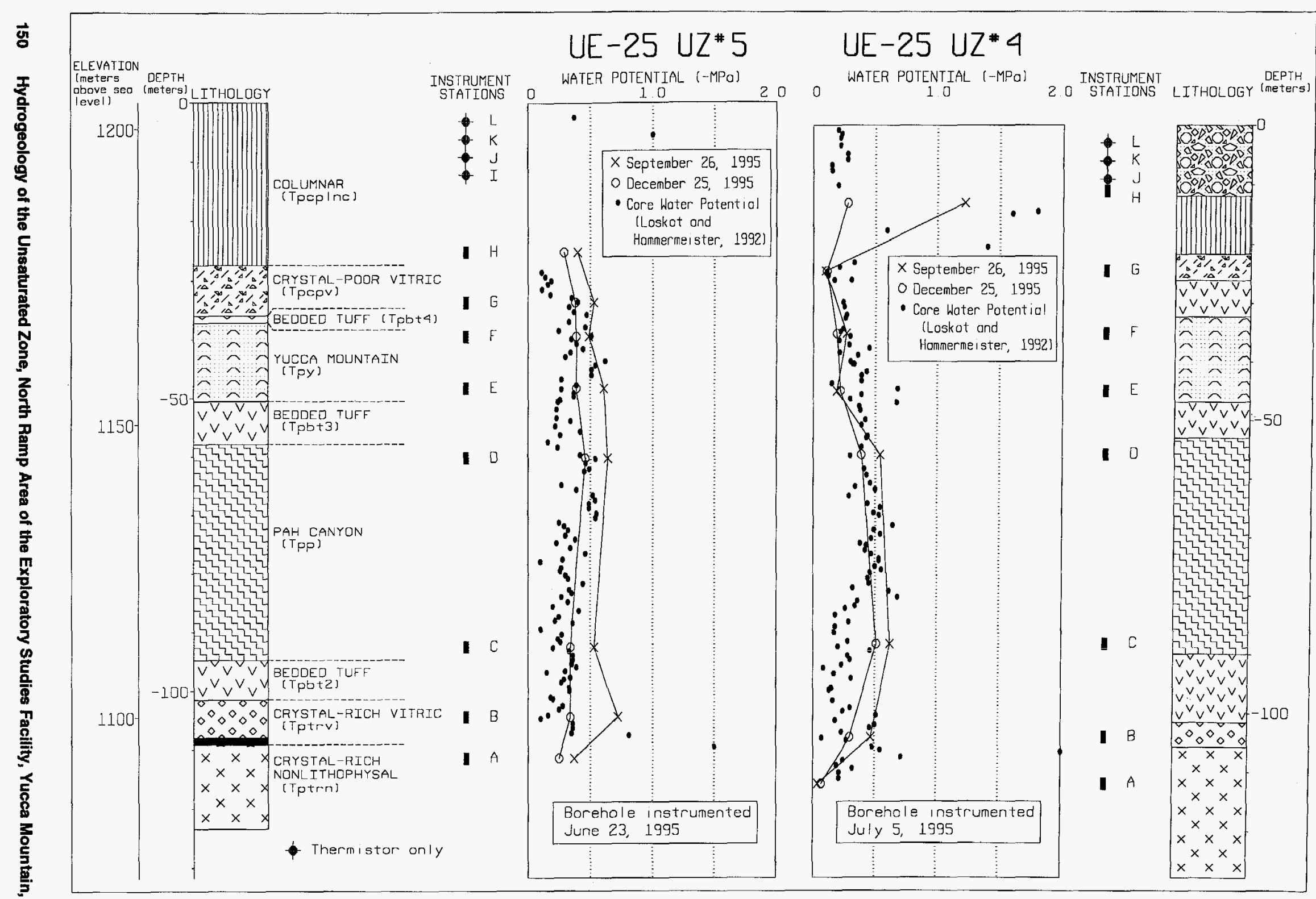

Figure 97. Selected water-potential profiles for boreholes UE-25 UZ\#5 and UE-25 UZ\#4. 
Water Potential UE-25 UZ\#4

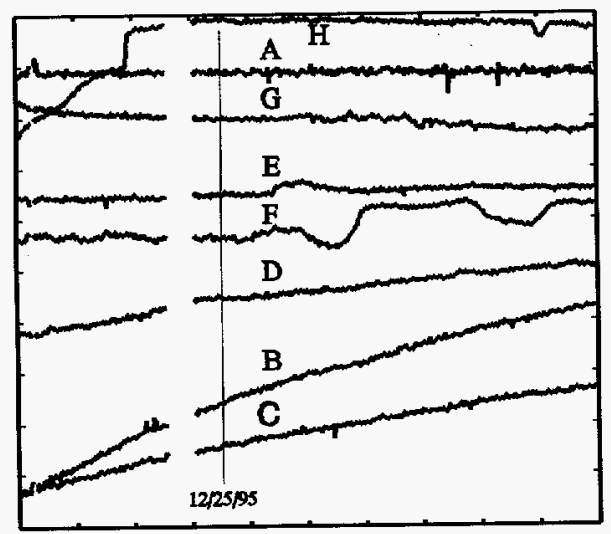

$11 / 19 / 95 \quad 2,400$ TOTAL HOURS 02/27/96

Figure 98. Time-series water-potential records for instrument stations in borehole UE-25 UZ\#4. (Borehole instrumented July 5,1995 )

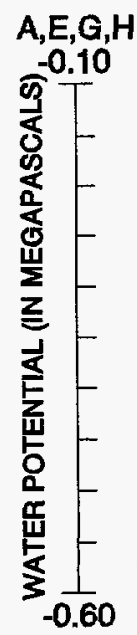

Water Potential UE-25 UZ\#5

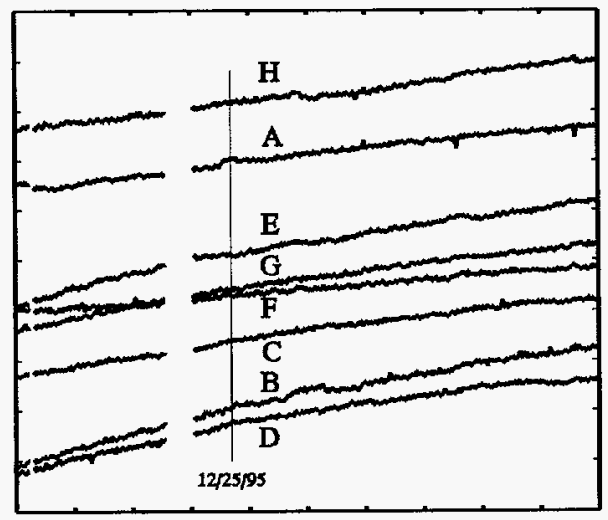

11/19/95 2,400 TOTAL HOURS 02/27/96

Figure 99. Time-series water-potential records for instrument stations in borehole UE-25 UZ\#5. (Borehole instrumented June 23, 1995)

\section{In-Situ Temperature}

In-situ temperature data obtained from six instrumented boreholes (UZ-1, UZ\#4, UZ\#5, NRG\#4, NRG-6, and NRG-7a) in the study area are presented in this section. These data, along with temperature data from 10 open boreholes, collected by Sass and others (1988) in the early 1980's as part of a regional heat-flow study of Yucca Mountain and vicinity, are used to describe heat flow within the unsaturated zone and to estimate net long-term, mean-annual percolation rates through the alluvium of Pagany Wash and Drill Hole Wash. Since the completion of the earlier heat-flow studies, the data base used to characterize the thermal and matrix hydrologic properties of the welded and nonwelded tuffs has been refined and
G flow studies were constrained by very limited thermalconductivity data (three measurements; Sass and others, 1988) and limited porosity and saturation data for the PTn. Thermal conductivity of the nonwelded tuffs has been shown to be particularly sensitive to variations in porosity and saturation (Rautman, 1995), a characteristic with significant implications for heat flow within this lithostratigraphic unit.

In-situ temperature data from two closely spaced, instrumented boreholes in Pagany Wash, UZ\#4 and UZ\#5, indicate the presence of large, horizontal components of heat flow beneath the alluvial fill of this wash. Temperatures within the alluvial fill and within the PTn immediately below Pagany Wash at UZ\#4 are significantly higher than temperatures in nearby UZ\#5, which is on a hillslope adjacent to the wash. An analysis of heat flow beneath the Pagany Wash site, which incorporates data from other boreholes, indicates that heat flow in the PTn is approximately 60 percent less than that in the underlying TSw. Elevated temperatures within the alluvium of Pagany Wash and throughout the underlying PTn may be a reflection of the insulating effects of the low thermal conductivity of the alluvial fill. However, the large, vertical heat-flow deficits within the PTn are difficult to reconcile without considering a coupled mass- and heat-transport process with substantial capacity to extract heat, such as infiltration and deep percolation. Therefore, the effect of infiltration and percolation on heat flow are investigated in detail in the section of this report titled Analysis of Percolation Flux Based on Heat Flow Estimated in Boreholes.

Although the earlier study by Sass and others (1988) concluded that heat flow in the unsaturated zone was primarily conductive, they did note that the average heat flow in the unsaturated zone, $41 \pm 3.5$ milliwatt per square meter $\left(\mathrm{mW} / \mathrm{m}^{2}\right)$, which is equivalent to $41 \pm 3.5$ millijoules per second per square meter $\left(\mathrm{mJ} / \mathrm{s} / \mathrm{m}^{2}\right)$, might be as much as 20 percent lower than that estimated for the saturated zone $\left(49 \pm 8 \mathrm{~mJ} / \mathrm{s} / \mathrm{m}^{2}\right)$. Sass and others (1988) examined the possibility of accounting for this heat-flow deficit through nonconductive heat-flow processes, specifically, (1) heat reduction from vertical percolation and (2) heat loss through vaporization and advective transport of vapor and air. In case (1) they estimated that it would require between 2 and $5 \mathrm{~mm} / \mathrm{yr}$ of deep percolation to account for the heat-flow deficit in 
the unsaturated zone. In case (2) they estimated that vaporization of $0.1 \mathrm{~mm} / \mathrm{yr}$, with an upward discharge velocity of air equivalent to $15 \mathrm{~m} / \mathrm{yr}$, would provide the necessary heat consumption to satisfy this deficit.

There is evidence to indicate that heat losses due to vaporization and advective transport of vapor and air may be locally important in the highly fractured and densely welded rocks of the Tiva Canyon Tuff. These rocks form the hillslopes and ridges bordering Pagany Wash and Drill Hole Wash. However, numerical simulation of the coupled transport of heat, liquid, and gas with TOUGH2 (Pruess, 1990) using a generic ridge and wash topographic setting indicates that these effects are secondary in comparison to the effects of percolation (see section of this report titled Analysis of Percolation Flux Based on Heat Flow Estimated in Boreholes).

\section{Temperature Measurements and Gradients}

In-situ measurements of temperatures are available from one previously instrumented and five recently instrumented (stemmed or packed off) boreholes in the North Ramp study area. Temperature measurements in NRG-6, NRG-7a, UZ\#4, and UZ\#5 were made with thermistors originally calibrated against primary temperature standards to an accuracy of \pm 0.005 degree Celsius $\left({ }^{\circ} \mathrm{C}\right.$ ) (95-percent confidence; Kume and Rousseau, 1994), and with uncalibrated thermocouples (back-up system) using thermocouple reference tables to convert voltage output to temperature (J.P. Rousseau, written commun., 1995).

Measurement precision of the thermistors, with all data-acquisition system components functioning properly, ranges between 0.001 to $0.003^{\circ} \mathrm{C}$. Thermocouple accuracy using the voltage-output reference tables is estimated to be on the order of 0.1 to $0.5^{\circ} \mathrm{C}$. Measurement precision of the thermocouples ranges between 0.05 to $0.10^{\circ} \mathrm{C}$. Temperatures in UZ-1, a stemmed borehole that was instrumented in 1983, and NRG\#4, a packed-off borehole instrumented by Nye County in 1994, were measured with thermocouples. Temperature data collected from boreholes NRG-6, NRG-7a, UZ\#4, and UZ\#5 are fully qualified under the USGS YMP QA program. However, temperature data from UZ-1 and NRG\#4 are non-Q because they were not collected under the approved USGS YMP QA program.

Additional unsaturated-zone temperature data were acquired from 10 open boreholes in the vicinity of the North Ramp during the early 1980's. Tempera- ture profiles for boreholes a\#1, \#4, \#5, \#6, \#7, G-1, G-4, H-1, WT\#4, and WT\#18 are presented in Sass and others (1988). Multiple temperature profiles were made in these boreholes intermittently between 1980 and 1984. Measurements were made using thermistors that were lowered either into water-filled tubes inserted into these boreholes (preferred method) or into air-filled access tubes that were used for waterlevel monitoring or for supporting the downhole instrumentation bundle in UZ-1. Measurement methodology, data limitations, and an analysis of heat flow within the unsaturated zone at Yucca Mountain based on these data are presented in Sass and others (1988). These data are non-Q because they were collected prior to implementation of the approved USGS YMP QA program.

Temperature measurements made in instrumented boreholes since 1994 confirm the general findings and conclusions presented in the earlier work of Sass and others (1988): (1) heat flow in the unsaturated zone primarily is conductive, and (2) temperature gradients in the unsaturated zone vary, but generally consist of multiple linear segments. Temperature profiles for NRG-7a and NRG-6 were presented in figures 93 and 94 along with the water-potential profiles for these two boreholes. Temperature profiles for UZ\#4, UZ\#5, UZ-1, and NRG\#4 (instrumented by Nye County; data provided by Multimedia Environmental Technology, Inc., 1995) are shown in figures 100 through 102.

For this report, temperature gradients were calculated using only the longest, continuous, linear segments of the borehole-temperature profiles for the various hydrogeologic units. The resulting gradients may or may not agree with those presented in the report by Sass and others (1988). This approach was used instead of a best-fit linear regression of all the temperature data for a given hydrogeologic unit used by Sass and others (1988) because temperature profiles across the contacts between major hydrogeologic units tend to be gradational or curved. The lack of a sharp break, or refraction, in gradients across the contacts of units with markedly different thermal conductivity is, to some extent, due to the subtle and transitional changes in the physical and matrixhydrologic properties, and hence the thermal conductivities, of the rock units on either side of the contact. This observation is particularly applicable to the contacts of the TSw with the overlying PTn and the underlying $\mathrm{CH}$. Temperature gradients across these 


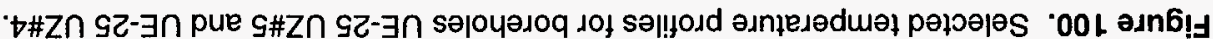

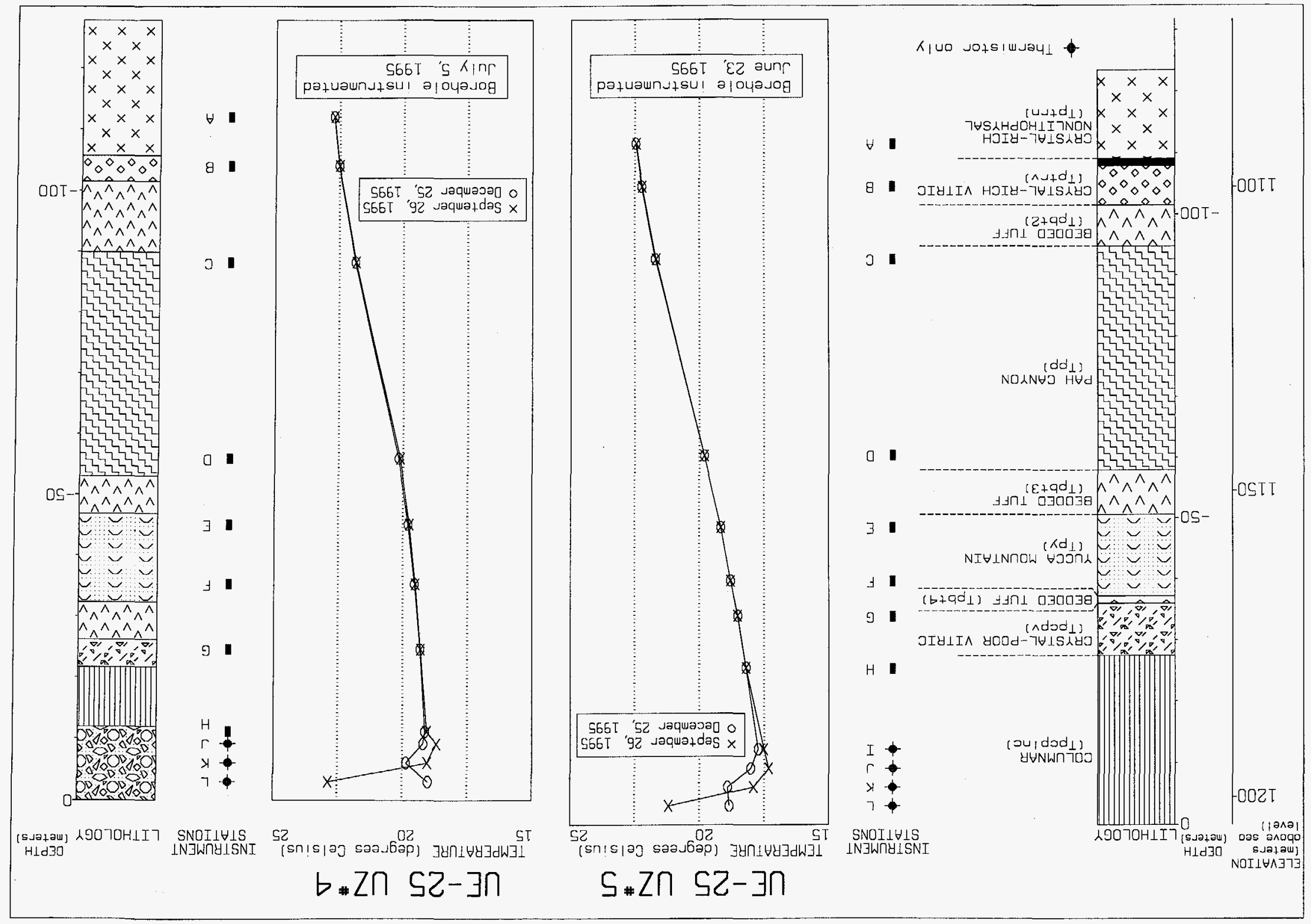




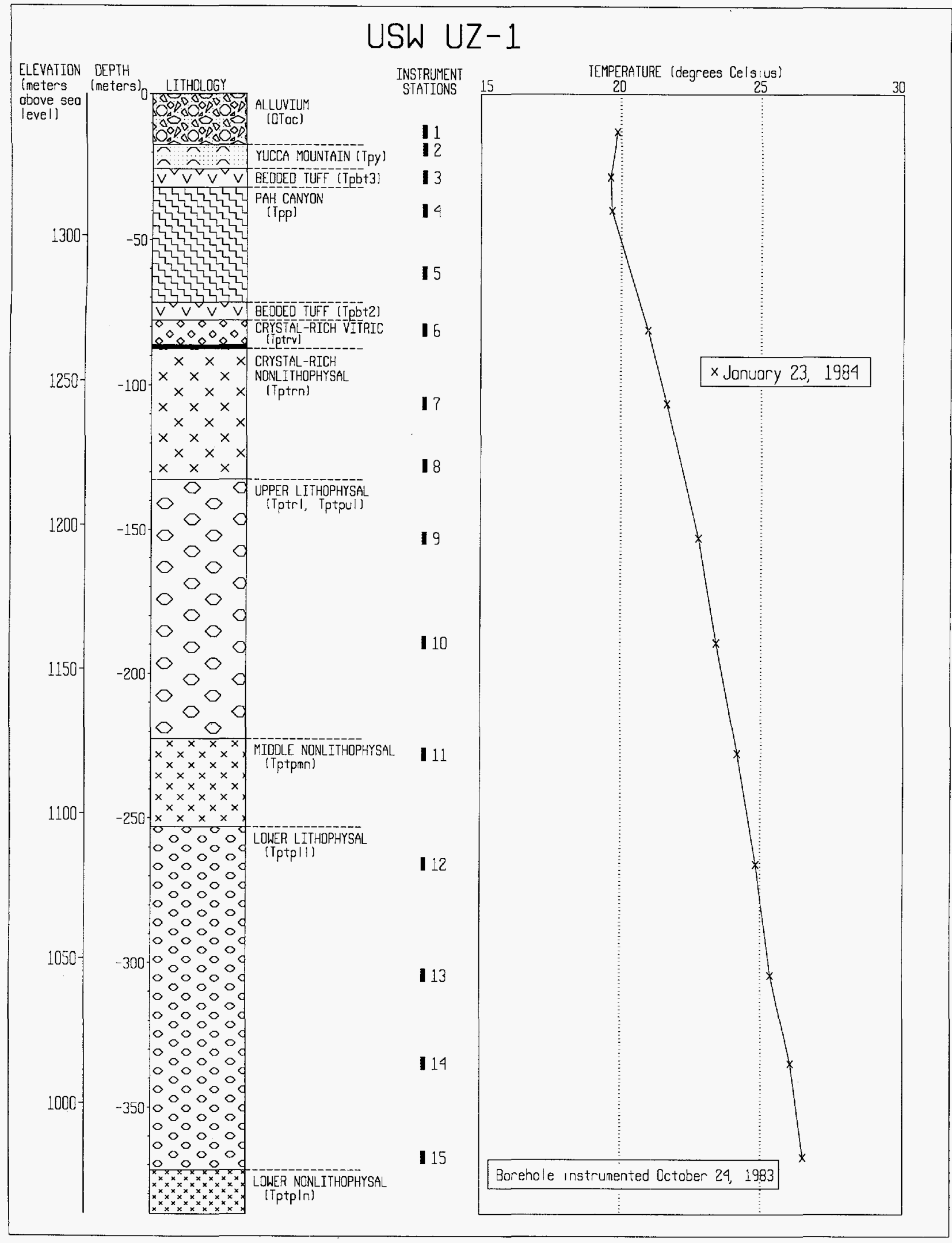

Figure 101. Temperature profile for borehole USW UZ-1. 


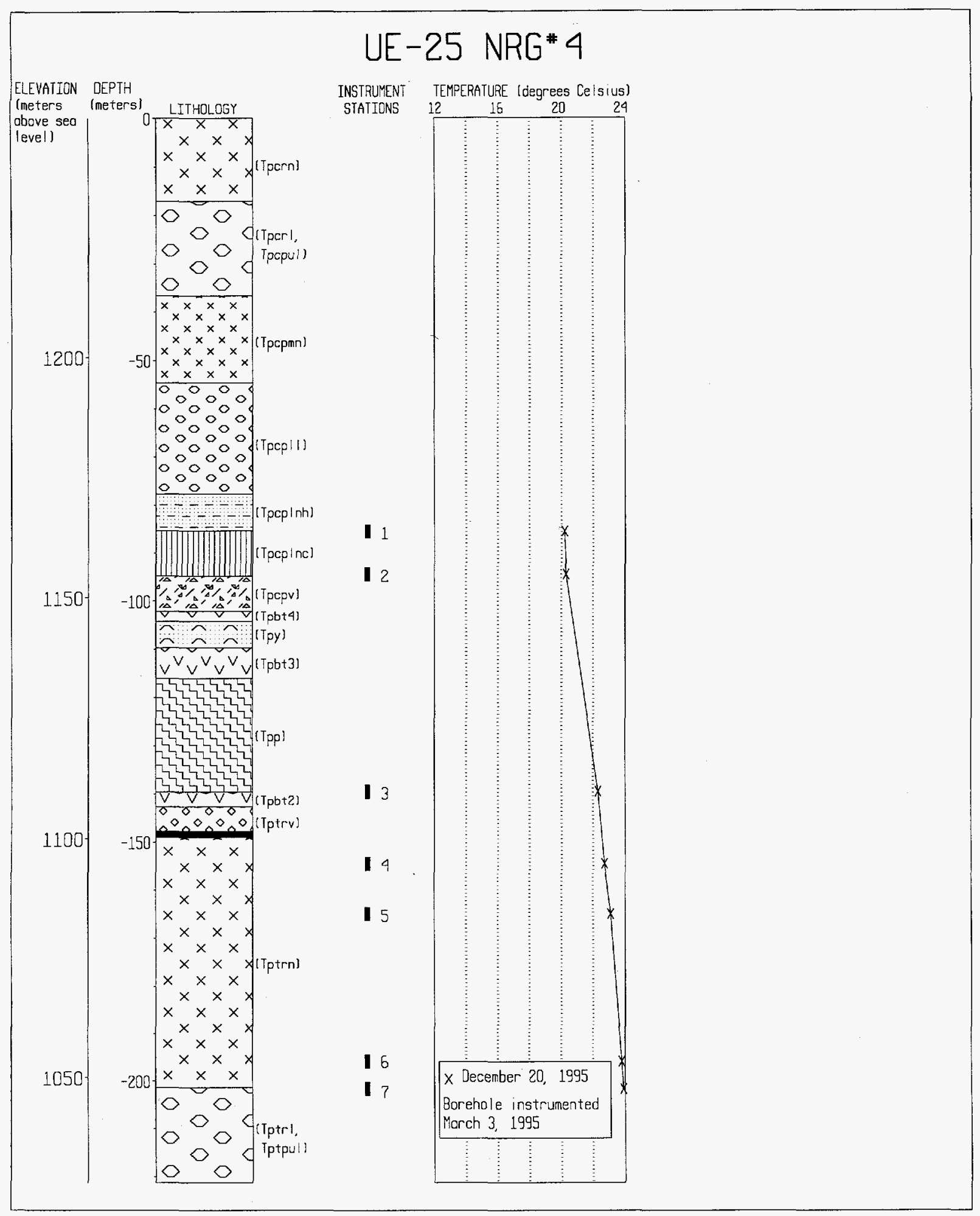

Figure 102. Temperature profile for borehole UE-25 NRG\#4. 
contacts are characterized by convex upward or concave upward profiles. Inclusion of these nonlinear segments in the calculation of temperature gradients would tend to overestimate or underestimate the magnitude of the gradient that is representative of most of the section.

Temperature profiles in the six instrumented boreholes and the temperature profiles presented in Sass and others (1988), indicate that temperature gradients in the TSw can be approximated by nearly linear segments that are continuous over large, composite thicknesses of this hydrogeologic unit. The gradients vary significantly from one location to. another within the study area, and range from a low of $1.59^{\circ} \mathrm{C}$ per $100 \mathrm{~m}$ at borehole a\#4 to a high of $2.55^{\circ} \mathrm{C}$ per $100 \mathrm{~m}$ at NRG\#4 (table 17). In general, smaller gradients in the TSw appear to be associated with boreholes that are located within active channels or in valley floors of major drainages. Larger gradients are present beneath channel margins and beneath hillslopes immediately adjacent to these channels, reaching a maximum beneath ridges (NRG\#4 located on Azreal Ridge) or in hydrologically inactive areas (WT\#4 and a\#6 located on hillslopes that are distant from major drainages). Two notable exceptions to this observation are a\#1 $\left(2.36^{\circ} \mathrm{C}\right.$ per $\left.100 \mathrm{~m}\right)$, located very near the active channel of Drill Hole Wash, and WT\# $18\left(1.77^{\circ} \mathrm{C}\right.$ per $\left.100 \mathrm{~m}\right)$, located along a very steep ridge near the northern boundary of the study area. The apparent association of gradient magnitude with geomorphic setting may be of some hydrologic significance for several reasons. It is clear from the analysis of heat flow in Pagany Wash that the presence of lowthermal-conductivity alluvial fill can have a significant influence on heat-flow and temperature gradients within the PTn (see the section of this report titled Numerical Analysis of Heat Flow and Percolation in Pagany Wash). Drill Hole Wash is much wider than Pagany Wash, and the alluvial fill in this wash is thicker (42 $\mathrm{m}$ at a\#7) and laterally more extensive than in Pagany Wash. Thus, it is conceivable that the insulation effects of the alluvial fill in Drill Hole Wash could affect temperature gradients deeper in the TSw. Smaller gradients in the TSw also probably are due to the effects of nonconductive heat-flow processes (such as infiltration and deep percolation) that involve coupled heat and mass transport. Alternatively, the smaller gradients may be due to lower, deep-seated, geothermal heat flow in this locality (Fridrich and others, 1994), although this seems unlikely. The possible hydrologic implications of channel fill and percolation on temperature gradients are examined in more detail in the section of this report titled Analysis of Percolation Flux Based on Heat Flow Estimated in Boreholes.

The association of small temperature gradients in the TSw beneath alluvium-filled channels and large temperature gradients along hillslopes and ridges indicates higher heat flow in the TSw where the unsaturated zone section is thickest. The thermal conductivity of the TSw is well constrained, ranging from 1.61 to 1.82 joules per second per meter per ${ }^{\circ} \mathrm{C}\left(\mathrm{J} / \mathrm{s} / \mathrm{m} /{ }^{\circ} \mathrm{C}\right)$ (see section of this report titled Analysis of Percolation Flux Based on Heat Flow Estimated in Boreholes). This cannot explain large differences in gradient in order to maintain a vertical and areally uniform heat-flow field (that is, a 45-percent difference in gradient and a 12-percent difference in thermal conductivity). The above generalization appears to be true for the North Ramp study area, which has two major drainages (Drill Hole Wash and Pagany Wash), but it may not be true elsewhere on Yucca Mountain. Sass and others (1988) noted an inverse correlation between total thickness of the unsaturated zone and heat flow in their one-dimensional analyses, which included data from many boreholes outside the North Ramp study area. This inverse relation is consistent with topographically induced heat-flow divergence beneath topographic highs and with heat-flow convergence beneath topographic lows. In contrast, the temperature data from boreholes in the North Ramp study area, with the exception of WT\#18, on a very steep ridge near the northern boundary of the study area, appear to support a direct correlation between heat flow and unsaturated-zone thickness.

Changes in temperature gradients occur in all boreholes across the PTn-TSw contact because of major differences between the thermal conductivities of nonwelded and welded tuffs. Temperature gradients within the PTn are larger than those in the underlying TSw because of the lower thermal conductivities for the nonwelded subunits of the PTn. Gradients across the composite PTn section vary from less than $2^{\circ} \mathrm{C}$ per $100 \mathrm{~m}$ to greater than 4 to $5^{\circ} \mathrm{C}$ per $100 \mathrm{~m}$ (table 17). Temperature gradients within the PTn tend to show more geographic variability than gradients within the TSw (see temperature profiles of Sass and others, 1988). Variability in the gradient across the PTn can be attributed to a number of factors: (1) differences in heat flow from the underlying $\mathrm{TSw}$, 
Table 17. Temperature gradients in boreholes for the Paintbrush nonwelded and Topopah Spring welded hydrogeologic units

[PTn, Paintbrush nonwelded hydrogeologic unit; TSw, Topopah Spring welded hydrogeologic unit; ${ }^{\circ} \mathrm{C}$, degree Celsius; $<$, less than; $\ll<$, much less than; --, not applicable or not measured; temperature gradients for open boreholes calculated using temperature data from Sass and others (1988)]

\begin{tabular}{|c|c|c|c|c|c|c|c|c|}
\hline $\begin{array}{c}\text { Borehole } \\
\text { (type) }\end{array}$ & $\begin{array}{l}\text { Geomorphic } \\
\text { setting }\end{array}$ & $\begin{array}{l}\text { Hydrogeologic unit } \\
\text { (including } \\
\text { formations within } \\
\text { PTn) }\end{array}$ & $\begin{array}{l}\text { Temperature } \\
\text { gradient } \\
\text { ("C per } 100 \\
\text { meters) }\end{array}$ & $\begin{array}{l}\text { Depth } \\
\text { interval } \\
\text { (meters) }\end{array}$ & $\begin{array}{l}\text { Thickness } \\
\text { of PIn } \\
\text { (meters), } \\
\text { data source }\end{array}$ & $\begin{array}{l}\text { Thickness } \\
\text { of alluvium } \\
\text { (meters) }\end{array}$ & $\begin{array}{c}\text { Temperature } \\
\text { (depth about } \\
15 \text { meters) } \\
\text { ("C) }\end{array}$ & Remarks for each borehole \\
\hline \multirow{7}{*}{$\begin{array}{l}\text { USW UZ-1 } \\
\text { (instrumented, } \\
\text { stemmed) }\end{array}$} & channel & Alluvium & -- & -- & -- & 17 & 20 & ${ }^{a}$ Measured with thermocouples. \\
\hline & & PTn & -- & -- & $1,268.9$ & -- & -- & \\
\hline & & Yucca Mountain Tuff & $<0^{c}$ & -- & - & -. & -- & \multirow{5}{*}{$\begin{array}{l}{ }^{c} \text { Gradient reversal across Yucca } \\
\text { Mountain Tuff. }\end{array}$} \\
\hline & & Pah Canyon Tuff & $3.16^{\mathrm{a}}$ & $40-81$ & -- & -- & -- & \\
\hline & & & $2.30^{\mathrm{h}}$ & $30-61$ & & & & \\
\hline & & TSw & $1.74^{\mathrm{a}}$ & $153-367$ & -- & -. & -- & \\
\hline & & & $1.72^{\mathrm{b}}$ & $122-360$ & & & & \\
\hline
\end{tabular}

\begin{tabular}{|c|c|c|c|c|c|c|c|c|}
\hline \multirow{3}{*}{$\begin{array}{l}\text { USW NRG-7a } \\
\text { (instrumented, } \\
\text { stemmed) }\end{array}$} & hillslope & Alluvium & -- & -- & - & 3 & 18.3 & \multirow{3}{*}{$\begin{array}{l}\text { Measured with thermistors. } \\
\text { ID - insufficient data to calculate } \\
\text { gradient. }\end{array}$} \\
\hline & & PTn & ID & - & ${ }^{4} 69.0$ & -- & -- & \\
\hline & & TSw & 2.05 & $118-204$ & -- & -- & -- & \\
\hline
\end{tabular}

\begin{tabular}{|c|c|c|c|c|c|c|c|c|}
\hline \multirow{3}{*}{$\begin{array}{l}\text { USW NRG-6 } \\
\text { (instrumented, } \\
\text { stemmed) }\end{array}$} & \multirow[t]{3}{*}{ hillslope } & Alluvium & -- & -- & -. & 0 & 19.3 & \multirow[t]{3}{*}{ Measured with thermistors. } \\
\hline & & PTn & 3.05 & $55-85$ & 538.5 & -- & -- & \\
\hline & & TSw & 2.03 & $85-220$ & - & -- & -- & \\
\hline \multirow{3}{*}{$\begin{array}{l}\text { UE-25 NRG\#4 } \\
\text { (instrumented, } \\
\text { packers) }\end{array}$} & \multirow[t]{3}{*}{ ridge } & Alluvium & -- & -- & -- & 0 & no data & \multirow[t]{3}{*}{ Measured with thermocouples. } \\
\hline & & PTn & 4.42 & $95-140$ & $3,553.1$ & - & -- & \\
\hline & & TSw & 2.55 & $154-202$ & -- & -- & -- & \\
\hline \multirow{5}{*}{$\begin{array}{l}\text { UE-25 UZ\#4 } \\
\text { (instrumented, } \\
\text { stemmed) }\end{array}$} & \multirow[t]{5}{*}{ channel } & Alluvium & -- & -- & - & 12 & 19.3 & \multirow{5}{*}{$\begin{array}{l}\text { Measured with thermistors. } \\
{ }^{a} \text { Measured across PTn-TSw tran- } \\
\text { sition zone. }\end{array}$} \\
\hline & & PTn & -- & -- & 684.1 & -. & -- & \\
\hline & & Yucca Mountain Tuff & 2.62 & $35-45$ & -- & -. & - & \\
\hline & & Pah Canyon Tuff & 5.17 & $56-88$ & -- & -. & - & \\
\hline & & TSw & $\ll<2.40^{\mathrm{a}}$ & $104-112$ & -- & .. & -- & \\
\hline
\end{tabular}




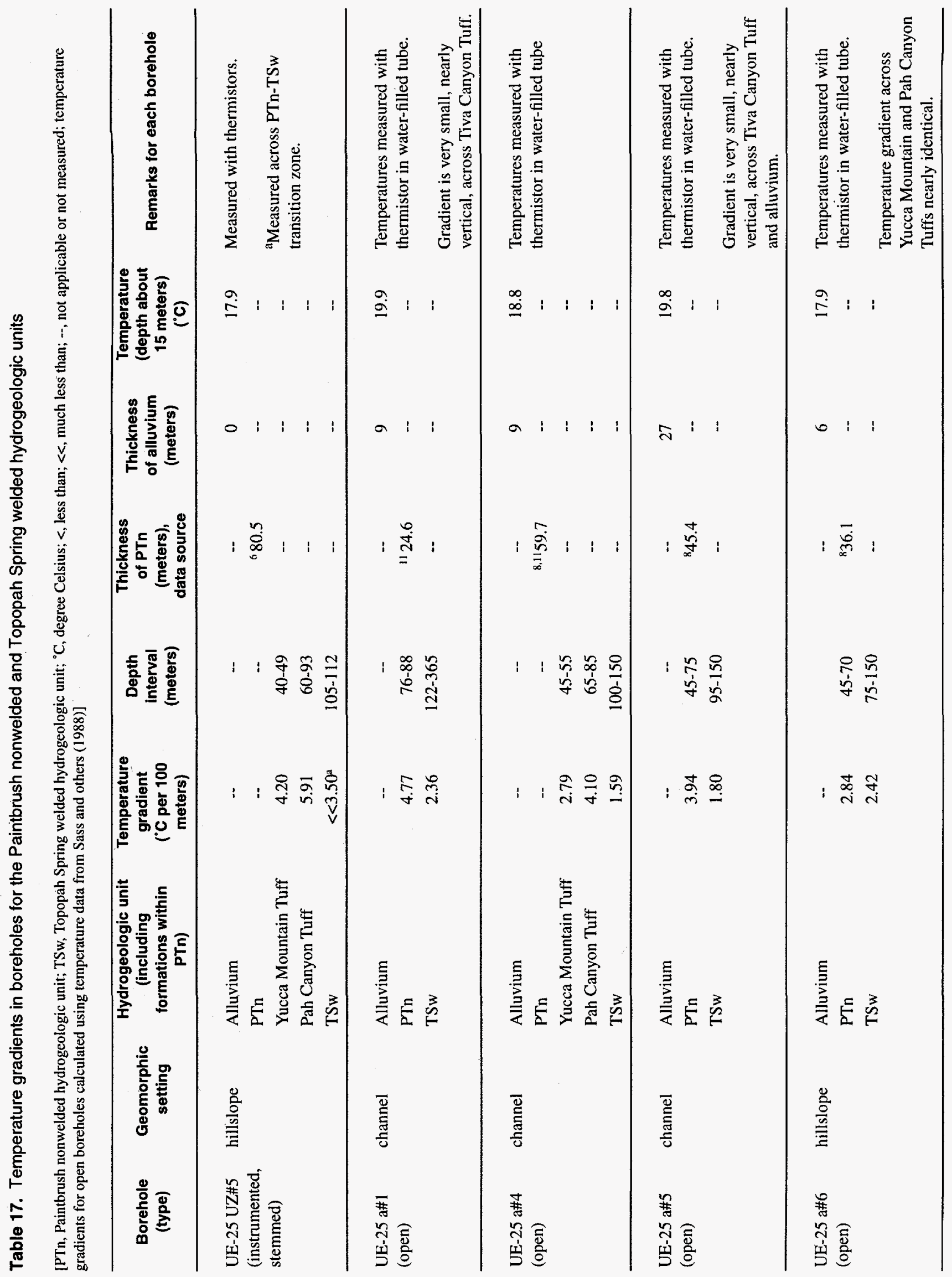


Table 17. Temperature gradients in boreholes for the Paintbrush nonwelded and Topopah Spring welded hydrogeologic units

[PTn, Paintbrush nonwelded hydrogeologic unit; TSw, Topopah Spring welded hydrogeologic unit; ${ }^{\circ} \mathrm{C}$, degree Celsius; $<$, less than; $<<$, much less than; --, not applicable or not measured; temperature gradients for open boreholes calculated using temperature data from Sass and others (1988)]

\begin{tabular}{|c|c|c|c|c|c|c|c|c|}
\hline $\begin{array}{c}\text { Borehole } \\
\text { (type) }\end{array}$ & $\begin{array}{l}\text { Geomorphic } \\
\text { setting }\end{array}$ & $\begin{array}{l}\text { Hydrogeologic unit } \\
\text { (including } \\
\text { formations within } \\
\text { PTn) }\end{array}$ & $\begin{array}{c}\text { Temperature } \\
\text { gradient } \\
\text { (C per } 100 \\
\text { meters) }\end{array}$ & $\begin{array}{l}\text { Depth } \\
\text { interval } \\
\text { (meters) }\end{array}$ & $\begin{array}{l}\text { Thickness } \\
\text { of PTn } \\
\text { (meters), } \\
\text { data source }\end{array}$ & $\begin{array}{l}\text { Thickness } \\
\text { of alluvium } \\
\text { (meters) }\end{array}$ & $\begin{array}{l}\text { Temperature } \\
\text { (depth about } \\
15 \text { meters) } \\
\text { ('C) }\end{array}$ & Remarks for each borehole \\
\hline \multirow{3}{*}{$\begin{array}{l}\text { UE- } 25 \text { a\#7 } \\
\text { (open, angle of } \\
\text { borehole } 26^{\circ} \\
\text { from vertical) }\end{array}$} & \multirow{3}{*}{ channel } & Alluvium & -- & -- & -- & 42 & 17.5 & \multirow{2}{*}{$\begin{array}{l}\text { Temperatures measured with ther- } \\
\text { mistor in water-filled tube. }\end{array}$} \\
\hline & & PTn & 4.68 & $48-70$ & 841.5 & -- & -- & \\
\hline & & TSw & 1.86 & $183-270$ & & -- & -- & $\begin{array}{l}\text { Very large gradient perturbation } \\
\text { across upper section of Topopah } \\
\text { Spring Tuff (Sass, 1988). }\end{array}$ \\
\hline
\end{tabular}

$\begin{array}{llllll}\text { USW G-1 channel } & \text { Alluvium } & -- & -- & 18 & 20.7\end{array}$

(open)

\begin{tabular}{llrl} 
Alluvium & -- & -- & -- \\
PTn & -- & -- & 964.0 \\
Yucca Mountain Tuff & $0.20-<0^{\mathrm{a}}$ & $30-45$ & -- \\
Pah Canyon Tuff & 2.07 & $45-75$ & -- \\
TSw & 1.50 & $125-270$ & -- \\
\hline
\end{tabular}

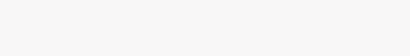

\begin{tabular}{|c|c|c|c|c|c|c|c|c|}
\hline \multirow{3}{*}{$\begin{array}{l}\text { USW G-4 } \\
\text { (open) }\end{array}$} & \multirow[t]{2}{*}{ channel } & Alluvium & -- & -- & $\therefore$ & 9 & 20.5 & \multirow{2}{*}{$\begin{array}{l}\text { Measured with thermistor in } \\
\text { water-filled tube. }\end{array}$} \\
\hline & & PTn & 3.71 & 45-67 & 1137.6 & -- & - & \\
\hline & valley floor & TSw & 1.72 & $137-395$ & -- & -- & -- & $\begin{array}{l}\text { Gradient reversal across the Tiva } \\
\text { Canyon Tuff. }\end{array}$ \\
\hline
\end{tabular}

\begin{tabular}{|c|c|c|c|c|c|c|c|c|}
\hline \multirow{3}{*}{$\begin{array}{l}\text { USW H-1 } \\
\text { (open) }\end{array}$} & channel & $\begin{array}{l}\text { Alluvium } \\
\text { PTn }\end{array}$ & -- & $\overline{0}$ & -- & 0 & No data & \multirow{3}{*}{$\begin{array}{l}\text { Measured with thermistor in air- } \\
\text { filled tube. }\end{array}$} \\
\hline & \multirow[t]{2}{*}{ valley floor } & & & & & & & \\
\hline & & TSw & 1.77 & $213-457$ & -- & -- & -- & \\
\hline \multirow{3}{*}{$\begin{array}{l}\text { UE-25 WT\#4 } \\
\text { (open) }\end{array}$} & hillslope & Alluvium & -- & -- & -- & 15 & No data & \multirow{3}{*}{$\begin{array}{l}\text { Measured with thermistor in air- } \\
\text { filled tube. }\end{array}$} \\
\hline & & PTn & 4.17 & $86-132$ & ${ }^{2} 66.4$ & -- & -- & \\
\hline & alluvial fan & TSw & 2.52 & $183-335$ & -- & -- & -- & \\
\hline
\end{tabular}


$\vec{g}$ Table 17. Temperature gradients in boreholes for the Paintbrush nonwelded and Topopah Spring welded hydrogeologic units

[PTn, Paintbrush nonwelded hydrogeologic unit; TSw, Topopah Spring welded hydrogeologic unit; ${ }^{\circ} \mathrm{C}$, degree Celsius; $<$, less than; $\ll$, much less than; --, not applicable or not measured; temperature gradients for open boreholes calculated using temperature data from Sass and others (1988)]

\begin{tabular}{|c|c|c|c|c|c|c|c|c|}
\hline $\begin{array}{l}\text { Borehole } \\
\text { (type) }\end{array}$ & $\begin{array}{l}\text { Geomorphic } \\
\text { setting }\end{array}$ & $\begin{array}{l}\text { Hydrogeologic unit } \\
\text { (including } \\
\text { formations within } \\
\text { PTn) }\end{array}$ & $\begin{array}{c}\text { Temperature } \\
\text { gradient } \\
\text { ("C per } 100 \\
\text { meters) }\end{array}$ & $\begin{array}{l}\text { Depth } \\
\text { interval } \\
\text { (meters) }\end{array}$ & $\begin{array}{l}\text { Thickness } \\
\text { of PTn } \\
\text { (meters), } \\
\text { data source }\end{array}$ & $\begin{array}{l}\text { Thickness } \\
\text { of alluvium } \\
\text { (meters) }\end{array}$ & $\begin{array}{c}\text { Temperature } \\
\text { (depth about } \\
15 \text { meters) } \\
\text { ("C) }\end{array}$ & Remarks for each borehole \\
\hline \multirow{3}{*}{$\begin{array}{l}\text { UE-25 WT\#18 } \\
\text { (open) }\end{array}$} & ridge & Alluvium & -- & $\cdots$ & $-\cdots$ & 0 & No data & \multirow{3}{*}{$\begin{array}{l}\text { Measured with thermistor in air- } \\
\text { filled tube. }\end{array}$} \\
\hline & & PTn & 3.28 & $91-152$ & ${ }^{2} 120.7$ & - & $\therefore$ & \\
\hline & & TSw & 1.77 & $213-457$ & -. & -- & -- & \\
\hline
\end{tabular}

${ }^{\mathrm{l}}$ Whitfield and others (1990)

Buesch, U.S. Geological Survey, written commun.(1996)

${ }^{3}$ Moyer, Geslin, and Buesch (1995)

${ }^{4}$ Geslin and Moyer (1995).

${ }^{5}$ Geslin, Moyer, and Buesch (1995).

${ }^{6}$ Loskot and Hammermeister (1992)

${ }^{7}$ Rush, Thordarson, and Pyles (1984).

${ }^{8}$ Spengler and Rosenbaum (1980)

${ }^{9}$ Spengler and others (1981)

${ }_{10}$ Buesch and others (1994).

"Moyer, Geslin, and Flint (1996). 
(2) proximity of the PTn to the land surface, and hence to the influence of topographic effects and seasonal temperature changes, (3) the presence or absence of alluvial fill, and (4) differences in thermal conductivity, which is sensitive to variability in porosity and saturation values (see the section of this report titled Analysis of Percolation Flux Based on Heat Flow Estimated in Boreholes).

Temperature gradients within the TSw tend to be small and are strongly affected by seasonal surfacetemperature changes. Temperature profiles for the instrumented and stemmed boreholes indicate that land-surface temperature changes are propagated down to depths of about $15 \mathrm{~m}$. These data also indicate that temperatures at this depth tend to be higher in boreholes located within or near active channels (table 17) because of the low thermal conductivity of the alluvial fill.

\section{Aqueous-Phase Chemistry}

Aqueous-phase hydrochemical data are interpreted in this section to determine possible flow mechanisms and residence times for pore water in the unsaturated zone. The data consist of chemical compositions (major cations and anions) and isotopic concentrations, which include tritium $\left({ }^{3} \mathrm{H}\right)$, carbon-14 $\left({ }^{14} \mathrm{C}\right)$, and carbon-13 $\left(\delta^{13} \mathrm{C}\right)$, of pore water in cores obtained from unsaturated-zone boreholes. From the present chemical and isotopic data, along with previously published data collected from borehole UZ-1 (Yang and others, 1993), preliminary conceptual hydrologic flow models are described. Also, chemical compositions of pore water in different lithologic units are presented in Piper (Piper, 1944) diagrams.

Chemical compositions of pore water in boreholes NRG-6, NRG-7a, and UZ-14 were analyzed from core samples obtained from nonwelded tuffs, bedded tuffs, and the Calico Hills Formation because of high moisture content in these units. Because of the small volumes of water obtainable by pore-water extraction (about $70-80 \mathrm{~mL}$ of water are required for each ${ }^{14} \mathrm{C}$ analysis), complete analyses of major- and trace-element concentrations in individual samples were not possible; only major ions were analyzed.

A trilinear (Piper) diagram is a convenient graphical method for displaying the chemical composition of a water sample. Major cations (sodium plus potassium, calcium, and magnesium concentrations in percentage of total milliequivalents per liter) are repre- sented by one symbol in the lower left-hand-side triangle, and major anions (chloride, sulfate, and bicarbonate plus carbonate in percentage milliequivalents per liter) of the same sample are also represented by the same symbol in the lower right-hand-side triangle (fig. 103). When these two major cation and anion locations are projected upward parallel to their respective grids, they intersect at one point in the upper diamond-shaped diagram and are represented by the same symbol for both major cation and anion compositions of that sample.

The locations in the diamond-shaped diagram represent the type of water composition for each sample. Calcium chloride or calcium sulfate recharging water interacting with near-surface or shallow-depth soils will be located near the top part of the diamond. The ground water that has interacted with deep Calico Hills Formation rocks will result in sodium carbonate bicarbonate type water, located near the lower part of the diamond. The middle part of the diamond represents intermediate chemical compositions for ground water in the Topopah Spring Tuff. The concentrations of dissolved solids in pore water, expressed in milligrams per liter $(\mathrm{mg} / \mathrm{L})$, are represented by the circle size.

\section{Pore-Water Composition from Boreholes USW UZ-14, USW NRG-6, and USW NRG-7a}

The trends of the pore-water compositions from UZ-14 (fig. 103) are, in general, consistent in that ground-water samples are calcium bicarbonate, sulfate, or chloride type at shallow depths (top of diamond in the Piper diagram) and sodium bicarbonate or carbonate types (near the bottom of diamond) in the Calico Hills Formation. The composition of the pore-water sample from $13.8 \mathrm{~m}$ in UZ-14 is an exception to this trend (point 1 in figure 103). This core sample is from the Yucca Mountain Tuff, and the pore water has very high concentration of dissolved solids. The water is not calcium chloride or sulfate type typical of the shallow-depth pore water, but it is similar to the Topopah Spring Tuff pore water, which has an intermediate composition on the diagram (points $\mathrm{G}$ and $\mathrm{L}$ ). Repeated concentration of pore water by evaporation and/or extended water/rock interactions might result in the observed larger dissolvedsolids concentration.

The pore-water compositions for samples from boreholes NRG-6 and NRG-7a are shown in the Piper 


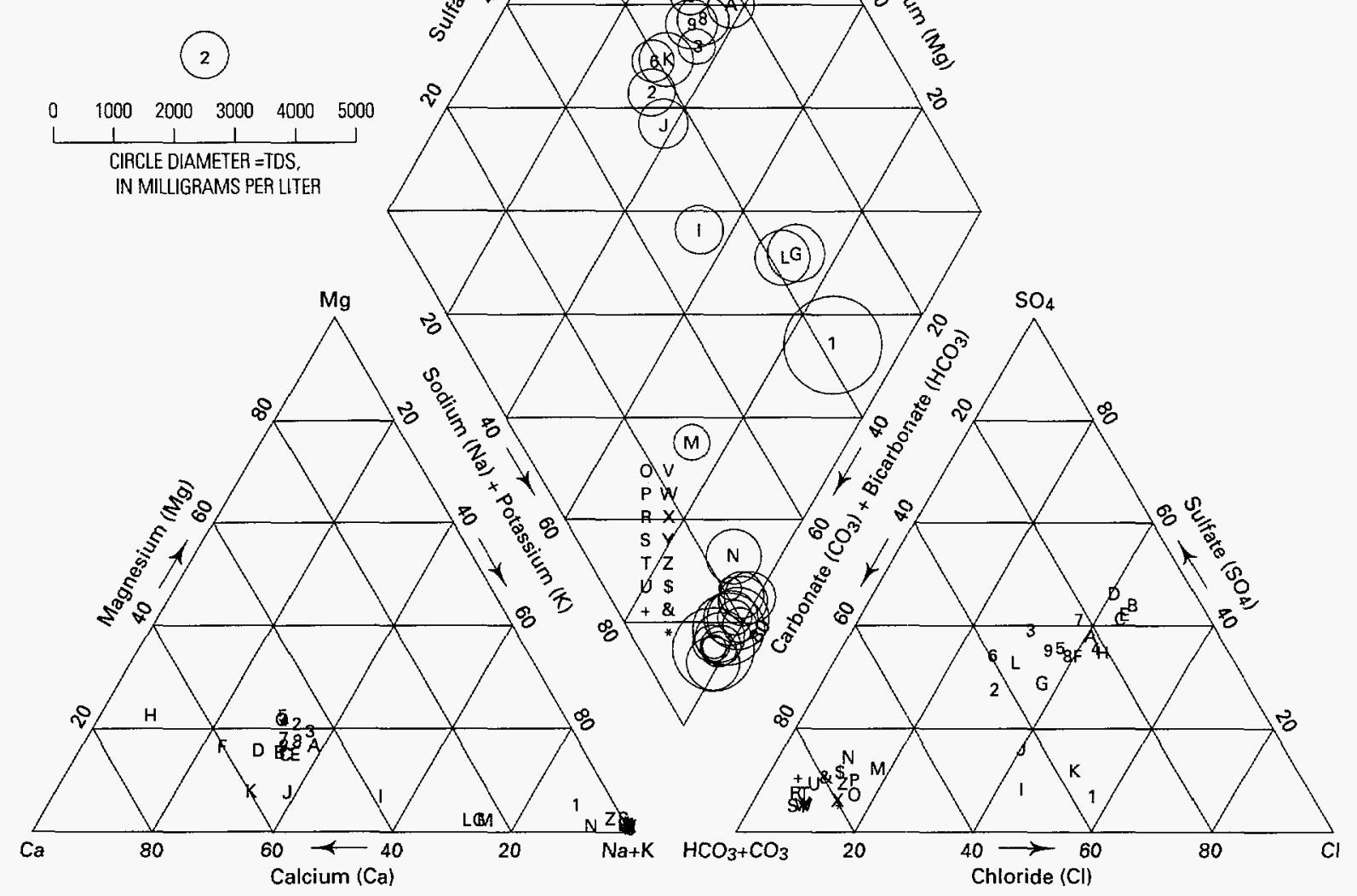

PERCENTAGE OF TOTAL MILLIEQUIVALENTS PER LITER

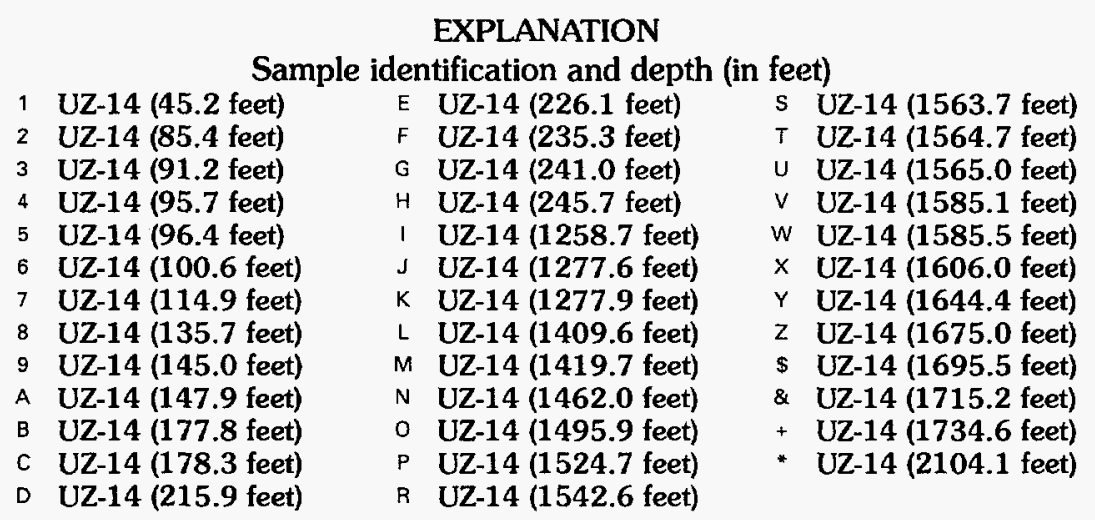

Figure 103. Piper diagram showing pore-water compositions of borehole USW UZ-14. 
diagram in figure 104. Most of the pore-water samples contain less than $1,000 \mathrm{mg} / \mathrm{L}$ in dissolved solids.

Sample G, however, which is pore water from the upper Topopah Spring Tuff at a depth of $78 \mathrm{~m}$ in borehole NRG-6, contains about $3,500 \mathrm{mg} / \mathrm{L}$ in dissolved solids. The sample is too deep in the borehole for the large concentration to be explained as a result of surface evaporation. Rather, such a large concentration of dissolved solids probably resulted from prolonged contact of percolating water with the less permeable silicate rocks without replacement by fresher, younger water.

\section{Aqueous-Phase Isotopic Data from Boreholes USW UZ-14, UE-25 UZ\#4, UE-25 UZ\#5, USW NRG-6, and USW NRG-7a}

A vacuum distillation method (Thatcher and others, 1977) was used to extract water from core samples for tritium measurement. In vacuum distillation, water from cores is distilled by heat in a vacuum system, and the vaporized water is captured in a cold trap. This method is especially useful for obtaining additional water from core samples which have already undergone high-pressure compression for pore-water extraction.

Delta carbon- 13 and ${ }^{14} \mathrm{C}$ data were obtained from analyses of pore water extracted from the cores by using a high-pressure, one-dimensional (uniaxial) compression procedure (Mower and others, 1991, 1994; Higgins and others, 1997). The densely welded Topopah Spring Tuff, which generally has less than a 5-percent moisture content by weight, cannot yield water by compression. Therefore, no $\delta^{13} \mathrm{C}$ and ${ }^{14} \mathrm{C}$ data were obtained from the low-moisture content cores.

Tritium

Tritium concentrations in pore-water samples were determined using a liquid-scintillation counter in a USGS laboratory in Denver, Colorado. The detection limit for the liquid-scintillation counter is 4 tritium units (TU). The precision of measurements is $3.5 \mathrm{TU}$. Accuracy of the measurement is routinely calibrated against the NBS/NIST tritium standard [Standard Reference Material 4947, 1.3 becquerels per gram (September 1978)]. The measurements are within 3 percent of the known value.

The tritium concentration in precipitation before atmospheric testing of nuclear weapons (pre-1952) was about 10 TU (Davis and Bentley, 1982). Between 1952 and 1963, however, atmospheric nuclearweapons tests conducted in the northern hemisphere produced significant amounts of tritium in the Earth's atmosphere. As a result, the tritium concentration in precipitation increased rapidly beginning in 1952 and peaked in the early 1960's. By 1954, atmospheric testing of nuclear weapons had increased the average annual tritium concentration in precipitation near Yucca Mountain to about $200 \mathrm{TU}$, with a monthly maximum of about 700 TU. By 1963, further nuclear tests in the atmosphere had increased the average annual tritium concentration in precipitation to about $2,000 \mathrm{TU}$, with a monthly maximum of about 4,000 TU (International Atomic Energy Agency, 1969-1986). Michael (1989) reported a yearly tritium-concentration average of $2,700 \mathrm{TU}$ in precipitation collected in 1963 at a Salt Lake City, Utah, station. A nuclear-test ban in 1963 stopped further tests in the atmosphere, and the tritium concentration gradually decreased to the present level of about 10 to 40 TU measured in precipitation at the Nevada Test Site (Milne and others, 1987). After three half-lives of tritium decay from 1954 to 1990 , the average annual tritium concentration in precipitation for 1954 that infiltrated into the subsurface would be about $25 \mathrm{TU}$, with a monthly maximum of about 87 TU. For 1963 infiltration, the average annual tritium concentration in precipitation after two half-lives from 1963 to 1987 would be about $500 \mathrm{TU}$, with a monthly maximum of 1,000 TU. Therefore, pore-water samples extracted from rock core with tritium concentrations between the 4-TU detection limit and $25 \mathrm{TU}$ in 1990 contain some component of post-1954 precipitation or are contaminated as a result of sample processing (Yang and others, 1996). However, there is a high level of confidence that water samples with tritium concentrations greater than 25 TU contain post- 1954 precipitation irrespective of any contamination that may have occurred during sample processing. Further, if the piston-flow model for flow through the unsaturated zone is assumed rather than the well-mixed model (Yang and others, 1996), tritium concentrations greater than 25 TU can be attributed to pore water that has been derived primarily from post-1954 precipitation. The piston-flow model does not consider hydrodynamic-dispersive mixing within the unsaturated zone (Yang and others, 1996) and is applicable to rapid flow of water through fractures where interaction with the rock matrix is minimal. 

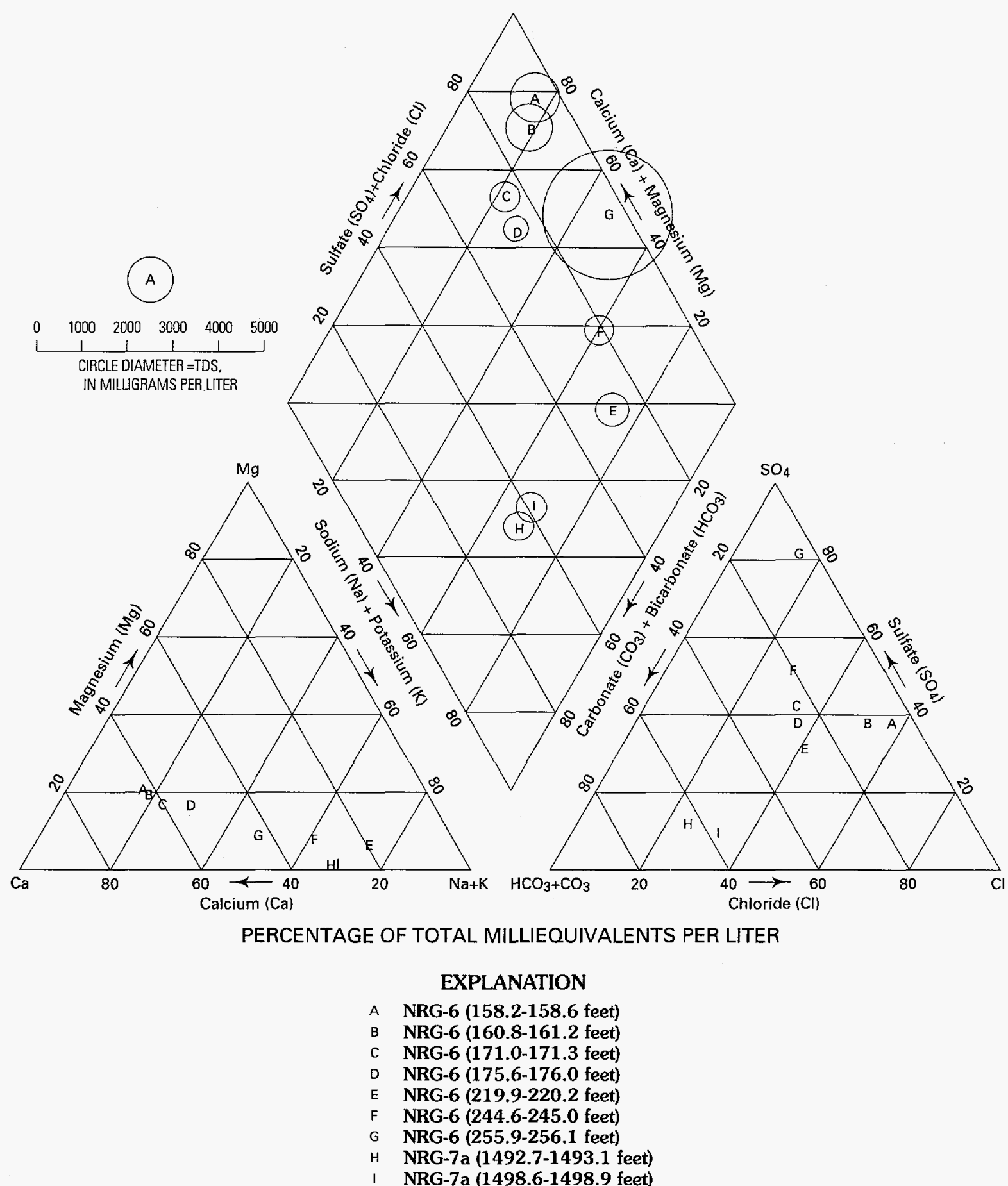

PERCENTAGE OF TOTAL MILLIEQUIVALENTS PER LITER

\section{EXPLANATION}

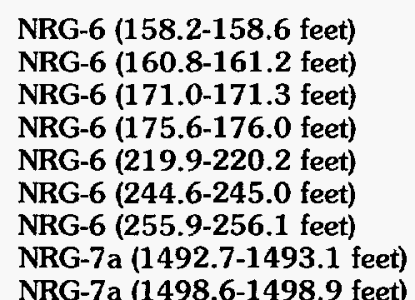

Figure 104. Piper diagram showing pore-water compositions of boreholes USW NRG-6 and USW NRG-7a. 
Previously analyzed tritium concentrations were interpreted, not to determine the age of pore water in the unsaturated zone (age determinations of water are performed most appropriately by a tritium-enrichment technique using at least 1 liter of water), but rather to identify pore water in which the presence of post-1954 precipitation is unequivocal. Water-content and tritium data of pore water from boreholes UZ\#4 and UZ\#5 cores and cuttings are shown in figure 105. Tritium data for UZ\#4 and UZ\#5 were collected prior to implementation of the approved USGS YMP quality-assurance program and, therefore, are non-Q. The tritium concentrations in UZ\#4 borehole range from 0 to $45 \mathrm{TU}$, and the peak concentration is present between 46 and $49 \mathrm{~m}$ (fig. 105A). In UZ\#5 the peak concentration of $75 \mathrm{TU}$ is at about $32 \mathrm{~m}$ (fig. 105B). The larger tritium concentrations at these depths relative to the tritium concentrations of 30 to $40 \mathrm{TU}$ in precipitation during the 1980 's are likely the result of water that infiltrated in the early 1960 's. No tritium data were obtained from the surface to a depth of $25 \mathrm{~m}$ in borehole UZ\#5 because the cores were not available for pore-water extraction. Similarly, no tritium data are available at depths between 50 and $95 \mathrm{~m}$ in UZ\#4 or between 47 and $67 \mathrm{~m}$ in UZ\#5.

UZ-14 tritium-concentration profiles for pore waters are shown in figure 106. They do not show any significantly large concentrations. Several peaks at 18 to 30 TU in the Pah Canyon Tuff, however, are likely relicts from the post-bomb era.

Only small intervals of the NRG-6 and NRG-7a cores were analyzed for pore-water tritium and ${ }^{14} \mathrm{C}$ (fig. 107). High tritium concentrations of about 30 to 150 TU in a broad peak are observed in NRG-6 (fig. 107A) at depths between 53.3 and $74.7 \mathrm{~m}$ in the Pah Canyon Tuff and near the top of the Topopah Spring Tuff. One such high tritium concentration (about $45 \mathrm{TU}$ ) also is apparent in NRG-7a near the top of the Topopah Spring Tuff.

From the tritium data observed in the boreholes mentioned above, tritium-concentration inversions (larger tritium concentrations below smaller ones) are present in many places. These inversions indicate that vertical water percolation through the matrix is not a normal flow mechanism at Yucca Mountain. Postbomb tritium concentrations were observed down to bedded tuffs and the Pah Canyon Tuff of the PTn in many boreholes. The presence of post-bomb tritium in waters below older water in a vertical profile is strong evidence of fracture flow at Yucca Mountain. This conclusion is supported by other, independent information. Field observations have shown that (1) several neutron holes in washes accumulated 0.3 to $0.6 \mathrm{~m}$ of water after storms or snowmelt in the spring, but the water had drained away a day later (A.L. Flint, U.S. Geological Survey, oral commun., 1995); and (2) in borehole UZ\#4 water was observed dripping from the borehole wall near fractures (from field log books and video-camera logs). Also, many fractures (although not all) are coated with calcite, as reported by Whelan and others (1994). These calcite deposits indicate that water has flowed through the fractures, depositing the minerals as they became saturated. These fractures are possible conduits for the rapid flow of young water to substantial depths.

\section{Aqueous-Phase Carbon Isotopes}

Carbon-14 data are reported in percent modern carbon (pmc) against the NBS/NIST oxalic acid Standard Reference Material 4990C standard of July 1983 with a precision of \pm 0.82 percent. Carbon-14 ages are reported in uncorrected radiocarbon years. One carbon-isotope value was obtained from the non-Q cores for each of boreholes UZ\#4 and UZ\#5; these data are non-Q. A ${ }^{14} \mathrm{C}$ age of 1,000 years is indicated for water in UZ\#4 at a depth of 96.0 to $100.6 \mathrm{~m}$, which is in the bedded unit above the Topopah Spring Tuff (fig. 105). The water ${ }^{14} \mathrm{C}$ age of 4,900 years at a depth of 103.5 to $105.2 \mathrm{~m}$ in the upper Topopah Spring Tuff in borehole UZ\#5 (fig. 105) is older than water from the corresponding depth in UZ\#4 by nearly a factor of five (Yang, 1992). Such an abrupt change in ${ }^{14} \mathrm{C}$ age implies rapid flow of younger water through fractures to the location where the younger ${ }^{14} \mathrm{C}$ age is observed (Yang, 1992).

For borehole UZ-14, pore water was extracted for ${ }^{14} \mathrm{C}$ analysis mostly from the high-moisturecontent intervals within the bedded tuffs above the Topopah Spring Tuff and the Calico Hills Formation. Aqueous-phase carbon-14 data from borehole UZ-14 cores are shown in figure 106 along with gaseous ${ }^{14} \mathrm{C}$ data from UZ-1 to indicate how they differ. Although no statistical analysis was performed, qualitative comparison of these data indicates that a nonequilibrium condition may exist between gaseous and aqueous phases. Carbon-13 from gaseous and aqueous phases also shows a nonequilibrium condition. Aqueous ${ }^{14} \mathrm{C}$ values from the top $91 \mathrm{~m}$ range from 70 to $95 \mathrm{pmc}$ and are similar to values for the 

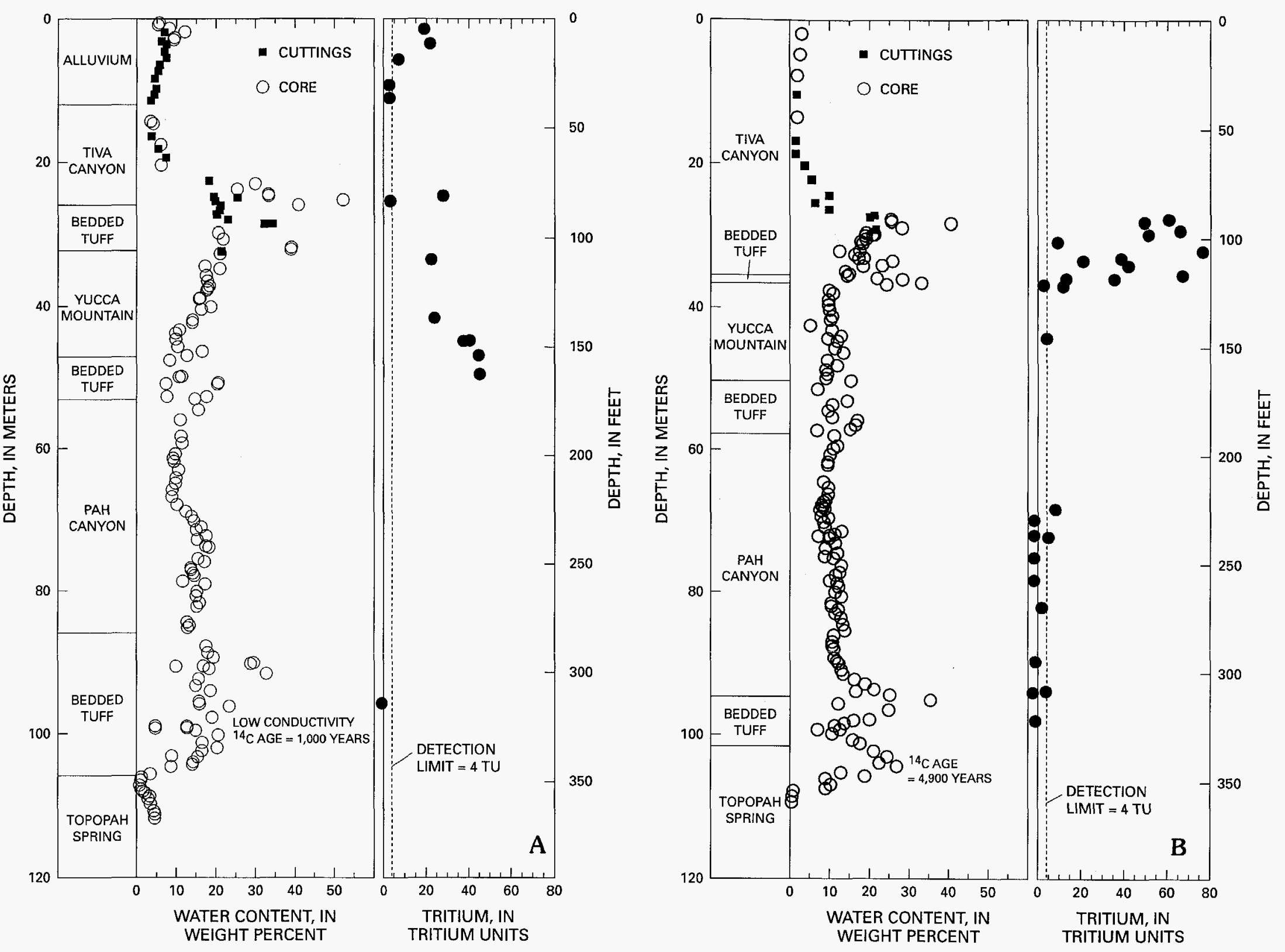

Figure 105. Water content and tritium concentrations from boreholes (A) UE-25 UZ\#4 and (B) UE-25 UZ\#5. 


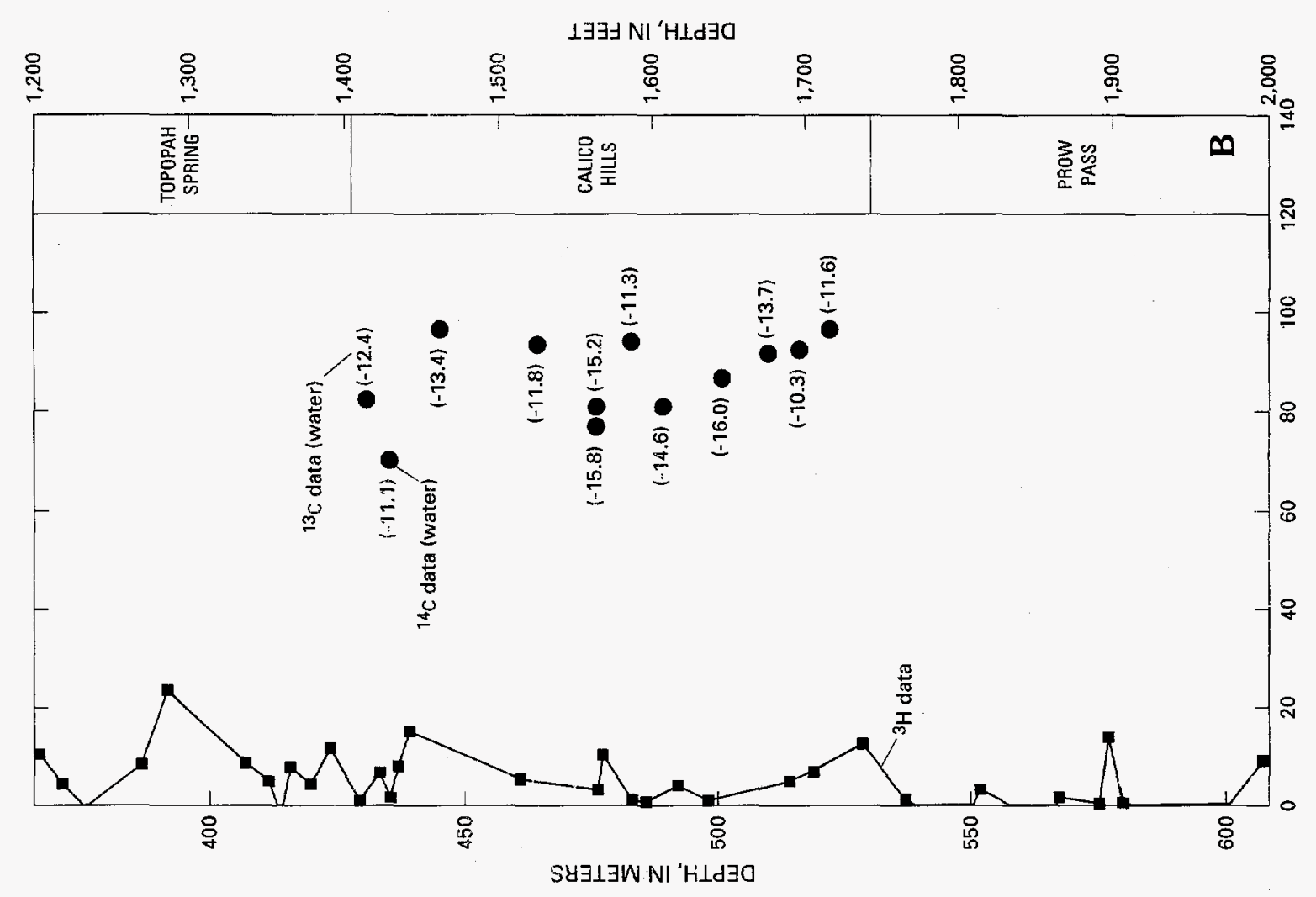

L $\exists \exists \pm N$ N $H \perp d \exists O$

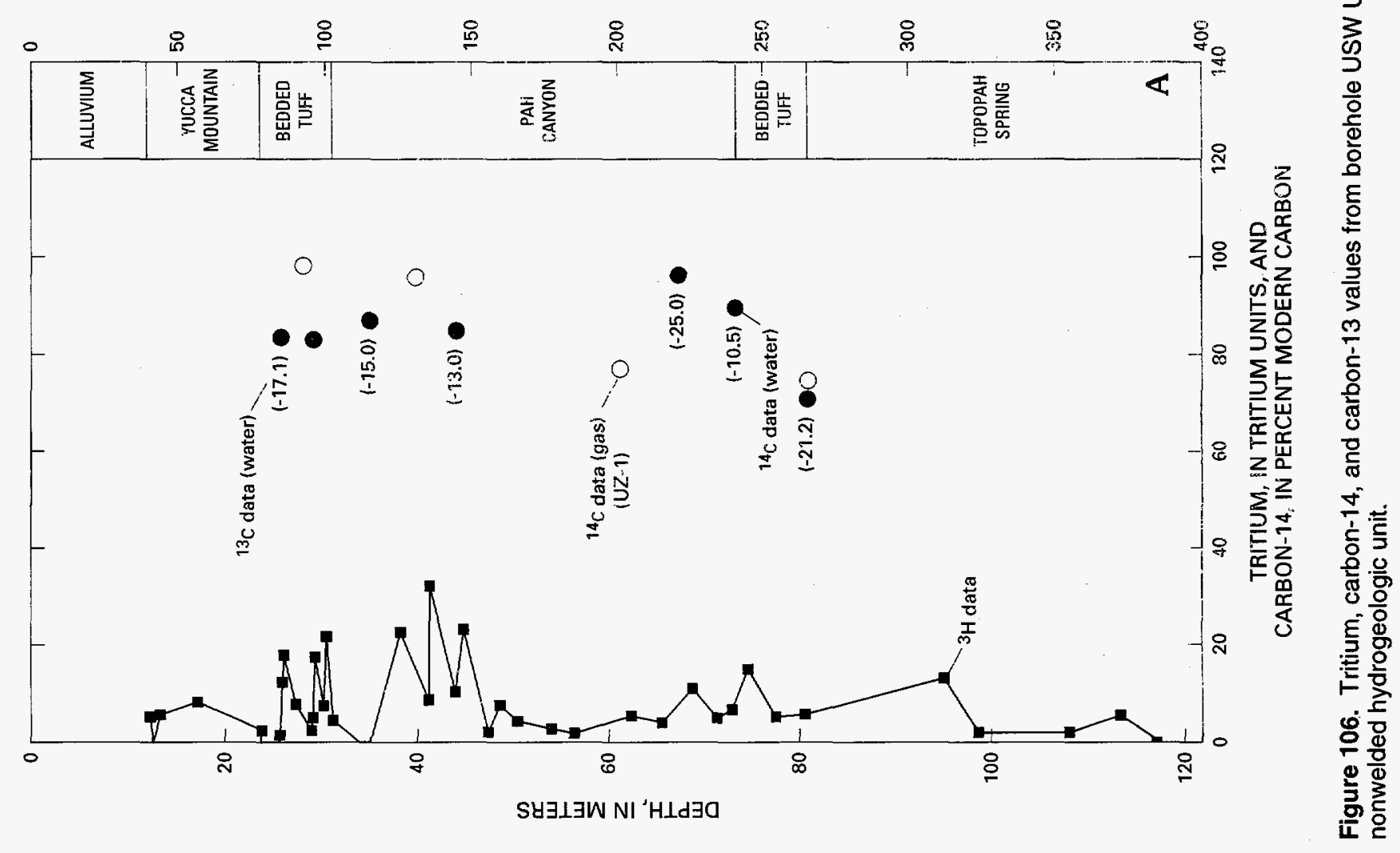



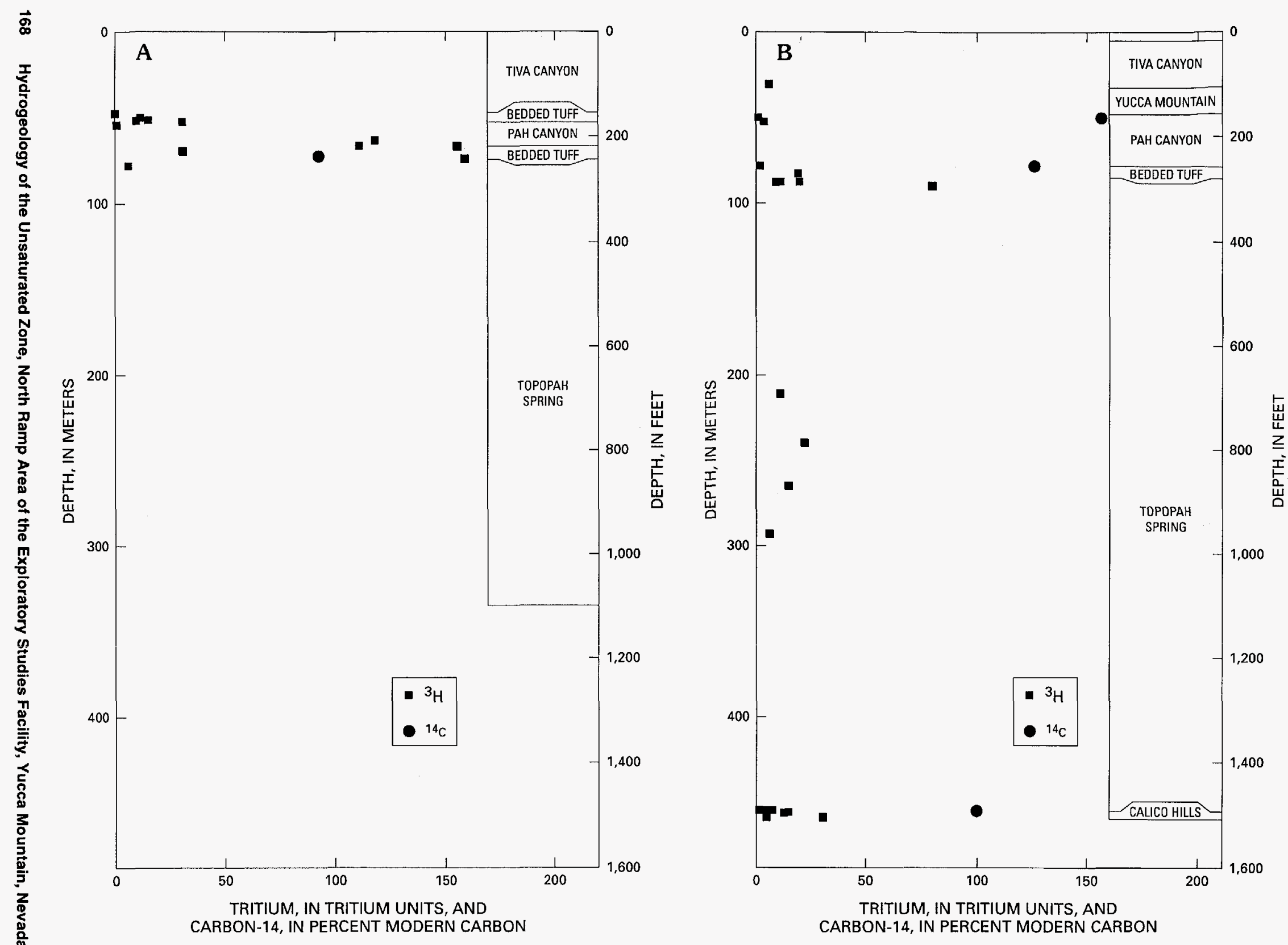

Figure 107. Tritium and carbon-14 (pore water) concentrations from boreholes: (A) USW NRG-6 and (B) USW NRG-7a. 
Calico Hills Formation pore water ${ }^{14} \mathrm{C}$ values, which are between 70 and $96 \mathrm{pmc}$ between depths of 426.7 and $522.4 \mathrm{~m}$ (fig. 106B). Surprisingly, ${ }^{14} \mathrm{C}$ values in the Calico Hills Formation of UZ-14 are between 80 and $96 \mathrm{pmc}$ at depths greater than $500 \mathrm{~m}$. The apparent young ${ }^{14} \mathrm{C}$ ages (or high ${ }^{14} \mathrm{C}$ pmc values) possibly could be due to contamination within the borehole because of (1) young carbon-14-rich carbon dioxide gas $\left({ }^{14} \mathrm{CO}_{2}\right)$ exchanging with the bicarbonate species in the pore water or (2) exchange of young ${ }^{14} \mathrm{CO}_{2}$ from the cement used below the perched-water reservoir at $383.1 \mathrm{~m}$ in order to seal off a borehole wall. Portland cement contains a small amount of calcium hydroxide $\left[\mathrm{Ca}(\mathrm{OH})_{2}\right]$, which will absorb atmospheric $\mathrm{CO}_{2}$ during mixing with water and release the $\mathrm{CO}_{2}$ during exothermic curation. However, the possibility of contamination from these two sources is extremely small because (1) many years of gas sampling at nearby UZ-1 has shown that the ${ }^{14} \mathrm{C}$ activity in $\mathrm{CO}_{2}$ at the base of the Topopah Spring Tuff is about 20 pmc (fig. 80), and (2) the amount of $\mathrm{CO}_{2}$ released from the cement was very small, as was the downward seepage from the perched-water reservoir into the borehole during drilling and after cementing of the borehole.

Although there were no gaseous-phase data for the Calico Hills Formation as of 1996, efforts were under way to obtain such gas samples. If the gaseousphase ${ }^{14} \mathrm{C}$ age from the Calico Hills Formation is significantly older than the aqueous-phase ${ }^{14} \mathrm{C}$ values as seen in UZ-1, the apparent young ${ }^{14} \mathrm{C}$ ages in the aqueous phase will not be attributable to gaseous $\mathrm{CO}_{2}$ and liquid bicarbonate exchange.

Delta carbon-13 values of pore water are shown in parenthesis in figure 106 near the respective ${ }^{14} \mathrm{C}$ data. [The standard for $\delta^{13} \mathrm{C}$ is the PDB standard that consists of $\mathrm{a} \mathrm{CaCO}_{3}$ obtained from a belemnite of the Peedee Formation of South Carolina, as described by Gonfiantini (1978). The precision of $\delta^{13} \mathrm{C}$ analysis is about \pm 0.2 per mil.] Delta carbon- 13 values are not expected to be widespread ( -10.3 to -25 per mil) in unsaturated-zone pore water compared to perched water or saturated-zone waters, which have a larger range of values. Soil $\mathrm{CO}_{2} \delta^{13} \mathrm{C}$ values that have been measured in samples from Yucca Mountain unsaturated-zone boreholes (Yang and others, 1993; Thorstenson and others, 1990) vary from -15 to -20 per mil. Furthermore, variations in ${ }^{14} \mathrm{C}$ ages of caliche that dissolved partially or totally into subsurface water can also affect the ${ }^{14} \mathrm{C}$ ages of the water, making good age corrections very difficult. However, a possible range of ages with some uncertainty might be assigned when more data become available.

An important consideration for apparent ages of water is the effect of mixing young ${ }^{14} \mathrm{C}$ water with the old ${ }^{14} \mathrm{C}$ water. As calculated by Liu and others (1995), if 99 parts (by volume) of 5,000-year-old matrix pore water are mixed with 1 part of bomb-pulse water derived from fracture flow, the effect on the matrix ${ }^{14} \mathrm{C}$ age would be negligible. Such mixing would not affect the apparent age of the matrix water significantly unless the matrix water was at least 35,000 years old.

The other consideration is the exchange of younger ${ }^{14} \mathrm{CO}_{2}$ gas with the pore-water bicarbonate, resulting in pore water that appears younger than it really is. This case is unlikely, as explained earlier, but further confirmation from other boreholes is needed.

\section{Summary of Aqueous-Phase Chemistry}

Unsaturated-zone pore water generally has significantly large concentrations of dissolved solids. Pore water from the Tiva Canyon, Yucca Mountain, Pah Canyon, and bedded tuffs generally is a calcium sulfate or calcium chloride type water. Calico Hills Formation water generally is a sodium carbonate or sodium bicarbonate type water. Pore water from the Topopah Spring Tuff generally is intermediate in composition.

Tritium profiles show inversions in several places. These inversions indicate that vertical water percolation through the matrix is not the dominant flow mechanism at Yucca Mountain. Rather, fracture flow likely is the dominant liquid-water flow mechanism. This conclusion is supported best by post-bomb tritium concentrations observed down to several hundred meters below the land surface in boreholes UZ\#4, UZ\#5, NRG-6, NRG-7a, and UZ-14.

Deep percolation of water by way of fracture flow is evidenced further by the fact that many of the ${ }^{14} \mathrm{C}$ values in the Calico Hills Formation at borehole UZ-14 are between 80 and 95 pmc, equivalent to apparent ${ }^{14} \mathrm{C}$ ages of about 1,800 and 400 years. Further investigations are in progress to confirm these apparent young ${ }^{14} \mathrm{C}$ ages.

The aqueous-phase chemical data described above and the gaseous-phase chemical data described in a preceding section of this report (see GaseousPhase Chemistry) indicate that the two phases are 
apparently not in equilibrium. This is most apparent at boreholes UZ-1 and UZ-14, where gaseous-phase ${ }^{14} \mathrm{C}$ ages in the Topopah Spring welded unit in UZ-1 are significantly older than the aqueous-phase ${ }^{14} \mathrm{C}$-ages in the underlying Calico Hills nonwelded unit in UZ-14 (figs. 80 and 106). This apparent lack of equilibrium between the gaseous and aqueous phases indicates that gas-water interaction has been minimal. If there were significant gas-water interaction, the effect should be readily detectable in the form of gaseous-phase ${ }^{14} \mathrm{C}$ ages significantly younger than those measured, given that most of the carbon in the flow system is in the aqueous phase (Yang and others, 1996). The apparent lack of equilibrium between the gaseous and aqueous phases may be due to one of the following sets of conditions: either (1) the water presently residing in the Calico Hills Formation migrated there along lateral flow paths (possibly from the west) and never came in contact with the gas that is diffusing slowly downward through the Topopah Spring Tuff, or (2) the water in the Calico Hills arrived there by way of rapid, episodic flow through vertical fractures in the Topopah Spring Tuff such that the contact time between the fracture water and the gas was so short that only minimal interaction occurred.

\section{Occurrences of Perched Water in the Vicinity of the Exploratory Studies Facility North Ramp}

By analogy with the definition of a water table, which is a surface along which water pressure is equal to atmospheric pressure, perched water may be defined as an accumulation of water above the regional water table within which water pressure is greater than atmospheric, and outside of which water pressure is less than atmospheric. According to this definition, perched water is not merely a volume of high saturation, but a reservoir from which water will flow freely when intersected by boreholes or tunnels that are under constant atmospheric pressure.

The fact that perched water exists in the vicinity of the potential repository has several implications. The very presence of perched water implies that, at least at some time in the past, the percolation rate through the unsaturated zone has exceeded the saturated hydraulic conductivity of the perching layer. The perched-water reservoir may be a remnant from a time during which percolation rates were higher or may reflect long-term steady-state conditions. Perched-water reservoirs of large volume could indi- cate that structural or stratigraphic traps are present that allow percolating water to accumulate. The mechanical stability of these trapping mechanisms becomes an important issue if perched water is discovered above or updip from the potential repository. Perched water in proximity to the waste-emplacement tunnels in a repository is an additional potential source of water that could become mobilized as vapor as a result of waste-generated heat.

Perched water has been identified in four drydrilled boreholes in the vicinity of the ESF North Ramp (UZ-1, UZ-14, NRG-7a, and SD-9). Because all of the data regarding perched water at UZ-1 were collected prior to implementation of the approved USGS YMP quality-assurance program, these data are non-Q. Although the existence of perched water in UZ-14, NRG-7a, and SD-9 and its relation to lithostratigraphy are based on fully qualified data (field notebooks, vicleo-camera logs), measurements of depth to water and elevation of the water table are non$Q$ because of the non- $Q$ status of measuring-point elevations. Although perched water was not detected in other boreholes in the North Ramp area, they probably were not drilled to sufficient depth to intercept the geologic units where perched water has been identified or they were drilled with water or foam that obscured any perched water that was encountered. Therefore, perched water probably exists near the base of the Topopah Spring Tuff virtually everywhere in the vicinity of the North Ramp.

\section{Borehole UZ-1}

Borehole UZ-1 is in Drill Hole Wash (figs. 5 and 21) at an elevation of $1,348.5 \mathrm{~m}$ above sea level. Drilling stopped at a depth of $387.1 \mathrm{~m}$ when a possible perched-water reservoir was detected (Whitfield and others, 1990, p. 6). The water encountered was at an elevation of $966.7 \mathrm{~m}$, which is about $190 \mathrm{~m}$ above the water table at nearby UZ-14. Although no geologic samples were collected below $370 \mathrm{~m}$ in UZ-1, based on stratigraphy from nearby UZ-14, the top of the perched water is within the lower nonlithophysal unit of the Topopah Spring Tuff (Tptpln) (fig. 41) about $8 \mathrm{~m}$ above the contact with the crystal-poor vitric unit (Tptpv). Chemical analysis of the water showed that it was contaminated by water used to drill G-1, a borehole located about $330 \mathrm{~m}$ to the southeast (Whitfield and others, 1990, p. 6). During the drilling of G-1, 
approximately 8.7 million liters of drilling fluid was lost into the rock (Whitfield, 1985, p. 418).

\section{Borehole UZ-14}

Borehole UZ-14, located about $26 \mathrm{~m}$ from UZ-1 in Drill Hole Wash at an elevation of 1,349.4 m (fig. 21), was drilled to a depth of $677.8 \mathrm{~m}$. Perched water was detected at a depth of $381.7 \mathrm{~m}$ (elevation of $967.7 \mathrm{~m}$ ), which is about $9 \mathrm{~m}$ above the contact between the lower nonlithophysal unit (Tptpln) and the crystal-poor vitric unit (Tptpv) of the Topopah Spring Tuff (fig. 82). The top of the perched water is about $190 \mathrm{~m}$ above the water table. After the water was detected, several pumping tests were conducted to determine if the reservoir could be dewatered (Richard Luckey, U.S. Geological Survey, oral commun., 1994). The perched water was pumped for about 3 days at an average rate of about $0.06 \mathrm{~L} / \mathrm{s}$ (Richard Luckey, written commun., 1994) but fully recovered about 5.6 days after the pumping stopped. This indicates that this perched-water reservoir may be extensive.

\section{Borehole NRG-7a}

Borehole NRG-7a is located in Drill Hole Wash (fig. 21) at an elevation of $1,282.8 \mathrm{~m}$. The borehole was drilled to a depth of $461.3 \mathrm{~m}$ into the top of the Calico Hills Formation (fig. 41). Water was first noticed in the borehole at a depth of $460.2 \mathrm{~m}$, below the contact between the bedded tuff (Tpbt1) and the crystal-poor vitric unit (Tptpv) at the base of the Topopah Spring Tuff. The water level in the borehole then rose about $30 \mathrm{~m}$ to stand at a depth of $430 \mathrm{~m}$ (elevation of $853 \mathrm{~m}$ ), which is $2 \mathrm{~m}$ above the base of the lower nonlithophysal unit (Tptpln). The perched water was initially detected about $91 \mathrm{~m}$ above the predicted water table at this borehole (Ervin and others, 1994, pl. 1). Because perched water was not a high priority at the time NRG-7a was drilled, no pumping tests or television logs were conducted to determine the exact nature and location of the water influx. On the basis of information from other boreholes, it is probable that water entered the borehole prior to the initial detection during drilling.

\section{Borehole SD-9}

Borehole SD-9 is located adjacent to Drill Hole Wash (fig. 21) at an elevation of $1,303.0 \mathrm{~m}$. The borehole was drilled to a total depth of $677.6 \mathrm{~m}$ and water was first noticed at a depth of $448.8 \mathrm{~m}$. Television logs revealed that water is seeping through a fracture into the hole at a depth of $413 \mathrm{~m}$ (elevation of $890 \mathrm{~m}$ ), which is $3 \mathrm{~m}$ above the contact between the lower nonlithophysal unit (Tptpln) and the crystal-poor vitric unit (Tptpv) of the Topopah Spring Tuff (figs. 41 and 81). The water seeping into the borehole is about $157 \mathrm{~m}$ above the predicted water table at SD-9 (Ervin and others, 1994, pl. 1). No pumping tests have been run on this perched-water reservoir, and the magnitude of the perched-water reservoir is uncertain.

\section{Relation of North Ramp Perched Water to Lithology and Geologic Structure}

The stratigraphic location of the perched water in all four boreholes discussed herein is similar. In each case, the top of the perched-water reservoir is just above the contact between the lower nonlithophysal unit (Tptpln) and the crystal-poor vitric unit (Tptpv) of the Topopah Spring Tuff. Although the bottom of the perched-water reservoir generally is unknown, the water must be perched upon a zone of relatively lower permeability underlying a zone of relatively larger permeability. The relevant permeability may be fracture permeability or matrix permeability, or both; but because it is likely that fractures provide the dominant pathways for water movement through the unsaturated zone, the perched water may be the result of water flowing through zones with high fracture density overlying zones with low fracture density. Figures 24 and 25 show fracture-density plots for boreholes UZ-14, SD-9, and NRG-7a along with the location of the top of the perched water within each borehole. In each borehole the perched-water reservoir lies within a zone of more intensely fractured rock of the lower nonlithophysal unit and upper part of the crystal-poor vitric unit of the Topopah Spring Tuff. In each case, the water is perched upon less intensely fractured bedded tuff underlying the crystal-poor vitric unit or the less intensely fractured lower part of the crystal-poor vitric unit. An alternative possibility involves the alteration of vitric material along fractures. Zeolitization along fractures could significantly reduce the fracture permeability regardless of the fracture density of the unit. The structure contour map of the vitric/zeolitic boundary of the Calico Hills hydrogeologic unit (fig. 17) and geologic sections through Drill Hole Wash boreholes (figs. 8, 9, and 10) indicate that zeolitization of vitric material is present just below the 
depths where perched water has been identified within Drill Hole Wash. This alteration may sufficiently reduce the permeability to allow the formation of perched water.

Structural maps of the top of the crystal-poor vitric unit of the Topopah Spring Tuff (fig. 14) and the vitric/zeolitic boundary of the Calico Hills hydrogeologic unit (fig. 17) and geologic sections through Drill Hole Wash boreholes (figs. 8, 9, and 10) also offer an explanation for the accumulation of perched water in the vicinity of the North Ramp. These figures all indicate that these boundaries form a northwestsoutheast-trending channel around Drill Hole Wash that may effectively funnel recharge into the basin. Also, estimates of shallow infiltration (D.B. Hudson and A.L. Flint, U.S. Geological Survey, unpub. data, 1996) indicate that within this structural basin to the north and west are areas with relatively higher infiltration rates. The possible funneling of water from this area of higher infiltration, laterally through the more intensely fractured lower nonlithophysal unit or crystal-poor vitric unit along the top of the less densely fractured bedded units or along the vitric/zeolitic interface, may explain the presence of perched water in all dry-drilled boreholes penetrating these units in the vicinity of the North Ramp.

Interestingly, the top of the perched-water reservoir at UZ-1 and UZ-14 is at a significantly higher elevation than at NRG-7a and SD-9. The top of the perched water at UZ-1 and UZ-14 is 8 and $9 \mathrm{~m}$, respectively, above the top of the crystal-poor vitric unit (Tptpv) and only 3 and $4 \mathrm{~m}$ above the Tptpv at NRG-7a and SD-9, respectively. A possible explanation for this is a hypothesis that a lateral barrier to flow effectively ponds the perched water in the vicinity of UZ-1 and UZ-14 (Barr and others, 1996, p. 91-95). In this hypothesis, the lateral barrier may be formed by a northeast-trending projected growth fault that is another splay off the Solitario Canyon Fault (fig. 108). Because it has been interpreted to be a growth fault, it is hypothesized to have greater offset and to be more laterally extensive at depth than at the surface. The surface expression of this fault does not extend northeast to the vicinity of UZ-1 and UZ-14 and, therefore, does not appear on the generalized maps presented in figures 19 through 21 , which include only faults with surface expression. Because the existence of this projected growth fault in the vicinity of UZ-1 and UZ-14 has not been verified, the hypothesis concerning the relation between the projected growth fault and the perched-water reservoir at UZ-1 and $\mathrm{UZ}-14$ is non-Q. This fault has been mapped along the escarpment of Solitario Canyon near UZ-6 to the southwest, where the offset of stratigraphic units at the base of the Topopah Spring Tuff is on the order of several meters. The structural trap that allows the perched water to accumulate is created by the juxtaposition of a more permeable layer (Tptpln) west of the fault against a less permeable layer (the lower Tptpv or Tpbt1) east of the fault (fig. 109). Presumably, this fault has intercepted the water flowing downdip along the crystal-poor vitric unit (Tptpv) or zeolitic alteration boundary and does not have sufficient transmissivity to allow the water to drain as rapidly as it accumulates. This combination could explain the presence of the thicker perched-water reservoir at UZ-14 and UZ-1. The location of this impediment to lateral flow along the perching layer between boreholes UZ-1 and G-1 does not necessarily conflict with the presence of $\mathrm{G}-1$ drilling fluid in the perched water at UZ-1. Because this fault is a growth fault, it is possible that drilling fluids from G-1 flowed laterally to the west above the stratigraphic intervals that were displaced by the fault and then percolated downward to contaminate the perched water at UZ-1 (fig. 109). Also, drilling fluids were injected into G- 1 at pressures on the order of 5.0 MPa (derived from drilling reports). This large positive pressure gradient may have caused some of the drilling fluid to migrate across the fault plane even if the fault permeability was low.

The hypothesis that the perched water at UZ-14 is in fact saturated-zone water diverted from the northern part of Yucca Mountain is unlikely. Although the original elevation of what is arguably the regional water table at G-2 (about $2.5 \mathrm{~km}$ north of G-1; see figure 6) was originally about $1,032 \mathrm{~m}$ (now 1,020 m) and the elevation of the top of the perched water at UZ-14 is only $967.7 \mathrm{~m}$, the regional water table at G-2 was originally about $24 \mathrm{~m}$ beneath the top of the Tptpv, based on figure 14. This implies that confinedaquifer conditions would need to exist in the unsaturated zone if perched water at UZ-14 and saturatedzone water at G-2 were part of the same water reservoir. For saturated-zone or unsaturated-zone water to move from G-2 to UZ-14 along the upper contact of the Tptpv, it would have to flow at a large angle to the dip of the Tptpv (fig. 14), across the Pagany Wash and Tea Cup Wash Faults (fig. 21) and the Drill Hole Wash Fault system (fig. 14 and 21). Although the 
EASTING, IN METERS

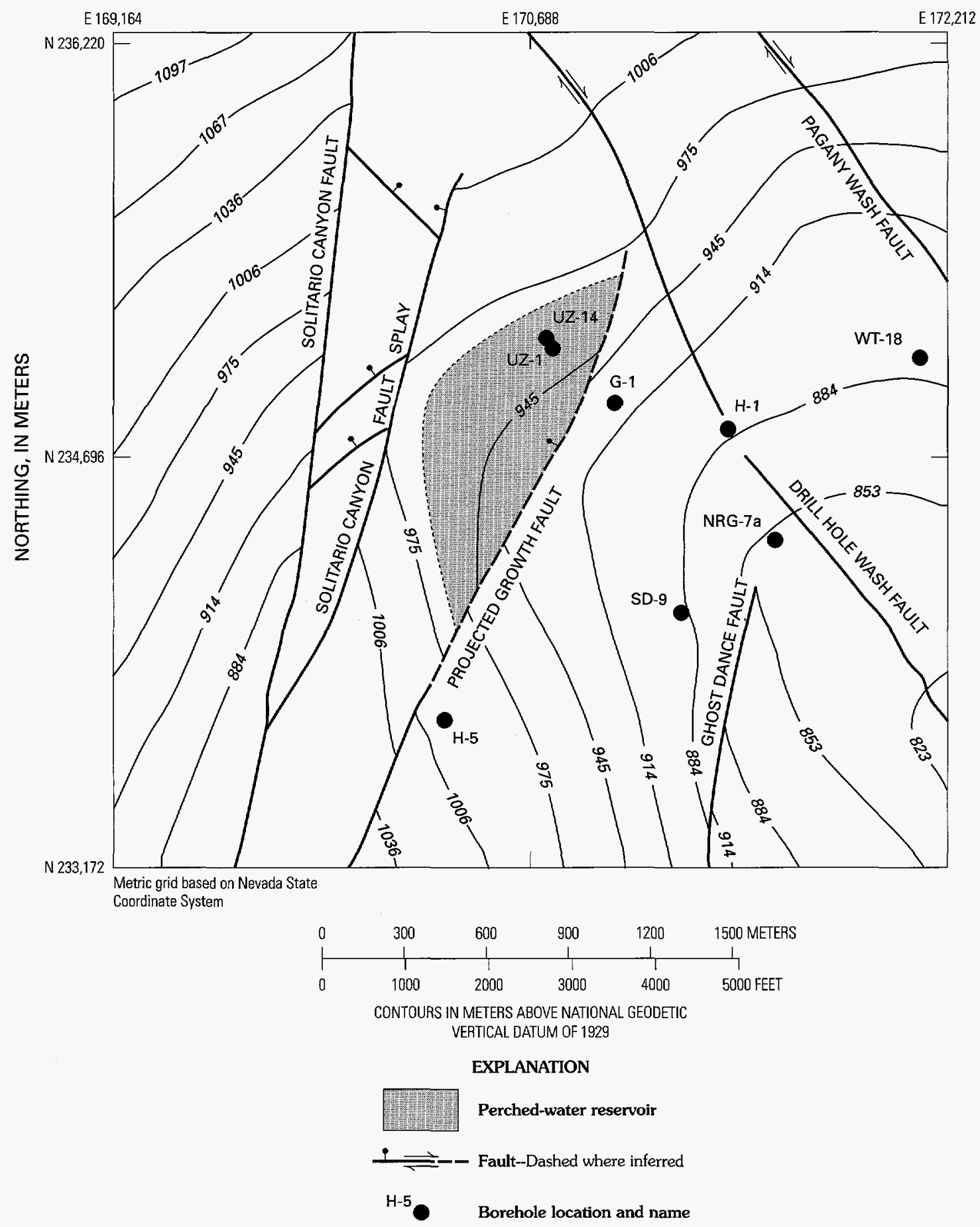

Figure 108. Structure contour map of the top of the crystal-poor vitrophyre of the Topopah Spring Tuff showing the estimated extent of the perched-water reservoir near borehole USW UZ- 14 . 


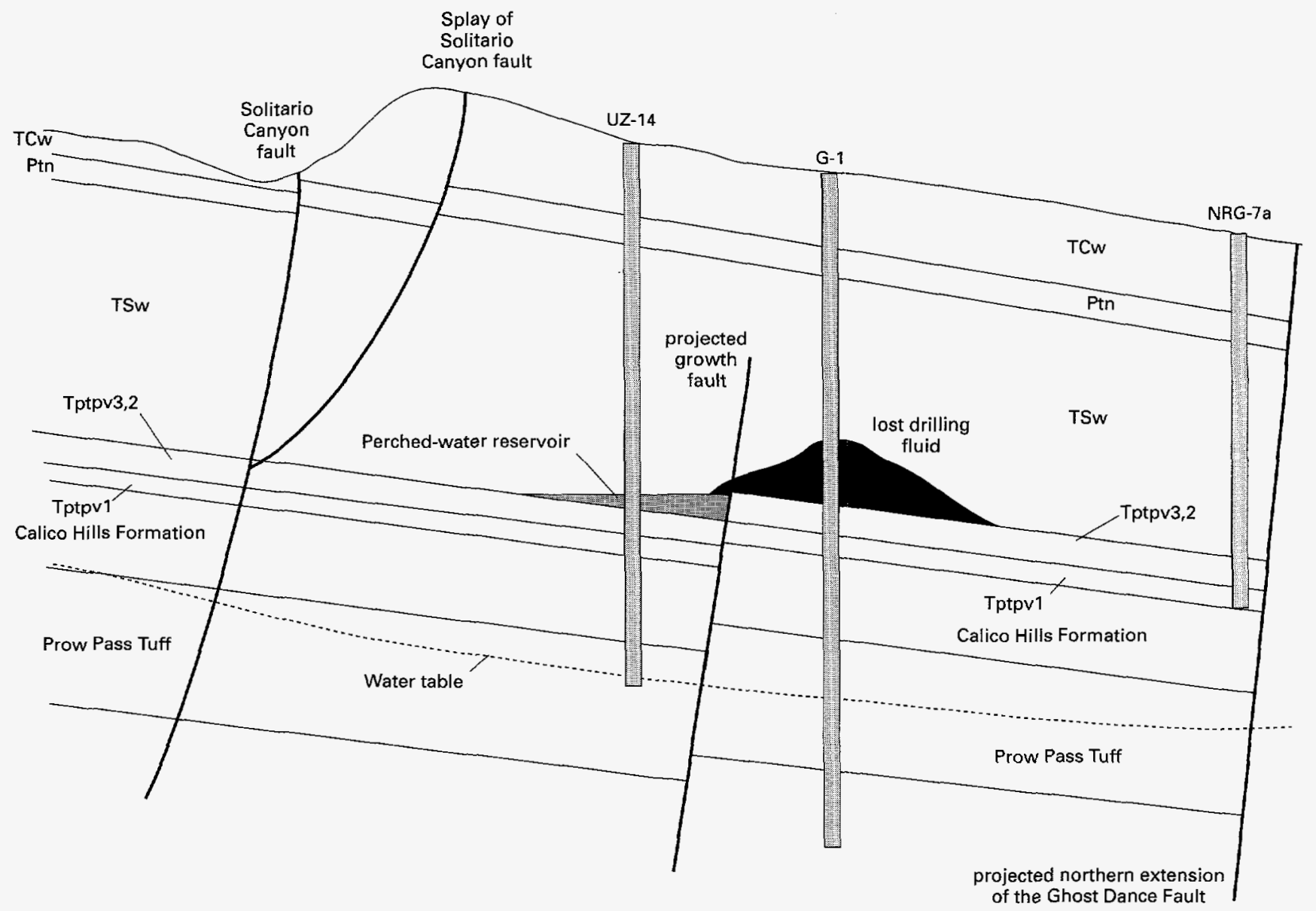

Figure 109. Relation between perched water in Drill Hole Wash boreholes and a projected growth fault in the vicinity of boreholes USW UZ-14 and USW G-1.

transmissivities of these faults are not known, their orientation indicates that they would tend to divert water flowing from G-2 away from the UZ-14 area, regardless of whether their permeability was greater or smaller than that of the unfaulted rock.

It also is unlikely that the perched water at UZ-14 can be attributed to an impediment formed by the northern extension of the Ghost Dance Fault. Figure 14 shows that the Ghost Dance Fault is projected to intersect the Tptpv very near NRG-7a at an elevation of about $853 \mathrm{~m}$. The top of the perched water at UZ-14 is at an elevation of $967 \mathrm{~m}$. If the ponding were caused by offset of the Tptpv along the Ghost Dance Fault, there should be $114 \mathrm{~m}$ of saturated rock above the Tptpv at NRG-7a and about $83 \mathrm{~m}$ at SD-9 where the top of the Tptpv is at an elevation of about $884 \mathrm{~m}$. These thick saturated sections were not recognized in either NRG-7a or SD-9. The fact that the top of the perched water at NRG-7a and SD-9 is just slightly above the top of the Tptpv indicates that there are no thick accumulations and that the mechanism responsible for the accumulation of water at UZ-14 and UZ-1 must be west of boreholes NRG-7a and SD-9.

\section{Chemistry and Isotopic Content of Perched Water}

The chemical composition of perched water reflects the extent of water/rock interactions between the recharge water and the matrix rock, providing insight on the nature of flow mechanisms that led to the accumulation and sustaining of perched-water reservoirs. Similarly, the isotopic content of perched water can provide insight on the source and residence time of the water. For this study, perched-water samples were collected from boreholes UZ-14, NRG-7a, and SD-9, and the analyses of samples collected previously from UZ-1 were reexamined. Because perched-water samples for UZ-1 were 
collected prior to implementation of the approved USGS YMP quality-assurance program, the UZ-1 samples and results are non-Q. Perched-water data from UZ-1 are used, however, only to support and corroborate findings made using samples from other boreholes such as UZ-14. Because the volume of perched water detected in UZ-14 was sufficient to conduct hydraulic pumping tests, a series of samples. were collected from that borehole during these tests. Only one sample of perched water was collected from each of the other boreholes. In addition, water samples were collected from the saturated zone immediately below the water table in boreholes $\mathrm{H}-1$ and G-2 for comparison. These saturated-zone samples were collected prior to implementation of the approved USGS YMP quality-assurance program, however, and therefore the data are non-Q. All water samples were collected using plastic or stainless-steel bailers except the three "UZ-14PT" samples, which were pumped to the surface from borehole UZ-14. Samples were stored in an ice cooler after collection and transferred to the Sample Management Facility at the end of the day for long-term storage in a $6-9^{\circ} \mathrm{C}$ cold room. Water-quality parameters, such as $\mathrm{pH}$, specific conductance, and temperature (and occasionally bicarbonate concentration), were measured in the field laboratory.

\section{Chemical Composition of Perched Water}

Perched-water compositions from boreholes UZ-1, UZ-14, NRG-7a, and SD-9 are plotted in the Piper diagram in figure 110 along with compositions of saturated-zone samples from J-13 and G-2. (Supply well UE-25 J-13 is in Fortymile Wash about $6 \mathrm{~km}$ southeast of the North Ramp study area.) Major cation and anion concentrations were fairly constant throughout the pumping tests for UZ-14. Chloride concentrations were fairly small, ranging from about 4 to $8 \mathrm{mg} / \mathrm{L}$ except one at $15 \mathrm{mg} / \mathrm{L}$. These chloride concentrations are much lower than the chloride concentrations of pore water from the PTn units and the TSw, indicating very little contribution of water from the matrix of the rocks overlying the perchedwater reservoir (table 3 in Yang and others, 1996).

The composition of perched water located near or in the upper part of the Calico Hills Formation is, in general, similar to the pore-water composition of the Calico Hills Formation from UZ-14 and also is similar to saturated-zone water. However, although the relative major-ion composition of the perched water (fig. 110) and the pore water at UZ-14 (fig. 103) are similar, the absolute concentrations (not shown) are significantly different. For example, chloride concentrations in all perched-water samples are significantly smaller than in the pore water based on the chloride data for UZ-14 presented in Yang and others (1996, table 3). These data indicate that chloride concentrations vary little with depth in the PTn and actually are lower in the CHn than in either the PTn or the TSw, indicating that chloride is behaving conservatively as it moves deeper into the system. Perchedwater samples collected from UZ-14 all have chloride concentrations between 6 and $15 \mathrm{mg} / \mathrm{L}$ (represented by symbols $\mathrm{C}$ through $\mathrm{J}$ in fig. 110). In contrast, the chloride concentration of pore water compressed from UZ-14 cores obtained from the borehole interval within the perched-water reservoir was about $87.5 \mathrm{mg} / \mathrm{L}$ (Yang and others, 1996), indicating nonequilibrium conditions between the perched water and pore water. (It is possible that entrapped air in the porous medium has prevented perched water from equilibrating with the pore water.) If matrix pore water had contributed significantly to the perchedwater reservoir, the chloride concentration of perched water would have been similar to that of the pore water, which was not observed. The smaller concentration of chloride in perched water means that there is less interaction of fluid with rock and that the perched water probably was derived from water flowing rapidly through fractures. These data are strong evidence that fracture flow is the principal source of perched-water reservoirs at Yucca Mountain.

It is important to note that analyses of UZ-14 perched-water samples collected before the pumping test (sample UZ-14C) indicated the presence of the same polymer found in the perched water detected in borehole UZ-1 in 1983, which was identified as the polymer used in the drilling of borehole G-1 (Whitfield and others, 1990). (Borehole UZ-1 is located only $26 \mathrm{~m}$ away from UZ-14.) Therefore, the relative composition of major ions in the earliest UZ-14 samples may not be representative of the natural perched water. However, on the basis of the nonequilibrium observed between the perched water and the pore water at borehole UZ-14, it is unlikely that the pore water was in contact with the polymercontaminated perched water. 


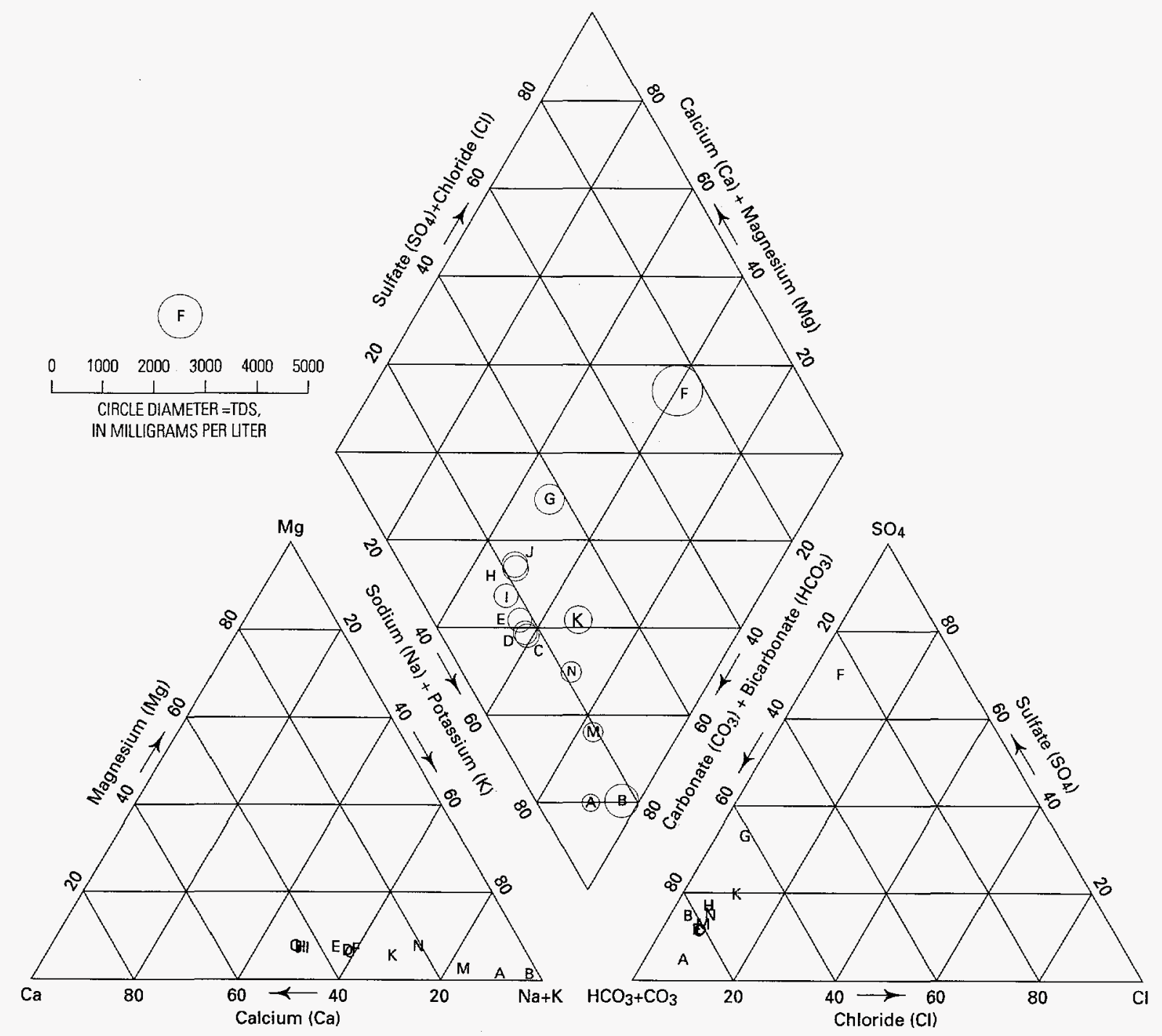

PERCENTAGE OF TOTAL MILLIEQUIVALENTS PER LITER

\section{EXPLANATION}

A NRG-7a (1510.0 feet)

B SD-9/TS (1489.0 feet)

C UZ-14A (1261.8 feet)

D UZ-14A2 (1261.8 feet)

E UZ-14B (1271.9 feet)

$F$ UZ-14C (1282.0 feet)

G UZ-14PT-1 (1282.0 feet)

H UZ-14PT-2 (1282.0 feet)

I UZ-14PT-4 (1282.0 feet)

$\downarrow$ UZ-14D (1282.0 feet)

K UZ-1 (1253.0 feet)

M USW-G-2 (SZ) (2292.6 feet)

N J-13 (SZ)

Figure 110. Piper diagram showing perched-water composition, along with saturated-zone water composition. 
Relation of Perched Water to Ground Water and Precipitation

Stable isotopic data (oxygen-18 and deuterium) are shown in table 18 and are plotted as $\delta^{18} \mathrm{O}$ relative to $\delta \mathrm{D}$ in figure 111 . Delta oxygen- 18 and $\delta \mathrm{D}$ values are reported in parts per thousand (per mil) with respect to Standard Mean Ocean Water (SMOW) as described in Craig (1961) and Gonfiantini (1978). Analytical precisions are 0.2 per mil for $\delta^{18} \mathrm{O}$ and 1.0 per mil for $\delta \mathrm{D}$. Perched-water values are heavier than the saturated-zone water values. On the basis of non-Q data, the saturated-zone water ${ }^{14} \mathrm{C}$ ages range from 9,000 to 18,000 years at Yucca Mountain (Benson and McKinley, 1985). All perched-water stable-isotopic values are between -12.1 and -13.8 per mil for $\delta^{18} \mathrm{O}$ and -87.4 and -102.0 per mil for $\delta \mathrm{D}$, generally heavier than the last ice-age water and similar to post-glacial water (last 8,000 years). Had the perched water been derived from a mixture of older water (more than 10,000 years old, last ice age) and post-glacial water (last 8,000 years), $\delta^{18} \mathrm{O}$ and $\delta \mathrm{D}$ values would have been closer to the saturated-zone values of -14 per mil for $\delta^{18} \mathrm{O}$ and -105 per mil for $\delta \mathrm{D}$, which was not observed. Therefore, both the ${ }^{14} \mathrm{C}$ and the stable-isotope $\left(\delta \mathrm{D}\right.$ and $\left.\delta^{18} \mathrm{O}\right)$ values are consistent with the perched-water residence time of less than 8,000 years. Although this conclusion is scientifically valid, it is non- $Q$ because it is based on non- $Q$ saturated-zone isotopic data that were collected prior to implementation of the approved USGS YMP quality-assurance program.

The yearly weighted average of $\delta^{18} \mathrm{O}$ values of southern Nevada precipitation ranges from -10 to -12.3 per mil (Ingraham and others, 1991). Differences of as much as 15 per mil are observed between the depleted winter precipitation and enriched summer precipitation. The weighted average of the $\delta^{18} \mathrm{O}$ of precipitation for the summer months from July to September ranges from -3.0 to -6.0 per mil (Ingraham and others, 1991, fig. 4). Delta deuterium and $\delta^{18} \mathrm{O}$ values of Yucca Mountain precipitation from several major storms that occurred in July and August of 1984 ranged from -67 per mil to -97 per mil for $\delta \mathrm{D}$ and from -10.5 per mil to -13.0 per mil for $\delta^{18} \mathrm{O}$ (Milne and others, 1987). From figure 111, it can be seen that isotopic values from several of these storms and Ingraham and others' summer values (not shown in fig. 111) are far heavier than the perched water. It is possible that some of the past major summer storms might have contributed only to the NRG-7a perched water but not to other perched-water reservoirs, as shown in figure 111. Also, the stable-isotopic data for both perched water and saturated-zone water plot to the right of the Yucca Mountain precipitation line, indicating that precipitation water had undergone evaporation before infiltration (Craig, 1961; Dansgaard, 1964). However, the perched-water data generally plot closer to the Yucca Mountain

Table 18. Isotopic composition for samples of perched water

[m, meters; \%o, parts per thousand; pmc, percent modern carbon; PDB, Pee Dee belemnite; SMOW, standard mean ocean water; ND, not determined]

\begin{tabular}{|c|c|c|c|c|c|c|c|}
\hline $\begin{array}{c}\text { Sample } \\
\text { identification }\end{array}$ & $\begin{array}{l}\text { Depth } \\
\text { (m) }\end{array}$ & Date & $\begin{array}{c}\text { Carbon-13 } \\
\delta^{13} \mathrm{C} \\
(\%) \\
\text { (standard } \\
\text { is PDB) }\end{array}$ & $\begin{array}{c}\text { Carbon-14 } \\
{ }_{14} \mathrm{C} \\
\text { (pmc) }\end{array}$ & $\begin{array}{c}\stackrel{\text { Tritium }}{{ }^{3} \mathbf{H}} \\
\text { (tritium units) }\end{array}$ & $\begin{array}{c}\text { Deuterium } \\
\delta D \\
(\%) \\
\text { (standard } \\
\text { is SMOW) }\end{array}$ & $\begin{array}{c}\text { Oxygen-18 } \\
\delta^{18} \mathrm{O} \\
(\%) \\
\text { (standard } \\
\text { is SMOW) }\end{array}$ \\
\hline SD-9/TS & 454 & $07-17-94$ & -14.4 & 41.8 & 0.0 & -97.8 & -13.3 \\
\hline UZ-14 A & 384 & $08-02-93$ & -10.2 & 41.7 & 0.3 & -98.6 & -13.8 \\
\hline UZ-14 A2 & 384 & $08-02-93$ & -10.1 & 40.6 & 3.1 & -97.5 & -13.5 \\
\hline UZ-14 B & 388 & $08-03-93$ & -9.5 & 36.6 & 0.0 & -97.1 & -13.4 \\
\hline UZ-14 C & 391 & $08-05-93$ & -9.2 & 66.8 & 0.4 & -87.4 & -12.1 \\
\hline UZ-14 PT-1 & 391 & $08-17-93$ & -9.8 & 32.3 & 1.8 & -97.8 & -13.3 \\
\hline UZ-14 PT-2 & 391 & $08-19-93$ & ND & 28.9 & 3.1 & -97.9 & -13.4 \\
\hline UZ-14 PT-4 & 391 & $08-27-93$ & -9.6 & 27.2 & 0.0 & -97.3 & -13.4 \\
\hline UZ-14 D & 391 & $08-31-93$ & -11.3 & 29.2 & 0.0 & -97.6 & -13.1 \\
\hline UZ-1/2 (Non-Q) & 382 & $07-07-83$ & -12.1 & 64.0 & 1.0 & -102.0 & -13.0 \\
\hline NRG-7a & 460 & $03-07-94$ & -16.6 & 66.9 & 10.4 & -93.9 & -12.8 \\
\hline
\end{tabular}




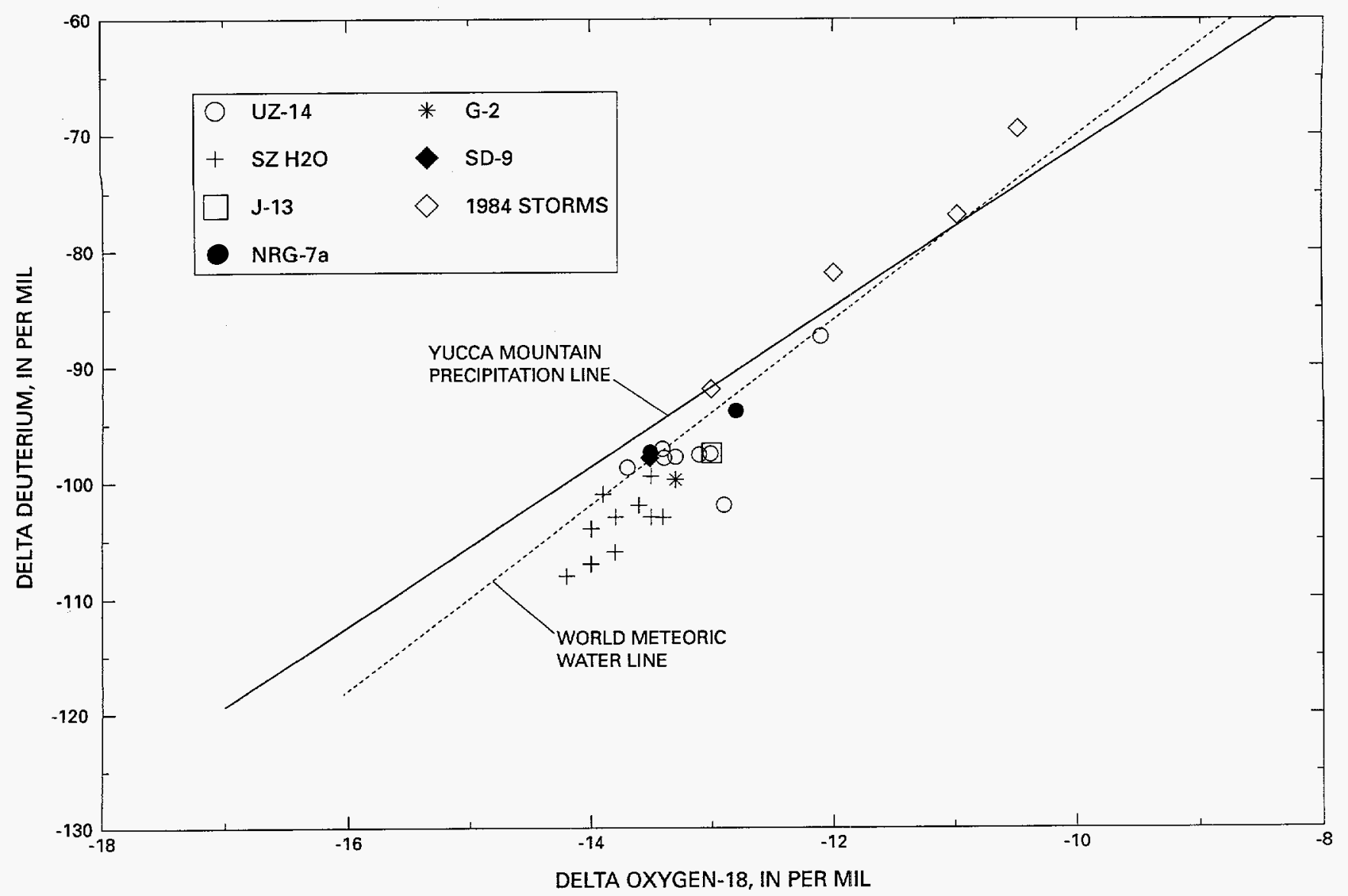

Figure 111. Delta oxygen-18 and delta deuterium for 1984 storms, saturated-zone water, and perched water.

precipitation line than the saturated-zone ground water, indicating that a smaller portion of the precipitation that ultimately entered the perched-water reservoir evaporated before infiltrating. Although scientifically valid, this conclusion is non- $Q$ because it is based on non- $Q$ isotopic data for precipitation and saturatedzone water that were collected prior to implementation of the approved USGS YMP quality-assurance program.

\section{Possible Source and Residence Time of Perched Water}

Carbon- 14 and $\delta^{13} \mathrm{C}$ values for perched-water samples are plotted in figure 112. As can be seen from these data, the ${ }^{14} \mathrm{C}$ values range from 66.9 to 27.2 pmc, corresponding to apparent ${ }^{14} \mathrm{C}$ ages (residence times) of about 3,500 years to 11,000 years. Water ${ }^{14} \mathrm{C}$ ages are affected by the dissolution of older caliche by the infiltrating water. This dissolution can be identified by the $\delta^{13} \mathrm{C}$ isotopic values because caliche generally has $\delta^{13} \mathrm{C}$ values in the range of -3 to -9 per mil (Whelan and Stuckless, 1990, non-Q).
Biogenic $\mathrm{CO}_{2}$ on the other hand, has $\delta^{13} \mathrm{C}$ values of -18 to -23 per mil (UZ-1 data in this report). The heavier $\delta^{13} \mathrm{C}$ values in the water will indicate the dissolution of caliche in the ground water. Carbon-14 ages of caliche at Yucca Mountain have been determined and range from 20,000 to several hundred thousands of years (Whelan and others, 1994, non-Q; Szabo and Kyser, 1990, non-Q). Adjustments to the apparent ${ }^{14} \mathrm{C}$ residence times of perched water cannot be made at this time. However, studies are underway to correct residence times using carbon mass-balance modeling that takes into account all sources of carbon in the reactant and product phases, such as carbon dioxide, carbonate minerals, and any organic matter present in the reaction path.

Because most of the perched water sampled from boreholes probably was derived from fractures instead of the rock matrix, one can logically conclude that once the water infiltrated the land surface, it flowed rapidly through fractures to depth without further loss of moisture to the atmosphere. In contrast, saturated-zone 

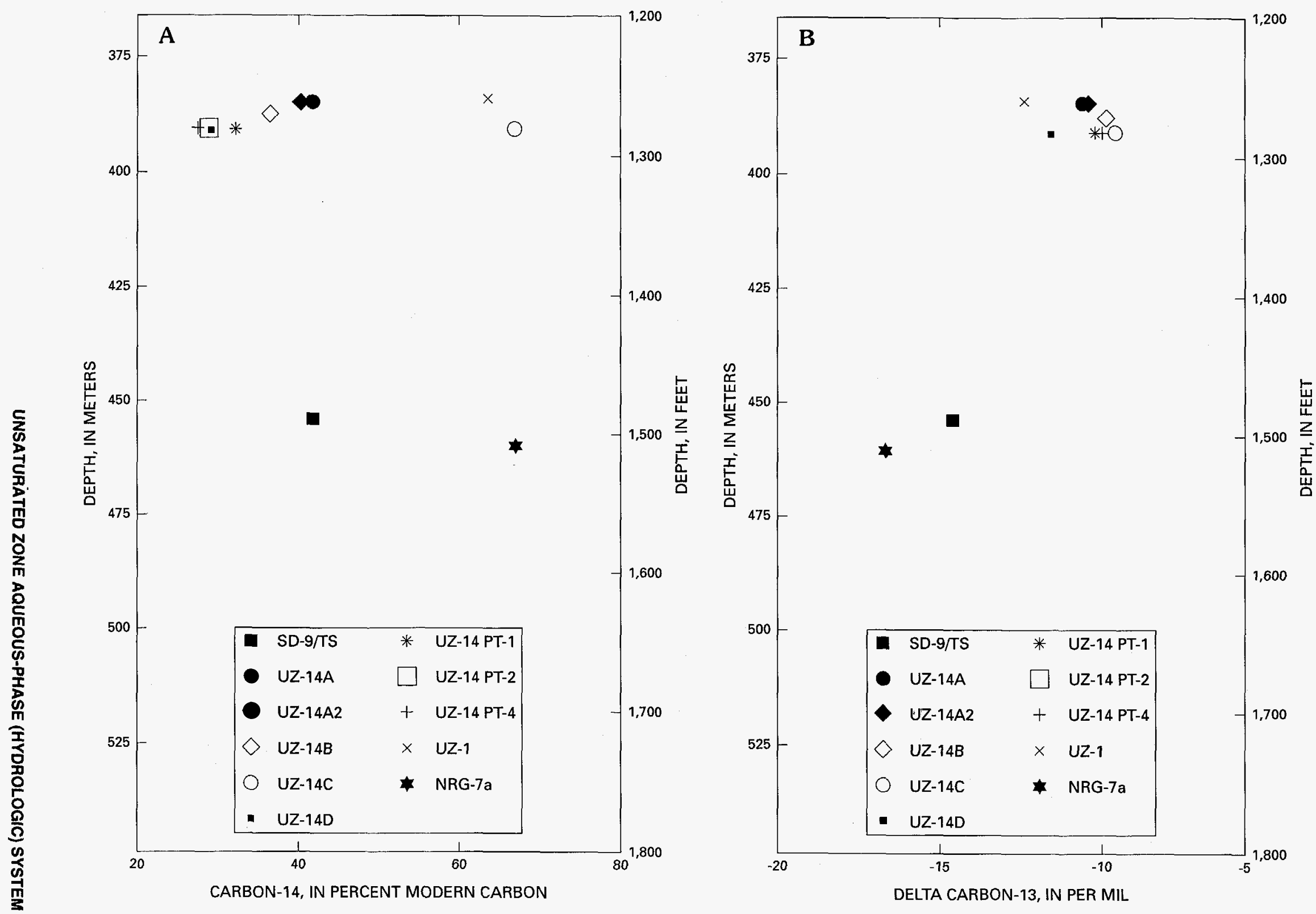

Figure 112. Carbon data for perched water: (A) apparent carbon-14 in percent modern carbon and (B) delta carbon-13. 
ground water, which is significantly older and more depleted in $\delta^{18} \mathrm{O}$ and $\delta \mathrm{D}$ than the perched water, likely was recharged from winter precipitation that fell on the higher elevations of Pahute Mesa to the north. This winter precipitation likely underwent evaporation before infiltration. This interpretation is consistent with the observation that the saturated-zone water $\delta \mathrm{D}$ and $\delta^{18} \mathrm{O}$ values are more depleted and plot farther away from the Yucca Mountain precipitation line than the values for perched water (fig. 111).

Analysis of perched-water samples for tritium indicated concentrations below the detection limit of $4 \mathrm{TU}$ in all cases except for the sample from NRG-7a, which contained $10.4 \mathrm{TU}$. The tritium value for NRG-7a indicates that either the perched water at NRG-7a has a component of post-bomb water or that the sample was contaminated. Overall, however, the relatively low tritium values imply that if post-1954 water has mixed with the perched water, the volume of such water must have been very small.

\section{Strontium Isotope Content of Perched Water}

The strontium $(\mathrm{Sr})$ isotopic composition and concentration of samples of perched water in NRG-7a, SD-9, and UZ-14 were determined by thermal ionization mass spectrometry and isotope dilution (table 19). The isotopic composition of $\mathrm{Sr}$, expressed as the atomic ratio ${ }^{87} \mathrm{Sr} /{ }^{86} \mathrm{Sr}$, varies in nature because of the beta decay of ${ }^{87} \mathrm{Rb}$ to ${ }^{87} \mathrm{Sr}$ with a half-life of 48.8 billion years. To illustrate the small but significant variations in ${ }^{87} \mathrm{Sr} /{ }^{86} \mathrm{Sr}$ values, it is convenient to express this ratio as a deviation in parts per thousand (per mil) from the ${ }^{87} \mathrm{Sr} /{ }^{86} \mathrm{Sr}$ ratio of modern seawater, which is globally uniform at a value of 0.70920 :

$$
\delta^{87} \mathrm{Sr}=\left[\left(\mathrm{R}_{\mathrm{samp}} / \mathrm{R}_{\mathrm{sw}}\right)-1\right] \times 1000
$$

where

$$
\begin{aligned}
\mathrm{R}_{\text {samp }} & ={ }^{87} \mathrm{Sr} /{ }^{86} \mathrm{Sr} \text { ratio of the sample, and } \\
\mathrm{Rsw} & ={ }^{87} \mathrm{Sr} /{ }^{86} \mathrm{Sr} \text { ratio of modern seawater. }
\end{aligned}
$$

The reported ${ }^{87} \mathrm{Sr} /{ }^{86} \mathrm{Sr}$ ratios (table 19) are accurate, relative to the seawater value, to \pm 0.01 percent or better at the two sigma level of confidence (thus, $\delta^{87} \mathrm{Sr}$ values are uncertain to \pm 0.1 per mil or better).
Strontium is an alkaline-earth element that closely follows calcium $(\mathrm{Ca})$ in the hydrologic cycle. Because of this relation and its isotopic variability, $\mathrm{Sr}$ is a useful natural tracer in ground water (Peterman and Stuckless, 1992). Ground water acquires Sr (and its isotopic signature) at the infiltration site and along the flow path. Unlike the environmental isotopes of oxygen and hydrogen, the $\mathrm{Sr}$ isotopic composition of ground water is not conservative, although as the concentration of $\mathrm{Sr}$ increases due to interaction with rocks along the flow path, the $\delta^{87} \mathrm{Sr}$ will become buffered against rapid change.

The $\delta^{87}$ Sr values for the rock and soil units at Yucca Mountain have been well characterized, and these values are summarized by Peterman and Stuckless (1993). The abundant surficial calcite in the soil zone at Yucca Mountain has a mean $\delta^{87} \mathrm{Sr}$ of +4.4 per mil. The high-silica rhyolite of the Topopah Spring Tuff is uniform in strontium content with a mean $\delta^{87} \mathrm{Sr}+9.6$ per mil, whereas the cap rock (quartz latite) has a lower value of +1.5 per mil. The Calico Hills Formation has a mean $\delta^{87} \mathrm{Sr}$ of +5.7 per mil, and units of the Crater Flat Group have values of +3.6 to -0.4 per mil. Generally, the Sr contents of these units and their $\delta^{87} \mathrm{Sr}$ values are inversely correlated (Peterman and Stuckless, 1993, fig. 5). Ground water from the saturated zone in the vicinity of Yucca Mountain has $\delta^{87} \mathrm{Sr}$ values typically in the range of +1.0 to +3.3 per mil with generally lower values present to the north in the recharge area.

Perched-water reservoirs detected in NRG-7a and SD-9 produced very small quantities of water from which bailed samples were obtained. All of the samples had a large amount of suspended material produced by the drilling. Concentrations of $\mathrm{Sr}$ in these samples are exceedingly small (table 19), ranging from 0.002 to $0.007 \mathrm{mg} / \mathrm{L}$, and $\mathrm{Sr}$ isotopic compositions are variable with $\delta^{87} \mathrm{Sr}$ values ranging from +2.6 to +11.7 per mil. Comparable local variability in water from the larger perched reservoirs or from the saturated zone has not been observed. This extreme isotopic variability of water from these perched reservoirs may reflect very large rock/water systems with small water zones isolated from one another in fractures. Alternatively, the low Sr concentrations of these waters would have made them susceptible to water/rock interaction during drilling. The finegrained suspended material could have dissolved much more readily than the intact rock along fracture zones. Because of this possibility, the reliability of 
Table 19. Strontium isotopic and concentration data for samples of perched water

[\%o, per mil; mg/L, milligram per liter; $S r$, strontium; ND, no data]

\begin{tabular}{|c|c|c|c|c|c|c|c|c|}
\hline Borehole & $\begin{array}{c}\text { Sample } \\
\text { identification }\end{array}$ & $\begin{array}{l}\text { Date } \\
\text { collected }\end{array}$ & $\begin{array}{c}\text { Date } \\
\text { analyzed }\end{array}$ & $\begin{array}{c}\text { Sample } \\
\text { type }\end{array}$ & $\begin{array}{c}\text { Volume } \\
\text { pumped, } \\
\text { cumula- } \\
\text { tive } \\
\text { (liters) }\end{array}$ & ${ }^{87} \mathrm{Sr} /{ }^{\beta 6} \mathrm{Sr}$ & $\begin{array}{c}\operatorname{del}^{87} \mathrm{Sr} \\
(\% 0)\end{array}$ & $\begin{array}{c}\mathrm{Sr} \\
(\mathrm{mg} / \mathrm{L})\end{array}$ \\
\hline$\overline{\text { USW NRG-7a }}$ & NRG-7 \#2 & $03 / 04 / 94$ & $06 / 17 / 94$ & Bailed & ND & 0.71270 & 4.94 & 0.005 \\
\hline USW NRG-7a & NRG-7 \#4 & 03/07/94 & $05 / 20 / 94$ & Bailed & ND & 0.71102 & 2.57 & 0.007 \\
\hline USW NRG-7a & NRG-7 \#6 & $03 / 07 / 94$ & $05 / 23 / 94$ & Bailed & ND & 0.71100 & 2.54 & 0.007 \\
\hline USW NRG-7a & NRG-7 \#3 & $03 / 07 / 94$ & $05 / 20 / 94$ & Bailed & ND & 0.71126 & 2.91 & 0.005 \\
\hline USW NRG-7a & NRG-7 \#1 & 03/08/94 & $05 / 20 / 94$ & Bailed & ND & 0.71748 & 11.68 & 0.002 \\
\hline USW SD-9 & SD-9 9/94 & $09 / 12 / 94$ & $12 / 19 / 94$ & Bailed & ND & 0.71340 & 5.92 & 0.003 \\
\hline USW UZ-14 & UZ-14A1 & $08 / 02 / 93$ & $12 / 03 / 93$ & Bailed & ND & 0.71250 & 4.66 & 0.22 \\
\hline USW UZ-14 & UZ-14A & $08 / 02 / 93$ & $12 / 03 / 93$ & Bailed & ND & 0.71240 & 4.51 & 0.23 \\
\hline USW UZ-14 & UZ-14A2 & $08 / 02 / 93$ & $12 / 03 / 93$ & Bailed & ND & 0.71237 & 4.47 & 0.12 \\
\hline USW UZ-14 & UZ-14B & $08 / 03 / 93$ & $11 / 19 / 93$ & Bailed & ND & 0.71228 & 4.34 & 0.27 \\
\hline USW UZ-14 & UZ-14C & $08 / 05 / 93$ & $11 / 26 / 93$ & Bailed & ND & 0.71230 & 4.37 & 0.45 \\
\hline USW UZ-14 & CCL930817UZ14.12 & $08 / 17 / 93$ & $11 / 18 / 93$ & Pumped & 1,798 & 0.71202 & 3.98 & 0.27 \\
\hline USW UZ-14 & UZ-14 8/17/93 21:00 & $08 / 17 / 93$ & $12 / 03 / 93$ & Pumped & 1,998 & 0.71197 & 3.91 & 0.25 \\
\hline USW UZ-14 & RRL930817UZ14.15A & $08 / 17 / 93$ & $12 / 23 / 93$ & Pumped & 2,199 & 0.71225 & 4.30 & 0.22 \\
\hline USW UZ-14 & UZ14 15:04 8/19 & $08 / 19 / 93$ & $12 / 23 / 93$ & Pumped & 3,441 & 0.71218 & 4.21 & 0.16 \\
\hline USW UZ-14 & UZ14 17:04 8/19 & 08/19/93 & $12 / 23 / 93$ & Pumped & 3,849 & 0.71217 & 4.19 & 0.24 \\
\hline USW UZ-14 & UZ14-19:04 8/19 & 08/19/93 & $11 / 18 / 93$ & Pumped & 4,269 & 0.71169 & 3.51 & 0.31 \\
\hline USW UZ-14 & UZ-14 8/19/93 20:00 & 08/19/93 & $12 / 03 / 93$ & Pumped & 4,360 & 0.71217 & 4.19 & 0.28 \\
\hline USW UZ-14 & GRB930823UZ14.04 & $08 / 23 / 93$ & $12 / 22 / 93$ & Pumped & 6,446 & 0.71225 & 4.31 & 0.20 \\
\hline USW UZ-14 & UZ14-17:00 & $08 / 23 / 93$ & $11 / 17 / 93$ & Pumped & 8,104 & 0.71232 & 4.40 & 0.17 \\
\hline USW UZ-14 & DHT930824UZ14.01 & $08 / 24 / 93$ & $12 / 22 / 93$ & Pumped & 8,955 & 0.71229 & 4.36 & 0.26 \\
\hline USW UZ-14 & DHT930824UZ17.07 & $08 / 25 / 93$ & $02 / 02 / 94$ & Pumped & 9,799 & 0.71233 & 4.41 & 0.24 \\
\hline USW UZ-14 & PT930825UZ14.13 & $08 / 25 / 93$ & $12 / 22 / 93$ & Pumped & 10,696 & 0.71234 & 4.43 & 0.23 \\
\hline USW UZ-14 & PT930825UZ14.19 & $08 / 25 / 93$ & $12 / 03 / 93$ & Pumped & 11,544 & 0.71235 & 4.44 & 0.18 \\
\hline USW UZ-14 & GRB930825UZ14.24 & $08 / 25 / 93$ & $12 / 22 / 93$ & Pumped & 12,388 & 0.71236 & 4.46 & 0.22 \\
\hline USW UZ-14 & DHT930825UZ14.27 & $08 / 25 / 93$ & $12 / 08 / 93$ & Pumped & 13,229 & 0.71241 & 4.53 & 0.23 \\
\hline USW UZ-14 & UZ-14-1430 & $08 / 25 / 93$ & $11 / 19 / 93$ & Pumped & 13,285 & 0.71219 & 4.22 & 0.23 \\
\hline USW UZ-14 & DHT930825UZ14.31 & $08 / 25 / 93$ & $01 / 03 / 94$ & Pumped & 13,512 & 0.71230 & 4.38 & 0.30 \\
\hline USW UZ-14 & duplicate & $08 / 25 / 93$ & $01 / 04 / 94$ & Pumped & 13,512 & 0.71240 & 4.51 & 0.30 \\
\hline USW UZ-14 & DHT930825UZ14.32 & $08 / 25 / 93$ & $12 / 23 / 93$ & Pumped & 14,500 & 0.71236 & 4.46 & 0.16 \\
\hline USW UZ-14 & duplicate & $08 / 25 / 93$ & $01 / 14 / 94$ & Pumped & 15,344 & 0.71240 & 4.51 & 0.24 \\
\hline USW UZ-14 & PT930826UZ14.36 & $08 / 26 / 93$ & $12 / 22 / 93$ & Pumped & 15,344 & 0.71238 & 4.49 & 0.24 \\
\hline USW UZ-14 & PT930826UZ14.40 & $08 / 26 / 93$ & $12 / 07 / 93$ & Pumped & 16,189 & 0.71239 & 4.50 & 0.27 \\
\hline USW UZ-14 & GO930826UZ14.51 & $08 / 26 / 93$ & $11 / 18 / 93$ & Pumped & 18,285 & 0.71238 & 4.48 & 0.30 \\
\hline USW UZ-14 & DHT930826UZ14.56 & $08 / 26 / 93$ & $12 / 22 / 93$ & Pumped & 19,572 & 0.71236 & 4.46 & 0.25 \\
\hline USW UZ-14 & duplicate & $08 / 26 / 93$ & $02 / 02 / 94$ & Pumped & 19,572 & 0.71232 & 4.40 & 0.29 \\
\hline USW UZ-14 & PT930827UZ14.59 & $08 / 27 / 93$ & $12 / 22 / 93$ & Pumped & 20,413 & 0.71239 & 4.49 & 0.27 \\
\hline USW UZ-14 & PT930827UZ14.63 & $08 / 27 / 93$ & $11 / 18 / 93$ & Pumped & 21,241 & 0.71236 & 4.46 & 0.15 \\
\hline USW UZ-14 & UZ-14 Pumping Test \#4 & $08 / 27 / 93$ & $11 / 26 / 93$ & Pumped & 22,298 & 0.71236 & 4.45 & 0.26 \\
\hline
\end{tabular}


these samples as pristine representatives of these small perched reservoirs is questionable.

In contrast to the small perched reservoirs in NRG-7a and SD-9, a large perched-water reservoir was detected in UZ-14 from which both bailed and pumped samples were obtained. This saturated zone is immediately above and within the upper part of the lower vitrophyre of the Topopah Spring Tuff. Water was initially detected at a depth of $384 \mathrm{~m}$. The hole was successively advanced and bailed (bailed samples, table 19). During the early stages of a pumping test, water from supply well J-13 was added to the discharge line to verify that the pump was working. (Supply well UE-25 J-13 is in Fortymile Wash about $6 \mathrm{~km}$ southeast of the North Ramp study area.) Fortunately, J-13 water has been characterized isotopically with a mean $\delta^{87} \mathrm{Sr}$ value of +3.2 per mil. A further complication was presented by the possibility that some or all of the perched water might have been lost drilling fluid from the nearby borehole $\mathrm{G}-1$, which had been drilled more than 10 years earlier with the loss of substantial amounts of drilling fluid, of which the water component also was $\mathbf{J}-13$ water.

Water samples were collected from UZ-14 for $\mathrm{Sr}$ isotopic analyses during the course of three successive pumping tests that were conducted on the perched-water reservoir at UZ-14 (table 19). The variation in $\delta^{87} \mathrm{Sr}$ as a function of cumulative pumpage is shown in figure 113. The five bailed samples taken before addition of J-13 water have an average $\delta^{87} \mathrm{Sr}$ value of +4.5 per mil and an average $\mathrm{Sr}$ content of $0.26 \mathrm{mg} / \mathrm{L}$. The $\delta^{87} \mathrm{Sr}$ values for these bailed samples are included in figure 113 for comparison with the pumped samples. The $\delta^{87} \mathrm{Sr}$ range for J-13 water also is shown for comparison.

The isotopic variability of samples taken during the pumping tests (fig. 113) is consistent with the presence of two isotopically distinct waters, one being transient. The extreme variability in $\delta^{87} \mathrm{Sr}(+3.5$ to +4.4 per mil) during the first $9,084 \mathrm{~L}$ of pumpage reflects the addition of $\mathrm{J}-13$ water with a $\delta^{87} \mathrm{Sr}$ value of +3.2 per mil and its gradual removal and replacement

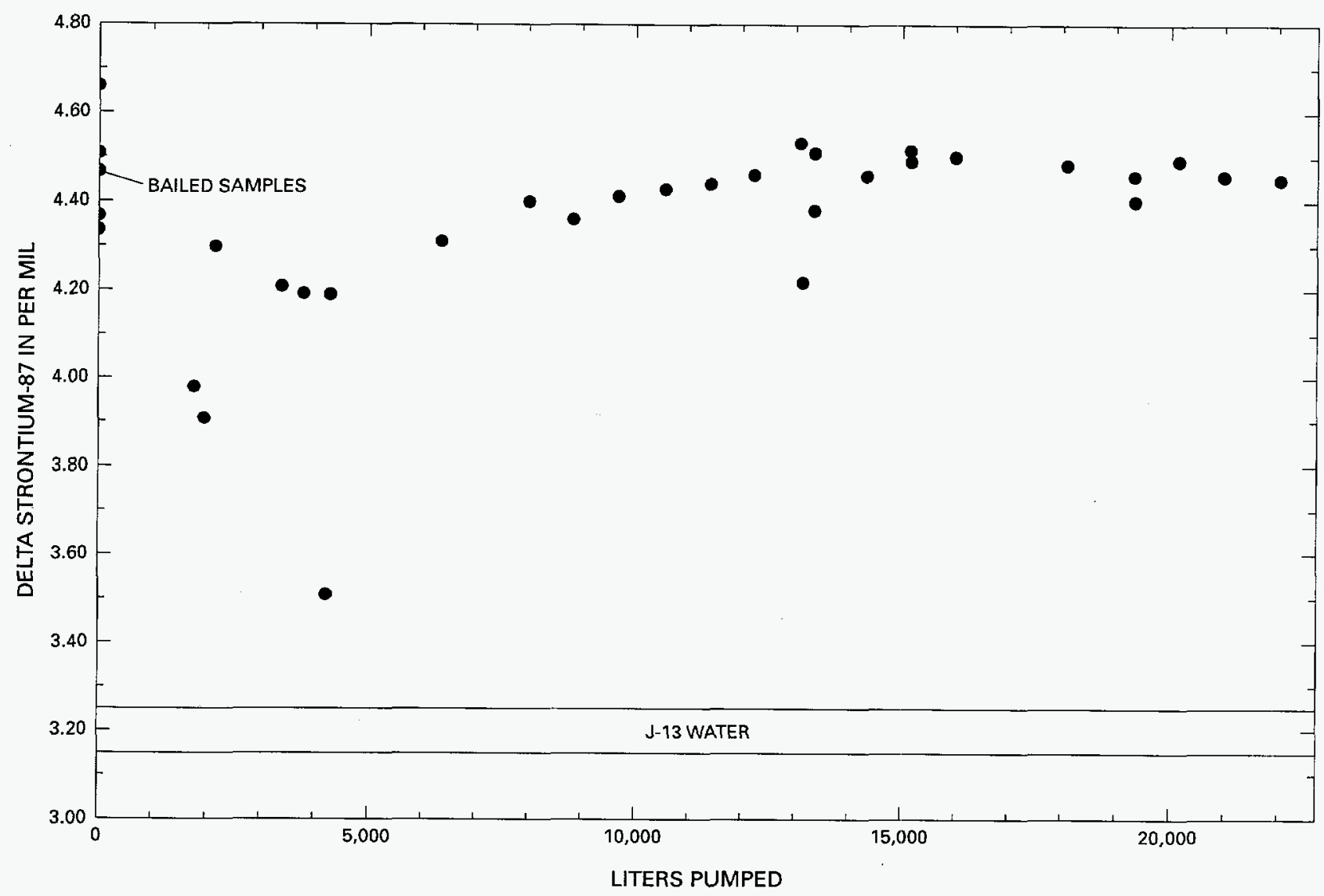

Figure 113. Variation in delta strontium-87 as a function of cumulative pumpage from borehole USW UZ-14. 
by perched water. With the exception of one sample $\left(\delta^{87} \mathrm{Sr}\right.$ of +4.2 per mil at $\left.13,285 \mathrm{~L}\right)$, the $\delta^{87} \mathrm{Sr}$ values stabilize after $9,084 \mathrm{~L}$ to a mean value of $+4.46 \pm 0.08$ per mil (two sigma). The variance in this mean value is commensurate with analytical uncertainties alone, and the mean is identical to the mean of values for the bailed samples, which were taken prior to the addition of $\mathrm{J}-13$ water. The deviant value of +4.2 per mil at $13,285 \mathrm{~L}$ is probably a reflection of the addition of $\mathrm{J}-13$ water into the fractured reservoir and the nonuniform release of this water during the subsequent pumping.

The stabilization of the $\delta^{87} \mathrm{Sr}$ values with increasing cumulative volume of water pumped indicates that the mean value of +4.46 per mil represents the $\mathrm{Sr}$ isotopic composition of the perched water. During this interval, the mean $\mathrm{Sr}$ concentration is $0.24 \pm 0.09 \mathrm{mg} / \mathrm{L}$, which is considerably larger than the $\mathrm{Sr}$ concentration of ground water from the saturated zone in the vicinity of Yucca Mountain. For example, the $\mathrm{Sr}$ concentration in ground water from supply well $\mathrm{J}-13$ and borehole UE-25c \#3 is $0.04 \mathrm{mg} / \mathrm{L}$. Multiple samples from borehole UE-25 WT\#12 have a mean Sr concentration of $0.022 \mathrm{mg} / \mathrm{L}$. Corresponding $\delta^{87} \mathrm{Sr}$ values for these saturated zone waters are +3.2 per mil for J-13, +0.9 per mil for $\mathrm{c \# 3}$, and +1.1 per mil for WT\#12. Thus, the perched water from UZ-14 has distinctly larger $\delta^{87} \mathrm{Sr}$ values and $\mathrm{Sr}$ concentrations than ground water in the saturated zone.

The mean $\delta^{87} \mathrm{Sr}$ value of +4.46 per mil for the perched water detected in UZ-14 is similar to the mean $\delta^{87} \mathrm{Sr}$ value of +4.51 per mil for surficial pedogenic calcite in the Yucca Mountain area (Marshall and others, 1993). This similarity and the fact that calcite fracture fillings in the unsaturated zone are isotopically similar to the mean $\delta^{87} \mathrm{Sr}$ value for surficial calcite, imply that the perched water probably attained its isotopic signature by dissolution of soil calcium carbonate and shallow calcite during downward percolation.

\section{Summary of Perched-Water Chemistry}

Chemical and isotopic compositions of perched water indicate that (1) major-ion chemistry of perched water generally is similar to that of saturated-zone ground water; (2) chloride concentrations in perched water generally are low and consistent with recharge derived mainly from fracture flow with little contribution from water in the matrix of the overlying rock;
(3) hydrogen and oxygen isotopic compositions of perched water are consistent with rapid infiltration into fractures with little or no evaporation; (4) apparent ${ }^{14} \mathrm{C}$ residence times of perched water range from 3,500 to 11,000 years; and (5) stable isotopic values of -12.1 to -13.8 per mil for $\delta^{18} \mathrm{O}$ and -87.4 to -102 per mil for $\delta \mathrm{D}$ in perched water generally support the post-glacial ${ }^{14} \mathrm{C}$ ages.

The $\delta^{87}$ Sr data from NRG-7a and SD-9 perched waters are variable, ranging from +2.6 to +11.7 per mil. This variability is caused by the small perched reservoirs and exceedingly small $\mathrm{Sr}$ concentration. Furthermore, the reliability of these samples as pristine representatives of these small perched reservoirs is uncertain. The mean $\delta^{87} \mathrm{Sr}$ value of +4.46 per mil for the perched water detected in UZ-14 is similar to the mean $\delta^{87} \mathrm{Sr}$ value of +4.51 per mil for surficial pedogenic calcite in the Yucca Mountain area. This similarity and the fact that calcite fracture fillings in the unsaturated zone are isotopically similar to the mean $\delta^{87} \mathrm{Sr}$ value for surficial calcite imply that the perched water probably attained its isotopic signature by dissolution of soil calcium carbonate and shallow calcite during downward percolation.

\section{Integration and Synthesis of Existing Hydrologic Data}

Certain complex phenomena and issues related to the hydrologic behavior of the unsaturated zone in the ESF North Ramp study area require integrated analysis of data from several disciplines. Several of these are discussed in the following sections: (1) comparison and assessment of water-potential data derived from in-situ borehole measurements and from analysis of rock-core samples; (2) estimates of percolation flux based on an analysis of heat flow; (3) the source, age, and permanence of the perched water; and (4) evidence for preferential fracture flow and lateral flow within the Paintbrush nonwelded hydrogeologic unit (PTn).

\section{Comparison and Assessment of Field-Scale and Core-Scale Water Potentials and Water-Potential Gradients}

Water potentials determined from field-scale, in-situ monitoring generally are large (greater than $-0.3 \mathrm{MPa}$ ) throughout the unsaturated zone and rela- 
tively depth-invariant (see the section of this report titled In-Situ Water-Potential Measurements). The measured values are considerably greater than those that would result if water potentials in the unsaturated zone were in a state of static equilibrium with the water table, implying that the downward percolation flux is non-zero. The relatively large water potentials also indicate that the rock matrix is sufficiently wet, at least near the fractures, that should water flow through the fractures, it would undergo little imbibition by the rock matrix because of the small matrix permeability and small water-potential gradients across the fracturematrix interface.

Water-potential data from rock cores exhibit much greater variability than do the in-situ data (see the section of this report titled Physical and Hydrologic Properties Determined from Analysis of Rock Cores). Core-scale water-potential profiles for SD-9 (fig. 81) and UZ-14 (fig. 82) do not display the depthinvariant characteristics of the in-situ data. This is readily apparent in the core water-potential data for the middle nonlithophysal (Tptpmn), lower nonlithophysal (Tptpln), and the crystal-poor vitric (Tptpv) units of the Topopah Spring Tuff. Although corrections were applied to the core-scale water-potential measurements to account for the effects of moisture losses during coring, processing, and handling operations, these corrections were not sufficient to reverse the apparent inversions in the water-potential gradient across the units mentioned above (figs. 81 and 82). These corrections were based on (1) laboratory measurements of the desaturation rates of core samples exposed to the atmosphere, (2) estimates of moisture losses based on desaturation rates and the time that the core samples were subjected to drilling and handling operations, and (3) use of representative moisture-retention curves for each hydrogeologic unit to compute the water-potential differential associated with estimates of total moisture losses from (1) and (2) above. Hydrogeologic units that display the most significant departure from a depth-invariant profile are those whose moisture-retention curves indicate the most sensitivity to small changes in saturation (Tptpmn, Tptpul, and Tptpv3; fig. 84).

Moisture losses and the effects on water potentials are difficult to quantify. The assumption that moisture losses can be derived, in part, from open-air evaporation rates may underestimate actual moisture losses resulting from high-volume, high-velocity air circulation during coring operations. This may be a limiting constraint on any attempt to correct the core-scale water-potential data for moisture losses, especially for those hydrogeologic units for which water potential is very sensitive to small changes in saturation. The low water potentials from core located immediately above, below, and within the perchedwater reservoirs at SD-9 and UZ-14 are inconsistent with an expected saturated or nearly saturated environment. These low water potentials may indicate that not all of the moisture losses from drilling and handling operations have been accounted for. Alternatively, measured core-scale water potentials for these and similar low-porosity, saturation-sensitive units may be lower than the actual in-situ water potentials.

Core-scale water-potential data from the PTn indicate a depth-invariant water-potential gradient at both UZ-14 and SD-9, with water potentials varying between 0.0 and $-0.3 \mathrm{MPa}$. At UZ\#4 and UZ\#5 there is remarkable consistency between the in-situ and core-scale water-potential measurements, with water potentials varying from -0.1 to $-0.5 \mathrm{MPa}$ (fig. 97). The moisture-retention curves for the nonwelded and bedded units of the PTn (fig. 84) indicate that the sensitivity of water potential relative to saturation is fairly limited over a wide range of saturation, thus lessening the effect of moisture losses on the measurement of water potentials in core samples.

In summary, the in-situ and core-scale waterpotential data are too ambiguous to rule out possible disruptions in the water-potential gradient across the Tptpmn, Tptpln, and Tptpv units of the Topopah Spring Tuff. It also is possible, however, that not all of the moisture losses from core samples of these units have been accounted for. Furthermore, because the water potentials of these units are particularly sensitive to small changes in saturation, the observed abrupt decrease in core-scale water potentials across these units should be viewed with caution.

\section{Analysis of Percolation Flux Based on Heat Flow Estimated in Boreholes}

Heat flow based on temperature measurements and gradients at boreholes UZ\#4 and UZ\#5 in Pagany Wash is analyzed in this section, including a discussion of the factors affecting the heat-flow distribution at this site. Temperature data for these boreholes was presented previously in the section titled Temperature Measurements and Gradients. In particular, the possible role of percolation on the inferred heat-flow 
distribution is discussed. The calculations of heat flow and associated percolation flux presented in this section are non- $Q$ because of their dependence on saturation and porosity data collected prior to implementation of the approved USGS YMP QA program and on the non- $Q$ thermal-conductivity models of Rautman (1995).
$\mathrm{UZ \# 4}$ and UZ\#5 were instrumented in late June and early July 1995. Time-series temperature data (figs. 114 and 115) indicate that the temperaturerecovery histories of these two boreholes were quite different. Following an initial rise and rapid decline in temperature from heat released during grout hydration, temperatures at all instrument stations in UZ\#4
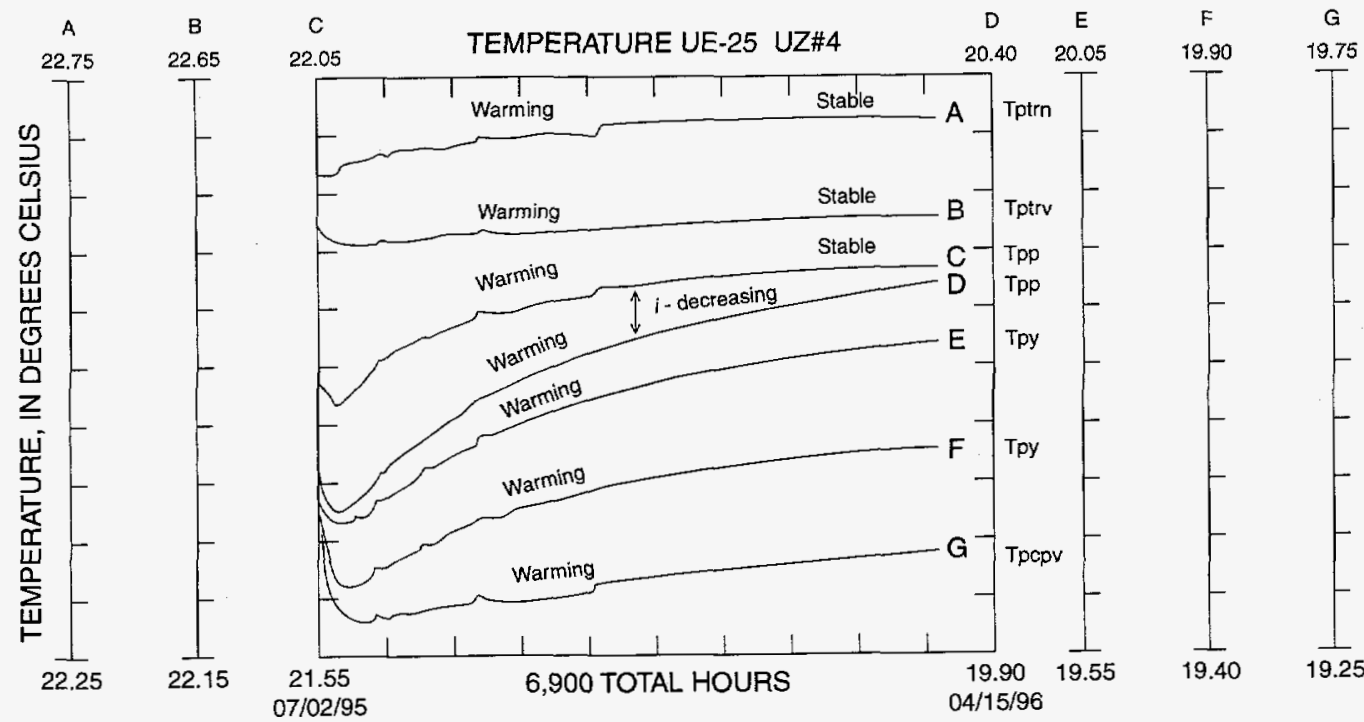

Figure 114. Time-series temperature records for instrument stations located below the influence of seasonal, land-surface temperature changes at borehole UE-25 UZ\#4.
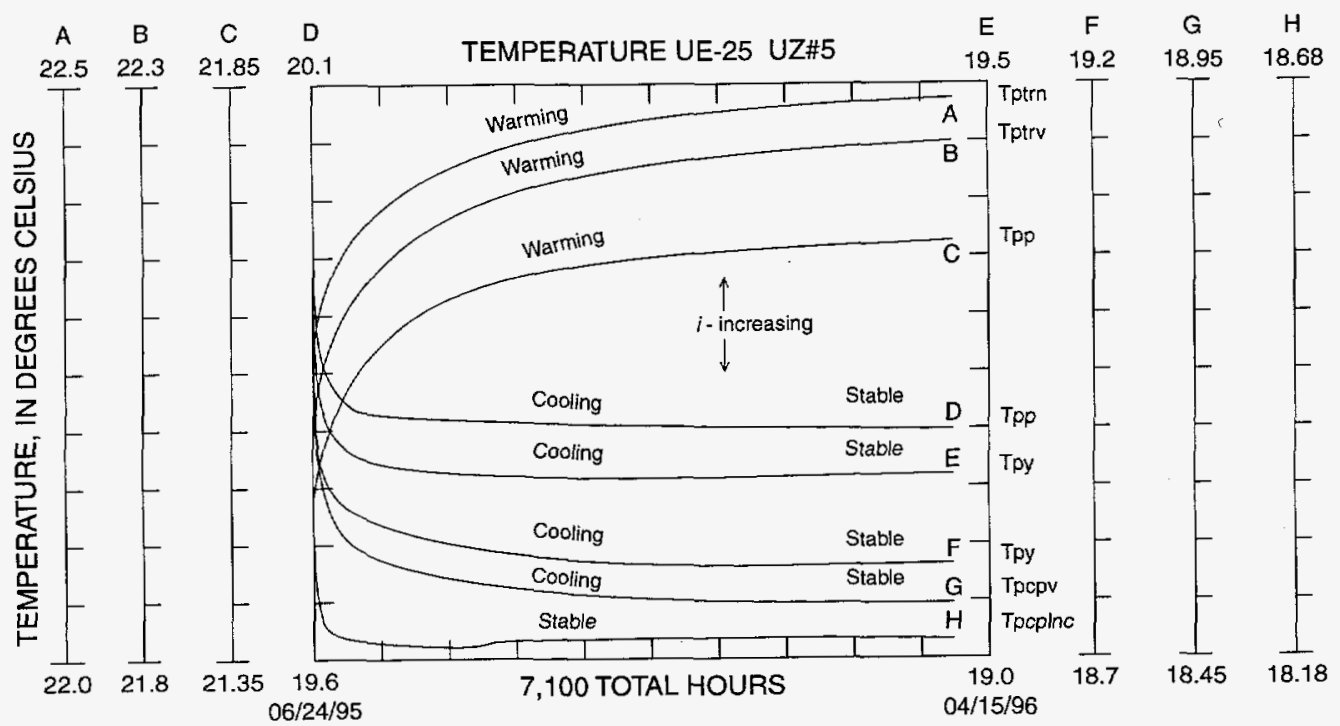

Figure 115. Time-series temperature records for instrument stations located below the influence of seasonal, land-surface temperature changes at borehole UE-25 UZ\#5. 
increased with time. At UZ\#5 the temperatures in the lowermost three instrument stations increased, and temperatures in the uppermost stations decreased. Data as of April 15, 1996, indicate that temperature equilibrium had not yet been achieved at all instrument stations in these two boreholes after more than 9 months of monitoring. The temperature gradient (i) across the Pah Canyon Tuff was still decreasing at UZ\#4 (fig. 114) and increasing at UZ\#5 (fig. 115) as of April 15, 1996. An isotherm section across UZ\#4 and UZ\#5 using temperature data for April 10, 1996, is shown in figure 116.

Although temperatures had not fully equilibrated as of April 15, 1996, consistent trends in temperature do indicate the essential similarities and differences in the temperature regimes at these two sites: (1) higher temperatures at UZ\#4 than at UZ\#5;
(2) small, vertical, temperature gradients across the Yucca Mountain and Tiva Canyon Tuffs at UZ\#4 and large, vertical, temperature gradients across these units at UZ\#5. Convex upward flexures in isotherms beneath Pagany Wash can be explained by the low thermal conductivity of the alluvial fill, which acts as an insulator, trapping heat in the underlying PTn and elevating temperatures at UZ\#4. The low thermal conductivity of the alluvial fill forces heat flow to diverge away from the channel and converge in the $\mathrm{TCw}$ located along the margins and hillslopes bordering this channel.

Temperature data also were collected from a series of shallow temperature stations located at depths of $3,6,9$, and $12 \mathrm{~m}$ at both UZ\#4 and UZ\#5. Time-lapse temperature profiles (fig. 117) depict the temperatures and dates of high and low temperature

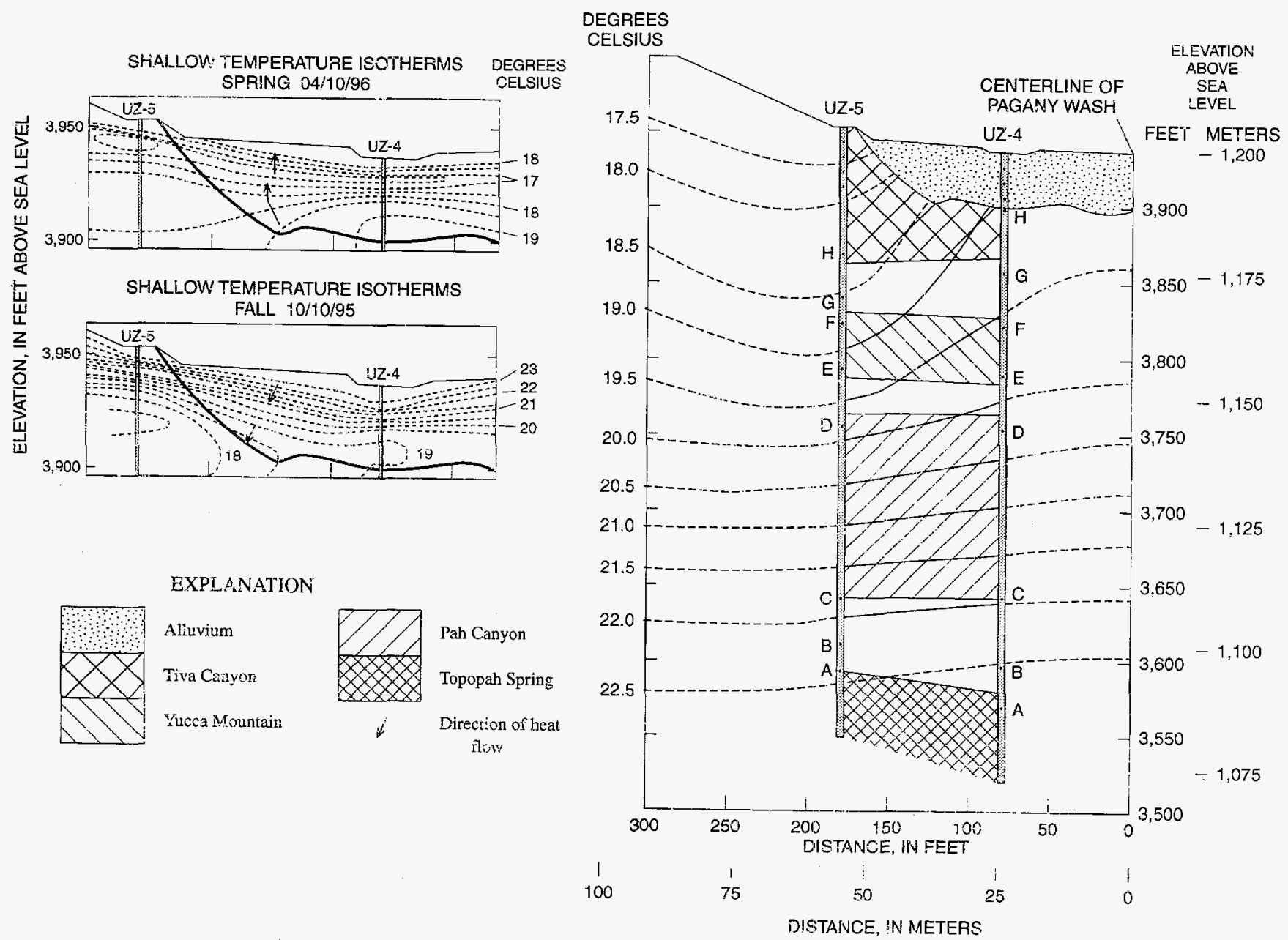

Figure 116. Isotherm section through boreholes UE-25 UZ\#4 and UE-25 UZ\#5 located in the Pagany Wash drainage, North Ramp study area. [Temperature data for 04/10/96 shown in main figure; insets reflect temperatures within the upper 50 feet (15 meters) of the land surface for $10 / 10 / 95$ and $04 / 10 / 96$. 


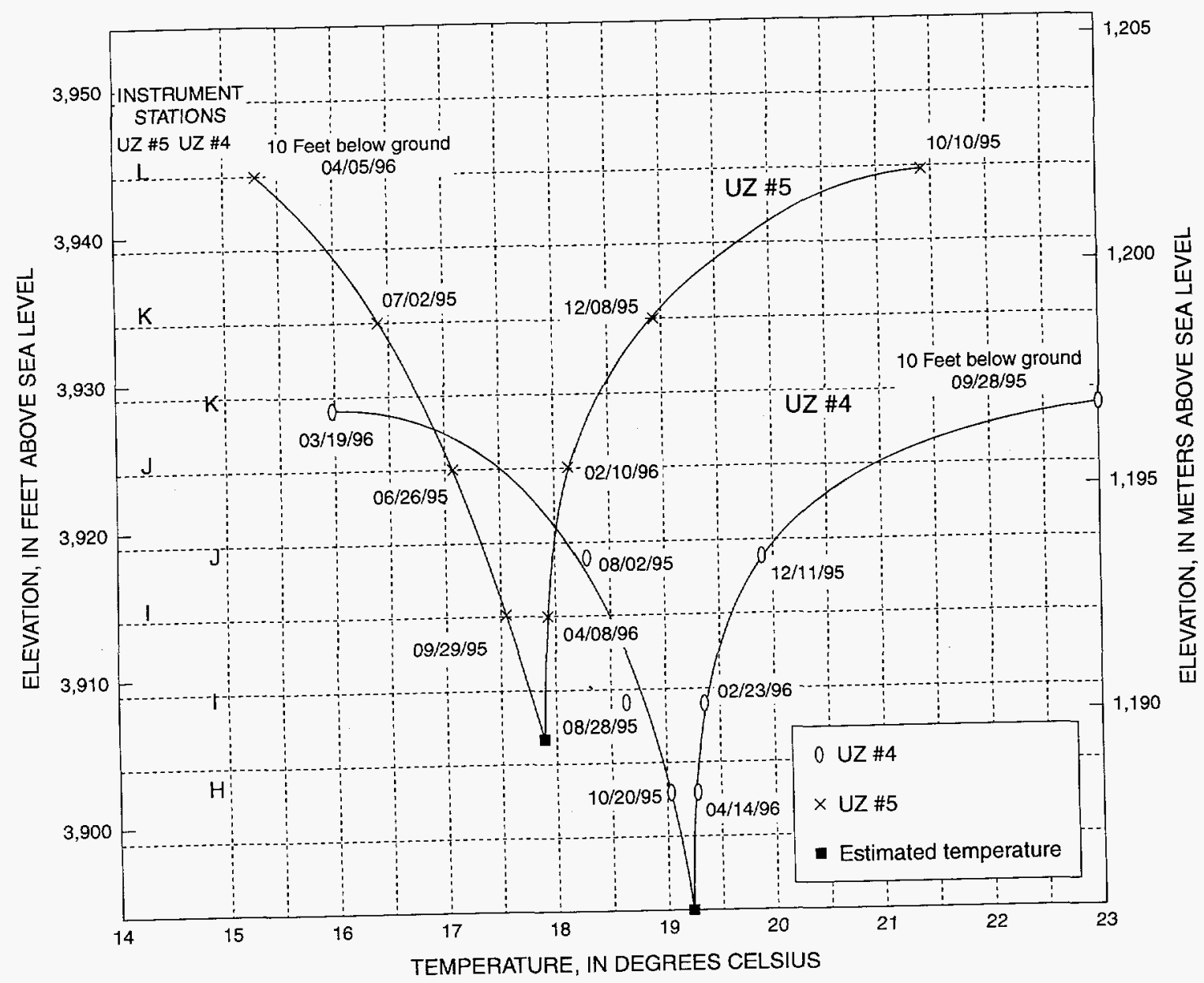

Figure 117. Shallow time-lapse temperature profiles at boreholes UE-25 UZ\#4 and UE-25 UZ\#5 in the zone affected by seasonal, land-surface temperature changes.

extremes in these shallow instrument stations. The depth of penetration of shallow, seasonal temperature changes, based on extrapolation of the shallow temperature data, is approximately $15 \mathrm{~m}$ at both borehole sites. However, the temperature at this depth in $\mathrm{UZ \# 4}$ is almost $1.4^{\circ} \mathrm{C}$ warmer than at UZ\#5 and nearly identical to the mean-annual surface temperature, $19.3^{\circ} \mathrm{C}$. The symmetry of the seasonal-temperature envelope at $\mathrm{UZ \# 4}$ and the lack of any significant temperature differential between the mean-annual surface temperature and the point at which seasonal surface-temperature effects decrease to zero indicate that heat flow on an annual basis is very low across the alluvial fill at UZ\#4. The asymmetry of this envelope at UZ\#5 and the fact that the mean temperature across this profile is less than the mean-annual surface temperature indicate that shallow heat flow at UZ\#5 may be strongly influenced by the rapid infiltration of cool water, by vaporization and shallow advective transport of vapor and air through the TCw, by reduced solar radiation due to its north-facing slope aspect, or by a combination of these mechanisms.

Results of preliminary calculations of vertical and horizontal heat flow across the Pah Canyon, Yucca Mountain, and Tiva Canyon Tuffs at UZ\#4 and UZ\#5 are presented in table 20 . Vertical heat flow at each borehole was calculated by multiplying the temperature gradient between instrument stations by the appropriate thermal conductivity of the lithostratigraphic unit. Horizontal heat flow between UZ\#4 and UZ\#5 was calculated by multiplying the temperature gradient between the boreholes within each lithostratigraphic unit by the thermal conductivity for that unit. Temperature data to compute gradients for the TSw are not available for these two boreholes. Therefore, vertical heat flow across the TSw was estimated to 
[w, welded; nw, nonwelded; $\mathrm{J} / \mathrm{s} / \mathrm{m} /{ }^{\circ} \mathrm{C}$, joule per second per meter per degree Celsius; $\mathrm{mJ} / \mathrm{s} / \mathrm{m}^{2}$, millijoule per second per meter squared; - , not applicable or no data]

\begin{tabular}{|c|c|c|c|c|c|c|c|c|c|c|}
\hline \multirow[b]{3}{*}{ Lithostratigraphic unit } & \multicolumn{6}{|c|}{ Vertical Heat flow } & \multirow{2}{*}{\multicolumn{3}{|c|}{$\frac{\text { Horizontal Heat flow }}{\text { UZ\#4 to UZ\#5 }}$}} & \multirow{4}{*}{ Comments } \\
\hline & \multicolumn{3}{|c|}{ UE-25 UZ\#5 } & \multicolumn{3}{|c|}{ UE-25 UZ\#4 } & & & & \\
\hline & $\begin{array}{l}\text { Pah } \\
\text { Canyon } \\
\text { Tpp } \\
(\mathbf{n w})\end{array}$ & $\begin{array}{l}\text { Yucca } \\
\text { Moun- } \\
\text { tain Tpy } \\
\text { (nw) }\end{array}$ & $\begin{array}{l}\text { Tiva } \\
\text { Canyon } \\
\text { columnar } \\
\text { Tpcplnc } \\
\text { (w) }\end{array}$ & $\begin{array}{l}\text { Pah } \\
\text { Canyon } \\
\text { Tpp } \\
\text { (nw) }\end{array}$ & $\begin{array}{l}\text { Yucca } \\
\text { Moun- } \\
\text { tain Tpy } \\
\text { (nw) }\end{array}$ & $\begin{array}{c}\text { Tiva } \\
\text { Canyon } \\
\text { columnar } \\
\text { Tpcplnc } \\
\text { (w) }\end{array}$ & \multirow[t]{2}{*}{$\begin{array}{l}\text { Pah } \\
\text { Canyon } \\
\text { Tpp } \\
(n w)\end{array}$} & \multirow[t]{2}{*}{$\begin{array}{l}\text { Yucca } \\
\text { Moun- } \\
\text { tain Tpy } \\
\text { (nw) }\end{array}$} & \multirow[t]{2}{*}{$\begin{array}{l}\text { Tiva } \\
\text { Canyon } \\
\text { columnar } \\
\text { Tpcpinc } \\
\text { (w) }\end{array}$} & \\
\hline Instrument stations & C-D & E-F & $H-I$ & C-D & $E \cdot F$ & G-H & & & & \\
\hline $\begin{array}{l}\text { Distance between instru- } \\
\text { ment stations (meters) }\end{array}$ & 32.24 & 8.79 & 13.26 & 32.33 & 9.78 & 13.41 & $38.11^{\mathrm{a}}$ & $38.11^{\mathrm{a}}$ & $38.11^{\mathrm{a}}$ & $\begin{array}{l}\text { a Distance between bore- } \\
\text { holes. }\end{array}$ \\
\hline $\begin{array}{l}\text { Difference in temperature } \\
\text { between stations (degree } \\
\text { Celsius) }\end{array}$ & 1.91 & 0.37 & 0.26 & 1.67 & 0.26 & 0.05 & $0.28^{b}$ & $0.72^{b}$ & $1.24^{\mathrm{b}}$ & $\begin{array}{l}{ }^{b} \text { Midpoint temperature } \\
\text { difference between UZ\#4 } \\
\text { and UZ\#5 for unit. }\end{array}$ \\
\hline $\begin{array}{l}\text { Temperature gradient } \\
\text { between stations (degree } \\
\text { Celsius per meter) }\end{array}$ & 0.059 & 0.042 & 0.020 & 0.052 & 0.027 & 0.004 & 0.007 & 0.019 & 0.033 & \\
\hline $\begin{array}{l}\text { Mean porosity of unit } \\
\text { (number of samples) }\end{array}$ & $\begin{array}{c}0.514 \\
(45)\end{array}$ & $\begin{array}{l}0.404 \\
(18)\end{array}$ & $\begin{array}{c}0.10-0.15 \\
--\end{array}$ & $\begin{array}{c}0.510 \\
(37)\end{array}$ & $\begin{array}{c}0.412 \\
(19)\end{array}$ & $\begin{array}{c}0.10-0.15 \\
--\end{array}$ & -- & -- & -- & \\
\hline $\begin{array}{l}\text { Standard deviation of } \\
\text { porosity }\end{array}$ & 0.039 & 0.037 & -- & 0.043 & 0.047 & - & -- & -- & -- & \\
\hline $\begin{array}{l}\text { Mean saturation of unit } \\
\text { (number of samples) }\end{array}$ & $\begin{array}{l}0.282 \\
(45)\end{array}$ & $\begin{array}{l}0.393 \\
(18)\end{array}$ & $\begin{array}{c}0.80-0.90 \\
\ldots\end{array}$ & $\begin{array}{c}0.319 \\
(35)\end{array}$ & $\begin{array}{l}0.537 \\
(18)\end{array}$ & $\begin{array}{c}0.80-0.90 \\
--\end{array}$ & -- & -- & - & \\
\hline $\begin{array}{l}\text { Standard deviation of satu- } \\
\text { ration }\end{array}$ & 0.075 & 0.010 & -. & 0.112 & 0.139 & -- & -- & -- & -- & \\
\hline $\begin{array}{l}\text { Thermal conductivity }{ }^{1} \\
\left(\mathrm{~J} / \mathrm{s} / \mathrm{m} /{ }^{\circ} \mathrm{C}\right)\end{array}$ & 0.265 & 0.576 & $1.61-1.82$ & 0.295 & 0.642 & $1.61-1.82$ & 0.280 & $0.609^{c}$ & $1.61-1.82^{c}$ & $\begin{array}{l}{ }^{c} \text { Average of } U Z \# 4 \text { and } \\
U Z \# 5 \text { for unit. }\end{array}$ \\
\hline $\begin{array}{l}\text { Heat flux } \\
\mathrm{mJ} / \mathrm{s} / \mathrm{m}^{2}\end{array}$ & 15.6 & 24.2 & $32.2-36.4$ & 15.3 & 17.1 & $6.4-7.3$ & 2.0 & 11.6 & $53.1-60.1$ & $\begin{array}{l}\text { Expressed in comparison } \\
\text { to } \mathrm{mJ} / \mathrm{s} / \mathrm{m}^{2} \text { for Sass and } \\
\text { others }(1988) \text {. }\end{array}$ \\
\hline
\end{tabular}
1988, fig. 15.) 
range between 32 and $40 \mathrm{~mJ} / \mathrm{s} / \mathrm{m}^{2}$, based on information presented in a preceding section of this report (see Analysis of Temperature Gradients) for the Drill Hole Wash boreholes and on the regional heat-flow map of Yucca Mountain and vicinity (Sass and others, 1988, fig. 15). The heat-flow estimate for the TSw was based on a range in temperature gradient of 0.0176 to $0.0248^{\circ} \mathrm{C} / \mathrm{m}$ and a range in thermal conductivity of 1.61 to $1.82 \mathrm{~J} / \mathrm{s} / \mathrm{m} /{ }^{\circ} \mathrm{C}$.

Thermal conductivities assigned to the welded and nonwelded tuffs at UZ\#4 and UZ\#5 in table 20 were calculated using two multiple linear-regression models developed by Rautman (1995) that express thermal conductivity as a function of porosity, temperature, and saturation:

$$
k t=C_{0}+C_{1} T+C_{2} S+C_{3} \phi
$$

where:

$$
\begin{aligned}
k t & =\text { thermal conductivity }\left(\mathrm{J} / \mathrm{s} / \mathrm{m} /{ }^{\circ} \mathrm{C}\right) \\
T & =\text { temperature }\left({ }^{\circ} \mathrm{C}\right) \\
S & =\text { liquid saturation } \\
\phi & =\text { porosity }
\end{aligned}
$$

and, for welded tuffs:

$$
\begin{aligned}
& C_{0}=1.748 \\
& C_{1}=3.52910^{-4} \\
& C_{2}=.4347 \\
& C_{3}=-3.210
\end{aligned}
$$$$
\text { number of samples: } 38
$$$$
\text { number of measurements: } 78
$$$$
r^{2}=0.58
$$

and, for nonwelded tuffs:

$$
\begin{aligned}
& C_{0}=1.250 \\
& C_{1}=2.09610^{-4} \\
& C_{2}=0.5853 \\
& C_{3}=-2.238
\end{aligned}
$$

number of samples: 7 number of measurements: 204

$$
r^{2}=0.95
$$

The functional forms of these equations are illustrated in figure 118. In this model, thermal conductivity is positively correlated with saturation and negatively correlated with porosity. Within the ranges of porosities and saturations that exist for the welded (mean saturation $=0.8 \pm 40.12$ ) and nonwelded (mean saturation $=0.51 \pm 0.17$ ) tuffs in the study area, figure 118 indicates that the thermal conductivity of the welded tuffs is fairly well constrained in comparison to that of the nonwelded tuffs. Mean values and standard deviations of saturation and porosity for the welded and nonwelded tuffs used in this analysis were derived from data presented in the section of this report titled Physical and Hydrologic Properties Determined from Analysis of Rock Cores.

The data in table 20 indicate the possible presence of a large heat-flow deficit across the TSw-PTn contact. The heat flow estimated for the Pah Canyon Tuff at boreholes UZ\#4 and UZ\#5 of approximately $15.5 \mathrm{~mJ} / \mathrm{s} / \mathrm{m}^{2}$ (table 20 ) is substantially less than the conductive heat flow of 32 to $40 \mathrm{~mJ} / \mathrm{s} / \mathrm{m}^{2}$ estimated as typical for the TSw in the North Ramp area, an estimate based principally on data from the Drill Hole Wash boreholes. Heat flow increases with elevation at borehole UZ\#5, and to a lesser extent at UZ\#4, presumably as a result of the lateral divergence of heat around the alluvium toward the more thermally conductive rocks of the TCw. Lateral divergence of heat around the alluvium is indicated by the isotherms in figure 116 and by the horizontal heat flow estimated to occur between boreholes UZ\#4 and UZ\#5 (table 20). As discussed in the following section, the tendency for the heat flow to converge beneath topographic lows also may have contributed to the increase in heat flow with elevation at UZ\#5. The reduction in heat flow from 32 to $40 \mathrm{~mJ} / \mathrm{s} / \mathrm{m}^{2}$ in the TSw to approximately $15.5 \mathrm{~mJ} / \mathrm{s} / \mathrm{m}^{2}$ within the Pah Canyon Tuff indicates the presence of heat-consuming processes, such as the downward movement of water from cooler to warmer thermal regimes. The vaporization of in-situ water by the entry of relatively dry desert air into the mountain, either because of barometric-pressure changes or as the result of topographically driven, buoyancy-induced air circulation, may be partially responsible for the cooler temperatures measured within the TCw at UZ\#5. However, it is unlikely that these processes would be capable of evaporating water from within the lower part of the PTn and upper part of the TSw, which is the depth interval over which the implied heat-flow deficit occurs.

The percolation necessary to cause a heat-flow deficit of a given magnitude can be estimated from:

$$
q_{h z}=q_{h o}-\Delta q_{h}=q_{h o}-q_{l} c_{h} \Delta T
$$




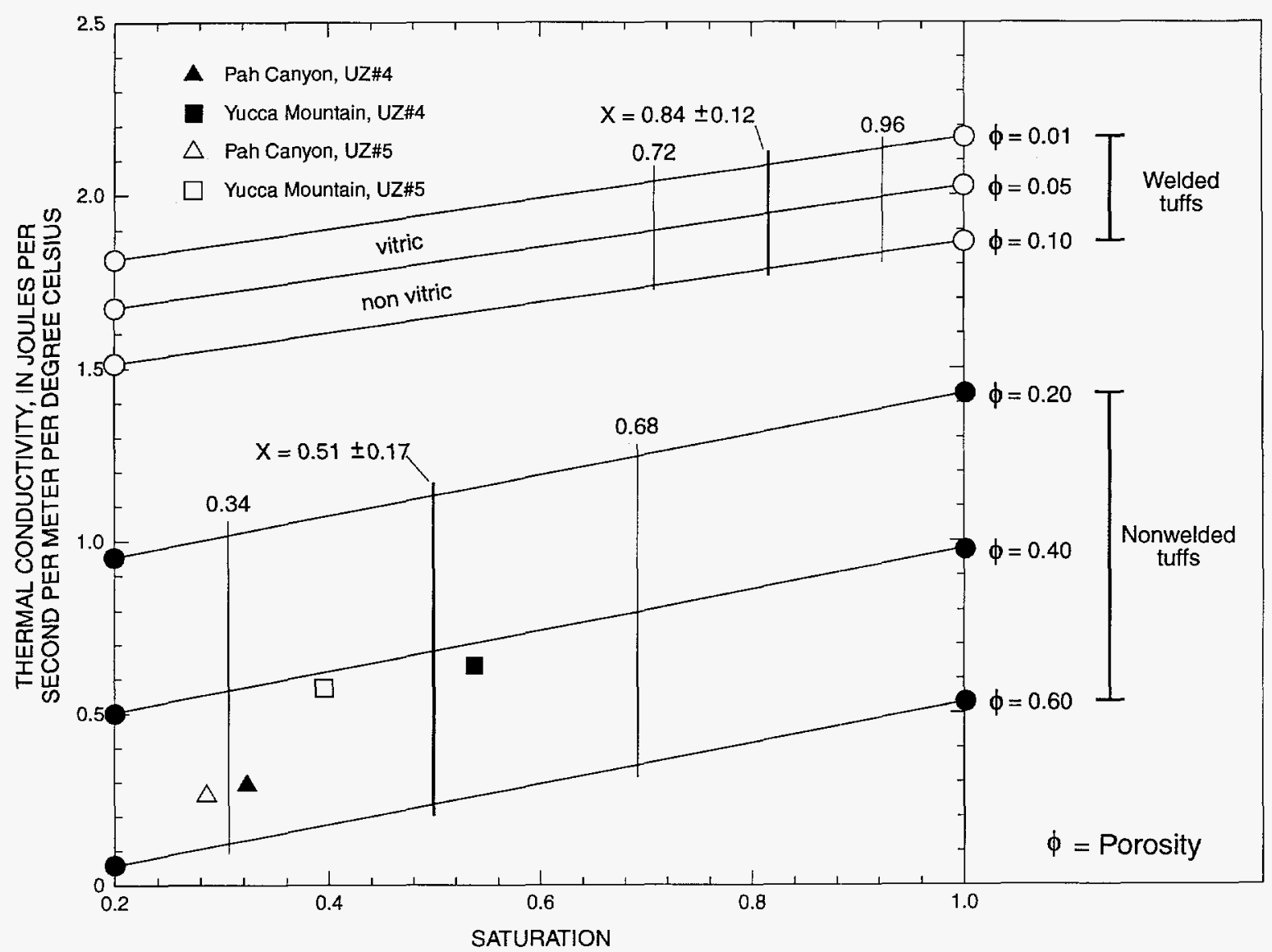

Figure 118. Thermal-conductivity values for welded and nonwelded tuffs as a function of saturation and porosity at a temperature of 20 degrees Celsius.

where $q_{h z}\left(\mathrm{~mJ} / \mathrm{s} / \mathrm{m}^{2}\right)$ is the heat flow at some elevation $z$ above the water table, $q_{h o}\left(\mathrm{~mJ} / \mathrm{s} / \mathrm{m}^{2}\right)$ is the heat flow at the water table, $\Delta q_{h}$ is the heat-flow deficit

$\left(\mathrm{mJ} / \mathrm{s} / \mathrm{m}^{2}\right), q_{l}$ is the mass flux of water $\left(\mathrm{kg} / \mathrm{s} / \mathrm{m}^{2}\right), c_{h}$ is the specific heat of water $\left(4.1868 \times 10^{6} \mathrm{~mJ} / \mathrm{kg} /{ }^{\circ} \mathrm{C}\right)$, and $\Delta T\left({ }^{\circ} \mathrm{C}\right)$ is the temperature change the water undergoes as it moves from a cooler environment at elevation $z$ to a warmer environment at the water table. The temperature in the middle of the Pah Canyon Tuff at UZ\#4 and UZ\#5 is approximately $21^{\circ} \mathrm{C}$ (fig. 116). The temperature at the water table beneath UZ\#4 and UZ\#5 is estimated from the map of water-table temperatures presented in Fridrich and others (1994, fig. 8) to be approximately $31^{\circ} \mathrm{C}$, so that $\Delta T \approx 10^{\circ} \mathrm{C}$. Assuming that heat flow at the water table is at least as great as that estimated for the TSw based on the Drill Hole Wash boreholes ( 32 to $40 \mathrm{~mJ} / \mathrm{s} / \mathrm{m}^{2}$ ), and that $\Delta q_{h}$ $=15.5 \mathrm{~mJ} / \mathrm{s} / \mathrm{m}^{2}$, it can be estimated from equation 5 that $q_{l}$ ranges between $3.94 \times 10^{-7}$ to $5.85 \times 10^{-7}$ $\mathrm{kg} / \mathrm{s} / \mathrm{m}^{2}$, which corresponds to percolation fluxes of 12.4 to $18.4 \mathrm{~mm} / \mathrm{yr}$. If the heat flow at the water table is larger than that estimated on the basis of the data from the TSw, the percolation flux required to satisfy the larger heat-flow deficit also would be larger.

Therefore, as a minimum, the long-term percolation flux beneath Pagany Wash within the lower part of the PTn and upper part of the TSw in the vicinity of UZ\#4 and UZ\#5 is 10 to $20 \mathrm{~mm} / \mathrm{yr}$.

It is possible that the percolation fluxes estimated above may have been affected by two artificialinfiltration or ponding experiments conducted at UZN\#7, a neutron-monitoring borehole located in Pagany Wash about $2 \mathrm{~m}$ north of UZ\#4 (W.R. Guertal, U.S. Geological Survey, to J.P. Rousseau, written commun., June 1996). The first infiltration experiment was conducted between September 23 and 26, 1994, lasted 76 hours, and involved application of $90,840 \mathrm{~L}$ of water. The second experiment was conducted 
between March 15 and 18, 1995, lasted 75 hours, and involved application of $94,625 \mathrm{~L}$ of water. Although the temperature of the water at the time of application is unknown, surface-temperature records at NRG-6 and NRG-7a indicate that the mean-daily surface temperature between March 15 and 18, 1995, was approximately $13^{\circ} \mathrm{C}$. Because the infiltrometer ring was open to the atmosphere throughout these experiments and the application rate was relatively low, it is likely that the temperature of the water in the infiltrometer was in equilibrium with air temperature. Therefore, the temperature of the water used in the second experiment probably was on the order of 13 to $15^{\circ} \mathrm{C}$.

Sufficient water was applied during both experiments to saturate a 3.7-m-diameter column of alluvium down to the alluvium-bedrock contact, which is about $13 \mathrm{~m}$ deep at UZN\#7. UZ\#4 and UZ\#5 were instrumented in late June and early July 1995, 3 months after the second infiltration experiment. The exact effects of these two infiltration experiments on in-situ temperatures at UZ\#4 and UZ\#5 is not known. However, the time-series temperature records and time-lapse temperature profiles for these two boreholes do not exhibit any aberrations. This observation appears somewhat counterintuitive in view of the large quantity of water applied at the UZN\#7 borehole site and the very close proximity of this borehole to UZ\#4. As noted in the discussion of the temperature record from UZ\#4, temperatures within the PTn above the base of the Pah Canyon Tuff were still increasing as of April 15, 1996 (fig. 114). The effects of the ponding experiment may be reflected in the long-term sustained warming trends that have been observed within the upper one-half of the PTn at UZ\#4. The temperature of the water applied during the second experiment would have been colder than temperatures in the alluvium of Pagany Wash at the time the second experiment was conducted (see spring 04/10/96 shallow temperature isotherms, fig. 116). So far the monitoring data at UZ\#4 and UZ\#5 provide no indication that the essential characteristics of the thermal regimes at these two boreholes have been significantly altered by the infiltration experiments. Perhaps additional monitoring will confirm or refute this conclusion.

\section{Numerical Analysis of Heat Flow and Percolation in Pagany Wash}

The preceding sections have discussed the possible factors affecting temperature distribution and heat flow within the unsaturated zone at Yucca Mountain. These factors include (1) the effects of topography and variable unsaturated zone thickness, (2) the insulating effects of alluvial cover, (3) the effects of natural air circulation within Yucca Mountain, and (4) the effects of spatially varying infiltration and percolation. In this section, heat flow through a thick unsaturated zone with pronounced topographic relief is simulated to illustrate these processes. A highly schematicized cross section of Yucca Mountain is used to investigate the relative magnitudes of the effects of these factors on heat flow and to develop a broad conceptual framework for unsaturated-zone heat flow. Descriptions of simulations of coupled gas, liquid, and heat flow through the schematic cross section of Yucca Mountain are followed by descriptions of detailed two- and one-dimensional simulations of coupled water and heat flow for the UZ\#4 and UZ\#5 site in Pagany Wash.

Gas, Liquid, and Heat Flow Through a Schematic Cross Section

Simulations of coupled gas, liquid, and heat flow using TOUGH2 (Pruess, 1991) were done using the computational grid shown in figure 119 for five cases (table 21) to isolate the effects of topography, alluvial cover, gas flow, and water flow on temperatures and heat flow through a thick unsaturated zone with ridge-and-valley topography. The effects of stratigraphy are not examined in this particular set of simulations but are considered in the more detailed simulations of heat flow within and beneath Pagany Wash that follow. The mountain is assumed to consist only of fractured, densely welded tuff with properties considered representative of the lower nonlithophysal unit of the Topopah Spring Tuff (Tptpln). The alluvial properties are those listed below for the Pagany Wash simulations. Average annual temperatures along the upper surface of the mountain are a function of elevation and decrease by $1^{\circ} \mathrm{C}$ for each $100-\mathrm{m}$ increase in elevation. The upper surface is a no-flow boundary for water and gas except in those simulations explicitly designed to examine the effects of air or water movement. The lower boundary of the model coincides with the water table and is represented as a specified constant-heat-flow $\left(36.5 \mathrm{~mJ} / \mathrm{s} / \mathrm{m}^{2}\right)$ and constant-liquid- 


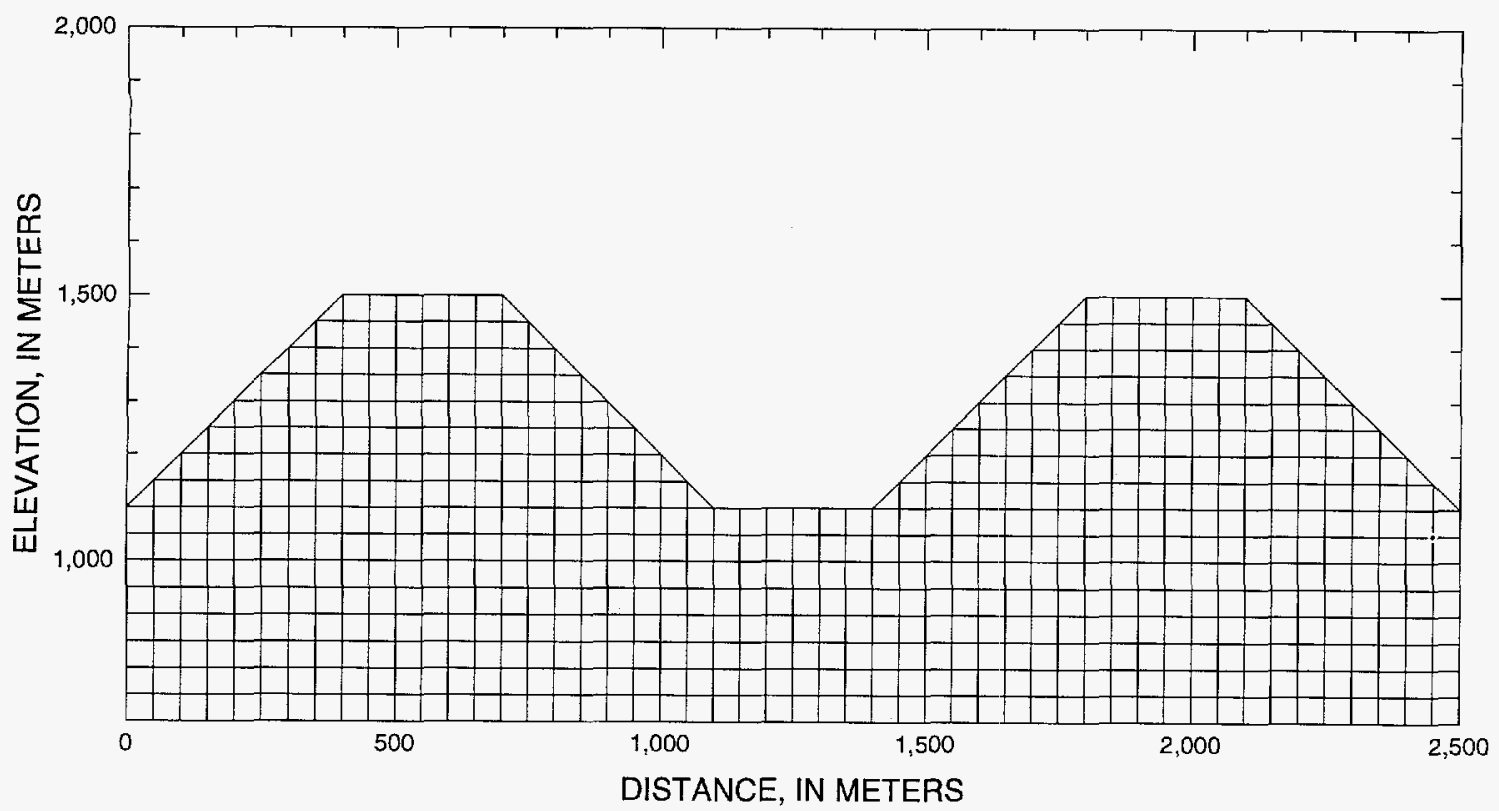

Figure 119. Computational mesh used in heat-flow simulations.

saturation (0.999) boundary. Water potentials and saturations are, therefore, in a state of static equilibrium with the water table except in those cases in which infiltration or natural air circulation occurs. Some features of Yucca Mountain, such as topographic relief and alluvium thickness of $75 \mathrm{~m}$, have been exaggerated for illustrative purposes.

The effects of topography alone on temperatures and heat flow in the unsaturated zone are illustrated by Case A (fig. 120). The temperature contours are a subdued reflection of the topography, and the heatflow vectors (values are proportional to length and expressed in $\mathrm{mJ} / \mathrm{s} / \mathrm{m}^{2}$ ), which are normal to the temperature contours, tend to converge toward the washes and diverge beneath the ridges. Temperatures are higher beneath the ridges and lower beneath the washes at comparable elevations when only the effects of topography are considered. For the simplified stratigraphy used in these simulations, temperature variations occur in the water-table temperatures as well. However, temperature gradients and conductive heat flow are larger beneath the wash due to the absence of insulating overburden and the deflection of the heat-flow vectors toward the wash.

The temperature contours and heat-flow vectors for Case B are shown in figure 121. A comparison of figures 120 and 121 illustrates the effects of a thick $(75 \mathrm{~m})$ layer of alluvium which, because of its high porosity and generally low saturation, is assumed to have a low thermal conductivity. The presence of a

Table 21. Summary of the five cases considered for the simulations of heat flow through a schematic cross section [mm/yr, millimeters per year]

\begin{tabular}{ccccc}
\hline Case & $\begin{array}{c}\text { Alluvial cover in } \\
\text { wash }\end{array}$ & $\begin{array}{c}\text { Active air } \\
\text { circulation }\end{array}$ & $\begin{array}{c}\text { 20 mm/yr infiltration } \\
\text { in wash }\end{array}$ & $\begin{array}{c}\text { 20 mm/yr infiltration } \\
\text { on ridgetops }\end{array}$ \\
\hline Case A & No & No & No & No \\
Case B & Yes & No & No & No \\
Case C & No & Yes & Yes & No \\
Case D & Yes & No & No & No \\
Case E & Yes & No & Yes \\
\hline
\end{tabular}


采。

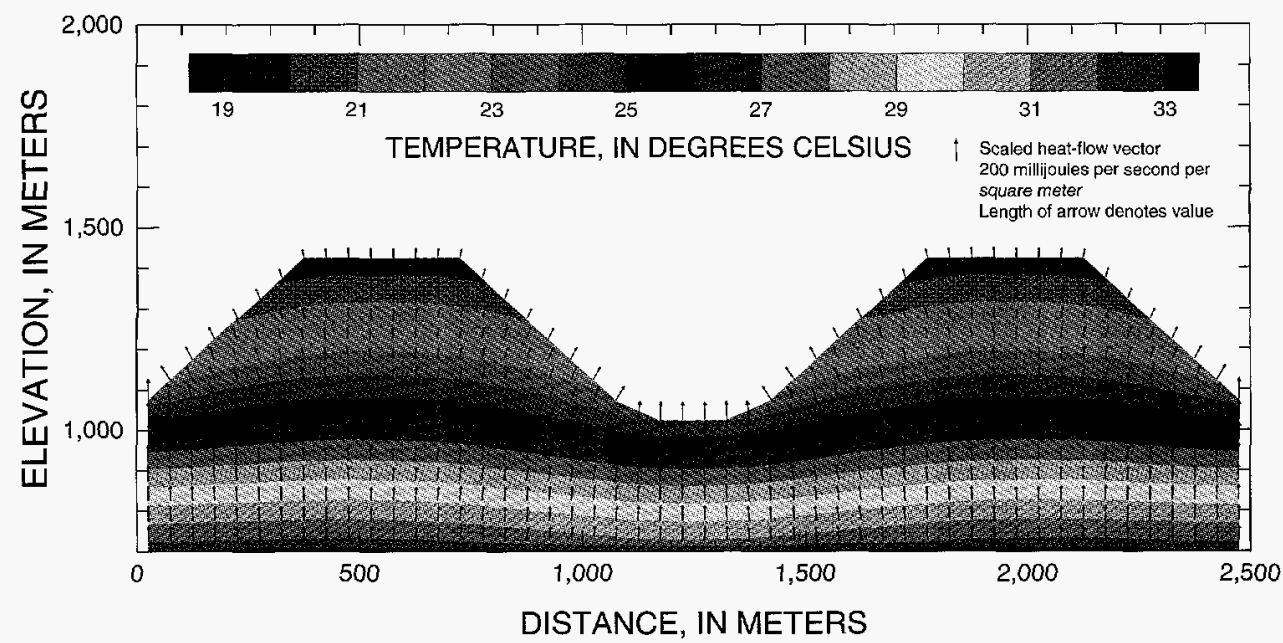

Figure 120. Simulated temperature contours and heat-flow vectors for Case A.
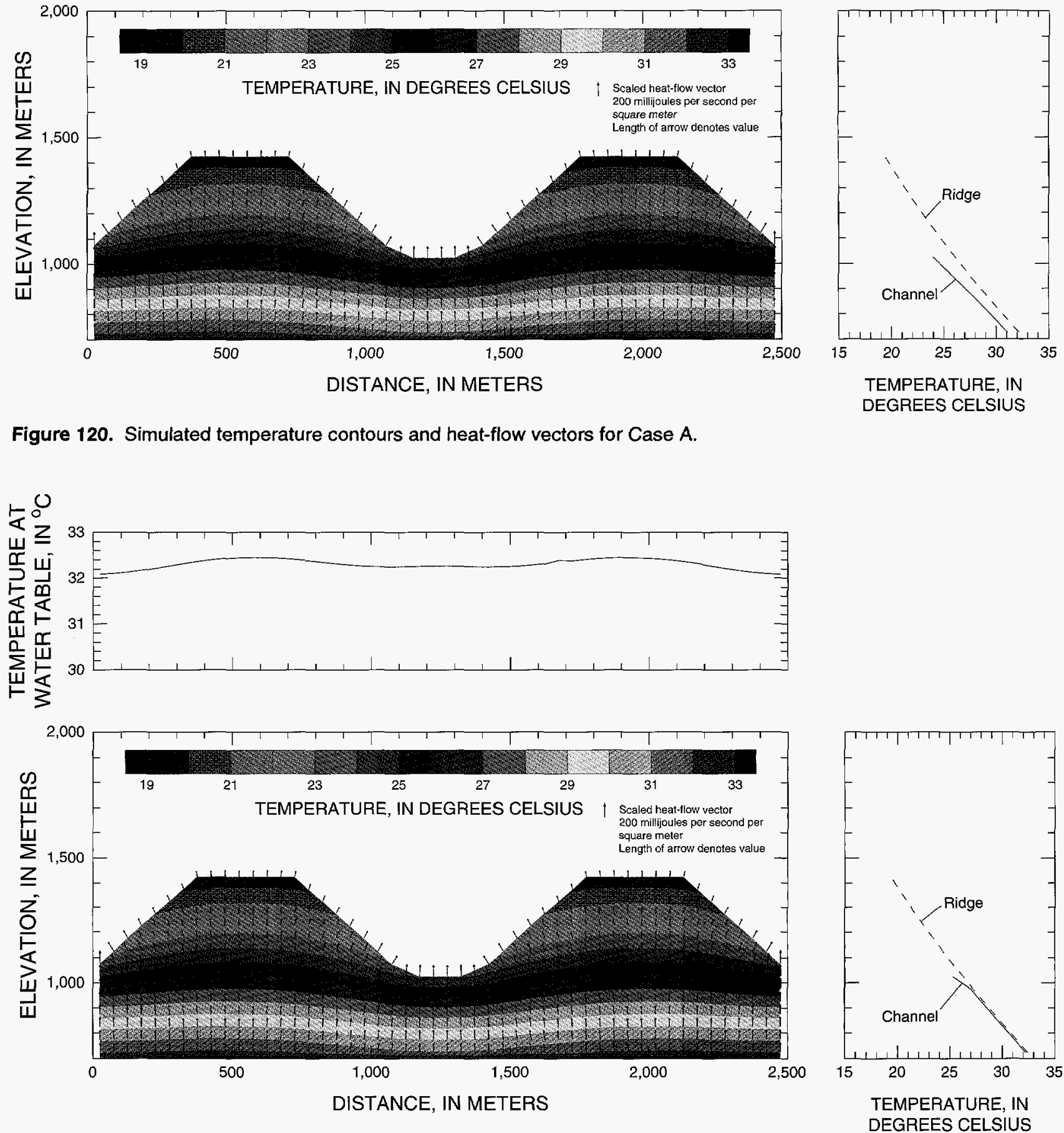

Figure 121. Simulated temperature contours and heat-flow vectors for Case B. 
thick layer of alluvium causes a rise in temperatures in the unsaturated zone beneath the wash, so that temperatures and temperature gradients are comparable to those under the ridgetops for the same elevation. The conductive heat flow decreases with elevation beneath the alluvium, as heat is deflected around the alluvium into the sideslopes bordering the wash. Because the effects of topography also are present, the sideslopes bordering the wash are now the areas of greatest heat flow. For this simplified stratigraphy and exceptionally thick layer of alluvium, the insulating effects of the alluvium also are reflected in an increase in the water-table temperatures.

The effects of natural air circulation on temperatures within the unsaturated zone were examined in Case C. As discussed in Weeks (1987), natural air circulation occurs in areas of high topographic relief because cooler, drier, and hence denser air on the flanks of a ridge or valley floor tends to sink and displace the warmer, moister, and hence lighter air within the mountain. As this descending mass of air is heated by the geothermal gradient, it rises and exits along the ridges and upper hillslopes. This pattern of natural air convection is illustrated in figure 122 with gas-flow vectors (values are proportional to length and expressed in $\mathrm{kg} / \mathrm{s} / \mathrm{m}^{2}$ ). As dry, relatively cool air enters the mountain, sinks, and is warmed, it evapo- rates water from the rock. As it rises out of the crest of the ridge, the circulating air begins to cool, and some of the water vapor it contains is deposited as liquid condensate, which then drains downward and back toward the sideslopes and channel bottoms where evaporation originally took place (fig. 123). Therefore, there is the potential that temperatures on the flanks of the ridges and valley floors may be lowered by evaporative cooling, and temperatures beneath the ridges will be raised by heat released during condensation of the vapor. However, because of the small amounts of moisture involved $\left(2.0 \times 10^{-10} \mathrm{~kg} / \mathrm{s}^{-\mathrm{m}^{2}}\right.$, which corresponds to a Darcy flux of $0.006 \mathrm{~mm} / \mathrm{yr}$ ), the effects of natural air circulation on temperatures appear to be negligible. The temperature contours and heat-flow vectors for Case $\mathrm{C}$ are indistinguishable from those for Case A (fig. 120).

In Case D, $20 \mathrm{~mm} / \mathrm{yr}$ of infiltration was applied to the alluvium within the channel bottom. Figure 124 shows the temperature contours and heat-flow vectors for Case D. To understand the effects of that amount of infiltration on temperature and heat flow within the wash environment, it is necessary to compare the results of Case D with those of Case B. Temperatures within the unsaturated zone beneath the wash are approximately 0.5 to $1.0^{\circ} \mathrm{C}$ cooler for Case D than for Case $\mathrm{B}$, which considered the effects of alluvium but

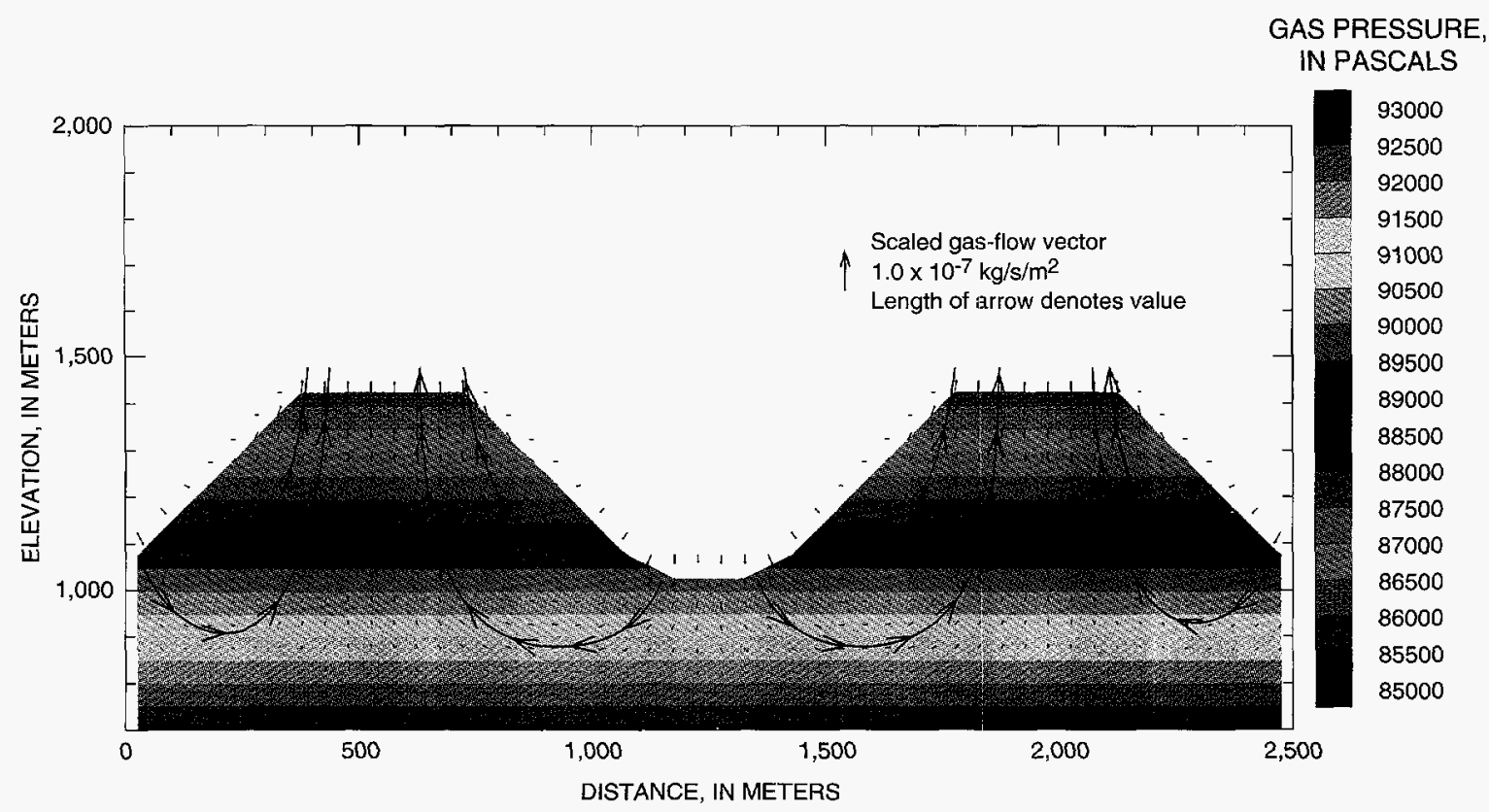

Figure 122. Simulated gas-pressure contours and gas-flow vectors for Case C. 
WATER POTENTIAL, IN PASCALS

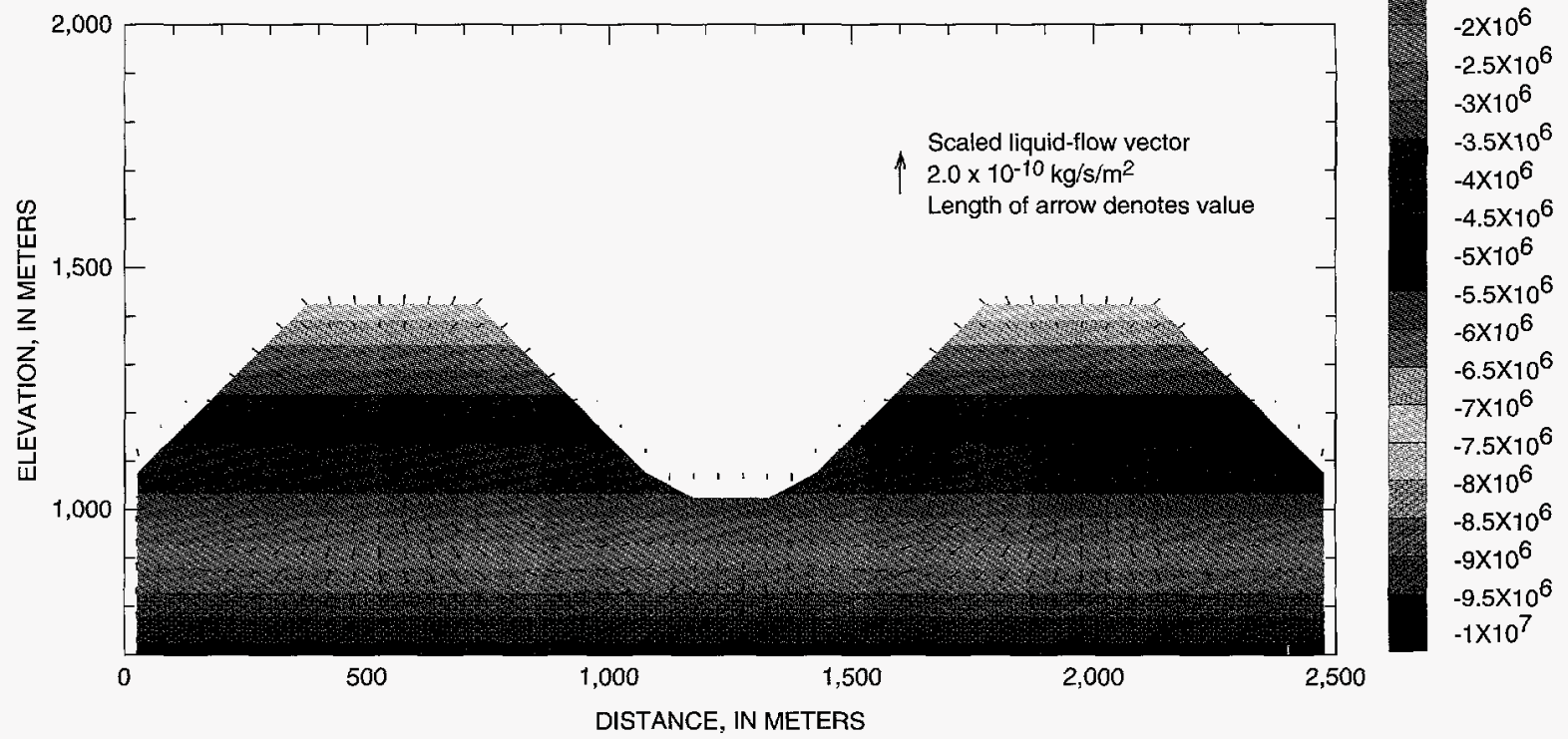

Figure 123. Simulated water-potential contours and liquid-flow vectors for Case $C$.
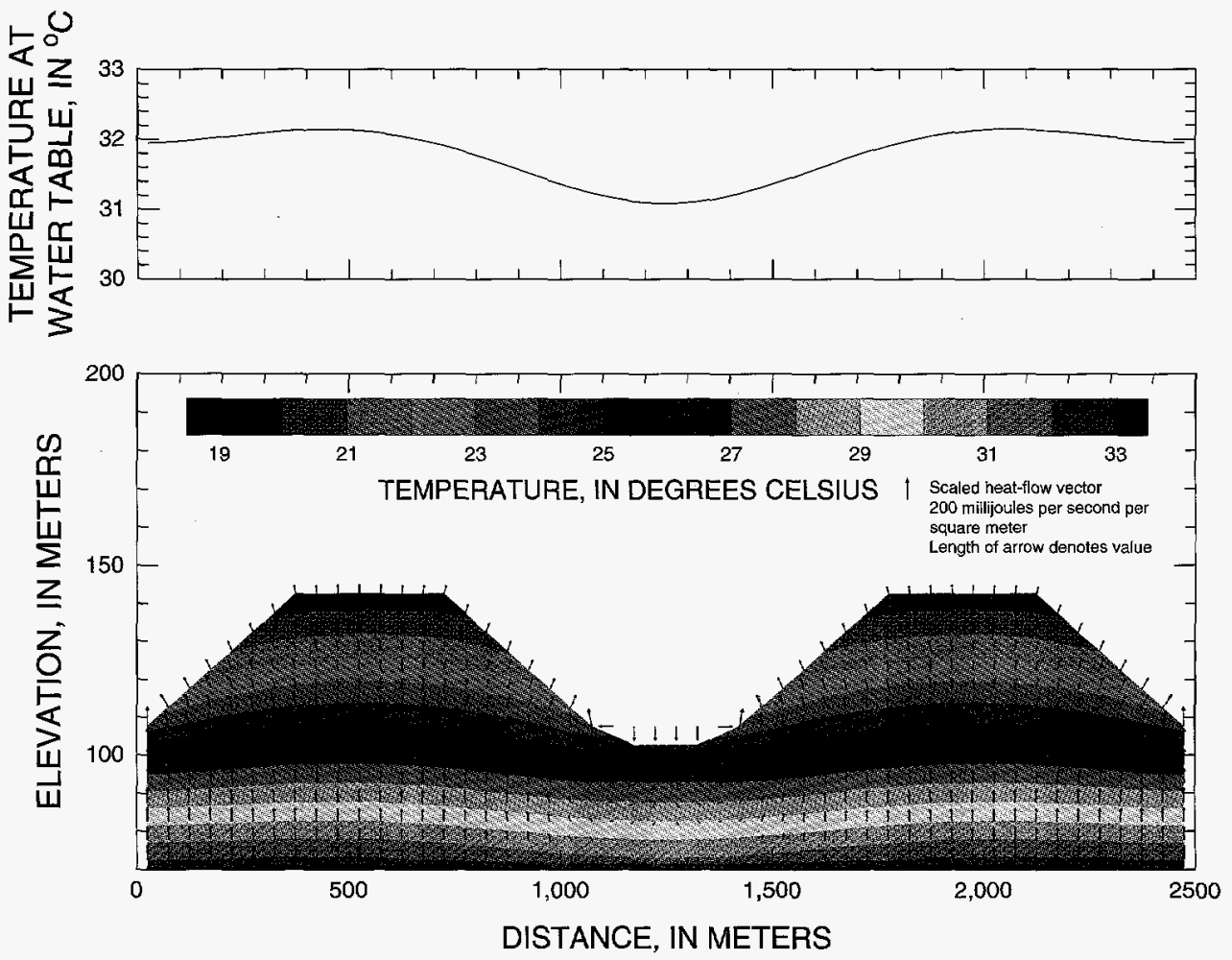

Figure 124. Simulated temperature contours and heat-flow vectors for Case D.

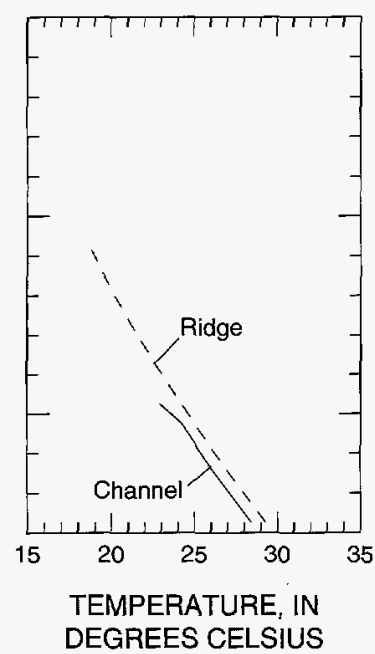


included no infiltration. However, temperatures beneath the wash for Case $D$, which are identical to those of Case A (fig. 120), remain slightly higher than in Case $\mathrm{C}$, which did not consider the effects of alluvium. Predicted increases in temperature for Case D were greatest in the uppermost part of the unsaturated zone, where the insulating effects of the alluvium were most pronounced. The heat-flow vectors, which represent the sum of the conductive and convective components, indicate that the total heat flow is downward beneath the wash. A comparison of the temperature gradients beneath the alluvium for Cases D and B indicates that the temperature gradient for Case $D$ is slightly smaller, reflecting the consumption of the upward conductive heat flow by the downwardly flowing water. Temperatures beneath the wash are again cooler than those at comparable elevations beneath the ridgetops, although the temperature gradients are similar. Figure 124 shows that the temperature rise at the water table caused by the presence of alluvium (figs. 120 and 121) is almost completely offset by the effects of the $20-\mathrm{mm} / \mathrm{yr}$ infiltration rate in the wash.

The effects of $20 \mathrm{~mm} / \mathrm{yr}$ of infiltration along the ridgetops (Case E) on temperatures and heat flow are shown in figure 125. The effect of this amount of infiltration is to suppress temperatures beneath the ridgetops to the degree that unsaturated-zone and watertable temperatures in those locations are lower than those at corresponding elevations beneath the wash. Infiltration along the ridgetop further reduces the temperature gradient and convective heat flow relative to the no-flux cases (for example, Case B). The temperature gradients beneath the ridgetops in Case $\mathrm{E}$ are reduced to a magnitude similar to that of the temperature gradient beneath the wash, which is low because of the presence of the alluvium.

The temperature profiles for the unsaturated zone beneath the wash and ridgetops and at the water table for each of the five cases are summarized in figure 126.
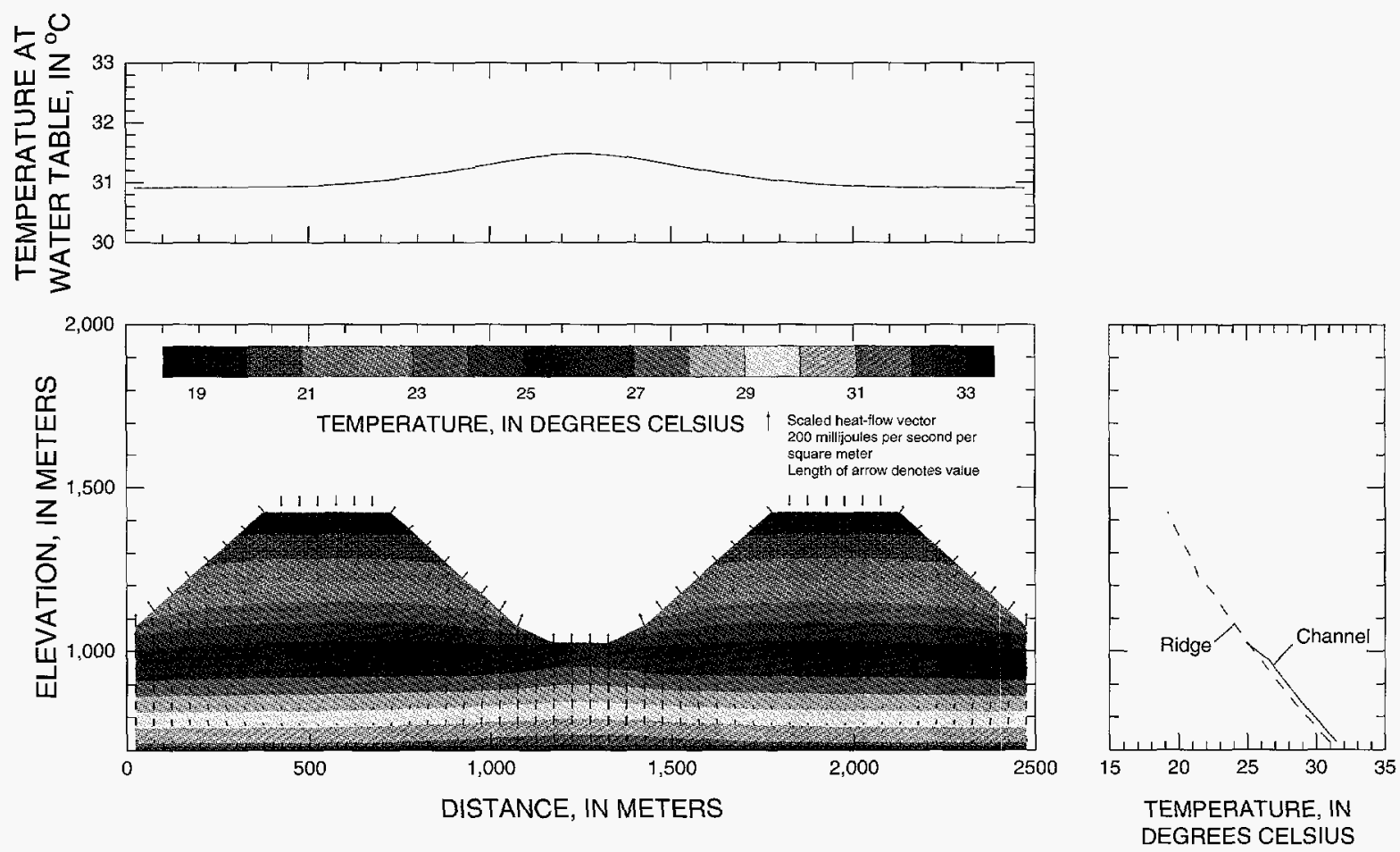

Figure 125. Simulated temperature contours and heat-flow vectors for Case $E$. 

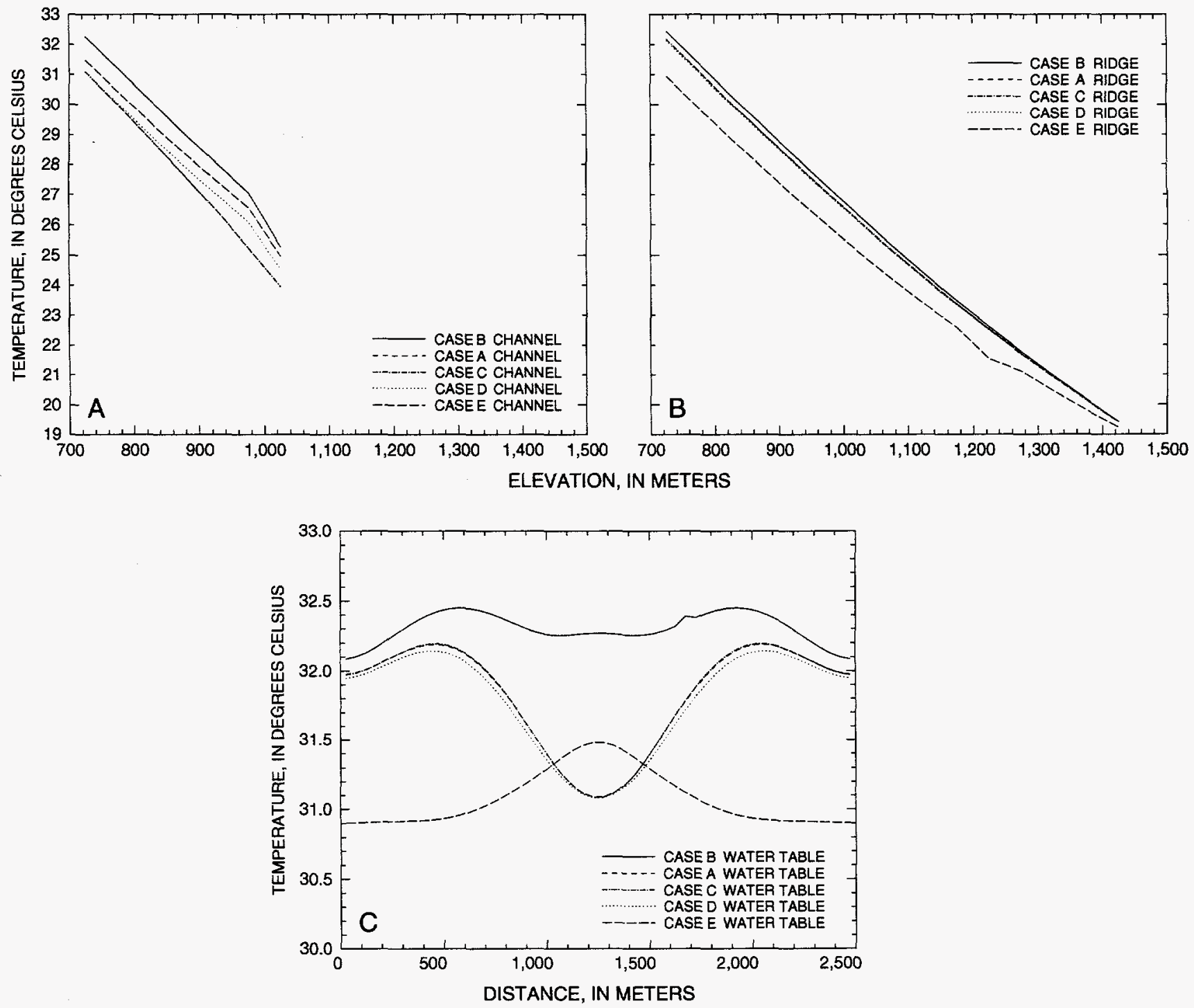

Figure 126. Simulated temperature profiles $(A)$ beneath the wash, $(B)$ beneath the ridgetops, and $(C)$ at the water table.

These simulations investigated unsaturated zone processes affecting temperature distributions and heat flow in a thick unsaturated zone with ridge-and-valley topography. Heat flow entering the unsaturated zone across the water table was assumed to be spatially invariant. Although these simulations have demonstrated that unsaturated-zone processes and the variable thickness of the unsaturated zone may affect water-table temperatures, horizontal flow within the saturated zone or water movement along faults in the saturated zone may produce spatial variations in water-table temperatures and unsaturated-zone heat flow (Fridrich and others, 1994; Sass and others, 1988) that may further complicate interpretation of the unsaturated-zone temperature profiles.

\section{Liquid Flow and Heat Flow in Pagany Wash}

A series of one- and two-dimensional simulations of liquid flow and heat flow were run in an attempt to verify the 12.4 - to $18.4-\mathrm{mm} / \mathrm{yr}$ percolationflux estimates calculated at UZ\#4 and UZ\#5 on the basis of equation 5 . These simulations were run using the computational grid and lithostratigraphy shown in figure 127 and, with the exception of the first twodimensional case presented, are based on the hydrologic and thermal properties listed in table 22 . In the first two-dimensional case, the liquid phase was immobilized by defining the relative water permeability to be zero within the model, and constant thermal properties were assigned to individual rock units on the basis of average unit saturations listed in 


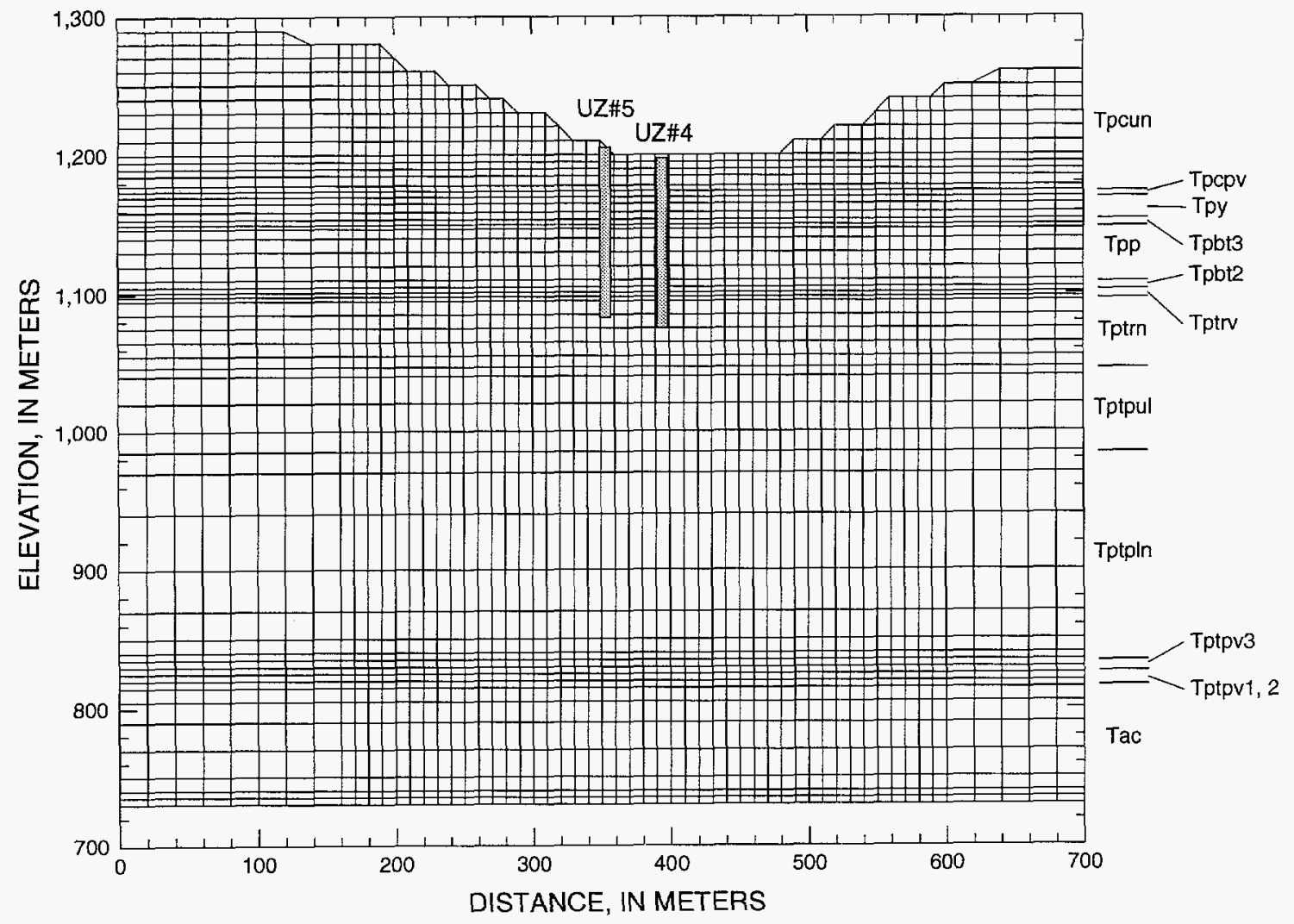

Figure 127. Computational mesh and stratigraphy used in the Pagany Wash simulations.

table 16 and the thermal conductivity-saturationporosity relation represented in figure 118 . Because of the excessive computational demands of the simulations, only a limited number of cases could be run in two dimensions. The two-dimensional simulations were supplemented by one-dimensional simulations that used the columns in the computational mesh corresponding to either borehole UZ\#4 or UZ\#5.

In the one- and two-dimensional simulations, the lower boundary, which coincides with the water table, was represented as a surface of uniform heat flow $\left(36.5 \mathrm{~mJ} / \mathrm{s} / \mathrm{m}^{2}\right)$ and liquid saturation $(0.999)$. In the first two-dimensional case, the upper boundary was represented as a zero-flux infiltration boundary with elevation-dependent surface temperatures that decreased $1.0^{\circ} \mathrm{C}$ with each $100-\mathrm{m}$ increase in elevation, using a baseline temperature of $19.3^{\circ} \mathrm{C}$ at $\mathrm{UZ \# 4}$. Because there is no infiltration in this case, the temperature contours and heat-flow distribution in the immediate vicinity of the wash reflect primarily the effects of local topography and the insulating effects of alluvium on heat conduction. The simulation results (fig. 128) show significant convex-upward flexures in the isotherms in the upper part of the PTn (shown in fig. 127), qualitatively replicating those implied by the borehole temperature data (fig. 116). The heat-flow vectors shown in figure 128 indicate significant lateral diversion of heat around the alluvium and into the rock sideslopes adjacent to the wash. The simulated temperatures and vertical heat flow in the columns of cells in the model corresponding to UZ\#4 and UZ\#5 are shown in figure 129. Because there is no downward percolation to consume the heat moving upward by conduction, the simulated temperatures are too high relative to the measured temperatures (fig. 129A). The plot of simulated vertical heat flow as a function of elevation (fig. 129B) indicates that in the upper part of both boreholes, substantial changes in heat flow can be expected solely because of the lateral diversion of conductively transported heat around the low thermalconductance alluvial fill. Because of this process, heat flow in the rock immediately beneath the alluvium is predicted to decrease to as little as $25.0 \mathrm{~mJ} / \mathrm{s} / \mathrm{m}^{2}$, and the heat flow in the rock in the adjacent sideslopes is predicted to increase to almost $63.0 \mathrm{~mJ} / \mathrm{s} / \mathrm{m}^{2}$. The predicted increase in heat flow with elevation at UZ\#5 
Table 22. Hydrologic and thermal properties used in simulations of water flow and heat flow beneath Pagany Wash

$\left[\rho_{g}\right.$, grain density; $\phi$, porosity; $k$, permeability; $m$, van Genuchten $(1980)^{l}$ fitting parameter related to pore size distribution; $\alpha$, van $G e n u c h t e n$ parameter related to characteristic pore size; $\mathrm{k}_{\mathrm{tw}}$, thermal conductivity at complete saturation; $\mathrm{k}_{\mathrm{td}}$, thermal conductivity of the dry rock; $\mathrm{c}_{s}$, specific heat of the rock; $\mathrm{kg} / \mathrm{m}^{3}$, kilogram per cubic meter; $\mathrm{m}^{2}$, meter squared; $1 / \mathrm{Pa}, 1$ divided by pascal; $\mathrm{J} / \mathrm{s} / \mathrm{m} /{ }^{\circ} \mathrm{C}$, joule per second per meter per degree Celsius; $\mathrm{J} / \mathrm{kg} /{ }^{\circ} \mathrm{C}$, joule per kilogram per degree Celsius; NA, not applicable]

\begin{tabular}{|c|c|c|c|c|c|c|c|c|}
\hline $\begin{array}{l}\text { Lithostrati- } \\
\text { graphic unit } \\
\text { (see table 2) }\end{array}$ & $\underset{\left(k g / m^{3}\right)}{\rho_{g}}$ & $\phi$ & $\underset{\left(m^{2}\right)}{k}$ & m & $\begin{array}{c}\alpha \\
(1 / \mathrm{Pa})\end{array}$ & $\underset{\left(\mathrm{J} / \mathrm{s} / \mathrm{m}^{\circ} \mathrm{C}\right)}{\mathbf{k}_{\mathrm{tw}}}$ & $\begin{array}{c}k_{t d} \\
\left(\mathrm{~J} / \mathrm{s} / \mathrm{m}^{\circ} \mathrm{C}\right)\end{array}$ & $\begin{array}{c}\mathrm{C}_{s} \\
\left(\mathrm{~J} / \mathrm{kg}^{\circ} \mathrm{C}\right)\end{array}$ \\
\hline Tac & 2,360 & 0.327 & $1.2 \times 10^{-16}$ & 0.270 & $5.04 \times 10^{-7}$ & 1.139 & 0.554 & 800.0 \\
\hline Tptpv1,2 & 2,300 & 0.350 & $1.2 \times 10^{-15}$ & 0.600 & $3.00 \times 10^{-6}$ & 1.095 & 0.509 & 800.0 \\
\hline Tptpv3 & 2,380 & 0.400 & $8.7 \times 10^{-19}$ & 0.317 & $4.20 \times 10^{-8}$ & 2.062 & 1.627 & 800.0 \\
\hline Tptpln & 2,550 & 0.110 & $1.9 \times 10^{-16}$ & 0.388 & $4.40 \times 10^{-7}$ & 1.837 & 1.402 & 800.0 \\
\hline Tptpul & 2,510 & 0.150 & $3.0 \times 10^{-17}$ & 0.292 & $2.96 \times 10^{-6}$ & 1.708 & 1.274 & 800.0 \\
\hline Tptrn & 2,560 & 0.140 & $3.8 \times 10^{-16}$ & 0.343 & $4.52 \times 10^{-6}$ & 1.741 & 1.306 & 800.0 \\
\hline Tptrv & 2,510 & 0.050 & $1.0 \times 10^{-18}$ & 0.397 & $1.31 \times 10^{-7}$ & 2.029 & 1.595 & 800.0 \\
\hline Tpbt2 & 2,350 & 0.455 & $5.3 \times 10^{-13}$ & 0.231 & $1.87 \times 10^{-4}$ & 0.848 & 0.263 & 800.0 \\
\hline Tpp & 2,270 & 0.512 & $1.4 \times 10^{-13}$ & 0.286 & $1.87 \times 10^{-4}$ & 0.737 & 0.151 & 800.0 \\
\hline Tpbt3 & 2,380 & 0.450 & $2.2 \times 10^{-13}$ & 0.286 & $1.87 \times 10^{-4}$ & 0.871 & 0.286 & 800.0 \\
\hline Tpy & 2,310 & 0.398 & $3.6 \times 10^{-14}$ & 0.230 & $1.00 \times 10^{-4}$ & 0.987 & 0.401 & 800.0 \\
\hline Tpcpv1 & 2,430 & 0.475 & $5.7 \times 10^{-14}$ & 0.245 & $2.90 \times 10^{-6}$ & 0.804 & 0.218 & 800.0 \\
\hline Tpcun & 2,380 & 0.150 & $3.0 \times 10^{-17}$ & 0.292 & $2.96 \times 10^{-6}$ & 1.708 & 1.274 & 800.0 \\
\hline Alluvium & 2,380 & 0.500 & $5.3 \times 10^{-13}$ & 0.231 & $1.80 \times 10^{-4}$ & 0.759 & 0.174 & 800.0 \\
\hline $\begin{array}{l}\text { Fracture } \\
\text { continuum }{ }^{2}\end{array}$ & NA & $7.5 \times 10^{-4}$ & $4.3 \times 10^{-12}$ & 0.641 & $3.44 \times 10^{-3}$ & NA & NA & NA \\
\hline
\end{tabular}

$\begin{array}{ll}{ }^{1} \text { The van Genuchten equations are: } & \mathrm{S}_{\mathrm{le}}=[1+(\alpha \psi)]^{\mathrm{n}-\mathrm{m}} \\ \text { where, } & \mathrm{S}_{\mathrm{le}}=\left(\mathrm{S}_{\mathrm{l}}-\mathrm{S}_{\mathrm{lr}}\right) \\ & \left(\mathrm{S}_{\mathrm{s}}-\mathrm{S}_{\mathrm{ll}}\right)\end{array}$

and $S_{1 \mathrm{l}}$ is "effective" water saturation, $S_{1}$ is water saturation, $S_{\mathrm{lr}}$ is residual water saturation, $S_{\mathrm{s}}$ is "satiated" or maximum field saturation, $\alpha$ is a scaling parameter related to the characteristic pore size, and $\mathrm{n}$ is a measure of the dispersion of those pore sizes around the characteristic pore size. The standard assumption is made that $n=1 /(1-\mathrm{m})$. The pore-size information described by the parameters of the moisture-characteristic curve were used to predict the relative permeability to water $\left(\mathrm{k}_{\mathrm{rw}}\right)$ as a function of Sle:

$$
\mathrm{k}_{\mathrm{rw}}=\mathrm{S}_{\mathrm{le}}^{0.5}\left[1-\left(1-\mathrm{S}_{\mathrm{le}}^{\left.1 / \mathrm{m})^{\mathrm{m}}\right]^{2}}\right.\right.
$$

It was assumed that relative permeability to air $\left(\mathrm{k}_{\mathrm{ra}}\right)$ is $1-\mathrm{k}_{\mathrm{rw}}$ and that $\mathrm{S}_{\mathrm{lr}}=0.10$ and $\mathrm{S}_{\mathrm{ls}}=1.0$ for all rock units.

\footnotetext{
${ }^{2}$ The fracture-continuum properties were added to those of the matrix for rock units Tptpv3, Tptpln, Tptpul, Tptrn, Tptrv, and Tpcun, according to the methods described in Klavetter and Peters (1986), to create rock properties for a fractured, porous continuum.
}

is consistent with the trend in heat flow calculated in table 20 for the Pah Canyon, Yucca Mountain, and Tiva Canyon Tuffs. Significantly, however, conductive processes alone do not appear capable of accounting for a heat-flow deficit of more than $9.0 \mathrm{~mJ} / \mathrm{s} / \mathrm{m}^{2}$ at

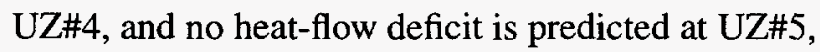
based on this purely conductive model. Moreover, the deficit at UZ\#4 is primarily in the upper part of the PTn and not across the PTn-TSw contact. The alluvium has little effect on the conductive heat flow in the lower part of the PTn and no apparent effect on the conductive heat flow in the TSw. These model results indicate that the inferred heat-flow deficit of nearly $20.0 \mathrm{~mJ} / \mathrm{s} / \mathrm{m}^{2}$ at the PTn-TSw contact in both UZ\#4 and UZ\#5 cannot be attributed to the insulating effects of the alluvium, implying that some other process, such as active percolation, is causing the heat-flow deficit.

The second two-dimensional case considered the effects of $20 \mathrm{~mm} / \mathrm{yr}$ of infiltration applied in the wash, with $0.1 \mathrm{~mm} / \mathrm{yr}$ applied along the adjacent sideslopes and ridges. Unlike the first case, temperatures along the upper boundary were assumed to be uniform $\left(18.5^{\circ} \mathrm{C}\right)$. An infiltration rate of $20 \mathrm{~mm} / \mathrm{yr}$ across the 


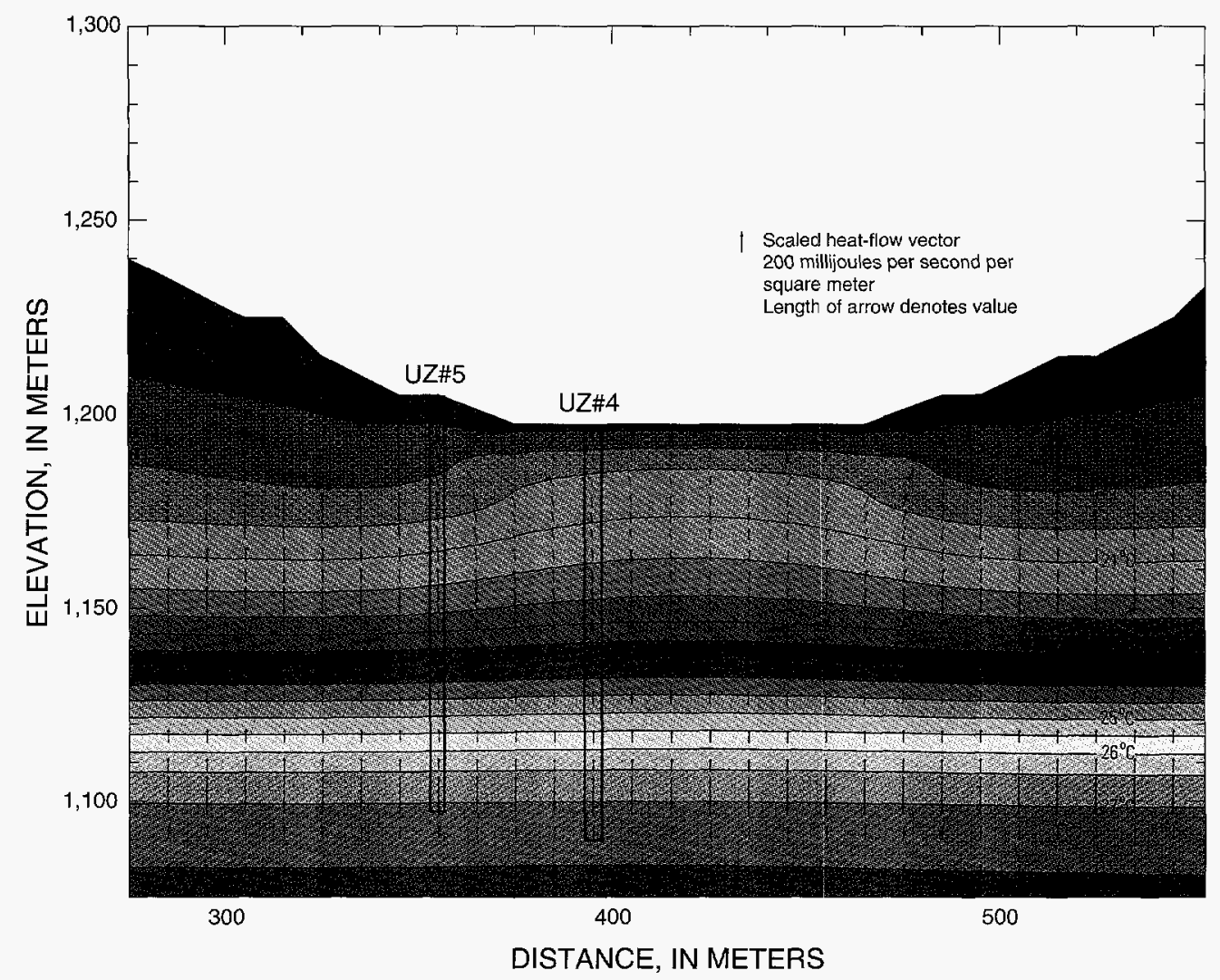

Figure 128. Simulated temperature contours and heat-flow vectors near Pagany Wash for a zero percolation flux.

entire wash, rather than just in the main drainage channel, was used to compensate for the fact that other processes, such as drainage from the sideslopes under the alluvium along the alluvium/bedrock interface, were not explicitly considered. The saturation contours and liquid-flux vectors for this case (fig. 130) show that, although saturation and deep percolation flux are higher in rock beneath the wash, lateral diversion along the top of the crystal-poor vitrophyre of the Tiva Canyon Tuff, at an elevation of about $1,178 \mathrm{~m}$, also causes a significant increase in the saturation and percolation flux in the rock beneath the adjacent side slope as well. The temperature contours and heat-flow vectors (expressed $\mathrm{mJ} / \mathrm{s} / \mathrm{m}^{2}$ ) for this case (fig. 131) show that heat is transported convectively along the top of the nonwelded unit of the crystal-poor vitrophyre of the Tiva Canyon Tuff (Tpcpv1) from UZ\#4 to UZ\#5. The resulting effect is to eliminate the differences in the borehole temperatures (fig. 132) that were evident in the upper part of the borehole in the first case, so that the vertical conductive heat flow is nearly the same. This result indicates that lateral diversion of infiltration and the convective transport of heat from
UZ\#4 to UZ\#5 are being overestimated by the model, possibly because too little infiltration $(0.1 \mathrm{~mm} / \mathrm{yr})$ was assumed for the sideslopes and ridges. In addition to the assumed distribution of infiltration, the assumption of uniform temperature $\left(18.5^{\circ} \mathrm{C}\right)$ along the upper boundary of the model also may have contributed to the absence of separation in the temperature profiles.

Additional one-dimensional simulations were conducted to examine a broader range of infiltration rates than could be investigated using the two-dimensional model, whose prohibitively long computation times prevented consideration of cases with different infiltration-flux distributions. The best-fit trial-anderror match between measured temperatures and simulated temperatures is shown in figure 133, using average annual land-surface temperatures estimated from the shallowest temperature measurements at $\mathrm{UZ \# 4}\left(19.3^{\circ} \mathrm{C}\right)$ and $\mathrm{UZ \# 5}\left(17.9^{\circ} \mathrm{C}\right)$ that showed no seasonal temperature changes (fig. 117). The infiltration fluxes that were estimated from the best-fit match of the temperature data with a one-dimensional model were $18 \mathrm{~mm} / \mathrm{yr}$ at $\mathrm{UZ \# 4}$ and $5 \mathrm{~mm} / \mathrm{yr}$ at UZ\#5. Overall, the match between the measured and 


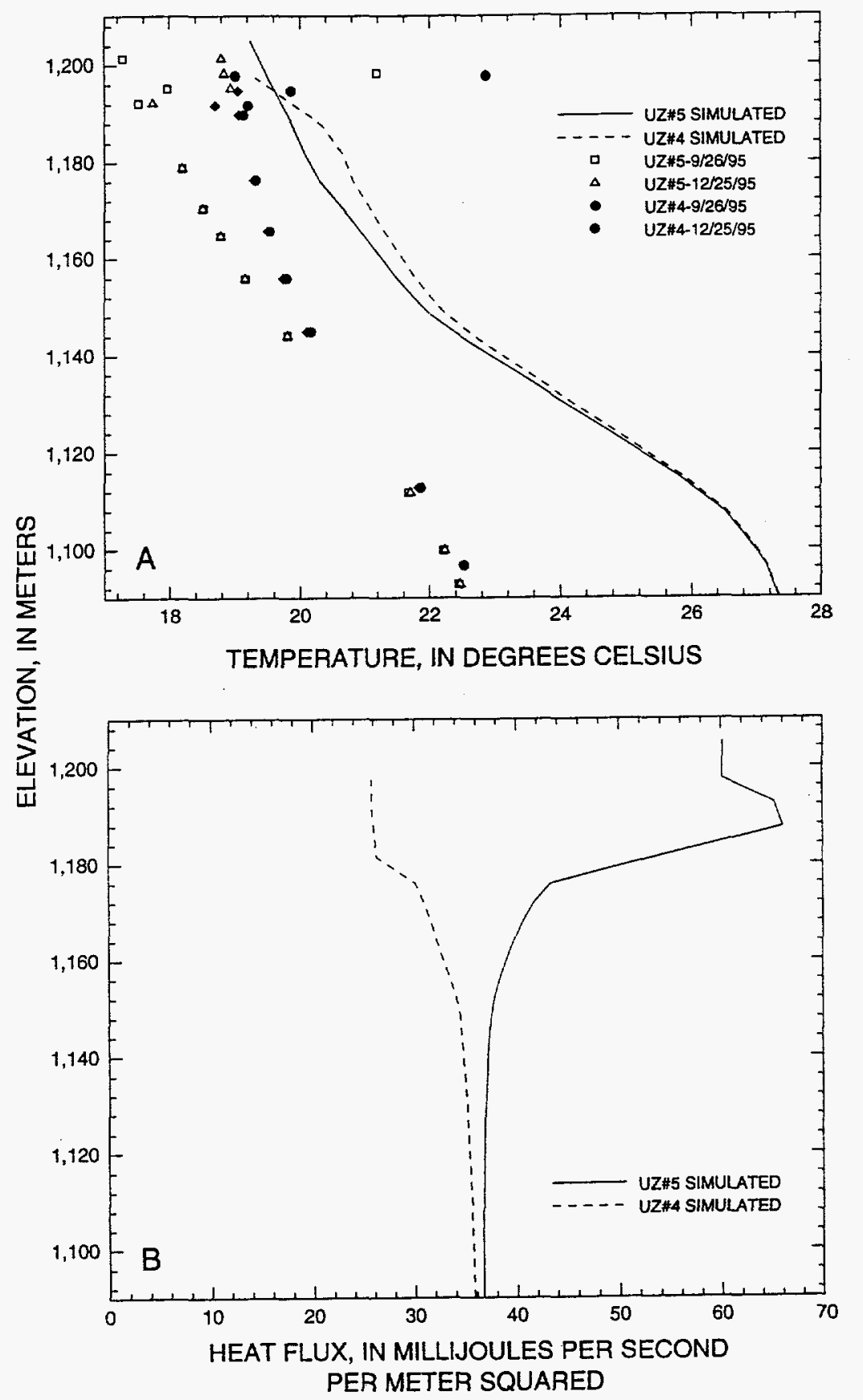

Figure 129. Simulated $(A)$ temperature and $(B)$ heat flow as a function of elevation at boreholes UE-25 UZ\#4 and UE-25 UZ\#5 for a zero percolation flux.

simulated temperatures is good at both UZ\#4 and UZ\#5. However, because the model is one-dimensional, it cannot reflect the nonvertical components in the heat and water fluxes beneath the wash. The reduction in heat flow in the upper part of UZ\#4 due to the deflection of heat around the alluvium is not accounted for in the results of the one-dimensional model. Consequently, to compensate for this overesti- mate of heat flow at UZ\#4, the model requires infiltration rates greater than the true values in order to reduce the simulated rock temperatures to their measured values. Similarly, because the one-dimensional model does not account for the increase in heat flow in the upper part of UZ\#5 that results from deflection of heat into the sideslopes, percolation rates smaller than the true values are predicted as necessary 


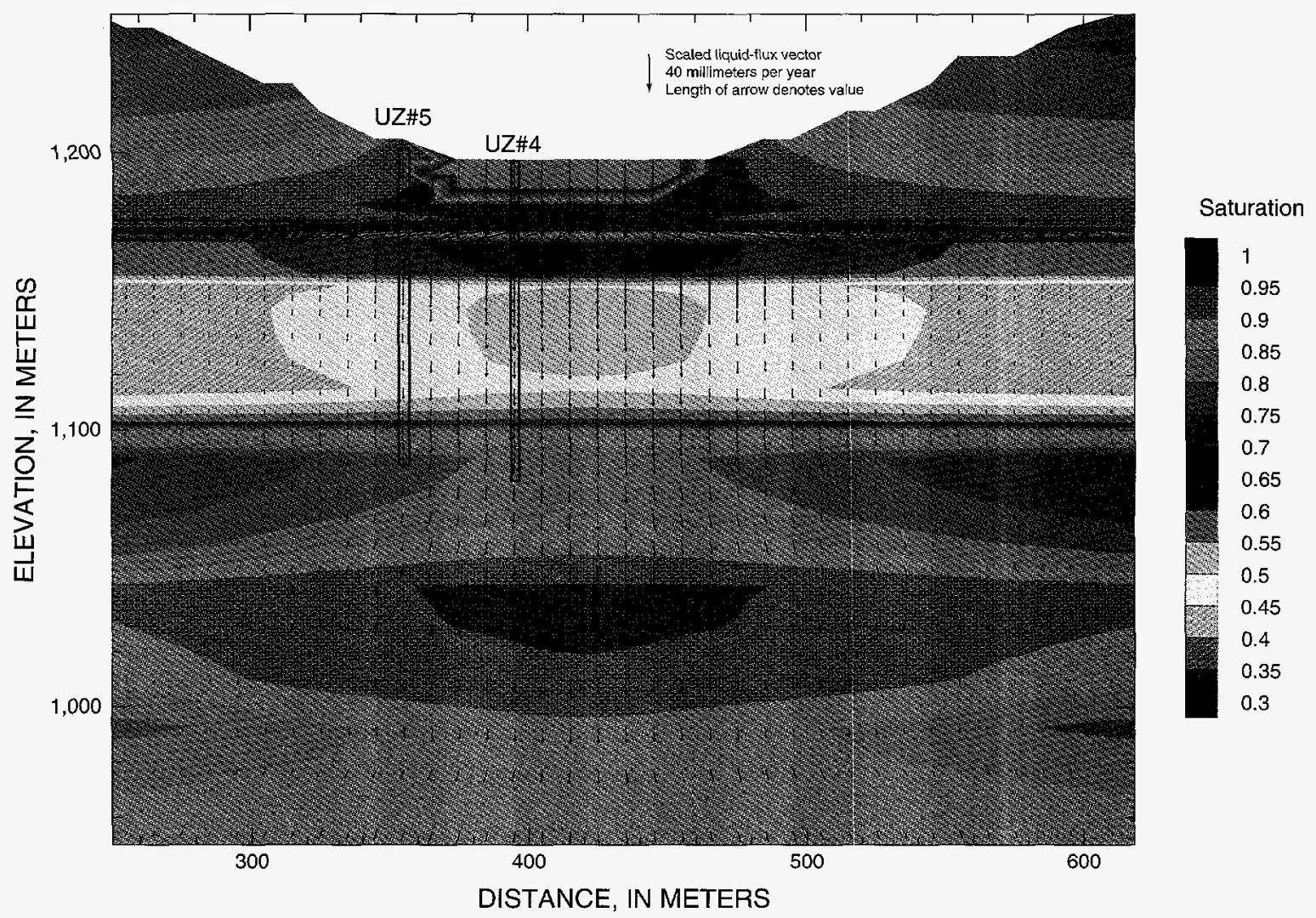

Figure 130. Simulated water-saturation contours and liquid-flow vectors near Pagany Wash for an infiltration flux of 20 millimeters per year in the wash.

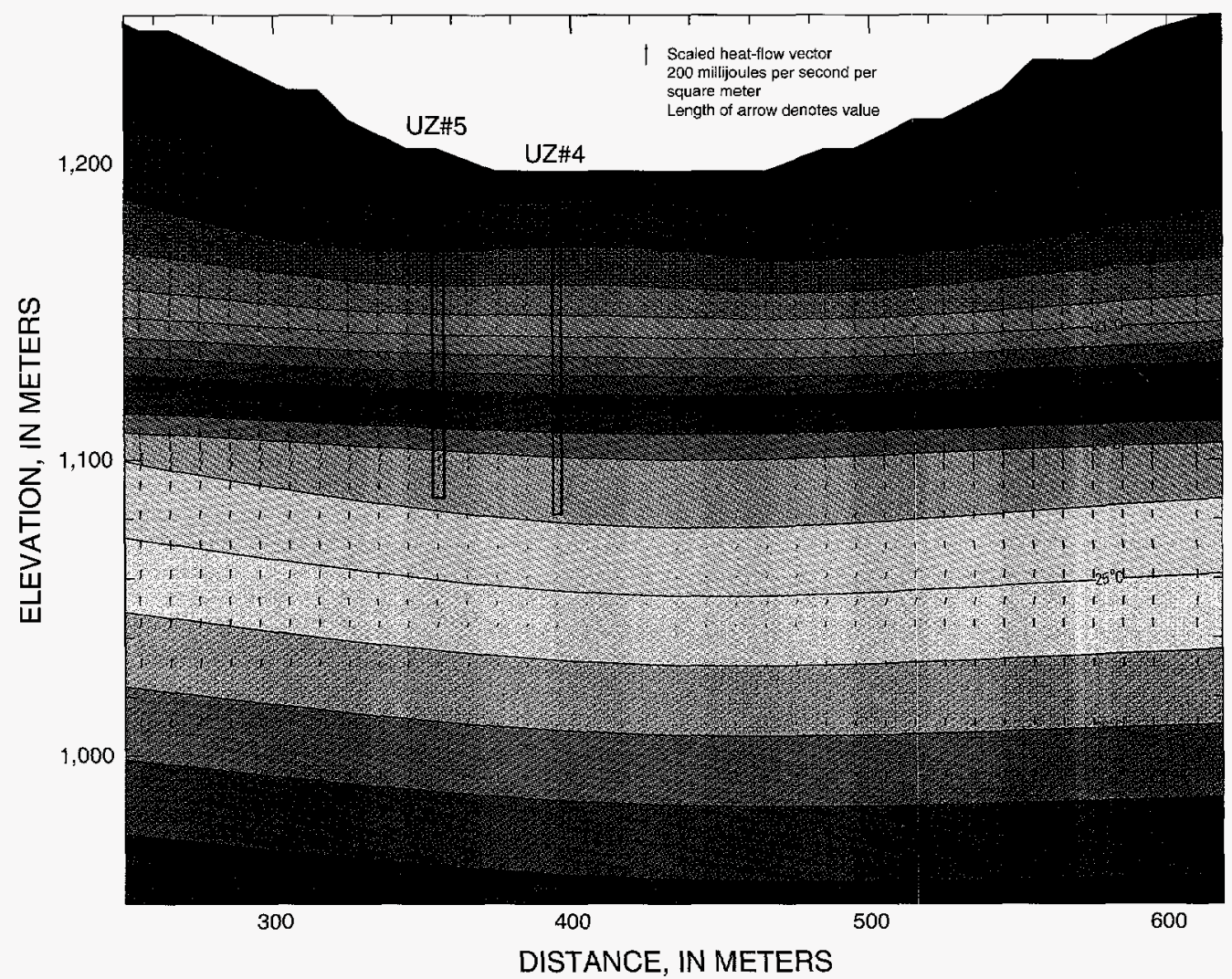

Figure 131. Simulated temperature contours and heat-flow vectors near Pagany Wash for an infiltration flux of 20 millimeters per year in the wash. 


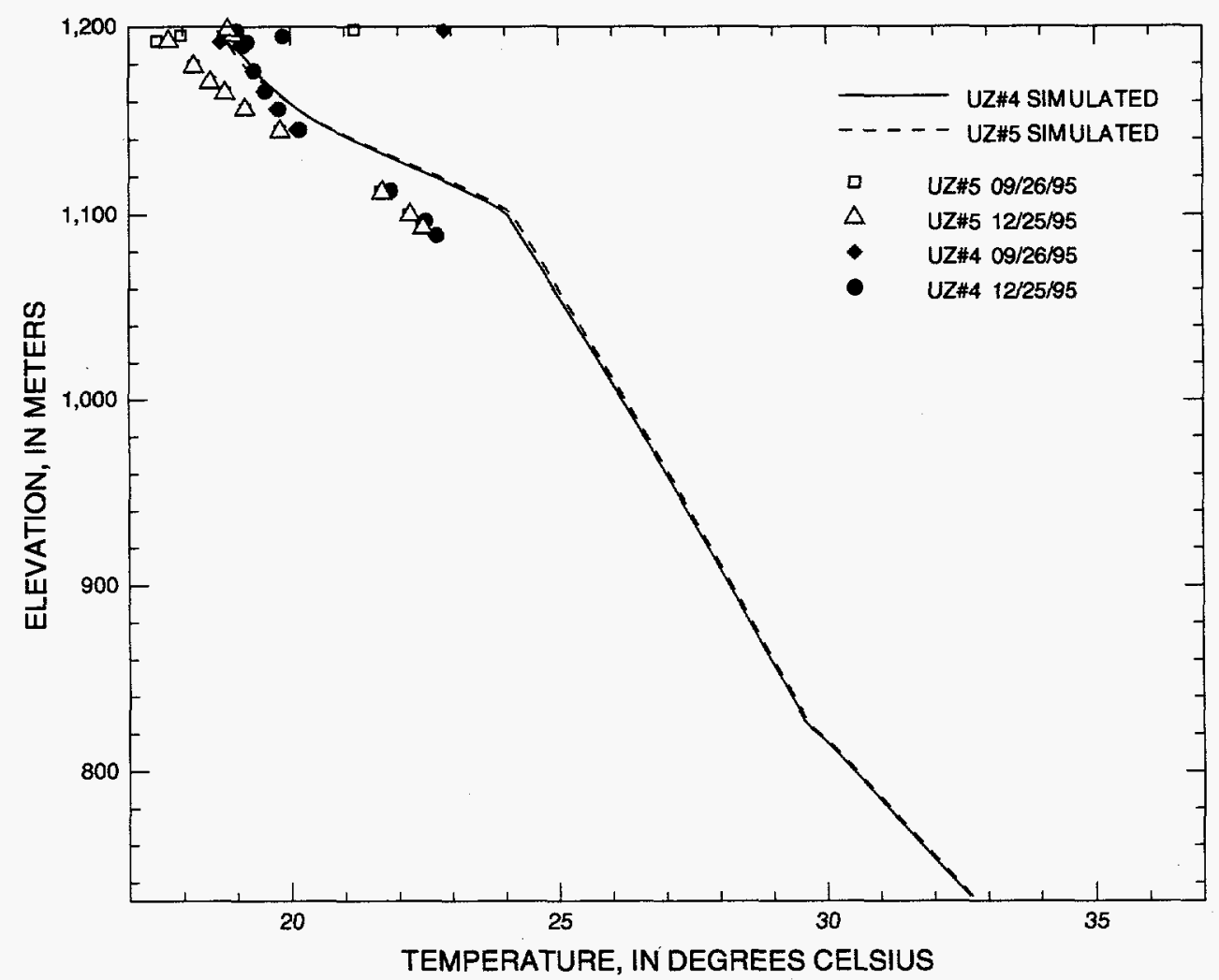

Figure 132. Simulated temperatures as a function of elevation at boreholes UE-25 UZ\#4 and UE-25 UZ\#5 for an infiltration flux of 20 millimeters per year in the wash.

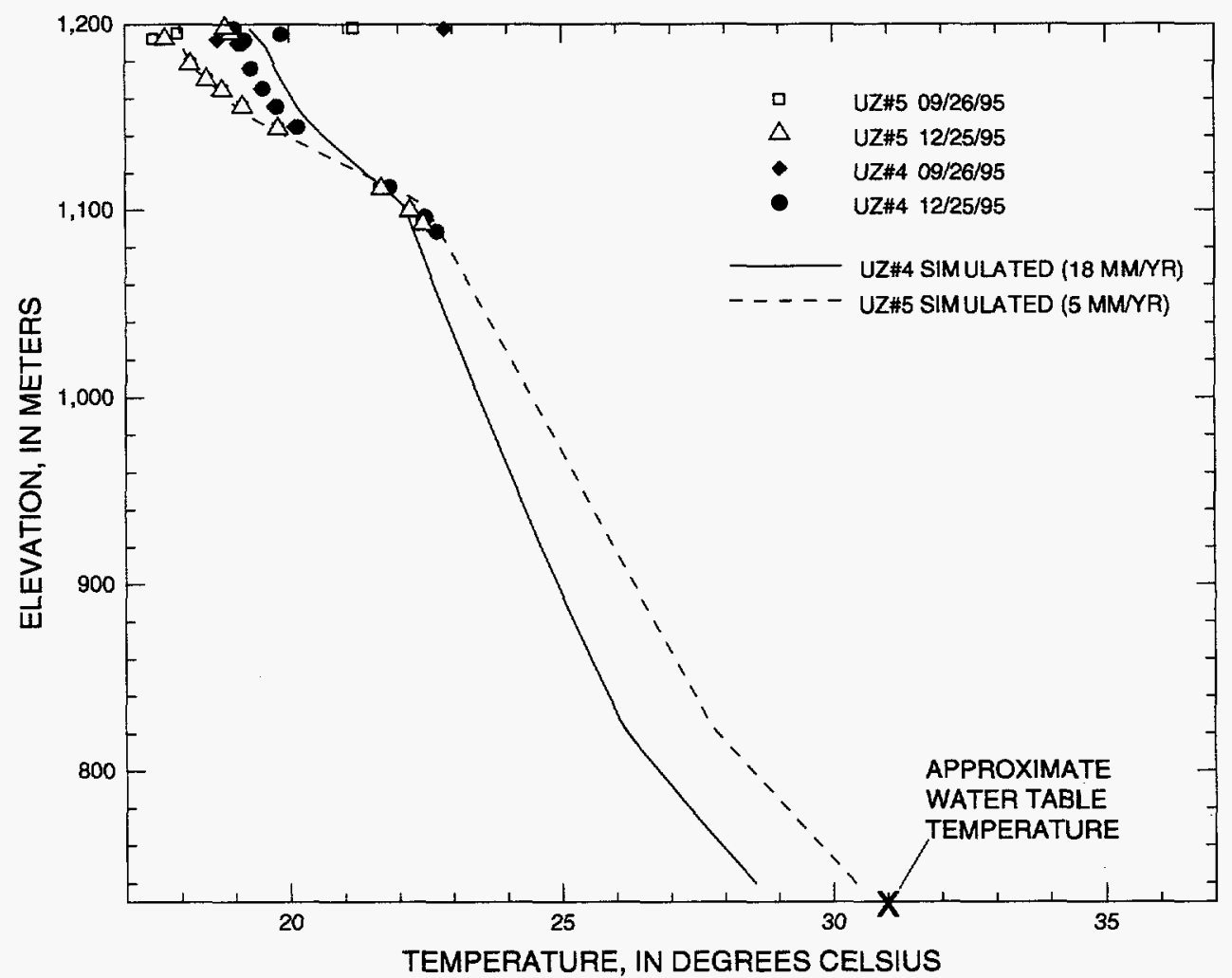

Figure 133. Comparison of measured temperatures at boreholes UE-25 UZ\#4 and UE-25 UZ\#5 with best-fit simulated temperatures using a one-dimensional model and steady-state infiltration fluxes of 18 millimeters per year at borehole UE-25 UZ\#4 and 5 millimeters per year at borehole UE-25 UZ\#5. 
to reproduce the measured rock temperatures. The one-dimensional model also cannot reproduce the reduction in heat flow with depth beneath the wash that occurs as a result of lateral spreading, which may explain why temperatures in the lower part of UZ\#4 are underestimated by the model results (fig. 133). The 5-mm/yr infiltration rate resulted in a simulated water-table temperature that closely approximated the water-table temperature beneath Pagany Wash $\left(31^{\circ} \mathrm{C}\right)$, estimated from the map of water-table temperatures in Fridrich and others (1994, fig. 8). The 18-mm/yr infiltration rate resulted in a water-table temperature that was $2^{\circ} \mathrm{C}$ cooler than this estimated temperature.

A sensitivity analysis was performed at $\mathrm{UZ \# 4}$ and UZ\#5 to investigate the effects of different percolation rates on borehole temperature profiles and on temperature gradients within the TSw. The simulations in this sensitivity analysis considered infiltration rates of $0.1,1.0,10.0$, and $20.0 \mathrm{~mm} / \mathrm{yr}$. The simulated temperature profiles, along with the calculated temperature gradients within the TSw, are shown for each infiltration rate for UZ\#4 in figure 134 and for UZ\#5 in figure 135. Results of the sensitivity analysis show that the temperature profiles are fairly sensitive to infiltration rate, indicating that the infiltration rates identified through matches with the borehole data (fig. 133) are well constrained. Although the temperatures calculated at UZ\#5 are several degrees cooler than those at UZ\#4 throughout the profiles because of the assumed cooler surface temperatures and absence of insulating alluvium, the temperature gradients within the TSw are nearly identical. These gradients, which were calculated based on simulated temperatures at 845 and $1,080 \mathrm{~m}$, decrease from a high of about $0.0218^{\circ} \mathrm{C} / \mathrm{m}$ for an infiltration rate of $0.1 \mathrm{~mm} / \mathrm{yr}$, to a low of $0.0137^{\circ} \mathrm{C} / \mathrm{m}$ for an infiltration rate of $20 \mathrm{~mm} / \mathrm{yr}$. Temperature gradients within the TSw decreased with increasing infiltration rates primarily because the simulated water-table temperatures became lower with increasing infiltration rates.

\section{Inferences Concerning Heat Flow and Percolation in Drill Hole Wash}

Both the conceptual and site-specific heat-flow model simulations presented in the previous section have shown that temperatures and temperature gradients developed within the unsaturated zone involve complex interactions between conductive and nonconductive heat-flow processes. Key factors affecting these heat-flow processes include (1) the presence or absence of alluvial fill, (2) surface-temperature boundary conditions, (3) topographic position and relief, (4) large contrasts between the thermal conductivities of the welded and nonwelded tuffs, (5) variations in the spatial distribution of infiltration, and (6) lateral diversion of downward percolation. Predicting the outcome of these complex interactions in advance was not intuitively obvious during the earlier stages of this study.

The one- and two-dimensional model simulations of Pagany Wash did not characterize the effects of spatial variations in the strength of the heat source that are indicated by temperature variations in maps of the water table, nor did these simulations characterize the three-dimensional effects of thickness variations on heat flow. However, on the basis of the insights gained through the modeling results, temperature data from other boreholes, particularly those in Drill Hole Wash, can be used as order-of-magnitude indicators of percolation fluxes elsewhere in the study area. Before proceeding with a discussion of the hydrologic implications of heat flow on percolation fluxes in Drill Hole Wash, some of the salient features of the Pagany Wash heat-flow studies will be reviewed.

The UZ\#4 and UZ\#5 model simulations used a specified constant heat-flow boundary positioned at the water table and a constant temperature in the second upper boundary $\left(18.5^{\circ} \mathrm{C}\right)$ two-dimensional case $(20 \mathrm{~mm} / \mathrm{yr}$ in Pagany Wash and $0.1 \mathrm{~mm} / \mathrm{yr}$ elsewhere) along the land surface. These prescribed boundary conditions were designed to simulate a constant heat-flow problem and were used in simulations that included both conductive and nonconductive heat-flow processes. Borehole temperature data and the temperature of the lower boundary, derived from a temperature map of the water table (Fridrich, 1994), were used as matching criteria to gage the adequacy of the models. Under low infiltration rates $(0.1 \mathrm{~mm} / \mathrm{yr})$, simulated steady-state temperatures were higher and temperature gradients larger than indicated by the field data. This result indicated that the conductive heat-flow capacity of the welded and nonwelded tuffs was too low to sustain constant heat flow without raising temperatures and increasing gradients to satisfy the heat-flow boundary condition. Conversely, infiltration rates of $20 \mathrm{~mm} / \mathrm{yr}$ resulted in lower temperatures and smaller gradients (more so at UZ\#5 than at UZ\#4) than indicated by the field data. This result indicated that too much heat was being removed by the 


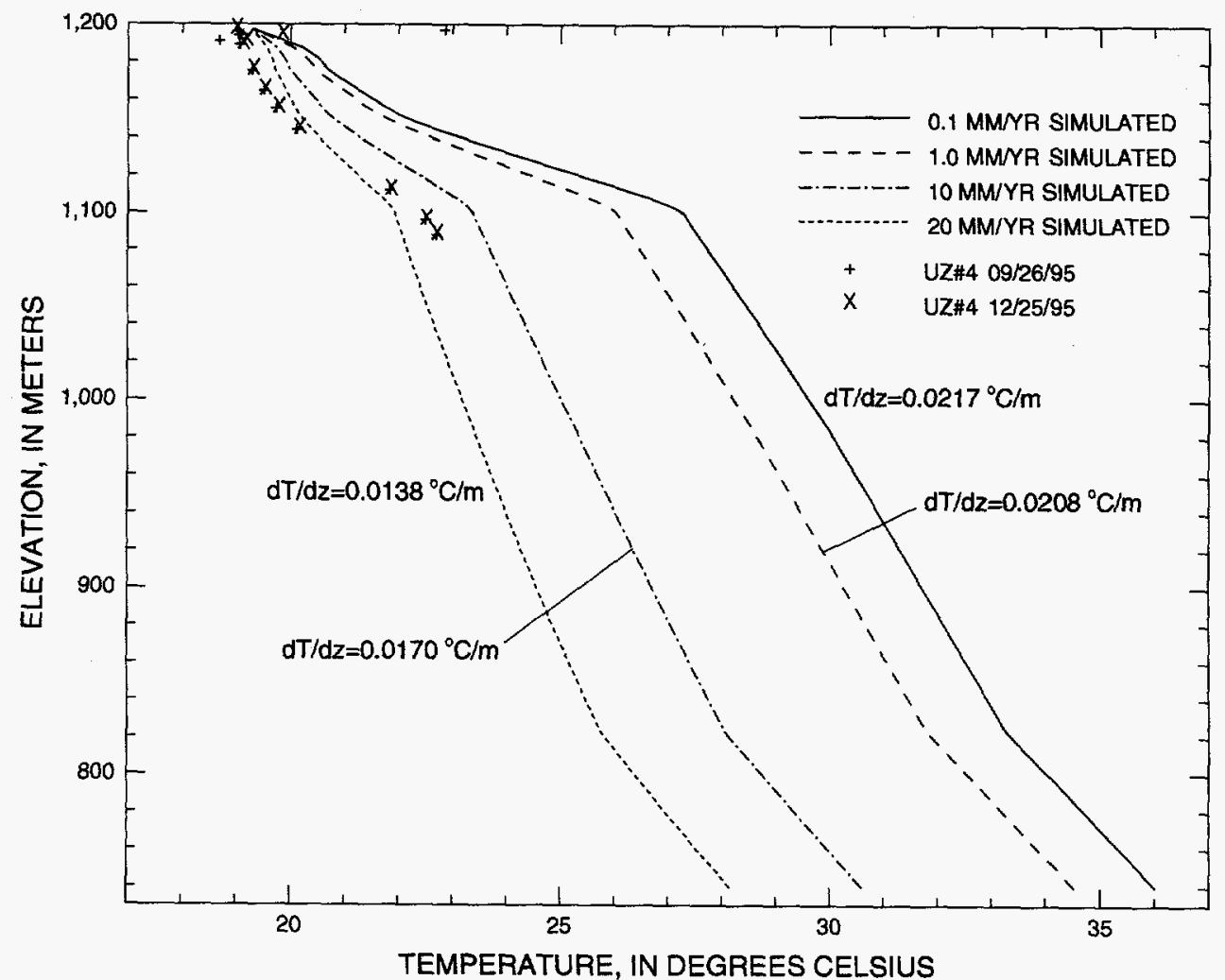

Figure 134. Comparison of measured temperatures at borehole UE-25 UZ\#4 with simulated temperatures using a one-dimensional model and steady-state infiltration fluxes of $0.1,1.0$, 10.0, and 20.0 millimeters per year.

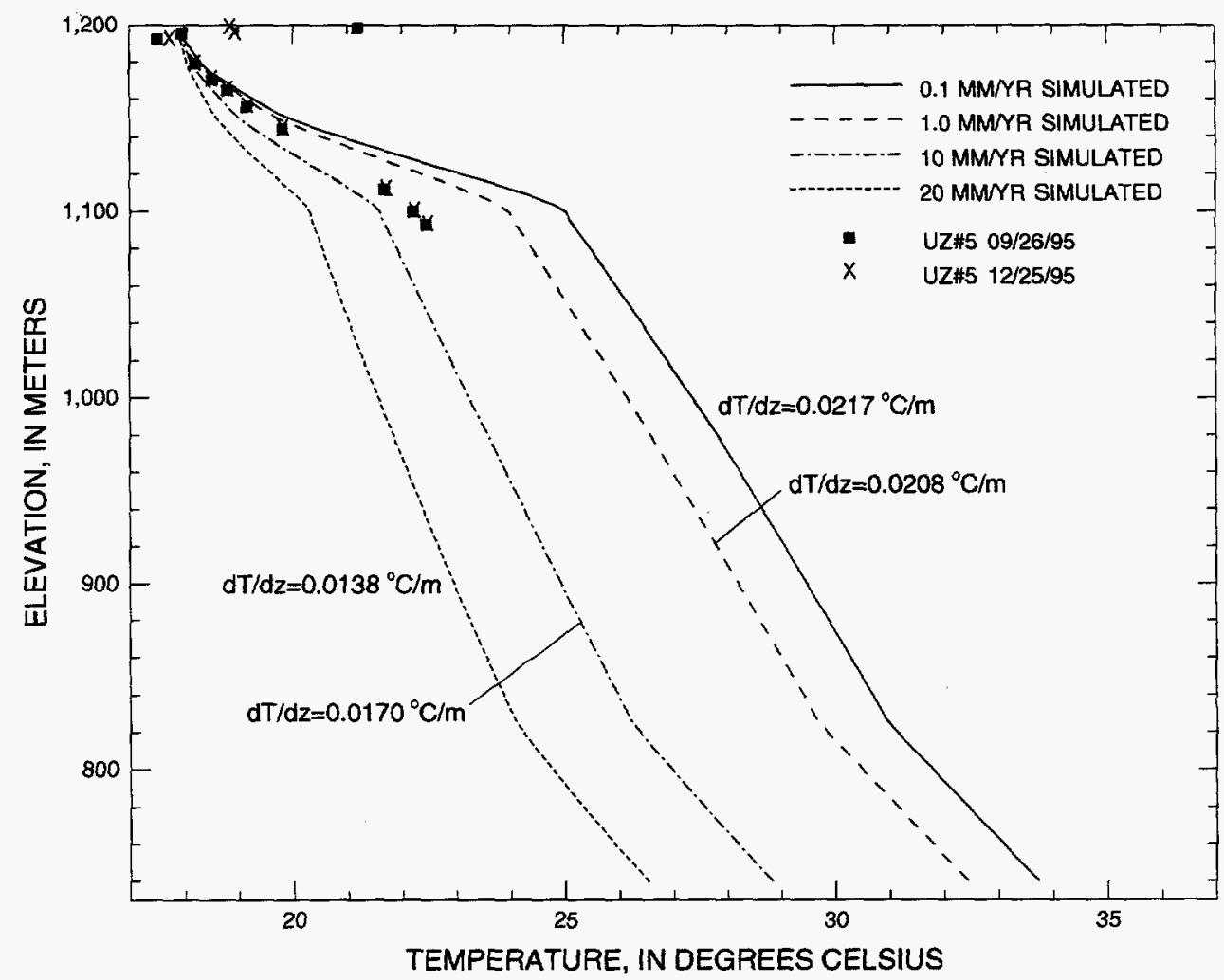

Figure 135. Comparison of measured temperatures at borehole UE-25 UZ\#5 with simulated temperatures using a one-dimensional model and steady-state infiltration fluxes of $0.1,1.0$, 10.0 , and 20.0 millimeters per year. 
nonconductive (infiltration) heat-flow process. In the one-dimensional simulations the best match with the field data was obtained by assigning infiltration rates of $18 \mathrm{~mm} / \mathrm{yr}$ at UZ\#4 and $5 \mathrm{~mm} / \mathrm{yr}$ at UZ\#5. Although the match with the field data was not perfect, a reasonable representation of temperatures and temperature gradients was achieved. Slight adjustments in specified infiltration rates and in the spatial distribution of infiltration would probably result in a better match.

The results of the Pagany Wash heat-flow studies can be used to draw some inferences about the hydrologic significance of temperature data from boreholes located in Drill Hole Wash. In particular, temperature gradients (table 17) calculated for the TSw at UZ-1 $\left(1.73^{\circ} \mathrm{C} / 100 \mathrm{~m}\right), \mathrm{H}-1\left(1.77^{\circ} \mathrm{C} / 100 \mathrm{~m}\right)$, $\mathrm{G}-1\left(1.50^{\circ} \mathrm{C} / 100 \mathrm{~m}\right)$, a\#4 $\left(1.59^{\circ} \mathrm{C} / 100 \mathrm{~m}\right)$, a\#5 $\left(1.80^{\circ} \mathrm{C} / 100 \mathrm{~m}\right)$, and a\#7 $\left(1.86^{\circ} \mathrm{C} / 100 \mathrm{~m}\right)$ are comparable to the simulated temperature gradients for $\mathrm{UZ \# 4}$ $\left(1.68^{\circ} \mathrm{C} / 100 \mathrm{~m}\right.$ in the one-dimensional, $10-\mathrm{mm} / \mathrm{yr}$ infiltration simulation and $1.37^{\circ} \mathrm{C} / 100 \mathrm{~m}$ in the onedimensional, 20-mm/yr infiltration simulation). By inference, using data from the Pagany Wash site, these temperature gradients indicate that percolation flux in the TSw at these borehole sites in Drill Hole Wash is on the order of 10 to $20 \mathrm{~mm} / \mathrm{yr}$. This preliminary interpretation is based on the observation that the above-cited boreholes, with limited exceptions, have similar characteristics in terms of unsaturated-zone thickness, PTn thickness, thickness of alluvial cover (except $\mathrm{H}-1$ and $\mathrm{a} \# 7$ ), water-table temperatures (30 to $31^{\circ} \mathrm{C}$ ), and geomorphic setting as those considered in the simulations used to determine gradients shown in figures 134 and 135. (Although there is no alluvial cover at $\mathrm{H}-1$, it is located in a valley floor very near the confluence of Tea Cup Wash, a tributary drainage to Drill Hole Wash. The alluvial thickness at a\#7 is much greater than for any other borehole in Drill Hole Wash.) It also should be noted that the PTn temperature gradients at $\mathrm{UZ}-1, \mathrm{G}-1$, and $\mathrm{H}-1$ are low relative to those developed within the underlying TSw. These low gradients indicate low conductive heat flow across the PTn at these sites even though the thermal conductivities may be high because of high saturations (see UZ-14 saturation data, table 16). However, high saturations also imply high percolation fluxes, indicating the possible presence of large, nonconductive heatflow losses in the vicinity of UZ-1, G-1, and H-1. The only borehole in the channel environment of Drill Hole Wash that does not display a low temperature gradient in the TSw is a\#1 $\left(2.36^{\circ} \mathrm{C} / 100 \mathrm{~m}\right)$, perhaps because this borehole is located near the distal end of Drill Hole Wash where infiltration rates may be low due to gradual widening of the drainage.

An extension of the above comparisons to temperature gradients developed within the TSw in boreholes located along hillslopes and channel margins also is possible. The simulated temperature gradient for UZ\#5 $\left(2.08^{\circ} \mathrm{C} / 100 \mathrm{~m}\right.$ for the $0.1-\mathrm{mm} / \mathrm{yr}$ infiltration simulation) is comparable to temperature gradients developed in the TSw at NRG-7a $\left(2.05^{\circ} \mathrm{C} / 100 \mathrm{~m}\right), \mathrm{NRG}-6\left(2.03^{\circ} \mathrm{C} / 100 \mathrm{~m}\right)$ and a\#6 $\left(2.42^{\circ} \mathrm{C} / 100 \mathrm{~m}\right)$. All of these boreholes are distant from the main drainage in Drill Hole Wash. These larger gradients are consistent with greater conductive heat flow adjacent to channels, which results from the insulating effects of alluvial fill.

Of all the factors that were considered, the insulating effects of alluvium are perhaps the most significant in terms of explaining the presence of smaller gradients beneath channels and valley floors and larger gradients along channel margins and hillslopes.

Because the alluvial fill in Drill Hole Wash is thicker and more laterally extensive than in Pagany Wash, suppression of temperature gradients within the PTn, similar to what was observed at UZ\#4, should be expected beneath the alluvium of this drainage. Model simulations at UZ\#4 and UZ\#5, as well as the temperature data from these two boreholes, indicated only marginal influence of the alluvial fill on temperatures in the TSw immediately below the PTn. Because the thermal conductivity of the PTn also is low relative to that of the TSw, the PTn also can be considered to act as an insulator. In the UZ\#4 and UZ\#5 simulations, the apparent heat-flow deficit across the PTn-TSw was ultimately accounted for by downward percolation, which reduced the magnitude of the gradient in the TSw at UZ\#4 from $2.08^{\circ} \mathrm{C} / 100 \mathrm{~m}(0.1 \mathrm{~mm} / \mathrm{yr})$ to $1.68^{\circ} \mathrm{C} / 100 \mathrm{~m}(10.0 \mathrm{~mm} / \mathrm{yr})$ to match the temperature differential between the water table and the base of the PTn. Thus, both conductive and nonconductive heatflow processes were required in the TSW and PTn to preserve heat flow in these one-dimensional simulations.

Percolation fluxes on the order of 10 to $20 \mathrm{~mm} / \mathrm{yr}$ in Drill Hole Wash do not seem unreasonable in view of the results of the Pagany Wash simulations and the strong similarities in the stratigraphy, geomorphology, and thermal regimes between the Pagany Wash study site and boreholes located in Drill Hole Wash. 


\section{Summary of Heat-Flow and Percolation-Flux Analyses}

The total heat flow within the unsaturated zone is the sum of its convective and conductive components. The conductive component can be calculated from the temperature gradient and thermal conductivity. The convective component can be inferred from decreases in the conductive component with increasing elevation along a borehole. Because the enthalpy and specific heat of water are well known, identification of the convectively transported heat component is equivalent to determining the percolation flux.

Temperature data from boreholes UZZ\#4 and UZ\#5 in Pagany Wash were examined in detail to determine the vertical distribution of upward, conductive heat flow at each borehole. The temperature data, in combination with estimates of thermal conductivity based on measured saturation and porosity data at these boreholes, and with the thermal-conductivity model of Rautman (1995), indicated that upward, conductive heat flow was approximately $15.5 \mathrm{~mJ} / \mathrm{s} / \mathrm{m}^{2}$ within the Pah Canyon Tuff at these boreholes. This is a substantial reduction from estimates of the deep, unsaturated-zone heat flow indicated by the regional heat-flow map of Sass and others (1988) and estimates of heat flow in the TSw at NRG-6, NRG-7a, and UZ-1, which averaged about 32 to $40 \mathrm{~mJ} / \mathrm{s} / \mathrm{m}^{2}$. The use of these values of heat flow as estimates of the heat flow at the water table beneath Pagany Wash resulted in estimated percolation rates of between 12.4 and $18.4 \mathrm{~mm} / \mathrm{yr}$ for the depth interval between the Pah Canyon Tuff and the water table at UZ\#4 and UZ\#5. Additional analyses indicated substantial lateral flow of heat from UZ\#4 to UZ\#5 in the shallower rocks so that vertical conductive flow of heat in the upper part of UZ\#5 achieved values comparable to those estimated for the water table ( 31.5 to $36.5 \mathrm{~mJ} / \mathrm{s} / \mathrm{m}^{2}$ ).

Numerical modeling studies of heat, water, and gas flow in the unsaturated zone were conducted using a computational grid with a simplified ridge-and-wash topography in order to examine the effects of conditions and processes anticipated to affect temperature distributions in the unsaturated zone at Yucca Mountain. Model results showed the following:

1. In the absence of percolation or thick alluvial cover, temperature contours for the unsaturated zone tend to be a subdued replica of the topographic contours, with higher temperatures but smaller temperature gradients beneath the ridges, where the unsaturated zone is thickest. Heat flow tends to converge toward the washes and diverge under the ridges in these cases.

2. Because of its high porosity and generally low saturation, alluvium is an insulator relative to the moderately to densely welded rock forming the sideslopes and ridges. Alluvium tends to raise the temperature of the unsaturated zone beneath the washes and cause vertical conductive heat flow to be diverted around the alluvium and into the sideslopes.

3. Density differences between relatively dry, cool, dense air on the flanks of a ridge and moist, relatively warm, light air within the rock beneath a ridge gives rise to natural, buoyant gas circulation in areas of high relief. However, the transport of heat associated with gas convection was shown in this series of simulations to have little effect on temperatures within the unsaturated zone.

4. Downward water percolation through the unsaturated zone consumes heat as water moves from cooler, shallower environments to warmer, deeper ones. The measurable effects of active water percolation were shown by these simulations to be the suppression of temperatures and thermal gradients in areas subjected to high percolation rates.

Two-dimensional numerical modeling of conductive heat flow beneath Pagany Wash predicted that the insulating effects of the alluvium caused heat to be diverted around the alluvium and into the bedrock sideslope, resulting in an increase in heat flow in the upper part of UZ\#5 and a decrease in heat flow in the upper part of UZ\#4. However, heat flow in the Pah Canyon Tuff and deeper stratigraphic units was unaffected by the alluvium, implying that the low heat flow through the Pah Canyon (approximately $15.5 \mathrm{~mJ} / \mathrm{s} / \mathrm{m}^{2}$ ) probably is the result of heat loss due to downward percolation of water. Two-dimensional modeling of the coupled flow of water and heat, assuming $20 \mathrm{~mm} / \mathrm{yr}$ of water infiltrated into the wash and $0.1 \mathrm{~mm} / \mathrm{yr}$ of infiltration along the sideslopes and ridges, provided a poor match to the observed borehole temperatures, apparently because the model overpredicted the lateral diversion of infiltration from UZ\#4 to UZ\#5. Trial-and-error matches to the borehole-temperature data using a one-dimensional model and different assumed infiltration rates resulted in percolation estimates of $18 \mathrm{~mm} / \mathrm{yr}$ at UZ\#4 and 
$5 \mathrm{~mm} / \mathrm{yr}$ at UZ\#5. Because the one-dimensional models could not account for lateral diversion of heat or water, the one-dimensional model may slightly overestimate the percolation rate at $\mathrm{UZ \# 4}$ and underestimate the percolation rate at UZ\#5. A sensitivity analysis was conducted to examine the effect of different infiltration rates on the temperature gradient within the TSw. This analysis showed that temperature gradients were sensitive to the assumed infiltration rate and ranged from $2.17^{\circ} \mathrm{C} / 100 \mathrm{~m}$ for an infiltration flux of $0.1 \mathrm{~mm} / \mathrm{yr}$, to $1.38^{\circ} \mathrm{C} / 100 \mathrm{~m}$ for an infiltration of $20 \mathrm{~mm} / \mathrm{yr}$, assuming the heat flow at the water table is $36.5 \mathrm{~mJ} / \mathrm{s} / \mathrm{m}^{2}$.

Assuming that saturation and porosity and, hence, thermal conductivity are relatively invariant within the TSw in the North Ramp Area, thermal gradients within the TSw can be used as indicators of the conductively (and hence, convectively) transported heat at other boreholes in the Drill Hole Wash area. Temperature gradients within the TSw at boreholes UZ\#1, H-1, G-1, a\#4, a\#5, and a\#7 had gradients comparable to the simulated temperature gradient for

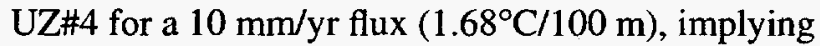
percolation fluxes of a similar magnitude at those boreholes. Conversely, temperature gradients within the TSw at NRG-7a, NRG-6, and a\#6 were similar to the simulated temperature gradients for UZ\#5 for a $0.1 \mathrm{~mm} / \mathrm{yr}$ infiltration rate, indicating smaller percolation rates within the TSw at these boreholes.

\section{Analysis of Percolation Flux Based on Observations Related to the Perched Water Underlying Drill Hole Wash}

Concepts and hypotheses regarding the source, age, and permanence of the perched-water reservoir underlying the Drill Hole Wash area are discussed in the following sections. First, aqueous-phase chemical data are reviewed and interpreted in an attempt to determine the source and age of the perched water. Second, stratigraphic, structural, and hydrologic information is interpreted in an attempt to determine the sustainability of the perched-water reservoir under present-day climatic conditions.

\section{Aqueous-Phase Chemical Considerations}

Chemical data are available for water samples pumped or bailed from the perched-water reservoir in the Drill Hole Wash area, and for water samples obtained by compression of core samples taken from nonwelded rock beneath the perched-water reservoir (see the sections of this report titled Chemistry and Isotopic Content of Perched Water, and AqueousPhase Chemistry, respectively). The water samples obtained from the matrix of the Calico Hills Formation at UZ-14 have ${ }^{14} \mathrm{C}$ values that range between 70 and $95 \mathrm{pmc}$, with the larger values present at greater depths (fig. 106B). In contrast, seven of eight water samples pumped or bailed from the perched-water reservoir in the lower part of the overlying Tptpln unit have ${ }^{14} \mathrm{C}$ values considerably less than $50 \mathrm{pmc}$. In particular, the pumped samples (UZ-14 PT-1, UZ-14 PT-2, and UZ-14 PT-4) have ${ }^{14} \mathrm{C}$ values of approximately $30 \mathrm{pmc}$.

The presence of apparently older water in fractures of the Tptpln unit in the perched-water reservoir overlying apparently younger water in the Calico Hills Formation may indicate that (1) true age of the perched water has been obscured, either because of water/rock interactions or possibly because of mixing of the native perched water with older water from well $\mathrm{J} \# 13$ used in the drilling fluid lost from borehole G-1 (Whitfield and others, 1990); (2) apparent ${ }^{14} \mathrm{C}$ age of the pore-water samples from the Calico Hills Formation is younger than the true age of the water, as a result of contamination (see the section of this report titled Aqueous-Phase Carbon Isotopes); or (3) perched water and the Calico Hills pore water arrived at their respective sampled locations through different pathways.

The $\delta^{13} \mathrm{C}$ values for pumped and bailed samples from the perched-water reservoir at UZ-14 range from about -9.2 to -11.3 per mil per mil (table 18 ), whereas the $\delta^{13} \mathrm{C}$ values for the Calico Hills core samples range from -10.3 to -16.0 per mil (fig. 106B). The heavier $\delta^{13} \mathrm{C}$ values associated with the perched-water samples may, therefore, indicate a greater degree of interaction of the water with carbonate fracture coatings, which have $\delta^{13} \mathrm{C}$ values of -8 to -3 per mil (Whelan and others, 1994). The lost drilling fluid from G-1 used water from supply well J\#13, which has measured $\delta^{13} \mathrm{C}$ and ${ }^{14} \mathrm{C}$ values of -7.3 per mil and 29.2 pmc (Benson and McKinley, 1985, table 1). As discussed in a preceding section of this report (see Possible Source and Residence Time of Perched Water), although the exact age corrections cannot be made because of variable soil $\delta^{13} \mathrm{C}$ values, the estimated ${ }^{14} \mathrm{C}$ age of the perched water is probably in the range of 4,000 to 7,000 years. 
The apparently young ${ }^{14} \mathrm{C}$ ages obtained for the Calico Hills pore-water samples are unlikely to have been caused by the exchange of ${ }^{14} \mathrm{C}$ between young pore gas and water with a true age that is older than its apparent ${ }^{14} \mathrm{C}$ age. Many years of sampling have consistently shown that gas at the base of the Topopah Spring Tuff at UZ-1, located a distance less than 30 meters from UZ-14, has ${ }^{14} \mathrm{C}$ values on the order of 20 to 30 pmc (fig. 80). It is clearly not possible to equilibrate old gas and old water and obtain a water with a ${ }^{14} \mathrm{C}$ age that is apparently younger than both the gas and the original water. Possible contamination of Calico Hills pore water (see the section of this report titled Aqueous-Phase Carbon Isotopes) by water dripping down the borehole from the perched-water reservoir (where this water may have interacted with atmospheric $\mathrm{CO}_{2}$ released from the cement grout used to stop seepage into the borehole) also is unlikely because of the extremely small water-inflow rates and the very large rates of air flow used to bring cuttings to the surface during drilling. It also should be mentioned that the younger water sampled from the Calico Hills Formation is unlikely to have been the result of a higher water table in the past. Water samples taken from the saturated zone at nearby $\mathrm{H}-1$ have $\delta^{13} \mathrm{C}$ values of -11.4 per mil but have average ${ }^{14} \mathrm{C}$ values of only $21.9 \mathrm{pmc}$ (Benson and McKinley, 1985, table 1).

Because the ${ }^{14} \mathrm{C}$ ages from the perched-water samples and Calico Hills pore-water samples cannot be easily explained, it appears that water sampled from these locations must have arrived through different flow pathways. The perched water detected in Drill Hole Wash at UZ-14 appears to have arrived there through a fracture-flow mechanism (see the section of this report titled Chemistry and Isotopic Content of Perched Water). The average $\delta^{87} \mathrm{Sr}$ value for the perched water of 4.46 per mil is similar to that of surficial calcites and calcite fracture coatings ( 4.51 per mil) but is distinct from the values for the Topopah Spring Tuff matrix ( 9.6 per mil). Chloride concentration data and selected summary ${ }^{14} \mathrm{C}$ data for borehole UZ-14 are shown in figure 136. The chloride concentration data were taken from Yang and others (1996, table 3). The average chloride concentrations of the pumped or bailed perched-water samples $(8.1 \mathrm{mg} / \mathrm{L})$ are dissimilar from the average values for samples taken from the PTn matrix (76.8 $\mathrm{mg} / \mathrm{L}$ ) overlying the

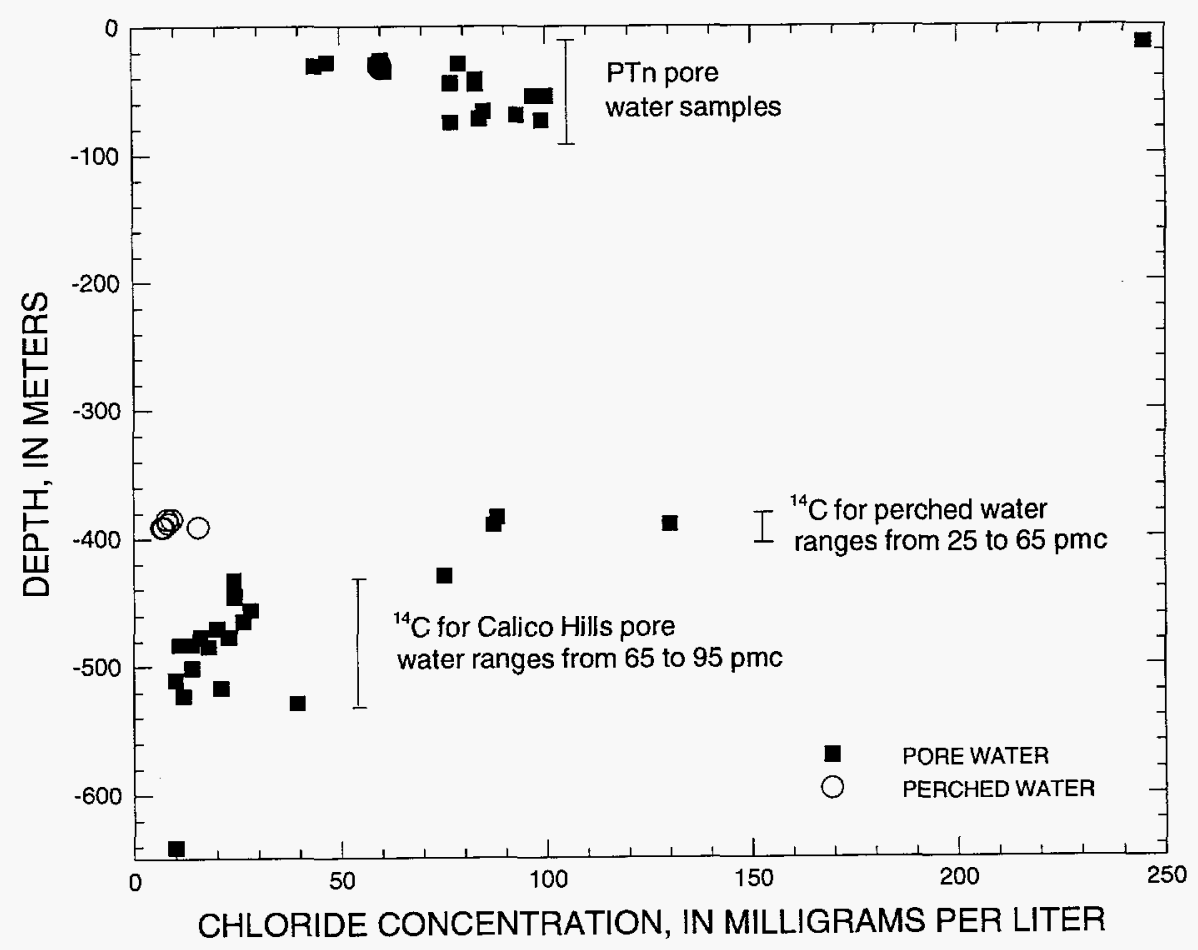

Figure 136. Chloride concentration and summary of selected carbon-14 data for water samples from borehole USW UZ-14. 
TSw and from the matrix within the base of the perched-water zone at UZ-14 (101.7 mg/L), indicating that the perched-water reservoir probably did not originate from water that had passed through the matrix of the overlying rock units.

The average chloride concentration for the Calico Hills Formation at UZ-14 is $19.8 \mathrm{mg} / \mathrm{L}$, which is higher than the value for the perched-water samples but still substantially lower than the values measured on core samples taken from the base of the perchedwater reservoir $(101.7 \mathrm{mg} / \mathrm{L})$. This contrast in chloride concentrations, along with the inversion of ages indicated by the ${ }^{14} \mathrm{C}$ data, indicates that water in the Calico Hills Formation did not originate by slow seepage of perched water through the matrix of the crystal-poor vitrophyre. Again, the chloride and ${ }^{14} \mathrm{C}$ data from the Calico Hills indicate that the pore water arrived through a predominantly fracture or fault flow mechanism and spent little time in the rock matrix before reaching the Calico Hills. Apparent ${ }^{14} \mathrm{C}$ ages within the Calico Hills range from about 3,500 years for a sample near the top of the formation, with 65 pmc (fig. 106B), to a value of approximately 500 years for a sample near the base of the formation, with almost 95 pmc.

The apparent ${ }^{14} \mathrm{C}$ ages of the both the perched water $(4,000$ to 7,000 years $)$ and of the Calico Hills pore water ( 3,500 to 500 years) postdate the pluvial periods of the Pleistocene and reflect active percolation through the unsaturated zone under the relatively arid climate of the Holocene. In the case of the perched-water samples, the ${ }^{14} \mathrm{C}$ age incorporates both the time of transport from the land surface to the sampling location and average residence time within the perched-water reservoir. Assuming that flow to and from the perched-water reservoir is at steady state and that the reservoir is well mixed, the mass-balance equation for ${ }^{14} \mathrm{C}$ in the perched-water reservoir can be written as:

$$
\begin{gathered}
Q \mathrm{AO}_{0}{ }^{14}\left(\mathrm{HCO}_{3}^{-}\right)_{0}-Q \mathrm{Apw}^{14}\left(\mathrm{HCO}_{3}^{-}\right)_{p w^{-}}-\mathrm{VAA}_{p w}{ }^{14} \\
\left(\mathrm{HCO}_{3}^{-}\right)_{p w}=0
\end{gathered}
$$

$Q$ is the steady-state inflow and outflow to the perched-water reservoir, in cubic meters per year,

$\mathrm{A}_{0}{ }^{14}$ and $\left(\mathrm{HCO}_{3}{ }^{-}\right)_{0}$ are the ${ }^{14} \mathrm{C}$ activity (expressed in percent modern carbon) and total carbon activity (expressed as bicarbonate activity, in moles per cubic meter), of the inflowing water,

$\mathrm{A}_{p w}{ }^{14}$ and $\left(\mathrm{HCO}_{3}{ }^{-}\right)_{p w}$ are the ${ }^{14} \mathrm{C}$ activity (in $\mathrm{pmc}$ ) and bicarbonate activity (in moles/per cubic meter) of the perched water,

$V$ is the volume of the perched-water reservoir, in cubic meters, and

$\lambda$ is the radioactive decay constant (1/year), which is equal to $\ln (2)$ divided by 5,730 years (the half-life of ${ }^{14} \mathrm{C}$ ), or $1.21 \times 10^{-4}$ /year.

The term $V \lambda A_{p w}{ }^{14}$ accounts for the change with time in the activity of ${ }^{14} \mathrm{C}$ due to radioactive decay of ${ }^{14} \mathrm{C}$ within the reservoir itself. If there are no carbonate reactions within the perched-water reservoir itself, the bicarbonate activities of the inflowing and outflowing water are equal, and equation 6 can be rearranged to solve for the residence time ( $\left.t_{\text {res }}\right)$ as follows:

$$
t_{\text {res }}=V / Q=\left(A_{0}{ }^{14}-A_{p w}{ }^{14}\right) \wedge A_{p w}{ }^{14}
$$

Because the $\delta^{87} \mathrm{Sr}$ and chloride data indicate that the perched water arrived through a fracture flow mechanism, it is likely that transport time from the land surface to the perched-water reservoir was short relative to the residence time in the perched-water reservoir itself, so that $A_{0}{ }^{14}=100.0 \mathrm{pmc}$. The ${ }^{14} \mathrm{C}$ activities associated with ${ }^{14} \mathrm{C}$ ages of 4,000 and 7,000 years are 61.6 and 42.9 pmc. From equation 7, the corresponding residence times of water with these ${ }^{14} \mathrm{C}$ activities are 5,150 and 11,000 years.

\section{Stratigraphic, Structural, and Hydrologic Considerations}

This section (1) describes a general conceptual model for perched water at Yucca Mountain upon which subsequent discussions are based, (2) summarizes evidence in support of, or in opposition to, more detailed conceptual models of perched water in the

where: 
North Ramp area, and (3) presents an analysis of the flux based on the preferred conceptual model.

As stated in a preceding section of this report (see Occurrences of Perched Water in the Vicinity of the Exploratory Studies Facility North Ramp), perched water accumulates when the downward percolation flux exceeds the capacity of a layer to transmit that flux. Vertical transmission is a function of the permeability and total head gradient across the perching layer. When vertically percolating water reaches the perching layer at rates greater than the transmission capacity of that layer and the perching layer is dipping, the fraction that exceeds the transmission capacity is diverted laterally and the fraction that can be transmitted by that layer continues downward through the perching layer into the underlying layers. The diverted fraction of percolation moves laterally until it reaches a fault, where it accumulates if the fault is sealed and/or impermeable layers are juxtaposed, or it drains to lower, more permeable layers or to the water table if the fault is open. In the downdip direction, the diverted fraction begins to accumulate, much as surface runoff would in the lower elevations of a watershed, so that the lateral component of flux along the perching layer can far exceed the vertical component of percolation flux. Because of lateral diversion, substantial ponding and positive head development above the perching layer does not generally occur, except where the appropriate structural conditions exist that allow it to accumulate. Therefore, although perched conditions may be widespread, they may only be obvious and easily detected where thick accumulations of water exist.

Within this general conceptual model, several more detailed conceptual models involving different perching layers and structural trapping mechanisms may be possible explanations for the perched water detected in the Drill Hole Wash area (see the section of this report titled Relation of North Ramp Perched Water to Lithology and Geologic Structure). In attempting to discriminate between these conceptual models, it is helpful to review some of the observations reported in preceding sections of this report (see Occurrences of Perched Water in the Vicinity of the Exploratory Studies Facility North Ramp):

(1) Perched water was first detected or ultimately rose to elevations that were above or coincided with the contact between the lower nonlithophysal (Tptpln) and densely welded, crystal-poor vitric unit (Tptpv3) of the Topopah Spring Tuff; (2) the thickness of the perched-water reservoir above the Tptpln-Tptpv3 contact was greater at UZ-14 than at either SD-9 or NRG-7a; and (3) the elevation of the top of the perched-water reservoir at UZ-14 was $967 \mathrm{~m}$, which is about $111 \mathrm{~m}$ and $81 \mathrm{~m}$ higher than the top of the densely welded crystal-poor unit (Tptpv3) at boreholes NRG-7a and SD-9, respectively.

The first observation indicates, but does not prove, that the densely welded crystal-poor unit (Tptpv3) may be the perching layer in the Drill Hole Wash area. It is possible that a deeper stratigraphic horizon, such as the zeolitic Calico Hills Formation, is actually causing the perching and that water has ponded on top of the Calico Hills and submerged the top of the Tptpv3 unit. This is more likely where the vitric material above the Calico Hills Formation is. thinner, such as at NRG-7a and in areas to the north of Drill Hole Wash, but is less likely at SD-9 and UZ-14, where the thickness of permeable vitric material above the top of the Calico Hills Formation is approximately $15 \mathrm{~m}$ (fig. 16). Of course, multiple perching layers are possible. The saturation profile at SD-9 (fig. 81) shows a zone of partial saturation within the vitric material above the top of the Calico Hills Formation, indicating that the perching layer at this borehole is clearly the densely welded, crystal-poor (Tptpv3) layer. The perching layer at UZ-14 is more difficult to identify on the basis of the saturation profile alone (fig. 82), which shows an unbroken interval of apparently complete saturation between the base of the lower nonlithophysal unit (Tptpln) and the upper part of the Prow Pass Tuff (Tcp). Indirect evidence that the Tptpv3 layer is the perching layer was cited in a preceding section of this report (see Top of the Crystal-Poor Vitrophyre of the Topopah Spring Tuff), where it was noted that the contact between the Tptpln and Tptpv 3 units is commonly marked by an interval of well-developed argillic alteration. Additionally, it was noted that alteration of the glass to clays or zeolites in the Tptpv3 unit may occur preferentially along fractures, which offer the greatest exposure of the rock matrix to altering hydrothermal or meteoric solutions (see the section of this report titled Aqueous Alteration of Glass and Fumarolic Alteration and Crystallization). The interval of argillic alteration may cause the permeability at the top of the crystal-poor vitrophyre to be lower than that of the interior part of the unit from which some of the higher permeability core samples originated (see figs. 89 and 90 ), especially if fractures in the interior of the unit were not 
globally connected and, therefore, not subjected to altering solutions.

The second observation, that the thickness of the perched-water reservoir above the Tptpln-Tptpv3 contact is greater at UZ-14 than at either SD-9 or NRG-7a, is based on observations made during the drilling of the boreholes rather than precise measurements. Although these observations were fairly systematic at UZ-i4, they were much less so at SD-9 or NRG-7a. However, if qualitatively correct, these observations indicate that different conditions, such as the presence of a stratigraphic or structural trap, may be needed to explain the differences in the thicknesses and volumes of the perched-water reservoir at UZ-14, which recovered fully after pumping $23,467 \mathrm{~L}$. As discussed in a preceding section of this report (see Occurrences of Perched Water in the Vicinity of the Exploratory Studies Facility North Ramp), boreholes SD-9 and NRG-7a were not pumped, but there did not appear to be a thick reservoir of perched water above the Tptpln-Tptpv3 contact in either borehole, indicating a smaller accumulation of water than at UZ-14.

The third observation, that the elevation of the top of the perched-water reservoir at UZ-14 is $111 \mathrm{~m}$ and $81 \mathrm{~m}$ higher, respectively, than the top of the densely welded crystal-poor unit (Tptpv3) at boreholes NRG-7a and SD-9, essentially eliminates structural features to the east of either NRG-7a or SD-9 as potential causes for the perched-water reservoir at UZ-14. If, for example, an extension of the Ghost Dance Fault is invoked to explain the perched-water elevation at UZ-14, then similar water elevations at NRG-7a and SD-9 should exist. However, a perchedwater elevation of $967 \mathrm{~m}$ at NRG-7a and SD-9 would result in a saturated interval above the Tptpln-Tptpv3 contact that would be $111 \mathrm{~m}$ thick at NRG-7a and $81 \mathrm{~m}$ thick at SD-9. Because such thick saturated intervals were not observed and could not easily have gone undetected during drilling, it is clear that if a structural feature is causing the perched-water reservoir at UZ-14, it must be located to the west of NRG-7a and SD-9.

Of the potential conceptual models discussed in a preceding section of this report (see Relation of North Ramp Perched Water to Lithology and Geologic Structure), none is completely satisfactory. The structural contour map of the top of the crystal-poor vitrophyre of the Topopah Spring Tuff (fig. 14) indicates that the Drill Hole Wash Fault system coincides roughly with a structural trough toward which perched water flowing laterally on top of the vitrophyre could be diverted. If the fault is open from the top of the crystal-poor vitrophyre to the water table, it could drain a substantial part of the unsaturated zone of northern Yucca Mountain. If the Drill Hole Wash fault system is relatively impermeable, it would tend to divert water north of Drill Hole Wash downdip to the southeast. In either case, it is unlikely that water from north of the Drill Hole Wash fault system could contribute substantially to recharging the perched reservoir above the crystal-poor vitrophyre in the UZ-14 area. Additionally, the Drill Hole Wash Fault system, either by itself or in conjunction with the other mapped faults in the area, cannot explain the thickness or elevation differences (observations 2 and 3 ) in the perched-water reservoirs at boreholes UZ-14, SD-9, and NRG-7a. Of the faults shown in figure 21 , only the unnumbered north-northwest-trending fault to the west of boreholes NRG-7a and SD-9 has a location and length that indicate potential importance as a barrier fault for perched water. However, this fault dips eastward at $35^{\circ}$ and therefore could not be responsible for the accumulation of perched water at UZ-14. The only conceptual model that cannot be eliminated based on observations 1 through 3 is the proposed growth-fault model shown in figures 108 and 109. The analysis presented in the following paragraphs is based upon that model and is valid only insofar as that model is valid.

\section{Calculation of Percolation Flux in the Vicinity of the UZ-14 Perched-Water Reservoir}

The existence of the perched-water reservoir intersected by borehole UZ-14 presents an opportunity to constrain the estimates of flux through the unsaturated zone in its vicinity. This analysis of percolation flux will proceed in the following steps:

1. Determine the seepage rate of the perched water through the crystal-poor vitrophyre, using estimates of the perched-water volume, areal extent, and residence time (equation 7 );

2. From the seepage rate and hydraulic gradient across the crystal-poor vitrophyre, determine a fieldscale value of permeability for the vitrophyre;

3. Under the assumption of spatial homogeneity, estimate the percolation flux through the vitrophyre 
in the potential contributing areas adjacent to the perched-water reservoir intersected by UZ-14;

4. Weight the percolation fluxes determined in steps 1 and 3 by their respective areas to determine an average percolation flux for the TSw; and

5. Determine the average diverted fraction of percolation flux at the Tptpln-Tptpv 3 contact in the contributing area.

These calculations are non- $Q$ because of their dependence on the non-Q lithostratigraphic information, non-Q data on the elevation of the perched-water reservoir, and the unproven hypothesis regarding the existence of the projected growth fault.

Step 1. Residence times of between 5,150 and 11,000 years were calculated for water within the perched-water reservoir in the previous section by using equation 7 . That equation also can be expressed as

$$
t_{\text {res }}=V / Q=A b \phi_{e} / q A
$$

where $A$ is the area of the perched-water reservoir, in square meters; $b$ is the thickness of the perched water above the Tptpln-Tptpv 3 contact, in meters; $\phi_{e}$ is the effective porosity within the perched-water reservoir; and $q$ is the Darcy flux, in meters per year. The area of the perched-water reservoir is estimated from the intersection of the plane corresponding to the elevation of the perched water with the top of the crystal-poor vitrophyre (fig. 108) to be approximately $430,000 \mathrm{~m}^{2}$. The thickness of the perched water varies between 0 and approximately $30 \mathrm{~m}$ (fig. 108), with an average thickness of perhaps $15 \mathrm{~m}$. These values rely on the structural contour map (fig. 108), which is not very well constrained by borehole data and therefore somewhat interpretive, as well as on the location of the hypothesized fault splay. It is useful to note from equation 8 , however, that Darcy flux does not depend directly on area $A$. Similarly, the appropriate value of $\phi_{e}$ is somewhat uncertain, because the porosity that participates in the active flow system may consist of only fracture porosity, fracture porosity plus a small component of matrix porosity, or the total porosity. To account for uncertainty in residence times and reservoir volumes, Darcy fluxes were calculated for different values of residence time and effective porosity (table 23), assuming $b=15 \mathrm{~m}$. The assumption that $\phi_{e}=0.001$ implies that effective porosity
Table 23. Darcy fluxes for the perched water through the Topopah Spring Tuff crystal-poor vitrophyre near UZ-14, calculated for different combinations of effective porosity and residence time

$\left[\phi_{e}\right.$, effective porosity; $\mathrm{m} / \mathrm{yr}$, meter per year; calculated values assume a perched-water reservoir thickness of 15 meters]

\begin{tabular}{llll}
\hline $\begin{array}{c}\text { Residence } \\
\text { time }\end{array}$ & $\phi_{e}=0.001$ & $\phi_{e}=0.025$ & $\phi_{e}=0.10$ \\
\hline 5,150 years & $2.9 \times 10^{-6} \mathrm{~m} / \mathrm{yr}$ & $7.3 \times 10^{-5} \mathrm{~m} / \mathrm{yr}$ & $2.9 \times 10^{-4} \mathrm{~m} / \mathrm{yr}$ \\
11,000 years & $1.4 \times 10^{-6} \mathrm{~m} / \mathrm{yr}$ & $3.4 \times 10^{-5} \mathrm{~m} / \mathrm{yr}$ & $1.4 \times 10^{4} \mathrm{~m} / \mathrm{yr}$ \\
\hline
\end{tabular}

equals only the fracture porosity, whereas the assumption that $\phi_{e}=0.10$ implies that the effective porosity is essentially equal to the total porosity, which is nearly equal to that of the matrix porosity alone. The assumption that $\phi_{e}=0.025$ implies that a small fraction of the matrix porosity also exchanges with the actively flowing water. Thus, the Darcy flux through the crystal-poor vitrophyre beneath the perched-water reservoir intercepted by UZ-14 is estimated to range between $1.4 \times 10^{-6} \mathrm{~m} / \mathrm{yr}(0.0014 \mathrm{~mm} / \mathrm{yr})$ and $2.9 \times 10^{-4} \mathrm{~m} / \mathrm{yr}(0.29 \mathrm{~mm} / \mathrm{yr})$. The volume of the perched-water reservoir intersected by UZ-14, assuming an areal extent of $430,000 \mathrm{~m}^{2}$ and an effective thickness of $15 \mathrm{~m}$, ranges from $6,450 \mathrm{~m}^{3}$ for a value of $\phi_{e}$ of 0.001 to a value of $645,000 \mathrm{~m}^{3}$ for an assumed value for $\phi_{e}$ of 0.10 . The value of $\phi_{e}=0.025$ results in an estimated reservoir volume of 161,000 $\mathrm{m}^{3}$, which corresponds well with the volume estimated by Fridrich (written commun., 1996) of $114,000 \mathrm{~m}^{3}$ $(30,000,000$ gallons $)$.

Step 2. The average vertical permeability across the stratigraphic interval containing the densely to moderately welded, crystal-poor vitrophyre, including the Tptpv 3 and Tptpv 2 units, was bounded using the range of seepage rates from the perched-water reservoir calculated in Step 1, the total head gradient across those units, and Darcy's law. The total head gradient across the Tptpv3,2 units was calculated assuming that (1) the pressure head at the top of the unit was equal to the pressure exerted by the height of the standing water column within the lower nonlithophysal unit (Tptpln), and (2) the pressure head at the base of Tptpv3, 2 unit was zero (the entire positive head was dissipated across the Tptpv3, 2 units). The thickness of the Tptpv3, 2 units beneath the perched-water reservoir at UZ-14 is approximately $25 \mathrm{~m}$ (fig. 82). The thickness of the perched-water reservoir above the top 
of the Tptpv3, 2 units varies with location within the perched-water reservoir and is approximately $6.8 \mathrm{~m}$ at UZ-14. However, as discussed in Step 1, a thickness for the perched-water reservoir of $15 \mathrm{~m}$ may be more representative of the average thickness. Using this value, the total head gradient across the Tptpv3, 2 units was calculated to be $1.6 \mathrm{~m} / \mathrm{m}$, and the saturated permeabilities necessary to transmit fluxes of 0.29 and $0.0014 \mathrm{~mm} / \mathrm{yr}$ under this gradient are $\mathrm{k}=5.9 \times 10^{-19}$ and $\mathrm{k}=2.8 \times 10^{-21} \mathrm{~m}^{2}$.

Step 3. The general conceptual model presented at the beginning of this section described how, as a result of lateral diversion at the top of the perching layer, some fraction of the water in the perched-water reservoir intersected by UZ-14 may have originated as percolation outside the area occupied by standing water, indicated by the shaded area in figure 108). Within these contributing areas, the fraction of the vertical percolation flux through the TSw that is not diverted at the Tptpln-Tptpv3 contact, but instead continues downward through the Tptpv3, 2 units, may be less than that calculated for the areas beneath the perched-water reservoir at UZ-14. This is because in these contributing areas, lateral flow prevents the development of substantial positive heads above the perching layer so that the head gradient across the Tptpv3, 2 units is approximately unity. Under the assumption that the vertical permeability of the Tptpv3, 2 units outside of the perched-water reservoir has not changed as a result of changes in fracture properties or degree of mineral alteration, the vertical flux through the Tptpv3, 2 units in the contributing areas is estimated to range from 0.0009 to $0.18 \mathrm{~mm} / \mathrm{yr}$, based on the range of permeabilities calculated for the Tptpv3, 2 units beneath the perched-water reservoir. The homogeneity assumption will be further discussed in following paragraphs.

Step 4. A steady-state water balance for the area that includes the perched-water reservoir at UZ-14 and its contributing areas can be established by equating the total flux draining through the crystal-poor vitrophyre with the total flux arriving at the upper boundary of the crystal-poor vitrophyre through the overlying TSw. As discussed in Steps 1 and 3, if spatial homogeneity is assumed for the permeability of the Tptpv3, 2 units, the bounding vertical seepage rates beneath the perched-water reservoir and in the contributing areas range from 0.0014 and $0.0009 \mathrm{~mm} / \mathrm{yr}$ at the low end of the range to 0.29 and $0.18 \mathrm{~mm} / \mathrm{yr}$ at the higher end of the range. By areally weighting these flux values and equating their sum to the total flux through the TSw over the same areas, the average vertical flux through the TSw can be determined:

$$
\begin{gathered}
q_{t s t} \times\left(\text { Area }_{p w}+\text { Area }_{c}\right)=q_{v p w} \times \text { Area }_{v p w}+ \\
q_{v c} \times \text { Area }_{v c}
\end{gathered}
$$

In equation $9, q$ is vertical percolation flux $(\mathrm{mm} / \mathrm{yr})$, Area is area $\left(\mathrm{m}^{2}\right)$, and the subscripts $t s t, v p w$, and $v c$ denote the values of the relevant variables within the TSw, the vitrophyre beneath the perched water, and the vitrophyre within the contributing areas, respectively. The areal extent of the perched-water reservoir $\left(A r e a_{v p w}\right)$ was estimated from figure 108 to be $430,000 \mathrm{~m}^{2}$, subject to the uncertainty discussed in Step 1. The value for the contributing area $\left(A r e a_{v c}\right)$ is less obvious. For the purpose of producing bounding estimates, two values for $A r e a_{v c}$ were chosen: (1) The area bounded by the Solitario Canyon Fault, the Drill Hole Wash Fault system, and the projected growth fault hypothesized as creating the structural trap minus the area of the perched-water reservoir $\left(2,540,000 \mathrm{~m}^{2}\right)$; and (2) zero. The zero value implies that lateral diversion to the perched-water reservoir is zero. It is included to account for the possibility that outside the perched-water reservoir, the permeability increases because of limited alteration or increased fracturing. If $A r e a_{v c}=0, q_{t s t}$ is simply equal to the range of values computed for $q_{v p w}$ in Step 1, 0.0014 to $0.29 \mathrm{~mm} / \mathrm{yr}$. For case (1), with Area $_{v c}=$ $2,540,000 \mathrm{~m}^{2}$, the values of $q_{t s t}$ range from 0.00097 to $0.20 \mathrm{~mm} / \mathrm{yr}$. Thus, considering the uncertainty in residence time, effective porosity, and contributing area, the flux through the TSw is estimated to be in the range of 0.00097 to $0.29 \mathrm{~mm} / \mathrm{yr}$. The larger value applies only to the area directly above the perchedwater reservoir when there is no lateral diversion, whereas the smaller value applies to the area bounded by the projected growth fault, the Solitario Canyon Fault, and the Drill Hole Wash Fault system.

Step 5. The last step in this analysis is to estimate the flux that is diverted at the contact between the lower nonlithophysal unit (Tptpln) and the densely welded, crystal-poor vitrophyre (Tptpv3) in the contributing area outside of the perched-water reservoir. The laterally diverted flux is calculated by equating the areally weighted sum of the vertical flux above the perched-water reservoir $\left(q_{t s t}\right)$ and the 
diverted flux in the contributing area $\left(\Delta q_{t s t}\right)$ to the total flux beneath the perched-water reservoir:

$$
\begin{gathered}
q_{t s t} \times \text { Area }_{v p w}+\Delta q_{t s t} \times \text { Area }_{v c}= \\
q_{v p w} \times A r e a_{v p w}
\end{gathered}
$$

As in Step 4, two values for $A r e a_{v c}$ were chosen: (1) The area bounded by the Solitario Canyon Fault, the Drill Hole Wash Fault system, and the projected growth fault hypothesized as creating the structural trap, minus the area of the perched-water reservoir $\left(2,540,000 \mathrm{~m}^{2}\right)$; and (2) zero. The zero value implies that lateral diversion to the perched-water reservoir is zero, an obvious lower limit. By using Area $_{v c}=2,540,000 \mathrm{~m}^{2}$, Area $_{v p w}=430,000 \mathrm{~m}^{2}, q_{v p w}$ $=0.29 \mathrm{~mm} / \mathrm{yr}$, and the larger value for $q_{t s t}$ calculated for case 1 in Step $4(0.20 \mathrm{~mm} / \mathrm{yr})$, equation 10 results. in a calculated value for the diverted flux of $\Delta q_{t s t}$ $=0.015 \mathrm{~mm} / \mathrm{yr}$. This model implies that even when the larger contributing area is assumed, approximately 70 percent of the perched-water volume arrives by vertical flow and the other 30 percent by lateral flow. As a bounding calculation, if it is assumed that all of the water in the perched-water reservoir originated from outside of the area of the perched-water reservoir (that is, the first term in equation 10 is dropped), the value of the diverted component of the flux is still only $\Delta q_{t s t}=0.049 \mathrm{~mm} / \mathrm{yr}$ for the value of Area $_{v c}$, given in case 1 . However, regardless of the relative proportions of vertical and lateral flux, the chloride concentration and $\delta^{87} \mathrm{Sr}$ data for the perched water indicate that most of this water arrived as a result of fracture flow (see the section of this report titled Aqueous-Phase Chemical Considerations).

A key assumption in the preceding analysis was that the permeability of the densely to moderately welded, crystal-poor vitrophyre was spatially uniform and bounded by the range of values calculated for the Tptpv3,2 unit beneath the perched-water reservoir in Step 2. If the permeability of the crystal-poor vitrophyre in the contributing areas is greater than the values estimated, either because of faulting or less intense alteration, the vertical percolation flux through the TSw in the contributing areas would exceed the value calculated using equation 9 by an amount that depends on assumptions made concerning the spatial variability in percolation flux. If spatial uniformity in the percolation flux is assumed, percolation flux in the contributing areas could be as large as the maximum estimated for the area above the perched-water reservoir $(0.29 \mathrm{~mm} / \mathrm{yr})$ when the contributing area was assumed to be zero (as in case 2 of Step 4). If spatial variability in percolation flux is assumed in addition to spatial variation in the permeability of the crystal-poor vitrophyre, then the upper bound on the percolation flux outside of the area of the perched-water reservoir cannot be determined.

\section{Summary and Implications of Percolation-Flux Calculations}

The growth-fault model presented in a preceding section of this report (see Relation of North Ramp Perched Water to Lithology and Geologic Structure) is the only model proposed thus far that is consistent with observations and inferences concerning the volumes and elevations of perched water in the Drill Hole Wash area. On the basis of this conceptual model of perched water, percolation flux was analyzed to attempt to account for uncertainty in the residence time, volume, and spatial extent of areas contributing flow to the perched-water reservoir intersected by UZ-14. The analysis is, of course, valid only insofar as the underlying conceptual model is correct. Under the assumption that the conceptual model is fundamentally correct, the following results were derived:

1. The Darcy flux through the crystal-poor vitrophyre beneath the perched-water reservoir intercepted by UZ-14 is estimated to range between 0.0014 and $0.29 \mathrm{~mm} / \mathrm{yr}$.

2. The field-scale saturated permeability of the combined Tptpv 3 and Tptpv 2 units beneath the perched-water reservoir at UZ-14 is estimated from the hydraulic gradient and seepage rates to be between $\mathrm{k}=5.9 \times 10^{-19}$ and $\mathrm{k}=2.8 \times 10^{-21} \mathrm{~m}^{2}$.

3. The vertical percolation flux through the TSw is estimated to be in the range of 0.001 to $0.29 \mathrm{~mm} / \mathrm{yr}$ if there is no lateral diversion, and 0.00097 to $0.20 \mathrm{~mm} / \mathrm{yr}$ if the area contributing lateral flow to the perched-water reservoir is defined as the area bounded by the projected growth fault, the Solitario Canyon Fault, and the Drill Hole Wash Fault system.

4. The component of the vertical percolation flux that is diverted at the contact between the Tptpln and Tptpv 3 units is estimated to be as large as $0.015 \mathrm{~mm} / \mathrm{yr}$ if the area contributing lateral flow 
to the perched-water reservoir is defined as the area bounded by the projected growth fault, the Solitario Canyon Fault, and the Drill Hole Wash Fault system. The flux values within the potential contributing areas adjacent to the perchedwater reservoir intercepted by UZ-14 should be viewed as lower bounds. Percolation fluxes could be higher if the permeability of the vitrophyre is higher in the contributing areas than beneath the perched-water reservoir.

The results of the percolation-flux analysis need to be reconciled with the observation made in a previous section of this report (see Aqueous-Phase Chemical Considerations) that pore water in the Calico Hills Formation at UZ-14 has distinctly younger carbon-14 ages than water samples that were collected from fractures in the overlying perchedwater reservoir. This inversion of apparent ages indicates that the water within the Calico Hills Formation at UZ-14 did not arrive predominantly as a result of downward vertical seepage of the overlying perched water, but as percolation that rapidly bypassed the crystal-poor vitrophyre where it is faulted or less intensely altered, and then was laterally redistributed within the permeable nonwelded tuffs that lie adjacent to the Calico Hills Formation (fig. 89). This relatively young water then flowed or diffused into the Calico Hills Formation from the nonwelded vitric base of the Topopah Spring (Tptpv1 and Tpbt1) and the upper, devitrified unit of the Prow Pass Tuff. On the basis of results of hydraulic testing and tracer-injection surveys at borehole $\mathrm{H}-1$, the Prow Pass Tuff was shown to have a permeability of about $4 \times 10^{-12} \mathrm{~m}^{2}$ (Rush and others, 1984, table 14). The faulted or less altered regions are presumably outside the boundaries of the perchedwater reservoir intersected by UZ-14 or their effects would have been reflected in the field-scale permeability value calculated for the Tptpv3,2 units in Step 2 (see the section of this report titled Calculation of Percolation Flux in the Vicinity of the UZ-14 Perched-Water Reservoir). Figure 137 illustrates this relatively complex flow field schematically, assuming that the Solitario Canyon Fault and associated fault splays or less altered parts of the crystal-poor

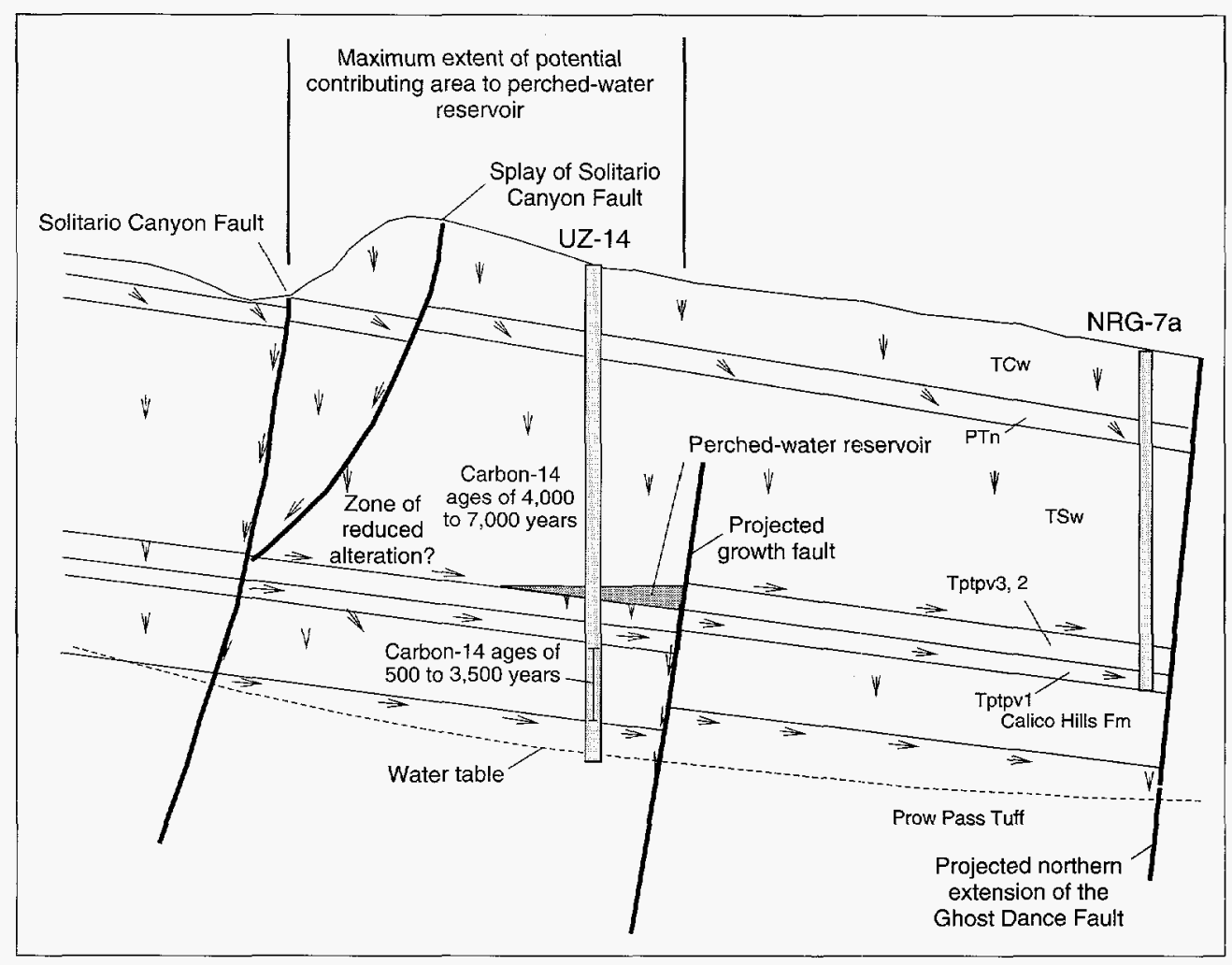

Figure 137. Conceptual model of the flow field in the vicinity of the perched-water reservoir intercepted by borehole USW UZ-14. 
vitrophyre at higher elevations near Yucca Crest may have introduced young water into the underlying layers. Another possibility, however, is that water flowing along the Tptpln-Tptpv3 contact north of the Drill Hole Wash fault system was intercepted by the fault and redirected downward, where it entered the Tptpv1-Tpbt1 and upper Prow Pass Tuff layers south of the fault. The exact source of the water in the Calico Hills Formation cannot be determined using data available at this time. Although the percolationflux analysis is not necessarily invalidated by the depth-inversion of water ages, this inversion does indicate that water movement in the deep unsaturated zone in the North Ramp area is more complex than simple bounding models, such as the one presented here, can fully describe.

\section{Evidence for Preferential Fracture Flow and Lateral Flow Within the Paintbrush Nonwelded Hydrogeologic Unit (PTn)}

Montazer and Wilson (1984) hypothesized that, because fractures within the PTn generally are sparse and commonly stratabound (see the section of this report titled Fracture Characteristics of the Paintbrush Nonwelded Hydrogeologic Unit), and because of its large drained porosity and primary permeability, the PTn has the potential to significantly attenuate the movement of water percolating downward through fractures within the TCw. Once within the pores of the nonwelded tuff matrix, water can (1) be released slowly to the underlying welded tuff matrix or fractures, (2) be held in the rock matrix until it can be removed by shallow convective air flow, or (3) migrate laterally downdip until it reaches a fault, whereupon it is redirected downward. The first mechanism delays the arrival of percolating water at the repository host rock (Topopah Spring Tuff crystal-poor middle nonlithophysal unit) and moderates the peak percolation fluxes but does not alter the total amount of downwardly percolating water. The second and third mechanisms delay the arrival of percolating water and moderate peak percolation fluxes, and they also cause the percolation flux within the TSw in nonfaulted areas to be less than that in the overlying $\mathrm{TCw}$. Because preferential fracture flow within the PTn makes it far less likely that any of these three attenuation mechanisms will be operative, it is important to review the data for evidence of fracture flow within the PTn.
The presence of environmental tracers within the PTn at concentrations indicative of nuclearweapons testing indicates that the PTn has been effective to at least some degree in capturing water that had moved through the overlying TCw as fracture flow. This conclusion is supportable using solely the fully qualified data. Fracture flow within the PTn is indicated by the tritium-concentration profiles for boreholes UZ\#4 and UZ\#5 (fig. 105), NRG-6 (fig. 107A), and UZ-14 (fig. 106A). At boreholes UZ\#4 and UZ\#5, high concentrations of tritium were measured within the nonwelded base of the Tiva Canyon Tuff and, at UZ\#4, within the base of the Yucca Mountain Tuff and subadjacent bedded tuffs. (As noted earlier, tritium data for UZ\#4 and UZ\#5 were collected prior to implementation of the USGS YMP quality-assurance program and, therefore, these data are non- $Q$.) The presence of high concentrations of tritium within the PTn at these boreholes is consistent with other geologic and hydrologic observations, such as the fact that the boreholes are in a fault-affected zone of higher fracture density (see the section of this report titled Azreal Ridge Subdomain), and that the PTn was inferred to have significant secondary permeability, based on an analysis of the in-situ pneumatic pressures (see the section of this report titled Interpretation of Pneumatic-Diffusivity Determinations). The highest concentrations of tritium at borehole NRG-6 (fig. 107A) are at depths of approximately $77 \mathrm{~m}$, which is just above the densely welded, crystal-rich vitric unit (Tptrv1) that defines the top of the TSw (table 2). The fracture densities reported for the Tptrv1 unit at NRG-6 (fig. 25) were among the highest observed for any boreholes in the study area. At $\mathrm{UZ}-14$, high concentrations of tritium were measured at depths of about $40 \mathrm{~m}$, within the upper part of the Pah Canyon Tuff. The fracture logs for this borehole do not record many fractures for this interval (fig. 24). It is interesting to note, however, that Montazer and others (1985), in analyzing the subsurface pressure response at nearby UZ-1 to barometric pressure changes at the land surface, were forced to assume a dual-porosity model that included both fracture and matrix permeability within the PTn. Although these examples do not prove that fracture flow continued into the TSw, they do indicate that at some locations, most notably at NRG-6, fracture flow has occurred to sufficient depth such that fracture flow into the TSw is a plausible hypothesis. 
The most compelling evidence that water moving within fractures of the PTn has bypassed the nonwelded tuff matrix is the presence of environmental isotopes such as tritium within the TSw at concentrations that are indicative of nuclear testing. The tritium-concentration profile for borehole UZ-14 (fig. 106) shows two locations in the TSw, at depths of about 96 and $390 \mathrm{~m}$, where tritium concentrations are between 10 and 30 TU. The tritium detected at $390 \mathrm{~m}$ is from within the zone of perched water. Because atmospheric-tritium concentrations remain at approximately these levels, possible contamination due to exposure to air during sample handling makes it difficult to interpret the significance of these samples with confidence. However, chlorine-36 data collected to date from rock samples from the ESF have included 11 sampling sites from the TSw with chlorine-36 ratios that are indicative of nuclear-weaponstest-related origins (Fabryka-Martin and others, 1996), lending support to the interpretation that the tritium data also reflect recent inputs of meteoric water into the TSw rather than atmospheric contamination. Significantly, although all but one of these 11 sampling sites with elevated chlorine-36 ratios were in the general vicinity of a fault zone that had been mapped at the surface, subsurface reconnaissance did not show a clear association of these sampling sites with major faults (Fabryka-Martin and others, 1996, p. 9).

The tritium data for the PTn and TSw, taken in conjunction with the isotopic data for the perched water at UZ-14 and recent chlorine-36 data reported by Fabryka-Martin and others (1996), support the contention that some percolation, although possibly only a minor fraction, has bypassed the PTn matrix and entered the potential repository host rock as fracture flow.

Evidence for extensive lateral flow within the PTn is more elusive. Evidence for at least limited lateral redistribution of percolation is provided by the aqueous carbon-14 data at borehole UZ-14 and gaseous carbon-14 data at nearby UZ-1 (fig. 106a). Although the average carbon-14 values for the gas and aqueous phases within the Pah Canyon and adjacent bedded tuffs are similar, their variations with depth indicate that two very distinct processes may have resulted in their observed distribution. The carbon-14 values within the gaseous phase for nearby UZ-1 (fig. 80) show a systematic decrease with depth and appear to be consistent with one-dimensional downward diffusion of gas (Thorstenson and others, 1998).
In contrast, the aqueous carbon-14 data indicate that water near the pre-Pah Canyon bedded tuff/Pah Canyon Tuff contact has a younger carbon-14 age than samples at shallower depths. This apparent age inversion is incompatible with the one-dimensional downward-diffusion mechanism indicated by the gaseous data, which indicates nonequilibrium distribution of carbon-14 between the gaseous and liquid phases. One of two alternative mechanisms might have resulted in such an age inversion. Relatively rapid aqueous transport could have taken place down steeply dipping fractures that were intercepted by the borehole near the base of the Pah Canyon Tuff, which is the explanation for the high concentrations of tritium in the upper part of the Pah Canyon Tuff. Alternatively, partial zeolitization of the lower part of the Pah Canyon Tuff and pre-Pah Canyon Tuff bedded tuffs (see the section of this report titled Alteration in the PTn Hydrogeologic Unit), or an argillic zone developed within the pre-Pah Canyon Tuff bedded tuffs (see section of this report titled Correlation of the Lithostratigraphic and Hydrogeologic Frameworks), may have formed permeability barriers that diverted water that had percolated rapidly elsewhere toward the UZ-14 area. Although lateral diversion can explain the apparent age inversion, it is important to point out that the distances across which this lateral migration occurred cannot be quantified with certainty and that other causes of the age inversion, such as fracture flow, are possible.

\section{SUMMARY AND CONCLUSIONS}

Lithostratigraphy and the geometry of the volcanic rocks at Yucca Mountain are fundamental controls on the spatial distribution of the hydrogeologic properties of the unsaturated zone. Hydrologic properties such as bulk density, porosity, permeability, water content, and saturation are governed by the distribution of volcanic glass and the crystallization or alteration of glass, nonwelded to densely welded textures, and fracture characteristics. Map relations in the Exploratory Studies Facility (ESF), in boreholes, and in outcrop indicate that fallout tephra that overlie the Topopah Spring Tuff are locally argillic, possibly due to fumarolic activity related to the cooling of the Topopah Spring Tuff. Although the basic process of alteration is the same in the Paintbrush nonwelded (PTn) and Calico Hills nonwelded (CHn) hydrogeo- 
logic units, alteration in the PTn appears highly localized and poorly developed; in contrast, pervasive zeolitization is characteristic of the $\mathrm{CHn}$ through much of the central block of Yucca Mountain. Contacts of lithostratigraphic units closely approximate the major changes in hydrologic properties associated with the four major, bedrock hydrogeologic units and most of the proposed subunits. Therefore, the lithostratigraphic framework is a critical consideration for conceptual and numerical modeling of the unsaturated zone.

Several lithostratigraphic units vary significantly in thickness and orientation in the vicinity of the North Ramp of the ESF. The Topopah Spring Tuff decreases in thickness and shifts orientation from a northerly strike in the south to an easterly strike in the north because of onlap of the tuff onto a paleotopographic highland formed from thick lava flows of the Calico Hills Formation along the northeastern part of * the central block of the mountain. Thickness of the PTn decreases relatively abruptly south of the North Ramp area, primarily as a result of the sharp decrease in thickness of the pyroclastic flow deposits in the Yucca Mountain and Pah Canyon Tuffs and pre-Yucca Mountain Tuff bedded tuffs. The Tiva Canyon Tuff decreases sharply in thickness and shifts orientation from a northerly strike in the south to a northeasterly strike in the north because of onlap of the tuff onto a paleotopographic highland formed from thick accumulation of pre-Tiva Canyon Tuff and post-Topopah Spring Tuff deposits along the northern part of the central block. Three-dimensional geologic modeling of the vitric-zeolitic boundary indicates the vitric material is typically less than $6 \mathrm{~m}$ thick in most of the northern and eastern areas of the central block, especially near the North Ramp of the ESF. Thick intervals of vitric material in the southwest, as much as $140 \mathrm{~m}$, probably resulted from tilting of structural blocks prior to zeolitization. The coincident alignment of the sharp increase in thickness aligned with the Ghost Dance and Sundance Faults, however, implies a possible structural control to the distribution of intense zeolitic alteration of the $\mathrm{CHn}$.

The orientation of the Tiva Canyon Tuff and underlying PTn units exposed at the surface makes a gradual transition from dominantly northeast-striking north of Drill Hole Wash in the Azreal Ridge structural subdomain to dominantly north-trending strike directions south of Drill Hole Wash in the Yucca Crest subdomain. Faults in eastern parts of the Azreal Ridge and Yucca Crest subdomains related to the imbricate fault zone do not project across Drill Hole Wash. Although individual faults cannot be correlated, the intense faulting that characterizes the imbricate fault zone in the Yucca Crest subdomain steps to the right (eastward) on the northeast side of Drill Hole Wash in the Azreal Ridge subdomain. This is consistent with a right-lateral sense of offset along the Drill Hole Wash Fault system, assuming the development of the northsouth-trending imbricate faults preceded development of the Drill Hole Wash system. West of borehole NRG\#5 the Azreal Ridge subdomain becomes structurally coherent and contains only a few northeasttrending faults. The intensities of faulting and brecciation beneath Drill Hole Wash are much less at depth in the ESF than in exposures at the surface and are much less than anticipated on the basis of previous borehole and surficial geophysical studies. Although offset is minimal, there are several splays of kinematically related northwest-trending faults, two of which define the Drill Hole Wash Fault system. A decrease in deformation with depth is evident on the basis of the amount of offset on the southwesternmost splay observed in outcrop compared with offset estimated from its exposure in the ESF. The Yucca Crest subdomain contains the Ghost Dance and Sundance Fault zones and is structurally coherent in the Diabolus Ridge area but becomes more faulted to the south of Dead Yucca Ridge. Cooling joints and tectonic fractures are preserved in both the Azreal Ridge and Yucca Crest subdomains. The regional distribution of fractures indicates that more of the stations studied in the Azreal Ridge subdomain contain cooling joints than those in the Yucca Crest subdomain. Both the older $\mathrm{T} 1$ (north-south-oriented) and T2 (northwest-trending) tectonic fractures are present in the Azreal Ridge and Yucca Crest subdomains. More of the younger T3 (northeast-trending) and T4 (east-west-trending) tectonic fractures were recorded in the Yucca Crest subdomain. Surface and subsurface exposures of the PTn unit show very low fracture densities. Fracture densities are expected to be higher in the northern part of the Azreal Ridge structural subdomain, where pyroclastic flow units within the PTn thicken and become welded.

Gas and water-vapor movement through the unsaturated zone at Yucca Mountain is driven by changes in barometric pressure, temperature-induced density differences, and wind effects. The subsurfacepressure response to surface barometric changes is 
dominated by the bulk pneumatic diffusivity of the layers of rock present at a given location. Consequently, the subsurface responses are controlled by the distribution and interconnectedness of fractures, the presence of faults and their capacity to conduct gas and vapor, and the moisture content and matrix permeability of the rock units. Changes in barometric pressure at land surface result in corresponding changes in pneumatic pressure at considerable depths in the unsaturated zone, which commonly are amplitude attenuated and time lagged relative to the pressure changes at the surface. Fractures are the primary medium through which the pressure changes are transmitted. Fracture data from a number of boreholes indicate similar trends in the distribution of fractures that are pathways for gaseous-phase movement. These trends include (1) high fracture density near the contacts between vitric units and nonlithophysal units, (2) relatively high fracture density within the nonlithophysal units as compared to the lithophysal units,

(3) relatively low fracture density within the PTn, and

(4) very low fracture density within the Calico Hills Formation, Prow Pass Tuff, and Bullfrog Tuff.

The contribution of the matrix of the tuff units at Yucca Mountain to bulk air permeability depends on the degree of fracturing in any given rock unit. Permeability through the rock matrix is a function of the interconnectedness of pores, pore size, degree of microfracturing, and the degree of filling of pore channels with the products of secondary alteration. Air permeabilities of 11 core samples from three boreholes in the welded, crystal-poor, upper lithophysal unit of the Tiva Canyon Tuff (Tpcpul) have an arithmetic mean of $1.5 \times 10^{-16} \mathrm{~m}^{2}$. Air permeabilities for a series of nonwelded core samples collected from boreholes in Pagany Wash and Drill Hole Wash ranged from $3.0 \times 10^{-13} \mathrm{~m}^{2}$ to less than $2.0 \times 10^{-17} \mathrm{~m}^{2}$. The air permeability of Calico Hills samples is about $2.5 \times 10^{-17} \mathrm{~m}^{2}$, whereas the permeability of samples from the nonwelded PTn averages about $3.0 \times 10^{-14} \mathrm{~m}^{2}$. Although water-permeability measurements were always lower than air-permeability measurements, they nevertheless can represent the relative differences between rocks units, except where there are large degrees of alteration such as in the zeolitized rocks below the Topopah Spring hydrogeologic unit (TSw). In general, the core-scale measurements of either air or water permeability adequately describe the permeability of the matrix of the various lithologic units and provide lower bounds for analyses of bulk-permeability measurements from borehole tests.

Air-permeability values for the welded units obtained from in-situ pneumatic testing of boreholes ranged from $3.5 \times 10^{-14} \mathrm{~m}^{2}$ to $5.4 \times 10^{-11} \mathrm{~m}^{2}$. This range indicates that, at the scale of testing (approximately $4 \mathrm{~m}$ ), the formations are heterogeneous. Although only seven intervals were tested in the Tiva Canyon hydrogeologic unit (TCw), the limited data indicate that the TCW is more permeable than the TSw. It is possible that the larger permeability values may be due to stress-relief fracturing or stress-relief opening of fractures associated with the lower overburden pressures. Air-permeability values obtained from testing of boreholes NRG-6 and NRG-7a indicate that the TSw is heterogeneous throughout the North Ramp area. Air-permeability values for the PTn ranged from $1.2 \times 10^{-13} \mathrm{~m}^{2}$ to $3.0 \times 10^{-12} \mathrm{~m}^{2}$ and, at the scale of testing (approximately $4 \mathrm{~m}$ ), the PTn is vertically heterogeneous. The mean of the 14 intervals within the PTn tested in NRG-7a is $0.58 \times 10^{-12} \mathrm{~m}^{2}$. On the basis of a small quantity of in-situ data from a single borehole (NRG-7a), comparison with the matrix values indicates that the PTn has secondary permeability due to fracturing.

The unsaturated-zone pneumatic system consists of four distinct but interconnected flow regimes or subsystems that can be differentiated, at least in part, on the basis of similarities in the in-situ pressure responses to atmospheric pressure changes. Pneumatic-pressure responses in the $\mathrm{TCw}$ indicate very little attenuation and lagging of the pressure signal with depth. The residual amplitudes of the synoptic signal from nearly all monitoring stations in the $\mathrm{TCw}$ are 97 percent or greater, and phase lags are less than 5 hours. One significant exception is the pneumatic-pressure record from the base of the Tiva Canyon Tuff columnar unit in NRG-6, where the residual amplitude is only 43 percent and the phase lag is 9.6 hours. Changes in residual amplitudes and phase lags between June and December of 1995 at all instrument stations in NRG-6 may have been the result of transient infiltration events that temporarily sealed near-surface fractures and shallow soil cover.

As a pneumatic subsystem, the PTn acts as a significant impeding layer to gas flow between the TCw and Topopah Spring welded (TSw) hydrogeologic units, primarily because of its very high air-filled porosity and low to moderate permeability. Variability in the pneumatic-impeding characteristics of the PTn 
is indicated by the residual amplitudes of the atmospheric synoptic signal in the crystal-rich nonlithophysal unit of the Topopah Spring Tuff for various boreholes, which ranges from about 5 percent at UZ-1 and NRG-7a to 29 percent at NRG\#5. Although the thickness of the PTn ranges from 38 to $84 \mathrm{~m}$ in boreholes within the study area, variations in thickness alone do not account for differences in attenuation of the atmospheric-pressure signal. At many monitoring sites, signal attenuation and lagging appear to be controlled by one or both of the relatively thin vitric subunits of the PTn. Furthermore, suppression of the atmospheric pressure signal across the PTn also appears to increase from east to west, consistent with a trend of increasing saturation within this unit and decreasing thickness of the TCw beneath Drill Hole Wash. This is especially evident where the PTn directly underlies alluvial fill in the upper washes of the western part of the study area. The impeding characteristics of the PTn, especially the nonwelded vitric subunits, thus appear to be strongly affected by saturation. Locally, fractures in the porous nonwelded and bedded units of the PTn appear to be open to gas flow, especially in areas immediately adjacent to faults.

Pressure data from instrument stations located in the TSw exhibit very little attenuation and lagging of the pneumatic pressure signals once the pressure signal is transmitted across the overlying PTn impeding layer. Pressure signals appear to be transmitted nearly instantaneously throughout the entire TSw. This is because of the very high pneumatic diffusivity of the TSw, resulting in part from matrix porosities of less than 0.1 and saturations ranging from 0.5 to 0.9 . Further, fractures within the TSw are apparently very permeable and highly interconnected within both the lithophysal and nonlithophysal units.

The nonwelded vitric and zeolitized rocks of the Calico Hills Formation form the lowermost pneumatic subsystem within the study area. In the one borehole within the North Ramp study area where the Calico Hills Formation has been monitored (SD-9), pneumatic-pressure changes follow a seasonal trend. Individual synoptic-pressure signals from the atmosphere do not appear in this record, but do appear as composite, time-averaged signals superimposed on the seasonal pressure wave. It should be noted, however, that the synoptic signal in the overlying TSw is strongly attenuated across the crystal-poor vitric unit of the Topopah Spring Tuff because the unit is saturated at this location and is a pneumatic-pressure- impeding layer to vertical propagation of pneumatic pressures. Core data indicate that matrix porosities are on the order of 0.35 , and saturations, for the most part, are between 0.95 and 1.0. Fracture densities of the Calico Hills Formation and underlying Prow Pass Tuff of the Crater Flat Group are very low (core recovery percentage is very high). Low fracture densities and low air-filled porosities indicate that the pneumatic diffusivity of the Calico Hills pneumatic subsystem is probably much lower than that of any of the other pneumatic subsystems in the study area.

Numerical modeling of the pneumatic-pressure data showed that pressure records from boreholes NRG-6, NRG-7a, UZ\#4, and UZ\#5 could be replicated accurately with a one-dimensional, gas-diffusion model originally developed for porous media. The simulations yielded estimates of effective permeability to air and air-filled porosity for the depth intervals bounded by the monitoring stations at these boreholes. These simulations indicated that the absence of phase offset or amplitude reductions in the pneumaticpressure signal at stations located in the TSw could be attributed to the relatively large (vertical) pneumatic diffusivity of that unit. The simulations also indicated that, although the nonwelded and partially welded units within the PTn hydrogeologic unit are the source of most of the phase shift and amplitude reductions of the pneumatic-pressure signal, these units nonetheless possess substantial permeability (generally greater than $10^{-12} \mathrm{~m}^{2}$ ). Comparison of the simulations of air permeability with those measured on unfractured core samples indicated that fracturing may have enhanced the permeability of the nonwelded units locally by as much as two to three orders of magnitude. The existence of secondary permeability was most strongly indicated by the data at boreholes UZ\#4 and UZ\#5, which may be in a fault-affected zone of greater fracture permeability. Comparison of simulations of air permeability with those derived from insitu air-injection testing indicated the presence of anisotropy in both the TCw and TSw. In the TCw, the ratio of horizontal to vertical permeability (approximately 10:1) was attributed to the predominance of subhorizontal unloading fractures in the shallow subsurface. In the TSw, this permeability ratio appeared to be reversed, probably as a result of the disappearance or partial closure of the subhorizontal fractures that appeared to dominate the shallower depths. 
Interference effects associated with excavation of the ESF North Ramp by the tunnel-boring machine (TBM) have been detected in the pneumatic-pressure records of all monitored boreholes within the study area. Many of the effects were not detected, however, until several days after the actual excavation activity that caused the interference. This is because the wave length of the atmospheric-pressure-change signal is about 4 days and because the rate of advance of the TBM itself tends to obscure detection of the first arrival of the pneumatic interference. Penetration of the PTn in the North Ramp tunnel by the TBM was first apparent in the pneumatic-pressure record of borehole NRG\#4 when subunits in the TSw began to exhibit less attenuated and less time-lagged responses to atmospheric-pressure changes. The changes are the result of the removal of the PTn pneumatic-impeding layer that exposed the TSw directly to the atmospheric pressure by way of the North Ramp tunnel. Pneumatic-interference effects at UZ\#4 and UZ\#5 were first detected when the TBM closely approached a north to northwest-trending, west-dipping, normal fault. The pneumatic interference detected at UZ\#4 and UZ\#5 was transmitted along the fault zone over a distance of 377 to $415 \mathrm{~m}$ and affected the pneumaticpressure responses in all of the PTn and TSw instrument stations in these two boreholes, indicating that the fault zone is highly permeable. The first indication of a pneumatic interference at borehole NRG\#5 was when face of the North Ramp tunnel was the about $93 \mathrm{~m}$ from the borehole in the lower section of the crystal-rich nonlithophysal unit of the Topopah Spring tuff. Interference effects appeared in the record for NRG-6 about 2 days after the TBM intersected the northern boundary of the Drill Hole Wash Fault system. Because of their subtlety, the effects at NRG-6 were not apparent immediately and required several months of additional data collection to confirm. It is likely that the weak interference seen at NRG-6 is the result of pressure changes that were propagated both along, and perpendicular to, the alignment of the Drill Hole Wash Fault system. It is clear from these data that faults in the Drill Hole Wash Fault system are open in the TSw. At borehole NRG-7a, pneumatic-interference effects were not observed until the TBM had advanced to within $26 \mathrm{~m}$ of the borehole and 5 days after the TBM crossed the southern boundary of the Drill Hole Wash Fault system. This implies that secondary, near-field fracturing associated with the fault system is very limited immediately south of where the North Ramp crosses the Drill Hole Wash Fault system.

Overall, significant change has occurred in the residual amplitudes and phase lags of the transmitted synoptic-pressure signal within the TSw for all monitored boreholes in the study area. Also, there is evidence of significant change in the pneumatic characteristics of the PTn in some of the boreholes, especially UZ\#4 and UZ\#5. Spectral analysis of pneumatic-pressure responses indicates that the pneumatic interferences from tunnel excavation are propagated differentially across the TSw, with larger interferences registering in instrument stations that are closer to the tunnel. This observation, coupled with observations of the first occurrence of interference to the pneumatic-pressure system, indicates that vertical fracture permeability is greater than lateral fracture permeability. The pre-ESF excavation pneumatic record indicates very little attenuation and lagging of the synoptic-pressure signal within the TSw once the signal has traversed the contact between the PTn and the TSw. Thus, an anisotropy ratio of vertical to horizontal fracture permeability within the TSw on the order of 3:1 (or perhaps greater) may be inferred from the existing data. The presence of anisotropy within the TSw probably is the result of (1) a fracture system that is dominated by high-angle fractures, and (2) the effect of differential loading on the openness, and hence permeability, of individual fracture planes. Thus, vertical flow pathways will tend to be much less tortuous than horizontal pathways that must communicate laterally by transmission through a network of vertically oriented fractures.

Gaseous-phase chemical studies indicate that gas composition in the unsaturated-zone at borehole UZ-1 is similar to that of atmospheric air, except that $\mathrm{CO}_{2}$ concentrations generally are larger in the gas in the unsaturated zone than in air. The $\delta^{13} \mathrm{C}$ (gas) values of $\mathrm{UZ}-1$ rock-gas $\mathrm{CO}_{2}$ average -20 per mil throughout, indicating biogenic sources. These $\delta^{13} \mathrm{C}$ (gas) values are fairly constant from the surface to a depth of $366 \mathrm{~m}$, indicating little interaction between the gas $\mathrm{CO}_{2}$ and caliche in the soil. On the basis of ${ }^{14} \mathrm{C}$ data, the dominant mechanism for gas movement in the unsaturated zone at the location of UZ-1 in Drill Hole Wash seems to be downward diffusion of atmospheric gas from the surface.

Many of the attributes of the hydrologic system incorporated into the conceptual model of fluid flow in the unsaturated zone at Yucca Mountain developed by 
the USGS in 1984 have been confirmed by recent studies conducted in the North Ramp study area. These attributes include low net infiltration as a percentage of annual precipitation, rapid infiltration into the fractures of the TCw, unit hydraulic gradients within the TSw and PTn, and perched water at the base of the Topopah Spring Tuff. However, despite not being emphasized in the 1984 conceptual model, there is very strong chemical and isotopic evidence for significant, local fracture flow within the PTn where secondary fracture permeability is evident in association with mapped faults. Fracture flow also is evident below the PTn in the highly fractured rocks of the TSw. Further, despite being strongly emphasized in the 1984 conceptual model, direct evidence of extensive lateral flow in the PTn and diversion of flow into structural pathways remains sparse. What data are available within the study area can be used only to infer the possible presence of lateral flow in the PTn within geographically restricted areas, primarily in channel environments. Although the 1984 conceptual model postulated significant capacity for lateral flow in the PTn matrix, in excess of $100 \mathrm{~mm} / \mathrm{yr}$, data available to date have not demonstrated large-scale lateral flow within this unit. Where data are available to infer lateral flow, it is not absolutely clear that fracture flow could not have produced the same result.

Although measurements of physical and hydrologic properties of borehole core samples in the North Ramp area represent conditions of the rock matrix at a point, they do not incorporate large-scale features such as lithophysal cavities or fractures, and generally represent only local moisture conditions. Porosity correlates well with lithostratigraphy and permeability, although the slope of the linear relation with permeability changes for lithostratigraphic intervals where clay, zeolite alteration, or microfractures are present. Core-scale variations in water potentials between rock units can be attributed to large errors due to sample handling or laboratory measurements in the lowporosity units. Error analyses of loss of water from core samples due to drilling and sample handling indicate that samples with very low porosity lose the highest percentage of volumetric water content. Corrections to saturation and water-potential results for core samples from boreholes UZ-14 and SD-9 did not provide an explanation for the apparent dryness of the low-porosity rock units that are deep within the unsaturated zone. The apparent dryness of these units is problematic given their proximity to suspected perched water or the water table. Core-scale saturations for boreholes in the North Ramp area indicate that the saturation of the PTn is low, whereas the saturation of the TCw and TSw is relatively high. Saturations in the PTn tend to be lower where the PTn is overlain by thick alluvium. Also, where the PTn is relatively thick, the saturation of the top of the TSw tends to be lower. The increase in water content deeper in the profile, therefore, likely is due to water that has moved through fractures, broken zones, or faults. For any single borehole, the core-scale physical and hydrologic properties in the transition from the PTn into the TSw imply that conditions may be favorable for lateral diversion of water, at least locally. When the same physical and hydrologic properties are compared from borehole to borehole, however, the heterogeneities present imply that conditions may not be favorable for lateral diversion at a larger scale. Measurement and analysis of water potential at different scales (core and in-situ) result in different estimates of moisture conditions for the matrix and the matrix/fracture systems at UZ-14 in the PTn and upper TSw. Both in-situ and core-scale measurements of water-potential conditions, however, indicate that water potentials are too high to be in static, no-flow equilibrium with either the water table or the perchedwater reservoir at borehole UZ-14.

In-situ water-potential measurements for instrumented borehole UZ-1 indicate that water-potential gradients in the TSw, with the possible exception of the lower lithophysal subunit, are very close to zero. Extrapolation of the equilibration trend in water potentials for the two stations in the lower lithophysal unit, however, supports the conclusion that the water-potential gradient within this unit is close to zero as well. Therefore, the gravitational potential may be the dominant component of the total hydraulic gradient, which is very close to unity. The time-series water-potential data for borehole NRG-6 indicate that water potentials throughout this borehole had equilibrated after about 1 year of monitoring. The equilibrated water-potential profile indicates a water-potential gradient that is very close to zero across the PTn and through the upper part of the TSw. The time-series data for borehole NRG-7a indicate that water potentials were still increasing very slowly after 1 year of monitoring. Nevertheless, the water-potential profile for NRG-7a indicates a gradient that is very close to zero throughout the borehole. Insitu water-potential data for boreholes UZ\#4 and U\#5 demonstrate the complex hydrologic system present in 
Pagany Wash, which may be indicative of conditions in other washes overlying fault zones at Yucca Mountain. Although not yet fully equilibrated, the final water-potential profiles for boreholes UZ\#4 and UZ\#5 probably will very closely follow the trend derived from core samples and probably will indicate gradients that are very close to zero across most of the PTn section. Comparison of water potentials in the two boreholes for the upper PTn subunits (crystal-poor vitric, Yucca Mountain Tuff, and the pre-Yucca Mountain Tuff bedded tuff) indicates that potentials in UZ\#5 are 0.2 to $0.3 \mathrm{MPa}$ lower than those in UZ\#4, possibly indicating that lateral flow may be occurring from UZ\#4 to UZ\#5.

Overall, water potentials determined from in-situ monitoring throughout much of the PTn and TSw are very high (greater than $-0.3 \mathrm{MPa}$ ) and are relatively depth-invariant. The measured values are considerably higher than those that would be expected if water potentials in the unsaturated zone were in static equilibrium with the water table, implying that the downward percolation flux is nonzero. The relatively large water potentials also indicate that the rock matrix, at least near the fractures, is sufficiently wet that, should water flow through the fractures, there would be little imbibition by the rock matrix because of the small matrix permeability and small waterpotential gradients across the fracture-matrix interface. Water-potential data from rock cores of the densely welded units exhibit much greater variability than do the in-situ data and do not display the depth-invariant characteristics of the in-situ data. This is readily apparent in the core water-potential data from SD-9 and UZ-14 for the middle nonlithophysal (Tptpmn), lower nonlithophysal (Tptpln), and the crystal-poor vitric (Tptpv) units of the Topopah Spring Tuff. Although corrections were applied to the core-scale water-potential measurements to account for the effects of moisture losses during coring, processing, and handling operations, these corrections were not sufficient to reverse the apparent inversions in the total potential gradient across these units. Hydrogeologic units that display the most significant departure from a depth-invariant profile are those whose moistureretention curves indicate the most sensitivity to small changes in saturation (Tptpmn, Tptpul, and Tptpv3). The low water potentials from core located immediately above, below, and within the perched-water reservoirs at SD-9 and UZ-14 are inconsistent with an expected saturated or nearly saturated environment.
These low water potentials may indicate that not all of the moisture losses from drilling and handling operations have been accounted for. Core-scale waterpotential data for the PTn indicate a depth-invariant water-potential gradient at both UZ-14 and SD-9, with water potentials varying between 0.0 and $-0.3 \mathrm{MPa}$. At UZ\#4 and UZ\#5 the consistency between the insitu and core-scale water-potential measurements is remarkable, with water potentials varying from -0.1 to $-0.5 \mathrm{MPa}$. The moisture-retention curves for the nonwelded and bedded units of the PTn indicate that the sensitivity of water potential relative to saturation is fairly limited over a wide range of saturation, thus buffering the effect of moisture losses on the measurement of water potentials in core samples. In general, both in-situ, field-scale water potentials and core measurements of water potential and saturation indicate a deep percolation environment that is conducive to sustaining deep fracture flow.

Since the completion of heat-flow studies conducted during the 1980 's, the data base used to characterize thermal and matrix-hydrologic properties of the welded and nonwelded tuffs has been refined and enhanced considerably, especially for the nonwelded and bedded tuffs of the PTn. Detailed temperature data now are available from five recently instrumented boreholes in the North Ramp study area. Temperature measurements in these boreholes since 1994 confirm the general findings and conclusions of earlier studies: (1) heat flow in the unsaturated zone is primarily conductive, and (2) temperature gradients in the unsaturated zone vary, but generally consist of multiple linear segments. Although the earlier studies concluded that heat flow in the unsaturated zone was primarily conductive, these studies did note that the average heat flow in the unsaturated zone might be as much as 20 percent lower than that estimated for the saturated zone and considered two possibilities for this heat-flow deficit through nonconductive heat-flow processes: (1) heat reduction from vertical percolation and (2) heat loss through vaporization and advective transport of vapor and air. Although heat losses due to vaporization and advective transport of vapor and air may be locally important in the highly fractured and densely welded rocks of the $\mathrm{TCw}$, these effects are secondary in comparison with the effects of percolation in Pagany Wash and Drill Hole Wash, which were investigated in detail during this current study.

On the basis of temperature profiles from five recently instrumented boreholes (NRG-6, NRG-7a, 
NRG\#4, UZ\#4, and UZ\#5), one borehole instrumented in 1983 (UZ-1), and 10 open boreholes studied in the 1980's, temperature gradients in the TSw vary significantly from borehole to borehole. Smaller gradients in the TSw are present in active channels and valley floors, whereas larger gradients are present beneath channel margins, hillslopes, and ridges, indicating a direct correlation between heat flow and unsaturated-zone thickness. Gradients within the PTn are larger than those in the underlying TSw because of the lower thermal conductivity of the PTn. Temperature gradients within individual subunits of the PTn show more spatial variation than gradients within the $\mathrm{TSw}$ because of (1) differences in heat flow from the underlying TSw, (2) proximity of the PTn to the land surface and the influence of topographic effects and seasonal temperature changes, (3) the presence of alluvial fill that tends to insulate underlying bedrock units, and (4) differences in thermal conductivity, which is sensitive to variations in porosity and saturation. Temperature gradients within the TCw are relatively small and are strongly influenced by seasonal surfacetemperature changes. Temperature profiles for the $\mathrm{TCw}$ indicate that ground-surface temperature changes are propagated to depths of about $15 \mathrm{~m}$.

Temperature data from two closely spaced, instrumented boreholes in Pagany Wash, UZ\#4 and UZ\#5, indicate large, horizontal components of heat flow beneath the alluvium. Further, temperatures within the alluvium and the PTn immediately below Pagany Wash at UZ\#4 are significantly higher than temperatures at nearby UZ\#5, which is located on the hillslope immediately adjacent to the wash. Elevated temperatures within the alluvium of Pagany Wash and the underlying PTn probably are due to the insulating effects of the low thermal-conductivity alluvium. An analysis of heat flow beneath the Pagany Wash site, which incorporates data from other boreholes, indicates that heat flow in the PTn is approximately 60 percent less than that in the underlying TSw. This large vertical heat-flow deficit within the PTn probably is due to infiltration and deep percolation.

Aqueous-phase chemical studies indicate that unsaturated-zone pore water generally has significantly large concentrations of dissolved solids. Pore water from the Tiva Canyon, Yucca Mountain, Pah Canyon, and bedded tuffs generally is a calcium sulfate or calcium chloride type. Calico Hills Formation water generally is a sodium carbonate or sodium bicarbonate type. Pore water from the TSw generally is intermediate in composition. Tritium profiles indicate older water overlying younger water in several locations in the North Ramp area, indicating that vertical water percolation through the matrix is not the dominant flow mechanism at Yucca Mountain. Rather, fracture flow likely is the dominant liquidwater flow mechanism. This conclusion is supported by post-bomb (after 1963, the end of atmospheric testing of nuclear weapons) tritium concentrations detected down to several hundred meters below the land surface in boreholes UZ\#4, UZ\#5, NRG-6, NRG-7a, and UZ-14. Deep percolation of water by way of fracture flow is evidenced further by the fact that many of the ${ }^{14} \mathrm{C}$ values in the Calico Hills Formation at borehole UZ-14 are between 80 and 95 pmc, equivalent to apparent ${ }^{14} \mathrm{C}$ ages of about 1,800 and 400 years. The aqueous- and gaseous-phase chemical data collected in the North Ramp area indicate that the two phases apparently are not in equilibrium and that gas-water interaction has been minimal. This is most apparent at the location of UZ-1 and UZ-14 where gaseous-phase ${ }^{14} \mathrm{C}$ ages in the TSw in UZ-1 are significantly older than the aqueous-phase ${ }^{14} \mathrm{C}$ ages in the underlying Calico Hills nonwelded unit in UZ-14. The apparent lack of equilibrium may be due to one of the following sets of conditions: either (1) the water presently residing in the Calico Hills migrated there along lateral flow paths (possibly from the west) and never came in contact with the gas that is diffusing slowly downward through the Topopah Spring Tuff, or (2) the water in the Calico Hills arrived there by way of rapid, episodic flow through vertical fractures in the Topopah Spring Tuff such that the contact time between the fracture water and the gas was so short that only minimal interaction occurred.

Perched water has been identified in four boreholes in the vicinity of the ESF North Ramp: UZ-1, UZ-14, NRG-7a, and SD-9. Boreholes in this area that did not detect perched water were not drilled to a depth sufficient to intercept the geologic units where perched water has been identified, or were drilled using wet drilling methods that may have obscured detection of perched water. Perched water probably exists near the base of the Topopah Spring Tuff virtually everywhere in the vicinity of the North Ramp. The stratigraphic location of the perched water detected in all four boreholes is similar in that the top of the perched-water reservoir is just above the contact between the lower nonlithophysal unit (Tptpln) and the crystal-poor vitric unit (Tptpv) of the Topopah 
Spring Tuff. Although the bottom of the perchedwater reservoir generally is unknown, the water must be perched upon a zone of relatively lower permeability underlying a zone of relatively higher permeability. The relevant permeability may be fracture permeability, matrix permeability, or both; but, because it is likely that fractures provide the dominant pathways for water movement through the unsaturated zone, the perched water probably results from water flowing through zones with high fracture density overlying zones with low fracture density. An alternative possibility is that zeolitic alteration of vitric material along fractures has significantly reduced fracture permeability to allow the perching of water. Structural data indicate that zeolitization of vitric material in the Calico Hills Formation is present just below the depths where perched water has been identified within Drill Hole Wash. The perched-water reservoir in the vicinity of boreholes UZ-1 and UZ-14 is believed to be caused by a northeast-trending growth fault that is a splay off the Solitario Canyon Fault but that has no surface expression in Drill Hole Wash. The structural trap that allows the perched water to accumulate is created by the juxtaposition of a more permeable layer (Tptpln) west of the fault against a less permeable layer (the lower Tptpv or Tpbt1) east of the fault. Presumably, this fault has intercepted the water flowing downdip along the crystal-poor vitric unit (Tptpv) or zeolitic-alteration boundary and does not have sufficient transmissivity to allow the water to drain as rapidly as it accumulates.

Chemical and isotopic compositions of perched water indicate that major-ion chemistry of perched water generally is similar to that of saturated-zone ground water, except for perched water in UZ-14, which is similar to water from the Topopah Spring Tuff. Chloride concentrations of perched water are consistent with recharge derived mainly from fracture flow with little contribution from water in the matrix of the overlying rock. Further, hydrogen and oxygen isotopic compositions of perched water are consistent with rapid infiltration into fractures with little or no evaporation. Apparent ${ }^{14} \mathrm{C}$ ages of perched water range from 3,500 to 11,000 years. Finally, stable isotopic values of -12.1 to -13.8 per mil for $\delta^{18} \mathrm{O}$ and -87.4 to -102 per mil for $\delta \mathrm{D}$ in perched water support the postglacial ${ }^{14} \mathrm{C}$ ages. The mean $\delta^{87} \mathrm{Sr}$ value of +4.46 per mil for the perched water detected in UZ-14 is similar to the mean $\delta^{87} \mathrm{Sr}$ value of +4.51 per mil for surficial pedogenic calcite in the Yucca Mountain area.
This similarity and the fact that calcite fracture fillings in the unsaturated zone are isotopically similar to the mean $\delta^{87} \mathrm{Sr}$ value for surficial calcite indicate that the perched water probably attained its isotopic signature by dissolution of soil calcium carbonate and shallow calcite during downward percolation.

Chemical and isotopic data for the perched water under Drill Hole Wash and for the pore water in the underlying Calico Hills Formation not only have provided compelling evidence for flow mechanisms but also were used as a basis for estimation of percolation flux deep in the unsaturated zone. The relatively older perched water overlying the relatively younger pore water in the Calico Hills Formation indicates that water must have arrived at these locations through different flow pathways. Further, chemical and strontium-isotope data indicate that the perched water arrived there through a fracture-flow mechanism and did not originate from water that had passed through the matrix of the overlying formations. The average chloride concentration for the Calico Hills Formation at UZ-14 is higher than that for the perched water but still is substantially lower than the values measured in core samples taken from the base of the perched reservoir. This contrast in chloride concentrations, along with the inversion of ages indicated by the ${ }^{14} \mathrm{C}$ data, indicates that water in the Calico Hills did not originate by slow seepage of perched water through the matrix of the crystal-poor vitrophyre. Similarly, the chloride and ${ }^{14} \mathrm{C}$ data from the Calico Hills indicate that the pore water arrived through a predominantly fracture- or fault-flow mechanism and spent little time in the overlying rock matrix. The ${ }^{14} \mathrm{C}$ ages of the both the perched water $(4,000$ to 7,000 years) and of the Calico Hills pore water ( 3,500 to 500 years) postdate the pluvial periods of the Pleistocene and reflect active percolation through the unsaturated zone under the relatively arid climate of the Holocene. In the case of the perched-water samples, the ${ }^{14} \mathrm{C}$ age incorporates both the time of transport from the land surface to the sampling location and average residence time within the perched-water reservoir. Assuming that flow to and from the perched-water reservoir is at steady state, the reservoir is well mixed, and the traveltime of water from the surface through fractures was relatively short, the residence time of water in the perched-water reservoir can be bracketed between 5,150 and 11,000 years. Using this and other information on the properties of the perched-water reservoir at UZ-14, and applying the hypothesis of a growth fault as the structural 
trap, vertical-percolation flux through the TSw was estimated to be in the range of 0.001 to $0.29 \mathrm{~mm} / \mathrm{yr}$ if there is no lateral diversion, and 0.00097 to $0.20 \mathrm{~mm} / \mathrm{yr}$ if there is lateral flow. The component of the vertical-percolation flux that is diverted at the contact between the Tptpln and Tptpv3 units is estimated to be as large as $0.015 \mathrm{~mm} / \mathrm{yr}$.

Detailed analysis of temperature gradients for boreholes UZ\#4 and UZ\#5 in Pagany Wash indicates that upward conductive heat flow within the Pah Canyon Tuff is substantially lower than estimates of the deep, unsaturated-zone heat flow from regional heat-flow studies and lower than estimates of heat flow in the TSw. Further, analysis of the heat-flow estimates resulted in calculated percolation rates of between 12.4 to $18.4 \mathrm{~mm} / \mathrm{yr}$ for the depth interval between the Pah Canyon Tuff and the water table at UZ\#4 and UZ\#5. Additional analyses indicated substantial lateral flow of heat from UZ\#4 to UZ\#5 in the shallower rocks. Results of numerical modeling studies of heat, water, and gas flow in the unsaturated zone indicate that (1) in the absence of percolation or thick alluvial cover, temperatures in the unsaturated zone tend to be a subdued reflection of the topography; (2) because of high porosity and low saturation, alluvium is an insulator relative to the moderately to densely welded rock forming the sideslopes and ridges, causing heat flow to be diverted around the alluvium and into the sideslopes; (3) although density differences between air on the flanks of ridges and beneath ridges give rise to natural, buoyant gas circulation in areas of high relief, the transport of heat has little effect on temperatures within the unsaturated zone; and 4) downward water percolation through the unsaturated zone consumes heat, resulting in the suppression of temperatures and thermal gradients in areas of high percolation. Two-dimensional numerical modeling of conductive heat flow beneath Pagany Wash demonstrated that the insulating effects of the alluvium caused heat to be diverted around the alluvium and into the bedrock sideslope, resulting in an increase in heat flow in the upper part of UZ\#5 and a decrease in heat flow in the upper part of UZ\#4. However, heat flow in the Pah Canyon Tuff and deeper stratigraphic units was unaffected by the alluvium, implying that the low heat flow through the Pah Canyon Tuff probably is due to downward percolation of water. A series of one-dimensional simulations along the trace of the two-dimensional model resulted in percolation estimates of $18 \mathrm{~mm} / \mathrm{yr}$ at UZ\#4 and $5 \mathrm{~mm} / \mathrm{yr}$ at UZ\#5.

Assuming that saturation and porosity, and hence, thermal conductivity, are relatively invariant within the TSw in the North Ramp area, thermal gradients within the TSw were compared to results of the Pagany Wash simulations to estimate percolation fluxes in the vicinity of Drill Hole Wash. This analysis indicates that percolation flux in the floor of Drill Hole Wash is about $10 \mathrm{~mm} / \mathrm{yr}$, whereas percolation flux on the sideslopes of the wash is about $0.1 \mathrm{~mm} / \mathrm{yr}$.

Despite the fact that the 1984 USGS conceptual model hypothesized that the PTn had significant potential capacity to attenuate the movement of water percolating downward through fractures within the $\mathrm{TCw}$ by diverting it laterally, there is substantial evidence for preferential fracture flow through the PTn. The presence of environmental tracers within the PTn at concentrations indicative of nuclear-weapons testing indicates that the PTn has been effective to at least some degree in capturing water that had moved through the overlying TCw as fracture flow. Fracture flow within the PTn is indicated by the tritium concentration profiles for boreholes UZ\#4, UZ\#5, NRG-6, and UZ-14. This is consistent with other geologic and hydrologic observations, such as the fact that boreholes UZ\#4 and UZ\#5 are located in a fault-affected zone of higher fracture density and that the PTn was inferred to have significant secondary permeability, based on an analysis of the in-situ pneumatic pressures. The most compelling evidence that water moving within fractures of the PTn has bypassed the nonwelded tuff matrix is the presence of post-bomb tritium within the TSw in boreholes UZ-14 and NRG-6. Further, chlorine-36 data collected on rock samples from the ESF have included 11 sampling sites from the TSw with post-bomb chlorine-36 ratios, lending support to the interpretation that the tritium data are reflecting recent inputs of meteoric water into the TSw.

Evidence for extensive diversion of downward vertical percolation and lateral flow within the PTn is sparse. Evidence for at least limited lateral redistribution of percolation is provided by the aqueous carbon14 data at borehole UZ-14 and gaseous carbon-14 data at nearby UZ-1. Although the average carbon- 14 values for the gas and aqueous phases within the Pah Canyon and adjacent bedded tuffs are similar, their variations with depth indicate that two very distinct processes may have resulted in their observed distribu- 
tion. While gaseous-phase carbon-14 values for nearby UZ-1 show a systematic decrease with depth consistent with one-dimensional downward diffusion of gas, the aqueous carbon-14 data indicate that water near the pre-Pah Canyon bedded tuff/Pah Canyon Tuff contact has a younger carbon-14 age than samples at shallower depths. This apparent age inversion indicates nonequilibrium distribution of carbon-14 between the gas and liquid phases and probably resulted from one of two alternative mechanisms. Aqueous transport down steeply dipping fractures that were intercepted by the borehole near the base of the Pah Canyon Tuff could have been relatively rapid, which is the explanation for the high tritium concentrations in the upper part of the Pah Canyon Tuff. Alternatively, partial zeolitization of the lower part of the Pah Canyon Tuff and pre-Pah Canyon Tuff bedded tuffs, or an argillic zone developed within the pre-Pah Canyon Tuff bedded tuffs, may have formed permeability barriers that diverted water that had percolated rapidly elsewhere toward the UZ-14 area. Although lateral diversion can explain the apparent age inversion, the distances across which this lateral migration occurred cannot be quantified with certainty. Therefore, other causes of the age inversion, such as fracture flow, are equally plausible.

\section{REFERENCES CITED}

Agapito, J.F.T. \& Associates, 1995a, Yucca Mountain Site Characterization Project geology and rock structure log for drillhole USW NRG-6, Revision 1: Las Vegas, Nevada, U.S. Department of Energy, Data Tracking Number SNF29041993002.041.

Agapito, J.F.T. \& Associates, 1995b, Yucca Mountain Site Characterization Project geology and rock structure log for drillhole USW NRG-7/7a, Revision 1: Las Vegas, Nevada, U.S. Department of Energy, Data Tracking Number SNF29041993002.042.

Ahlers, C.F., Bandurraga, T.M., Bodvarsson, G.S., Chen, Gang, Finsterle, Stefan, and Wu, Y.S., 1995, Summary of model calibration and sensitivity studies using the LBNL/USGS three-dimensional unsaturated zone sitescale model: Berkeley, Calif., Lawrence Berkeley National Laboratory, $117 \mathrm{p}$.

Anderson, L.A., 1994, Water permeability and related rock properties measured on core samples from the Yucca Mountain USW GU-3/G-3 and USW G-4 boreholes, Nevada Test Site, Nevada: U.S. Geological Survey Open-File Report 92-201, 36 p.
Barr, G.E., Borns, D.J., and Fridrich, C.J., 1996, Scenarios constructed for the effects of tectonic processes on the potential nuclear waste repository at Yucca Mountain: Sandia National Laboratories Report SAND96-1132, $106 \mathrm{p}$.

Bedinger, M.S., Langer, W.H., and Reed, J.E., 1989, Ground-water hydrology, in Bedinger, M.S., Sargent, K.A., and Langer, W.H., (eds.), Studies of geology and hydrology in the Basin and Range Province, southwestern United States, for isolation of high-level radioactive waste-Characterization of the Death Valley region, Nevada and California: U.S. Geolological Survey Professional Paper 1370-F, $49 \mathrm{p}$.

Bendat, J.S., and Piersol, A.G., 1986, Random dataAnalysis and measurement procedures: New York, John Wiley, $566 \mathrm{p}$.

Benson, L.V., and Klieforth, H., 1989, Stable isotopes in precipitation and ground water in the Yucca Mountain region, south Nevada-Paleoclimatic implication: Geophysical Monograph 55, p. 41-59.

Benson, L.V., and McKinley, P.W., 1985, Chemical composition of ground water in the Yucca Mountain area, Nevada, 1971-84: U.S. Geological Survey Open-File Report 85-484, 10 p.

Bikerman, J.J., 1958, Surface chemistry theory and applications: New York, Academic Press Inc., 501 p.

Bish, D.L., and Aronson, J.L., 1993, Paleogeothermal and paleohydrologic conditions in silicic tuff from Yucca Mountain: Clays and Clay Minerals, v. 41, no. 2, p. $148-161$.

Bish, D.L., and Chipera, S.J., 1989, Revised mineralogic summary of Yucca Mountain, Nevada: Los Alamos National Laboratory Report LA-1 1497-MS, 68 p.

Bish, D.L., Chipera, S.J., Guthrie, G.D., and Vaniman, D.T., 1995, The occurrence and distribution of erionite in drill holes at Yucca Mountain, Nevada: Los Alamos National Laboratory Letter Report, Milestone LA4058, $20 \mathrm{p}$.

Blout, D.O., Hammermeister, D.P., Loskot, C.L., and Chornack, M.P., 1994, Geohydrologic data collected from shallow neutron-access boreholes and resultantpreliminary geohydrologic evaluations, Yucca Mountain Area, Nye County, Nevada: U.S. Geological Survey Open-File Report 92-657, 65 p.

Brechtel, C.E., Lin, Ming, Martin, Eric, and Kessel, D.S., 1995a, Geotechnical characterization of the north ramp of the Exploratory Studies Facility-Volume I of II, data summary: Sandia National Laboratories Report SAND95-0488/1, $276 \mathrm{p}$.

Brechtel, C.E., Lin, Ming, Martin, Eric, and Kessel, D.S., 1995b, Geotechnical characterization of the north ramp of the Exploratory Studies Facility-Volume II of II, NRG corehole data appendices: Sandia National Laboratories Report SAND95-0488/2, 430 p. 
Brocher, T.M., Hart, P.E., Hunter, W.C., Langenheim, V.E., 1996, Hybrid-source seismic reflection profiling across Yucca Mountain, Nevada-Regional lines 2 and 3: U.S. Geological Survey Open-File Report 96-28, $110 \mathrm{p}$.

Brown, R.W., 1970, Measurement of water potential with thermocouple psychrometers-Construction and applications: U.S. Department of Agriculture Forest Service, Research Paper INT-80, 27 p.

Broxton, D.E., Bish, D.L., and Warren, R.G., 1987, Distribution and chemistry of diagenetic minerals at Yucca Mountain, Nye County, Nevada: Clays and Clay Minerals, v. 35, no. 2, p. 89-110.

Broxton, D.E., Chipera, S.J., Byers, F.M., Jr., and Rautman, C.A., 1993, Geologic evaluation of six nonwelded tuff sites in the vicinity of Yucca Mountain, Nevada for a surface-based test facility for the Yucca Mountain Project: Los Alamos National Laboratory Report LA-12542-MS, 83 p.

Buesch, D.C., Dickerson, R.P., Drake, R.M., and Spengler, R.W., 1994, Integrated geology and preliminary cross section along the north ramp of the Exploratory Studies Facility, Yucca Mountain, in High level radioactive waste management: Proceedings of the Fifth Annual International Conference, Las Vegas, Nevada, May 22-26, 1994, American Nuclear Society, Inc., and American Society of Civil Engineers, v. 2, p. 10551065.

Buesch, D.C., Nelson, J.E., Dickerson, R.P., Drake, R.M., Spengler, R.W., Geslin, J.K., Moyer, T.C., and San Juan, C.A., 1996, Distribution of lithostratigraphic units within the central block of Yucca Mountain, Nevada-A three-dimensional computer-based model, version YMP.R2.0: U.S. Geological Survey Open-File Report 95-124, $61 \mathrm{p}$.

Buesch, D.C., Spengler, R.W., Moyer, T.C., and Geslin, J.K., 1996, Proposed stratigraphic nomenclature and macroscopic identification of lithostratigraphic units of the Paintbrush Group exposed at Yucca Mountain, Nevada: U.S. Geological Survey Open-File Report 94-469, 45 p.

Buesch, D.C., Spengler, R.W., Nelson, J.E., and Dickerson, R.P., 1993, Three-dimensional lithostratigraphic model at Yucca Mountain, Nevada-A framework for fluid transport modeling and engineering design in FOCUS'93-Site Characterization and Model Validation: Las Vegas, Nevada, September 26-29, 1993, American Nuclear Society, La Grange Park, Ill,, p. 226-231.
Buesch, D.C., Spengler, R.W., Nelson, P.H., Vaniman, D.T., Chipera, S.J., and Bish, D.L., 1995, Geometry of the vitric-zeolitic transition in tuffs and the relation to fault zones at Yucca Mountain, Nevada: International Union of Geodesy and Geophysics, XXI General Assembly, Boulder, Colorado, USA, Abstracts Week A, p. A426.

Burchfiel, B.C., Fleck, R.J., Secor, D.T., Vincelette, R.R., and Davis, G.A., 1974, Geology of the Spring Mountains, Nevada: Geological Society of America Bulletin, v. 85, p. $1013-1022$.

Buscheck, T.A., and Nitao, J.J., 1994, The impact of buoyant, gas-phase flow and heterogeneity on thermohydrological behavior at Yucca Mountain, in High level radioactive waste management: Proceedings of the Fifth Annual International Conference, Las Vegas, Nevada, May 22-26, 1994, American Nuclear Society, Inc. and American Society of Civil Engineers, vol. 4, p. $2450-2474$.

Byers, Jr., F.M., Carr, W.J., Orkild, P.P., Quinlivan, W.D., and Sargent, K.A., 1976, Volcanic suites and related cauldrons of the Timber Mountain-Oasis Valley Caldera Complex, southern Nevada: U.S. Geological Survey Professional Paper 919, 70 p.

Carr, W.J., 1984, Regional structural setting of Yucca Mountain, southern Nevada, and Late Cenozoic rates of tectonic activity in part of the southwestern Great Basin, Nevada and California: U.S. Geological Sur vey Open-File Report 84-854, 109 p.

Carr, W.J., Byers, F.M. Jr., and Orkild, P.P., 1986, Stratigraphic and volcano-tectonic relations of the Crater Flat Tuff and some older volcanic units, Nye County, Nevada: U.S. Geological Survey Professional Paper $1323,28 \mathrm{p}$.

Carr, M.D., and Monson, S.A., 1988, A field trip guide to the geology of Bare Mountain, in Weide, D.L., and Faber, M.L., eds., This extended land, geological journeys in southern Basin and Range: Cordilleran Section field trip guidebook, Geological Society of America, p. 50-57.

Carr, M.D., Waddell, S.J., Vick, G.S., Stock, J.M., Monson, S.A., Harris, A.G., Cork, B.W., and Byers, Jr., F.M., 1986, Geology of drill hole UE25p\#1-A test hole to pre-Tertiary rocks near Yucca Mountain, southern Nevada: U.S. Geological Survey Open-File Report $86-175,87 \mathrm{p}$.

Cas, R.A., and Wright, J.V., 1987, Volcanic successions modern and ancient: London, Allen and Unwin, 528 p.

Chapin, C.E., and Lowell, G.R., 1979, Primary and secondary flow structures in ash-flow tuffs of the Gribbles Run paleovalley, central Colorado, in Chapin, C.E., and Elston, W.E., eds., Ash-Flow Tuffs: Boulder, Colo., Geological Society of America, Special Paper 180 , p. $137-154$. 
Chipera, S.J., Vaniman, D.T., Carlos, B.A., and Bish, D.L., 1995, Mineralogic variation in drill core UE-25 UZ\#16, Yucca Mountain, Nevada: Los Alamos National Laboratory Report LA-12810-MS, 40 p.

Christiansen, R.L., and Lipman, P.W., 1965, Geologic map of the Topopah Spring northwest quadrangle, Nye County, Nevada: U.S. Geological Survey Geologic Quadrangle Map GQ-444, scale 1:24,000.

Christiansen, R.L., Lipman, P.W., Orkild, P.P., and Byers, Jr., F.M., 1965, Structure of the Timber Mountain caldera, southern Nevada, and its relation to Basin and Range structure, in Geological Survey Research 1965: U.S. Geological Survey Professional Paper 82-B, p. B43-B48.

Craig, Harmon, 1961, Isotopic variations in meteoric waters: Science, v. 133, p. 1702-1703.

Crank, J., 1975, Simultaneous diffusion of heat and moisture, in The mathematics of diffusion: New York, Oxford University Press, chap. 15, p. 352-374.

Czarnecki, J.B., O'Brien, G.M., Nelson, P.H., Sass, J.H., Bullard, J.W., and Flint, A.L., 1994, Is there perched water under Yucca Mountain in borehole USW G-2?: American Geophysical Union Transactions, v. 75, no. 44 , p. $249-250$.

D'Agnese, F.A., Faunt, C.C., Turner, A.K., and Hill, M.C., 1997, Hydrogeologic evaluation and numerical simulation of the Death Valley regional ground-water flow system, Nevada and California: U.S. Geological Survey Water-Resources Investigations Report $96-4300,124 \mathrm{p}$.

Dansgaard, W., 1964, Stable isotopes in precipitation: Tellus, v. 16 , no. 4 , p. $436-468$.

Davis, S.N., and Bentley, H.W., 1982, Dating groundwater in nuclear and chemical dating techniques, in Currie, L.A., ed., Interpreting the environmental record: Washington, D.C., American Chemical Society, symposium series 176, p. 193.

Day, W.C., Potter, C.J., Sweetkind, D.S., Dickerson, R.P., and San Juan, C.A., 1998, Bedrock geologic map of the central block area, Yucca Mountain, Nye County, Nevada: U.S. Geological Survey Miscellaneous Investigations Series Map 2601, scale 1:6,000, 2 sheets.

Dullien, F.A.L., 1992, Porous media: San Diego, Calif., Academic Press Inc., 574 p.

Ervin, E.M., Luckey, R.R., Burkhardt, D.J., 1994, Revised potentiometric-surface map, Yucca Mountain and vicinity, Nevada: U.S. Geological Survey WaterResources Investigations Report 93-4000, 17 p., scale 1:24,000.

Fabryka-Martin, J.T., Dixon, P.R., Levy, S., Liu, B., Turin, H.J., and Wolfsberg, A.V., 1996, Summary report of chlorine-36 studies-Systematic sampling for chlorine-36 in the Exploratory Studies Facility: Los Alamos National Laboratory Milestone Report 3783M, $53 \mathrm{p}$.
Fisher, R.V., and Schmincke, H., 1984, Pyroclastic rocks: Berlin, Springer-Verlag, 472 p.

Flint, A.L., and Flint, L.E., 1994, Spatial distribution of potential near surface moisture flux at Yucca Mountain, in High level radioactive waste management: Proceedings of the Fifth Annual International Conference, Las Vegas, Nevada, May 22-26, 1994, American Nuclear Society, Inc. and American Society of Civil Engineers, v. 4, p. 2352-2358.

Flint, L.E., and Flint, A.L., 1990, Preliminary permeability and water-retention data for nonwelded and bedded tuff samples, Yucca Mountain area, Nye County, Nevada: U.S. Geological Survey Open-File Report 90-569, $57 \mathrm{p}$.

Flint, L.E., and Flint, A.L., 1995, Shallow infiltration processes at Yucca Mountain-Neutron logging data 1984-93: U.S. Geological Survey Water-Resources Investigations Report 95-4035, 46 p.

Flint, L.E., Flint, A.L., Rautman, C.A., and Istok, J.D., 1996, Physical and hydrologic properties of rock outcrop samples at Yucca Mountain, Nevada: U.S. Geological Survey Open-File Report 95-280, 54 p.

Fox, K.F., Jr., and Carr, M.D., 1989, Neotectonics and volcanism at Yucca Mountain and vicinity, Nevada, in Laul, J.C., and others, eds., Radioactive Waste and the Nuclear Fuel Cycle, Nuclear Waste Management, 1988-Perspectives on national and international programs and technology, Part II, v. 13 (1-4), p. 37-50.

Fox, K.F., Jr., Spengler, R.W., and Myers, W.B., 1990, Geologic framework and Cenozoic evolution of the Yucca Mountain area, Nevada, in Proceedings of the International Symposium on Unique Underground Structures: Denver, Colo., June 12-15, 1990, Colorado School of Mines, Golden, Colo., v. 2, p. 56-1 to $56-18$.

French, R.H., 1983, Precipitation in southern Nevada: Journal of Hydraulic Engineering, v. 109, no. 7, p. 1023-1036.

Fridrich, C.J., Dudley, W.W., Jr., and Stuckless, J.S., 1994, Hydrogeologic analysis of the saturated-zone groundwater system under Yucca Mountain, Nevada: Journal of Hydrology, v. 154, p. 133-168.

Fridrich, C.J., and Price, J., 1992, Tectonic framework of Crater Flat Basin, adjacent to Yucca Mountain, Nevada, a preliminary report: Geological Society of America A.bstracts with Programs, National Meeting, p. A 189.

Frizzell, V.A., Jr., and Shulters, J., 1990, Geologic map of the Nevada Test Site, southern Nevada: U.S. Geological Survey Miscellaneous Investigations Map I-2046, scale 1:100,000. 
Gauthier, J.H., and Wilson, M.L., 1994, Infiltration and percolation rates, in Wilson, M.L. and others, Total-system performance assessment for Yucca Mountain-SNL second iteration (TSPA-1993): Sandia National Laboratories Report SAND93-2675, v. 1 , chap. 8 , p. 8-1 to 8-17.

Geslin, J.K., and Moyer, T.C., 1995, Summary of lithologic logging of new and existing boreholes at Yucca Mountain, Nevada, March 1994 to June 1994: U.S. Geological Survey Open-File Report 94-451, 16 p.

Geslin, J.K., Moyer, T.C., and Buesch, D.C., 1995, Summary of lithologic logging of new and existing boreholes at Yucca Mountain, Nevada, August 1993 to February 1994: U.S. Geological Survey Open-File Report 94-342, 39 p.

Gonfiantini, R., 1978, Standards for stable isotope measurements in natural compounds: Nature, v. 271 , no. 5645 , p. 534-536.

Grayson, D.K., 1993, The desert's past-A natural prehistory of the Great Basin: Washington, D.C., Smithsonian Institution Press, 356 p.

Haas, H.H., Fisher, D.W., Thorstenson, D.C., and Weeks, E.P., $1983,{ }^{13} \mathrm{CO}_{2}$ and ${ }^{14} \mathrm{CO}_{2}$ measurements on soil atmosphere sampled in the subsurface unsaturated zone in the western great plains of the U.S.: Radiocarbon, v. 25, no. 2, p. 301-314.

Hevesi, J.A., and Flint, A.L., in press, Geostatistical model for estimating precipitation and recharge in the Yucca Mountain region, Nevada-California: U.S. Geological Survey Water-Resources Investigations Report 964123.

Higgins, J.D., Burger, P.A., and Yang, I.C., 1997, The onedimensional compression method for extraction of pore water from unsaturated tuff and effects on porewater chemistry: U.S. Geological Survey WaterResources Investigations Report 96-4281, 34 p.

Hinrichs, E.N., 1968, Geologic map of the Camp Desert Rock quadrangle, Nye County, Nevada: U.S. Geological Survey Geologic Quadrangle Map GQ-726, scale 1:24,000.

Houghton, J.G., 1969, Characteristics of rainfall in the Great Basin: Reno, Nev., Desert Research Institute, University of Nevada System, 205 p.

Hvorslev, M.J., 1951, Time lag and soil permeability in ground-water observations: U.S. Army Corps of Engineers, Waterways Experiment Station, Vicksburg, Miss., Bulletin No. 36, 47 p.

IAEA (International Atomic Energy Agency), 1969-1986, Environmental isotope data No. 1-8-World survey of isotope concentration in precipitation (1953-1963, 1964-1965, 1966-1967, 1968-1969, 1970-1971, 1972-1975, 1976-1979, and 1980-1983) and Technical Report Series 96, 117, 129, 147, 165, 192, 226, and 264: IAEA, Vienna, 1969, 1971, 1973, 1975, 1979, 1983 , and 1986.
Ingraham, N.L., Lyles, B., Jacobson, R.L. and Hess, J.W., 1991, Stable isotopic study of precipitation and spring discharge in southern Nevada: Journal of Hydrology, v. 125 , p. $243-258$.

Istok, J.D., Rautman, C.A., Flint, L.E., and Flint, A.L., 1994, Spatial variability in hydrologic properties of a volcanic tuff: Ground Water, v. 32, no. 5, p. 751-760.

Katz, D.L., Cornell, D., Vary, J.A., Kobayashi, R., Elenbass, J.R., Poettmann, F.H., and Weinaug, C.F., 1959, Handbook of natural gas engineering: New York, McGraw-Hill, 408 p.

Kearl, P.M., Zinkl, R.J., Dexter, J.J., and Cronk, T., 1990, Air permeability measurements of the unsaturated Bandelier Tuff near Los Alamos, New Mexico: Journal of Hydrology, v. 117, p. 225-240.

Klavetter, E.A., and Peters, R.R., 1986, Estimation of hydrologic properties of an unsaturated, fractured rock mass: Sandia National Laboratories Report SAND842642, $51 \mathrm{p}$.

Klinkenberg, L.J., 1941, The permeability of porous media to liquids and gases, in Drilling and production practice: New York, American Petroleum Institute, p. $200-213$.

Kume, Jack, and Rousseau, J.P., 1994, A borehole instrumentation program for characterization of unsaturated zone percolation, in High level radioactive waste management: Proceedings of the Fifth Annual International Conference, Las Vegas, Nevada, May 22-26, 1994, American Nuclear Society, Inc., and American Society of Civil Engineers, v. 4, p. 2076-2083.

Kwicklis, E.M., Flint, A.L., and Healy, R.W., 1994, Simulation of flow in the unsaturated zone beneath Pagany Wash, Yucca Mountain, in High level radioactive waste management: Proceedings of the Fifth Annual International Conference, Las Vegas, Nevada, May 22-26, 1994, American Nuclear Society, Inc. and American Society of Civil Engineers, v. 4, p. 2341-2351.

LeCain, G.D., 1995, Pneumatic testing in 45-degreeinclined boreholes in ash-flow tuff near Superior, Arizona: U.S. Geological Survey Water-Resources Investigations Report 95-4073, 27 p.

LeCain, G.D., 1997, Air-injection testing in vertical boreholes in welded and nonwelded tuff, Yucca Mountain, Nevada: U.S. Geological Survey, Water-Resources Investigations Report 96-4262, 33 p.

Levy, S.S., 1984a, Petrology of samples from drill holes USW H-3, H-4, and H-5, Yucca Mountain, Nevada: Los Alamos National Laboratory Report, LA-9706MS, 77 p.

Levy, S.S., 1984b, Studies of altered vitrophyre for the prediction of nuclear waste repository-induced thermal alteration at Yucca Mountain, Nevada, in McVay, G.L., ed., Scientific basis for nuclear waste management: Proceedings of the 7th Material Research Society Symposium, Boston, Mass., November 14, 1983, p. 959-966.

REFERENCES CITED 
Levy, S.S., 1993, Surface-discharging hydrothermal systems at Yucca Mountain-Examining the evidence, in Interrante, C., and Papblan, R., eds., Scientific basis for nuclear waste management XVI: Proceedings of the Materials Research Society Fall Meeting, Boston, Mass., November 30-December 5, 1992, p. 543-548.

Levy, S.S., Norman, D.I., and Chipera, S.J., 1996, Alteration history studies in the Exploratory Studies Facility, Yucca Mountain, Nevada, USA, in Murphy, W.M., and Knecht, D.A., eds., Scientific basis for nuclear waste management XIX: Materials Research Society Symposium Proceedings 412, Pittsburgh, Pa., Materials Research Society, p. 783-790.

Little, J.N., and Shure, Loren, 1988, Signal processing toolbox for use with MATLAB-User's guide [August 29, 1988 version]: Natick, Mass., The MathWorks, Inc., various pagination.

Liu, B., Fabryka-Martin, J., Wolfsberg, A., Robinson, B., and Sharma, P., 1995, Significance of apparent discrepancies in water ages derived from atmospheric radionuclides at Yucca Mountain, Nevada, in Hotchkiss, .W.R., Downey, J.S., Gutentag, E.D., and Moor, J.E., eds., Water Resources at risk, a selection of the papers presented at the conference held in Denver, Colo., May 14-18, 1995: American Institute of Hydrology, p. NH-52-NH-62.

Loskot, C.L., and Hammermeister, D.P., 1992, Geohydrologic data from test holes UE-25 UZ\#4 and UE-25 UZ\#5, Yucca Mountain Area, Nye County Nevada: U.S. Geological Survey Open-File Report 90-369, $56 \mathrm{p}$.

Loskot, C.L., Rousseau, J.P., and Kurzmack, M.A., 1994, Evaluation of a 6-wire thermocouple psychrometer for determination of in-situ water potentials, in High level radioactive waste management: Proceedings of the Fifth Annual International Conference, Las Vegas, Nevada, May 22-26, 1994, American Nuclear Society, Inc., and American Society of Civil Engineers, v. 4, p. 2084-2091.

Lundstrom, S.C., Mahan, S.A., and Paces, J.B., in press, Preliminary surficial deposits map of the northwest quarter of the Busted Butte 7.5-minute quadrangle, Nye County, Nevada: U.S. Geological Survey OpenFile Report 95-133, scale 1:12,000.

Maldonado, F., and Koether, S.L., 1983, Stratigraphy, structure, and some petrographic features of Tertiary volcanic rocks at the USW G-2 drill hole, Yucca Mountain, Nye County, Nevada: U.S. Geological Survey Open-File Report 83-732, 90 p.
Marshall, B.D., Peterman, Z.E., and Stuckless, J.S., 1993, Strontium isotopic evidence for a higher water table at Yucca Mountain, in High level radioactive waste management: Proceedings of the Fourth Annual International Conference, Las Vegas, Nev., April 26-30, 1993, American Nuclear Society, Inc. and American Society of Civil Engineers, v. 2, p. 1948-1952.

Michael, R.L., 1989, Tritium deposition in the continental United States, 1953-1983: U.S. Geological Survey Water-Resources Investigations Report 89-4072, 46 p.

Mifflin, M.D., and Wheat, M.M., 1979, Pluvial lakes and estimated pluvial climates of Nevada: Nevada Bureau of Mines and Geology Bulletin 94, 57 p.

Milne, W.K., Benson, L.V., and McKinley, P.W., 1987, Isotope content and temperature of precipitation in southern Nevada, August 1983-August 1986: U.S. Geological Survey Open-File Report 87-463, $32 \mathrm{p}$.

Montazer, Parviz, 1987, Monitoring hydrologic conditions in the vadose zone in fractured rocks, Yucca Mountain, Nevada, in Evans, D.D., and Nicholson, J.T., eds., Flow and transport through unsaturated fractured rock: Geophysical Monograph 42, American Geophysical Union, Washington, D.C., p. 31-42.

Montazer, Parviz, Weeks, E.P., Thamir, Falah, Yard, S.N., and Hofrichter, P.B., 1985, Monitoring the vadose zone in fractured tuff, Yucca Mountain, Nevada, in Proceedings of the National Water Well Association conference on characterization and monitoring of the vadose (unsaturated) zone: Denver, Colo., Nov. 19-21, 1985, National Water Well Association, Dublin, Ohio, p. 439-469.

Montazer, Parviz, and Wilson, W.E., 1984, Conceptual hydrologic model of flow in the unsaturated zone, Yucca Mountain, Nevada: U.S. Geological Survey Water-Resources Investigation Report 84-4345, 55 p.

Mower, T.E., Higgins, J.D., and Yang, I.C., 1991, Pore-water extraction from unsaturated tuffs using one-dimensional compression, in High level radioactive waste management, Proceedings of the Second International Conference: Las Vegas, Nev., April 28May 3, 1991, American Nuclear Society, Inc. and American Society of Civil Engineers, v. 2, p. 999-1006.

Mower, T.E., Higgins, J.D., Yang, I.C., and Peters, C.A., 1994, Pore-water extraction from unsaturated tuff by triaxial and one-dimensional compression methods, Nevada Test Site: U.S. Geological Survey WaterResources Investigations Report 93-4144, 79 p.

Moyer, T.C., and Geslin, J.K., 1995, Lithostratigraphy of the Calico Hills Formation and Prow Pass Tuff (Crater Flat Group) at Yucca Mountain, Nevada: U.S. Geological Survey Open-File Report 94-460, 59 p. 
Moyer, T.C., Geslin, J.K., and Buesch, D.C., 1995, Summary of lithologic logging of new and existing boreholes at Yucca Mountain, Nevada, July 1994 to November 1994: U.S. Geological Survey Open-File Report 95-102, $22 \mathrm{p}$.

Moyer, T.C., Geslin, J.K., and Flint, L.E., 1996, Stratigraphic relations and hydrologic properties of the Paintbrush Tuff nonwelded (PTn) hydrologic unit, Yucca Mountain, Nevada: U.S. Geological Survey Open-File Report 95-397, 151 p.

Multimedia Environmental Technology, Inc., 1995, Interim report on the results of instrumentation and monitoring of the UE-25 ONC\#1 and USW NRG-4 boreholes, Yucca Mountain, Nevada: Newport Beach, Calif., Multimedia Environmental Technology, Inc.

Nelson, P.H., 1993, Estimation of water-filled and air-filled porosity in the unsaturated zone, Yucca Mountain, Nevada in High level radioactive waste management: Proceedings of the Fourth Annual International Conference, Las Vegas, Nev., April 26--30, 1993, American Nuclear Society, Inc., and American Society of Civil Engineers, v. 1, p. 949-954.

Nelson, P.H., 1994, Saturation levels and trends in the unsaturated zone, Yucca Mountain, Nevada, in High level radioactive waste management: Proceedings of the Fifth Annual International Conference, Las Vegas, Nevada, May 22-26, 1994, American Nuclear Society, Inc., and American Society of Civil Engineers, v. 4, p. 2774-2781.

Nelson, P.H., Muller, D.C., Schimschal, U., and Kilber, J.E., 1991, Geophysical logs and core measurements from forty boreholes at Yucca Mountain, Nevada: U.S. Geological Survey Geophysical Investigations Map GP-1001, 64 p.

Ortiz, T.S., Williams, R.L., Nimick, F.B., and South, D.L., 1985, Three-dimensional model of reference thermal/mechanical and hydrological stratigraphy at Yucca Mountain, southern Nevada: Sandia National Laboratories Report SAND-84-1076, 80 p.

O'Farrell, T.P., and Collins, E., 1984, 1983 biotic studies of Yucca Mountain, Nevada Test Site, Nye County, Nevada: Goleta, Calif., EG and G, Inc., EGG Report 10282-2031, 46 p.

Peterman, Z.E., and Stuckless, J.S., 1992, Paleohydrogeological methods and their applications, in Proceedings of the Nuclear Energy Association Workshop: Paris, France, November 9-10, 1992, p. 59-84.

Peterman, Z.E., and Stuckless, J.S., 1993, Isotopic evidence of complex ground-water flow at Yucca Mountain, Nevada, in High level radioactive waste management: Proceedings of the Fourth Annual International Conference, Las Vegas, Nev., April 26-30, 1993, American Nuclear Society, Inc. and American Society of Civil Engineers, v. 2, p. 1559-1566.
Piper, A.M., 1944, A graphic procedure in the geochemical interpretation of water analyses: American Geophysical Union Transactions, v. 25, p. 914-923.

Potter, C.J., Dickerson, R.P., and Day, W.C., in press, Nature and continuity of the Sundance Fault, Yucca Mountain, Nevada: U.S. Geological Survey Open-File Report 98-266.

Pruess, Karsten, 1990, TOUGH2-A general-purpose numerical simulator for multiphase fluid and heat flow: Lawrence Berkeley Laboratory Report LBL-29400, $103 \mathrm{p}$.

Rautman, C.A., 1995, Preliminary geostatistical modeling of thermal conductivity for a cross section of Yucca Mountain, Nevada: Sandia National Laboratories Report SAND-94-2283, $60 \mathrm{p}$.

Rautman, C.A., and Flint, A.L., 1992, Deterministic geologic processes and stochastic modeling, in High level radioactive waste management, Proceedings of the Third Annual International Conference: Las Vegas, Nev., April 12-16, 1992, American Nuclear Society, Inc., and American Society of Civil Engineers, v. 2, p. 1617-1624.

Rautman, C.A., Flint, L.E., Flint, A.L., and Istok, J.D., 1995, Physical and hydrologic properties of outcrop samples from a nonwelded to welded tuff transition, Yucca Mountain, Nevada: U.S. Geological Survey Water-Resources Investigations Report 95-4061, 28 p.

Riehle, J.R., Miller, T.F., Bailey, R.A., 1995, Cooling, degassing and compaction of rhyolitic ash flow tuffsA computational model: Bulletin of Volcanology, v. 57, no. 5 , p. 319-336.

Robinson, G.D., 1985, Structure of Pre-Cenozoic rocks in the vicinity of Yucca Mountain, Nye County, Nevada-A potential nuclear-waste disposal site: U.S. Geological Survey Bulletin 1647, 22 p.

Robison, J.H., 1984, Ground-water level and preliminary potentiometric surface maps, Yucca Mountain and vicinity, Nye County, Nevada: U.S. Geological Survey Water-Resources Investigations Report 84-4197, 8 p.

Ross, Benjamin, 1990, The diversion capacity of capillary barriers: Water Resources Research, v. 26, no. 10, p. 2625-2629.

Rousseau, J.P., Kurzmack, M.A., and Greengard, A., 1994, Results of prototype borehole instrumentation at the Hydrologic Research Facility, Area 25, Nevada Test Site, Nevada, in High level radioactive waste management: Proceedings of the Fifth Annual International Conference, Las Vegas, Nevada, May 22-26, 1994, American Nuclear Society, Inc., and American Society of Civil Engineers, v. 4, p. 2764-2773.

Rowley, P.D., Kuntz, M.A., and Macleod, N.S., 1981, Pyroclastic-flow deposits, in Lipman, P.W., and Mullineaux, D.R., eds., The eruptions of Mount St. Helens, Washington: U.S. Geological Survey Professional Paper 1250, p. 489-512. 
Rush, F.E., Thordarson, William, and Pyles, D.G., 1984, Geohydrology of test well USW H-1, Yucca Mountain, Nye County, Nevada: U.S. Geological Survey WaterResources Investigations Report, 84-4032, 56 p.

Sargent, K.A., and Stewart, J.H., 1971, Geologic map of the Specter Range NW quadrangle, Nye County, Nevada: U.S. Geological Survey Quadrangle Map GQ-884, scale 1:24,000.

Sass, J.H., Lachenbruch, A.H., Dudley, W.W., Jr., Priest, S.S., and Munroe, R.J., 1988, Temperature, thermal conductivity, and heat flow near Yucca Mountain, Nevada-Some tectonic and hydrologic implications: U.S. Geological Survey Open-File Report 87-649, $118 \mathrm{p}$.

Sawyer, D.A., Fleck, R.J., Lanphere, M.A., Warren, R.G., and Broxton, D.E., 1994, Episodic volcanism in the Miocene southwest Nevada volcanic field-Stratigraphic revisions, ${ }^{40} \mathrm{Ar} /{ }^{39} \mathrm{Ar}$ geochronologic framework, and implications for magmatic evolution: Geological Society of America Bulletin, v. 106, no. 10, p. 1304-1318.

Scott, R.B., 1990, Tectonic setting of Yucca Mountain, southwest Nevada, in Wernicke, B.P., ed., Basin and Range extensional tectonics near the latitude of Las Vegas, Nevada: Geological Society of America Memoir 176, Boulder, Colo, p. 251-282.

Scott, R.B., Bath, G.D., Flanigan, V.J., Hoover, D.B., Rosenbaum, J.G., and Spengler, R.W., 1984, Geological and geophysical evidence of structures in northwest-trending washes, Yucca Mountain, southern Nevada, and their possible significance to a nuclear waste repository in the unsaturated zone: U.S. Geological Survey Open-File Report 84-567, 23 p.

Scott, R.B., and Bonk, Jerry, 1984, Preliminary geologic map of Yucca Mountain, Nye County, Nevada, with geologic sections: U.S. Geological Survey Open-File Report 84-494, 9 p., scale 1:12,000.

Scott, R.B., and Castellanos, M., 1984, Stratigraphic and structural relations of volcanic rocks in drill holes USW GU-3 and USW G-3, Yucca Mountain, Nye County, Nevada: U.S. Geological Survey Open-File Report 84-491, 121 p.

Scott, R.B., and Rosenbaum, J.G., 1986, Structural and paleomagnetic evidence of rotation about a vertical axis during extension at Yucca Mountain [abs.]: Eos, Transactions American Geophysical Union, v. 67, no. 16, p. 358.

Scott, R.B., Spengler, R.W., Diehl, Sharon, Lappin, A.R., and Chornack, M.P., 1983, Geologic character of tuffs in the unsaturated zone at Yucca Mountain, southern Nevada, in Mercer, J.W., Rao, P.S.C., and Marine, I.W., eds., Role of the unsaturated zone in radioactive and hazardous waste disposal: Ann Arbor Science, p. 289335.
Smith, R.L., 1960a, Ash flows: Geological Society of America Bulletin, v. 71, p. 795-842.

Smith, R.L., 1960b, Zones and zonal variations in welded tuffs: U.S. Geological Survey Professional Paper 354-F, p. 149-159.

Smith, Christian, and Ross, H.P., 1982, Interpretation of resistivity and induced polarization profiles with severe topographic effects, Yucca Mountain area, Nevada Test Site, with an introduction by D.B. Hoover: U.S. Geological Survey Open-File Report 82-182, 101 p.

Snyder, D.B., and Carr, W.J., 1984, Interpretation of gravity data in a complex volcano-tectonic setting, southwestern Nevada: Journal of Geophysical Research, v. 89, p. 10193-10206.

Spengler, R.W., Braun, C.A., Linden, R.M., Martin, L.G., Ross-Brown, D.M., and Blackburn, R.L., 1993, Structural character of the Ghost Dance Fault, Yucca Mountain, Nevada, in High level radioactive waste management: Proceedings of the Fourth Annual International Conference, Las Vegas, Nev., April 26-30, 1993, American Nuclear Society, Inc. and American Society of Civil Engineers, v. 1, p. 653-659.

Spengler, R.W., Braun, C.A., Martin, L.G., and Weisenberg, C.W., 1994, The Sundance Fault-A newly recognized shear zone at Yucca Mountain, Nevada: U.S. Geological Survey Open-File Report 94-049, $11 \mathrm{p}$.

Spengler, R.W., Byers, Jr., F.M., and Warner, J.B., 1981, Stratigraphy and structure of volcanic rocks in drill hole USW-G1, Yucca Mountain, Nye County, Nevada: U.S. Geological Survey Open-File Report 81-1349, $33 \mathrm{p}$.

Spengler, R.W., Chornack, M.P., Muller, D.C., and Kibler, J.E., 1984, Stratigraphic and structural characteristics of volcanic rocks in core hole USW G-4, Yucca Mountain, Nye County, Nevada: U.S. Geological Survey Open-File Report 84-789, 77 p.

Spengler, R.W., and Fox, K.F., Jr., 1989, Stratigraphic and structural framework of Yucca Mountain, Nevada, in Radioactive waste management and the nuclear fuel cycle, Harwood Academic Publishers, v. 13(1-4), p. 21-36.

Spengler, R.W., Muller, D.C., and Livermore, R.B., 1979, Preliminary report on the geology and geophysics of drill hole UE25a-1, Yucca Mountain, Nevada Test Site: U.S. Geological Survey Open-File Report 79-1244, $43 \mathrm{p}$.

Spengler, R.W., and Rosenbaum, J.G., 1980, Preliminary interpretations of geologic results obtained from boreholes UE25a-4, -5, -6, -7, Yucca Mountain, Nevada Test Site: U.S. Geological Survey Open-File Report $80-929,39$ p. 
Stock, J.M., and Healy, J.H., 1988, Stress field at Yucca Mountain, Nevada, in Carr, M.D., and Yount, J.C., eds., Geologic and hydrologic investigations of a potential nuclear waste disposal site at Yucca Mountain, Southern Nevada: U.S. Geological Survey Bulletin 1790, p. 87-93.

Sully, M.J., Detty, D.P., Hammermeister, D.P., and Hauth, J.C., 1993, Deep vadose zone air permeability tests at the area 5 radioactive waste management site: Prepared for the REECO Environmental Restoration and Technology Development Department, 38 p.

Swolfs, H.S., Savage, W.Z., and Ellis, W.L., 1988, An evaluation of the topographic modification of stresses at Yucca Mountain, Nevada, in Carr, M.D., and Yount, J.C., eds., Geologic and hydrologic investigations of a potential nuclear waste disposal site at Yucca Mountain, Southern Nevada: U.S. Geological Survey Bulletin 1790, p. 95-101.

Sylvester, A.G., 1988, Strike-slip faults: Geological Society of America Bulletin, v. 100, p. 1666-1703.

Szabo, B.J., and Kyser, T.K., 1990, Ages and stable-isotope compositions of secondary calcite and opal in drill cores from tertiary volcanic rocks of the Yucca Mountain area, Nevada: Geological Society of America Bulletin 102, p. 1714-1719.

Thatcher, L.L., Janzer, V.J., and Edwards, K.W., 1977, Methods for determination of radioactive substances in water and fluvial sediments: Techniques of WaterResources Investigations of the U.S. Geological Survey, book 5, chap. A5, 243 p.

Thorstenson, D.C., Weeks, E.P., Haas, H.H., Busenberg, E., Plummer, L.N., and Peters, C.A., 1998, Chemistry of unsaturated zone gases sampled in open boreholes at the crest of Yucca Mountain, Nevada-Data and basic concepts of chemical and physical processes in the mountain: Water Resources Research, v. 34, no. 6 , p. $1507-1529$.

Thorstenson, D.C., Weeks, E.P., Haas, H.H., and Woodward, J.C., 1990, Physical and chemical characteristics of topographically affected airflow in an open borehole at Yucca Mountain, Nevada, in Nuclear waste isolation in the unsaturated zone: Proceedings, Focus ' 89 , Sept. 17-21, 1990, Las Vegas, Nev., p. 256-270.

Throckmorton, C.K., and Verbeek, E.R., 1995, Joint networks in the Tiva Canyon and Topopah Spring Tuffs of the Paintbrush Group, southwestern Nevada: U.S. Geological Survey Open-File Report 95-2, 47 p.

Tucci, Patrick, and Burkhardt, D.J., 1995, Potentiometricsurface map, 1993, Yucca Mountain and vicinity, Nevada: U.S. Geological Survey Open-File Report 95-4149, $15 \mathrm{p}$.
U.S. Department of Energy, 1988, Site characterization plan, Yucca Mountain site, Nevada Research and Development Area, Nevada: Office of Civilian Radioactive Waste Management, DOE/RW-0199, 9 volumes.

U.S. Department of Energy, 1995, Site characterization progress report-Yucca Mountain, Nevada, October 1, 1994-March 31, 1995, Number 12: Office of Civilian Radioactive Waste Management, DOE/RW-0477, variously paginated.

U.S. Department of Energy, 1996, Thermohydrologic Modeling and Testing Program-Peer Review Record Memorandum, P.A. Witherspoon, Chairperson: Las Vegas, Nev., Office of Civilian Radioactive Waste Management, Yucca Mountain Site Characterization Office.

U.S. Geological Survey, 1984, Summary of geologic studies through January 1, 1983, of a potential high-level radioactive waste repository site at Yucca Mountain, southern Nye County, Nevada: U.S. Geological Survey Open-File Report 84-792, 164 p.

van Genuchten, M.Th., 1980, A closed-form equation for predicting the hydraulic conductivity of unsaturated soils: Soil Science Society of America Journal, v. 44, p. 892-898.

Waddell, R.K., Robison, J.H., and Blankennagel, R.K., 1984, Hydrology of Yucca Mountain and vicinity, Nevada-California-Investigative results through mid1983: U.S. Geological Survey Water-Resources Investigations Report 84-4267, 72 p.

Weeks, E.P., 1978, Field determination of vertical permeability to air in the unsaturated zone: U.S. Geological Survey Professional Paper 1051, 41 p.

Weeks, E.P., 1987, Effect of topography on gas flow in unsaturated fractured rock-Concepts and observations, in Evans, D.D., and Nicholson, T.J., eds., Flow and transport through unsaturated fractured rock: Geophysical Monograph 42, American Geophysical Union, Washington, D.C., p. 165-170.

Whelan, J.F., and Stuckless, J.S., 1990, Reconnaissance $\delta^{13} \mathrm{C}$ and $\delta^{18} \mathrm{O}$ data from Trench 14 , Busted Butte, and drill hole G-4, Yucca Mountain, Nevada Test Site, in High level radioactive waste management: Proceedings of the International Topical Meeting, Las Vegas, Nev., April 8-12, 1990, American Nuclear Society, Inc., and American Society of Civil Engineers, v. 2, p. 930-933.

Whelan, J.F., Vaniman, D.T., Stuckless, J.S., and Moscati, R.J., 1994, Paleoclimatic and paleohydrologic records from secondary calcite, Yucca Mountain, Nevada, in High level radioactive waste management: Proceedings of the Fifth Annual International Conference, Las Vegas, Nevada, May 22-26, 1994, American Nuclear Society, Inc., and American Society of Civil Engineers, v. 4 , p. $2738-2745$. 
Whitfield, M.S., 1985, Vacuum drilling of unsaturated tuffs at a potential radioactive-waste repository, Yucca Mountain, Nevada, in Proceedings of the National Water Well Association conference on characterization and monitoring of the vadose (unsaturated) zone: Denver, Colo., Nov. 19-21, 1985, National Water Well Association, Dublin, Ohio p. 413-423.

Whitfield, M.S., Thordarson, William, Hammermeister, D.P., and Warner, J.B., 1990, Drilling and geohydrologic data for test hole USW UZ-1, Yucca Mountain, Nye County, Nevada: U.S. Geological Survey OpenFile Report 90-354, $40 \mathrm{p}$.

Williams, T.R., and Bedinger, M.S., 1984, Selected geologic and hydrologic characteristics of Basin and Range province-Pleistocene lakes and marshes: U.S. Geological Survey Miscellaneous Investigations Series Map I-1522-D, scale 1:2,500,000.

Winograd, I.J., and Thordarson, William, 1975, Hydrogeologic and hydrochemical framework, south-central Great Basin, Nevada-California, with special reference to the Nevada Test Site: U.S. Geological Survey Professional Paper 712-C, p. C1-C126.

Wittwer, C.S., Bodvarsson, G.S., Chornack, M.P., Flint, A.L., Flint, L.E., Lewis, B.D., Spengler, R.W., and Rautman, C.A., 1992, Design of a three-dimensional site-scale model for the unsaturated zone at Yucca Mountain, Nevada, in High level radioactive waste management: Proceedings of the Third Annual International Conference, Las Vegas, Nev., April 12-16, 1992, American Nuclear Society, Inc. and American Society of Civil Engineers, v. 1, p. 263-271.
Wittwer, C.S., Chen, G., Bodvarsson, G.S., Chornack, M.P., Flint, A.L., Flint, L.E, Kwicklis, E.M., and Spengler, R.W., 1995, Preliminary development of the LBL/USGS three-dimensional site-scale model of Yucca Mountain, Nevada: Lawrence Berkeley Laboratory, Earth Sciences Division, LBL-37356, 69 p. and Appendices A and B.

Yang, I.C., 1992, Flow and transport through unsaturated rock-Data from two test holes, Yucca Mountain, Nevada, in High level radioactive waste management: Proceedings of the Third Annual International Conference, Las Vegas, Nev., April 12-16, 1992, American Nuclear Society, Inc., and American Society of Civil Engineers, v. 1, p. 732-737.

Yang, I.C., Haas, H.H., Weeks, E.P., and Thorstenson, D.C., 1985, Analysis of gaseous-phase stable and radioactive isotopes in the unsaturated zone, Yucca Mountain, Nevada, in Proceedings of the National Water Well Association conference on characterization and monitoring of the vadose (unsaturated) zone: Denver, Colo., Nov. 19-21, 1985, National Water Well Association, Dublin, Ohio, p. 488-506.

Yang, I.C., Peters, C.A., and Thorstenson, D.C., 1993, Carbon isotopic data from test hole USW UZ-1, Yucca Mountain, Nevada, in High level radioactive waste management: Proceedings of the Fourth Annual International Conference, Las Vegas, Nev., April 26-30, 1993, American Nuclear Society, Inc., and American Society of Civil Engineers, v. 1, p. 401-406.

Yang, I.C., Rattray, G.W., and Yu, Pei, 1996, Interpretation of chemical and isotopic data from boreholes in the unsaturated zone at Yucca Mountain, Nevada: U.S. Geological Survey Water-Resources Investigations Report 96-4058, 58 p. 
APPENDIX 



\section{Implications for Waste Isolation at the Potential High-Level Radioactive Waste Repository at Yucca Mountain, Nevada}

The data presented in this report have been interpreted as reflecting the presence of certain hydrologic conditions within the Exploratory Studies Facility (ESF) North Ramp area of Yucca Mountain. Although most of the repository would be constructed outside of the present study area, current repository design (TRW Environmental Safety Systems, Inc., 1995, fig. 3.2-2) calls for the northernmost waste emplacement drifts of the repository to be located within the North Ramp study area as defined in this report. The hydrologic conditions identified as existing within the study area would affect those emplacement drifts directly. Moreover, because the unsaturated-zone flow system in more southern areas of Yucca Mountain has not yet been analyzed to the same extent as for the North Ramp area, the findings of this report may serve as useful indicators for hydrologic conditions elsewhere at Yucca Mountain until such time as those location-specific data can be analyzed more completely.

On the basis of current understanding of the data, the following observations and implications for waste isolation can be made concerning hydrologic conditions existing in the North Ramp area and perhaps in more southern areas of Yucca Mountain as well.

\section{IMPLICATION \#1:}

Secondary permeability due to fracturing may exist locally within the PTn hydrogeologic unit in the North Ramp area.

The section of this report titled Evidence for Preferential Fracture Flow and Lateral Flow Within the Paintbrush Nonwelded Hydrogeologic Unit summarized evidence for the existence of secondary permeability locally within the PTn. This evidence included (1) isotopic evidence from tritium within and below the PTn; (2) inferred field-scale air permeabilities, based on analysis of the pneumatic pressure record, that were substantially higher than matrix permeabilities measured on unfractured core samples; and (3) chloride and carbon-14 concentrations and strontium-isotope values from the perched-water reservoir at UZ-14 that implied a fracture-flow origin for the perched water. The inference from these data that secondary permeability exists locally within the PTn was supported by chlorine-36 data collected from the ESF (Fabryka-Martin and others, 1996), which found that meteoric water with an origin that postdated the onset of nuclear-weapons testing existed at 11 sampling sites within the TSw. In some cases, most notably at boreholes UZ\#4 and UZ\#5, there is a clear association of secondary permeability due to fracturing with mapped faults (fig. 21). In instances in which the distances from mapped faults are greater, such as at boreholes NRG-6 and UZ-1/UZ-14, the connection between secondary permeability within the PTn and mapped faults is more tenuous than at UZ\#4 and UZ\#5. A similar observation was made by Fabryka-Martin and others (1996), who noted that although samples with elevated chlorine-36 ratios showed a general correspondence with mapped surface faults, there was no clear association of these samples with major faults in the subsurface. Nonetheless, observations of secondary permeability within the PTn may be biased by the proximity of the boreholes UZ\#4, UZ\#5, NRG-6, and UZ-1/UZ-14 to mapped faults. It is possible that a similar degree of secondary permeability would have been found within 
the PTn in less faulted areas had these areas been explored with boreholes to the same extent.

Localized secondary permeability within the PTn may have both adverse as well as positive effects on waste isolation. Water moving through fractures in the PTn is unlikely to be retarded by capillary-barrier effects at the interface with the TSw; therefore, lateral diversion or removal by shallow air circulation within Yucca Mountain is not likely to result in a reduction of the deep-percolation flux entering the repository horizon. On the other hand, numerical simulations have predicted that following waste emplacement, a considerable volume of in-situ water will be mobilized as vapor and deposited as condensate in the rock above the repository (Buscheck and others, 1994). Local fracturing within the PTn makes it less likely that permeability to air within the PTn will be completely precluded as a result of condensate deposition, facilitating the continued long-term exhaust of vapor to the atmosphere through shallow air circulation above and within the PTn.

\section{IMPLICATION \# 2:}

The ratio of vertical to horizontal bulk permeability within the TSW appears to be approximately 3:1 to 10:1 in the North Ramp area.

These ratios were derived from an analysis of the pre- and post-tunnel construction effects on measured pneumatic pressures, and comparison of permeabilities estimated from monitored pneumatic pressures with those estimated from air-injection testing. These ratios imply that vertical flow through the TSw will be enhanced relative to horizontal flow.

A large amount of in-situ water is expected to be mobilized as vapor by waste-generated heat. A portion of this vapor will condense in cooler regions above and between the emplacement drifts. Anisotropy in fracture network permeability may be important for repository design if the spacing between individual waste-emplacement drifts and thermal loads are to be engineered to promote maximum drainage of condensate in the rock pillars between the drifts.

\section{IMPLICATION \# 3:}

At least some of the mapped faults in the North Ramp area possess permeabilities that, within the TSW, exceed that of the adjacent rock.

The section of this report titled Effects of Excavation of the North Ramp on In Situ PneumaticPressure Measurements describes how the pneumatic behavior of several monitoring stations in boreholes UZ\#4 and UZ\#5 in Pagany Wash and NRG-6 in Drill Hole Wash were changed when the tunnel crossed through particular mapped faults in the North Ramp area. In the case of boreholes UZ\#4 and UZ\#5, the pneumatic-pressure interference was transmitted by a north-south-trending fault (fault 2 in fig. 21) over a horizontal distance of about $400 \mathrm{~m}$. At borehole NRG-6, pneumatic-pressure interferences were noted after the tunnel had crossed the northern splay of the Drill Hole Wash Fault system. The path along which pneumatic-pressure changes in the tunnel were transmitted to NRG-6 probably involved the northern (fault 11 in fig. 21) and southern splays (fault 9 in fig. 21) of the Drill Hole Wash Fault system and possibly any intervening cross-cutting faults obscured by the alluvial cover. At the time pneumatic-interference effects became evident in the pneumatic-pressure record, the horizontal distance from the tunnel to the borehole was about $550 \mathrm{~m}$, although because of tortuosity along the transmission path, the actual propagation distance was probably much greater. These horizontal propagation distances were substantially greater than those recorded at boreholes that were not in general alignment with the strike of a mapped fault, in which cases pneumatic-interference effects were not evident until the horizontal offset between the tunnel and borehole were on the order of 50 to $100 \mathrm{~m}$. From these observations, it is inferred that the faults under discussion are substantially more permeable within the TSw, where the interference effects were most pronounced, than in the surrounding, unfaulted rock. Faulting also may be associated with the inferred increases in secondary permeability within the PTn at boreholes UZ\#4, UZ\#5, and NRG-6 (see Implication \#1).

In general, the effects of open faults within the TSw on waste isolation depends on the location, frequency, and detectability of these faults, as well as on the capacity of the PTn to divert water laterally toward these faults. If these faults serve as drains for water that is laterally diverted within the PTn, and are 
relatively scarce and readily identified, then waste emplacement drifts can be offset from them with few detrimental and some beneficial effects. If water is not laterally diverted within the PTn, or if faults in the subsurface emplacement areas are more difficult to identify or are too numerous, then the presence of open faults within the TSw may have neutral or negative consequences for waste isolation. The effect of faults on waste isolation also depends on whether or not these faults are open within the nonwelded to partially welded tuffs between the Topopah Spring Tuff and the water table. No concrete evidence exists concerning the character of faults within these units in the North Ramp area.

The faults within the North Ramp area that have been identified as being open within the TSw (faults 2 , 9 , and 11 in fig. 21) do not directly intersect any of the areas presently identified for potential development as waste-emplacement drifts (TRW Environmental Safety Systems, Inc., 1995, fig. 3.2-2). The primary emplacement areas within the lower block are located to the southwest of faults 2,9 , and 11 , between the Ghost Dance Fault and the imbricate fault zone. Because of similarity in orientation, however, the transmissive properties of fault 2 in figure 21 may imply a similar degree of transmissivity for individual faults of the imbricate fault zone, which is located just southwest of the Drill Hole Wash fault system at Live Yucca Ridge in the lower right quadrant of figure 21.

\section{IMPLICATION \#4:}

\section{Long-term percolation rates beneath the alluvial channels providing surface drainage for the eastern slope of Yucca Mountain may be from several to several tens of millimeters per year.}

Within the North Ramp area, heat-flow deficits were inferred to exist in the unsaturated zone beneath both Drill Hole and Pagany Washes on the basis of measurements of temperature and thermal conductivity (see the section of this report titled Analysis of Percolation Flux Based on Heat Flow Estimated in Boreholes). Results of calculations presented in this section show that these inferred heat-flow deficits are consistent with those that would be expected from downward water-percolation rates of several to several tens of millimeters per year. These percolation rates are considerably higher than those that have been esti- mated for these washes from water-balance calculations using recent neutron moisture-meter measurements made in shallow boreholes (D.B. Hudson and A.L. Flint, U.S. Geological Survey, unpublished data, 1996). Estimates of net shallow infiltration based on neutron moisture-meter measurements typically varied from about $5 \mathrm{~mm} / \mathrm{yr}$ beneath active channels to approximately $0 \mathrm{~mm} / \mathrm{yr}$ for the adjacent alluvial terraces, with spatial variations that depended on the local thickness of the alluvium. The differences between these estimates and those obtained from the analysis of borehole temperature profiles are thought to stem primarily from differences in the time scales being reflected in the moisturebalance and temperature measurements. The neutron moisture-meter measurements reflect processes and events that are likely to be observed under present climatic conditions over a decade-long time span. Temperature measurements, by virtue of their greater depth and the longer response-time associated with predominantly conductive processes, may reflect the average percolation flux over several decades or centuries. Thus, although the actual present-day percolation fluxes may differ from the values estimated on the basis of the heat-flow analysis, the latter estimates may be effective, long-term averages.

If the pattern of infiltration determined from neutron moisture-meter measurements is correct, and present-day net infiltration beneath the alluvium-filled washes is minor compared with that occurring beneath sideslopes and ridges (D.B. Hudson and A.L. Flint, unpublished data, 1996), then the much larger percolation fluxes estimated for the washes from the heat-flow analysis imply that different infiltration patterns existed in the past and, similarly, that a different pattern of infiltration may exist under future climatic conditions, if these were to differ from those of the present day (1996). Consequently, attempts to evade percolating water by concentrating waste packages in areas estimated to have low infiltration rates (based on measurements that reflect short-term, near-surface conditions) may fail because of shifts in the infiltration pattern that occur in response to longer term climate cycles. 


\section{IMPLICATION \#5:}

Perched water is present above the densely welded, crystal-poor vitrophyre (Tptpv3) within the North Ramp area.

The section of this report titled Stratigraphic, Structural, and Hydrologic Considerations presented arguments that perched water in the North Ramp results from the presence and character of the densely welded, crystal-poor vitrophyre (Tptpv3) within the North Ramp area. These arguments involved the observations that (1) perched water was first detected or ultimately rose to elevations that were above, or coincided with, the contact between the lower nonlithophysal (Tptpln) and the densely welded, crystalpoor vitric units (Tptpv3) of the Topopah Spring Tuff, (2) the above-mentioned contact is marked by an interval of well-developed argillic alteration, and (3) the saturation profile at SD-9 shows that partial saturation exists within the nonwelded, crystal-poor vitric unit of the Topopah Spring Tuff (Tptpv1), which underlies the perched water detected at the TptplnTptpv 3 contact at this borehole.

The occurrence of perched water, in combination with the age dates obtained from the perchedwater reservoir at UZ-14, implies that, even under the relatively arid climatic conditions of the Holocene, the vertical percolation flux has equaled or exceeded the vertical transmission capacity of the densely welded, crystal-poor vitrophyre over some fraction of the North Ramp area. On the basis of calculations that assumed the validity of the growth-fault model, and which considered uncertainty in the residence time, volume, and contributing area of the perched-water reservoir, long-term percolation fluxes through the TSw have been 0.001 to $0.29 \mathrm{~mm} / \mathrm{yr}$, as a minimum. Percolation fluxes could have been higher if the permeability of the moderately to densely welded units of the crystal-poor vitrophyre were higher in the surrounding contributing areas. The real significance of these values, however, may be the implication that, because the transmission capacity of the densely welded, crystal-poor vitrophyre has already been equaled or exceeded by the relatively low percolation fluxes of the present arid climate, any future increases in percolation flux associated with climate change would result in corresponding increases in the flux that is laterally diverted. In the downdip direction, the diverted fraction will accumulate, much as surface runoff would in the lower elevations of a watershed, so that the lateral component of flux along the perching layer can far exceed the vertical component of the percolation flux, with correspondingly high pore-water velocities. If dissolved radionuclides were to be mixed with this diverted perched water, these radionuclides might be transported to an as yet undetected perched-water reservoir with a comparatively long residence time and low seepage rates, such as the one detected by borehole UZ-14. Or, perhaps more likely, dissolved radionuclides might be transported to an open fault that provides relatively direct access to the water table or to less altered, permeable horizons beneath the Calico Hills Formation, such as the devitrified unit within the Prow Pass Tuff.

\section{IMPLICATION \#6:}

Fracture flow is a major, if not dominant, component of the total percolation flux through the TSW in the North Ramp area of Yucca Mountain.

As discussed in preceding sections of this report (see Chemistry and Isotopic Content of Perched Water and Aqueous-Phase Chemical Considerations), chloride and carbon- 14 concentrations, and strontiumisotope values from the perched-water reservoir at UZ-14 imply a predominantly fracture-flow origin for the perched water. The average percolation fluxes required to sustain this perched-water reservoir, given uncertainty in estimates of its residence time, its volume, and the extent of its contributing areas, ranged from 0.001 to $0.29 \mathrm{~mm} / \mathrm{yr}$ (see the section of this report titled Calculation of Percolation Flux in the Vicinity of the UZ-14 Perched-Water Reservoir). Larger percolation fluxes, on the order of several to tens of millimeters per year, were inferred from the heat-flow deficit that was estimated to exist in the unsaturated zone beneath some of the major washes, based on analysis of temperature profiles (see the section of this report titled Analysis of Percolation Flux Based on Heat Flow Estimated in Boreholes). Recent efforts to determine percolation flux by optimizing the match between simulated and measured water potential and saturation profiles for boreholes distributed across the Yucca Mountain site have determined that a percolation flux of $0.02 \mathrm{~mm} / \mathrm{yr}$ provides the best fit to the entire set of borehole data (Ahlers and others, 1995, table 3.5.2, p. 39). Because the 
measurements used to optimize that estimate of flux were obtained from matrix-core samples, this estimate reflects only the matrix contribution to the percolation flux. A matrix percolation flux of $0.02 \mathrm{~mm} / \mathrm{yr}$ is well within the range of percolation flux through fractures required to sustain the perched-water reservoir $(0.001$ to $0.29 \mathrm{~mm} / \mathrm{yr}$ ) and substantially lower than the percolation flux inferred from the heat-flow analysis.

Therefore, fracture flow is a major, and perhaps dominant, component of the overall percolation flux.

The movement of the dominant component of the percolation flux through fractures has several implications for waste isolation and performanceassessment calculations: (1) If percolation through fractures is episodic and channeled along a few fracture pathways, as borehole tritium data and chlorine36 data from the ESF (Fabryka-Martin and others, 1996) have implied, and the number of waste packages in a repository likely to come in contact with liquid water is a function of the fracture percolation flux (Gauthier, 1994), then a larger fracture percolation flux implies that the probability of a flowing fracture intercepting a waste package will increase; and (2) pore-water chemistry, as represented by samples obtained from the matrix of the nonwelded tuffs overlying the potential repository, might not reflect the chemistry of water that might contact the waste packages. The chemistry of the contacting water may be more like that of the perched water intersected at UZ-14, which arrived through a predominantly fracture-flow mechanism. Canister-corrosion and wastedissolution rates might be sensitive to the chloride, bicarbonate, and fluoride concentrations, as well as the volume, of contacting water (see, for example, chapter 13 in Wilson and others, 1994). The dilute nature of the fracture water needs to be considered when analyzing canister-corrosion and waste-dissolution rates.

\section{IMPLICATION \#7:}

Water movement within the deep unsaturated zone may be relatively complex and follow preferential pathways created by variations in the degree of mineral alteration and by faulting.

The depth inversion of apparent carbon- 14 ages at UZ-14 indicates that the pore water in the Calico Hills Formation did not arrive predominantly as a result of downward seepage from the perched-water reservoir through the crystal-poor vitrophyre of the Topopah Spring Tuff (see the section of this report titled Aqueous-Phase Chemical Considerations). One possible set of hydrogeologic conditions that could explain the observed age distribution was presented in this report. In this hypothesis, preferential flow through the Solitario Canyon Fault and its associated fault splays, or through less altered parts of the crystalpoor vitrophyre, may have permitted more direct access of percolating water to the permeable nonwelded to partially welded tuffs adjacent to the Calico Hills Formation. Lateral flow within the Tptpv1 unit and downward flow through the Calico Hills Formation, or lateral flow within the partially welded, devitrified unit within the upper Prow Pass Tuff, with upward diffusion of carbon-14, could have resulted in younger ages for the Calico Hills Formation pore water than for the perched-water reservoir. The top of the Prow Pass Tuff is within about $37 \mathrm{~m}$ of the water table at UZ-14, and because of the eastward dip of this unit, it is only about $23 \mathrm{~m}$ above the water table at borehole G-1. Therefore, if the upper Prow Pass Tuff is a conduit for the movement of young water, this young water has traversed nearly the entire thickness of the unsaturated zone.

The depth inversion of carbon-14 ages at UZ-14 indicates that percolation may be able to bypass lowpermeability layers such as the crystal-poor vitrophyre and the zeolitic zone of the Calico Hills Formation along faults, or in areas where these layers have undergone less extensive alteration, or both. If this is the case, travel times from the repository to the water table would be considerably shorter than those that would be predicted under the assumption that percolation occurs only as one-dimensional vertical seepage through those low-permeability layers. Although young water may have reached the Prow Pass Tuff through faults to the west or north of the potential repository area, and radionuclides leached from the repository would not have ready access to those faults because of the dip of the beds, these observations indicate that similar access to deeper stratigraphic horizons or to the water table may be available through the Ghost Dance Fault, the imbricate fault zone, or the Bow Ridge Fault. 


\section{REFERENCES CITED IN APPENDIX}

Ahlers, C.F., Bandurraga, T.M., Bodvarsson, G.S., Chen, Gang, Finsterle, Stefan, and Wu, Y.S., 1995, Summary of model calibration and sensitivity studies using the LBNL/USGS three-dimensional unsaturated zone sitescale model: Berkeley, Calif., Lawrence Berkeley National Laboratory, $117 \mathrm{p}$.

Buscheck, T.A., Nitao, J.J., and Saterlie, S.F., 1994, Evaluation of thermo-hydrological performance in support of the thermal loading systems study, in High level radioactive waste management, proceedings of the fifth annual international conference, Las Vegas, Nevada, May 22-26, 1994: La Grange Park, Ill., American Nuclear Society, Inc., v. 2, p. 592-610.

Fabryka-Martin, J.T., Dixon, P.R., Levy, S., Liu, B., Turin, H.J., and Wolfsberg, A.V., 1996, Summary report of chlorine-36 studies-Systematic sampling for chlorine-36 in the Exploratory Studies Facility: Los Alamos National Laboratory Milestone Report 3783M, $53 \mathrm{p}$.

Gauthier, J.H., 1994, Nominal-case releases-Weeps model, in Wilson, M.L., and others, Total-system performance assessment for Yucca MountainSNL second iteration (TSPA-1993): Sandia National Laboratories Report SAND93-2675, v. 2, chap. 15, p. 15-1 to 15-72.

TRW Environmental Safety Systems, Inc., 1995, Total system performance assessment-1995-An evaluation of the potential Yucca Mountain repository: Las Vegas, Nev., TRW Environmental Safety Systems, Inc., B00000000-01717-2200-00136, Rev. 01, variously paginated.

Wilson, M.L., Gauthier, J.H., Barnard, R.W., Barr, G.E., Dockery, H.A., Dunn, E., Eaton, R.R., Guerin, D.C., Lu, N., Martinez, M.J., Nilson, R., Rautman, C.A., Robey, T.H., Ross, B., Ryder, E.E., Schenker, A.R., Shannon, S.A., Skinner, L.H., Halsey, W.G., Gansemer, J.D., Lewis, L.C., Lamont, A.D., Triay, I.R., Meijer, A., and Morris, D.E., 1994, Total-system performance assessment for Yucca MountainSNL second iteration (TSPA-1993): Sandia Report SAND93-2675, Sandia National Laboratories, Albuquerque, New Mexico and Livermore, California, v. 1, v. 2, and executive summary, variously paginated. 